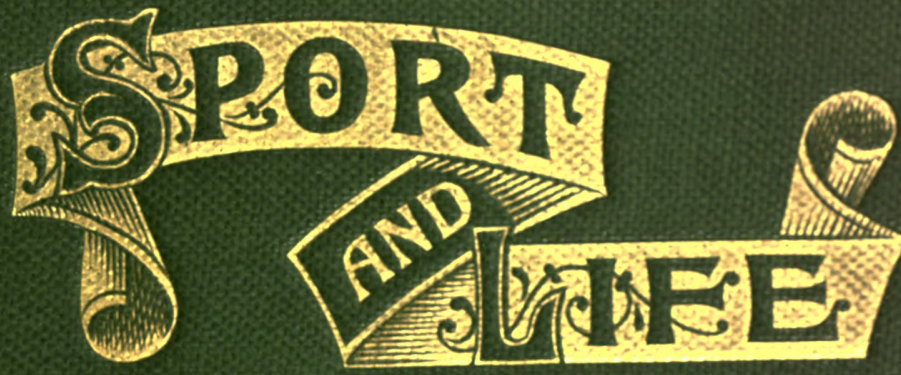

BALUE-CROHMAN 
3is 



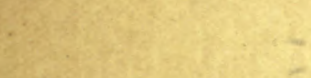



FIFTEEN YEARS '

\section{SPORT AND LIFE \\ IN THE}

HUNTING GROUNDS OF WESTERN AMERICA AND BRITISH COLUMBIA. 

My farrourite Wapiti Head, Study in Schloss Matzen
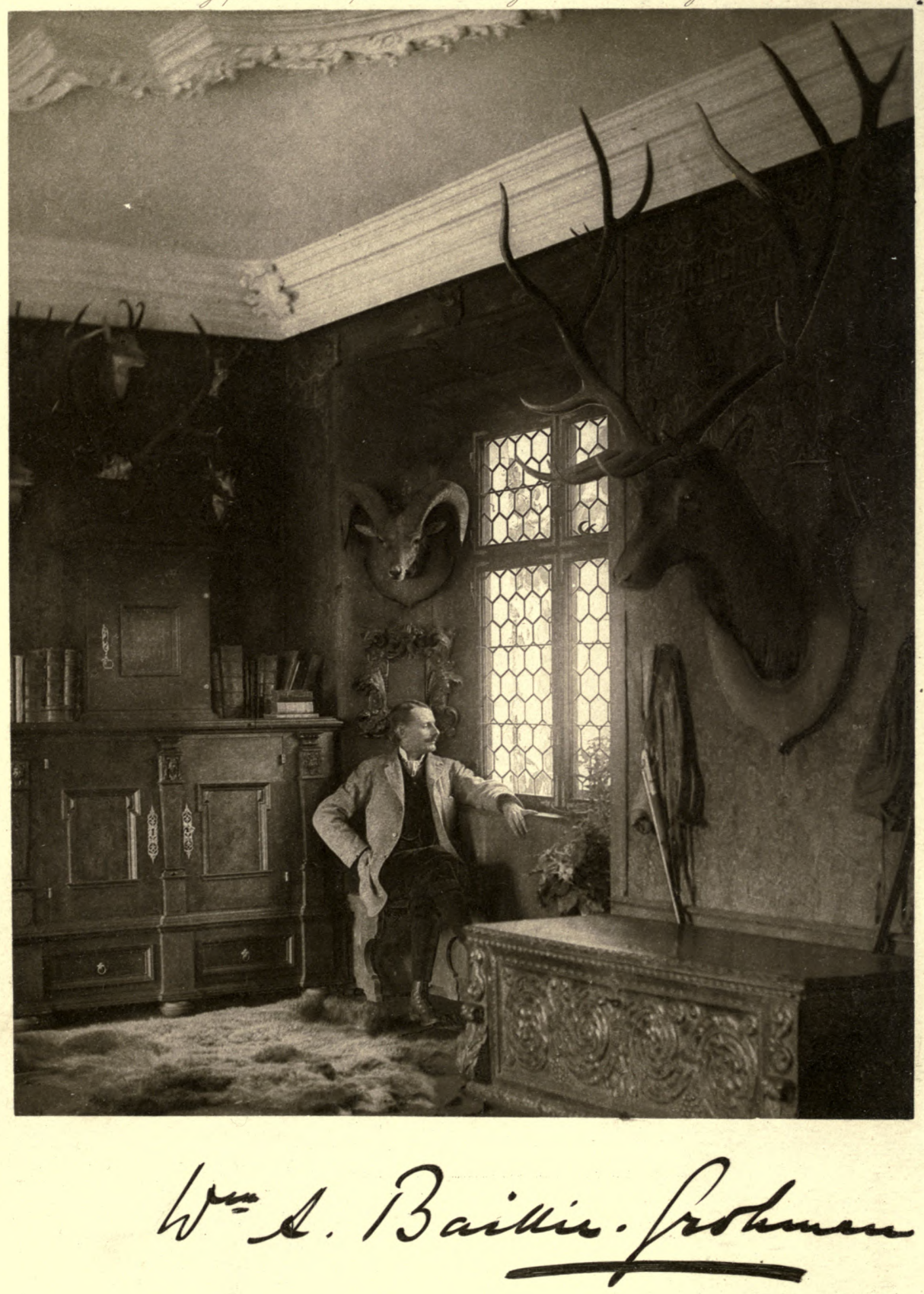


\title{
FIFTEEN YEARS'
}

\section{SPORT}

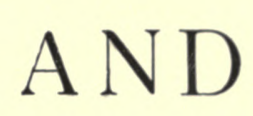

LIFE

IN THE

\section{HUNTING GROUNDS OF WES'TERN AMERICA ANI) BRITISH COLUMBIA.}

\author{
BY \\ W. A. BAILLIE-GROHMAN,
}

Author of "Camps in the Rockies," "Sport of the Alps," $\mathcal{E C}_{\mathrm{c}}$; Contributor to the "Badminton Library" volumes on Big Game.

Member of the Al.pine Club.

WITH A CHAPTER BY

Mrs. BAILLIE-GROHMAN.

ILLUSTRATED BY SEVENTY-SEVEN PHOTOGRAPHS, INCLUDING THE BEST Trophies OF NORTH AMERICAN BIG GAME KILled BY

ENGLISH AND AMERICAN SPORTSMEN, WITH TABLE OF MEASUREMENTS AND NOTES.

With Three specially prepared Maps of the North-west Coast of the United States, British Columbia, and the Kootenay District.

\author{
LONDON : \\ HORACE COX,
}

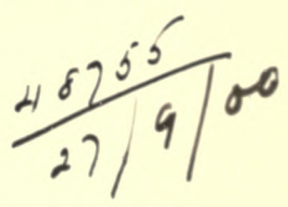

"FIELD" OFFICE, WINDSOR HOUSE, BREAM'S BUILdINGS, E.C.

$$
\text { 1900. }
$$


LONDON
PRINTEd BY HORACE COX, WINDSOr HoUSE, BREAM'S BUILDINGS, E.C. 


\section{PREFACE.}

To be quite accurate in the use of the title that I have selected, I must qualify it by stating that I did not live for fifteen consecutive years on the Pacific Slope of North America. I spent the majority of each of fifteen years out there, making British Columbia-a land of great beauty and of promising future - my temporary home for some years. The ocean I crossed some thirty times, and the Continent of North America a few odd times oftener.

The first four or five visits were exclusively devoted to big game shooting. Sport such as I enjoyed in the "seventies" and early "eighties" is no longer to be obtained-nothing approaching it-and for this reason, if for no other, these pages will, I hope, be of interest to fellow sportsmen. So far as record trophies are concerned I have spared no trouble to make this volume up-to-date, and as much as possible free from mistakes. The second half of the book is devoted to life on the Pacific Slope. These chapters contain personal reminiscences and experiences which will perhaps assist the casual visitor or the stay-at-home reader to gain an insight into the practical issues of life on the frontier. To those who propose to make "the Slope" their future home they may possibly convey useful 
information. Though more than five years have elapsed since I bid good-bye to the West, the process of opening up a new country remains ever the same, though the supply of it is becoming daily more limited.

To the sportsmen who have assisted me with photographs and details of their trophies, I wish to express my sincere thanks, and I trust that they will find that my chief aim, viz., accuracy, has been attained.

For the closing chapter of this book, which deals with the "Yellow and White Agony," as has been called the servant question out West, I am indebted to my wife. Much that she describes would have escaped the masculine eye, and may possibly prove of use not only to those proposing to try their hand at housekeeping on the Slope, but also to prophets who predict an invasion of John Chinaman into European households.

Portions of two chapters appeared in the Fortnightly Review and in the Century Magazine of New York, and I am indebted to the editors for permission to reprint the passages I have selected.

The Author. 


\title{
LIST OF CHAPTERS.
}

\author{
CHAPTER I.
}

PAGE.

$\begin{array}{llllll}\text { Travelling in the Western Hunting Grounds } & \ldots & \ldots & \ldots & \ldots & \text { I }\end{array}$

CHAPTER II.

The Slaughter of Big Game and the Game Laws of America $\ldots{ }_{27}$

CHAPTER III.

The Wapiti, its Antlers and its Chase

CHAP'TER IV.

The Antelope-Goat of Pacific Slope Mountains, and its Chase ... 85 CHAPTER V.

The Moose, Caribou, and Deer of the Pacific Slope $\quad \ldots \quad \ldots r$ I 22 CHAPTER VI.

The Bighorn and the Antelope I 39

CHAP'TER VII.

The Bears and the Bison of North America I 60

CHAPTER VIII.

The Seal and other Fur-bearing Animals of the Pacific Coast ... $17+$

CHAPTER IX.

The Salmon of the Pacific Coast 
CHAPTER X.

How Kootenay Emerged from its Wild State

CHAPTER XI.

Early Days in Kootenay

CHAPTER XII.

Running a Saw-mill and Store up country ...

CHAPTER XIII.

Path-finding in Kootenay

\section{CHAPTER XIII.}

CHAPTER XIV.

Some Personal Recollections of Victoria

CHAPTER XV.

The Yellow and White Agony: a chapter on Western Servants... 333

$\begin{array}{lllllllllllll}\text { Appendix } & \ldots & \ldots & \ldots & \ldots & \ldots & \ldots & \ldots & \ldots & 363\end{array}$

$\begin{array}{llllllllllll}\text { Index } & \ldots & \ldots & \ldots & \ldots & \ldots & \ldots & \ldots & \ldots & \ldots & 395\end{array}$ 


\section{LIST OF PLATES AND ILLUSTRATIONS.}

The Author's Farourite Wapiti Head

The After-Dinner Pipe in the Wilds ...
PAGE

Frontispiece.

Facing $\quad$ I 8

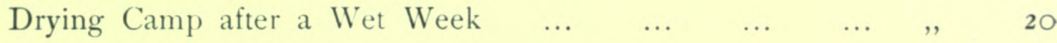

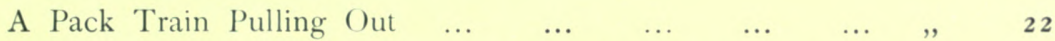

What was once the Best Hunting Ground in North America ,, 24

The Arid Interior Uplands of British Columbia ... ... , , 4 I

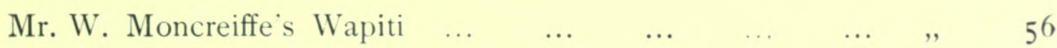

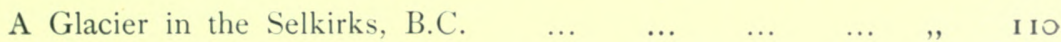

The Largest Moose Antlers on Record $\ldots \quad \ldots, \quad \ldots \quad$, , 22

The Great Tetons ( $13,800 \mathrm{ft}$.) on the Borders of Wyoming $\begin{array}{lllllllll}\text { and Idaho } & \ldots & \ldots & \ldots & \ldots & \ldots & \ldots & , & \text { I } 42\end{array}$

Civilisation's Progress: Collecting the Last Relics of the

Bison (Buffalo) for Fertiliser Manufactories ... ... , $\quad$ I 70

Fur Seal Rookery on the Prybiloff Islands ... $\quad \ldots \quad \ldots \quad,, \quad$ I 84

A Salmon Run in a British Columbia River $\quad \ldots \quad \ldots \quad$, 202

The Yellowhead Pass, British Columbia $\quad \ldots \quad \ldots \quad \ldots \quad \ldots \quad, \quad, 304$

Indian Papoose on Cradle Board, in which manner Babies

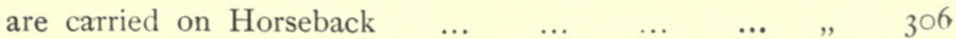

The Country at the Head of Fraser River, B.C. ... $\quad . . \quad, \quad 310$ 


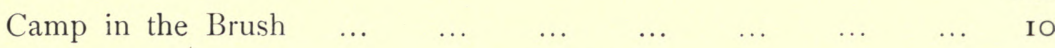

Swimming the Thompson River in British Columbia $\ldots$ I $_{3}$

A Forenoon's Basket of Trout in the Teton Basin $\ldots . \quad \ldots \quad$ I5

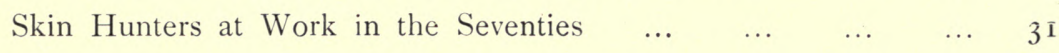

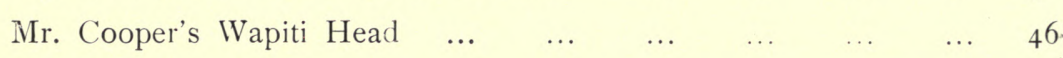

$\begin{array}{lllllllllll}\text { The Author's Wapiti } & \ldots & \ldots & \ldots & \ldots & \ldots & \ldots & \ldots & 47\end{array}$

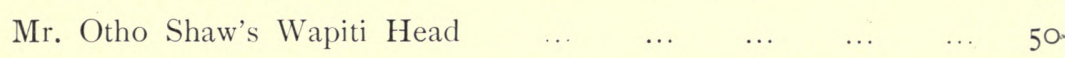

'The Author's r 8-point Wapiti Head with Caribou Palmation ... 52

$\begin{array}{lllllllllll}\text { Count E. Hoyos' Wapiti } & \ldots & \ldots & \ldots & \ldots & \ldots & \ldots & 53\end{array}$

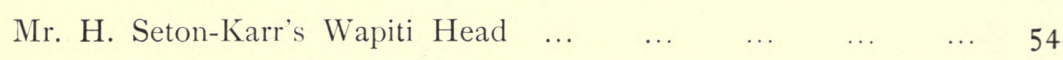

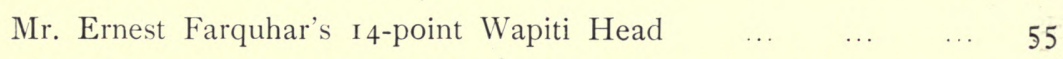

Wapiti Shot by Mr. T. Bate, of Kelsterton $\quad \ldots \quad \ldots \ldots \quad \ldots \quad{ }^{6} 6$

Sir Edmund Loder's remarkably Wide Wapiti Head $\ldots{ }^{2} \quad \ldots$

Fine 20-point Wapiti Head Exhibited by Mr. A. L. Tulloch $\quad . .60$

Wapiti Antlers dug out of Quicksands in the Saline River (Kansas) 6 I

Some of the Author's Trophies in Schloss Matzen, Tyrol $\quad \ldots \quad 62$

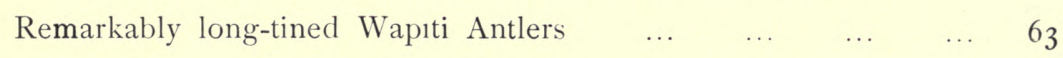

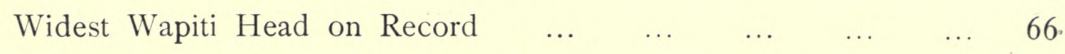

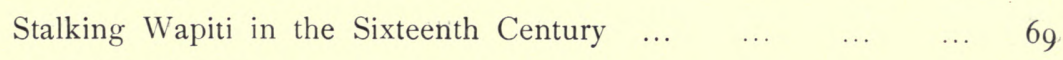

$\begin{array}{lllllllllll}\text { Wapiti in Winter } & \ldots & \ldots & \ldots & \ldots & \ldots & \ldots & \ldots & 75\end{array}$

Skeleton of the Antelope Goat (Haplocerus montanus) $\quad \ldots \quad$. $\quad \ldots \quad 87$

A Family Group of Haplocerus in Sir Edmund Loder's Museum 89

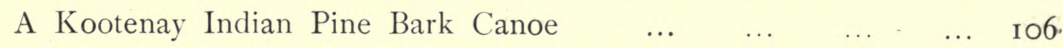

Scenery in Kootenay, B.C. $\quad \ldots \quad \begin{array}{lllllllll} & \ldots & \ldots & \ldots & \ldots & \ldots & \text { I08 }\end{array}$

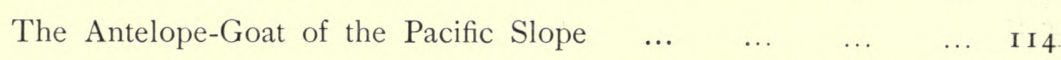

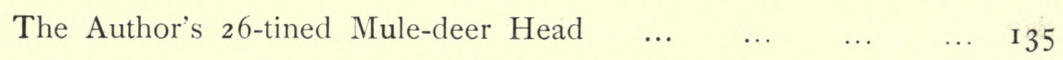

Mr. Morton Frewen's unique White-tail Deer Head $\ldots \quad \ldots \quad$ I 36

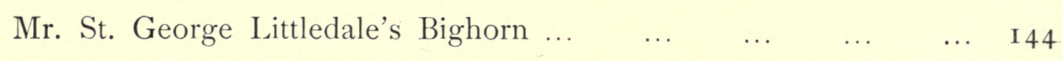

$\begin{array}{lllllllllll}\text { Largest Bighorn on Record } & \ldots & \ldots & \ldots & \ldots & \ldots & \ldots & \text { I } 45\end{array}$

Horn of Prongbuck as shed $\ldots \begin{array}{llllllll} & \ldots & \ldots & \ldots & \ldots & \ldots & \text { I } 53\end{array}$ 
Horn just before it was shed, showing the new Horn beneath ... ${ }^{1} 53$

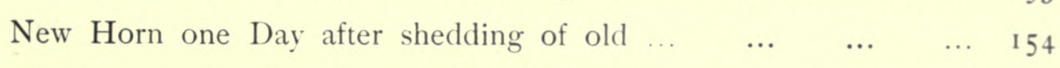

New Horn after Twenty-one Days Growth ... $\quad \ldots \quad \ldots \quad \ldots \quad \ldots \quad$ I 54

Head of Prongbuck immediately after shedding the old Horns ... I5 55

"Never Sweat," Bonanza Clark's Cabin in the Big Windriver

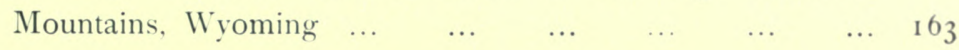

One of the Oldest Pictures of the American Bison $\quad \ldots \quad \ldots \quad \ldots \quad$ i 68

Bison Head claimed to be the Largest on Record... $\ldots \ldots \ldots$ I7 I

Bull Musk Ox Head belonging to W. F. Sheard, Tacoma $\ldots{ }^{172}$

The Native Village on St. Paul (Prybiloff Islands), with a Seal

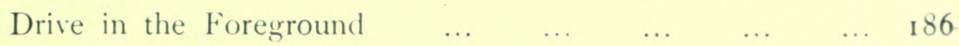

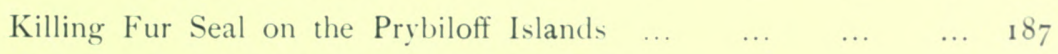

How Seals were Killed in the Sixteenth Century ... $\quad \ldots \quad \ldots \quad \ldots \quad$ I94

Thirty Silver Fox Skins, belonging to W. F. Sheard, Tacoma,

$\begin{array}{llllllllllll}\text { Wash. } & \ldots & \ldots & \ldots & \ldots & \ldots & \ldots & \ldots & \ldots & 197\end{array}$

Salmon leaping an I8ft. high Fall on White Bear River, Labrador 204

Salmon "Sailing Home" in leaping an I8ft. high Fall on White

$\begin{array}{lllllllll}\text { Bear River, Labrador } & \ldots & \ldots & \ldots & \ldots & \ldots & \ldots & 205\end{array}$

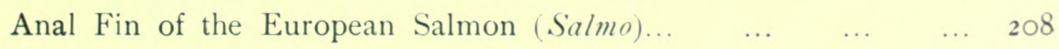

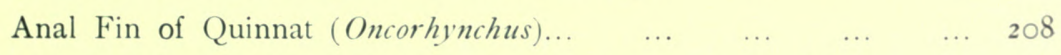

Fraser River Fishermen landing a Forenoon's Catch of Salmon ... 22 I

The Midge, he first Steamcraft on the Kootenay Waters... ... 253

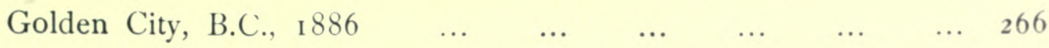

The Upper Columbia Lake, the source of the Columbia River, looking towards the Foothills of the Selkirk Chain $\quad \ldots \quad 275$

$\begin{array}{llllllllll}\text { Week-day } \text { Work } & \ldots & \ldots & \ldots & \ldots & \ldots & \ldots & \ldots & 282\end{array}$

$\begin{array}{llllllllllll}\text { Sunday } & \text { Rest } & \ldots & \ldots & \ldots & \ldots & \ldots & \ldots & \ldots & \ldots & 283\end{array}$

Kootenay Indians pondering over their Short Shirts _.. $\quad \ldots \quad 29$ I

Natural Hot Springs near the Source of the Columbia River ... 295

A Snow Plough at Work on the C. P. Railway in the Kootenay

$\begin{array}{llllllllllll}\text { Country } & \ldots & \ldots & \ldots & \ldots & \ldots & \ldots & \ldots & \ldots & 297\end{array}$ 
A "Mogul" Locomotive, used by the C. P. Railway to cross the

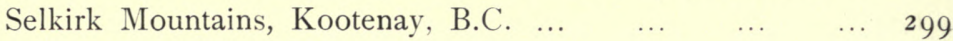

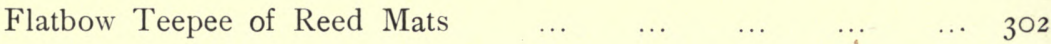

Passion Play performed by Roman Catholic Indians o the Fraser $\begin{array}{llllllllll}\text { River, B.C. } & \ldots & \ldots & \ldots & \ldots & \ldots & \ldots & \ldots & \text { 3 } 2\end{array}$

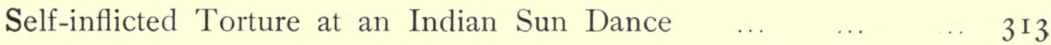

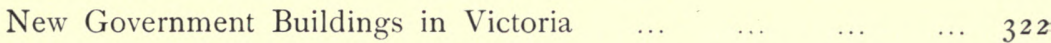

Sir Matthew Baillie Begbie, Chief Justice of British Columbia ... 342 


\section{CHAPTER I.}

\section{TRAVELLING IN THE WESTERN HUNTING GROUNDS.}

THERE was nothing in the least unusual about our first camb on the Pacific watershed of the Rocky Mountains one fine September evening in the latter part of the "seventies." A thirsty ride of some fourteen days over the elevated sagebrush-covered plateaux of Central Wyoming had tried the patience of man and beast. All that day ever slackening cinches and loosened lash.ropes, with a commensurate flow of strong language, had betokened how severely even the most skilfully thrown Diamond hitch on the pack-horses could be tested by the exceptional steepness of the mountain slope up which we were labouring, or by the snaggy branches of the stunted timber through which we were forcing our way. Bent upon crossing the Great Divide, or Continental watershed, here represented by that most formidable of Rocky Mountain chains, the Big Windriver range, we had to rely upon our pathfinding instincts, for none of us had ever been there before. For the last few days we had been following, as our sole guide, a watercourse which some Soshoné Indians had told us headed at the foot of one of the few notches visible in that formidable one hundred and twenty miles long and fifty miles wide barrier, the highest elevations of which could nearly vie with those of Mont Blanc and Monte Rosa. Indeed, the view presented to our eyes as we were approaching the eastern face reminded me of the first sight of the Alps as the traveller approaches them over the great plains of Lombardy. 
Nature marked the elevation of this pass, for it was on a level with timber-line, which in these latitudes is reached at a height of 9oooft. or 950oft.

We had made a long day of it, for water, though nigh at hand, was ungetatable, and--better reason-were we not heading for the promised land, to gain which we had made strenuous efforts? To man and beast it was to be a veritable paradise. To me it meant a practically primeval hunting ground, abundantly stocked with wapitis by the thousand, bighorns, grizzlies, as well as with the grotesquely-shaped white antelope goat of the Rockies, which latter was the special object of my expedition. For my trapper companions it meant a big harvest of peltry, for had not reliable Indians reported that the rivers and lakes of this, then practically unknown, region were teeming with beaver and otter? And, lastly, to the horses, poor brutes, it held out the promise of grass up to their bellies, good clear water, and complete rest, wherein to recuperate after the hardships of forced rides and heavy packs, endured upon a desperately meagre diet of sagebrush and alkali water.

A last preposterously steep slope of sharp-edged shale, on which it seemed impossible for man or beast to gain a firm foothold, and we had at last conquered that forbidding eastern face of the Big Windriver chain, and were standing on the lieight of land from which we saw both the Atlantic and the Pacific slopes of the great Continental backbone stretching away into dim distance that seemed so vast as almost to promise a glimpse of the Pacific Ocean, quite 600 miles westwards of us. The view that burst on our eyes contrasted strangely with the one upon which we were turning our backs. For the arid, treeless steppes and bizarrely-shaped hills of bright red and yellow tints, which are the principal features of the parched mauvaise terre landscape of Western Wyoming, were replaced by a glorious vista of boundless dark green forests, emerald glens and bottom lands, snow-topped mountains of grand Alpine type, at the base of which lay embosomed beautiful lakes, or flowed great rivers whose long green stretches were broken here and there by the white water of rapids. Even the panting, 
sweat-covered horses gave vent to their pleasure by neighs. In the immediate foreground we perceived a delightfully green flat, covered with grass so high as almost to hide a little band of prongbucks which had been feeding, and were now gazing in alarmed surprise at the unwonted sight of human beings ere they dashed off in jerky leaps. At the further end of the little meadow there was a tiny tarn fed by the drainage from the two high peaks flanking the pass, and close to it stood a few gnarled old pines, the uppermost sentinels of the great army below. One of them had been laid low by lightning, the upper third of the trunk lying immersed in the lake, the calm surface of which was undisturbed, save by countless rises of hungry trout.

A little brook issued forth from the further end of the tarn, remaining visible, however, only for a short distance, for soon it dipped over the edge of the flat, taking its first plunge down the Pacific Slope on its long journey westward, where the seiting sun was now throwing a golden halo over a very ocean of mountain. ranges that rose like the crests of a storm-tossed sea into a peaceful and gloriously tinted evening sky.

It was an ideal mountain picture, and, however reluctant a hungry and travel-fagged man usually is to go into rhapsodies, it was one which stancis out in bold relief in a memory fairly well stored with the beauties of mountain scenery in the Old and New World. Young Henry, or to give him his usual name, "The Kid " - a hopeiessly matter-of-fact Western youth, who acted as our cook, scullion and horse-boy, riding by my side in charge of the kitcheri pony, reminded me that we were out West, in the unconventional, "strictly business" frontier-land. Even he was impressed by the sight.

"Golly!" he exclaimed, "If this ain't the first Pacific water! T'aint every kid's funeral to wash up his pots and pans in that er water; and doggarn it, ain't this a bully camp, grass belly-high for the cayuses, game and fish just a wanting to hop into the frying-pan, and there," with a sly reflection upon the only duty concerning which a reprimand was ever necessary, "and 
there a whole raft of firewood, dry and handy, if you please, to yours respectfully."

Such were the sufficiently commonplace incidents of my first glimpse of the Pacific Slope. Bordered on the one side by the Continental watershed formed by the Rocky Mountains, on the top of which we were standing, and on the other by the waters of the Pacific, about 600 miles away, this strip of country is of great length, for it extends from the frontier of Mexico for three thousand miles, up almost to the ice-bound Behring Sea, a land of which. in the vernacular of the West, one speaks as the Pacific Slope, or: "The Slope."

On the occasion in question I was travelling solely for sport: two or three previous shooting expeditions to Central Wyoming and Colorado, then still teeming with big game, had whetted my appetite, and, experto crede, had taught me at least how not to do things when arranging one's expedition, so as to obtain really good sport in those matchless game countries, and to enjoy to the full the untramelled freedom of the breezy West. I had bought my experience at the cost of many dollars, and some wasted months, for a greener "tender-foot" than I was had, I am convinced, never crossed the famous old ferry over the Missouri, at Council Bluffs.

There are several ways of "doing the West"; the orthodox manner, to-day still in use among the well-to-do "globe-trotting" sportsmen, is at once the most expensive and the least satisfactory. For a valet is a more than useless incumbrance when one's bed consists of a couple of buffalo robes and a blanket, with one's saddle as pillow, one's bathtub is the nearest cree $^{*}$, and one's articles of

* Speaking of bathtubs reminds me of an amusing incident that once happened to a well-known English sportsman. Sir John —_, its hero, undertaking a shooting expedition to the Rockies, included in his vast camp equipage, to the sore trial of his packers, even a tin bathtub. Sir John's English valet struck the very morning the caravan was to pull out of Rawlins, and after some search among the whisky saloon loafers, a man willing to undertake the duties was at last found. One of his duties was to fill the baronet's bathtub every morning. The first three mornings this was done, but on the fourth, the outfit being camped close to a branch of the Platte, the valet suggested that a handy pool was close 
toilet comprise but a toothbrush and comb, both the worse for wear; while one's wardrobe has been fined down to a flannel shirt with buckskin strings in lieu of buttons, patched "overalls," and home-made moccasins that, if dry, don't leave one's feet day or night, or, if wet, are dried at the camp fire. Equally a source of worry and delay is the amazingly complete camp outfit, the folding tables and chairs, the camp bed and air-mattress, the heavy tents with hinged poles, and all the other etceteras with which the would-be explorer usually saddles himself at the advice of the Bond-street or Cornhill outfitter. Every couple of hundredweight means an extra horse; every three horses means an extra man; every extra man means at least two extra horses to carry his impedimenta, store of provisions, and himself ; and last, but not least, every extra man adds to the chance of internecine camp feuds, every extra horse to the probability of trouble and delay in consequence of sore backs, straying, or of a stampede. To travel light, with an ample store of everything that is really essential, but with nothing that is not absolutely needed, is the true secret whereby to ensure a good bag and a good time, especially if the exploration of as yet unmapped countries happens to be among the objects of the expedition.

A score of years ago, short as that span appears in Old World time-keeping, things out West were very different to what they are to-day. The hunting ground might then be said still to comprise a great portion of that 1200 miles wide, and 3000 miles long belt of country lying between the Missouri and the apex of the Rockies known as the Plains. The pick of it all was in the North-west Colorado, in Central and Western Wyoming, in Montana, the whole of Idaho, and all the Eastern part of Washington. What are

to the tent. Sir John, however, was not in the humour to take the hint, and the engagement between the two came to a sudden termination. more to the disturbance of Sir John's temper than to that of his quondam valet. 'The latter's parting shot was full of Wyoming humour. "You ain't quite the top-shelfer you think you is, you ain't even got a shower-hath for cooling your swelled head [Angl. pride], but I'll make you a present of one, boss," and pulling his six-shooter, he smilingly made a sieve of the bottom of the hatpless lathtub by emptying the six chambers into it ! 
now States were then thinly populated Territories where settlements, except in some few mining centres were often hundreds of miles apart. Only a single line of rail connected the Atlantic with the Pacific, while to-day some seven or eight trans-Continental lines of rail communication, and scores of branch lines have assisted in populating vast districts then still the home of the bison, wapiti, and antelope. About that time the short-lived boom of the cattle-ranching industry was commencing to deplete the pockets of English shareholders, and to strew the plains with the bleaching carcases of tens of thousands of kine, while in the companies' balance sheets they were figuring for years afterwards as among the living and kicking assets. The truth, now long recognised, concerning the fallacy of the expert's opinion that, because the shaggy-coated bison could withstand the blizzards and extreme winter cold, domestic cattle; driven from the semi-tropical Texas, would evince a similar hardiness, had then still to be demonstrated at the cost of millions of dollars.

Cattle ranching rang the death-knell of big game in some of the very best game countries in the world.

Some sixty years ago a distinguished traveller paid a lengthy visit to the trans-Missourian hunting grounds, and has left us an elaborate account of it. If one compares his narrative of what he saw with the conditions of to-day, and with those of five and twenty years ago, it will be seen that the "westward march of empire"-to use a favourite American phrase - has been reaching its goal on the shores of the Pacific at record pace. Civilisation in the three hundred and fifty'years preceding Prince Wied's visit had covered less ground than in the past quarter of a century. In A.D. 1832 it took this traveller forty-six days in a fast clipper to get from Europe to Boston, and seventy-five days from St Louis to Fort Union, at the junction of the Yellowstone and Missouri, where for the first time he saw a bighorn. Twenty odd years ago it took the writer only ten days to cross the ocean, but it took him almost as long as it had done the traveller in 1832 to reach the haunts of bighorn, while, as a matter of fact, the precise locality was 
actually a trifle further east - that is, nearer the fringe of civilisation - than the point where the Prince had first set eyes on this, the noblest of America's game. To-day steamers and railways take you to that spot in less time than it took me to cross the ocean. But the bighorn-where are they?

A curious similarity is noticeable in the old and new sporting literature of the West, written at periods as wide, or wider, apart than are the localities to which they refer. With no exception that I know of, writers on Western sport bewail the extermination of big game in North America, forgetting, it would seem to me, that their travels have, in nine cases out of ten, been limited to an insignificant portion of the trans-Missourian West. Prince Wied, writing sixty-five years ago, and only of the country in the immediate vicinity of the Missouri, which was then the highway into the Indian country, leaving quite untouched the great bulk of the West, deplores the disappearance of bighorn and wapiti. Lord Dunraven, writing more than twenty years ago, declares the West as "shot out." Here is what he says in his "Great Divide":- - An Englishman going to the States or to British American territory for big game shooting, and for nothing else, is sure nowadays to be disappointed." Both were right so far as the country they passed through was concerned, both were wrong in their generalisation. There are even to-day countries, the size of small kingdoms, in British North America, into which no hunting party has ever penetrated, and where the frying pan's capacity of a - few isolated prospectors has, so far, measured the destruction of game; countries where moose, caribou, and antelope-goat are still unfamiliar with the sight of white-skinned human beings. It is not quite correct, therefore, to speak of a total extermination of the larger species of North America's ferx naturx, except in relation to the bison, and even then only partially so, for a few small bands are reported to still roam the Peace River country. I enjoyed unrivalled sport in years subsequent to the period when the author of the "Great Divide" expressed such a pessimistic view, and that concerning localities not a hundred miles west of the country" 
through which he passed. Others as persevering and lucky in finding primeval spots have within the last ten years obtained first-class trophies.

The one great detrimental change that unquestionably has overtaken the once unsurpassed Western hunting ground during the last score of years is one which only those who have travelled widely through the West can realise. It is that in those districtsnotably Wyoming, Montana, and Idaho-where sport was made easy by the absence of dense timber, where all but the most elevated points could be reached on horseback, where an unsurpassed climate during summer and autumn added immensely to the pleasures of the expedition, the cattle raising and mining industries have so thinned out the more prized species of big game as to make the success of a hunting trip in most cases a matter of grave doubt.

Without repeating myself too much concerning details I have given in a previous volume on my earlier sport in the Rockies, it will, perhaps, serve a useful purpose if I premise a brief description of the ways and means I pursued to procure, at comparatively very inconsiderable cost, sport of the very best kind.

There are three ways of visiting the Far West for sport. The orthodox mode, to which already reference has been made, is one to which only a long purse can aspire. As a rule, none but men of more than independent means visit trans-Missourian countries for pleasure. The frontiersman calls them "top-shelfers," they are accompanied by their servants from England, they hire some western "hunters" as guides, and their expedition is provided with an amazingly complete camping outfit. They are asked very high wages - and they pay them.

The second way is cheaper, but far less independent. It is to get letters to, or, if you chance to be of commanding personal attractions, endeavour to make friends with, the officers in charge of such of the frontier military forts that are near good game ground. There were many of this kind in the northern Territories; and there, if properly introduced, you met with rare 
hospitality and readiness to further your object; you were supplied with stores, waggons, horses, and escort-everything yøu required. The American officers, notwithstanding the weary loneliness of their desolate posts, hundreds of miles from the nearest companionable being, are as a rule no sportsmen, but they will nevertheless enter with zest into your plans; and if they see that their presence is not unwelcome, one or the other of them will accompany you on your little shooting expeditions, and will make a very welcome addition to the number of mouths to be fed with venison, and hence also to the number of wapiti or bighorn you can legitimately kill. There will be plenty of whiskey-indeed, very often its supply is far too abundant; for on returning to camp from a long day's stalk, you now and again find the cook, or the other underling troopers, in a state not conducive to good cooking or handy help.

The third was the cheapest, the freest, the most pleasant manner, provided its rough side has no terrors for you. It was to eschew the usual run of western guides, who take their parties year after year over the same well-beaten ground, and to choose for your companions professional trappers.

I have tried all three ways. My first trip, on which I was accompanied by a friend, partook of the "top-shelfer's" outfit. We were laden down with unnecessary camp luxuries, stored away on two waggons. I shot very little game, I saw the people as they are not, and, owing to the very bad habit of asking questions, I' was told more tall stories than the proverbial Colonel from Texas could invent in a year, for, as the frontiersman will himself tell you, the West is a country where "talk is cheap, and lies worth nothing." Had it not been that on this trip I made the casual acquaintance of my future companion, genial Port, there would not have been a single redeeming feature about my first experience. The second manner had never very great attractions for me; though at a considerably later period I had occasion to be one of the party of three Englishmen, who had every cause to remember the remarkable hospitality of the commanding officers in a certain 
Wyoming fort, who fitted us out in right royal style with men, horses, waggons, and escort, enabling us to visit the Ute Indian country in the depth of a very severe winter, a few months after their last outbreak in the autumn of 1879 , in which, by the way, I had very nearly come to grief.

Far more preferable was the third way: to join a trapper outfit,

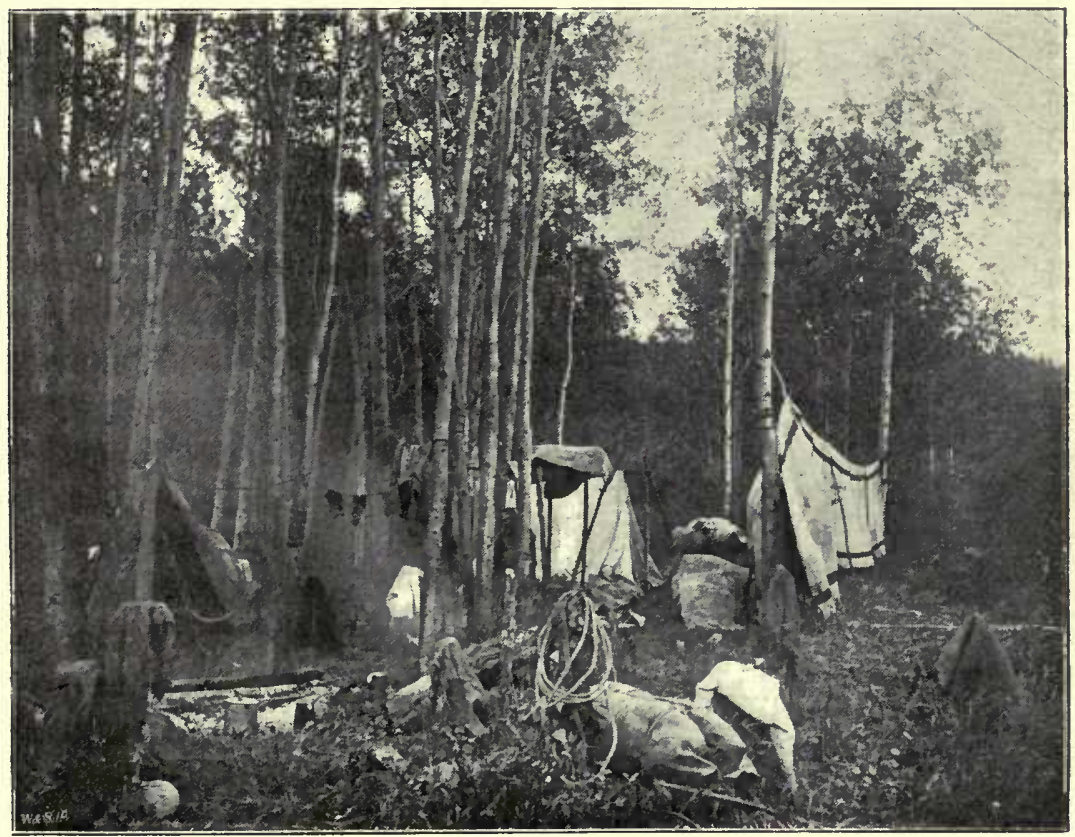

CaMP IN THE BRUSh.

and, at a cost which, under the circumstances, and in comparison to the $\mathcal{E}_{1} \mathrm{i}$ or $\mathcal{E}_{\mathrm{i}} 5$ per diem cost of many "top-shelfer" expeditions, must be called exceedingly moderate, turn for all intents and purposes trapper yourself. Only the most remote districts were visited by the genuine fur-hunters-by no means a numerous class -for the much persecuted beavers and other valuable fur-bearing animals had long retired to a few uninvaded districts, and there 
only could they be found in paying numbers. You enjoyed the good fellowship of thoroughly trustworthy men, and while they did their trapping or wolf-poisoning, you, who were tacitly considered the "boss," or master, and were also addressed as such, could roam about at your own free will, gradually extending your side expeditions as you became versed in woodcraft. Of course, for the newly arrived "tenderfoot" this roaming about, and not losing himself or getting into other more awkward dilemmas, necessitated some preliminary experience in woodcraft. But this, under the tuition of capable trapper-masters, if one had previous training in other parts of the world, was soon acquired; and, when once mastered, the pleasure of knowing oneself perfectly independent vastly enhanced the charm of life in the woods and in the mountains.

It was not every sportsman fresh from the East or from Europe who had either the time, opportunity, or desire to hunt for men of this stamp. The Union Pacific landed him at Rawlins, Greenriver City, or Ogden; and while in his innermost soul he felt defrauded by not finding dead men festooning the nearest trees or telegraph poles, he expected to fall into the arms of a revised edition of a Bridger, Kit Carson, or old Joe Clark. At the first glance, perhaps, his disappointment on this score was not so great; for the modern representatives of those old scouts of classic renown who forthwith interviewed him in front of the hotel bar were got up in embroidered buckskin suits, broad sombreros, cartridge belts, and at least one large-size six-shooter at the waist. Their hair was long, and their name some startling imitation of "Buffalo Bill" or "Wild Will," and they claimed to be old Indian fighters, who know the whole -West as they know their pockets.

I can, alas! speak from experience of the wiles and of the traps that waylaid the newly-arrived sportsman; for I was as verdantly "fresh" as are most strangers, be they bent upon business or pleasure, when first striking the West. Hence I fell an easy prey to certain "Bearclaw Joes" and "Scalp Jacks." "Trundling tenderfeet outfits through the country" was, in the seventies and early eighties, a favourite occupation for " ne'er-do-well loafers." 
The genuine trapper was a very different being, his unobtrusive and taciturn manners in the presence of strangers being a ready means of recognising the right sort.

Of the old guard of famous Rocky Mountains voyageurs there were, even then, but very few left; the two or three I got to know were grizzly septuagenarians. The younger race were generally men who had passed a long apprenticeship under old veterans. The genuine trappers were rarely met with in the haunts of frontier civilisation. They were out all the year round, visiting outlying settlements only every six months to renew their stock of "grub." Many of them had not slept in a bed for years, and they loved not the luxuries of civilisation, living a life as independent of social fetters as it is well possible to imagine. Very few of them ever married, though many took to themselves dusky daughters of the soil, a proceeding which earned for them the title of "squaw men," and generally resulted in a total cutting loose from white men's companionship. Death, which had stared them in the face times out of number, finally surprised them in the shape of scalp-hunting redskins, or a fierce eight-day snowstorm in a shelterless region, or an infuriated she grizzly, or in any one of the many other guises in which the grim master is wont to call in the lonely hunter's checks. Few missed them; and when one failed to put in his appearance at the frontier store where, in spring and autumn, he was in the habit of purchasing his modest "grub outfit," a casual "Guess the old stag has gone up!" and a regretful sigh on the part of the enterprising owner of the general emporium where the unworldly old buck used to trade his valuable peltry for third-class flour and adulterated coffee, was about all that mankind spared for the wanderer.

Among these rough and uncouth "tramps of the wilderness," beneath a very shaggy exterior there lay hidden many of the largehearted qualities of ideal man in his primitive state. You found among them men-true men-on whose word one could build, and on whose quiet, cool-headed, though subdued, courage you could implicitly depend. Happily, not a few of our best sportsmen who 
well knew the West have on different occasions stood up for the sterling stuff of the genuine frontiersman.

Port, the leading spirit in my party, was such a man-about thirty-four years of age, tall, squarely built, with very sound bodily strength and as sound constitution, which, as he would tell you, not even the two nights he slept in a proper bed in eleven years have succeeded in undermining. His face was tanned to a Sioux

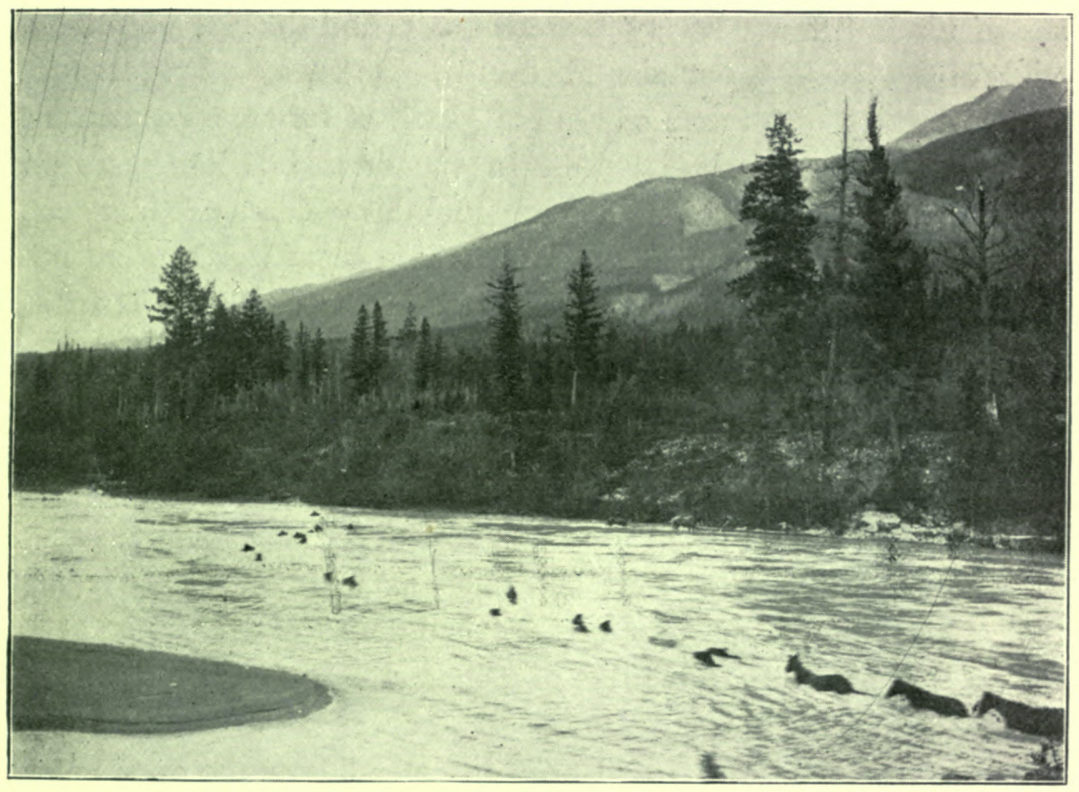

Swimming the Thompson River in British Columbia.

brownish-red; and a fine beard, kept very cleanly, hid the lower portion of his pleasant features. A glance at the outer shell, a look into the grey-blue eyes, betrayed the character of the man before you. Very silent in the presence of strangers - always a good sign in this western country-his appearance pleased me from the first. He was born in West Kansas in its earliest days, when the eastern portion of that State was the "bleeding Kansas" of which, forty years ago, we heard so much. Settlements were far apart; and 
the dreaded invasions of the bloodthirsty red man, chiefly the Cheyennes, followed by the unheard-of ravages of the fiendish white man's Border-Roughian war that turned such men as Quantrell and the first edition of the James boys into beasts more savage than hyenas, made Port from his earliest youth acquainted with rapine.

Before he left his mother's lap, he saw bloodshed; before he could walk, he saw neighbours strung up and shot; and before he could read, he had killed his Indian. He left his home at the early age of nine; "going West" was his fancy, and the yet untrodden wilds of the Rocky Mountains his dream. He passed a long trapper apprenticeship under one of the old guard of fur-hunters, and his subsequent career as Indian scout in one or two Indian wars on the plains developed in him all those qualities which made him such an invaluable companion in a country where certain risks were not absent if the party was so numerically weak as ours was. It takes moments of danger to discover a man's true grit-the "bottom sand," as a plainsman would say. On the one or two occasions of such a nature, when I happened to be at his side, his self-reliant coolness convinced me that in times of risk, no less than at the quiet camp fireside, I could have had no trustier companion.

The manliness about Port and other men of his calling is not that of the bravado, or that of the "bad man " of literature; it is the quiet unobtrusive manliness of a character that, while it knows not what pusillanimous fear is, yet knows what death is-of a nature that, while born and bred to carry life on the open palm, is yet for ever ready to do grim battle in its defence.

Port was full of quiet, dry, western humour. His sallies spared neither present nor absent ones.

The two remaining men will take up less space. What I have said of Port holds good for Edd and Henry. The first of the two was Port's junior by several years. Born in the East, he had come West twelve or thirteen years before, and had ever since been hunting and trapping.

Henry, the boy cook and general factotum, was a lad of seventeen, who had been with me for the last two expeditions. 
"Skipping" three years ago from his Iowa home, where his father, so I was told, held the position of judge, he came West, and luck guided him into Port's camp. More of a character than Edd, he bid fair to become a genuine old mountaineer in an astonishingly short time. Intelligent, full of western humour, life in the

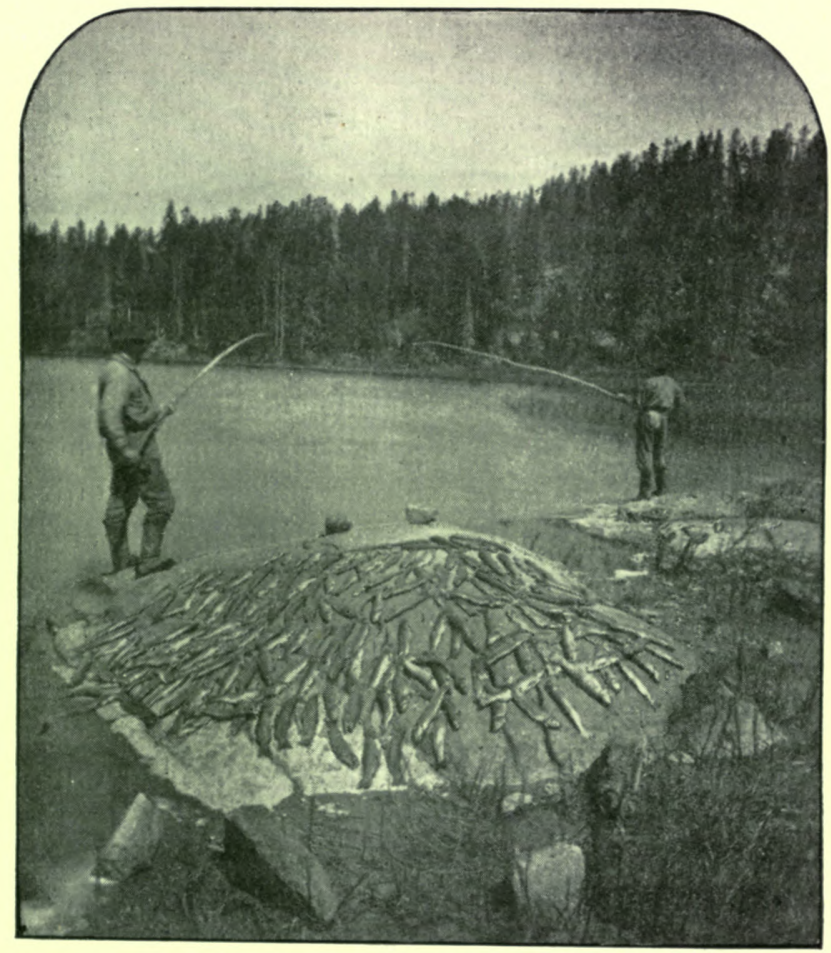

A Forenoon's Basket of Trout in the Teton Basin. Caught with a "pole" and a "bug."

wilds had already removed from hım most traces of a more civilised existence.

From Master Henry, who I had strong proof was much attached to me, it would have gone hard to get out a " thank you," except perhaps for some unusual or specially gratifying gift; but I cannot say I liked him much the less for it. At first I was often 
exasperated by this habit, but the boy soon showed me that he meant not what his manner implied.

A ludicrous interview to which a half-starved "cattle-boss," who had lost himself and who happened to stray into the vicinity of our camp, subjected me, after partaking of our hospitality, shows that "Thank you" is, according to the laconic and not over polite manners of the West, a superfluous form. The meal over, I happened to be left alone with the now good-humouredly satiated " cow-puncher." "Say, mister," he began, "aint you the boss as runs this outfit?" To my affirmative answer he replied, "Well, say, that's kinder strange. Why, I'll be darned if you wasn't the only cuss who said thank ye when the grub pile was trundled over to yer side." I told him that I hadn't got over that habit yet; to which he naïvely replied, "Them's bad habits of civi-ly-sashon. Out here them tony chin-music don't pan worth a cent."

Henry was full of western repartee. An acquaintance once remonstrated with him in quite undeservedly severe words for some defective cooking. Being no particular favourite among the men, the boy answered him "right smartly," "Wa'al," he said, "I was born for a cook, but the devil stole the pattern and ran off with it. I kinder reckon he must have loaned it to you." There was no more fault-finding.

In the days I am speaking about, an invasion of "Indian Country," such as was the one we had passed through, by such a small party had about it a zest-giving spice of risk. Only the year before while travelling, in much the same manner, through country even less remote from civilisation, the Indians inhabiting it had suddenly gone on the war-path without our knowing anything about it till it was almost too late, and we were compelled to " git out," with a band of Utes hovering round us for several days, whose bullets on one occasion came much too close to be comfortable, while one of them ended the career of a personal friend who had hunted with me but a week or two before.

The country we were now in was claimed by the peaceful Soshonés, whose fine old chief, the celebrated "Washakie"-the 
white man's friend he loved to call himself - was always exerting his influence to keep his more turbulent young bucks from joining any of the warlike demonstrations of other tribes. But the Government had recently allowed a much less ruly tribe, i.e., the Arrapahoes, under a noted fighting chief, "Black Coal," to share the Soshonés' hunting grounds, and trouble between the new comers and their old enemies the Utes, who again were allies of the Soshonés, might break out at any moment. The fact that the hunting grounds of the powerful "Crow" tribe adjoined immediately to the north only complicated the situation.

It is now time to introduce the reader to the incidents of our daily life, and I shall first of all ask him to visit our camp.

There is a business-like air about it which shows that some of its inmates have lived from early youth in the wilderness, and have long learnt all the tricks of the backwoods to make themselves as comfortable and cosy as circumstances will permit. In such a camp it suffices to cast a glance at the manner the tent-if, indeed, there be one at all in fine weather-is stretched; a look at the way the rifles are secured on stout pegs driven into a handy tree, and at the manner in which the fire is made up so that the wind does not drive the smoke in the direction of the tent, to show that it is not a "tenderfoot's" camp.

Everything is in its place: the steel beaver traps with their stake chains are neatly hung up on a convenient branch; the rawhide pack-panniers, of material as stout as sole leather, wherein are placed one's worldly goods while en route, are stacked up in a heap with a sail-cloth cover over them; the saddles, all of the heavy Mexican type, each with the bridle belonging to it looped over the horn, and the wooden pack-saddles, their cinche and lashropes neatly hung over the cross-trees, are piled up and similarly protected by a canvas cover. For no snug packing can be done if the ropes get wet. In several big "nicks" cut in the camp tree repose bits of soap, and on a peg hangs what is politely called the "dish-cloth," which is, or rather once was, an old flour sack. The two axes and my "antler saw"-really an ordinary butcher's 
saw-recline against the same tree, and from the new coil of halfinch rope, which the men have brought with the provisions from the fort, the Kid is just cutting new lengths of lash-ropes to replace some worn-out ones.

A square piece of elk or moose skin, dry and stiff as a board, nailed to the top of four upright posts under the spreading boughs of the camp tree, makes a capital table. The big iron camp bucket, into which fit all the culinary utensils required for the somewhat primitive cooking of the party, makes, when turned upside downor, as the Kid will persist in saying, "downside up "- - comfortable seat when any writing has to be done at the table. The four beds, each consisting of two buffalo robes and a thick California blanket, are neatly rolled up in their strip of waterproof canvas, which protects them. When tightly corded, they are slung as sidepacks on to the horses. Of luck, one can speak, if these same blankets have not to take the place of those worn out under the saddles, or those that are lost, for it is one of the most puzzling things how blankets used as saddle-cloths for the pack-animals will manage to wriggle out and get lost in a long "drive" over country where steep ascents and descents cause the packs to shift if the saddle girths are not constantly tightened. And a blanket thus lost, is not only irreplaceable, but it generally means a sore back and a horse rendered unfit for work for a week or two, ofteli just at a time when the carrying power of every animal is taxed to the utmost.

Every article of this camp is, as we have seen, in its place, for the due observance of the old axiom that it is just as easy to put everything in its proper place at the start, rather than just drop it anywhere, saves in the end time, trouble, and temper. The dilemmas caused by untidiness in this respect are often most vexatious, and never more so than if during the night a snowstorm covers the ground unexpectedly with half a foot or a foot of snow, as I have seen it do on many occasions. Where are you next morning? In the tidiest of camps it is not an agreeable fix to be in, but in an untidy one it means-well, to put it mildly-some lively 


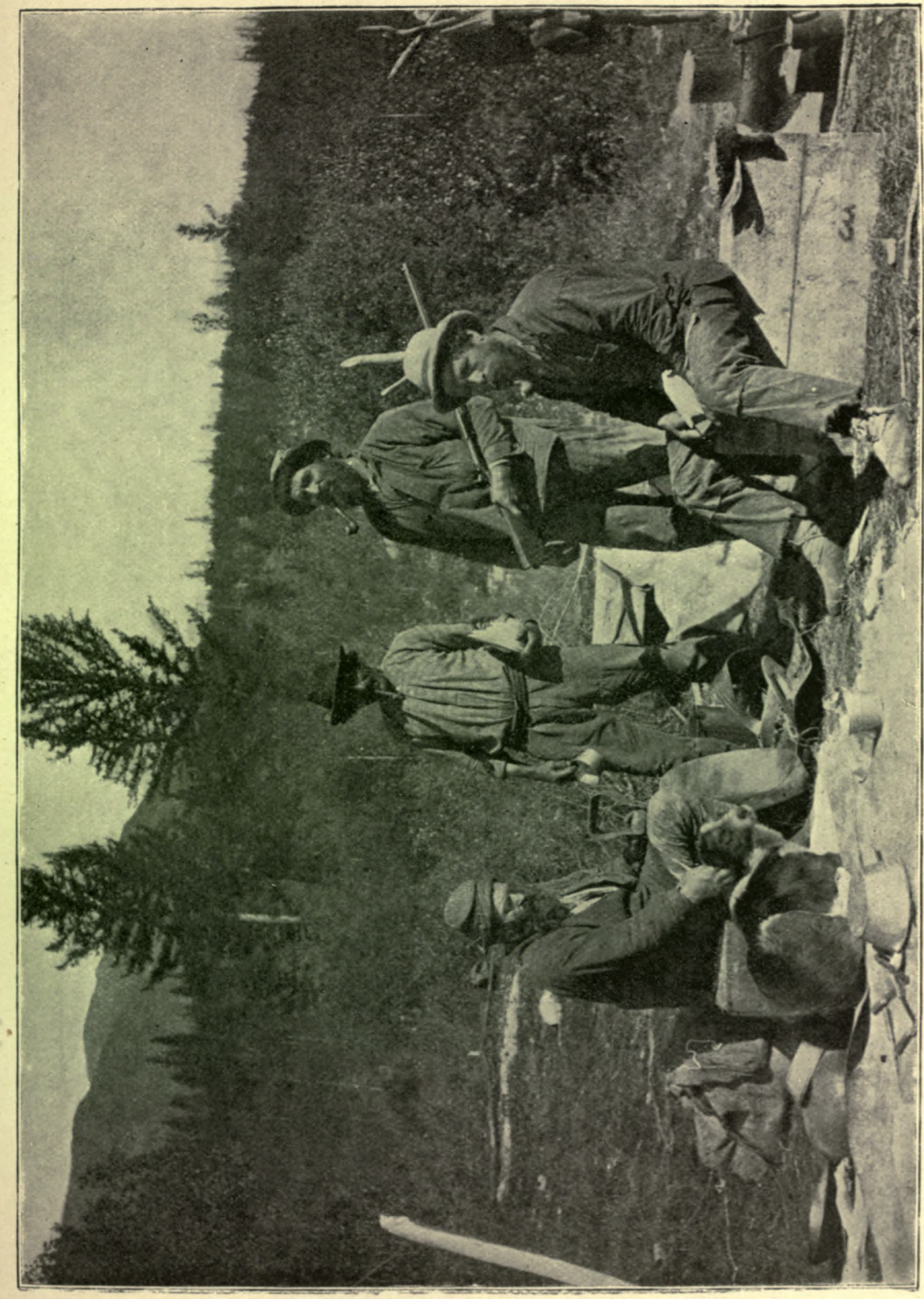

促 

recrimination, hard language, and the loss of half a day or more in digging up the hundred-and-one camp belongings scattered in a wide circle all over the place, while another half day will have to be spent in drying the ropes and blankets and saddles before the fire ere they can be used. What wonder, therefore, that all old hands are punctiliously tidy, and that they can lay their hands, blindfolded, on the canister containing the stock of precious matches, or on the whetstone whereon to sharpen their skinning knives, or on any other small "icta" you like to mention.

Leaving such a comfortable camp is like departing from home. You have had time to place a layer of soft pine boughs under your bed, the angularities of mother earth not being usually thus softened. You have discovered a delightful stretch of sandy beach on the lake for your matutinal dip. By means of a few logs tied together by odds and ends of rope you have fashioned a raft, on which you have pushed out into the middle of the tarn, where, with an improvised rod-the real article having long ago come to utter grief under the hoofs of one of the horses-you have landed some splendid trout, and the experience of the odd hours thus devoted to the gentle art has taught you that when fishing for the pot, i.e., to feed four hungry members and an occasional dog or two, a plentiful supply of fat grasshoppers, vulgo "bugs," will accomplish the trick far more speedily than do artificial flies that tear, or get lost, or turn out not the right sort, or for which your body evinces a magnetic attraction.

The surrounding hills have been scoured, and yonder, as yet unnamed, peak, which the aneroid tells you is something over 13,oooft. in altitude, has been climbed in a long day on the rocks and snow. The topographical details seen from this outlook have been added to the material already collected, which will assist in compiling a new map, which, bad as it may be, will yet be an improvement upon the only existing one, based, as the latter appears to be, on guess work, and bad guesses at that.

When the actual start comes to be made, one does not get off as early as was intended. Some of the horses are "playing mean," and object in sundry ways to be packed and to leave such a good 
camp and such abundant bunch-grass. The packs have to be re-divided among the lot of horses, or, rather, among the number of pack-horses, for there are a couple of spare mares, as well as two colts which were born on the trip, in the outfit. Each horse has, of course, its own particular pack-saddle, fitted to its back as well as such simple tools as a jack-knife and a file can manage. Some have only one cinche or girth, others have two, which latter, if the animal will stand the double pressure, is always better, for it insures steady "riding" for the load in a mountainous country. Not a few horses, however, raise such persistent objections to the double girth as to endanger the load, however securely it is lashed to their back.

The pack-horses must be packed last, for otherwise they will roll and try other little dodges to rid themselves of the loads while the riding horses are being saddled. At last everything is ready, the men swing themselves into the saddle, the dogs jump about barking, and, with a loud whoop from the rear men, the cavalcade sets itself into motion. For two or three hours the pack-horses will keep in file without much urging, but as soon as they get hungry there will be more trouble to prevent them from straying.

Let me say a word here about packing. To accomplish this in approved western fashion is a thing easier to write about than to learn. Let it be remembered that there are two ways of "packing," the difference lying in the rigging, which again is dependent upon the ends in view. Where time is less of an object than the question of transporting the greatest weight upon horse or mule, the old-fashioned Spanish aparejo is used. This consists of two great bags of heavy leather that hang down on either side connected by a broad band of the same material that goes over the horse's back. The part that comes to lie upon the animal's sides is stiffened with ribs of round willow sticks that can be slipped in and out for repairs. Inside these ribs is placed a layer of hay, making a sort of pad to take the strain of the lash-ropes which fasten the load down. Thus, the pressure of a properly "set up" aparejo comes upon the sides, leaving the backbone and withers as free as possible. The weight of this rig is very much greater than 


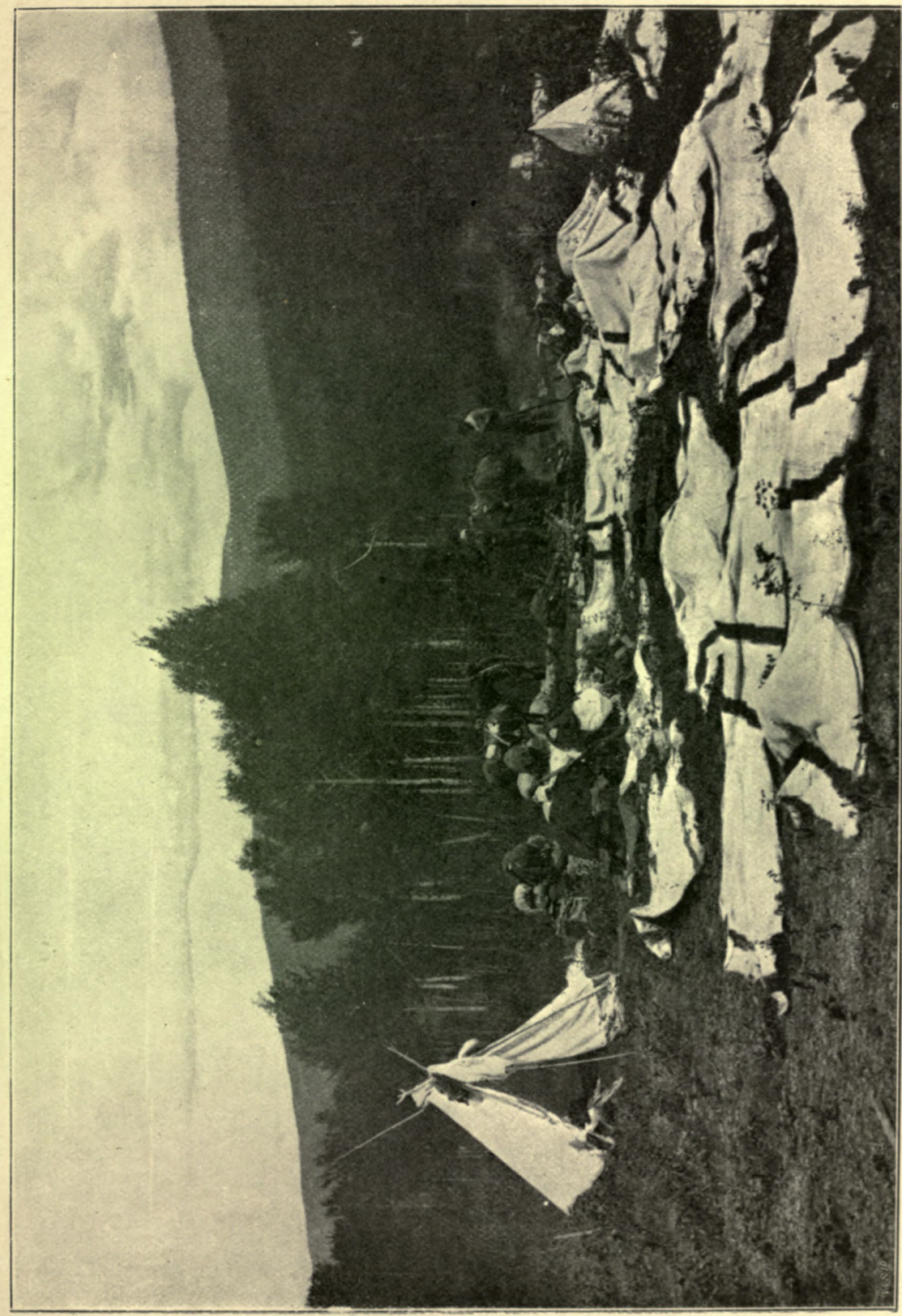

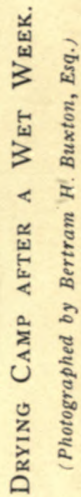



that of the pack-saddle, with its cross-trees at both ends, but, notwithstanding this, far greater weights can be transported on the aparejo, though the pace can never be more than a walk. All packing for commercial purposes and the bulk of all military packing is done in this way, the most unlikely looking articles, such as safes, big iron cooking-stoves, chests of drawers, bits of heavy mining machinery, and other unwieldy things, weighing as much as 4oolb., have frequently been transported over steep mountain passes, though the average load is only about $25 \mathrm{olb}$.

The pack-saddle packing is a different thing altogether. Two side panniers of stout canvas or leather, the weight in each being as equal as possible, being slung by loops to the cross-trees; then comes a top pack, generally a roll of blankets, and over all a piece of canvas is spread, the whole being kept in position by a lash-rope forming a "criss-cross" on top of the pack. The secret of good packing consists in the manner in which the rope is thrown, drawn together, and fastened down.* There are a number of hitches, the diamond hitch being the best of all, not only on account of the fact that it can be thrown by a man alone, but also because there is less "give" about it than any other. To clumsy, non-nautical hands this hitch is a standing puzzle, and though I have learnt to throw the diamond scores of times, the slightest break in practising it, invariably resulted in a muddle of the worst kind. I acknowledge, however, that clumsier hands than mine never handled a rope. A far easier hitch, to which I generally resorted when doing my own packing, is the squaw, also called tenderfoot hitch, which is less intricate, but also loosens its grip more easily, particularly when, having but light loads, you trot the pack animals. This, of course, tests any kind of hitch most effectually. Under favourable conditions, with the loads nicely balanced and fitting snugly into the panniers-one can do without these-and the saddle as snugly fitted to the horse, with ropes

* The rope is provided with a short length of girthing which comes underneath the horse's belly so as to prevent the rope cutting into the horse. 
nice and dry, and worn smooth, so that they "come tought," with that business-like, tidy look by which a well-put-up brown paper parcel shows at a glance that skilled hands have made it up, then, I say, packing is a pleasantly invigorating exercise. Very different is the aspect of things when ropes are wet, or, worse, frozen, and your stock of blanket-pads that come between the horse's back and the saddle has been reduced by losses or the wear and tear of a long trip, and you have to use your bedding blankets. For, under these conditions your hands are as liable to suffer as is the animal's back, and, once sore, the greatest and most constant care is required if the horse is not be rendered entirely useless for weeks.

As the direction of our day's ride is plainly indicated by a very visible landmark in the shape of a fine peak, I ride ahead. Boreas, my old hunting horse, after his week's rest and the bounteous bunch-grass is "feeling good," and kicks up his heels as a preliminary exercise to the canter which he knows well enough is before him.

It is, let us take it, the latter half of October, and the days are getting short, so no noon camp will be made. The pack-train will keep on until the base of the aforesaid peak is reached, where I shall have picked out a camping place by the time the slower moving pack-horses can get there. A bit of lunch in the cantinas of my saddle makes me quite independent of the party for the rest of the day.

Game is almost constantly in view. On the bare ridges, often of quite rugged formation, which form the undulations which we have to traverse at right angles, mule-deer in little bands can be seen grazing, but no specially good head is among the different lots, so they are not molested, and a few graceful leaps soon put the ridge between the deer and the hunter. A couple of old bison bulls I come upon in a secluded dell lumber away with that awkward gait so peculiar to them. Their hides are scabby, and not even worth the cartridges it would take to obtain them. As I pass through a thicket of quaking asps which cover the bottom of one 


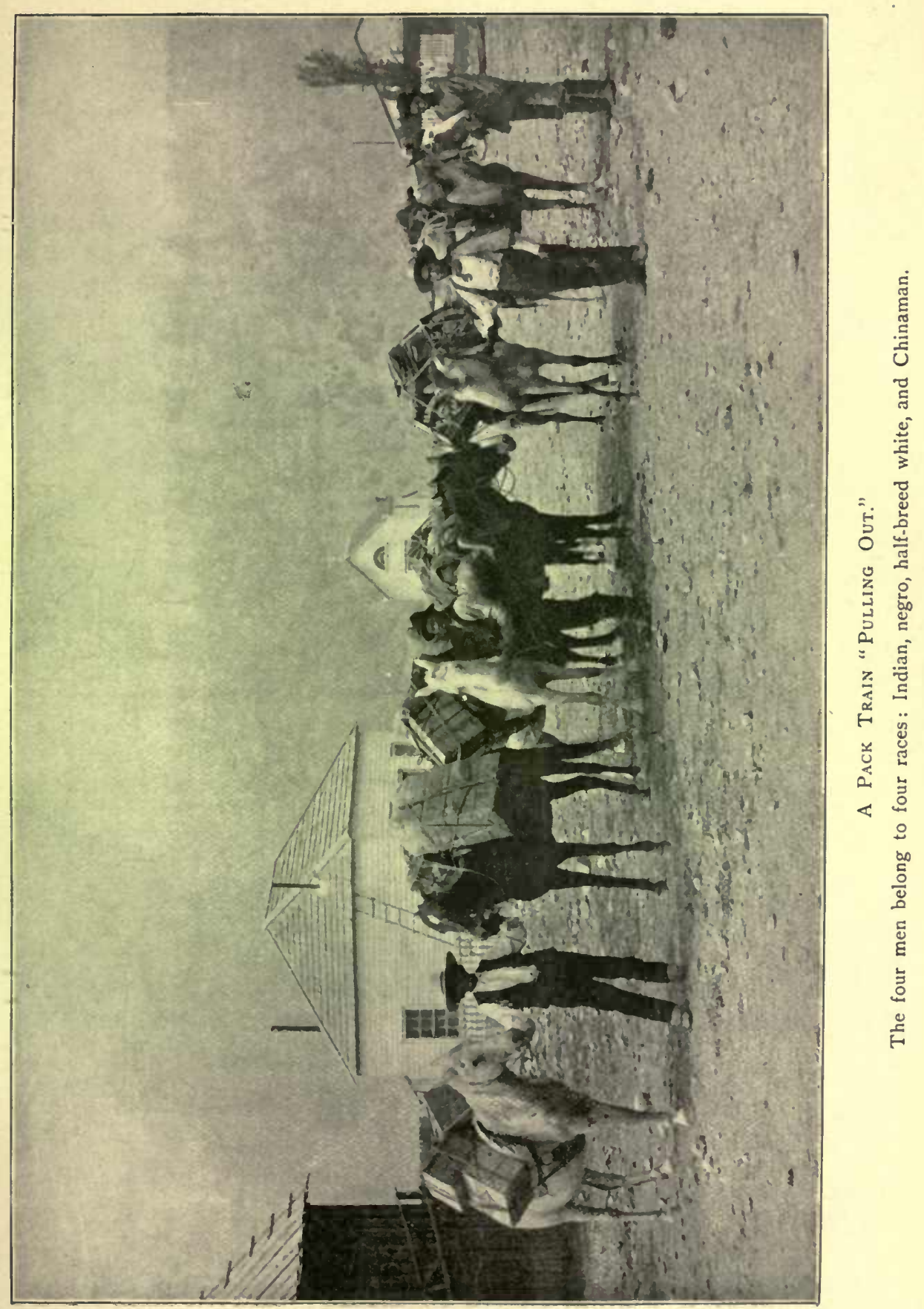



of the gullies, half a dozen white-tail deer jump up and, with a whisk of their long-haired tails, disappear in the brush. Their grotesque "stiff-kneed" bounds, unlike those of any other deer, as well as the fact that they are rarely seen outside of dense cover, make them difficult shooting. By and bye I have to cross soft ground, where a big spring has made the ground for many acres round it sodden and swampy. Here, apparently, a big band of wapiti must have passed not many hours before, for the ground is one mass of tracks; the biggest herd of cattle one ever saw could not have made more. They were going in the same direction we are travelling, and they bear out what the Indians had told us, namely, that all the wapiti in the higher range we have been hunting in leave it at the approach of winter and collect in the sheltered breaks and gullies whither we are heading.

As meat is wanted for the pot, a young mule-deer buck is shot shortly before we get into camp, and by the time the horses are unpacked and have had their roll in the grass, and the fire is lighted, I have had the two hind-quarters hanging in camp. There is nothing left of one of them by the time we four and the two dogs have appeased our appetites. As we are to move on early in the morning, and the weather is fine, the tent is not stretched, and the evening is passed in the usual pleasant manner, lounging round the camp fire, each individual busy with something or other. Garments need the proverbial stitch in time, moccasins want new raw-hide soles, saddles require a wire stitch or other repairs, lash or cinche ropes need splicing, hobbles lack new rings to replace worn-out ones, or the "fire-irons" - the heavy, but sure, Sharp, the Winchester -repeater, and the 500 Express rifle-want the tender eare which the mountain man is wont to bestow on his old favourite. Is his arm not as precious to the burly trapper as the babe is to its mother? His life may any day depend upon the care which ho has given it, and an irreparable accident to it may have more serious consequences than if he had broken his own bones.

But space will not permit one to dwell longer on the details of camp life, for otherwise one could not describe, however briefly, 
the events to which one has hitherto been leading up-namely, the winter sport which fell to our share after reaching our goal and taking up our quarters in a cave-like "dug-out," which proved the best possible shelter in the extremely severe weather which set in later on in November.

In the days I am speaking of there was, as the reader will probably have gleaned for himself, no difficulty whatever about finding and shooting game, but rather to remember constantly the duty one owed to prolific Nature of not killing more than one could make use of, and of thus wasting life merely for the sake of gratifying that deplorable lust of killing.

My chief aim in visiting the Rockies so repeatedly was to bag big heads. To get a dozen wapiti antlers over 6oin. in length, or a like number of bighorn with a circumference of $\mathrm{I} 7 \mathrm{in}$. and I $8 \mathrm{in}$., meant the securing of prizes which only a few sportsmen who have visited the Rockies have been able to obtain. And while I will not deny that, notwithstanding great care and discrimination in the selection of one's quarry, one now and again killed animals which, when they lay dead on the ground before one, turned out to be smaller than one thought, and whose trophies therefore would not warrant transportation; these were occurrences which one tried to aroid as much as possible. Transporting these big heads was the chief difficulty in my case, as only a few horses were available for that duty. Transporting wapiti antlers on pack-horses, often for weeks at a time, is a most troublesome job, not only because one cannot get more than two heads on one horse, but on account of their bulk, which makes travel through timbered mountain country most difficult, if not entirely impossible. It is not always the easiest sacrifice after a long stalk, or a weary day's scramble on the rocky ledges which are the home of the bighorn, to stay the hand which is instinctively clutching the rifle, and curb that keen desire to make the prourl quarry one's own. The head the animal bears is, as the glasses tell one, a good one, but not a "best" one, and as there is more than enough venison in camp already, the beast must not be killed. Under these circumstances, it was therefore a pleasant 


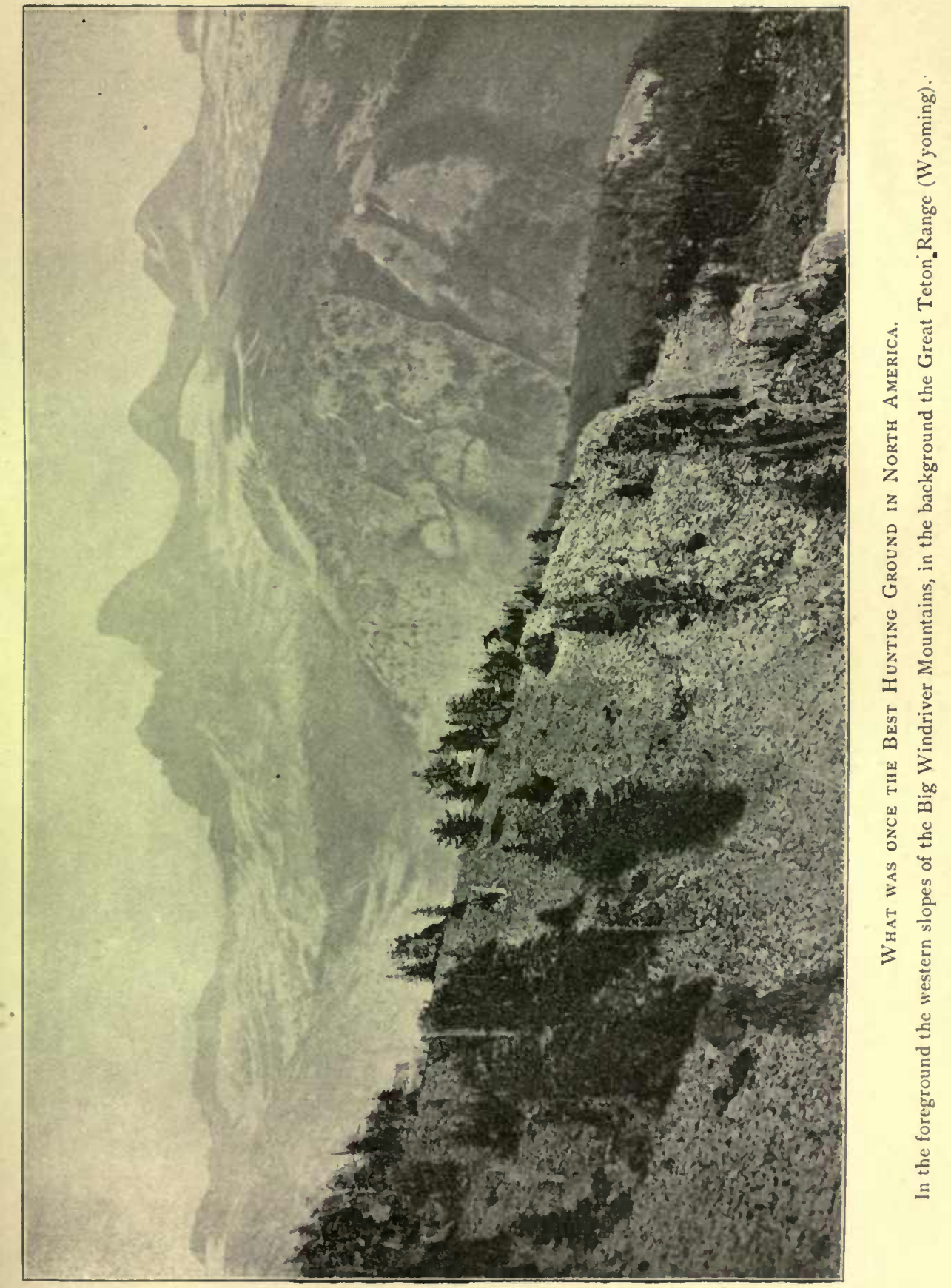



surprise to discover that the large hunting party of Soshonés, which we found one morning camped close to us, and amongst whom there were several bucks we had met before, were, after a few days' hunting and wasteful expenditure of cartridges, short of ammunition.

The fact was, as I learnt later on, that they had given the greater part of their stock of this highly-prized article to their allies the Ute Indians, who were out on the war-path; and, as no fresh supply could be obtained at the fort, most of the party were deprived of the means wherewith to obtain their winter supply of meat, which, of course, is the primary object of the great autumn or "fall" hunt.

This circumstance opened to me a most desirable chance of shooting all the game I desired to kill without wasting more than a few carcases of sheep, which tumbled down places where they could not be easily got at, for the Indians were glad to make use of all the meat I could procure for them. Had I desired, and had my ammunition held out, I could have killed many hundred head, for I have never, either before or since, seen so much game as on that occasion. The bighorn, whose rutting season falls in November, had come down from the high ground which the old rams seek during the hot weather, and were now with the does and small fry. These animals, though not quite rivalling the chamois in agility, are bold rock climbers; and there is a sturdy pride and consciousness of strength about the pose of an old ram as he stands on some crag overlooking his realm, which is most attractive to the man fond of mountain sport. They take a great deal of killing too, and fine shooting is often necessary, not only on account of the deceptive nature of distances in the dry and clear atmosphere of the Rockies, but also on account of their vitality.

With wapiti* I was also very lucky, for, of course, there were literally thousands. upon thousands from which to pick and choose. Had I had more ample means of transporting these bulky trophies, and had not such unprecedentedly severe weather set in, the like of

* It is probably hardly necessary to say that in America the wapiti is known as the elk. A great dcal of confusion has arisen in consequence, many English authors believing the American elk to mean the European elk. 
which I never experienced in all the winters I have spent in different parts of the West, some of them in regions a good deal further north, I could have delighted many more sportsmen's hearts with trophies such as are now unobtainable, and made my own collection a more ample one. But of course in those days one had no idea that the extermination of big game would take place with such appalling rapidity. Tens of thousands were butchered for the sake of a few shillings obtained for the skin. The end to our good time came with a heavy fall of snow and the commencement of the cold spell, to which reference has already been made. Shooting became practically impossible, and for days raging blizzards prevented one leaving the "dug out" at all. When our stock of flour, tea, and sugar began to wane, we thought it about time to make a break for the fort. It was decidedly the unpleasantest journey I had ever taken. What the exrremest cold was I had no opportunity to ascertain, for the quicksilver in my thermometer congealed, but at the fort spirit instruments marked, we were told, $52^{\circ}$ Fahrenheit below zero, or $84^{\circ}$ of frost, during the week we were on the journey down from the Sierra Soshoné. For a couple of days we were travelling over a bare, steppe-like tableland, which looked on those December days, without exception, the most dreary spot man ever set eyes on. The wind there was so fierce that it was impossible to put up the tent or find any other shelter. From Fort Washakie there were still I55 miles to Green River City (the nearest railway station), and two passes, one of $10,000 \mathrm{ft}$. above the sea, had to be crossed. And yet would not one willingly undergo the same passing hardships were sport such as then rewarded one's efforts still obtainable? But railways, ranchemen, and miners have taken possession of what was once the sportsman's paradise. Many parts of Montana, Wyoming, and Idaho are still worth visiting for the sake of sport, but the old glory of those States is gone never to return. 


\section{CHAPTER II.}

\section{THE SLAUGHTER OF BIG GAME AND THE GAME LAWS OF THE UNITED STATES AND CANADA.}

IF you had told an average American twenty years ago that before the century would end the enactment of game laws-not the mere passing but also their enforcement-would become a burning question from the Atlantic to the Pacific, you would have been informed that you knew nothing about "the greatest and freest people on earth." But events march sometimes rather more quickly than the American himself is aware of, and this suggestive sign of up-to-date democracy which is closely copying, in a slightly disguised form, the class legislation of effete old feudalism, is the best possible proof, not only of the mellowing effects of time, but also that there is no frontier, no "West," left. That wild game living in a natural state, and therefore, according to the Constitution, the property of the American people as a whole, should ever be made the subject of private ownership, be hedged in by the muchadvertised "buffalo and elk proof wire fences," and thereby become the property of the owner of the fence as were it cattle on a ranch, is in itself such a climbing down of the old-fashioned American ideas of freedom, that, while welcoming this end-of-thecentury reform, one rubs one's eyes and exclaims, "What next?"

But this chapter has nothing to do with the extensive game parks that multi-millionaires are establishing in many of the Atlantic States, highly useful as they certainly will prove:* let

* Similar experiments are now being made also in Western States; thus, in Wyoming, on ground I knew very well indeed, a large game park is now 
us rather glance at the cause of the extraordinarily rapid destruction of the herds of big game that made the hunting grounds on the eastern and western slopes of the Rockies the best of their kind in the world. To have to acknowledge that the destruction of the bulk of big game there was the work of one single generation is not a pleasant truth for the "Makers of the West." Until the completion of the first trans-continental railway, thirty years ago, the muzzle-loaders of white men had made no serious impression upon bison and wapiti, upon bighorn and deer. That gunpowder, whisky, and civilisation generally should have effaced in four centuries the aborigines of a great continent is a detail of the world's history that is even to-day being repeated in other parts of the globe, and is one which was brought about as much by the Old World as the New, for had Europe not poured its superfluous millions into America the westward march of civilisation would hardly have succeeded in so speedily elbowing the natives out of existence, or in linking the Atlantic to the Pacific by a chain of farms, cattle ranches, mining camps, and deforested lumber regions. Unjustifiable as the rapid extinction of the red man will appear to our grandchildren, the extermination of the animals that dwelt on his plains, that roamed his forests, or that filled his rivers, must seem even less excusable, for, in their case, protection should have been as possible, as is in civilised communities the enforcement

being established. According to the New York Shooting and Fishing, the site selected is an ideal one for the purpose. It will embrace 50,000 acres of mountainous land lying in the Soshoné Range, the tract being well watered, and with food plentiful both in summer and winter. Twenty prominent New York sportsmen have already, agreed to subscribe 5ooodols, each to carry forward the enterprise. It is proposed to enclose the preserve with an $8 \mathrm{ft}$. woven wire fence. It is estimated that $\mathrm{I}, 000,000 \mathrm{lb}$. of material will be required for the fencing. A clubhouse, costing 5o,ooodols., is also contemplated. A force of guardians will be employed the year round to take care of the property, and to prevent trespass or poaching. The region abounds in elk, antelope, deer, mountain sheep, bear, and other big game found in the Rocky Mountains, besides feathered game of many kinds. No game will be killed in the preserve during the next five years. It is reported that John W. Mackay and Theodore Roosevelt, are in the forefront of the movement. 
of laws protecting human life. But the frontiersman, as one knew him in those days, was not an ordinary personage.

In.his fierce and utterly selfish attack upon Nature, he waged a merciless war the like of which no country has ever seen, for in days of older conquests the scientific means of wreaking destruction in such a wholesale manner were lacking. 'The finely-sighted Sharp breechloader with which he rolled over in one "stand" as many as forty or fifty bison in as many minutes, shooting them purposely rather below the heart so that they should not drop in their tracks and thus scare the herd, is as much an invention of our time as is the giant powder (dynamite) cartridge, with which he kills by one explosion literally hundreds of salmon and trout in a single deep pool. A vastly increased network of railways assists him in reaching hunting grounds, which in the olden days would have been far too remote for remunerative "skin hunting," or the less inexcusable market hunting, for, in the latter case at least, part of the venison is consumed by human beings. Even the telegraph wire that reported to him the fluctuations of the fur and hide market was pressed into service, for in the early eighties, when the Northern Pacific was being built through Dacota and Montana, the movements of the "Northern herd," which was practically the last big band of bison in existence, was known from day to day to the gang of market hunters along the railway, who were supplying the contractors with game with which to feed cheaply the four thousand navvies in their employ. When this was happening the cattle ranch business was enjoying its boom, and the Press of the West, as well as individuals, agreed that the bison, if not also the wapiti, doomed anyhow to destruction, could not be slaughtered too quickly, for were not their thousands wasting the bunch grass upon which the more valuable domestic kine, driven in vast herds from distant Texas, were to fatten. As results too late proved, a large portion succumbed to the climate, but this discovery came too late; the work of annihilation had been accomplished. The same merciless war against Nature was waged by the miner and the prospector: the one, by depositing 
vast masses of worthless "tailings" and rock débris into fertile valleys, turning some of the best tracts of California for ever into a verdureless desert; or by setting fire to the forests in spots likely to contain mineral wealth. Thus were denuded by conflagrations, which the writer has known to last in the Kootenay country and along Puget Sound from May to October, thousands and tens of thousands of square miles of country covered with the most superb woods to be seen in any part of the world.

Twenty years ago one C. J. Jones, following the example of thousands of his fellow-frontiersmen engaged in hide hunting, received 50 cents $(2 s h$.) for each of the many thousands of bison he killed. Fifteen years later bison were practically extinct, save in the National preserve in Yellowstone Park, where game is guarded by cavalry and by the machinery of law. And this same man, more far-seeing than his fellows, has become a prosperous bison-rancher, having raised a numerous herd of hundreds from the seven calves with which he started. To judge by the last reports, he finds a ready sale for his offspring at from 4oodols. to rooodols. ( $£, 80$ to $£ 200)$ per head, to zoological gardens and museums, and crowds of sightseers gladly paid $2 s h$. for a peep at his beasts!*

In the case of the wapiti, one factor that helped to ring his death knell was the sudden discovery, made about twenty years ago, that the skin of this deer, which formerly was considered the most valueless game hide, because porous, was of use in certain branches of the leather industry. And though the value of the wapiti skin never approached that of the bison, it nevertheless, when the latter animal became scarce, held out sufficient inducements to hundreds of skin hunters to penetrate into distant hunting grounds into which they otherwise would never have dreamt of venturing. ${ }^{-}$This hide hunting, which went on until the most

* Since writing the above, Jones has sold his herd.

+ Poland states that from 80,000 to I00,000 wapiti skins are imported into England annually. 'The same writer mentions a curious circumstance, i.e., that in 1890 the Hudson Bay Company bought at one time in L.ondon 9Io Russian elch skins for their Indians in Canada. 
recent days, if, indeed, it is not still going on, in spite of game laws and a revulsion in the public opinion, has been the real cause of the wapiti's rapid disappearance; the further inducement, which fashion has created, of endowing the antlers with a marketable value, doing its share in hastening the extermination of this noble deer.

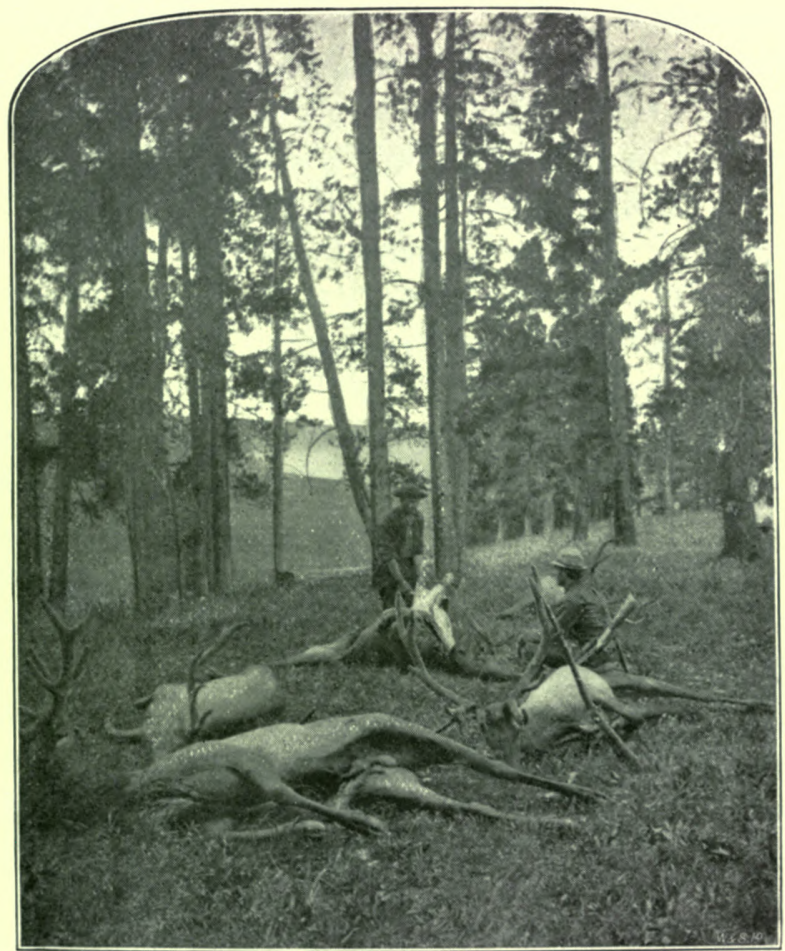

Skin Hunters at Work in the Seventies.

Seven wapiti stags shot in one minute.

Not a few English sportsmen's books, where they refer to this topic, contain exaggerated tales of slaughter as reported to the writers by Western Munchausens. The statement that men have killed 2000 or 2500 wapiti in a few months, while pursuing their 
vocation as skin hunters, can safely be considered gross exaggeration; one-tenth in such cases is nearer the truth.

Let me mention an incident that bears upon what I say, and which happened to me in the early 'eighties not far from the Yellowstone Park. One of four skin hunters, who had spent the preceding winter in a remote mountain basin with which I was acquainted, told me that he and his partners had got 2500 wapiti skins. Convinced that this was not true, the following crossexamination ensued. I must premise that the spot to which they alluded was 130 miles from a railway station, and could only be reached by crossing two rather difficult passes; also that the dried skin (green) of a wapiti stag weighs from thirty to fifty pounds. To take the average at fifteen pounds is therefore certainly below rather than above the real weight.

"How many horses did you have?" I asked.

"Eleven pack animals and four saddle horses, but we used the latter, too, for packing," came the answer. "Well, how many trips did you make to get the 2500 skins to the railway?"

"Oh, we just loaded down the cayuses, and did it in two trips." Taking a charred stick from the camp fire around which we were sit:ing, I made on the canvas of the tent behind me the following calculation, " I I $+4=15$ horses multiplied by two (trips) $=30$ horseloads." Taking a heavy load for crossing the passes to be 12 skins $=18 \mathrm{olb}$., the number of skins that could have been transported in the two trips would have been at most between 300 and 400 !

This is one instance of many that I have sifted down to similar proportions. At other times, when the difficulties of transportation were considerably less, it. was easy to trip up the breezy lie by a calculation anent the ammunition that was used for the feat of killing 2500 wapiti. To bring down that number it would take at the very least from 5000 to 6000 cartridges, which would weigh 300 or 400 pounds, or several pony-loads, and cost very much more than men of that stamp could afford to spend after purchasing their winter stores and outfit. In some cases, it is true, and these 
were the worst instances, outfits would be "grub-staked" by dealers who would provide everything that the men needed, and share the profits, much in the same way that the buffalo hunters were outfitted in the seventies in Kansas and Eastern Colorado.

As a rule, the hide hunters took to this occupation as a makeshift by which they could cover expenses during the winter, for all hide hunting was done at that period. By profession they were mostly miners, ranch hands, or navvies, whose regular occupation came to an end with the advent of winter, while their means did not permit of their returning for the season to their eastern homes.

In severe winters Nature seemed occasionally to assist the work of extermination. Thus, in a severe blizzard which swept over Colorado in the last week of January, I893, a band of about rooo wapiti became imprisoned by the snow on a high and heavily timbered mesa in the mountains near Steamboat Springs. Ranchmen, prospectors, and hide hunters, on hearing of this windfali, "waded in," killing many with clubs, as the local papers reported, and I believe not a single beast was allowed to escape.

And what about the game laws? the reader will exclaim. Were there no laws which could be enforced to stop such slaughter?

The laws, and sufficiently good laws, were there all right enough on paper, and, what is more, they had been framed at a sufficiently early date to have saved the bulk of the game, only there was nobody to enforce them. That was the crux of the whole question, as indeed it could not help being in those vast, then thinly populated, regions where horse thieving was about the only crime that roused a community to action, where men who had committed half a dozen murders were the lions to whom it was an honour for the newly arrived stranger to be introduced. Though such lawlessness was never rampant in British Columbia - thanks to the strong hand of the late Chief Justice Begbie, a man among ten thousand-the evolution of the British Columbian game laws manifest of late years a pettifogging meanness as well as 
an absurd jealousy of English sportsmen which was far less noticeable in the territories south of the line.* Some funny tales could be told about the men who framed Western game laws, also about the arguments one heard. But to give the devil his due, no Wyoming, Montana, or Idaho legislator gave vent to such preposterous opinions about English sportsmen, or gave expression to such gross slanders about their doings as were to be heard in the British Columbian House of Assembly when the annual tinkering of the game laws of the province afforded an opportunity. The Wyoming, Montana, and Idaho legislatures, composed as they were, too, of some rough elements, were sensible enough to recognise the true cause of the evil, no less than the fact patent to every ranchman and frontiersman from the Platte to the Snake river, that the Englishmen visiting for sport their mountain fastnesses belonged to a class that did not seek to gain pecuniary profits from their hunting expeditions. They knew only too well that the visitors were men to whom it was wise to extend open arms. To speak of my own experience, no welcome could be heartier than that which greeted me throughout the American West. In British Columbia, on the other hand, where game was never exposed to the same danger of extermination, for the density of the woods, which makes pursuit such a matter of difficulty there, is the best possible protection against slaughter, a very different feeling towards English sportsmen visiting the province for sport was often manifested. Not so much by the up-country settlers, who knew too well what such visits meant to them, but by certain professional

* The British Columbian game laws at present in force compel the nonresident sportsmen, under threats of heavy fine or imprisonment, to obtain a licence costing 5odol. $(f 10)$, and limit his bag of wapiti to two stags; while the Indians, on the other hand, are under - no sort of control to prevent them from hide hunting (indeed they are not even told that they must not do so), and settlers may kill as much as they desire, as they quite rightly should, for their own use; so that practically the only persons against whom the game laws of British Columbia, so far as big game is concerned, are directed, are the visiting sportsmen, whose knickerbockered presence appears to be decidedly unwelcome to the professional legislators who framed these laws. 
politicians, who gave expression both in speeches and in letters to the newspapers to invectives of which the following may be cited as specimens: "What do we want with titled asses . . . . who parade upon the streets dressed in the most fantastic style, with their waistcoats over their overcoats, and their shirts over their waistcoats. . . . who take more money out of the country than they brought in," and, alluding to one particular sportsman who had dared to criticise the provincial game laws, "who might be seen driving many a hard bargain with the Indians with all the avidity of a Shoreditch Jew," or in another place, referring to the same person, "was a trader who tried to pass as a sport-a regular Shoreditch Jew." Mr. Joseph Hunter, M.P.P. (Member of the Provincial Parliament), the gentleman who expressed these prettily phrased personalities, could hardly be expected to know very much about the sentiments of English sportsmen as a class, but at the same time it seems a pity that such bombastic rhetoric should add insult to the injury done by this fatuous blindness to his country's true interests.

How ineffectively the British Columbia game-laws are framed, and how efficiently they are carried out, the following instance taken from late numbers of the Victoria Times (July 21 and August 21, 1899) will illustrate. According to the evidence produced before the city magistrate, a more than usually vigilant law officer attempted to seize a shipment of some twenty-one thousand pickled and raw skins of black-tail deer, which a Victoria firm of hide merchants were about to export to San Francisco. Section 4 of the statute under which this firm was prosecuted, runs as follows :-

No person shall at any time purchase or have in possession with intent to export, or cause to be exported or carried out of the limits of this province, or shall at any time or in any manner export, or cause to be exported or carried out of the limits of this province, any or any portion of the animals or birds mentioned in this Act, in their raw state : and this provision shall apply to railway, steamship, and express companies.

To put the result as briefly as possible, the judge dismissed the case, because, according to a fair construction of the above quoted 
section, "it is the possession with intent to export in their raw state which is prohibited, and there is no evidence here of any such intention." Probably he was legally quite right, and that the fault lies at the door of the legislature, through whose act these $2 \mathrm{I}$, ooo deer skins were driven on a triumphal car.

Probably all these deer were killed the previous winter by Indian and white skin-hunters on the numerous densely timbered islands that dot the channel between the mainland and Vancouver Island, and slaughtered in most cases simply for the sake of their skins, worth a few shillings each, for it appears from the local press that "hundreds of carcasses of deer may be found rotting on the mountain sides and in the woods."

Other writers as well as myself have been accused in some quarters of crabbing the game resources of British Columbia, and as many a sportsman's as well as goldseeker's eye is turned towards the North Pacific coast just now, a word of explanation will be not out of place here. What constitutes "GOoD" big game shooting must ever remain a matter of individual opinion. Be that opinion whatever it may, it should, to give it value, spring from bonâ fide motives that have no connection with any desire to benefit other than the sportsman. When I say that I do not by any means consider British Columbia the big game hunter's paradise which it has been made out to be, it is only fair to premise that my judgment may possibly be more or less warped by the exceptionally good sport I had previously enjoyed in American territory-Wyoming, Montana, and Idaho. For big game shooting I consider the two countries could simply not be compared, for in the latter the quantity and diversity of big game was as far beyond one's most sanguine expectations, as it was below pessimistic anticipations in British Columbia. When I turned for the first time towards British Columbia, entering the Kootenay District from Idaho, I very speedily discovered that the dense forests, even if an equal quantity of game were there, reduced the sportsman's chances to a minimum, save in the case of mountain "goat," for which British Columbia is by far the best field that I know, for in their case dense woods, 
though sadly obstructing one's approaches to the above timberline regions inhabited by this animal, do not interfere with the actual shooting of beasts inhabiting the regions above vegetation.

Taking it all round, I can safely say that on many occasions I have seen in Wyoming and Idaho, in one single day, more big game, not counting bison, than I have in all the ten or eleven years put together in British Columbia. When the Montana and Idaho hunting grounds were first invaded by railway builders, we have already heard that thousands of navvies were fed for months on game only; when the same thing occurred in British Columbiai.e., the Canadian Pacific was being built through the excessively rough Selkirks or down the Fraser Cañons-narry a bit of venison did the navvies ever see. Better proof of the extreme difference between the game conditions in two countries could hardly be adduced.

In most of my subsequent expeditions I tried to combine what sport I could fit in with interests in land and mining ventures, which entailed the exploration of practically quite wild districts. For, while disappointed with British Columbia's big game resources, I was much taken with other features of that beautiful country. During the ten or eleven years that I practically resided either wholly or during a part of the year in British Columbia, I travelled very many thousand miles on horseback, in coast and river canoes as well as on rafts, on foot with rifle, and occasionally with my sleepingbag on my back, as well as by more civilised means of conveyance over its mountain trails, picturesque lakes, and rushing rivers, which - teem with trout in quantities probably unrivalled by any other country in the world. I have slept on the ground with and without tents for six months at a time, and from occupying for a fortnight the inside of a spare boiler on a steamer, have sought "the downy" in the usual variety of strange places with which every pioneer is familiar. And what, concerning the question at issue, is more important, I have lived several summers and autumns in the districts that were considered the best game countries in British 
Columbia, and this at a time when they were not yet over-run by miners. I have also visited the east and west coast and some of the practically unexplored interior of Vancouver Island. During these ten or eleven years peregrinations in British Columbia I have never seen, much less killed, a single wapiti; and, what is more, I know of only two visitors who succeeded in shooting any at all.* I have never heard of a visitor ever killing a moose in British Columbia, and in the ten years I have only seen one small bull. In the extreme north of the province a fair number are said to exist, and this by such an entirely reliable sportsman as Mr. Warburton Pike, who, in his excellent "Through Sub-Arctic Forests," gives a most interesting account of the sport obtainable in those far-off regions. To exploit these great solitudes for sporting purposes, entails wintering, at least once, if not twice, in a very inhospitable country, where starvation is an uncomfortable possibility. And let it be said here that none but the extremely hardy and thoroughly experienced in woodcraft should ever venture to follow that sportsman's example, for he is one in ten thousand when it comes to roughing it. Hardships of which the stay-at-home sportsman can form no conception are as nothing to this born explorer.

Black-tail deer are still plentiful on the islands off Vancouver lsland and on that island, facts to which I have alluded. They are principally hunted in winter, and the sport they give is but poor. In some parts of the mainland the finer mule deer (C. macrotis) takes its place with advantage to the pot and to the gunner, for on account of the less dense timber frequented by this deer, there is more chance of getting a shot at it.

In contrast to the opinion of those upholding the splendid sporting facilities obtainable in British Columbia, unprejudiced observers have from early days onward declaimed upon the

* I remember only one instance of wapiti (four inferior ones) being killed by two non-professional hunters residing in British Columbia (Messrs. Hayes and Walker), and Sir Matthew Begbie, Chief Justice of British Columbia, a keen sportsman, himself told me at the time that no such thing had been done in the last twenty years. 
absence of game on the mainland of British Columbia. Lieutenant Mayne, R.N., the famous explorer of the country between Jervis Inlet and Lilloet River, which is to-day practically in the same wild state in which it was thirty or forty years ago, wrote thus :

"The same absence of animal life was observable on this journey as I remarked on my excursion last year. Here, where man hardly ever comes, one would think game would abound, but we only saw one deer, half a dozen grouse, and as many small birds. We saw the marks of several bears and sufficient indications of deer to show us that the solitary one we had seen was not the only one in British Columbia." On page $22 \mathrm{I}$, when describing a trip into the interior, in the neighbourhood of Shushwap, he says: "The absence of animal life is also very remarkable." Many other equally wellinformed writers could be quoted in support of my contention that British Columbia's big game resources are on the whole disappointing, and at best very "spotty."

Returning to the question of unbiassed opinions in expressing views concerning British Columbia sport, it is probably needless to warn the reader against accepting the advice of persons financially interested in booming the sporting resources of a country. Railway companies and the silvery-tongued land speculators or "real estate agents" are the worst sinners in this respect, hence, caveat emptor! To the amusing, not to call them extraordinary, discussions on the Game Bill in the House of Assembly in Victoria during the session of 1892 ; another typical instance how history comes to be written can be added. At that time an English resident in Victoria, who very soon afterwards came rather prominently before the British sporting world as the editor and chief contributor to a well-known standard series of English books on sport, was editing a local newspaper in Victoria. In letters and leading articles he advocated the repeal of certain game laws then about to be passed by the legislature, and in doing so he gave expression to opinions regarding British Columbia's big game resources which hardly bore out the very high opinions which he published in the 
English series and other works intended to meet the eye of the British sportsman. In the latter he says, "there is no doubt that the home par excellence of the wapiti to-day, is in the dense timber of the Olympian range in Washington, Oregon, and, to a certain extent, in Vancouver Island"; while for bighorn and bear he was even more emphatic in his praise of British Columbia. These attractive recommendations his newspaper articles intended for a local circle of Victoria readers, and written at the time he was completing the two volumes of the series I have alluded to, do not voice. "There is reasonable hope," he wrote, "that Victoria will again this year benefit by the advent of moneyed strangers prepared to part with their dollars for the sake of a few hides and horns, or rather for the sake of the remote chance of obtaining these trophies" (Daily Ner's, Victoria, April 9, 1892). In another passage he acknowledges that "three parties of good men came back this season from good hunting districts empty-handed." From other passages one infers that one of the objects in inducing Britishers to come out for sport is to thereby benefit the land speculators and hotel-keepers; at least, such is the impression the following passages leave on one's mind: "The rich men of Europe come out here to hunt our sheep and bear and wapiti, leaving a hundred pounds in the country for every beast which they took out of it. . . . Nor is this the chief part of the good which the bighorn, fairly killed, brings to British Columbia. The men who hunt big game must be moneyed men, more or less, and not only do they bring a good many dollars into our hotels, but real estate agents will tell you that a large number of those who come to hunt stay to invest." To ride with the hotelkeepers and real estate agents, and to run with the British sportsmen in quest of game in British Columbia, are tasks which, I fear, it is somewhat difficult to combine, at least, with advantage to the latter. Of the efficiency of the game laws he speaks thus: "Our game laws are a dead letter. Nobody minds them a bit," and proceeds to declare that of the $£$ ro shooting licences which every stranger should procure before he may shoot a head of big game: 
$=$ 


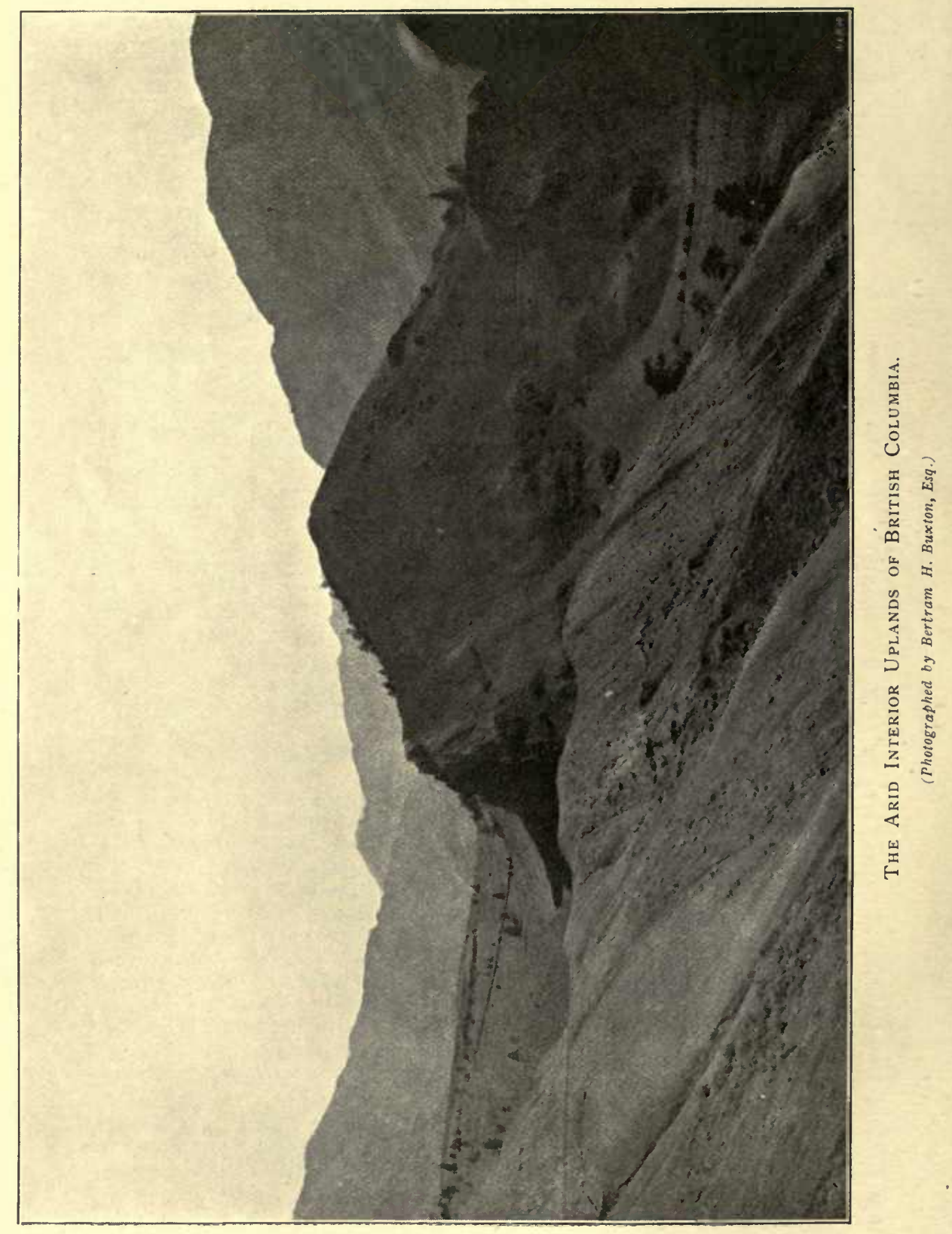


"I doubt if a single licence has ever been procured, yet there were more than a dozen men in town this fall who ought to have paid for one."

For bighorn certain limited districts in the arid interior of British Columbia were once somewhat frequently visited by sportsmen who had never shot that beast in Wyoming or Colorado. But even there I have heard of only three moderately good bags ever being made, the one by Admiral Sir Michael Culme-Seymour, whose keenness and walking powers were altogether above the ordinary. Along the main chain of the Rockies in East Kootenay, in the extreme south-east corner of the province there was very good ground (approachable from the Great Northern Railway), but whether it is so still is a question I would not like to answer offhand, considering the actively carried on construction of the Canadian Pacific Railway. A region where I think good sport can still be obtained is in the Rockies, between the Crow's Nest Pass in Kootenay and where the Great Northern crosses the Rockies.

For black bear British Columbia is a good country, but local knowledge concerning the favourite feeding places at particular periods of the year is absolutely necessary if success is to be achieved. In all my roamings through British Columbia I have only added two black bears to my fourteen or fifteen in the States, but I had bad luck in both regions with them. Caribou are hard to get, and at best do not offer anything like the attraction other big game does. In two instances that I know of, the lazy man who stayed in camp bagged fine specimens, while the keen and tireless friend, roaming the woods all day, failed to obtain a single shot.

In conclusion, let me give a few practical hints concerning the working of the game laws of the Western States. Considering that of late years the various State legislatures are constantly tinkering at their game laws-always in the direction of greater stringency - it might be misleading to give definite details of the regulations concerning the rights of aliens to shoot game 
As a general thing, with the exception perhaps of Idaho, the law has gone to the other extreme, and the bag a stranger is legally entitled to make is of such ridiculously limited proportions as on the face of it to suggest that a wide berth had better be given to the Western States. The resident, on the other hand, enjoys the wide privileges of a "settler" who can kill game practically at any season of the year, and in quantities no law has as yet attempted to define, always provided that the game is for his own use and no part of it is sold.

What is the use one may well ask of the Montana law limiting a stranger to two wapiti so long as there are no officials to see that this number is not exceeded? In a country where in the wilder parts you can still travel and hunt for weeks without seeing a human being, it would require an army far larger than that of the whole United States to enforce such regulations.* And even were such an army available, the investment of $£ 55^{\circ}$ in a "ranch" makes the stranger a "settler" in the eyes of the law.

In one respect care has to be exercised; it is concerning the trophies. These should not be brought to the railway stations in numbers exceeding the Iaw's limit, for blackmailers, prompted by the reward in the shape of half the fine, have of late years more than once caused English as well as American shooting parties considerable trouble and expense. The task of transporting the trophies out to the railway should be left to your hunter or guide to accomplish after you have left. If he is worth his salt, he will manage to get eight or ten picked heads to the railway and dispatch them, packed in cases, without any trouble.

* How difficult such supervision of less vast areas is, actual experience nas shown. Thus the force of cavalry that guards the National Park has often proved useless in preventing regular poaching raids, in some of which the small remaining herd of bison has severely suffered 


\section{CHAPTER III.}

\section{THE WAPITI AND HIS ANTLERS.}

AMERICAN millionaires have for years past, it is well known, ransacked the picture galleries of Europe, where they garnered many of the masterpieces that once adorned the walls of England's mansions or the marble-flagged galleries of Continental palaces. Europe has revenged itself by sending to the Western hunting grounds her sportsmen, who have succeeded in capturing there quite as many, and probably quite as irreplaceable, chefs d'cuvre, not of man's, but of Nature's choicest handiwork. In both cases the demand exceeds the supply, with the result that second-class masterpieces are pressed into the first rank, and the sportsman of to-day has to be satisfied with trophies which would have been regarded as second-rate ones ten years before.

Before proceeding further, let me clear the ground on one important point. Trophies of the chase can be regarded from two different points of view-i.e., from that of the naturalist, as more or less valuable contributions to our knowledge of natural history; and, secondly, from a purely sporting point of view. To the scientific investigator desirous of establishing the length, the widest spread, or the greatest circumference of the "largest on record" of some particular species, it is naturally a matter of indifference who killed the bearer of the trophy deserving that distinction. To the sportsman, on the other hand, who disdains to adorn his walls with spoils that he has not obtained himself, it is a matter of interest what other fellow sportsmen have shot, while the fact that some skin hunter of Wyoming or Montana has bagged a wapiti with antlers, 
or a bighorn with horns an inch or two larger than the best of his own killing, remains a matter of indifference.

The line we draw in other departments of sport between the amateur and the professional can, and should be, extended, to the realm of sporting trophies. But in those books that deal with the latter, such as Rowland Ward's "Records of Big Game," we find that the naturalist's rather than the sportsman's interests are consulted, some great pair of antlers bagged in some remote corrie of the Rocky Mountains by a "horn hunter" or "hide hunter," or a giant bighorn head obtained by some nameless meat-hunter's Winchester, ranking, by merit of its superior dimensions, in front of the trophy which rewarded a journey of 10,000 miles and the hardships incidental to sport in the wild regions where such noble game can still be found. In books of this type the name of the owner of the trophy and not that of the sportsman who bagged it, is given if, what is often the case, these two are not identical.

The great private collections of natural history specimens, highly interesting and useful as they no doubt are, which figure so prominently in these books, can be formed only by rich men, and the collector need not necessarily be a sportsman in the sense of the word here used.

In the following pages the question of trophies has, in the first place, been dealt with in this spirit, and the reader will find collected together the records of most of the principal spoils of the chase obtained, not only by English, but also by foreign sportsmen.

What superb trophies could still be obtained half a generation ago could well be seen by the visitor to the American Trophy Exhibition, held, in I 887 , at Earl's Court. It was a loan collection the like of which the present generation will probably not see again, for only those who took upon themselves the endless trouble and responsibility of inducing owners of choice trophies to dismantle their walls of their treasures, can form an idea of the hard work and the immense amount of correspondence it entailed upon those who initiated the movement. 
Prominent among these, it will be remembered, was Mr. E. N. Buxton, who was assisted by a committee,* while Mr. J. E. Harting and Mr. Oldfield Thomas, of the Natural History Museum, undertook the extremely onerous and responsible duty of carefully measuring the exhibits, of which there were close upon two hundred. The catalogue prepared and issued by the committee contained the result of this arduous work with the measuring tape, as well as some notes upon the chase of the principal game animals whose grand trophies graced the lofty room. These were furnished by members of the committee, and Mr. Harting contributed a very useful systematic list of the species exhibited. Woodcuts and photographs (with the latter only a very limited number of copies were provided) lent a further value to this catalogue.

Unfortunately, only an inadequately small edition was printed, and the result is that to-day it is practically impossible to obtain copies, and those furnished with photographic representations of the chief heads are, I am told, worth (the plates having been destroyed) a $£$ io note. Under these circumstances a selection of its principal contents may be welcome.

It will be remembered that on the occasion in question most of the antlers were mounted on stuffed heads, which, of course, made it impossible to ascertain what, in the opinion of those versed in antler lore, is the most important quality, i.e., weight. The dimensions ascertained by the two gentlemen I have already named as having taken upon themselves this laborious duty were: $A$, length of horn measured along curve behind, from base to tip of longest tine; $B$, circumference at thinnest place between bay and tray; and $C$, greatest clear width between the main beams (not, as many suppose, greatest lateral width between tips of tines furthest apart).

* It consisted of the following sportsmen :-Messrs. E. N. Buxton, H. Seton-Karr, M.P., J. M. Hanbury, A. Pendarvis Vivian, J. E. Harting, Moreton Frewen, T. Bate, W. A. Baillie-Grohman, and Gerald Buxton, Hon. Sec. 
In accordance with what has been said, precedence is given in the present pages to trophies killed by sportsmen, other heads being mentioned only in illustration of some peculiarity meriting remark.

One of the most remarkable among the former was a wonder-

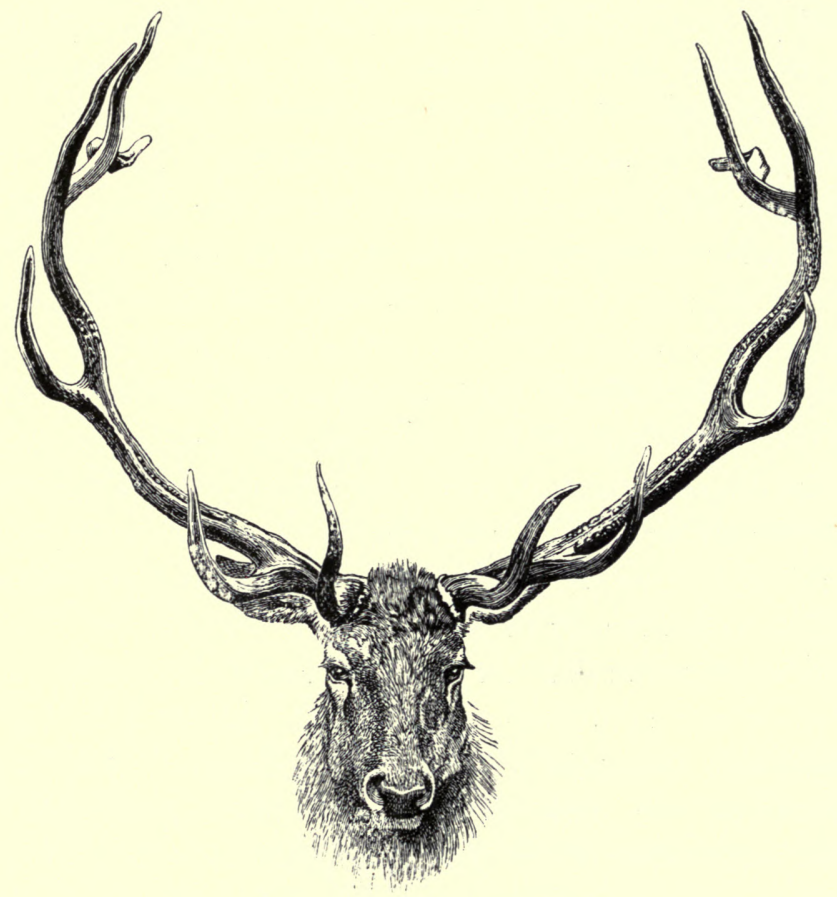

Mr. Cooper's Wapiti Head.

The longest wapiti at the Trophy Show of 1887 .

fully long pair of antlers shot by an American sportsman, $\mathrm{Mr}$. Frank Cooper, who, accompanied by his brother, hunted in Wyoming in the good old days of the seventies. They exhibited what was decidedly the best collection of American trophies at the exhibition. The greatest length of their best head was $62 \frac{1}{2}$ in., while another shown by the same gentleman had the biggest 
circumference, i.e., $8 \frac{1}{2}$ in., but in other respects it was of rather too stunted proportions to enter into competition. Of the former head the catalogue unfortunately contained no photographic

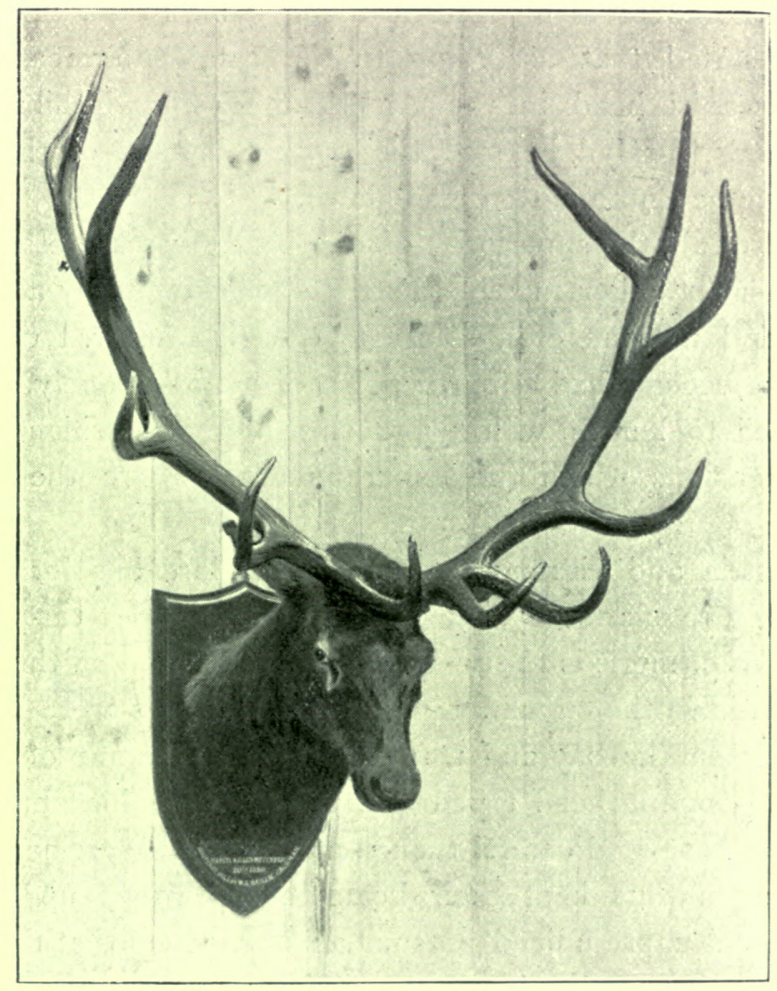

The Author's Wapiti.

For size and spread the best at the Trophy Show of 1887 .

representation. The illustration is taken from a drawing of it by Mr. G. E. Lodge, which appeared in the catalogue.

Among the great wealth of fine heads it was no easy thing for the judges to select the best head all round. According to the verdicts recorded in the catalogue (pages 23 and 38 ), as well as in 
the Field and elsewhere, this honour was accorded to the head of the second largest wapiti I have ever killed.*

I am tempted to indulge in this blowing of my own little trumpet in vindication of a trophy $\mathrm{I}$ am rather proud of, as the writer of the chapters on American big game in the "Badminton Library," stated that according to the catalogue measurements the best wapiti head in the American Trophy Exhibition was Mr. Cooper's. Had he said the longest instead of the best, I should have had nothing to complain of.

But, after all, the superiority of one head over the other was in this, as in most other instances, strictly speaking, only a matter of opinion, and not one of absolute fact, which latter, I contend, it would have become had a fourth point of merit-namely, weightbeen added to length, width, and circumference, which were the three dimensions which the experts decided were the essential ones.

In Austria and Germany, where antler lore has for centuries been made a regular study, the best judges consider that the most telling point of merit is the weight of the antlers. In the instance under discussion the circumferences of the antlers were invariably taken between the bay and tray tine. At this point of measurement Mr. Cooper's head taped $\frac{1}{8}$ in. more than mine; but, on the other hand, as several careful though unofficial measurements amply proved, my antlers kept their beam much further up than $\mathrm{Mr}$. Cooper's, and unprejudiced persons acknowledged that there could be no doubt that my head was the heavier of the two. I am very sure that, could both sets of antlers have been detached from the stuffed heads on which they were unfortunately mounted, and then placed on the scales, my trophy would have been found to weigh

* The catalogue said (p. 23) that it " has justly been selected by many as the best head in the room for weight, length, and symmetry," and (p. 38) "for size and spread of horns it is by far the best." The Field (May 21, '87) : "The first for size." The Sporting and Dramatic: "Carries off the palm as the finest wapiti head in the show," \&c.

+ Field, October 6, I894. 
pounds heavier than the other. Weight would thus have spoken the determining word in this friendly rivalry.

While on the topic of length, I may mention that the longest wapiti antlers I have ever seen was a wonderful old head I picked up on the Grosventre Creek in 1880 . It measured 68in. The longest head I have ever killed myself was a 64 in. head. Unfortunately it shared the fate of two of ny largest bighorn heads, which were lost to me by a fire which destroyed a log cabin where I had them stored. I believe I am right in saying that no European sportsman has killed finer heads.

My favourite head of all is one of over 6oin., with peculiarly long and gracefully shaped tines of good curve-the sur-royals are 2ft. in length-and for this reason I am tempted to reproduce a likeness of it as it hangs in my study (see Frontispiece). The grizzly old stag that carried it gave me one of the most exciting stalks man ever enjoyed.* Two other fine heads were presented by me to two great Continental collectors; one of the trophies hanging in the great dining hall at Reinhardsbrunn, amid giant red deer heads of past centuries grassed by the matchlocks and flintlocks of the Dukes of Saxe-Coburg; while the other is hanging in Langenburg, the ancient castle of the Hohenlohe dynasty, amid similar "good and worthy fellows."

Measuring heads is ticklish work, and should not be undertaken by the owner if he wants to quote the result. What made the American Trophy Show such an interesting event was not only the fact that most of the best heads in Europe were collected together, but chiefly because they were measured by impartial and reliable judges according to one and the same principle. Anybody who has ever had to do with measuring antlers knows only too well the perplexing variety that exists of taking measurements, and how easily mistakes, notwithstanding the best intentions, will occur. As already observed, the weight of antlers would add an important

* It was described in an illustrated article in the Illustrated London Verus, Nov. 6, I886, and pictures of this head have appeared in the principal sporting papers of England and the Continent. 
"point of merit" of scientific value to the dimensions arrived at by means of the tape, and it is to be hoped that in future more attention will be paid to it by English sportsmen.

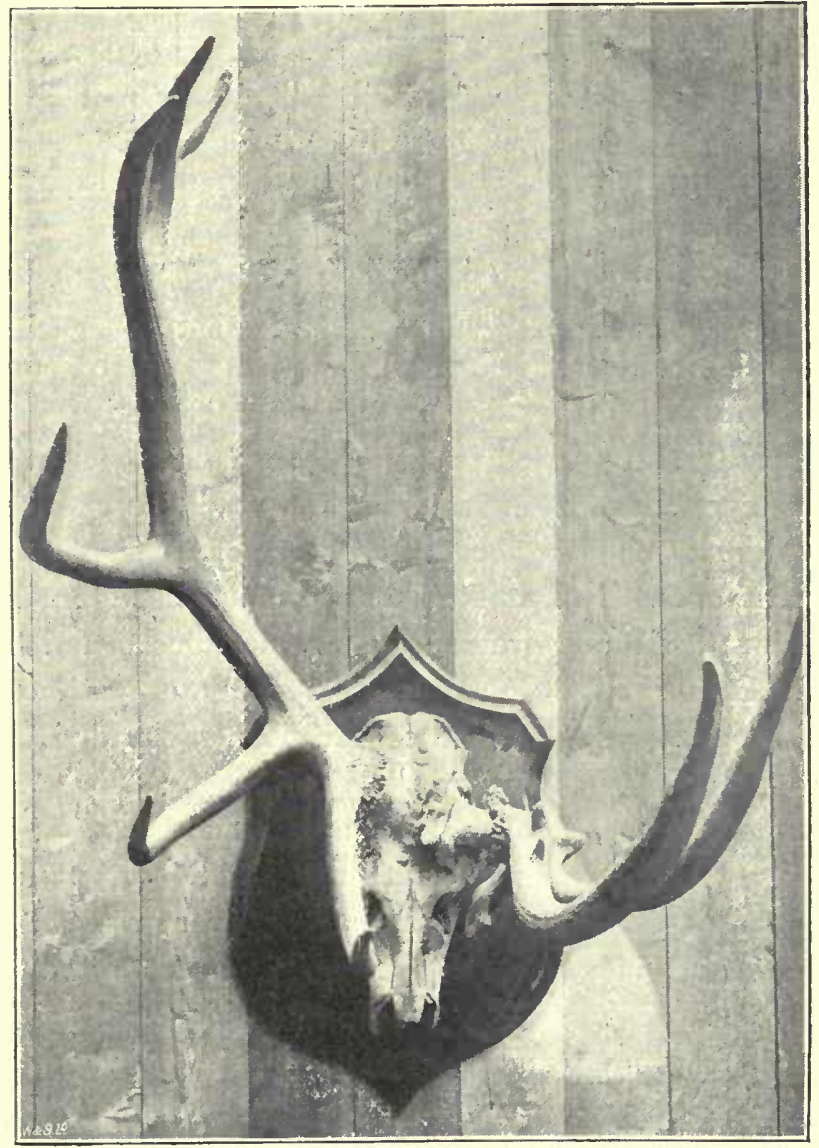

Mr. Otho Shaw's Wapiti Head,

Showing the healing process.

Abnormal formations are far less rare with the wapiti than with red deer, and some very curious malformations are known 
among the former trophies. Not the least so is the deformed head exhibited by Mr. Otho Shaw at the Trophy Show (see illustration), which those who saw it there, will probably remember. The blow which had fractured the skull, a year or more previous to his death, had failed to kill him, and, as Mr. E. N. Buxton very correctly says, "Nature asserted herself in an attempt to throw a bridge over the cavity."*

Curious as this malformed head is, one of my own shooting has also features of interest. It is one of the only two I 8-point wapitis I have ever shot, and though of very moderate dimensions so far as beam and length are concerned, it was no doubt a very old stag. The abnormal character of the head lies more in the whole type than in any one particular. The whole growth (see illustration) has about it features reminding one rather of the woodland caribou. It was shot, however, so far from the nearest caribou country (I killed it in I 879 in Central Wyoming), and a crossing of wapiti with either of the two Rangifer species is so extremely unlikely and unknown, that one cannot regard the resemblance as more than a chance one. Singularly enough, the coat of this stag was of an unusual grey, and the hair seemed to be more brittle and coarse than ordinarily. With these details I became acquainted in a sufficiently unpleasant manner, for this stag very nearly proved to be the last one I was to grass. It was about the middle of the rutting season, and the country I was in (the Fort Casper Hills) was simply alive with wapiti, whose weird whistling and clash of antlers in angry combat seemed to be going on all day and all night. The country being very broken, it was difficult to spot big heads, and still more difficult to follow one's selection across the timbered ravines and gullies that criss-crossed the country in every direction. However,

* An even more curious instance was brought to my notice by Sir Douglas Brooke, when showing me his father's most interesting collection. A fallow buck, in a fight with another buck, had lost one antler as well as a piece of the skull, which came off with the horn. The wound, very serious as it was, nevertheless healed, and the following year the buck not only shed his antlers, but the newly-formed bone came off too. 
I had seen this stag, and watched him with my 'glasses as he "bossed" a herd of hinds along a narrow game trail that skirted a deep ravine. I saw that it was a large bodied animal, and of a peculiarly greyish tint, which was enough to make me keen to bag him. It was easy enough work; by keeping along the bottom of the ravine I got under the band, and, though I had to bend backwards to an unpleasant degree, so as to get my faithful old "Trailstopper" to bear upon my victim, who was stalking along-

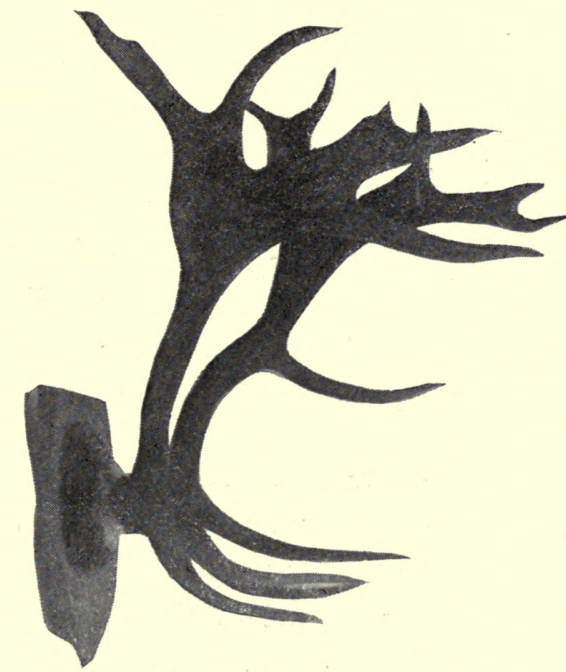

The Author's i8-point Wapiti Head with Caribou Palmation. Shot i879.

at the tail end of the band some four hundred feet straight above me, I managed to get in my right and left. In fact, almost too successfully, for the stag was knocked off his legs and off the narrow trail, and as the slope was far too steep for him to regain a footing, the great beast came down the hillside-half falling, half slithering-straight for the spot in the V-shaped bottom of the ravine where I was standing. The rapidity with which this happened, and the fact that the smoke of my shots was still 
hanging about, left me no time for escape, and I was knocked down. Fortunately by his hind quarters and not by "the business end" of the beast, as my trapper facetiously remarked when I narrated to him this incident.

My two Austrian friends, Counts Ernst Hoyos and Ferd. Trauttmansdorff, who in 1887 made, what I think was, in some

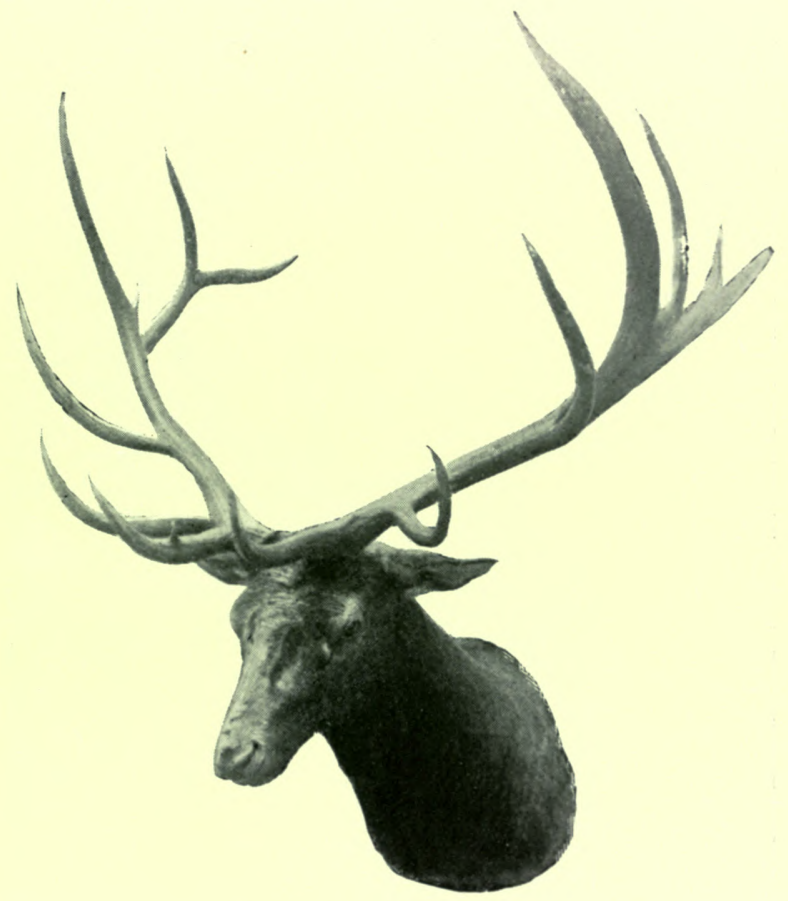

Count E. Hoyos' Wapiti.

respects, one of the most successful shooting expeditions ever undertaken by European or American sportsmen, secured some fine wapiti heads in the region to which I advised them to go, i.e., the headwaters of the Green River and Snake River, on the western slope of the Windriver range. Their heads rank well up in the list of trophies, and had the guns been able to stay longer 
there, one or the other would probably have bagged a 6oin. wapiti.

Why I consider their western jaunt such a successful one, is that they obtained within two months all the principal North

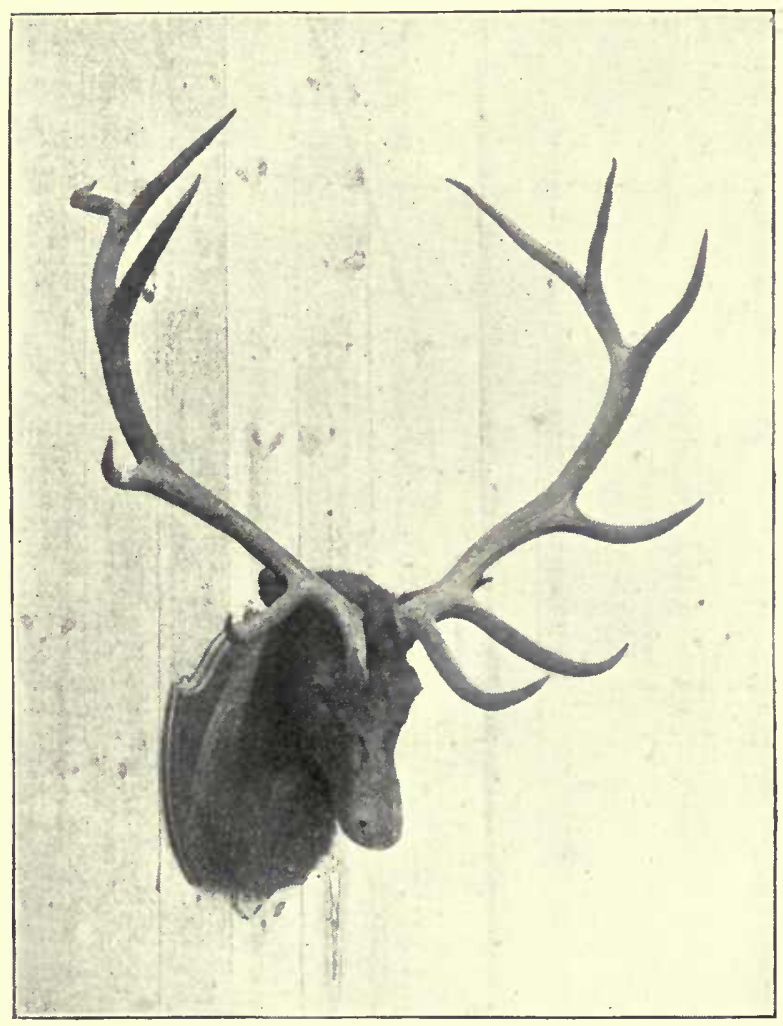

Mr. H. Seton-Karr's Wapiti Head.

American big game, from a nice bag of white antelope-goat on the Upper Columbia, in the Kootenay district-ground I knew well as harbouring these beasts within sight of steamer communication, and which then had not been hunted much-to wapiti, bighorn, bear, and the smaller deer. Communication between the then 
very isolated Upper Kootenay country and the borders of Idaho and Wyoming was, in 1887 , very much more roundabout and slower than it is to-day, hence some sharp work in camp moving was necessary. Count Hoyos had been out West before in earlier years, when, notwithstanding that game was far more plentiful

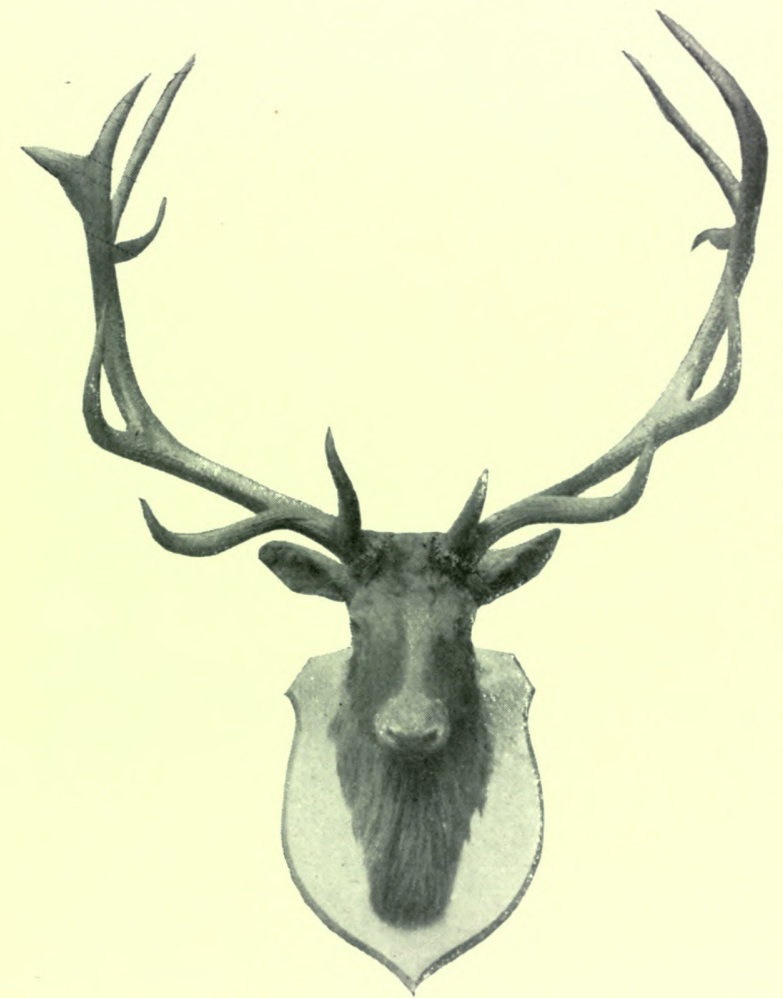

Mr. Ernest Farguhar's i4-point Wapiti Head.

than in 1887 , the expedition was as unsuccessful as the later one was the contrary. A systematically worked out itinerary, arranged by one knowing the country to be traversed, makes, in such a case, all the difference.

Sportsmen nowadays express doubt concerning the possibility 
of obtaining decent wapiti heads in America. That nothing like record heads can be bagged is a sad truth, for the number of animals has within the last two decades shrunk by at least nineteen-twentieths. At the same time, good heads can

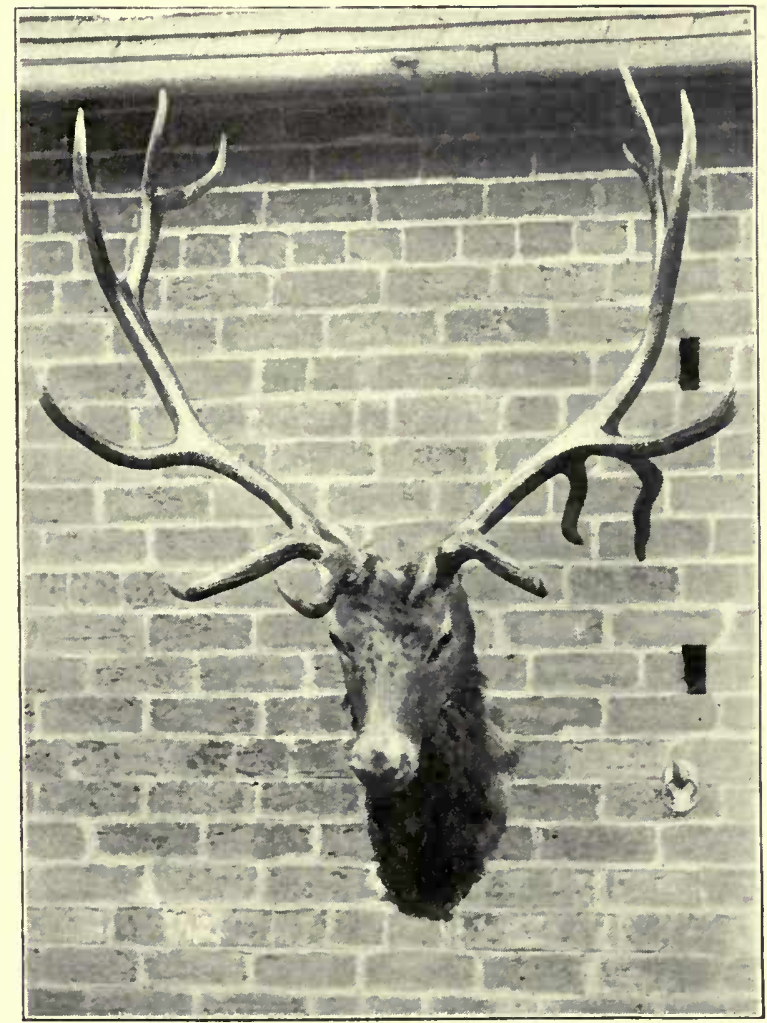

- Wapiti Shot by Mr. T. Bate, of Kelsterton.

occasionally still be got, and, as the best evidence of this, I am tempted to reproduce the photograph (see illustration) of a fine trophy of the dimensions given in the table, obtained by Mr. Moncreiffe as late as 1896 in what is now considered a "shot out" region, namely, the Bighorn Mountains in Wyoming. 


$$
4
$$





\section{TABLE OF MEASUREMENTS OF WAPITI ANTLERS MEASURING} 55 INCHES AND MORE, KILLED BY ENGLISH SPORTSMEN.

(Names arranged alphabetically.)

\begin{tabular}{|c|c|c|c|c|c|}
\hline Name of Sportsman. & $\begin{array}{l}\text { Length } \\
\text { along } \\
\text { curve of } \\
\text { antler. }\end{array}$ & $\begin{array}{c}\text { Circum. } \\
\text { above } \\
\text { bez } \\
\text { line. }\end{array}$ & $\begin{array}{l}\text { Width } \\
\text { inside } \\
\text { main } \\
\text { beam. }\end{array}$ & 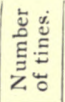 & Where killed. \\
\hline Captain Abdy & $57 \frac{1}{2}$ & $6 \frac{7}{8}$ & $35 \frac{5}{8}$ & I 2 & Montana \\
\hline Lord Ava .................. & $5^{6}$ & $7 \frac{1}{4}$ & $43 \frac{1}{2}$ & I5 & $?$ \\
\hline Late Sir Samuel Baker $\ldots$ & $59 \frac{3}{4}$ & - & - & - & Bighorn Mts., Wyoming \\
\hline W. A. Baillie-Grohman & 64 & - & $5^{\mathrm{I}}$ & I5 & $\begin{array}{c}\text { Gros Ventre, borders of } \\
\text { Wyoming and Idaho }\end{array}$ \\
\hline ", $\quad,($ Am. T. Exh. $)$ & $60 \frac{3}{4}$ & $7 \frac{7}{8}$ & $5^{2}$ & 12 & Windriver, Wyoming \\
\hline , $\quad$, $\ldots \ldots \ldots$ & $6 \mathrm{o}^{\frac{1}{2}}$ & $7 \frac{3}{4}$ & - & I3 & Windriver Mts., Wyoming \\
\hline , $\quad, \quad$, $\quad \ldots \ldots$ & - & - & - & I8 & Caspar Mts., Wyoming \\
\hline E. N. Buxton (Am. T. Exh.) ... & $55^{*}$ & $7 \frac{1}{8}$ & $47 \frac{1}{2}$ & I I & Windriver Mts., Wyoming \\
\hline T. D. Cobbold ….................. & $5^{8 \frac{1}{2}}$ & $8 \frac{1}{2}$ & $44 \frac{1}{2}$ & 12 & $\begin{array}{l}\text { Borders of Colorado and } \\
\text { Wyoming }\end{array}$ \\
\hline Frank Cooper $\quad \ldots \ldots \ldots \ldots \ldots \ldots$ & $63 \frac{3}{4}$ & $8 \frac{1}{4}$ & $48 \frac{1}{2}$ & I6 & Wyoming \\
\hline$" \quad, \quad($ Am. T. Exh. $)$ & $62 \frac{1}{2}$ & 8 & $48 \frac{1}{2}$ & I6 & $"$ \\
\hline Lord Dumore..................... & 55 & $7 \frac{3}{4}$ & $35 \frac{1}{2}$ & I3 & $?$ \\
\hline Major C. C. Ellis ................ & $60 \frac{3}{8}$ & $7 \frac{1}{4}$ & $46 \frac{1}{4}$ & I 2 & Wyoming \\
\hline Hon. Ch. Ellis $\ldots \ldots \ldots \ldots \ldots \ldots \ldots$ & $57 \frac{3}{8}$ & 7 & $48 \frac{5}{8}$ & I 2 & , \\
\hline Ernest Farquhar .................. & 62 & $7 \frac{3}{8}$ & $50 \frac{5}{8}$ & 14 & Bighorn Mts., Wyoming \\
\hline$" \quad, \quad$ " $\quad, \quad \ldots \ldots \ldots \ldots \ldots$ & $61 \frac{1}{2}$ & $7 \frac{1}{2}$ & 45 & 12 & 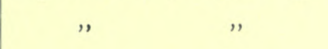 \\
\hline E. Grant $\ldots \ldots \ldots \ldots \ldots \ldots \ldots \ldots \ldots \ldots \ldots \ldots \ldots \ldots$ & $60 \frac{1}{2}$ & $8 \frac{1}{4}$ & 55 & I3 & $"$ \\
\hline H. Seton-Karr $\ldots \ldots \ldots \ldots \ldots \ldots \ldots$ & $6 \mathrm{I}$ & 8 & $5^{2}$ & 12 & Bate's Hole, \\
\hline$" \quad, \quad$ (Am. T. Exh.) & $59 \frac{1}{2}$ & $7 \frac{1}{2}$ & 45 & I 2 & , \\
\hline Major Maitland Kirwan ......... & 55 & $8 \frac{1}{4}$ & $4 \mathrm{I} \frac{1}{4}$ & 12 & ", \\
\hline St. George Littledale $\ldots \ldots \ldots \ldots$ & $55 \frac{3}{8}$ & $7 \frac{1}{8}$ & $46 \frac{1}{4}$ & I3 & Montana \\
\hline W. Moncreiffe .................... & $5^{8}$ & $7 \frac{3}{8}$ & 49 & 17 & Bighorn Mts., Wyoming \\
\hline Sir H. B. Meux, Bart. ............. & 55 & $8 \frac{1}{2}$ & $54 \frac{1}{2}$ & 17 & $?$ \\
\hline Otho Shaw ........................... & $55 \frac{1}{2}$ & $7 \frac{1}{2}$ & $48 \frac{3}{4}$ & I5 & $?$ \\
\hline Sir Humphry de Trafford, Bt. & $57 \frac{1}{4}$ & - & $42 \frac{1}{4}$ & 14 & Wyoming \\
\hline A. PendarvisVivian(Am.T.Exh.) & 55 & $8 \frac{1}{8}$ & $4 \mathrm{I} \frac{1}{4}$ & 12 & ," \\
\hline Captain G. Dalrymple White... & $55 \frac{5}{8}$ & 7 & $47 \frac{5}{8}$ & II & Saskatchewan, Canada \\
\hline \multicolumn{6}{|c|}{ AUSTRIAN AND AMERICAN SPORTSMEN. } \\
\hline Count F. Trauttmansdorff $\ldots \ldots$ & 57 & $7 \frac{1}{4}$ & - & I4 & $\begin{array}{l}\text { Gros Ventre Range, } \\
\text { Wyoming }\end{array}$ \\
\hline Count Ernst Hoyos ................ & $53 \frac{1}{2}$ & 8 & $44 \frac{1}{2}$ & I5 & $"$, \\
\hline Theodore Roosevelt ............... & $56 \frac{1}{2}$ & 67 & - & 12 & Windriver, Wyoming \\
\hline
\end{tabular}

* In the Am. Trophy Exh. catalogue the length of this head is, I believe, given as 5 oin. 
In Rowland Ward's third edition there are several other heads over 55 inches in length. I have not mentioned them, first of all, because I could not find out whether they were killed by sportsmen, and secondly, because some of the dimensions given

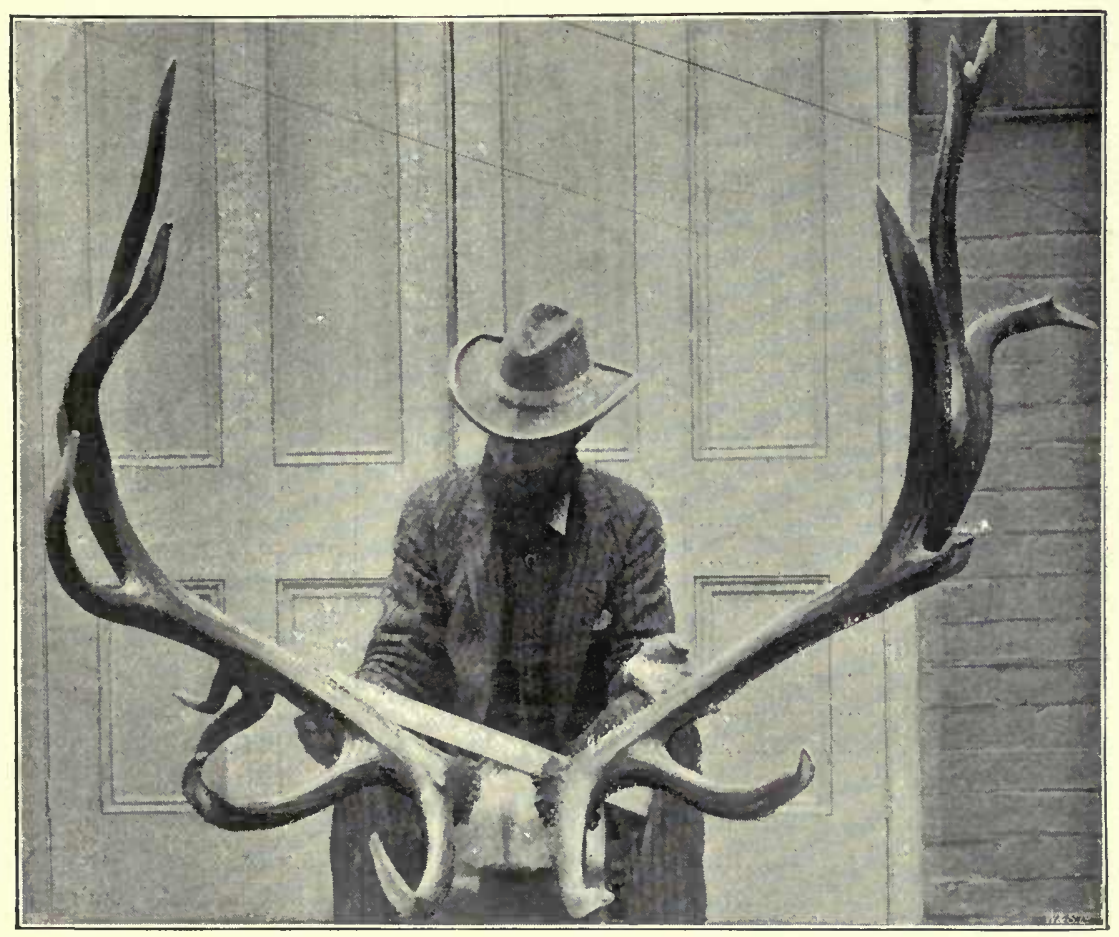

Sir Edmund Loder's Remarkably Wide Wapiti Head.

by him are quite impossible. Thus, the twenty-third head is said to measure 42 inches round the burr!

Having now dealt with some of the principal wapiti heads known to me as the legitimate trophies secured by English or foreign sportsmen, I will mention a few interesting specimens, either bought or picked up, of which I have record. One of the most remarkable I know is Sir Edmund Loder's immensely 
wide head (see illustration), which he bought many years ago in Colorado. When I first saw it hanging on the walls-unfortunately rather high up-in the very interesting and complete museum at Leonardslee, I had to take two good looks before I realised the extraordinary outside spread of this head, which is no less than 6 rin. Being also very massive, though not of great length, its weight (42lb.) approaches that of my heaviest pair of antlers, which I believe could claim to be the record weight, i.e., $48 \mathrm{lb}$. This head, owing to house-moving and absence, Sir Edmund could not exhibit at the Trophy Show in 1887 . The American Trophy Show of 1887 , at Earl's-court, contained also heads acquired by purchase or gift.

The head which was pronounced to be the most beautifully shaped wapiti at this exhibition was shown by Mr. W. A. Tulloch, who obtained this grand twenty-pointer from a professional hunter (Dick Binningham) in Montana. It was killed in 1883 , the year in which was perpetrated such wanton slaughter in the "Bad Lands" of Montana. The "pearling" and shape of this pair of antlers were as near perfection as any I have ever seen.

A British collection, containing the best show of wapiti antlers acquired by purchase, is Lord Powerscourt's well-known Sammlung at Powerscourt, his beautiful country seat near Dublin. It contains some very remarkable wapiti heads, one, the longest in England, being $64 \frac{1}{2}$ inches in length, and another 55 inches in width (outside), as well as some very fine Continental red deer antlers. To-day this collection is without question the best one of its kind in this country, where, as a matter of fact, antler collecting has hitherto been strangely neglected. Lord Powerscourt has travelled much on the Continent, and few men know the unrivalled Austrian and German collections, on the lines of which he has shaped his own, better than he does. Some of the rare ancient troplies of the chase mounted on curious carved heads could not be bought to-day at any price.

An interesting pair of wapiti antlers, which Caton pronounced to be the longest pair known to him, is in possession of Messrs. Parker 
Brothers, the well-known American gunmakers in Meriden, Conn., U.S.A. They were found in the quicksand in the Saline River, Kansas, with only the points visible, the remainder being totally

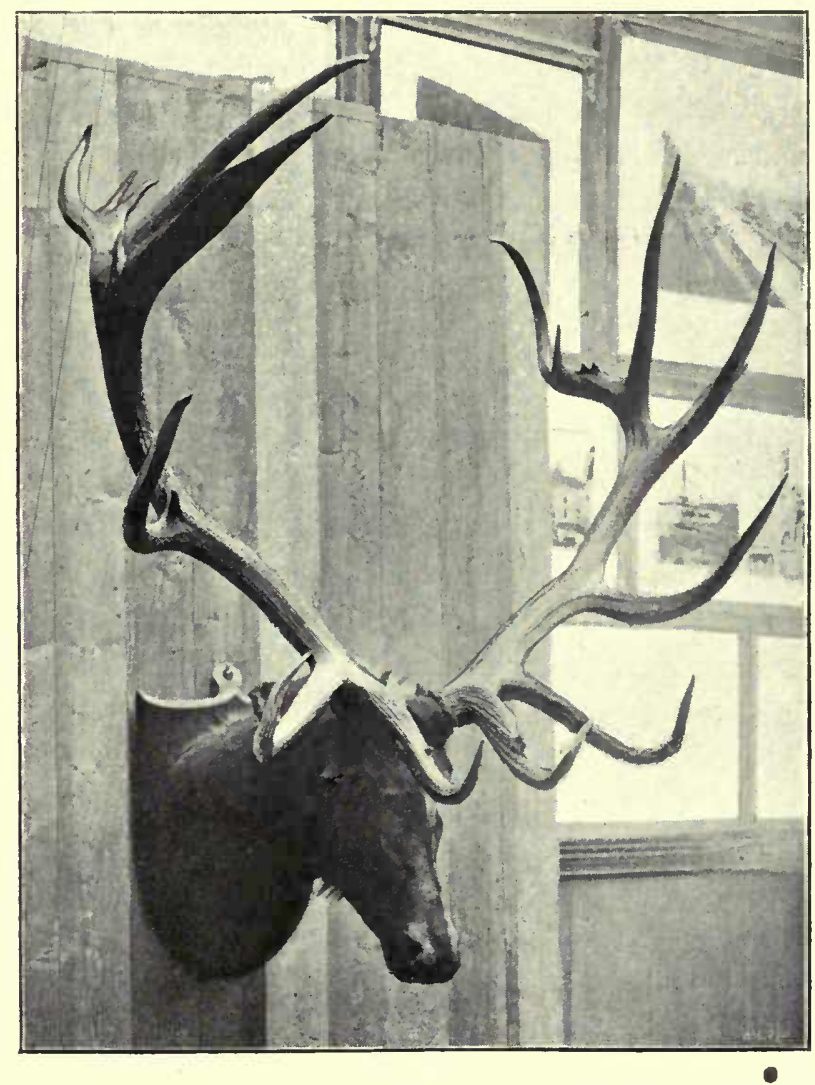

Fine 20-point Wapiti Head Exhibited by Mr. A. L. Tulloch.

Shot 1883 , in Montana, by Dick Binningham.

submerged in the sand. It is probable that the animal attempted to cross the river and was lost in the quicksand, for the entire skeleton was found embedded. They are (see illustration) a very perfect pair of antlers, of the following dimensions: Length, 59in. 
and 6oin.; width, $50 \frac{3}{4}$ in.; fourteen points. Caton, in his excellent work "The Deer of America," remarks (page 2 I6) that this head is the largest head he knew, " $5 \mathrm{ft}$. being the extreme length of which I have authentic account." The distinguished American naturalist and Director of the Smithsonian Institute in Washington, the late Professor Spencer Baird, states, in a letter now before me, that they exceed in length "by a few inches" those in the National

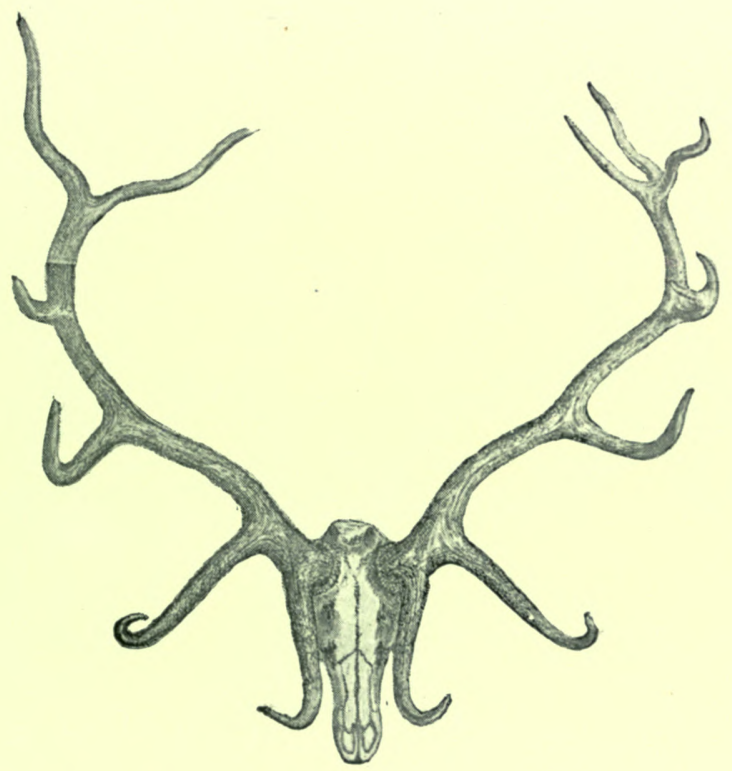

Wapiti Antlers dug out of Quicksands in the

Saline River (Kansas).

Museum at Washington, which is the National Natural History Collection of the United States. In the last chat I enjoyed with this distinguished naturalist a short time before his sudden death, we were discussing the size of the pre-historic wapiti. A passage in a letter from him referring to this subject runs: "We have a broken part of a shed horn, embracing burr, portion of shaft (beam), base of brow antler, and a portion of second brow antler 
(bay); of the last $15 \frac{3}{4}$ in. remain, the girth at the point of fracture being $5 \frac{3}{4} \mathrm{in}$. The length of the brow antler must have been at

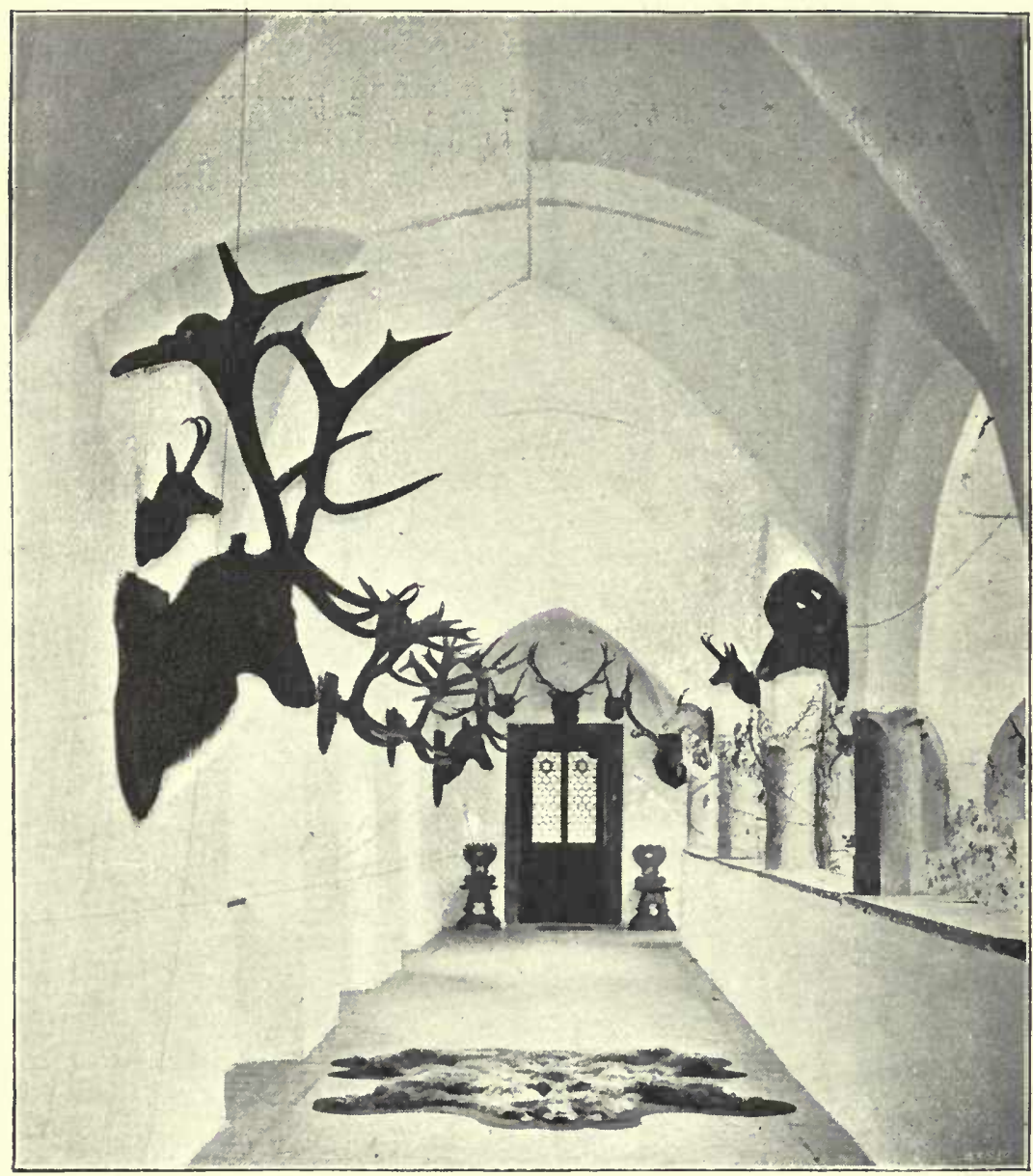

Some of the Author's Trophies in Schloss Matzen, Trrol.

(In foreground_abnormal Wapiti Antlers.)

least $2 \mathrm{ft} .3$ in., measured from the burr. These dimensions indicate proportions much in excess of anything we have at the present day." 
A very long, but somewhat slim, pair of wapiti antlers hangs in Messrs. Schoverling and Daly's gun shop in New York. I have

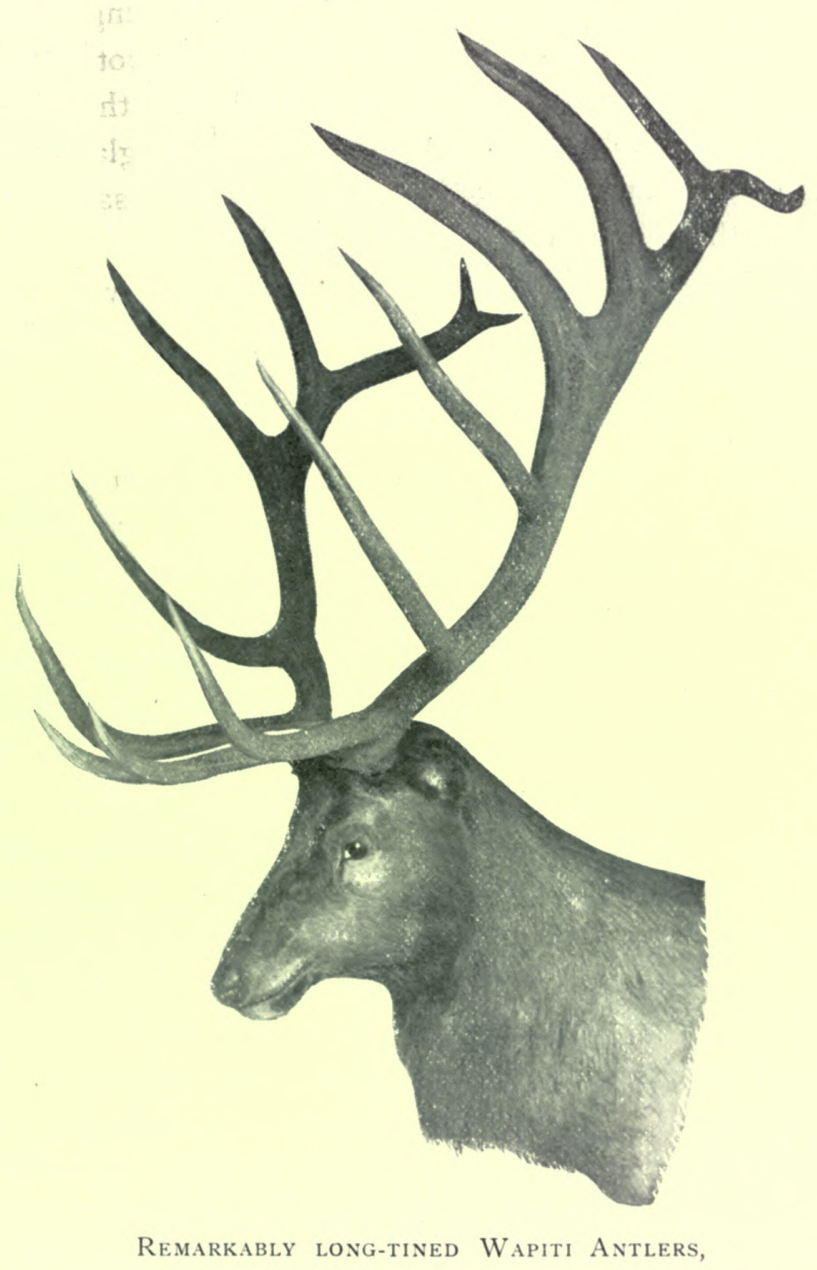

Picked up in Wyoming, and belonging to General Hankey.

not been able to obtain any authoritative measurement of this head. They are reported to be 64in. in length.

Two rather remarkable abnormal wapiti heads, with broad 
shovels of unusual size, can be seen in the picture of the corridor where I have a number of my trophies hanging. Both heads I picked up years ago, not very far from the spot where I got my biggest heads, viz., on the western slopes of the Big Windriver Mountains, of which favourite region I am glad to be able to reproduce a good photograph. In this locality I saw more and finer wapiti than I have anywhere else.

Not all that one reads about largest wapiti heads on record can be believed. Thus last year the Field contained a detailed notice, copied, I believe, from an American paper, of such a gigantic Colorado trophy, "the largest pair of elk-horns in the world," which the Emperor of Germany was about to receive as a present. Measuring " $\mathrm{I} 2 \mathrm{ft}$. from tip of beam to tip of beam across the skull," it gave other astonishing dimensions. Being interested in the matter I wrote, some five months afterwards, to the person named as the donor, and also to the Emperor of Germany's chief private secretary, with the view of finding out what truth there was in the notice. The former left my letter unanswered, the latter replied that nothing was known to the Emperor of such antlers.

Sometimes, strange to say, men who consider themselves good judges are taken in by made-up antlers. A case in point occurred, as it is perhaps hardly necessary to remind the reader, some thirty-six years ago, when the late Mr. Frank Buckland was deceived by a "record" red deer head from Transylvania, which Lord Powerscourt had a short time previously bought through a friend in Vienna, without having himself seen the head. These antlers continued to figure in the "Encyclopædia Britannica" and in Rowland Ward's "Horn Measurements" as the largest red deer antlers in the world. Their recorded weight of $74 \mathrm{lb}$. was so manifestly impossible that I was led to examine into the matter, with the result that soon afterwards I was enabled to publish a letter from the owner in which he freely acknowledged the spuriousness of his trophy (Field, Jan. 26, I 895).

I little thought at the time that I should have to lift the curtain 
in a similar manner on two other occasions in respect to the "largest wapiti head on record."

According to the second edition of Rowland Ward's "Records of Big Game," a head belonging to Major-Gen. Sir Wm. Crossman was the largest on record, the antlers measuring $73 \mathrm{in}$. and 6gin. respectively. I was anxious to verify these astonishing dimensions, and wrote to the owner in Northumberland about it, asking him to allow me to publish an illustration of the head. He very kindly at once sent me a photograph of the trophy, with the permission to do anything I liked with it. He also gave me the following account of how he came into possession of the antlers: "I happened, in the year I88I, to be in Portland, Oregon, U.S., and strolled one day into the hall of a fire brigade station in which a number of very fine heads were fixed on the walls. This one particularly struck me from its size and symmetry, and the peculiarity of the antlers crossing at the tips. The owner refused to sell any at first, but after some talk and bargaining I got possession of it and sent it here, where it has been ever since."

The first glance at the photograph sent me, removed from my mind all doubt about this head being the identical one which I had examined a short time before the General's visit to Portland, and which I found was built up of two pairs of antlers. The head was hanging at the time, also, in a fire brigade hall, and at first the people refused to take it down. Being acquainted with some of the "leading citizens" of Portland, I managed at last to examine it. It revealed what I had suspected from the first, namely, that it was built up of two pairs of wapiti antlers, the upper length being cleverly joined on above the fourth tine, the seam being covered with cement or plasterof-Paris stained in close imitation of the dark reddish brown tint which, we know, is a peculiarity of Pacific coast wapiti antlers.

On receiving this photograph, which instantly recalled the incident to my mind, I at once communicated my suspicions to the 
owner of the head, suggesting that he should subject it to a closer examination, and tap the upper length of either antler with a hammer, which would cause particles of the cement to become

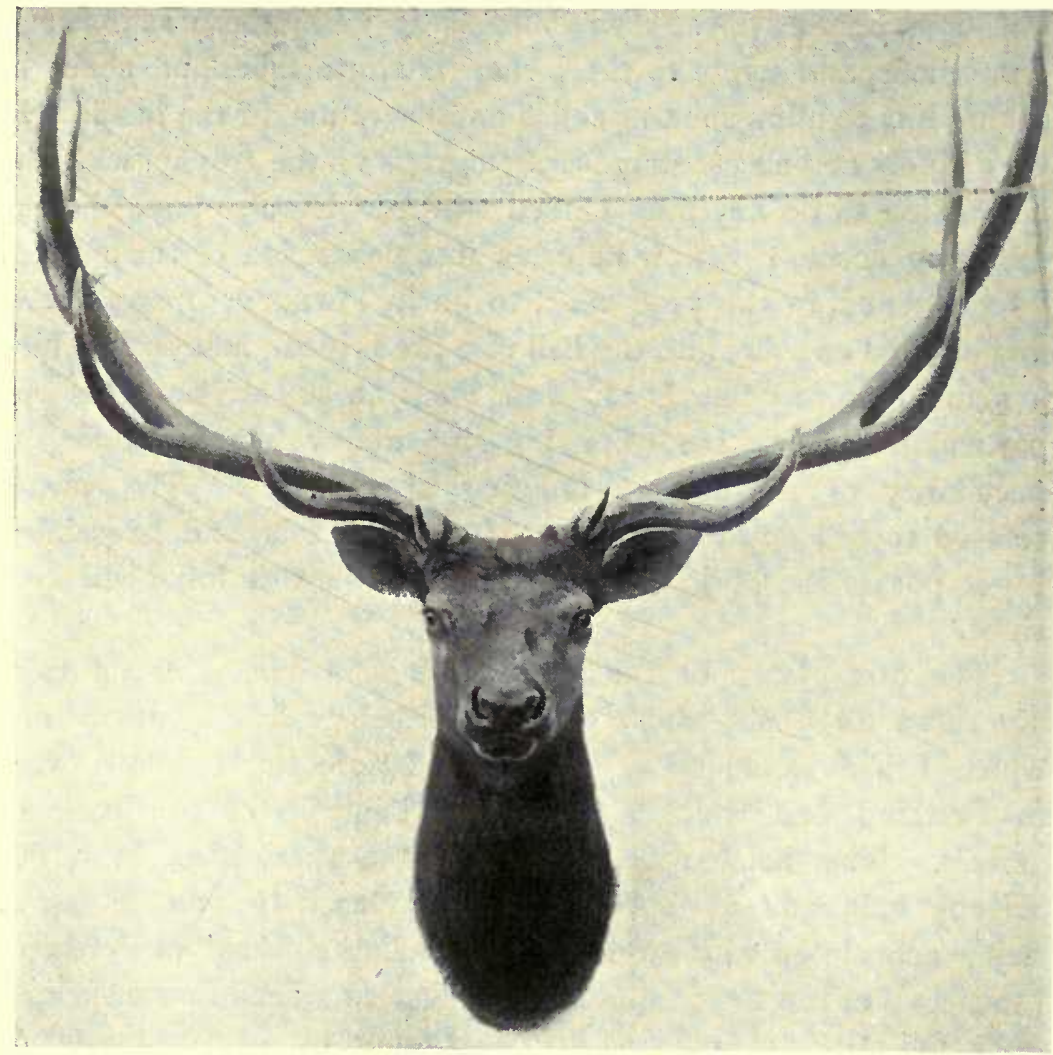

Widest Wapiti Head on Record.

Reported outside width, 68in. Property of W. F. Sheard, Tacoma.

dislodged. A letter received from him by return of post confirmed the correctness of my conviction concerning the true character of the antlers, a large piece of the stained cement being enclosed as a 
proof of the skill employed in the manufacture of these spurious antlers.

In the recently published third edition of Rowland Ward's "Records of Big Game," the faked-up Oregon head is omitted, and in its place, as the largest wapiti head on record, we find a head belonging to Sheard, the Tacoma taxidermist, and which, it is stated, measures 7 oin. in length, 68in. in outside width, and $14 \frac{1}{8} \mathrm{in}$. in circumference. No such head, I am convinced, is in existence, the compiler of "Records" having probably copied into his pages the largest dimension of each of three wapiti heads, and endowed one head with these three record dimensions. That this is the case is proved, it would seem to me, by a letter published in the New York magazine Recreation, and signed by Sheard, in which he distinctly speaks of three heads. The passage in question runs: "I will show you a pair of elk horns that are perfectly even, which spread 68in. between the extreme outside edge of the main beams. I will also show a photograph of a pair of elk horns the left beam of which is 7 oin. long, the right beam $68 \frac{1}{4}$ in. long, spread 62in. I will show you a photograph of a pair of elk horns that are $14 \frac{1}{2}$ in. in circumference around the burr, spread 58in." As this letter appeared in a well-known New York periodical, American sportsmen and naturalists probably know all about these three heads, and it would be interesting to learn their opinion about them.*

* I take this opportunity to add the following further explanation concerning this matter. On observing in the third edition of "Records" the mistake into which I consider its compiler had fallen, I wrote at once to Sheard, in order to make quite sure, asking him to send me a photograph of the long (7oin.) head, he having previously sent me a photograph of the widest (68in. trophy). His reply, under date of June 10,189 . runs as follows: "I have no photo of the elk head 7 oin. length and $62 \mathrm{in}$. spread; the plate got broke, and this head is sold. But I believe I sent you a photo of the elk head that spread 68 in ; if not, I will." The photograph he sent me is the one here reproduced. On receiving this letter I mentioned in a letter to the Field the fact that Rowland Ward had endowed his record wapiti head with dimensions that I thought it did not possess. This letter appeared in the issue of Sept. 9. 1899. In the following week's Field (Sept. I6, I899) there appeared an editorial note stating. in 
One word more and I have done with this record head. It is to express regret that Sheard, the owner of this wonderfully wide 68in. trophy, did not leave the antlers unmounted. It would have allayed any possible suspicion of the spread being artificially obtained, and, besides, would have permitted the weight to be ascertained at all times. I do not think that it is too much to say that natural history lays upon all persons claiming to be the owners of record specimens the moral obligation to facilitate as much as possible a verification of their claim.

In the eyes of the connoisseur of antlers the wapiti head-and be it the finest ever bagged-lacks one important point of merit, one which distinguishes the European red deer, and endows a fine head of that species with a beauty all its own. It is that wapiti antlers never form a "crown" or cup-shaped cluster of tines on top, but invariably bifurcate to the very end. I am convinced that there is no regular crowned wapiti head in existence; the one depicted by Caton, and which he says is the only one he has ever met with, has the crown only on the right side.

The student of the older literature on America is struck by the scarcity of written and pictorial records relating to the wapiti, considering that this deer was plentifully represented in the Atlantic States. With one single exception, none of the early travellers who published their accounts in the latter half of the sixteenth and the

reference to my criticism, "that on the authority of Mr. Sheard (the owner of the specimens), who supplied Mr. Rowland Ward with the particulars he gives in his 'Records of Big Game,' the measurements and locality as published are correct." In the face of the evidence which I have adduced in the above, I am inclined to think that the editorial correction is based upon a mistake, and that the cable inquiry which I am informed was made by Rowland Ward simply proved a fact which was never in dispute, viz., that the dimensions he gives are correct, the fact that they belong to two or three trophies and not to one having probably escaped the necessarily brief cable inquiry. That one and the same wapiti head should be by far the longest, by far the widest, and by far the thickest in the beam of which we have any record, is, so far as my experience goes, so extraordinary a combination as to be next to impossible, and this view, I may add, is shared by all those versed in antler lore with whom I have conversed about it. 
first half of the seventeenth century, and which in many instances De Bry's diligent graver adorned with copious illustrations, contain a picture of this deer. The exception I allude to occurs in Laudonnière's narrative, illustrated by Le Moyne, a French artist, who accompanied the former in his expedition to Florida in 1564 . It is (see illustration) a picture representing the Indians' method of

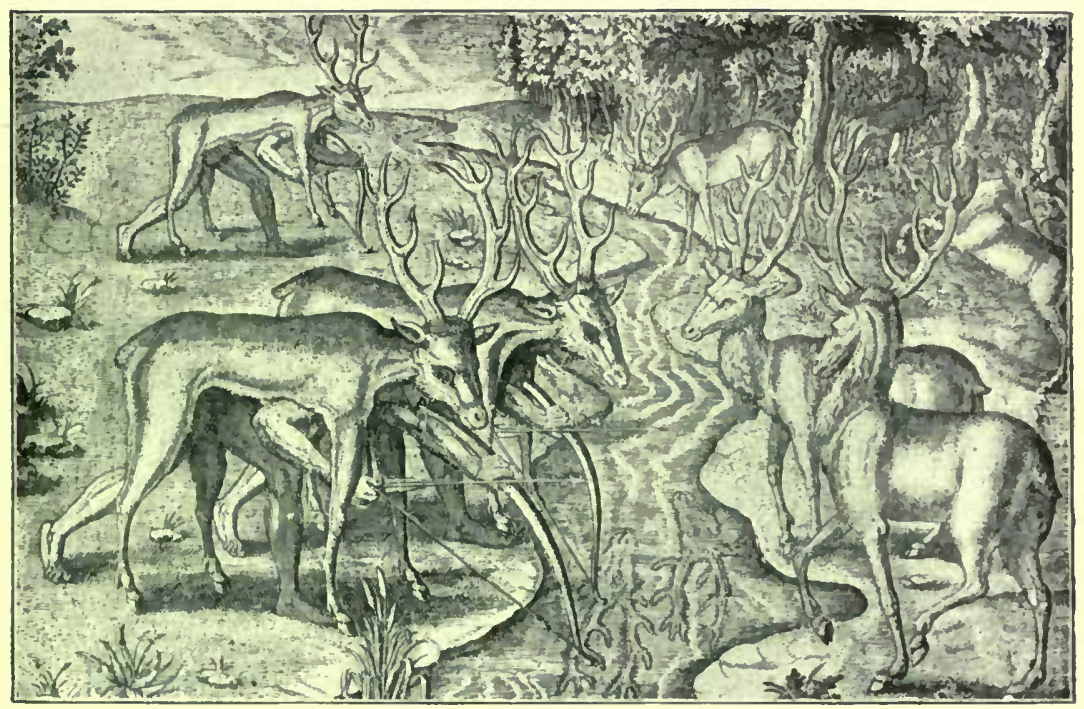

Stalking Wapiti in the Sixteenth Century.

(From Laudonnière's Narrative of his Expedition to Florida, A.D. 1564.)

stalking wapiti, for which purpose they threw deer skins over their bodies so as to enable them to approach their quarry.* The artist who drew the picture had evidently not realised the peculiarity of wapiti antlers never forming a crown on top, and probably copied a handy pair of red deer antlers.

* Messrs. Osgood and Co., of Boston, republished in 1875 , in a small edition, this highly interesting narrative. 
It is rather curious that such a close observer as Caton, having at his disposal the material and the best of opportunities to ascertain the live weight of adult wapiti, has failed to give us a single weight excepting in the case of a three-year-old stag after a journey of four days on steamboats and railways. This animal he appears to have actually weighed $(65 \mathrm{olb}$.), while of older specimens in his own park he invariably only speaks of "estimated" figures (up to rooolb. or 1 1oolb.). It is all the more gratifying, therefore, to be able to state that it was left to an English sportsmannaturalist, Sir Edmund G. Loder, Bart., to ascertain in an accurate manner the clean weight as well as the measurements of a fairly large wapiti stag.

He furnished me with the following particulars concerning the largest wapiti he killed in Western Montana.* From root of tail to tip of nose, 108in.; tail, with hair, $7 \frac{1}{2} \mathrm{in}$. Girth, at brisket, $6 \mathrm{ft}$. Circumference of neck, $54 \mathrm{in}$. Weight, without entrails or liver, lungs and heart, $75^{2 \mathrm{lb}}$., but as he was killed on October 4 , the fat was all gone. Weight of liver, lungs, and heart, 4olb. It is therefore certain that the beast as he entered the rut must have scaled over goolb., and most probably close upon I ooolb., a weight which some of my largest stags must have exceeded by many pounds, for according to my notes several taped as much as $7 \mathrm{ft}$. 2in. girth at brisket. I should therefore not be the least surprised to hear that a really big stag was found to exceed 1 roolb. live weight as he entered the rut. Considering that to-day stags exceeding 53st., or $746 \mathrm{lb}$. (avdp.) dead weight are

* This stag was killed in the Flathead country, where the forests are a good deal denser than in Wyoming and Eastern Montana, so that it was not a typical wapiti country, but, as Sir E. loder's trip was undertaken with the special object of getting Rocky Mountain "goat," following for this purpose a route I suggested to him, it was impossible to combine in one expedition visits to any of the few remaining really good wapiti countries, where he probably would have killed some larger wapiti. Mr. E. N. Buxton's expedition in I 884 to the Windriver Mountains, in Wyoming, for which I also supplied him with particulars of route, \&c., was, so far as wapiti were concerned, more successful. 
reported to exist in Europe, a I Ioolb. wapiti would be far less remarkable.*

To the connoisseur in antlers the Pacific Coast districts of Oregon and Washington present less inducements than those of the interior, say Western Wyoming, and Eastern Idaho, which may be considered to be the best places for really fine antlers. Of course, as these are more or less timberless highlands, where game is far more easily seen and pursued than in the dense coast forest, the remaining bands of wapiti will be killed off in a very few years, and certainly the next generation of sportsmen will be relegated to the less attractive coast regions, where a rainy climate and dense timber not only make sport far less enjoyable and much harder work, but renders the bagging of good heads if not impossible, at least more a matter of chance.

One of the regions deserving the attention of sportsmen are the Olympic Mountains, in the north-west corner of Washington. They are a rugged mass of irregular and steep ridges, some of which attain a height of over 7 oooft., rushing streams and small lakes occupying the forest-clad depressions. Fortunately for the sportsman, no paying mines have so far been discovered in the Olympic Mountains; and another circumstance favouring him is the fact that the Government has caused several trails to be opened by which means some fair hunting-grounds can be reached. It is, of course, no longer an untrodden wilderness, but, at the same time, the roughing that has to be undergone to obtain good sport, though perhaps of a mild sort, will be sufficient to give zest to the expedition. $†$

* I am alluding to a big Caucasian stag, of which Prince Demidoff has published an interesting account in the "Encyclopredia of Sport," Vol. 1., p. 308. He tells me that this stag as he dropped must have weighed even more, for in order to weigh the carcass it had to be cut into pieces and carried down, and the weight thus ascertained ( $53 \mathrm{st} .4 \mathrm{lb}$.) made no allowance for loss of blood. It seems almost incredible that red deer of this weight should exist in Europe to-day.

+ For further details 1 think the visitor could not do better than inquire of Mr. W. F. Sheard, 910, A-strect, Tacoma (Wash.), who, though I can only speak froin hearsay, as I do not know him personally, seems willing to assist sportsmen visitors so far as he can. 
The Biological Society of Washington has lately proposed to mark this difference between wapiti inhabiting the Rocky Mountains and those frequenting the Pacific Coast districts by calling the latter Cervus roosevelti, or Roosevelt's Wapiti, a distinction with which I entirely agree. The following is the description given by $\mathrm{Mr}$. C. Hart Merriam, of the Smithsonian Museum :

General characters: Size, large; head and legs, black (probably only in winter pelage); skull and antlers, massive; beams of antlers relatively short and straight, with terminal prong aborted.

Cranial characters: The skull of Cervus roosevelti, compared with that of Cervus canadensis from the Rocky Mountains, is much larger, broader, and more massive. The frontals are not only conspicuously broader but are very much flatter, giving the cranium a different profile. The muzzle also is much broader. The cavities in front of the orbits, on the other hand, are decidedly smaller.

The antlers are large, heavy, and relatively short, with the terminal prongs aborted, so that the total length from burr to tip is about $500 \mathrm{~mm}$. (about 2oin.) less than in well-formed antlers of the Rocky Mountain elk. The brow, bez, trez, and fourth tine are similar to those of the ordinary wapiti, but above the fourth the antler is flattened and sub-palmate, and ends in two or three sharp points, the tips of which reach only slightly above the tip of the fourth prong.

Gengraphic distribution: Roosevelt's wapiti inhabits the dense coniferous forests of the humid Pacific coast strip, from near the northern end of Vancouver Island southward through the coast ranges of Washington and Oregon to north-western California.

It will be seen that this description does not refer to another very characteristic difference, namely, the more rufous colour of the coast district antlers and their smoother appearance. Rarely does one see finely pearled antlers, for in consequence, I suppose, of the density of the timber they appear much more " rubbed," i.e., less. pearled. To me, if I may express an opinion, they lack some points of beauty possessed by most of the trophies obtained in the Rockies proper.

Concerning the present distribution of the wapiti, a few remarks may be offered in correction of the misleading statements made by 
Ward in the second edition of his "Records," in which he says that the wapiti is to be found in the Alleghany regions of Pennsylvania, Virginia, North Wisconsin (?), Minnesota, \&c. It seems hardly credible that in a text book of this sort, written A.D. 1896 , there should appear such an incorrect statement as that wapiti still inhabit the Alleghany Mountains of Pennsylvania, or the Virginia hills, where they became extinct in the first quarter of the present century.

Caton, the best authority possible, states that in the woods of North Illinois, a region many hundreds of miles further west, and one which became settled up a century or two later than Virginia, the last wapiti was seen in 1820 , or thereabouts.

From Wisconsin and Minnesota the wapiti has, I am informed, also long disappeared.

A few remarks concerning an historical landmark made of wapiti antlers may not be out of place. Prince Wied, in most respects a painstaking and observant investigator of early days, has left us, in his interesting account of his travels in what is now Dacota and Montana, a somewhat brief account of the famous Elkhorn Pyramid on the Prairie à la Corne de Cerf. It was one of the early historical landmarks on the banks of the Missouri when fur-traders and trappers were the only whites who visited the transMissourian West. Composed, so he says, of certainly more than Iooo pairs of wapiti antlers, the pyramid was about I $8 \mathrm{ft}$. high and $15 \mathrm{ft}$. in diameter when he saw it in 1832 . His account of its origin varies triflingly from other contemporary reports, according to which it was the result of a certain famous fall hunt by a Sioux hunting party, armed, it must be remembered, not with flintlocks, but with the less effective bow and arrow. According to Prince Wied, the antlers were contributed by different hunting parties at different times as offerings to ensure "good medicin" on future occasions. He also remarks that the strength of the party making the offering was marked in red strokes on the antlers. Long after it had disappeared many a camp-fireside legend busied itself with this curious pyramid, increasing its altitude, it is needless to say, to 
treble its real height, and making of the Iooo pair of antlers I 0,000 ! *

As probably the majority of these trophies or sacred offerings were picked heads, the finest of their kind, it is regrettable that this traveller did not take the trouble to ascertain the dimensions of the largest, for it would have thrown light upon a vexed question, i.e., whether wapiti antlers have experienced the same deterioration within the last fifty or roo years, which, for instance, is noticeable when we compare trophies of European red deer, say, of the seventeenth century with those obtainable to-day. To judge by the measurements of the finest head obtained by his party-a twenty pointer with a length of antlers of $4 \mathrm{ft}$. rin. in a straight line, and a weight of $26 \mathrm{lb}$. - such deterioration has not occurred, for many better heads have been obtained in our days. Another fact would seem to corroborate this assumption, namely, that among the old heads dug out of bogs and quicksands there are, as already mentioned, few of superior proportions to those of to-day.

Another matter of interest in connection with wapiti heads is the following. That the normal number of tines on wapiti heads is twelve, and that fourteen, sixteen, eighteen, and twenty-point heads are very much rarer than among red deer, is a well known fact. Among the many thousands of wapiti antlers I have seen there were not half a dozen of more than eighteen tines, and among the 400 or 500 stags I have killed myself or had a share in killing, almost all of which were picked animals, there were only two heads of eighteen and not one of more points.

* The Scientific American tells us that at Mammoth Hot Springs, in the Yellowstone Park, there is a fence made of wapiti horns. It encloses the greater part of the grounds of photographer F. Jay Haynes' studio. The fence is composed of over 303 selected "elk" horns. All of them have twelve points, and a great many have fourteen points. They were shed in March, I895, and were gathered in June of the same year by Mr. Haynes and three of his men, within a radius of ten miles of Mammoth Hot Springs, and within four days' time. There were about 2500 wapiti in the park then. 
Curious, therefore, is the result of a very interesting experiment of turning out wapiti in an Alpine district in Europe. I am referring to Count Arco's attempt to domesticate the wapiti in the mountains of Berchtesgaden, near Salzburg, made in $185^{6}$. After losing some of the imported stock there were left two stags and two does. When he finally, in $\mathrm{I} 86 \mathrm{I}$, abandoned the experiment, and sold his herd of four American-born wapiti,

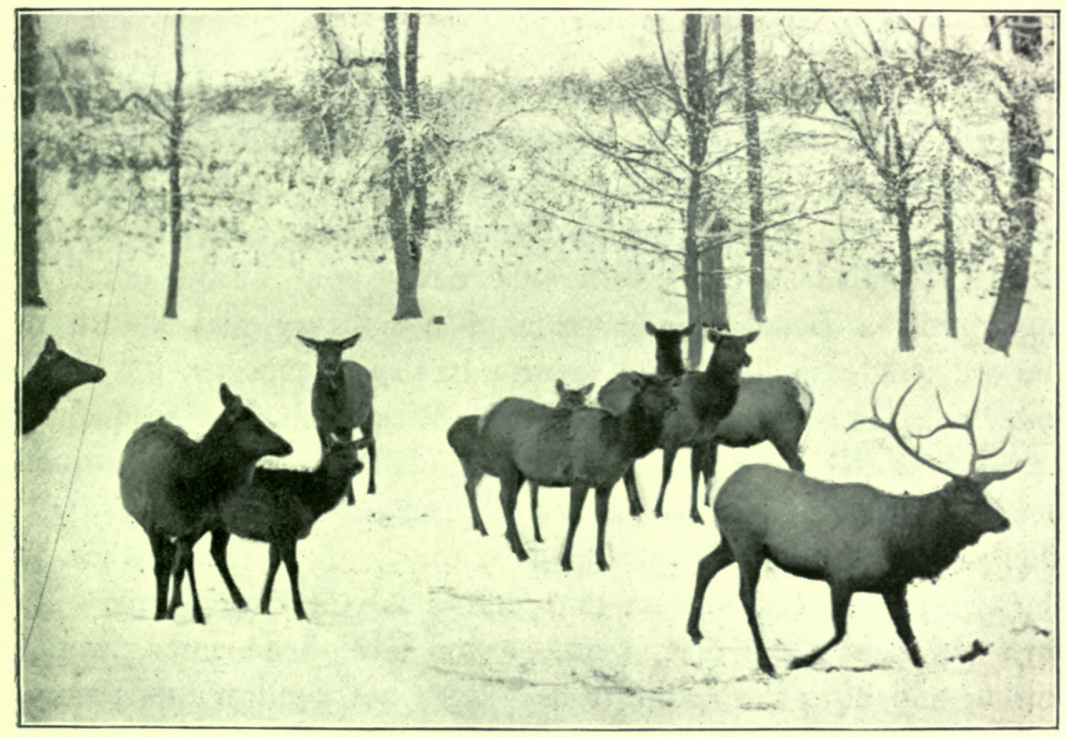

Wapiti IN Wintek.

together with their offspring, consisting of four stags and six hinds, to Prince Pless, in whose vast Silesian deer park-the largest in Europe - their progeny are still to be seen, the following details concerning the antlers of the American-born stags were noted. The one stag when sold was ten years old, his last antlers when shed weighed almost 3 olb. avdp., and had eighteen points; the other stag was nine years old, his last antlers had twenty-tw' points, those of the previous year twenty points, and those of the 
year before that twenty-four points !* To what must these quite unusual instances of extreme bifurcation be ascribed? If to the artificial feeding during the major part of winter and early springfor those seasons are extremely trying ones in the elevated and inhospitable regions where this experiment was carried out-it would be an unanswerable argument in favour of the writer's theory that artificial food influences the growth of antlers more than anything else, a hypothesis which a certain school of Scotch theorists combat as not in accordance with their theory that heads are inherited. $\dagger$

"Setting back" - that is, putting on a less number of points on the new antlers than the animal carried the preceding year, and which often occurs with the red deer of Europe-seems to occur also with wapiti, though the circunistance that by far the largest number of old wapiti bulls carry only twelve points is apparently a strong confirmation of the theory that nature in the wapiti's case limits the growth to that number, a limitation known also in the case of other deer. Western hunters frequently assert that the reason one so rarely finds more than twelve-tined heads is caused by the fact that all the older wapiti bulls, who would have more points, get killed by the young ones, or rather by the twelve-pointers, who at that period are in their prime. My own experience, and that of others who have been among wapiti during and after "whistling time," does not confirm this theory, though, in view of the characteristic of wounded deer always seeking the densest covert, one must not jump at too hasty conclusions in this respect.

* In counting the points the German fashion, which obtained also in England in old days, of doubling the number of tines on the antler having the most points, was followed. The antlers are preserved in the Arco Palace in Munich.

+ I am glad to be able to say that a friendly peace has now been established between my most formidable opponent, Mr. Allan Gordon Cameron, and myself, for, as he was good enough to write to me, when asking me for some special information anent a work he is preparing on the distribution and affinity of the stag group, he has seen reason to modify his views upon the points concerning which we were most at variance. 
Another circumstance that I noticed, and one that my previous and subsequent experience with wapiti during the rutting season confirms, was that the master stags were by no means distinguished by the largest antlers, but appeared, with a few exceptions, to be the largest in body.

To watch wapiti fighting-a sight that in the old days frequently stirred the heart of the sportsman who had the patience and skill to get close up to the scene of battle-was to witness grand exhibitions of endurance and prowess. Not quite so quick in their movements as the European red deer, they would yet rush at each other with the same angry impetuosity, and one could often hear the sound of clashing antlers for some distance off, and be guided by it to the spot where the battle royal was proceeding; the hinds, graceful but coy representatives of their sex, calmly looking on, nibbling at the grass, and, while permitting forbidden attentions from the younger stags, taking apparently but slight interest in the issues of the mortal combat.

So far, however, as my experience goes, only a minority of these engagements terminated fatally - at least, on the spot. The majority of fights between old bulls that I have had occasion to watch ended in consequence of the exhausted state of the combatants, who finally would drop on their knees, and, with antlers apparently inextricably interlocked, thrust and push till their last particle of strength was exhausted, and their panting breath issued from their open mouths like so much steam.

One more than ordinarily striking battle I once watched in a then nameless range of mountains in Western Wyoming, on one of those bright moonlight October nights one would like so much to live over again. The air was keen with frost, while a thin vapoury mist veiled the depressions in the broken surface of the country. Distant "whistling" of wapiti lured me from our snug camp fire soon after an ample supper had satisfied an appetite made ravenous by a long day after some distant bighorn. With my pipe and old Express, I strolled forth into the still bright night. The wind came straight from the direction of the band, now hardly more 
than half a mile off, but separated from the "sink" where we were camped by a belt of forest, through which a slow-flowing stream meandered. It was the home of generations of beaver, who had dammed up the stream in numerous places, thereby forming large pools. At the head of each was to be seen a patch of beaver-meadow, with smooth green sward. As I entered the forest I found it alive with wapiti, moving about in the semi-darkness in spectre-like silence, while now and again a broad moonbeam, stealing its way through some break in the bower of branches overhead, would cast its light upon a doe or young stag startled by signs of my close presence, standing with pricked ears, peering into the darkness that hid all but the dimmest outlines of my form from their ken. Slowly and cautiously I pursued my walk. My moccasined footfall disturbed but few of the deer, and I soon reached the brink of a smooth, glade-like beaver-meadow, rather larger than the rest, and now bathed in the mellow, silvery light of one of the brightest fuli moons I have ever seen. Every blade of the velvety sward appeared to sparkle, and the surface seemed as smooth and level as a billiard table. There were only a few wapiti on the meadow, but they were all bulls, and "whistling" away as if it were the first, and not the third or fourth, week of the mating time. This whistling is always a singularly weird, inimitable sound, and one that can only be likened to the quairt and yet melodious strains of an Eolian harp; the stillness of the night, too, as well as the other surroundings, added to its peculiarity.

Off and on, while making my way through the forest, I had heard the clashing of antlers; but it was mere play in comparison to what I was presently to see. On reaching the glade, I had seated myself on a fallen log, overlooking the tranquil scene, and there, hidden by the deep shadow of some overhanging trees, I was effectually screened from observation by the wapiti peopling the meadow. I had not been seated for more than five minutes, when suddenly the whistling on the glade stopped, and the half-dozen stags who were just then close together in the centre, dashed off in different directions, as if a bomb had fallen in their midst; and 
probably they had good reason for doing so, for the stately old wapiti bull who, with majestic gait, stepped out from the deep shadow into the flood of silvery light, was no doubt a match for any two of the young striplings who had disported themselves on the glade. Slowly he stalked toward the middle of the meadow, occasionally whistling, but more frequently stretching out his distended neck and lowering and raising his head, as if testing the supple strength of his shoulder muscles, in all the consciousness of his unvanquished strength. He was not further than seventy-five yards from me, and in the bright light I fancied I almost could see the eye of the noble beast, or count the branching tines, as he swayed his many-pointed antlers to and fro. One by one, with furtive tread, the young fry returned to the glade; and presently a couple of young ones, more venturesome and impudent than the rest, actually made a boldly planned but feebly executed dash towards the master stag, for before they got within reach of his massive horns, five feet long, they swerved to one side and began - butting each other with considerable vigour. Not long, however, did this by-play last, for presently another great wapiti, moving at a fast trot, came out of the forest, and put the young combatants to much the same sudden rout as the first master stag had done when he appeared on the scene. The latter, however, stood his ground, and for a minute or so the two faced each other, all but their heads motionless. The last comer did not appear alone on what was soon to prove a hard-fought battlefield, for four or five hinds had followed him out of the forest. With gingerly step, raised heads, and pricked ears, they came out into the open. Probably they had been alarmed by some sign of my presence, and were now on the qui vive, while their lord-quite oblivious to other danger - had centred his attention upon his rival. How the two stags approached each other, as well as the actual commencement of hostilities I was prevented from seeing, for the wary hinds, making a circle, as if to spy out whether the coast was really clear, had placed themselves between the two stags and my hiding-place. 
Soon the clashing of antlers and angry snort of the combatants told its tale, and, as I knew from former experience that stags while they are fighting are quite oblivious to what occurs around them, I stepped out into the light, and gave a low shout, which sent the non-combatants in double quick time back into the forest.

Probably I might have walked close up to the stags without interrupting the tussle; but I was afraid that one or the other, or both, might turn against me, as I knew our European red deer do during the rutting season, and an Express is but a poor weapon at night time. So I kept at a respectful distance, some twenty or thirty yards from cover, and from there I watched the fight for quite half an hour. For several minutes at a time the antlers appeared inextricably locked together, and as one of the stags seemed the stronger, though not the more agile of the two, superior weight would in those moments enable the heavier animal to fling his adversary from side to side, without, however, being able to free his own horns wherewith to do grievous injury to his foe. Before long one was on his knees, pressed down apparently by main force; then the other, staggering back, would for a brief moment halt before rushing with deadly intent at his adversary; but by the time he had regained his breath, and was ready for the onslaught, the foe was on his legs again, and antler crashed against antler with a force that seemed irresistible. The heavier of the two stags appeared to be well aware of the one advantage his superiority in weight gave him, for the tactics just described were repeatedly tried by him, only to be foiled by his agile adversary, who invariably managed to regain his feet and receive the charge with lowered head and antlers en garde. The combatants had moved about the meadow, much as expert boxers would, though after a quarter of an hour's fighting, weight had told its tale, and the smaller stag had to retreat more frequently than ever, and the adversaries were fast approaching the edge of the forest at the latter's back. Here a last stand was made by the defeated one, and a ten minutes' tussle ended by bringing both on to their knees ; and here, too, the repulsed one received his death wound, though 1 
failed to see exactly how it was inflicted, the movements being so rapid and the light too indistinct. It appeared to me, however, that the weaker stag, on regaining his leet first, made a dash at his foe, but from some cause or other his lunge missed its aim, and, while the impetus carried him past his still kneeling adversary, his whole flank was exposed to the thrust of the latter's horns. The next second he was down too, but this time with a heavy thud stretched out at full length, just out of reach of the kneeling victor's horns, who, too exhausted to rise, kept butting at the body which he could not reach. A minute !ater they were both up again, but the battle was decided, and the wounded hart fled into the forest, where I found him the next morning dead, with a ghastly slash two feet in length, that had ripped open his side and penetrated to his vitals.

While on the subject of deer and their antlers, let me say a word or two here concerning the subject of measuring stags antlers. Some years ago the columns of the Field contained a lively correspondence anent this very matter, a well-known sportsman, writing under the nom de plume of "Smoothbore," having started the ball by suggesting that it was high time that there should be established an uniform principle of measuring and judging antlers, horns, \&c. As everyone knows who has given attention to the subject, the usual run of English sportsmen either do their measuring according to their own ideas, or do not sufficiently regard certain useful features connected with, or bearing upon, natural history. It was, I thought, a most timely suggestion, for do not British sportsmen go further afield than any other? To judge by some of the replies, the go-as-you-please spirit, which has hitherto tabooed scientific accuracy, is still very much to the fore. "Smoothbore" suggested that a committee of experts should issue a circular to all well-known sportsmen and naturalists with the view of collecting expert opinion for the purpose of framing a definite standard of measurements and points of merit.* "Smoothbore," with whom, I must add, I am not

* Field, Nov. 9, 1895. 
personally acquainted, had been good enough to single me out for the leading position upon the committee, and though I at once strongly deprecated my qualifications for this post, I had no hesitation in expressing my conviction that such a scheme, if properly carried out, would not only fill a long-felt want and prevent the now-existing confusion, but also would lead the way to the publication of more correct sportsmen's handbooks than are some of those which at present figure under that title.

Among the opponents to "Smoothbore's" proposal was one gentleman in particular, whose somewhat vehement criticism* forced upon one the conclusion that he had failed to grasp the real object which "Smoothbore" had in view. Had he understood it he would hardly have written that "the proposal to establish a committee to tell me what I prefer to estimate for myself jars upon my sporting instinct, and violates the true sentiment of sport." In further explanation of what his sporting. instinct is like, he stated that "the trophy in my own collection that, perhaps, I value most, is a miserable little six point red-deer head, badly set up by a country stuffer - the head of the first stag I ever killed, 'A poor thing, but mine own.' "

Now, so far as I grasped "Smoothbore's" proposition, nobody had the slightest intention of dictating to any sportsman which of his heads he himself should value most; on the contrary, his own opinion, as that of the sportsman who killed and owned the trophy, would, in accordance with the ordinary principles governing a judge or jury, have no weight whatever with a properly constituted committee. Reverse this writer's case, and say that his first stag, instead of being a "miserable little six pointer," had been a twenty-four pointer of extreme size, as was that of a lucky young friend of mine. Would he have written in the same strain? But leave all such personal considerations out of play. Certain it is that till some such basis of common agreement be arrived at, confusion and inaccuracy will reign in a department 
of natural history which should be the most attractive to the British sportsman, with his unrivalled chances to make sport yield useful scientific results. Take it this way: I think I am safe in saying that there are not two men in England to-day who know the correct details of the three best red-deer heads. In Rowland Ward's second edition of his "Records of Big Game," there are no fewer than ten mistakes in the three lines concerning the three largest heads he gives, in addition to which errors two of the three trophies he mentions deserve by no means the rank he gives them! To these and to other instances of carelessness to which I shall have to refer, "Smoothbore's" committee would speedily put an end, and if for no other reason, its results should be welcomed by all those who prefer simplicity combined with scientific accuracy, to loose, haphazard "estimates," inaccurate measurements, and the inclusion of faked-up makebelieves.

It is not uninteresting to drag from the yellow leaves of "Annals of Sporting" of the year 1822 (Vol. II., p. 305) the following account of what was probably the first introduction of the "wapeti" into England. According to this source it occurred about the year 1817 at the instance of Lord James Murray, subsequent Lord Glenlyon, who gave Iooo guineas for four. They were put on a farm near Datchet, where the breeding from the stock was "attended with complete success." Part of the produce were subsequently "sent to his lordship's estate in Scotland, seven remaining on the farm." Two more, male and female, arrived (I 821 ?) at Glasgow from South Carolina, and were taken by way of Liverpool to London by canal. They were natives of the Upper Missouri, where "they are domesticated and supply the inhabitants of that far secluded district. They also draw sledges, bounding along at a swing trot nearly twenty miles an hour." According to the Literary Gazette of Oct. 12, I822, a herd of wapiti were exhibited at the Egyptian Hall. They were probably the lately imported Upper Missouri animals.

Since then a number of wapiti have been imported into England, G 2 
though for purposes of crossing them with red deer, to improve the latter's heads, I should call it an unsatisfactory proceeding, for the crossed heads soon lose the more beautiful red deer type. Probably the last addition to the semi-feral fauna of this country was made by Sir Peter Walker, Bart., who introduced in 1893 into his park at Osmaston Manor, near Derby, some fourteen females and six male wapiti which had been captured by $\mathrm{Mr}$. Root, of Laramie, Wyoming. In 1896 the biggest stag set up a head of nineteen points, and eleven young wapiti were born that year.

In conclusion, I should like to say a word upon the relatively inferior quality of trophies shown at the few trophy exhibitions that have been held in the United States. To the sportsman the lack of such a show at the otherwise so wonderfully complete Chicago "World's Fair," was a sad disappointment, and deprived the world of what could have been made one of the most interesting sights. For though the Smithsonian Department exhibited some good specimens of stuffed animals, there was no attempt at a show of trophies. Lately some sportsmen's exhibitions have been held at New York, but the quality of the heads, as can be seen from the accompanying list of the best heads, taken from an American paper (Fishing and Shooting), was by no means as good as one expected to find in the home of the wapiti, the bighorn, and the moose. There are hundreds of superior heads hanging in English countryhouses.

\begin{tabular}{|c|c|c|c|c|}
\hline & Girth. & & Length. & \\
\hline ntain sheep & $16 \frac{1}{4}$ & & $42 \frac{1}{2}$ & \\
\hline Tirginia deer $\ldots$ & 4 & & $22 \frac{1}{2}$ & \\
\hline ti ......... & $6 \frac{7}{8}$ & & $56 \frac{1}{2}$ & \\
\hline deer.. & $5^{\circ}$ & & $26 \frac{7}{8}$ & \\
\hline Caribou ... & $5 \frac{7}{8}$ & & $50^{\circ}$ & \\
\hline $\mathrm{Tr}$ & $29 \frac{3}{4}$ & & $2 \circ \frac{1}{2}$ & \\
\hline & I 4 & & I $8 \frac{1}{2}$ & \\
\hline Ioose ....... & $8 \frac{1}{2}$ & & 41 & \\
\hline
\end{tabular}




\section{CHAPTER IV.}

\section{THE ANTELOPE-GOAT OF THE PACIFIC SLOPE MOUNTAINS.}

WHEN first bitten with the desire to slay what was then considered North America's rarest game I met with many unexpected disappointments, for at the time very little authentic information regarding its appearance and habits, as well as of its home, was obtainable in Europe or in the States, the sole place where more definite knowledge could be got being British Columbia, which was at that time a very little known part of the world. Naturalists had, it is true, written about it, but in almost every case their information was of the vaguest kind. The naturalist Ord wrote a learned treatise on this animal, but as his knowledge of it was based on "the scalp with one horn attached to it, and the skin without head or legs," not very much useful information was to be gleaned from it. Ord acknowledged that this remnant had once served an Indian as a cloak, and it was for years the sole material upon which also a number of other writers, who copied from him, based their accounts. Fathers Piccolo and de Savatiera are said to have first discovered the animal on the Pacific Slope, while Vancouver brought home, more than a century ago, the mutilated skin to which we have referred. In the latest edition of the "Encyclopædia Britannica" the animal is still spoken of as the Rocky Mountain Sheep or Goat. In fact, I think I can rightly claim that a series of articles that I published in the Field not more than seventeen years ago were the first accounts based upon personal 
experience in the shooting of adult males of this species ever published in Europe.

Well do I remember my first introduction to a picture of this beast in the quiet halls of the British Museum Library. After writing my ticket for Richardson's Fauna Boreali-Americana, I was duly requested to repair to an inner room, where two gigantic volumes were brought to me. Of such enormous size are they that they can be opened only on a very large table, and they were conveyed to me on a smoothly-running young railwaytruck! There, amid a bewilderingly ample margin, on a page the size of a dissecting table, I found, not a picture, but a sort of nightmare of the animal. From these works I turned to Ord, from Ord to Gray, from Gray to de Blainville, Hamilton Smith, Raffinesque, Ogilby, Desmarest, Harlan, Sundwall, Fischer, Agassiz, and more than a dozen other authorities, winding up with a second careful perusal of Lewis and Clarke's account of their famous expedition to the Rocky Mountains in the first decade of the present century, and to the remarks by Professor Spencer Baird-America's greatest then-living naturalist.

The result was as puzzling as it was amusing, if levity be permissible in the study of dry science, for I found that, with the only exception of the last-named authority, none of these writers had ever seen either a live or a dead Rocky Mountain "goat," and that some of the earlier writers had built up very elaborate theories, and published long and very scientific accounts of it, on the strength of such exceedingly scanty material as has already been mentioned. I further found that the twenty-three authors who had written about this mysterious beast had given it thirteen different generic names; and, further, that some ranked it among sheep, others classing it as a goat, some as a deer, while others spoke of it as belonging to the chamois tribe; only one of the early authorities, i.e., de Blainville, coming to the same, and undoubtedly correct, conclusion at which Professor Baird arrives, i.e., that it belongs to the antelopes with the generic name Aplocerus montanus. English authorities spell the name Haplocerus 
(Haploceros), the Greek word for "simple," "haploos" being aspirated. No zoological gardens of America or Europe has ever possessed a live specimen, and, so far as my researches went, only three natural history museums in the world possessed stuffed

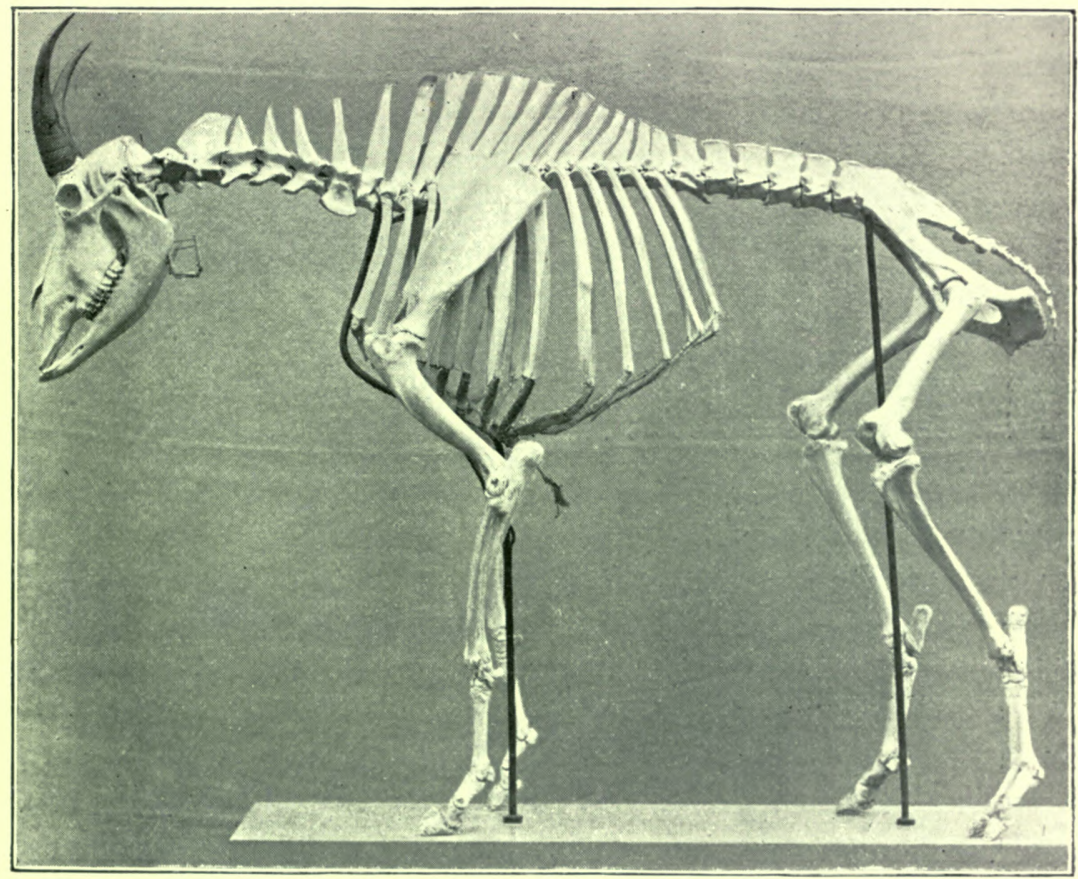

Skeleton of the Antelope-Goat (Haplocerus montanus).

(In Sir Edmund Loder's Museum.)

representations, i.e., a very small and very indifferently "taxidermed" one in the British Museum,* a slightly better one at

* Since then Mr. Thomas Bate, of Kelsterton, has presented a good stuffed specimen to our National Museum, and Sir Edmund Loder, Bart., a skeleton. Both specimens were obtained by these gentlemen in expeditions to localities indicated by me. 
Leyden, and two good specimens (male and female) in the National Museum at Washington.

The result, so far as information concerning its home went, was, if possible, even more meagre than that which existed concerning its appearance and its habits, \&c. "The highest peaks of the Rocky Mountains," where "human foot cannot follow them," appeared a favourite phrase when describing their home.

My curiosity and eagerness to kill one of those mysterious animals was naturally roused to a high degree, and my next expedition, undertaken the following year, had only one endnamely, to find goat or perish in the attempt. Several of the older writers, who seemed to furnish the few at all reliable data regarding the locality of its home, at best scanty information, but which the rest (always with the exception of Professor Baird) had found sufficiently authoritative to copy and make the most of, spoke more in particular of the Pacific Coast ranges as the home of the animal. Vancouver it was who, almost a century ago, had secured in that region, during his renowned expedition that led to the circumnavigation of Vancouver's Island, that much-prized Indian breech-clout sample skin, upon which so many learned theories were established. It was in consequence of this and other information that I made the Bitter-Root range, on the boundaries of western Montana and Idaho Territory, the goal of my 1882 trip, and there at last my patient hunt was rewarded by a bag of nine head. Subsequent expeditions, undertaken in the years 1883 , I 884 , and I 885 , however, proved to me that the true home of this game is British Columbia, especially the Kootenay district, in the easternmost portion of that province, where the animal appears to grow rather larger than in the coast ranges of British Columbia.

The chase of the white "goat," or, as it properly should be called, antelope-goat, is a most exciting one, if the surmounting of obstacles counts for anything. Indeed, as I look back, for purposes of comparison, to the successful days I have had after chamois in different parts of Europe-for the unsuccessful ones, of which there were a goodly number, slip one's memory with gratifying 
ease-I recollect very few indeed which entailed harder work than I underwent in the chase of the American chamois, as one might term these hardy inhabitants of the rocky wastes above timber-line in North America.

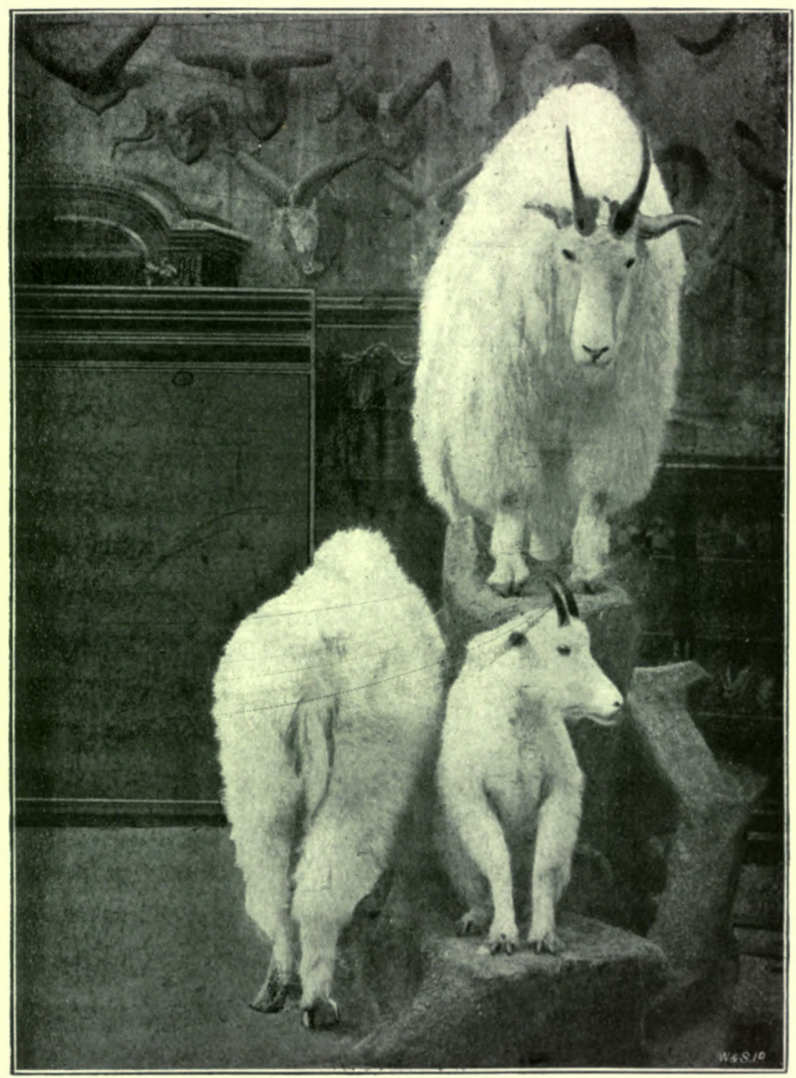

A Family Group of Haplocerus in Sir Ed. Loder's Museum.

The old rams are of curiously grotesque proportions, a great hump and high withers give them more the appearance of a mountain buffalo with a goat's head and a long white coat, than anything one could liken them to. The females are very much 
smaller, and their horns are also a trifle shorter and not quite as thick at the base.* They are jet black and smooth, and, while they are much less crooked, they are as sharply pointed as those of the chamois, making them very formidable weapons. When wounded, they are decidedly nasty foes to tackle. I have seen four or five large hounds either disabled or put to the rout by a wounded female goat, while an old ram would, I should say, remain master against half a dozen dogs so long as he could not be tackled from the back.

There are two ways of hunting it: firstly, stalking (or still hunting, as it is called out West); and secondly, with dogs to "tree"-i.e., corner them on ledges or crags, giving the sportsman time to get up to them. The former, of course, is the only manner really worth going in for, though sometimes, as the ground is always of the roughest, and the narrow ledges to which these amazingly sure-footed beasts ordinarily take refuge are not the easiest to crawl along, even following the hounds is sufficiently arduous work to please an average climber. Where I found them the first time-i.e., the Bitter-Root Mountains - they had probably never been hunted before, for the few Indians who remained in that locality after the battle of the Big Hole river, in the Nez Percés' War of 1878 , never penetrated to these uplands. They had all the deer and wapiti they wanted nearer home, and white men had probably never penetrated to regions above timber-line.

The sportsman of to-day is far better off than was his predecessor in bygone years, when he set to work to obtain reliable information respecting the home of the mountain antelope, or about the animal itself, for now scores of men have shot them and know all about their geographical distribution. In those days it also took him very much longer to reach the place than it does to-day, when the numerous railways of the northwest traverse countries which harbour this game.

* I do not agree with Mr. Pike when he says in the Encyclopadia of Sport that the horns of the female are usually the best. 
Passingly, it may be mentioned that the Great Northern and the Canadian Pacific (Crow's Nest branch) traverse the Kootenay country, which is one of the best grounds for them. It is a region which the writer visited before any of the three transcontinental northern railways were built, and when it still took as many weeks to reach it as now it takes days, and when a leaky canoe or a fagged horse were the only means of travel.

But it had its good sides, too; for, unlike the traveller of 1899 who steps from his luxurious Pullman, a "car-weary" and slack individual, whose soft muscles are hardly fitted to tackle the inaccessible haunts of this game, his predecessor, on the other hand, reached the hunting ground in prime condition. The inside as well as the outside of the man was thoroughly toughened by weeks of rough camp "grub" and hard beds, with mother earth as a mattress, a saddle as pillow, and the star-lit sky as a tent. They were experiences which made him capable of enduring the hardships, and of enjoying the sport, and caused him probably, when it was over, to vow to return again another year and do likewise, or perhaps even better.

In taking the reader back to the good old days, I will ask him to accompany me on my first successful attempt at shooting antelope-goat on the head waters of the Big Hole river, and then request to be favoured with his company on an expedition to the aforesaid north-westerly corner of Montana, and the southern part of Kootenay. The former is a land of serrated mountain chains, rushing rivers, beautiful lochs, fine forests, and open prairies, more verdant and pleasing to the eye than the parched steppes of eastern Montana, and less difficult to travel through than the wilds of the Selkirks of British Columbia, immediately to the north.

In the three preceding years I had hunted on the breezy mountain ranges of Wyoming, Colorado, Idaho, and eastern Montana, but I had failed utterly to find my game elsewhere than in the imagination of romancing trappers and guides, a circumstance that created in my mind a decided tendency to look upon all 
"goat" stories with a good deal of suspicious reserve. I heard a great number of such tales. Men told me that they had shot, knifed, lassoed, stalked, staked in pitfall, and otherwise "gone for" the mysterious beast. And in their turn they had been gored, spitted, "treed," butted, trampled on, and generally roughly handled by redoubtable old rams, and though the stranger in the land in this instance declined to be "filled up, boots and all," with these hoary old myths of the ultra Western type, they yet generated in me an irrepressible desire to get at the bottom of these wonderful natural history revelations. A letter I received in May, I882, from a reliable friend residing in western Montana, declaring that he had actually seen not a live, but, what was the next best thing, a dead mountain goat, made me pack my trunks and engage my passage in hot haste.

Two or three weeks later I was in Butte City, that promising. mining town, the "Leadville" of Montana territory. Here I "outfitted," and, joined by my aforementioned friend, we were in a few days on our way to the Bitter-Root Mountains. Our party had a businesslike look about it; the men and the seven or eight horses were old friends of former seasons, and our minds were of equally businesslike bent. We wanted goat, and goat we would get or perish in the attempt. As the country we were about to visit was strange to us, we decided, on reaching the last outpost of civilization, to hire a local guide acquainted with the trails that led up into the chain on which the animals had been seen and even killed.

It was an isolated, long abandoned, old mining camp called "Dead Man's Flat." The dozen or so "old-timers" who still resided there were one and all willing to take their oath that they had slaughtered goats since they could handle shooting-irons. We picked out three from which the man was to be selected. The choice was not the easiest. The first was known as the fellow "who could stand more rest than any other man in the territory," or, in other words, was supposed to be the laziest man in Montana. The second was reputed to be decidedly a "bad" man, an old- 
time Virginia City vigilante, known as "Judge Neversweat." According to his own story he had gained this name by the equanimity of mind exhibited by him at a certain most critical moment of his life, when he held at bay, with an unloaded revolver, four doomed and desperate men thirsting for his life and their liberty. Judge Neversweat evinced much anxiety to act as our guide across the Bitter-Root Mountains, every foot of which he professed to know from his "prospecting" days. "We'll have a blank good time, you bet your bedrock flume on that," he said, adding, sotto voce, "Anyhow, as long as the whiskey don't peter out." His indignation when informed that this was not likely to occur, for the reason that on principle we never took whiskey on our shooting trips, was at first rather amusing, then startling, to behold. The mere idea of a good time without unlimited whiskey was a dire imposition, nay, an insult to frontier manhood. He was too angry to give vent to the usual unbridled flow of bad language; his otherwise loud voice toned down to an angry snarl, his eyes glittered, his form grew erect, his whole being assumed an austerely dignified air ; in one word, Judge Neversweat became polite. It was a mood the half dozen mountaineers, silent witnesses of this scene, seemed to understand and to fear, for they all suddenly discovered they had business elsewhere, leaving us, as I heard one mutter, "to our own funeral." Then spoke up the Judge: "Gentlemen, let Judge Neversweat po-litely inform you, on the first call of his hand, that this yar camp aint lost no goat; and if this yar straddle aint going to find your approvement, Judge Neversweat's record aint one that'll stand a second call." Our egregious exhibition of insular prejudice cost us some odd dollars. Judge Neversweat had not, we found, included a call to the nearest saloon among those incompatible with his "record." Of the three men from whom we decided to pick our guide, the third man, known as Arcles, enjoyed a more harmless reputation-none less than that he was "the biggest liar this side of the Rocky Mountains." He was the son of a French-Canadian-hence his name, which was the phonetic rendering of Achilles-and of a mother with rather more than less 
Indian blood in her veins. He had grown up with the lusty northwest. On his seven fingers, which were all a certain cold winter had left him, he could count as he was proud to tell you, all the white "ladies" he had ever seen. His language was free, even for the West, his aim having apparently been to select and incorporate in his vocabulary the most blasphemous terms of both English, French, and Chinook. He was of a sanguine temperament, and what with the exhilarating champagne-like atmosphere which is such a constant temptation to indulge in talk commensurate with the gigantic size of one's surroundings, it was no wonder that Arcles was found to be worthy of his reputation. Aside from the fact that his qualification to act as our guide was about the biggest of all lies he had ever fabricated, he proved a willing fellow and a good cook; so while we did his guiding he did our cooking, a combination satisfactory to both parties.

A peculiarity of the several great mountain chains in the interior of the Pacific slope, such as the Bitter-Root, Cœur d'Alene, and Selkirk ranges, are the vast stretches of exceedingly dense forests which clothe their precipitous slopes up to an altitude of 7oooft. or 8oooft., in unbroken, and then practically untrodden, masses. The western slopes of the Bitter-Root peaks make no exception, and this we saw when, after two days' travel through a partly open country, we reached the foot of the chain, and camped on one of the last open grassy spaces. At an early hour the following morning we entered the forest, hoping by a long day's scramble to reach timber-line; for the country looked comparatively easy to cross, and we could not imagine that, with our pack animals trained to such work, we possibly could fail to penetrate the dark green maze that mantled the slopes in a primeval luxuriance of growth. But the forests of the Pacific slope belie appearance, and as our guide had begun his duties by telling us, just as a sample of his powers in the way of yarning, that he knew a trail which would lead us in six or seven hours up to timber-line, we spent more than three days in getting through the woods, intersected as they were by bits of burnt forests and numerous "windfalls" of 
trees thrown pell-mell over, under, and astraddle of each other by gales or avalanches. There are few more temper-trying moments than when you find yourself "stalled" in one of these traps. After an hour's hard and incessant work with two axes, you have managed to penetrate one or two hundred yards into the labyrinth of fallen trunks; now creeping under an uprooted tree slanting against a frail support, a slight push liable to send it crashing down on you; then "stomaching" a prostrate log three or four feet in height, and by angry tugs and strong language coaxing your horse to follow you, which he does by a grotesque buck-like leap, putting to a sore test the "give" of the lash-ropes that fasten his pack; here clearing away with your hands a tangle of "snags," which protrude like daggers from the fallen giant trees; then cautiously testing the miry ground in spots which are liable to engulf man and horse. After perhaps an hour's work, you have reached the centre of the "windfall," when suddenly you find yourself brought up by a formidable barrier of trunks higher than your head, and garnished with a nasty chevaux de frise of snags of more than ordinary density. It is impossible to penetrate it, and you turn to your right, and then to your left, vainly seeking an outlet, but there is none visible. Nothing remains but to turn back and retrace your steps; but, lo! a similarly desperate state of things faces you, for, as you happen to be on ground sloping downward, the side of the barrier which you now face is much higher, and therefore more impassable than the one you breasted on your way into the snare. You are "corralled," and without the aid of the axe, wielded by sturdy arms, you cannot possibly escape. In burnt timber the difficulties are much the same, if not greatcr; for many of the burnt trees are still standing, requiring apparently but a push to send them to the ground. Here the pack-horses, with their unwieldy packs, become a source of imminent danger. You cannot lead them, for there are not enough men; they refuse to be driven, and so you have to let them pick their way at their own sweet will, bumping against fragilely poised trees, which come down with a force that is liable to stampede or to kill the beasts. 
Notwithstanding all these difficulties that hamper travelling, these upland forests, where not swept by fire or avalanches, are very beautiful, and they grow more so the further north-west you penetrate. The trunks, as you approach timber-line, are clothed with the fantastic "beard of the Alps," pendant tresses of grizzly moss, often more than a yard in length, hanging in festoons from the gnarled branches of the larger pines. When fierce gales sweep through these elevated forests, these tresses wave to and fro in a weirdly fantastic manner. The flora, too, is more varied than on the eastern ranges; the beautiful, inimitable blue of the Alpine gentians, sunk in their mossy cushions, the delicate perfume of the wood orchids, and the trailing creepers of the clematis, all remind one of the Alpine uplands of the Old World. On approaching timber-line, where the dense forest scatters out, patches of snow, the last shreds of the deep, solemn pall that had covered living nature for the past seven months, begin to show in the gullies and ravines.

Towards evening of the fourth day we at last stood on the breezy slopes of the great chain, some 8 oooft. or 9oooft. over the broiling Atlantic and Pacific coasts. One or two avalanches, where the snow was still piled up 3 oft. high, had to be crossed before we reached a small rock-embowered lake, where further progress with the pack-train became impossible. It was a lovely sheet of water, the further side enclosed by huge walls of rock that rose sheer from the water's edge to an altitude of many hundred feet. Thrice beautiful it appeared that day to the parched men and animals of our party, and it needed not the order to camp to strew an inviting bit of smooth emerald green meadow, lapped by the water of the lake, with the loads of the horses. The next minute the jaded animals were rolling on the refreshingly cool turf, and the "bosses" were throwing aside their scant garments to dive from a great protruding boulder into the limpid depth of the lake.

But where are the goats, the reader will exclaim. They are nearer than we think, for presently there is a hushed cry of amazement, and all eyes are turned to the top of the great walls 
at the farther end of the tarn. There, on the "saw tooth" top of these singularly bold cliffs, we see, clearly uutlined against the blue horizon, some five or six snow-white apparitions, which, on examination with the glass, prove to be the long-looked-for, much-doubted mountain antelope. We have come, we have seen, bur we have yet to conquer.

In the waning light of the afternoon and evening an unsuccessful stalk was tried, for the wind was unfavourable, and the game had probably seen us. So no wonder that long before we had climbed the ridge, which, on reaching it, we found to be broader than it appeared from below, our quarry had vanished. The whole ground, however, was tracked up by the sharp and unmistakable impressions of their hoofs, while long, tangled masses of the woolly hair of their winter coat, which they evidently were just then shedding, festooned the rocks, against which the animals were apparently in the habit of rubbing themselves. From these and other signs we conjectured that the giddy ridge we were standing on, with deep, almost sheer precipices falling off on both sides, was a favourite resort of our game. And so it proved to be, for nowhere else were they so frequently to be seen as on precisely such ridges, which formed the highest points in the neighbourhood.

For the next few days we saw little of each other, for when we returned to camp at or after dusk, hungry and fagged by twelve or fourteen hours' stiff rock-climbing, the morrow's stalk made us seek our cosy sleeping bags at an early hour. Our party got, all told, fifteen of these beasts, of which nine fell to my rifle

In those parts of the Bitter-Rout Mountains visited by us, - stalking is about as difficult as it can be; for the slopes, where they are not actual precipices, are covered with masses of débris, loose slabs, and boulders, with the sharpest corners and edges imaginable. On this ground it is nearly impossible to approach game noiselessly. Let you be ever so careful and circumspect, using knees, toes, and fingers, you cannot proceed very far before a slab, poised in a secure-looking position, will rattle away from under you, and in nine cases out of ten start a miniature avalanche of 
stones, awakening the echoes among the impending cliffs. I found, however, that so used do the denizens of these rocky wastes get to such noises from their own inability of moving over these slopes without starting rocks, that, so long as they do not see or wind you, they will not be alarmed. The antelope-goat is a singularly fearless animal, while its innate curiosity will lead it to face signs of danger from which most other wild animals will flee.

Let me relate one incident that will prove this. I had sighted a solitary ram grazing on one of the frequent amphitheatre-shaped steep slopes, but well down about the middle of the declivity, while I was on the top of the knife-backed ridge. Unfortunately the goat had seen me, and had taken to his hoofs, but in a very leisurely manner, keeping in his flight a course parallel to mine, i.e., approaching neither the top nor the bottom of the slope. It was a very long shot, and my trial shot, taken very steadily while he was making one of his frequent stands, missed him a little to the left, proved that my distance judging was fairly correct. I hoped to get nearer, so I reserved my fire, and for the next three-quarters of an hour a most exciting steeplechase took place, my only course being to follow out the ridge. A chamois would have put himself beyond danger in a few minutes, though our respective paths were not smooth ones. Indeed, his was as rough as mine, huge boulders, piled over each other, or separated by dark yawning chasms, generally too broad even for a goat's muscles, making progress very slow. But no doubt there was a good deal of fooling about the old billy's proceedings, for from time to time he would squat down and take a rest, much amused, no doubt, by the frantic scrambles of his breathless pursuer above him, clearly outlined against the horizon, and feeling very sure that the shaking aim would be anything but dangerous to him. In this he was right; for eleven times in the course of that singular race did I throw myself flat on some handy rock, and take as deliberate aim at my distant quarry as my unsteady hands, trembling from the exertion in the trying atmosphere of these high altitudes, would allow. Eleven times the bullet whizzed past him, once detaching a fragment of 
rock, which must have hit him, for I could distinctly perceive him make a side jump. I was very nearly at my wind's and wits' end, fagged out by my run, which, as I looked back, I saw covered very nearly the whole semicircle of the ridge, and which, as I afterwards found, was keenly watched with glasses by my friend and some of the men from their camp, far down the mountain side. The worst about it was that by this time I had only one cartridge left. Hunter and hunted were approaching the end of the semicircular ridge, where it fell off in one enormous precipice, a configuration of the ground that, of course, would shortly terminate the chase, a continuation being only feasible to winged creatures. The ram was steering for a tooth-like crag, separated from the main ridge by a profound abyss. Here, evidently, he felt himself secure, and as I watched him sit down very leisurely to take in all the fun of my defeat, very uncharitable sentiments escaped my parched and breathless lips. A quarter of an hour's much needed breathing spell gave me at this juncture a chance to survey the ground a little more critically than I had hitherto done. It would have been folly to risk my last cartridge at an impossible range. The old billy was evidently feeling very much at home, and, as I could easily see with my glasses, kept his gaze steadfastly fixed in my direction.

The formation of the ground, as I presently discovered, favoured the employment of the following ruse: Retiring behind the top of the ridge, I took off my canvas jacket and hat, dressed up a handy stone with these garments, and slowly lifting it on the top of the ridge, deposited it there, in plain sight of the watchful ram. Then I disappeared from his vision, and made a long detour, including a disagreeable creep along a ledge of shelving rock, in places only a foot or two in width, with the object of getting round the great buttress of rock at a considerably lower level, and so approach the ram from a direction he little expected, to within one hundred and fifty yards or so. It was an anxious minute as I lifted my head inch by inch over a projecting ledge, and there, in plain view, saw my game, his gaze still fixed upward at my dummy. For full 
five minutes I lay there; what with the excitement and my breathlessness, I instinctively felt that every minute thus gained would bring my bullet an inch nearer to my quarry. When finally the old 500 Express sped its solid 480gr. bullet, the ram was my meat.

A most singular, not to say fantastic, habit of the antelopegoat is worthy of special notice. It is the practice of sitting up on his haunches like a dog, and, when anything startles him, to raise his front legs from the ground and sit up much in the position of a begging poodle. The hide and hair on the rump of old animals are quite worn, and much thicker than elsewhere. On one occasion I approached such squatting goats to within sixty yards. On another occasion a friend and I left camp together for a long day after goat. We had not proceeded very far along a steepish ridge when we discovered almost simultaneously, two different "outfits" of goats. Mine, three in number, were lying on a narrow shelf of rock, overhanging a stupendous precipice, about twelve hundred yards from, and considerably below, us. His, four head all told, were yet lower, and were rambling about on the green sward surrounding a tiny glacier lake. Among the former there was a big ram-a sight which made our pulses beat high. Deciding to separate, I took the route along the top of the knife-back ridge, hoping to be able to circumvent, while he took a lower level, and was to work down to them under cover of a buttress of rock.

An hour's scramble along the ridge, where in places perfect sure-footedness and freedom from giddiness were imperatively necessary, brought me to the spot selected by me from below as the point of vantage from which I could cut off the only two ways of escape, should the goat take an upward course after my friend had opened fire on them. I lay down panting on a projecting crag, which was so small in size that my legs dangled over the brink of a perpendicular wall of rock, several hundreds of feet in depth, that here formed the end of the ridge. My friend, who appeared not 
much larger than a fly, was making fair time down the slope, using hands and feet to find what was in most cases very precarious footing. A few weeks before I had made a successful stalk down this very declivity; and, as on that occasion I was saved from a very bad, if not fatal, fall, only by the merest chance, and hence knew its dangerous character, I breathed more freely when finally, following my instructions respecting details of his course, he reached the bottom. Notwithstanding that he had sent quite a number of boulders rattling down the precipitous declivity, the nearest band of goat had shown no marked alarm; and, as I could watch them from my post, while his view of them was obstructed by intervening rocks, I let him know by a preconcerted signal, watched with glasses, that the goats were yet in their old place. He was now at the bottom of the rocks, which surrounded him in an amphitheatreshaped half circle, a configuration I have always found most awkward and puzzling in regard to the wind. What I feared came true. He had not proceeded many steps on the extensive snow-field in the direction of the goats, which were still 7ooyds. or 8ooyds. off, when I saw them rise on their haunches, evidently alarmed by an obnoxious whiff. They could not see my friend, and his progress across the hard snow was naturally noiseless; and yet, after a minute or two, led by the large billy, they made off for the top of the ridge with the intention of crossing it. Now was my time to get near the point where the beasts were evidently proposing to cross the ridge. Hardly had I done so when I heard the booming report of my friend's '500 Rigby. This turned their flight slightly to one side, so that for the next ten minutes some "tall" climbing and crawling along uninvitingly narrow ledges had to be accomplished. But I got my shots in, though at very long range, bagging two goats, one of whom had been wounded by my friend.

I may here mention that no sportsman should venture to stalk goat without having provided himself with a sheath for the muzzle of his rifle. Made of the stoutest sole leather, covering about six or eight inches of the barrels, it should slip off and on with perfect ease. Not only will it protect the muzzle against hardly avoidable 
jars and knocks, but, so protected, the rifle can be used in critical moments as a sort of alpenstock, in which character I have known it to save life and limb. A $6 \mathrm{ft}$. bamboo pole, consisting of three jointed lengths, answers the purpose, of course, much better, and is of the greatest assistance in goat country. On my first visit I lugged about with me a young pine tree, $7 \mathrm{ft}$. long, and as many inches in circumference, and weighing half a tonat least, that appeared to be its weight when the alpenstock and the very fagged goat hunter were stalking campward in the dusk after a long day.

Goats are uncommonly slow in their flight, the nature of the ground in most cases forbidding rapid running. If the animals are not absolutely on the very top of the ridge, you can generally get in eight or ten shots before they get out of sight, which is decidedly a redeeming feature; for I have found that, when stalking this game, the majority of the shooting has to be done at long ranges. If you know your rifle, and have the chance of marking the first two or three shots, so as to ascertain the distance, taking your shots, of course, from a steady rest, you will finally get your hand in, and, with a little care, surprise yourself by the close shooting a good rifle and fine sights can do. The new small bores are, of course, far and away better for such shooting than the oldfashioned Expresses, not only on account of their greater accuracy but also owing to their higher velocity, and consequently flatter trajectory. Only those who have actually tried either the 256 Mannlicher or the Mauser can appreciate their wonderful accuracy. With the former at rooyds. a certain phenomenal shot has put five consecutive bullets within a circle not larger than a threepenny bit. While, to show the advantage of a flat trajectory, the following details will illustrate the immense advantages of the $\cdot 256$ Mannlicher over a 5 oo Express.

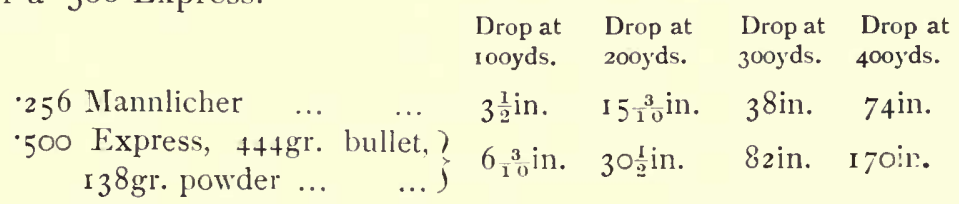


Putting it into other words, this table reads as follows: If you under-estimate the distance and use the rooyds. sight at a beast which is really $200 y d s$. off, the 256 Mannlicher bullet will strike about 8 in., while the 500 Express will strike I 8 in., too low. If you under-estimate the distance still more, and use the rooyds. sight at a beast which is really $300 y d s$. off, the Mannlicher will strike $27 \frac{1}{2} \mathrm{in}$. too low, while the 500 Express will strike no less than $5 \mathrm{ft} .6 \frac{1}{2} \mathrm{in}$. too low. If you under-estimate the distance not quite so much, and use the 20oyds. sight at a beast which is really $300 y \mathrm{ds}$. off, the Mannlicher will strike I 5 in. too low, while the Express will be $3 \mathrm{ft}$. $3 \frac{1}{2}$ in. too low, differences which will turn an otherwise effective shot into a miss.*

After brittling my two victims, I had a long afternoon left for another stalk, and by crossing a steep " divide," or ridge, I hoped to strike a fresh band not alarmed by our fusillade. Two hours' stiff climb took me to the place, another vast amphitheatre-shaped semicircle of rocks, with a lake or two in the arena, and numerous goat trails up and down the precipitous slopes. My glasses soon betrayed to me, on the opposite side of the amphitheatre, two goat feeding apparentiy on rock and snow, for there was not a trace of vegetation visible to me. The basin was about a mile and a half in diameter, and the animals were about half-way up, the most awkward place for them to be in. As a rule, it is of course wiser to approach all mountain game from above, and the further advantage attached to a stalk along the ridge of the semicirclei.e., of having a chance of discovering another goat on the off-side of the slope-decided my course.

Apparently the distance was not more than a mile and a half, but it took me a couple of hours to do it, every foot of the way being downright climbing, now straddling huge slabs standing on

* These details, which I think many a sportsman will find of ptactica use, have been worked out by Sir Edmund I.oder, Bart., and Hon. T. F. Fremantle, two experts, whose practical as well as theoretical knowledge is probably unequalled. The latter's "Notes on the Rifle" should be read by every sportsman interested in or using the new small bores. 
end, then again letting myself down miniature precipices formed by awkwardly shaped boulders piled upon the ridge. Keeping as much as possible on the off-side, I finally got to the spot where I thought I was just above the goats. For the last hour I had had no chance of seeing my game, hence was unaware that, while I was approaching them, they had taken an upward course, and were actually within 6oyds. or 7oyds. of the top. My surprise, therefore, can be imagined when, on raising my head over the ridge, with my rifle slung over my shoulder, I found myself face to face with them. At this moment a stone gave way beneath my feet, and they looked up, seeing, however, only my head. Keeping the latter perfectly still, I slowly got down my rifle, but before I succeeded in this both goats had squatted down on their haunches, and, raising their forefeet from the ground, occupied the position I alluded to. It was the strangest sight imaginable, but I was too eager to enjoy it long, and I rolled them over, and, alas! down the slope to the very foot, with a right and left. One, a young ram, on receiving the bullet, made a high leap in the air, pitching on his head when he came down. Fortunately, their fall down the almost perpendicular declivity did not injure the horns, though their bodies were in a jelly-like condition.

I have already mentioned that British Columbia is the true home of the Haplocerus. A description of my first goat hunt there will make the reader acquainted with a picturesque district as well as with some of the obstacles which the stalker had to face, when invading that then perfectly wild and practically unknown district.

To-day a four days' railway journey takes the traveller from New York across the main Rockies to the attractive Flathead country, as good a starting point for a summer's hunt as there is left. If he is a lover of canoe work he has a good chance of trying his mettle by taking to the rushing Kootenay River, and following it through the more than hundred miles long canons it has burrowed through the southern extremity of the Selkirk range, till he reaches at Bonner's Ferry more open country. It will make him acquainted with all the mysteries of canoe travel, "portaging," running swift 
water, shooting rapids, negotiating whirlpools, and other exciting incidents. If he values his life he will, however, have an experienced man in the bow of his craft, for at most stages of the water it is a decidedly dangerous trip.

In the year I made the trip in question, the Great Northern had not been thought of, and even the Northern Pacific was still under construction, so it took me four weeks' travel from the Atlantic, including a long horse-back journey to reach Bonner's Ferry. There it became necessary to abandon horses altogether, and to cover the rest of the distance-some 160 miles-by canoe down the Kootenai river and lake (in British Columbia this name is spelt Kootenay) to the foot of the mountains, which were said to harbour the game I was seeking.

Bonner's Ferry, now a prosperous settlement with a newspaper, an important station on the Great Northern line, and the starting point of several steamers, was, in the days I am speaking of, a place that had a name, but only one white inhabitant, by profession a trapper, Indian trader, and miner, and last, but not least, father of an extensive half-breed family, which filled to overflowing the 1 wo log shanties of which "Fry's ranch" consisted.

It was an extremely out-of-the-way spot, the only means of reaching it being a zig-zag Indian trail winding through dense forests for many a weary day's travel. Walla Walla was the nearest "city," and when Fry made his bi-annual trip "to town" to exchange his peltry and gold dust for flour and goods for his Indian trading-post, it meant an eight or ten days' ride each way.

Near his ranch was a large Indian village of American Kootenais, as they were called, to distinguish them from the Kootenays, another part of the same tribe who lived immediately to the north in the same valley but on Canadian soil. Domiciled on the banks of the Kootenai river, one of the principal head waters of the Columbia, these Indians were more canoe than horse Indians. the surrounding country being much too densely timbered to allow the general use of horses. After the austere and sullen Indians of $W_{\text {yoming }}$ and Eastern Montana, I was much struck with the 
pleasant, laughter-loving Kootenais and Kootenays. They were also by far the most unsophisticated and primitive aborigines I had ever met. A breech cloth, a string of blue and red glass beads round their necks, and a curiously-shaped conical white felt hat, adorned with mink and sable tails, being the only clothing the males sported, while the women wore a nightgown-like garment of coarse sacking imported by astute Fry from Walla Walla. Their teepees were picturesquely situated under a grove of fine old cottonwood trees. Outside each tent, resting on light trestles, one saw one or two canoes lying bottom upwards and covered with mats or boughs

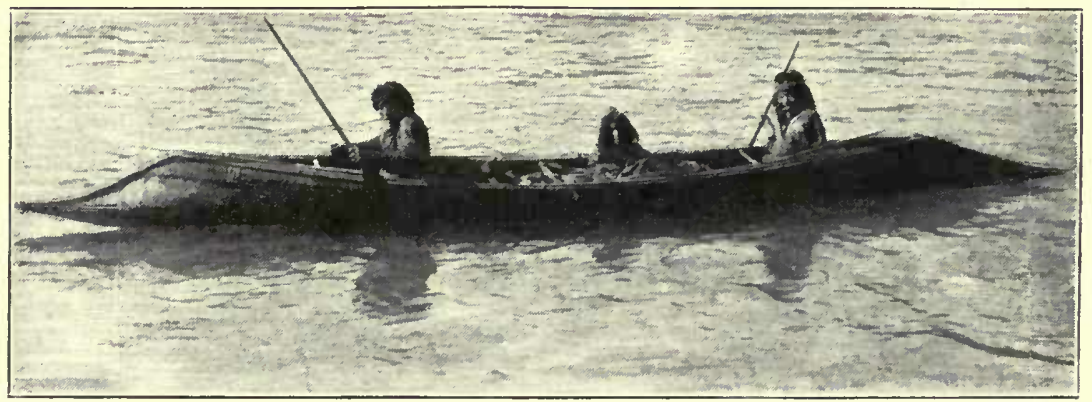

A Kootenay Indan Pine Bakk Canoe.

The shape is peculiar to this tribe.

to prevent the sun from cracking the frail bark of which they are constructed. Their shape was peculiar to the tribe, and very pretty "lines" these craft possessed. Both prow and stern, slightly turned up, were pointed and shaped similar to the ram of an ironclad. When not too heavily laden neither touched the water, so that only the broad rounded bottom of the canoe rested on the surface, making the craft a crank but swift traveller.

Several of the younger bucks understood Chinook, that hotchpotch of French, English, Spanish, with a good many Indian terms thrown in, which used to assist intercourse between the whites and the numerous tribes of the Pacific Slope. My wants were soon 
known among the tribe, and, as high water would soon oblige the whole tribe to vacate their present camping place, and disperse on hunting and fishing expeditions, I had no trouble in finding what I wanted, i.e., two Indians and a good roomy canoe wherewith to reach the northern end of the great lake into which the river emptied, from where we would "pack" to good goat-ground on the mountains which rise steeply from the lake. Half an hour's consultation produced the man: a youngish "buck" of smiling face and fine physique, his bristly jet black hair covered by the usual cone-shaped hat adorned with more tails than I had seen on any other. In his arms, nursing it as a woman would her baby, he fondled one of the few Winchester rifles then to be found in the tribe, while his brawny chest showed very distinctly the marks of a bear's claw. He was, as I at once surmised, a noted hunter, and really belonged to the Canadian Kootenays whose hunting grounds I was intending to visit.

Terms were soon arranged, a dollar a day for him and the same for his "clootchman." a Chinook term which I did not understand at the time, but which I thought meant a friend or relation. The start was to be made early next morning, and the interval was occupied in re-pitching the cance and collecting the required simple provisions for the month's hunt, and in writing a few letters, for which there was at present, however, no known means of conveyance, for Fry's pack-train to Walla Walla would not be starting for another fortnight or three weeks.

It was only as I was about to step into the canoe at dawn next morning that the identity of the "clootchman" was revealed; it was "my friend's squaw! Unlike the horse Indians of the Plains, whose squaws occupy a far more subservient position towards their lords and masters, the squaws of the Kootenays accompany the males on all their hunting expeditions and are better treated. Noticing my discomfiture at the discovery, Fry, who was watching our start, explained to me that this was the usual order of things, and assured me that I wouldn't be long in finding out that, so far as willingness to work and general handiness went, the clootchman 
would prove the better "man" of the two: and eminently right the Indian trader was.

The hundred mile trip down the lovely river to the lake was a delightful one. Comfortably ensconced in the centre of the canoe, my waterproof yachting bag giving me a comfortable "back," I could wield the paddle or remain idle, my dusky Darby and Joan keeping up their regular steady stroke for a long five hours till it was time to land and get lunch. The river, though now

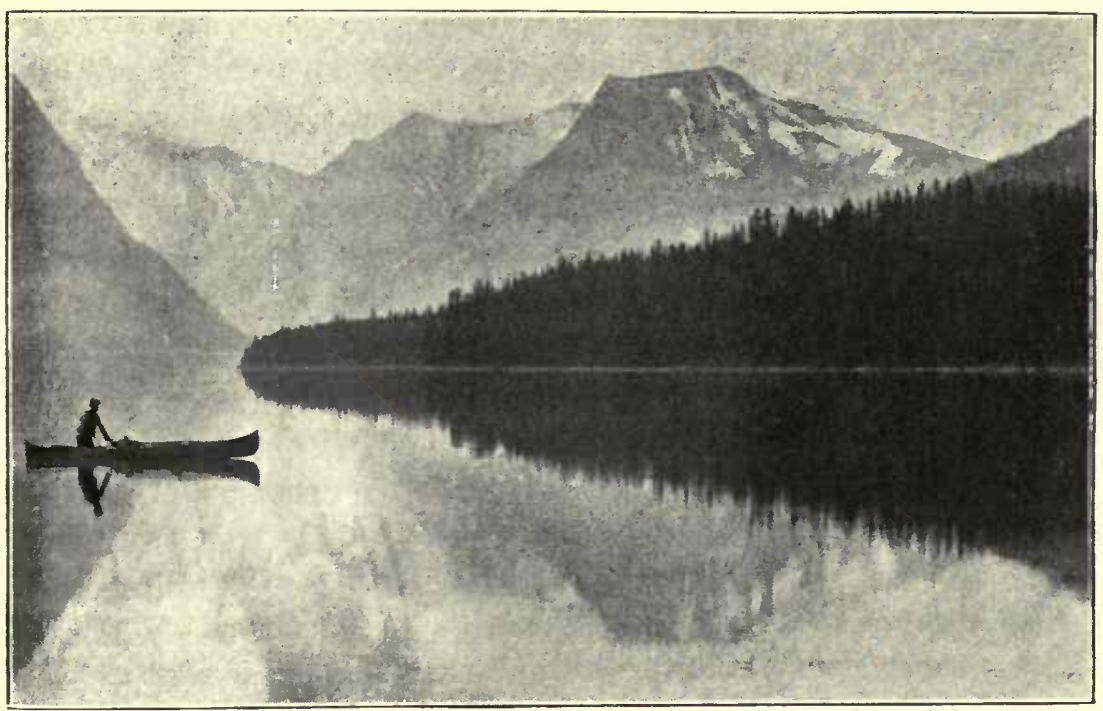

Scenery in Kootexiy, B.C.

"bankful," had but little current, and serpentined in huge loops through the beautiful valley, both banks being, covered with a fringe of fine cottonwood and other deciduous trees. The whole country from Fry's onward was totally uninhabited by whites, the only other inhabitant in the entire valley, aside of Indians, being another squaw-man, old Dave MacLoughlin, rather a remarkable personage, of whom I shall have to speak in another place at greater length. His shanty was built close to the boundary line 
where the $49^{\text {th }}$ Par. divides by an imaginary line the United States from Canada. This point we reached the following afternoon after a memorably uncomfortable night on the banks of the river, where, in spite of "smudges" and netting, one was simply eaten up by mosquitoes, which filled the air in masses the like of which I have never seen in any part of the world. Another night, if possible worse, had to be spent on the banks of the overflowing river, and then, by taking a short cut in the canoe across a sort of inland lake, which at other seasons is a swamp, we reached the lake, and with it comparative immunity from the curse of summer travel in that country.

It was a glorious June afternoon when we glided out of the treebowered mouth of the river, and saw before us the lake. One could see almost to the end of the mirror-like sheet, in which the row of peaks on both sides, still capped with snow, were reflected most effectively. Over the whole scene lay the charm of absolute wildness and solitude, for not a single white dweller and only a few roaming Indians lived on its shores. To-day, alas! that charm has long vanished; prosperous though dishevelled looking mining settlements line the shores, the forests have suffered by great fires which, for several summers, enveloped the whole country for five or six months in dense smoke. Steamers filled with miners and land speculators awaken the echoes by their shrill whistles, which are answered by the yet more discordant locomotive bell of several railway lines, and at night electric light shows up the nakedness of the numerous "towns" that have sprung up on its shore, while the surrounding mountains are over-run by indefatigable prospectors in quest of silver-bearing galena veins, with which these mountains are scored.

After a night in a quiet cove on the rockbound shore we reached the northern end of the lake the following evening, having laid in a goodly stock of fish - splendid land-locked salmon - which I caught trolling as we paddled along. Long before we reached our goal, a bit of a sandy beach a few miles from the extreme end of the lake, shock-headed Darby had pointed out to me a prominent 
peak as the akokle where there were hiyou kianooko - the mountain where there were lots of goats. It was a "bald"-looking eminence, rising some 5oooft. or 6oooft. over the lake, the last Ioooft. apparently entirely bare rock. Câching the canoe and the main stock of provisions in the brush, we made on the following morning an early start. Our loads were heavy, considering the climb and the country we were about to tackle, and what was really surprising was the tremendous load shouldered by the slim and diminutive Joan, who I am sure would, including her sole garment, not have turned the scales at seven stone. The first few hundred yards into the forest, which was a mass of dense underbrush, made my heart sink within me, for I did not know that we would presently strike a faint trail, the commencement of which was thus hidden from intruders, who had no business there.

It took us all day to climb less than foooft., i.e., to reach the rocks beyond timber-line, where, just at the outskirts of forest vegetation, we made as skookum (snug) a camp as the somewhat limited level space permitted. My tiny "A" tent, which, with my sleeping bag and rifle, had been my load, was soon pitched, and next morning, while indefatigable Joan went down to the lake for a second load of things, Darby and I went after game. Signs innumerable we soon struck, and as we reached higher altitudes and obtained a wider outlook, the sharp-eyed Darby, who, of course, knew exactly where to look, had soon spotted a band lying motionless like heaps of snow on a patch of green grass at the bottom of a couloir, filled with névé, about three-quarters of a mile off. At that time I knew very little Chinook, so it was difficult to tell Darby how I proposed to arrange the stalk, sign-language and pantomime had to assist in bringing about an understanding between us. Darby was as hard as nails, fleet of foot, and blessed with lungs which enabled him to run up the steepest slopes at a speed most men would be content to develop on level ground. Moreover, he was not much hampered by clothes; moccasins on his feet, a breech-cloth round his loins, and a string of beads, was all that encumbered 


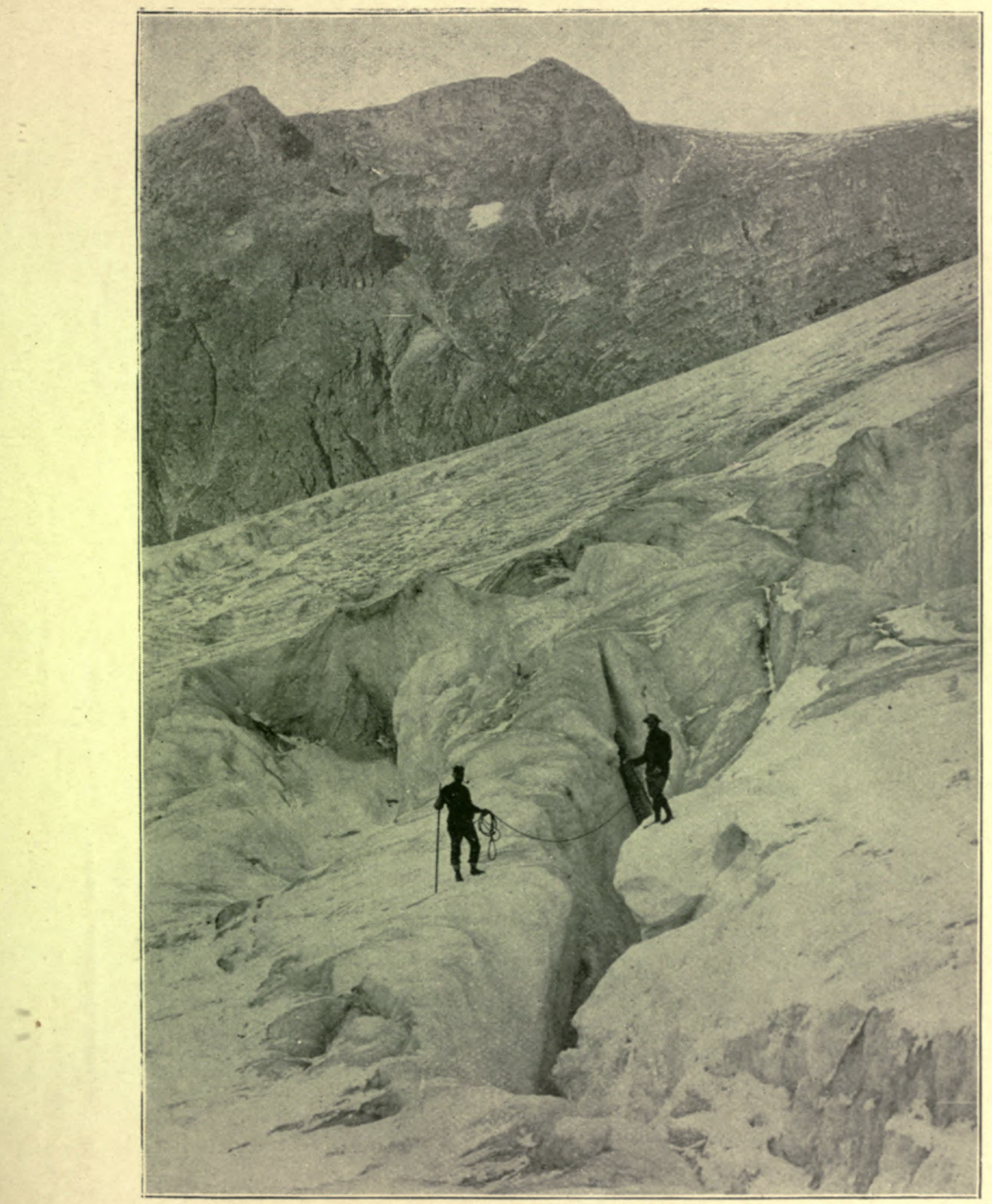

A Glacier in the Selkirks, B.C. 

him, the treasured hat having been left behind at Bonner's Ferry. I thought it wise, therefore, if I was to have a "look in" at those goats, to let him take the longer route, while I determined to approach the game from the upper side, entailing no great détour.

Darby started off under cover of a steep ridge, at a good round pace, which made me wish he was more heavily handicaped, but it was too late to alter the programme. Putting my best foot foremost I found myself fifteen minutes later craning over the precipice, at the bottom of which I had last seen the goats apparently quite unconscious of danger. A few yards to my right was the steep snow couloir, at which in my hurry to get a glimpse at the "goat" below me, I had, however, not looked. No game was visible on the patch of verdure, but there, squatting behind a rock, I saw Darby, who, to judge by the direction of his rifle, appeared to be in the act of shooting at me. At this moment a clinking of stones close to me at my right attracted my attention. Turning my head sharply, what was my surprise to see seven mountain antelopes calmly climbing up the snow couloir not fifteen yards off. They had already seen me, or rather my head and rifle, for the rest of my body was still under cover of the sharp ridge on the off-side of which I was lying. Other mountain game would have been sent scurrying away by such a suspicious sight; not so, however, these curious animals. There wasn't a big buck among the lot, so I thought I would just see what they would do. On reaching the top of the couloir where the slant became gentler, they all halted gazing at me, and one, a three or four year old male, absolutely sat down on his haunches in the most unconcerned manner. A rude interruption was, however, in store for them, for Darby, as soon as the animals had got out of his sight, had followed them up the couloir - how he ever managed it with slippery moccasins on his feet is a mystery to me-and presently I saw his head, with his long hair fluttering wildly in the breeze, pop up over the crest of the ridge. The next second he had opened fire. But even then these queer animals did not dash 
off, as chamois or bighorn would have done, and Darby dropped four of them before they got beyond i 50 yards, while I contented myself with bringing down the biggest of the lot. Darby appeared greatly surprised at my not shooting more, but finally was made to understand that I had come to shoot only big old males. A couple of days afterwards luck favoured me, and I bagged what proved to be one of the largest Haplocerus I have ever killed, a fine old buck that weighed quite $18 \mathrm{olb}$.

The weeks I passed in the company of my primitive Indian couple in that then immeasurably remote corner of the world were among the most interesting I look back upon. One's mode of life assumed exceedingly primordial features, showing one that a temporary reversion to the habits of untutored savages had about it no real hardships. An accident while loading up the canoe one morning on our way up the lake had deprived me of some of the few essential commodities with which I had encumbered the outfit. The three tin plates, bread-pan, basin, knife and fork, my store of soap, and all my very simple toilet articles, sponge, hairbrush, comb-in fact, all except the toothbrush had been lost overboard. As a consequence, one frying pan, a pot, two cups, and one old preserved fruit tin, that had served my Indian friends as a baler for their canoe for I do not know how long, were all the cooking and eating utensils at our command. Our flour for bread was mixed in the "sag" of a bit of waterproof I cut from my sleeping bag cover, and it was baked in the frying pan stuck up at an angle in front of the fire. Fish, fool-hens (wood grouse), and venison were cooked in the same utensil, if it was not roasted on an improvised spit made out of my steel cleaning rod. And as to the manner and ways our food was eaten-well, over that detail a curtain had best be drawn. In one respect I think I can claim that I revolutionised native etiquette. Among all American Indian tribes the women occupy, as everyone knows, a very inferior rank, for they are drudges, the real workers-not to say slaves-of their lords and masters. Among the Kootenays, as already mentioned, the squaw's lot was a better one, but still one we would call that of 
a menial. When sitting down to our meals, my brawny Darby had from the very first assumed the right to squat down a little way off and polish off his food at the same time I was so occupied, poor Joan having to content herself with the leavings, which she ate with her back turned towards us while we were smoking our pipes. The above described loss of cooking and eating utensils gave me the chance to work a change in this respect which at first met not only with the indignant refusal of the husband, but with that of humble Joan, to whom the idea of sharing food out of the same pan with her lord appeared to be an unheard-of act of lèse majesté, more particularly so in the presence of a white stranger. Neither of these children of nature had ever set eyes upon a white woman, and I suppose they had never come into contact with white men, so my task was not an easy one, but by insisting on serving myself first, and only when I had finished giving an equal share to the squaw and to proud Darby, I finally accomplished my purpose. In a day or two man and wife were eating quite domestically out of the same frying pan or amicably rending a roasted grouse by the concentrated efforts of two pairs of greasy paws, a smile of masculine condescension and a feminine titter being the only outward signs of the surprise with which the extreme novelty of this new fangled domestic equality was regarded by them.

But I have wandered afield and must hie back to our subject.

The antelope-goat attains now and again a very formidable size. An old ram, killed by a friend of mine, had a girth around the body of $7 \mathrm{ft}$. $3 \frac{1}{2}$ in. It was impossible to ascertain his weight, but from the fact that two powerful men could not lift him $4 \mathrm{ft}$. it must have been at least 3oolb. Another big ram, killed in 1888 in the Selkirks by Mr. W. R. Bentley, of the Academy of Science of California, measured, so the sportsman reported, from muzzle to tip of tail $6 \mathrm{ft}$. gin.

About thirty years ago some enterprising Californians, desiring to try an experimental crossing of the antelope-goat with the Angora goat of Asia, visited Montana and offered large rewards, I believe, as much as 8opdol. apiece, for live adult goats. In the 
course of a year they succeeded in getting several, but I was told only one reached California alive. Four hardy mountaineers of Deerlodge devoted a full year to the task of catching the wary animals, necessarily living all the time, even in winter, in the inhospitable regions above timber-line. They succeeded in doing so by bringing them to bay with trained hounds on some rocky ledge, and then approaching from above and lassoing the cornered victims while they were busily engaged keeping the dogs off

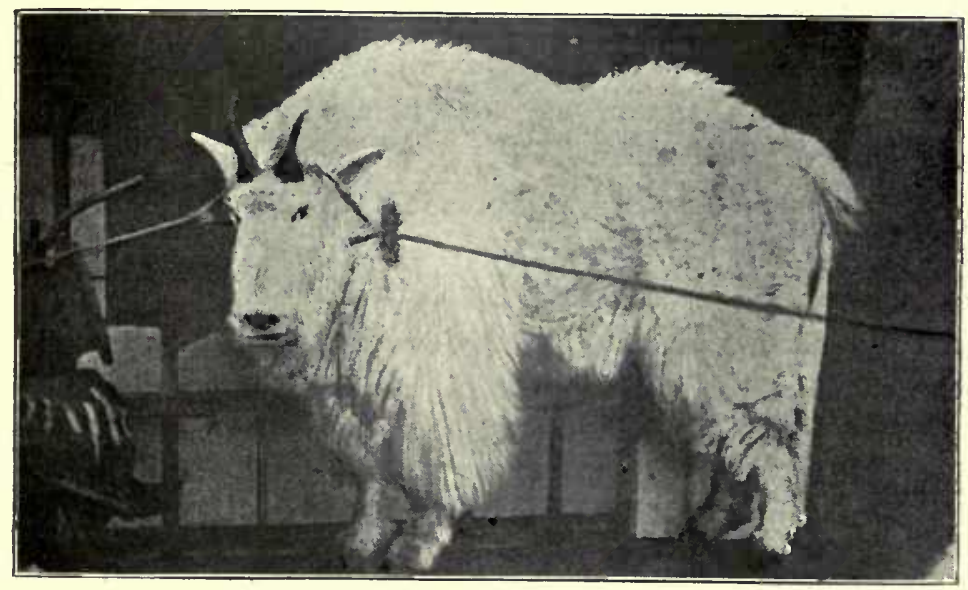

The Antelope-Goat of the Pacific Slope.

Photograph of a very large live specimen said to have weighed $480 \mathrm{olb}$.

by vicious thrusts of their sharp horns. On such occasions they are most dangerous to approach, for they are perfectly reckless, and have fierce courage, great muscular activity, and wonderful tenacity of life, and one can imagine how difficult the whole proceeding must have proved amid the deep snow and winter gales of those inhospitable regions.

One of the rams caught by these hunters is supposed to have been by far the biggest of its kind ever seen, a claim one cannot dispute provided its reported weight is true. It was brought alive to Deerlodge and kept in confinement there for some time. A 
week after its capture it was weighed and was found to turn the scales at 48 olb! It was also photographed by two men (William Hyde and Th. H. Rutter), the first photographers who set up shop in Montana, and from them I received what is believed to be the only copy extant, for the negative came to grief in a fire soon after the picture was taken. Only a few copies had been secured, and all but the one I was fortunate enough to secure shared, I was told, the fate of the plate. The illustration on p. II 4 is a reproduction, and has, therefore, peculiar interest. It represents this monster ram in his winter coat, securely tied up to a heavy iron mining-pump and is, so far as I know, the only photograph of a live Haplocerus that exists. The only large male specimen in the Smithsonian Institute at Washington was, I believe, mounted by a taxidermist who strictly copied the pose of the Deerlodge monster.

Sir Edmund Loder did for the antelope-goat what he achieved for the wapiti, i.e., he ascertained the weight of a ram as it stood when the bullet ended its career. It was a big specimen, and it scaled $246 \mathrm{lb}$. as it fell, and $183 \mathrm{lb}$. clean, so that an extreme live weight of $300 \mathrm{lb}$., or even $35 \mathrm{olb}$., is quite within the bounds of possibility. There seems little doubt that the antelope-goat inhabiting the mountains immediately adjacent to the Pacific do not attain the same great size reached by those of the interior. I arrive at this conclusion, not so much from actual experience, for I have never hunted the animal in the former regions, but from remarks made by those who have, and who appear to consider I5olb. as the weight "of about. as large a goat as ever I saw," ${ }^{*}$ and by the size of many hundreds of coast skins I have seen at different times, which is even more conclusive evidence.

Concerning the distribution of the Haplocerus, the general statement that they only inhabit the Pacific slope mountains north of Mount Shasta, close to the boundary of Oregon and

* Forest and Stream, August 27, 1885. 
California, and are never found on the Atlantic slope of the main divide, needs a few explanatory remarks. Two writers, to whose judgment I lend much weight - Mr. Grinnell and Mr. Warburton Pike-entertain the belief that the animal has occasionally been seen in Colorado and Wyoming. The latter, writing in the "Encyclopædia of Sport" (Vol. I, p. 456), says :"In Colorado, Wyoming, and Nevada, authentic instances of their occurrence have been noticed within the last twenty years."

On this point I cannot agree with either until a positive proof of such an occurrence is furnished. It is quite true that one has heard of many such discoveries of the Haplocerus on the mountains of Wyoming, Eastern Montana (near the National Park), and in Colorado, but on following up the reports they have invariably simmered down to hearsay evidence, or to the equally frequent error made by men, who had never seen a mountain goat, mistaking a female bighorn for it. Of another cause of these mistakes an English sportsman, who is an old resident of Wyoming and Colorado, has lately given me an interesting account. According to him, some of the Angora goats imported years ago have run wild, and are to be found in one or two districts of Western Colorado and Northern Utah, he himself having seen their horns. As the exterior appearance of these animals resembles in certain respects the antelopegoat, it is easy to account for the mistake made by otherwise perfectly reliable men.

If there is one region where they might dwell, if once their existence east of the Rocky Mountain divide be admitted, it is the Soshoné range south of the National Park. There I have looked for them fairly thoroughly without discovering a single sign of them, notwithstanding the positive assurance of hunters, and even of men above the ordinary run of western "tall-talkers," that it was to be found there. Further north, in the Flathead and East Kootenay country, where the main range of the Rocky Mountains consists really of three parallel mountain chains, the most westerly being skirted by the deep depression formed by the Upper Kootenay 
and Flathead valleys, the Haplocerus inhabits in large flocks the last-named of the three ridges, and is found also on the western slope of the centre chain. Both of these drain to the Pacific. On the most easterly chain, which rises from the Calgary and McLeod plains, it is, I believe, occasionally found, but there is good reason to believe that such occurs only in consequence of the fact that the Stonies and Flathead Indians hunt them with dogs, and thus cause the animals to stray beyond their natural confines. Such, at least, was the explanation I received from Stonie Indian hunters who do the most "goat" hunting.

To give the $41^{\circ} 30^{\prime \prime}$ N. Lat., or the Mount Shasta region as the most southerly point at which the Haplocerus is found, is also not strictly correct, for there is good evidence that they exist on Mount Whitney, in California, a high, somewhat isolated mountain block in Central California about $36^{\circ} 30^{\prime \prime} \mathrm{N}$. Lat., though none are to be found for $5^{\circ}$, or more than 300 miles, north, until Mount Shasta is reached. Mount Whitney may, I think, be safely accepted as the extreme southern boundary of the Haplocerus's range, the great altitude of this peak ( $14,886 \mathrm{ft}$.) explaining their existence in what is practically a semi-tropical region. Rowland Ward, in his latest "Text-book for English Sportsmen" (Records of Big Game), says "that it is distributed in North America throughout the Rocky Mountains from about lat. $36^{\circ}$ in California at least as far north as lat. $60^{\circ} . "$ This, as I have already remarked, is a misleading description, for the beast is not found in the Rocky Mountains proper, but only on the mountains of the Pacific Slope.

In the Badminton Library, Mr. Phillipps-Wolley devotes but a little over two pages to it and to its chase, declaring "that it appears to be the biggest fool that walks upon four legs," and "that there is no wild animal easier to stalk." "I felt thoroughly ashamed of myself," he writes, when he put an end to a big ram with a bullet.

I cannot at all agree with this writer in what he says of the "goat." Were what he says true about its chase being the easiest of any wild animal, it would surely have long ago shared 
the fate of the bison instead of being to-day in many places more numerous than it was a generation ago, when the Coast Indians pursued it with zeal for the sake of its fleece, of which they made their blankets. According to my experience the Haplocerus is by no means such a stupid animal, and to see it defend itself against enemies. such as dogs, bears, or wolves, to the attacks of which latter it is ever exposed, betrays anything but stupidity. What makes it appear stupid is its ingrained curiosity that causes it to stand gazing at any unwonted sight, such as a man. A dog, a bear, or a wolf, it does not waste time looking at, but betakes itself off, or seeks speedily a place of vantage where it can defend itself against enemies with which it knows perfectly well how to deal. The Flathead and Stonie Indians, who used to do a lot of goat hunting, have repeatedly told me that in places where goats are often hunted they become as difficult of approach as bighorn, which, if true, amply corroborates my impression.

A much more correct description of the country frequented by the Haplocerus is given by another British Columbian, Mr. John Fannin, curator of the Provincial Museum in Victoria. This writer on our subject says that it is abundant "along the rugged peaks of the Coast Range." "Here," he says, "amidst nature's wildest scenes of storm-swept beetling crags and snowy peaks, where the silence is seldom broken even by the rush of mountain torrents or the crashing of the treacherous avalanche; here, far removed from the trail of the ordinary hunter, the mountain goat enjoys freedom of action, unmolested by the persecution of man, to a much greater extent than is allotted to any other animal in the mountains, and it may be safe to say that it will exist when all other animals of the forest shall have been exterminated or driven beyond our boundaries." *

According to the same writer, the Haplocerus inhabiting the rugged mountains adjacent to salt water along the countless inlets of the British Columbian coast descend to lower regions in January

* "Western Recreation," April, I897. 
and February, and he has known of goats being killed within a few hundred yards of the sea level, and to be captured while actually swimming wide stretches of salt water. He, himself, on one occasion bagged three goats and got back to his canoe within an hour from the time of starting. The interminable heavy rain and squalls make hunting along the inlets at this season a somewhat disagreeable sport.

Mr. Theodore Roosevelt, in the "Encyclopædia of Sport," when speaking of the chase of this beast, says that "there is no game animal in America the pursuit of which entails such severe toil," and this is certainly very true, except along the coast of British Columbia.

No animal leaves upon the mind of the observer the impression of greater stubbornness than does the Haplocerus. One great peculiarity of its structure is the remarkable shortness of the metacarpal bones, which, in the case of the skeleton of an adult specimen presented by Sir Edmund Loder to the Natural History Museum (see "P. Z. S," I 889, p. 59), measure only about 4 in. in length. To this fact reference is also made in Sir J. Richardson's "Zoology of the Voyage of the Herald" (I854), It no doubt explains the animal's peculiar gait, which, on a level rarely exceeds a sort of fast walk, be the danger ever so threatening.

Extremely little is known about the rutting season of this animal, on account of the great difficulty of reaching its elevated dwelling-places in the depth of winter. The few Indian tribes that formerly made a practice of hunting these animals systematically, aver that they rut in December, and this coincides with my experiences. I have had these animals under my observation, at various times and places, in every month between May and November; and with the exception of once noticing, in the latter month (in the Flathead country), a butting match between large adults, I have never perceived any signs of the rut. Mr. Geo. B. Grinnell, one of the most experienced observers of this quaint denizen of the Pacific Slope mountain ranges, also considers that the rut occurs in December. The young are born in the latter 
half of May. I have seen, and in two or three cases handled, quite young beasts in the first half of June, and two instances mentioned by the above writer confirm this. So far as I know, no zoological society possesses, or has ever possessed, a live specimen.

Hitherto stalking the goat has been mainly dealt with; a quicker and less arduous method of bagging this beast is to employ dogs, who save one no end of "bootless" climbing and fatigue, though it is, of course, not so sportsmanlike a feat. It must be remembered, however, that even with dogs the sportsman's endurance is tested by attaining the above timber-line regions where, except perhaps in the immediate vicinity of the Pacific coast ranges in sight of salt water, the goat is to be found during the open seasons of the year. Some excuse therefore is to be made if men, short of time and no longer able to stand the hard work of stalking, take refuge to the employment of a few hounds trained to their work.*

When cornered by man or hound its habit of defending itself with its sharp horns gives an old ram a fierce and yet somewhat comical appearance. Its ever lowered head, sturdy assurance in its strength, and the fact that it observes its enemies much as an irate old gentleman would over his spectacles, no less than its shaggy bison-like "humpiness" of appearance, make it an unique sight, especially in autumn, winter, and early spring, when its winter coat has attained its full growth.

There is great similarity between the hoof of the Haplocerus and that of the chamois, in so far as the inside surface of both are of an elastic india-rubber like texture, while the outside edge is extremely hard and as sharp as a chisel. The one breaking the jar when leaping down great heights, the other taking advantage of the smallest crevice or unevenness to gain a foothold.

* This hunting was described by me in an illustrated article in the Century Magazine, December, I884. 
The Haplocerus has behind its horns a musk gland, not unlike that of the male chamois during the rut, and the meat of both male and female is strongly impregnated with a musky flavour, which makes it repulsive to all but the semi-starved. And, even in the case of the latter, almost anything is preferable to goat venison if it is not that of a kid. I remember once being out after goat with my friend Medhurst, when we ran completely out of provisions, the man whom we had sent down for a fresh supply not having returned as quickly as we expected. We had been out stalking all day, and I had brought back a bit of meat from a fat black bear I had killed. We had absolutely nothing else in camp, and when Medhurst got back, long after dark, he brought in a piece of goat venison of an old ram he had killed. He had eaten nothing since early that morning, and he and the dog he had with him were pretty well starved. Medhurst had never been hungry enough to touch goat or bear meat, for he had the strongest possible aversion to both. Even in this instance he could not swallow either, and made a very meagre supper off the blackened rind of bacon with which we had for the past week greased the frying-pan when baking bread. This, at no time very appetising rind, Medhurst literally took out of the mouth of the dog who had discovered the discarded treasure lying about camp, and was gnawing at it when his master forced him to give it up and accept in lieu of it a chunk of the venerable goat's "venison." It was the funniest sight in the world to see that dog tackle this meat. Aversion to the musky flavour seemed to be almost as pronounced as in the case of his master, and even when he had swallowed it, certain sounds which we presently heard led us to suppose that goat's meat may possibly possess valuable pharmaceutical qualities as an emetic of speedy action. 


\section{CHAPTER V.}

\section{THE MOOSE, CARIBOU, AND SMALL DEER OF THE PACIFIC SLOPE.}

As a rule sportsmen are the first to penetrate into unexplored regions, leading the way for miners and others engaged in occupations that bring them into contact with the wilderness. In Africa, Australia and Asia, the amateur or professional hunters were invariably the forerunners. The only exception to this rule known to me is to be found in the case of Alaska, where the miner preceded the hunter. Up to three years ago it was, I believe, absolutely unknown that by far larger moose than anywhere else were to be found in the dense scrub forests and marshy valley bottoms of that inhospitable land. It was as unknown as the fact that white bighorn could be found there, and that a species of bear very akin to the practically extinct Californian grizzly roams through the Alaskan woods.

The largest unquestioned moose head exhibited at the American Trophy Show was Mr. Otho Shaw's trophy with a spread of $65 \mathrm{in}$. About Mr. Bierstadt's moose antlers, which measured rin. more, I have heard some doubts expressed whether the spread was a perfectly natural one, and not attributable to an artificial widening of the antlers on the part of the taxidermist who mounted them, so as to increase the spread. For this reason I think it fairest to consider Mr. Otho Shaw's as the largest at the exhibition. Nothing much better turned up for ten years, when suddenly certain giant antlers came down from Alaska as a result of the first rush of prospectors to the Yukon; and Sheard, whose 


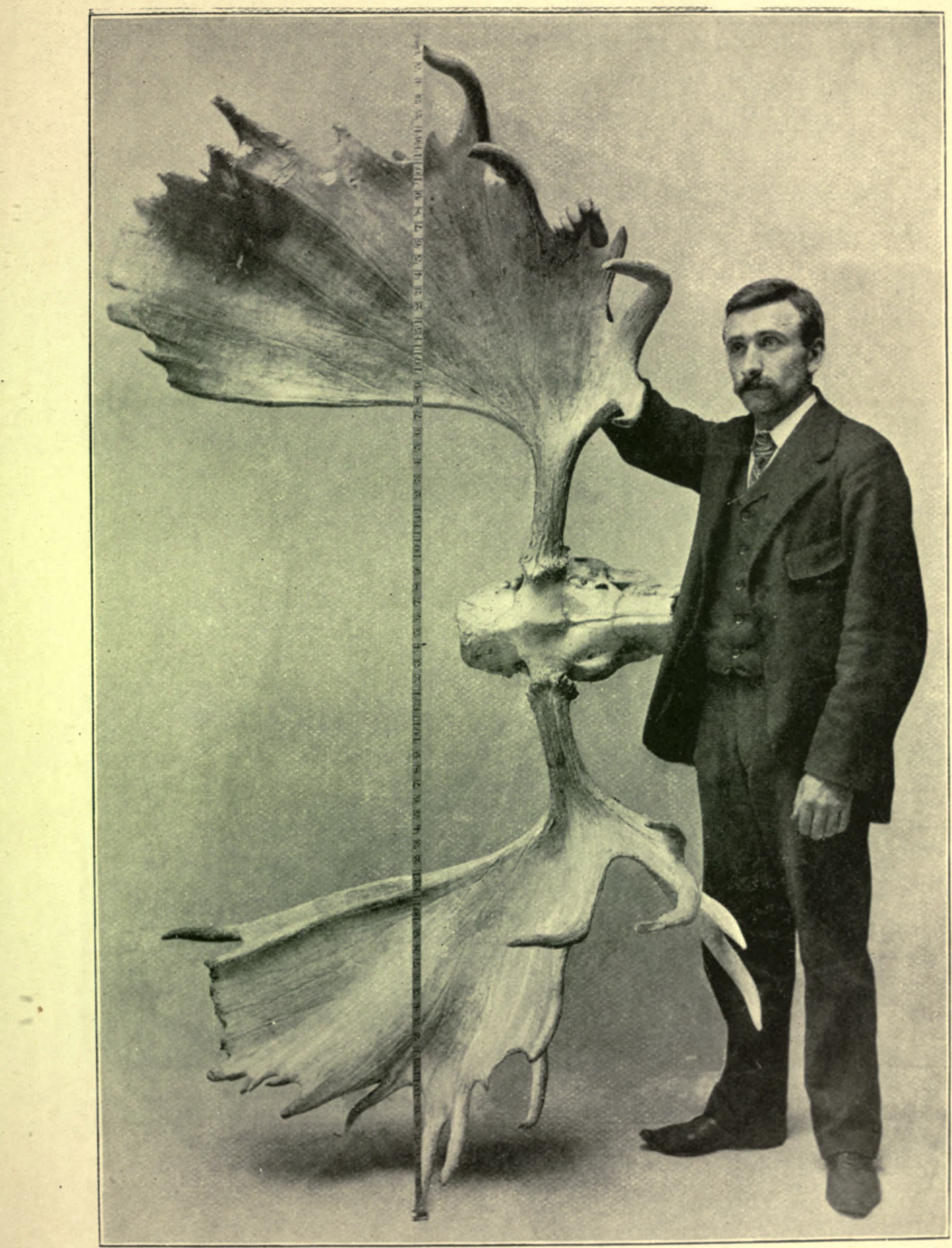

The Largest Moose Antlers on Record.

Shot in 1897 , in the Yukon Basin, Alaska. $78 \frac{1}{2}$ in. spread, with 43 points. (Owned by W. F. Sheard, of Tacoma.) 

residence at Tacoma (from which place steamers run to Alaska), of course, gave him unrivalled opportunities to collect the best there was, soon afterwards became the owner of several splendid antlers.* One of them was bought, I am told by Sheard, for 5oodols. by Sir Bache Cunard. It is the head now owned by the Duke of Westminster. As its picture has been published on many occasions, I do not think it necessary to give more than the following particulars which, I see from a photograph sent to me by the present owner, are as follows: 72in. spread with forty points ("Records of Big Game" gives it credit only for thirty-seven points).

Another giant pair of yet larger dimensions followed down from Alaska soon afterwards. It is the wonderful trophy of which I give a photographic representation. Sheard informs me that it measures $78 \frac{1}{2} \mathrm{in}$. in width, and has forty-three tines, and I think he has every right to call it the record moose head of the world. He offered me this interesting head mounted for 5oodols. I immediately wrote to him, closing with him on those terms, but to my disappointment he subsequently withdrew his offer, stating that he would not sell the head at all at present.

"Records of Big Game" is again sadly at fault respecting this head, for not only is the head placed third instead of first, as it, on account of its record span, deserves, but the number of tines is understated by three, for, according to the owner, whose accuracy I have no reason to doubt, it has forty-three points, several being invisible on the photograph I have reproduced.

Sheard, writing to me quite lately (June I 2, r 899), complains of Ward having only given this head credit for forty points, and makes the following remark concerning the two heads which Ward has placed before this $78 \mathrm{in}$. one, and which measure, according to Ward, $70 \frac{3}{4}$ in. and 6gin. respectively in width. Sheard, writing to me in reference to this matter, says: "As to the measurements of

* In a late letter from Sheard, he telis me that he has " just received sixty. fcur large moose heads from the north, and six whole specimens." 
Mr. Tolhurst's and Mr. Hart's moose heads, I am surprised at the measurements given, as I owned both of these heads at one time."

Sheard's great trophy weighs, he tells me, as we see it in the photograph, $8 \mathrm{Ilb}$. I20z., while Mr. Hart's specimen is reported to me as weighing only $58 \mathrm{lb}$. It is likely that the live weight of the larger of the two animals must have been nearer 3ooolb. than 2ooolb. It was killed in 1897 in the Yukon Basin.

The two moose heads of Sir Peter Walker, which Ward in his third edition states came from British Columbia, were not killed in that country, as Sir Peter informs me in reply to an inquiry on my part. In the same letter he tells me that the measurements of the Norwegian elk head of his are wrong in Ward's book, as it is bigger than the head belonging to Mr. Bate, which stands at the top of the list.

Leaving the subject of heads to touch briefly upon the chase of the moose, one must premise that between moose hunting as occasionally practised in a haphazard sort of way on the western watershed of the Rockies, and the highly elaborated manner in which that sport is pursued in the Eastern and Central provinces of Canada, Manitoba included, there is a vast difference. It arises not only from the fact that most of the Indians inhabiting the coast districts of the North-west, where the moose is found, are more fishermen than hunters, but also in consequence of the far more impenetrable character of the forest in the latter countries, which makes hunting very much more difficult.

Of moose hunting in the Yukon District of Alaska as well as in the numerous hunting grounds at the head of the great inlets, such as Cook and Copper River, in which these big heads were obtained, I know nothing by personal experience. I am told that most of the moose are killed by Indians who go out meat hunting to supply mining camps. As much as 1 dol. per $\mathrm{lb}$. is paid for venison where grub is scarce. This will probably lead, in all the mining regions, to a speedy diminution of their number which was never very great, to judge by the prevalence of scurvy, and the frequency in past days of men starving to death in Alaskan 
wilds, a fate which could not well have befallen them had game of any sort been plentiful.

The Indians kill the moose, of course, in the easiest manner, i.e., running them down on snow, but as this is not a method that will appeal to non-professional sportsmen, I am tempted to reprint, with the author's kind permission, a paper published three or four years ago in the Field (Dec. I4, i 895), by General Richard Dashwood, in which he describes moose-calling by a white caller in Eastern Canada. This is very fine sport, for it not only tests one's skill in the perfect imitation of a weirdly unfamiliar sound, but also in the stealthy approach of a highly suspicious and shy beast. Both require great experience in woodcraft, as those who have ever tried to call a moose or even a red deer stag know full well. They will also realise how unjustified are the sneers of those who declare that calling moose is nothing but potting at the shortest range an animal blinded with passion, and whose venison, they never fail to add, with more vehemence than regard for truth, is totally unfit for human food. These cavillers generally point to the Norwegian fashion of elk hunting as the acme of sport. To follow a hound turned loose on the tracks of an elk till the latter turns at bay, may require as great or even greater endurance, but it certainly calls for no woodcraft, and has about it, I should have thought, none of those supremely exciting moments that rejoice the heart of the moose caller.

But let the already mentioned master moose-caller relate his experience which, though garnered in the Eastern districts of Canada, will apply, I see no reason to doubt, in the main also to the magnificent Pacific Slope representatives of the largest existing specimens of the largest deer species in the world.

General Dashwood writes:

Some years had elapsed since I had heard the welcome grunt of a bull moose in response to my call on a birch bark caller; I therefore decided to have another turn in the Canadian forests in the rutting season, hoping that by good luck I might possibly kill a moose whose antlers should measure $5 \mathrm{ft}$. across. Hitherto the largest moose I had shot 
measured 53in. in that respect; 50in., if well pronged and palmated, may be considered a good head, but 6oin. and over is very rare, especially in these days.

Leaving Liverpool last August, I arrived at the place where I decided to camp on the 26 th of that month. I was on a chain of lakes connected by a brook, which in some parts was dead water, and in others so shallow and rocky as to necessitate portaging. We spent the time prior to the rutting season in prospecting the lakes in the vicinity, and the sluggish parts of the brook, looking for open spaces wherein to call, and carefully noting tracks and other signs, which denoted the near presence of the animals we intended to hunt. It was patent that although there was a fair sprinkling of moose in the vicinity, they were by no means plentiful, having been much disturbed of late years by lumbermen, and also killed in the deep-crusted snow, in defiance of the law, by red and white pot-hunters.

My Indians consisted of a first-rate caller and creeper from the Maritime Provinces, and a local man, who was a good cook and lugger, but a poor hunter, and absolutely ignorant of calling.

Having spotted on two occasions the fresh tracks of a big bull on the shores of a lake not far off, we tried him on the night of Sept. 5, but, although the animal answered the call, he would not come, as the rutting season had not commenced; or, as the Indians say : 'he had not started.' Two mornings later my Indian Joe, the caller, brought him up, and I shot him; a fine beast, his horns measured $54 \frac{1}{2}$ in. across, were beautifully pronged and palmated, and very symmetrical

For the next three weeks or more the weather was windy, and we never had a single night or morning that was really good for calling; for to call when there is any wind is worse than useless. The animals come up and smell you, and then good-bye to them, for they at once leave the neighbourhood.

By Oct. 4 both my men were ill in camp from chills, caught lying out night after night with no fire, in the hopes of the morning turning out still, which it never did. On the $5^{\text {th }}$ it promised to be a first-rate evening, so, leaving the Indians in camp, I went out alone, got into a canoe with gun, rifle, and blanket, paddled across a lake, and then crossed a narrow strip of land that divided the lake I had just left from another one. I was at the bottom of the lake, which extended over two and a half miles, there was a clear space, where the trees and bank had been cut by lumberers, of about 8 oyds. long by 5 oyds. wide; an old lumber road ran along about rooyds. from the water to a camp situated at the further end of the lake, the bank 
of which, at this spot, was about 3 oft. high, descending at a steep angle to the shore, and quite clear of trees or unclerwood. This afforded an excellent calling station. As the sun dipped below the trees which surrounded the lake, I commenced operations, calling at intervals of about twenty minutes. Soon the moon, which was only one day past the full, arose. There was a considerable frost, the night was perfectly still, the atmosphere very clear, and I could hear my call echo and re-echo for miles in all directions, truly a splendid night. For four hours I continued, listening intently between each call; no sound was hearcl, save the hoot of an owl or the splash of a musk rat. Once I thought I heard a bull moose grunt a long way down the lake on the left side, if it was a moose he had a cow, as I heard him no more. It was intensely cold, and standing listening with one's aural nerves continually at the highest tension is a great strain. At 9.30 I decided to lay down till morning, and was soon under my blankets, with some spruce boughs over my head to keep off the dew.

I awoke at daylight, got up, and gave three calls, rather louder (it flashed across me just as I had finished) than Indians usually make the first call, for the reason that, if a moose happened to be near, if the call was loud he would more readily detect any flaw there might be in the sound made by a man who was not an absolute master of the art. Well, the echoes had hardly died away when I heard a tremendous crash in the woods - to my right, quite handy-not more than 200 or 300 yards off, followed by the grunt of a bull moose. I knew by his voice he was not a small one. Then a short interval of silence as he stopped to listen, as they do ; then more crackling of sticks, and the noise made by horns coming through a thick place. After one or two such intervals I suddenly heard him in the water; though coming along shore. Now, I thought, I shall get a clear shot. I squatted down some six or eight yards from the edge of the bank in line with a bunch of young cherry, which, while it served as a screen, was too small to stop or turn aside a round bullet. I hadl my gun in my hand, as it was not quite light enough to see the sights of a rifle.

There was a thick fog on the lake, and at first I only heard the animal walking in the water, but in a few moments the form of a gigantic moose emerged from the mist, walking steadily along about thirty yards out in the water. His coat seemed black as jet, his horns wide-spreading on each side of his head, he did not stop or hesitate, but came on confidently. A splendid sight, indeed! Now I knew that, although there was no wind, so to speak, yet a little air was drawing out from the land where I was into the lake, therefore, that I must not let the animal get opposite me. So when 
he was at an angle and about forty-five yards off, I pulled a trigger. On feeling the ball he gave a plunge and jump and stood still; on getting the second barrel he jumped and wheeled round and went ten yards back, and stopped. I put my right hand into my coat pocket for another cartridge. It was empty. I had taken them out when I laid down the previous evening and forgotten them in the morning, gross carelessness, I admit. I ran for my rifle, which was loaded, leaning against a $\log$ about ten yards off. The moose now saw me, and trotted off the way he had come; I had just time to fire my rifle before he turned into the woods. Loading my gun, I now went down to where the animal had landed, which was at an old logging road; there were his tracks, plain enough, but no blood. Good gracious, I thought, can it be possible that I have only slightly wounded him, and may lose him after all. The thought was too possible to dwell on. A little further on I detected some spots on the crimson leaves of some young maple which seemed of a deeper shade than the rest of the leaves. Then, a few paces further a pool of blood! Now, it is a mistake to press even a mortally wounded animal; I knew also that Joe, on hearing the shot, would very soon be on the spot, moreover, his assistance would be useful in tracking the animal, so I went back to where I had fired, and, on coming out of the woods, the first thing I saw was Joe's face, which was a picture-a picture of expectation, delight, and anxiety. Well, I took him to where I had left the trail. "Noose not get far, Joe, see froth on blood; shot through lungs." In about 200 yards he came on the beast lying down. He staggered to his feet and glared at us, when I gave him a finishing shot. I had hit him every time behind the shoulder; but moose at this season, old Indians say, are very tenacious of life, and will often go some way, unless their backs or necks are broken, or their hearts pierced. "His horns bigger than the last moose," said Joe. "Well, we will soon see," I said. "Out with the tape." On his producing a $5 \mathrm{ft}$. tape, I directed him to place the end on the widest tip of the horns on one side, and, taking the reel, proceeded to unwind it so as to place the tape on the opposite tip. I was within an inch or two of the opposite prong when there was a check in the reel. I glanced down; the tape was too short! A 6o-incher at last! The correct measurement was 5 ft. $1 \frac{1}{2}$ in. across the horns, and the animal stood $19 \frac{1}{2}$ hands at the shoulder.

We afterwards saw where he had come down the lumber road, probably from over two miles off, but as I ceased to call at 9.30, on coming near and hearing no further calls he turned into the forest, and lay down until he heard me call at daylight, about 250 yards from him; this goes to 
show how erroneous is the statement made by the writer on moose in the "Badminton Library," in a hypothetical account of moose calling, viz., " that no Indian, however good a caller he might be, would dare to call when a moose was near." I have seen Joe call a moose up when he was not distant over roo yards, and I have on two occasions done the same myself.

Last year I took the greatest exception to the assertion made in the same work by Mr. Wooley, that moose eat grass and moss, which I denied in toto, while in their wild state. This year I have spent sixty days in a moose country, and, to make assurance doubly sure, took most careful observations as regards the food of these animals, with the result that $\mathrm{my}$ contention (which was backed by all the old moose hunters of Nova Scotia) that moose, when wild, never eat grass or moss of any kind was confirmed. At the same time, I can see how this mistake may have been made by people of little knowledge of the woods, or the beasts therein. Moose and musk rats frequent the same places in the summer, and the chief food of the rat is the long coarse grass that grows often on the margin of lakes and "dead waters," and also certain grassy weeds which they pull up to get at the roots, of which they are fond. But moose never touch either of the above, but they feed on a short aquatic plant, a few inches high, with a spear shaped leaf, which grows in the same localities, and also on the water lilies that have a red flower.

I saw plenty of all these plants, and there was no evidence whatever of moose ever having eaten the food which is confined to the musk rat. Any old Indian will tell you they never eat grass or moss of any kind, which entirely agrees with my observations made this autumn. Therefore any statement to the contrary, by whomsoever made, whether past or in the future, may be put down as unworthy of credence.

So far General Dashwood. I have but to add that 1 have never hunted moose in Eastern Canada, my experience being confined to the Teton Basin, Jackson Hole, Northern Idaho, and Western Montana, in none of which regions 1 found them as plentiful as $I$ expected.

On the only occasion that I have tried to call moose myself, the success of my call, though not of my rifle, was so sudden that $I$ ignominiously failed to bring to book the finest old bull 1 have ever seen. I had, not without failures, at last succeeded in manufacturing a call from some birch bark. This instrument I 
used to carry with me while hunting for other game, in case an opportunity should arise for using it. One September day, whilst riding along the dense timber at the base of the Tetons, I struck fresh moose tracks in the thin layer of snow. As they led into a dense swamp at the southern end of Jackson's Lake, I thought I would see how my call worked ere I entered the swamp. Dismounting from old Boreas, I was idiotic enough to leave my rifle in the sling on the horn of my Mexican saddle, intending, of course, to take it out prior to tying up my horse to a tree.

Imitating the bull's call, with which I was more familiar than with that of the cow, almost the first note was answered by the rush of my would-be prey, who came forth into the open from the " fringe of the dense alder brush with such an alarming suddenness, that it not only took away my breath, but scared out of its wits my otherwise reliable old hunting horse, standing untied at my side. I suppose it must have been the unwonted sight of a horse kicking up its heels and galloping off that attracted the curiosity of the old bull, for he stood stupidly staring at the disappearing horse for quite two or three minutes, apparently taking no notice whatever of my motionless self less than thirty yards off, a small bush half hiding my body.

When Boreas's form had disappeared, and the sound of the wooden stirrups clattering against trees had died away, the old bull quietly turned and retired at a walking pace to the brush from whence he had issued.

It was hours before I caught up Boreas, who, for a wonder, had not added injury to insult, for my rifle had received no damage whatever. That I haunted the swamp for the next week need hardly be added, but it was all in vain; there was not an ounce of curiosity left in the 1500 or $2000 \mathrm{lb}$. avoirdupois of that moose.

In an interesting article on the distribution of the European elk or elch and the American moose, in the Field (September 2nd and

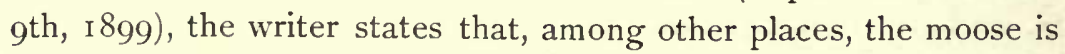
to be met with in the Rocky Mountains, "especially near the sources of the Elk River." There are dozens of Elk Rivers in the 
west, whereby wapiti and not "moose" are meant. On none of the Elk Rivers I have ever heard of are moose to be found at present.

\section{CARIBOU.}

It would be difficult to discover a more telling proof of what modern means of transportation can accomplish, than is shown by the experiment of introducing reindeer into Alaska, which until quite lately was carried on by the United States Government. Into this excessively remote corner of the world, large herds of this animal have been brought, not only from far away Norway, on the other side of the globe, but also from the tundras of Siberia. From the East and from the West the reindeer was made to invade Alaska, crossing oceans in the swiftest steamers and the continent in special trains. On reaching the Pacific coast, the animals were re-embarked in coast steamers, and after a long and rough journey were at last landed on the shores of their future home.

Should the expectations of the competent naturalists who recommended this novel attempt to improve upon the provisions of nature become fulfilled, science will have achieved what nature for some mysterious reason did not see fit to bring about. Tens of thousands of an allied species, the Barren-ground caribou, inhabit regions adjacent to Alaska, where, as anybody who has read $\mathrm{Mr}$. Warburton Pike's book will remember, vast herds-the $L a$ Foule of the French half-breeds-can be watched when migrating towards the end of October to the frozen barrens north of Great Slave Lake. None stray, however, to those regions of Alaska where the native and the white miner is so much in need of a beast eminently suited for purely domestic as well as for commercial purposes. For three hundred years hordes of human beings from all quarters of the globe have invaded the New World, testing to breaking point her wonderful powers of assimilating the most incongruous elements. It is safe to say, however, that no more curious ship load of emigrants ever stepped the shore of North America than the one that issued forth from the good ship Manitoban in February, I898. Five hundred and forty-seven 
Norwegian reindeer, and I 8 Laplanders to tend the herd were added on that February day to the fauna and to the population of the great Republic, and the two special trains that forthwith hurried this strange crowd at express speed across the Continent to Puget Sound, and from thence by ship to Alaska, offered a sight worthy of the curiosity it excited.

To the imported reindeer that reached Alaska from the west less public interest was attached, for that part of the experiment was carried on far from centres of population, and the transshipment of the Siberian deer across the Behring Straits, under the able direction of Dr. Sheldon Jackson, though fraught with great trouble, was naturally one that does not appeal to the same extent. to one's imagination.*

Having said this much about this interesting addition to the indigenous caribou of the Pacific coast, a brief account must be given of the latter. The woodland caribou of British Columbia are, we are told, the same that inhabits Newfoundland. They are quite a third larger than the Barren-ground caribou, and their antlers show the same difference.

They are shy, exasperatingly uncertain and restless denizens of the upland plateaux of British Columbia.

I confess I never could get up the slightest enthusiasm to slay this beast by stalking, or to expend time and trouble to secure their unattractive, dishevelled-looking antlers. Fifteen years ago. they were plentiful on the steep slopes round Kootenay Lake; at least, to judge by the well-beaten trails they had made up and down the mountains surrounding that sheet of water. But the great forest fires that occurred as the inevitable result of mining prospectors invading this region, soon drove them from their haunts to regions further north. The few I shot were killed for the pot,

* In January, i 897 , there were I I oo Siberian reindeer in the five establishments where these experiments are being carried on, In the preceding year 416 fawns had been born, of which 357 were reared. The Central Government reindeer station is known as the Teller station. The Field of March 5, I898, contains some further details. 
when I happened upon them on the trail, or when I discovered them swimming across arms of the lake, and as I have never seen a decent caribou head on the Slope, or one I would care to bring home, I do not look back on any chances I may have missed with particular regret.

It has one peculiarity which, I believe, is not generally known, i.e., that it does not shed its coat as other deer do by the hair falling out. The annual change in the coat is brought about by the extreme tips losing vitality, and getting rubbed off. Anybody who has ever seen a caribou swim cannot help being struck by the ease, swiftness, and endurance evinced. The fact that they show much more of their neck above the surface than any other deer is explained by the peculiar texture of the hairs. These are not only much coarser, but the duct inside is larger than in other hair, and being filled with air, each acts as a sort of miniature natural life-belt. So great is the buoyancy of caribou hair that they have been used to fill life-belts, and a German, Dr. Mintz, has invented a cloth made of caribou or reindeer hair which, when made into suits, prevents the human body from sinking.

\section{THE SMALLER DEER OF NORTH AMERICA.}

Sportsmen and naturalists, such as Caton, the Wards, of Rochester, U.S.A., as well as the savants of the Smithsonian, know only three species of the small deer in North America (north of Mexico). They are the white-tailed deer (C. virginianus), the mule deer ( $C$. macrotis), and the black-tailed deer ( $C$. columbianus). They are so distinct from each other that the difference can be 'detected at a glance. The colour of the coat, the shape of the ears, the tail, and the antlers all mark the distinction. Rowland Ward, of Piccadilly, in London town, on the other hand, tells the sportsmen of the world, to whom he dedicates his text-book, that there is no distinction between the two last named kinds.*

* When this was written, the quite recently published third edition of Ward's book had not been published. 
This is what he says of this new species of "Piccadilly deer"-it is found nowhere else- "The mule or black-tailed deer (Cariacus macrotis var. Columbianus). The variety has much larger ears than the white-tailed deer, and, owing to its having the tip of the tail black, is often called black-tailed. Distribution: Along the Pacific coast, Oregon, California, Washington, Nebraska, Dakota, Wyoming, Colorado, and Kansas."

Not one of these statements is correct, for he has not only bunched together as one, two distinct animals, but neither inhabit all these distinct regions. No mule deer has ever been seen on the Pacific coast, and no black-tailed deer has ever set foot of its own accord within Iooo miles of Nebraska, Dakota, Colorado, or Kansas. According to this text-book, we have, therefore, only the white-tailed deer and these "Piccadilly" deer in North America (north of Mexico). Taking up the latest of all English text-books, Mr. Lydekker's “The Deer of all Lands," published also by Rowland Ward, we are told that, not counting wapiti, moose, and caribou, there are fifteen different kinds of deer in North America!* Fifteen to Ward's two !

In striking contrast to the latter's distribution of his "Piccadilly deer," Mr. Lydekker goes to the other extreme. Thus of one species, which he calls Crooke's black-tailed deer, Mr. Lydekker tells us, that it is confined to the "Dog Mountains, Grant County, New Mexico!" No, not even a whole county does this rare beast own for its playground. And rare it must be, for he acknowledges that he has founded this new race of deer on the strength of a single female specimen! On trying to localise "Dog Mountains" on my map of New Mexico (one of Rand McNally's), I am unable to find any trace of them in any of the thirteen counties into which the territory is divided. In his introduction Mr. Lydekker remarks that: "An exceedingly difficult and unsatisfactory part of the subject has been that relating to scientific nomenclature." By his

* Mazama americana typica, macrura, osceola, texana, mexicana, tolteca, savannarum, truci, crookei, hemionus, H. typica, H. californica, H. peninsula, eremica, M. columbiana. 
wholesale creation of new and hitherto unheard of species $\mathrm{Mr}$. Lydekker redeems with a vengeance his assertion that "zoological nomenclature is undergoing a complete revolution."

But, pace new names, three old-established species of the smaller deer, as Caton enumerated them, and no more, inhabit, I am convinced, North America. Of these three the mule deer is by far the handsomest, though not approaching the wapiti in size. The antlers, with their peculiar backward sweep of the main beam, throw out occasionally a great number of tines. The largest of the great

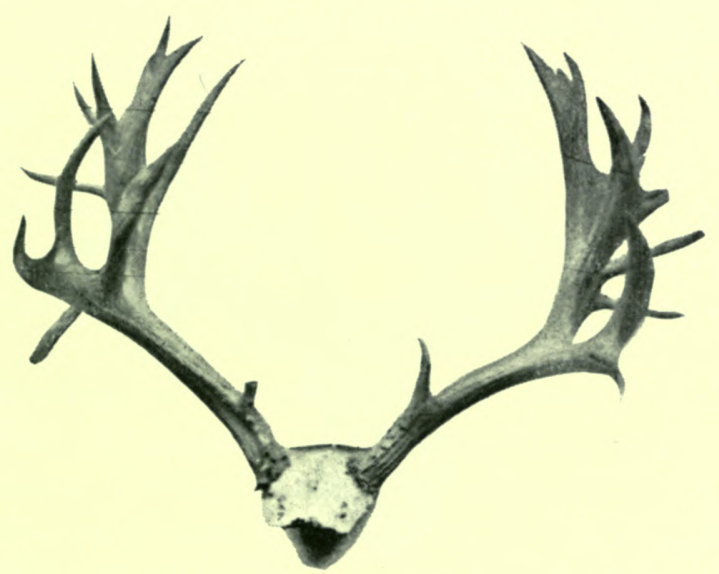

The Author's 26-tined Mule-deer Head.

number I have killed had twenty-six tines, but I believe $\mathrm{Mr}$. Theodore Roosevelt has one bearing the extraordinary number of thirty-five, while Mr. Moreton Frewen has one with twenty-nine. I do not know, however, whether they were killed by the present owners.

The autumn coat resembles the mouse-grey of a roebuck's winter coat. They love timber, and are hard to see, a fact of which they are perfectly well aware. When they think one will pass them undetected, they will stand thirty or forty yards off, staring at one with the greatest composure. But at the slightest 
sign of a halt they are off, and hard shots they give one, for they are splendid hands at making the most of cover, and dodge about in a most puzzling manner.

The black-tailed deer of the Pacific coast districts has probably the most limited lateral distribution of any deer, for it is not found, except in some isolated cases, to the east of the coast range; and, as Caton already observed, I know of no authentic instance of it being found anywhere near the Rocky Mountains proper. Mr. TurnerTurner has published, in his "Three Years' Hunting and Trapping,"

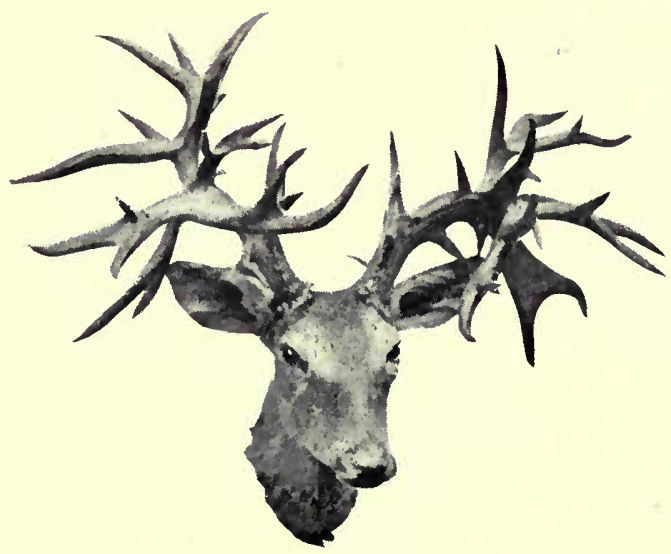

Mr. Morton Frewen's unique White-tail Deer Head.

(Bought in Texas.)

a map showing its distribution. As he has had much experience in Northern British Columbia, more than any other sportsman I know of, always excepting Warburton Pike, his observations should be very useful.

I do not think that anybody who has done much hunting in Wyoming, Montana, or Colorado, can possibly care very much for the sport afforded by the true black-tail of the Pacific coast. This deer keeps almost entirely to the dense timber, where stalking in the usual sense is next to impossible. And when got, the head, very 
like that of the white-tail, is hardly a trophy about which a travelled sportsman will wax very enthusiastic. On some of the islands round Vancouver Island, and in many parts of the latter, it is very plentiful as has already been shown in a previous chapter.

When speaking of the mule deer and black-tailed deer one must, of course, not confuse the scientific with the popular nomenclature, for the Montana, Idaho, and Colorado professional hunter or guide, who has never seen a true black-tailed deer, insists in calling the familiar mule deer a black-tail, the black tassel at the end of its tail exercising apparently an irresistible attraction that way. At the same time, the most ignorant hunter will not bunch the two species together, for he knows there is a Pacific coast deer. In this, as in many other similar cases, not only the Western hunter, but also the educated sportsman, runs counter to the decision arrived at long ago by his own scientific men, amongst whom Caton and the late Professor Baird occupy, of course, a foremost rank. Thus most, if not all, the new sporting literature of the United States, including the thoroughly well got up publications of the Boone and Crockett Club (which contain very reliable accounts of modern sport in the west), almost invariably speaks of the mule deer as the black-tail deer. No doubt this name will soon be as ingrained in the language of American sport as is the equally erroneous appellation of elk to describe the animal which should be called wapiti. For centuries the European moose has been known as the elk or elch, and hence, if only on account of priority, the name elk should not have been bestowed by American sportsmen upon an entirely different species of deer, and all the more so as the American moose and the European elk are one and the same animal.

Now that everything connected with the wonderfully rich ferw nature of North America is receiving much more attention than formerly in the United States, some decision respecting the black-tailed deer by an authoritative body of sportsmen, such as the Boone and Crockett Club, would be most desirable and prevent the confusion now existing in this interesting department 
of Natural History. I may mention in this connection that years ago I initiated in a humble way a campaign against this misuse of names. With Professor Baird I had several long discussions, and with Caton some correspondence concerning a suggestion I ventured to make, namely, to let the Montana hunter have his way, and to adopt also as the scientific name, black-tail, in lieu of the somewhat libellous name, mule deer, and to call the Pacific coast species the Columbian deer. The usefulness of this suggestion was not denied, but owing to the lamented death of Professor Baird, which occurred soon afterwards, no official notice was taken by the Smithsonian of the suggested change. Is it too late to do so now? 


\section{CHAPTER VI.}

\section{THE BIGHORN AND THE ANTELOPE.}

MAN has exterminated many species of wild game in his day, but at no period of history has he succeeded in destroying animals with the appalling rapidity observable to-day. It is to a far greater degree than one might suppose the direct result of the invention of the breech-loading rifle. In many a secluded mountain valley in the Alps of Europe, which from time immemorial was the home of chamois, the last of that race has now been shot by modern small-bores*; and much the same result has been effected in other parts of the world, Africa, perhaps, affording just now the most depressing example.

Science has not only vastly improved the precision of small arms and, by perfecting the repeating mechanism, in sreased the rapidity of fire, but it has overcome to a perilous degree, by the new high-pressure powders, one of the principal safeguards of hunted animals, namely, errors in the judging of distances. And a skilful adaptation of the telescope has added a further and very deadly improvement to the sportsman's weapon of attack. The Express rifle, with which the big game hunter sought his quarry fifteen or twenty years ago, is to-day for mountain game as obsolete in comparison with a Mannlicher or Mauser, as in its day it was an improvement upon the muzzle-loader, throwing a sixteen to the pound ball.

In another direction, too, has science stolen a march upon big

* On the whole chamois have increased in the Alps in consequence of the greatly increased preservation, but in places where they are not preserved the above has of late occurred. 
game, making the battle a more one-sided one than ever. For modern explosives detonate with a far less loud report than did black powder, and, owing to their smokeless qualities, they do not obstruct the gunner's vision, enabling him to fire ten times the number of shots that he could a generation ago, and kill his victim at distances quite twice as great.

Though these considerations have apparently very little to do with the subject of this chapter, I am tempted to remind the critical young sportsman, wont to smile at old duffer's performances, of what the last third of a century has done for him. Those who, like myself, passed their apprenticeship to venery with the muzzleloading rifle, and who killed their first stag with the spherical ball carefully rammed home by their own hand, and fired from a weapon to which the preceding three hundred years had added but comparatively unimportant improvements, will, I am sure, recall experiences to which none of us were strangers. Bighorn stalking was probably richer in such episodes than any other, and my mind is stored with pictures of quietly grazing or resting bands of this noble game that I have watched for hours. Hours which seemed days to the excited hunter, debating with himself whether a shot at I $5^{\circ}$ or 175 yards was to be risked! An error of forty or fifty yards in estimating the distance, a mistake excusable under most circumstances, but doubly so in the bright shadowless glare of the western atmosphere, would, one knew perfectly well, turn a hit into a miss, and if the trophy happened to be a really fine one, make one supremely miserable.

But it is time to introduce the reader to those bizarre mauvaises terres ranges on the elevated steppes of Wyoming, Montana, and Idaho, where bighorn (Ovis montana) loved to roam. Professor Sir A. Geikie has given such a capital. description of this strange scenery with which the bighorn is so closely associated, that I cannot do better than to quote his words:

They are tracts of irreclaimable barrenness, blasted and left for ever lifeless and hideous. To understand their peculiar features, it is needful 
to bear in mind that they lie on the sites of some of the old lakes already referred to, and that they have been carved out of flat sheets of sandstone, clay, marl, or limestone that accumulated on the floors of these lakes. Everywhere, therefore, horizontal lines of stratification meet the eye, giving alternate stripes of buff, yellow, white, or red, with here and there a strange verdigris-like green. These strata extend nearly horizontally for hundreds of square miles. But they have been most unequally eroded. Here and there isolated flat-topped eminences, or "buttes," as they are styled in the West, rise from the plain in front of a line of buff or cliff to a height of several hundred feet. On examination, each of these hills is found to be built up of horizontal strata, and the same beds reappear in lines of terraced cliff along the margin of the Plain. A butte is only a remnant of the original deep mass of horizontal strata that once stretched far across the Plain. IIs siles and the fronts of the terraced cliffs, utterly verdureless and bare, have been scarped into recesses and projecting buttresses. These have been further cut down into a labyrinth of peaks and columns, clefts and ravines, now strangely monumental, now uncouthly irregular, till the eye grows weary with the endless variety and novelty of the forms. Yet beneath all this chaos of outline there can be traced everywhere the level parallel bars of the strata. The same band of rock, originally one of the successive floors of the old lake, can be followed without bend or break from chasm to chasm and pinnacle to pinnacle. 'Tumultuous as the surface may be. it has no relation to underground disturbances, for the rocks are as level and unbroken as when they were laid down. It owes its ruggedness entirely to erosion.

But there is a further feature addling to the repulsiveness of the "bad lands." There are no springs or streams. Into the soil, parched by the fierce heats of a torrid summer, the moisture of the subsoil ascends by capillary attraction, carrying with it the saline solutions it has extracted from the rocks. At the surface it is at once evaporated, leaving behind a white crust or efflorescence, which covers the bare ground and encrusts the pebbles strewn thereon. Vegetation wholly fails, save here and there a bunch of salt weed or a bunch of the ubiquitous sage-brush, the parched, livid green of which serves only to increase the desolation of the desert.

A broad vista of such verdureless bad-land "buttes" or peaks, lighted up by the intensely searching achromatic sunlight peculiar to these regions, where the glaring brilliancy of day is unrelieved by shadow or nebulous half-distances, leaves on one's mind the 
impression of bizarre crudeness. Wherever we glance we see the stratified bands of successive layers of differently coloured conglomerates, some of clay-like, others of pumice-like consistency. Here stands one great isolated crag, 5ooft. or 6ooft. in height. The next pinnacle of equally fantastic shape is half a mile off, yet it is easy to see that every one of the six or eight various bands of disintegrating rock, or the seams of oxides, silicates, sulphates, or carbonates which are very plainly visible on the precipitous faces of both, exactly correspond with each other, and that in both the black, the brown, the pea-green, the purple, and the vermilion streaks follow each other with the same regularity. These bands being of different homogeneity offer not precisely the same resistance to the denuding effects of rain and frost, and hence narrow shelves are formed, that run generally horizontally, but always parallel to each other across the precipitous face of the peak or hill. Generally these ledges are not wider than a few feet; while in other places they will be broad, and rise tier-like from the bottom. Notwithstanding the very scanty growth of grass-so scanty indeed as to be hardly perceptible to the eye-these ledges are, nevertheless, the favourite dwelling-places of our quarry, the bighorn. Here, too, the stalker has a good chance of approaching them unobserved from above. He must, however, to be able to undertake this, possess a clear head, and not know what giddiness is; for often the ledges are very narrow, and the height of the precipice stupendous. Many an enjoyable creep along such places have I risked, and many a pleasant family still-life scene have I watched in close proximity, scenes that were rudely disturbed, if the paterfamilias happened to have good horns, by the crack of my Express. In such localities it was not infrequently quite impossible to save any of the meat, for often it was as much as I could do to saw off the horns, and, tying a short cord to them, drag them behind me as I crept back to safer ground.

But let us now speak of the reality-the bold and majestic ram, standing motionless on yonder giddy shelf, showing in perfect repose the classic outline of his noble head against the blue of the 


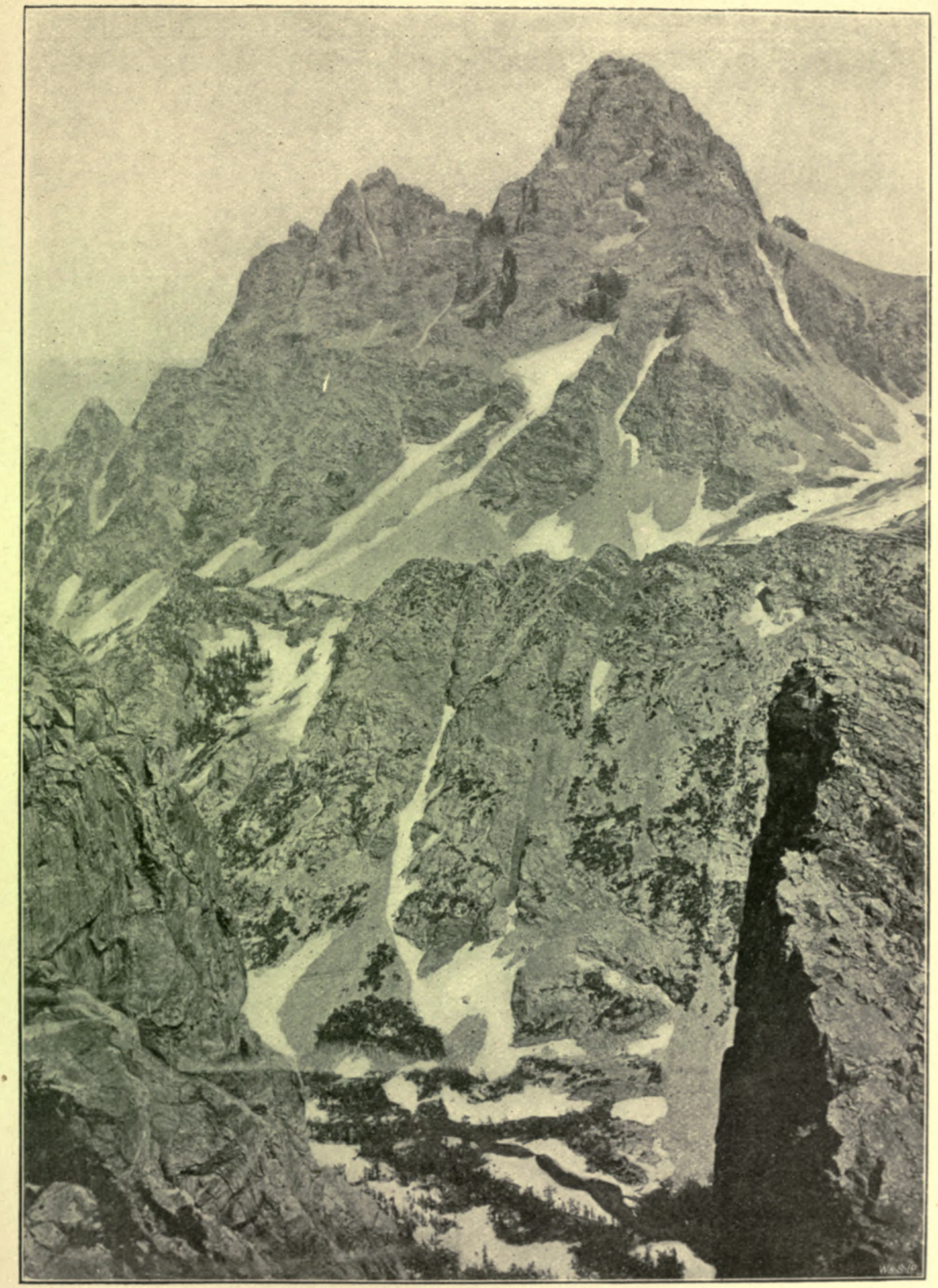

The Great Tetons (13,80oft.) on the Borders of Wyoming and Idaho.

Some of the author's favourite stalking ground.

(Trees in the foreground are large pines.) 

Rocky Mountain sky, as if cut in cameo fashion by the deft hand of a Grecian sculptor. With his sturdy, massive body, his thick-set limbs firmly planted on the ledge, his small head carried high, as if the heavy horns were a mere feather's weight, he looks the emblem, not of agility, as does the chamois, but of strength. Of all game that calls the Rocky Mountains its home, he is the truest type of their grand solitude and barren vastness.

The bighorn, of which the fur hunters used to speak as the Grosse corne, Cimarrón, is known in the West as the mountain sheep. It is closely related to the monster of his species, the Nyan Argali, or Ovis ammon, the most famous game of Thibet. Our game is slightly smaller, but the horns are very similar in curve and shape.

The horns of the largest bighorn are of stupendous girth, the head weighing as much as $4 \mathrm{olb}$. I was fortunate enough to bag, among the seventy or eighty bighorn I got, an uncommonly fine ram, each of his horns girthing igin. at the base. It is, or rather was-for I lost this grand trophy by fire as already mentionedprobably one of the finest heads of which we have any record.

At the American Trophy Show at Earl's Court there were no really Ar bighorn heads. Mr. H. Seton-Karr, M.P., had a good ram's head, $38 \frac{1}{4}$ in. long and I $6 \frac{3}{8}$ in. circumference, while Mr. Gerald Buxton exhibited three fine trophies he bagged in one stalk on ground where I had stalked a few years before. The largest of the three measured $36 \frac{1}{2} \mathrm{in}$. and $14 \frac{1}{2} \mathrm{in}$. Unforeseen circumstances prevented me from sending my best (which were in Austria), and the one I sent, which was the longest there (39in.), was not of my own killing, but a head I found on the roof of a deserted hunter's cabin in the Flathead country.

Mr. St. George Littledale shot a very fine ram in Colorado in I 874 (see illustration), measuring $39 \frac{5}{8}$ in. and $15 \frac{3}{8}$ in.

The extent to which the horns of this beast shrink in circumference after death is surprising, so one cannot be too particular in stating whether measurements were obtained at the time the beast was shot, or years afterwards. Tapes, too, are by no means as 
uniform as they should be, hence it is advisable to check off any measurements in important cases.

By far the largest head I know to be extant to-day is the enormous bighorn head owned by the Tacoma taxidermist, Sheard,

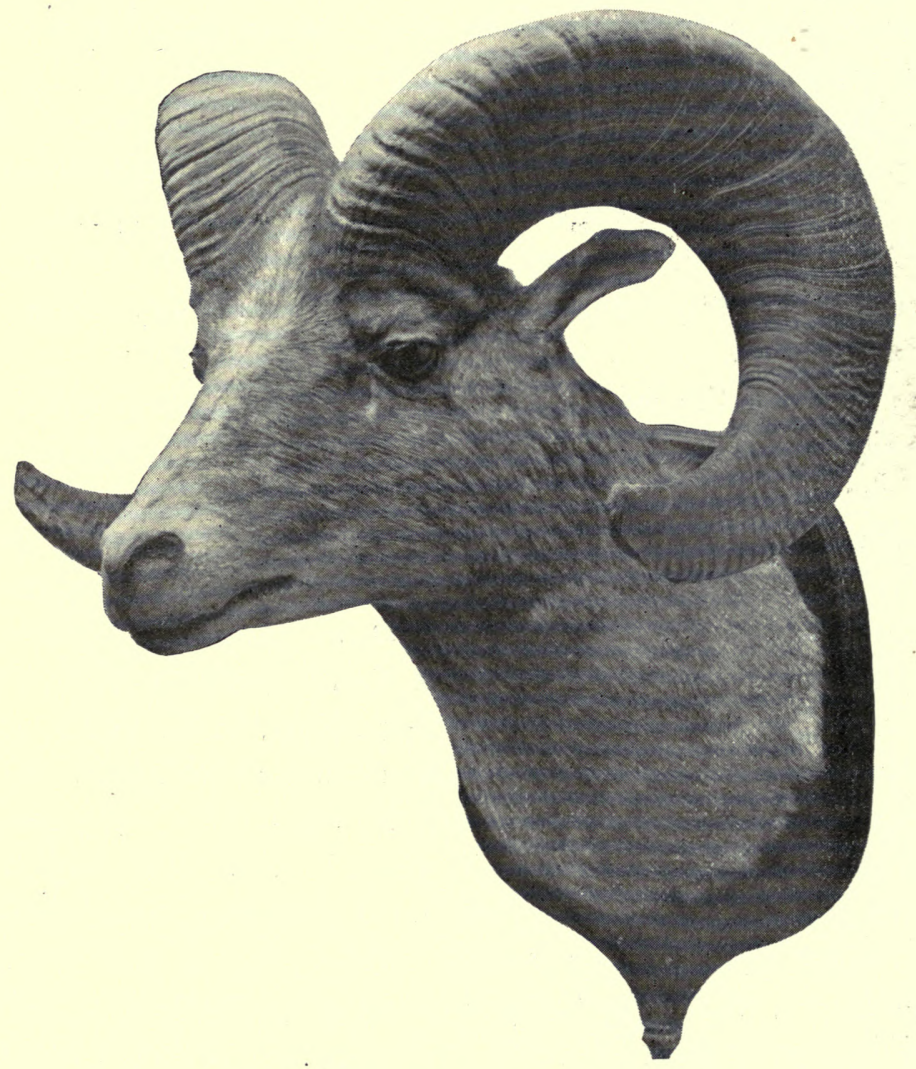

Mr. St. George Littledale's Bighorn.

of whose remarkable collection I have already had to speak. $\mathrm{He}$ gives the length as $52 \frac{1}{2}$ in. and circumference as $18 \frac{1}{2}$ in. As my big head was nothing like as long, and measured igin. as it fell, which measurement would speedily have been reduced by $\frac{3}{4}$ in. or more, I can raise no claim whatever for my head's superiority. Sheard's 
trophy, according to the measurements, for the correctness of which he vouches, is far and away the best of anything I have seen or heard of. It was killed, he erroneously states, in the

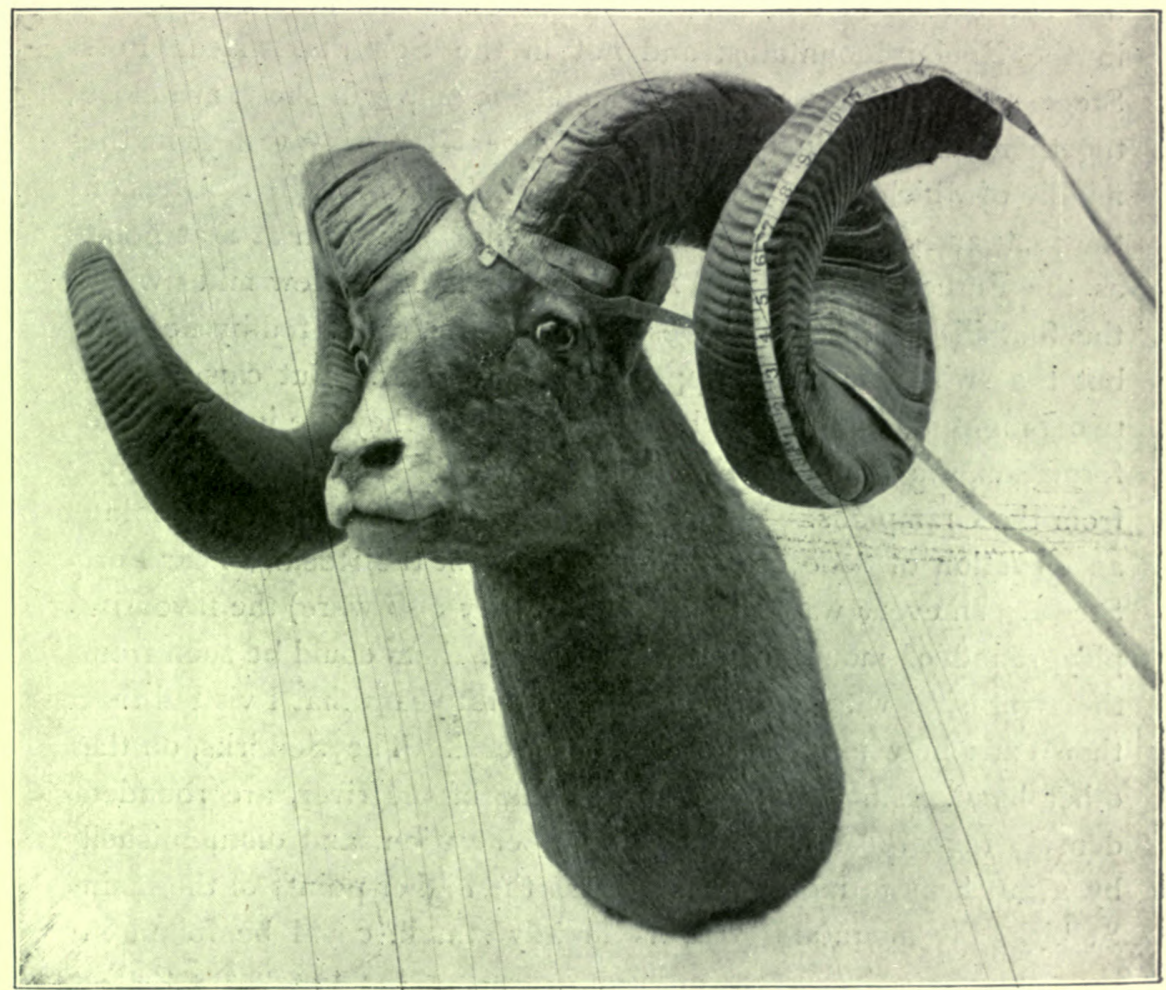

LARGEST BIgHORN ON RECORD.

Shot in the winter of $1892-3$ in the Rocky Mountains near Fort Steele, Upper Kootenay Valley (East Kootenay), B.C.

(Owned by W. F. Sheard, of Tacoma.)

Selkirks, near Fort Steele (East Kootenay), and Rowland Ward, who gives a reproduction of Sheard's photograph of this trophy in the third edition of "Records," promulgates what I know to be an incorrect piece of information. 
Let me tell briefly how Sheard, whose assertions I have so far always found accurate, inadvertently fell into this error, for, as the reader will be able to see, I am in the position of proving, so far as one can attest the truth of an event which one has not witnessed oneself, that the ram was shot near Fort Steele in the Rocky Mountains, and not in the Selkirks. Near Fort Steele the two ranges, as a glance at the map will show, are close together, for the ninety-mile long Upper Kootenay valley, in the middle of which Fort Steele is situated, is formed by the Rockies on the east, and on the west side by the Selkirks, known at that point as the Purcell Mountains. As the valley is only a few miles wide, the foothills of the two ranges are, in places, separated by nothing but the swiftly running Upper Kootenay river. But close as the two ranges are to each other at this point, they are in respect to formation, shape, flora, and fauna, as widely different as are the Alps from the Grampians. Bare, boldly rising limestone crags, attaining an elevation of 8000 or 9000 feet, represent the Rockies near Fort Steele. In every way suited to be (as they also were) the favourite playground of mountain sheep, bands of them could be seen from the river side with a telescope in the first years that I visited that then extremely isolated part of the world. The Selkirks, on the other hand, rising on the opposite side of the river, are rounded densely timbered hills of much lower elevation, and distinguished by a much more moist climate. On the higher points of the main Selkirks the mountain goat, as already stated, could be found in great numbers, but never bighorn. During the ten years that I was personally intimately acquainted with the Kootenay valleyshow intimately the reader will see in some of my subsequent chapters-I have never seen or heard of a mountain sheep being shot or seen in the Selkirks.

But I have other and more direct evidence to offer concerning the point in question. Sheard, in answer to my assertion that he was mistaken concerning the mountains where the ram was killed, gave me the following details, many of which were already known to me. The ram was killed in the winter of $1892-93$, and was 
brought into Fort Steele by the man who killed it, one Scotty MacDougall, and from there it was taken to Tobacco Plains, just south of the boundary. Poor Scotty got wiped out himself four years after the event by a snow slide, and Sheard bought the ram's head from Scotty's partner after the former's death. Sheard does not claim to know the Kootenay country himself, and when writing to me reiterated the opinion that the ram was bagged near "Fort Steele in the Selkirks." This at once shows how the mistake arose, for Sheard has fallen into the error-a common one in the States - of supposing Fort Steele to be in the Selkirks, which it is not, for it lies on the Rocky Mountain side of the valley. But more is to follow, for not only did I hear about the killing of the ram four or five years before Sheard did, i.e., at the time it was shot, when I passed through the Kootenay country in the winter of $1892-93$, but I knew Scotty quite well, he having worked for me some years previously when I was carrying out the extensive works in this very valley, with which some of my subsequent chapters will deal.

The reader will probably exclaim: Why make such a long story about an error of a few miles, a mistake which can make no difference? In answering this objection, I take the opportunity of giving the reason of my constant fault-finding with Rowland Ward's handbooks for sportsmen. I contend that to make such books of real use, the information they contain should be correct. Incorrect data are far worse than none, for not only are they misleading in themselves, but they tend to prevent a person from searching for information in better informed quarters, or from addressing inquiries to people who have personal experience, - and who, if they lay any claim to be sportsmen, should be ready to impart the burden of their own experience to fellow sportsmen. The instance before us is as good an illustration of what I mean, as could be cited. X-a keen sportsman, who has shot in the mountains of India the various Asiatic ovis, is now bitten with the desire to slay a really good specimen of the American sheep. $\mathrm{He}$ turns to "Records of Big Game," and there finds that by far the largest head has been killed in "The Selkirks, British Columbia, 
I 885 " (vide, page 366). "By Jove!" says X-, "that's the very place I'll go to next August," and go he does, after finding out at the Canadian Pacific Railway office in King William-street that the best starting points for an expedition into the Selkirks are Glacier or Kootenay Lake. Thither he wends his way, and from there, after expensive outfitting, he will start to explore those self-same Selkirks. Six weeks or two months will probably be sacrificed to what I am positive will prove a bootless search, for so convinced am I that bighorn will not be killed there by $\mathrm{X}$ - or any other man, that I shall be glad to make a suitable donation to a hospital or charitable object if it can be proved that a bighorn has ever been shot in the Selkirks proper.

$\mathrm{X}$ - returns to civilisation, as I have done from similar futile searches for game that never existed in the locality in which I looked for it, more or less irate with the cause of his non-success. Had "Records of Big Game" not contained the incorrect data (doubly so), $\mathrm{X}$ - would have taken some trouble to find out from others acquainted with America where this great ram was killed, or, at any rate, informed himself about the best regions in which to seek bighorn, and he would have been spared the time, expense, trouble, and disappointment to which he has been put by those two little words, "The Selkirks."

In the previous chapter I have mentioned that by putting "British Columbia" against the only two moose heads which Ward mentions as having been obtained there, he is stating what is not correct. Also, in this instance, might sportsmen be easily misled and visit British Columbia in quest of moose.

I have no personal feelings whatever against the compiler of these sportsman's "text-books," for I have never as much as seen or spoken to him, but I certainly consider that the promulgation year after year of incorrect and, as I have shown, misleading information in edition after edition (when not corrected in the columns of the Field and Land and Water) is not the best way to increase the fair fame of British sportsmanship. It is rather a curious fact that so much of our sporting lore should be open to 
harsh criticism on the score of inaccuracy. Two years ago showed in the pages of a leading review* that our literature on old as well as new sport was full of mistakes, mistakes of facts, figures, and quoted information. To a nation deservedly proud of its premier rank in most matters connected with sport, books of the kind I refer to do no credit.

The weight of a good five-year-old ram hardly exceeds 3 oolb. (Audubon mentions the weight of one as being 344lb.), though you will often hear of 450-pounders, statements which of course lack the authority of an Audubon. Amongst the wonderful stories of the bighorn that are current, the most absurd is that of their pitching themselves headlong down precipices, striking the sharp rocks with their horns, and thereby breaking their fall. Fremont (the great explorer) is, alas! one of the first to start this ridiculous rumour in the account of his travels ( 1842 ), when describing the "mountain goat," as he calls the bighorn. He says that "the use of those huge horns seems to be to protect the animal's head in pitching down precipices to avoid pursuing wolves." How history does repeat herself! Pietro Cirneo, the $1^{5}$ th century chronicler of Corsica, says that the moufflon throw themselves down precipices head first, and break the fall by their horns. While De Saussure, whose career has some points of similarity with that of Fremont, says of the Swiss chamois, that " when pressed by foes, or driven to places from which they cannot escape, they will hang themselves to the rocks by the crook of their horns, and thus perish."

I have already hinted that bighorn are often mistaken for "goat" (Haplocerus) and vice versâ. To what extent this occurs the following instance, culled from official experience, will prove. It arose during the erection of the handsome new Parliament buildings at Victoria, when it became necessary to adorn the frontage of this palatial pile with the newly-adopted coat of arms of the province of British Columbia. Lest I be accused of exaggeration I shall quote verbatim the following public

* Fortnightly Review, August, 1897, and November, 1897. 
announcement published in the Government organ of the province (Colonist, Oct. 3, I895):

It does not seem to be generally known that the great device in stone recently placed in position over the main entrance to the new parliament buildings is the coat of arms of British Columbia. Hitherto there was no provincial coat of arms, but a crowned lion standing upon an imperial crown was used as a badge, a survival from the Crown colony days. This has been used as the crest of the "achievement," as it is termed in heraldry.

Above the shield is the crest, a lion standing upon the Imperial crown. Supporting the shield on the left is a stag wapiti, to represent Vancouver Island, and on the right a mountain goat, indicative of the Mainland. The figure of the wapiti was drawn from one in the provincial museum, while the model for the head of the mountain sheep was a magnificent specimen in the possession of Mr. A. W. Vowell.

The best part of the story is to follow, however, for it would. appear that the provincial authorities had compiled their new coat of arms without consulting the Dominion Government, an omission which caused a great rumpus, the unauthorised assumption of the "goat-sheep" arms ending, I believe, in their disallowance by the Federal Government. Throughout the official correspondence to which this incident gave rise, the fact that in the description of the arms the one "supporter" was a mountain goat, while in effigy it was a mountain sheep, remained undiscovered!

Concerning the chase of the beast, I have given in my "Camps in the Rockies" such a lengthy account of my personal experiences that I fear wearying the reader by recounting more recent ones.*

Within the last year or two exploration in the extreme southern and in the extreme northern districts of North America's Pacific littoral appear to have led to the discovery of two new sub-species of Ovis montana. The name of the one is $O$. nelsoni, so-called in honour of Mr. F. W. Nelson, of the Biological Survey of the U.S.A., who was the first sportsman of scientific training

* "Camps in the Rockies." New Edition. 5s. A. and C. Black, London ; and Ch. Scribner's Sons, New York. 
to discover this new mountain sheep in the parched deserts of Lower California. According to published descriptions of it the horns are more slender and have a more outward twist than those of the common bighorn. Of the other species which inhabits the arctic regions of North-east Alaska, and more particularly the Kenai Mountains, I know equally little from first hand. It is called Ovis dalli, after Professor Dall, and is distinguished, according to the published accounts, by a perfectly white coat throughout the whole year. Mr. Dall de Weese, a sportsman who visited the Kenai range in 1897 and 1898 , was lucky enough not only to kill several good specimens, but actually to photograph the live beast in its home surroundings, a task of extreme difficulty, as it is needless to point out. The best head he obtained measured $4 \mathrm{I} \frac{1}{4} \mathrm{in}$. in length and $\mathrm{I}_{4} \frac{1}{2} \mathrm{in}$. in girth, which dimensions bear out his surmise that the horns of the $O$. dalli are slimmer than those of the bighorn of the Rocky Mountains. This is but in accordance with the geographical position of its home. For there can be little doubt that it forms the connecting link between the $O$. montana of North America and the $O$. nivicola of Kamschatka, which is said to turn white in winter, and to be possessed of horns a trifle more slender than those of the Rocky Mountain bighorn; indeed, Guillemard, who was one of the first to describe the $O$. nivicola, declares it to be identical with the bighorn. As I know nothing whatever of this new sheep from personal observation, it would be worse than useless to occupy space with idle theories. To readers interested in the Alaskan sheep, Mr. Dall de Weese's illustrated account in the July, I 899, number of Outing will prove very instructive reading.

\section{THE ANTELOPE OR PRONGBUCK (Antilocapra americana).}

In a book devoted exclusively to the Pacific Slope, the antelope and its chase need occupy but little space, for, though numbers of them inhabit the southern portions of this region, its true home is on the uplands of Montana, Wyoming, Dacota, and Colorado. 
The few remarks I propose to make relate to a circumstance which, until recent years, seems to have escaped the ken of the naturalist, and which even now is the subject of dispute among those who have hunted the prongbuck. I allude to the shedding of its horns, or, more correctly, the dropping of the sheath which covers the core. It was considered so contrary to all zoological experience that a hollow horned ruminant should shed its horns, that when the first definite information upon this point came before Professor Baird, of the Smithsonian, he refused to publish the letter of Dr. Cranfield, of California, in which the latter positively asserted the truth of this fact. Audubon and Bachmann's "Quadrupeds of North America" denies it, for on page I98 we find the following sentence: "It was supposed by the hunters of Fort Union that the prong-horned antelope dropped its horns, but as no person had ever shot or killed one without these ornamental and useful appendages, we managed to prove the contrary to the men at the fort by knocking off the bony part of the horn and showing the hard, spongy membrane beneath, well attached to the skull and perfectly immovable." As Mr. Tegetmeier, in an interesting article in the Field (August Io, I 889), from which I have, with his permission, borrowed the illustrations here given, very truly says: "As not infrequently happens, the practical hunters were right and the naturalists wrong."

It was left to Mr. Bartlett, the Superintendent of the Zoological Gardens, to make the first authoritative announcement of this curious fact, but even then some naturalists refused to believe its truth, and no less an authority than Professor F. Cope, in a note published in the American Naturalist, 1878 , stated that, after several years familiarity with the animal in a wild state, he never met with an undoubted case of shedding the horn sheath.

It is singular that doubts should exist regarding a fact which is now as well ascertained as any fact can be in natural history. As previously stated, it was first definitely described by Mr. Bartlett, 
who published his remarks in the "Proceedings of the Zoological Society" for 1865 , p. 720 . Mr. Bartlett writes:

On the morning of November 7 the keeper, somewhat alarmed, called my attention to the fact that one of the horns of the prongbuck had fallen off (as shown in the illustration). I hurried to the spot immediately, fearing that some accident had happened, and reached the paddock in time to see the second horn fail to the ground. My astonishment was much increased at observing that two fine new horns were already in the place of those just dropped; that these new horns were soft and covered with long, straight,

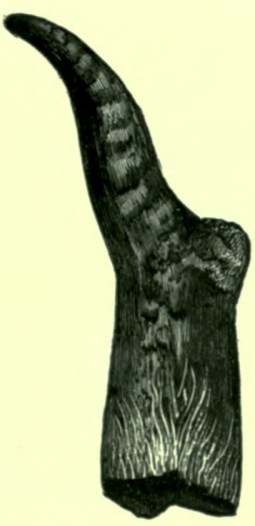

Horn OF PRONGBUCK AS SHED.

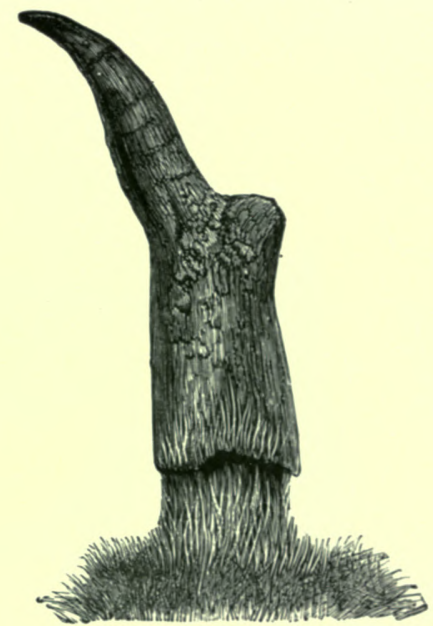

HORN JUST BEFORE IT WAS SHED, SHOWING THE NEW HORN BENEATH.

smooth, and nearly white hairs, and that the bony core (that I had expected to see) was thickly covered with soft new horny matter. These new horns appeared larger than the hollow portion of the horns just castan appearance due to the fact of their having pushed off the shed horns by their growth. This long hair at the base of the horns (see illustration) had concealed the separation that was taking place. As a proof that the shedding of these horns was not the result of any disease or accident, I may remark that whenever the hollow horn of any ruminant is broken or torn from its bony support, a copious discharge of blood immediately follows; and the horn so removed is never replaced by any subsequent growth. This remark applies equally to any injury done to the outer or 
velvety covering during the progress of growth of the solid horns of the genus Cervus. With reference to the frequency of the shedding of the horns of this animal, I can only offer a surmise. Judging from the rapidity of the growth of the young horn, I reasonably conclude that it occurs annually. In support of this, it may be remembered that our animal's horns in January last were barely 3 in. in length, while by June of the same year they were fully formed, and measured 8in.; they were cast the first week in November-that is, on the 7 th; the new horns on that day (see illustration) were about 4 in. long; they are now 6in. long, having grown in. in twenty-one days.

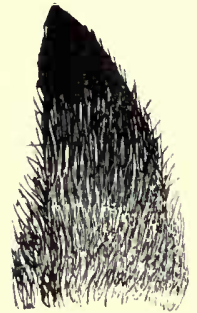

New Horn ONE Day after SHEDDING OF OLD.

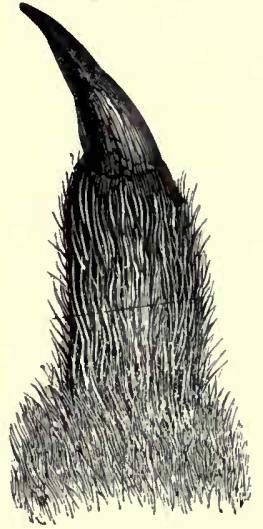

NEW HORN AFTER TWENTY-ONE Days' Growth.

Judge Caton, who had many of these antelopes in his possession, fully bears out the evidence of $\mathrm{Mr}$. Bartlett. He writes as follows :

The older the animal, the earlier the horn matures, and the sooner it is cast. On old bucks the horn is shed in October; while on the early kids it is shed in January, and still later on later kids; or else it is carried over till the next year. A late kid in my grounds on Dec. $\mathbf{I}$ had the horn not more than a quarter of an inch above the skin. It grew slowly all winter, and till the time of its death in May following. Let us observe the horn of the adult male antelope, which is shed in October. If we make our examination so soon as the horn is cast off, we can readily understand the process by which it is removed. By looking into the cavity of the 
cast-off horn we shall see that it extends but about half-way its length, or a little way above the prong; and we shall also see that it contains a large number of coarse, lightish coloured hairs, all of which are firmly attached to the horn, and many of them, towards the lower part, passing quite through it. We see the core of the horn is covered with a thick vascular skin, which is pretty well covered with the same kind of hairs as those seen in the cavity of the horn. We now appreciate that these hairs grew from the skin, and more or less penetrated the shell or horn; and, when this was removed, some were torn from the skin, and others from the horn. Now

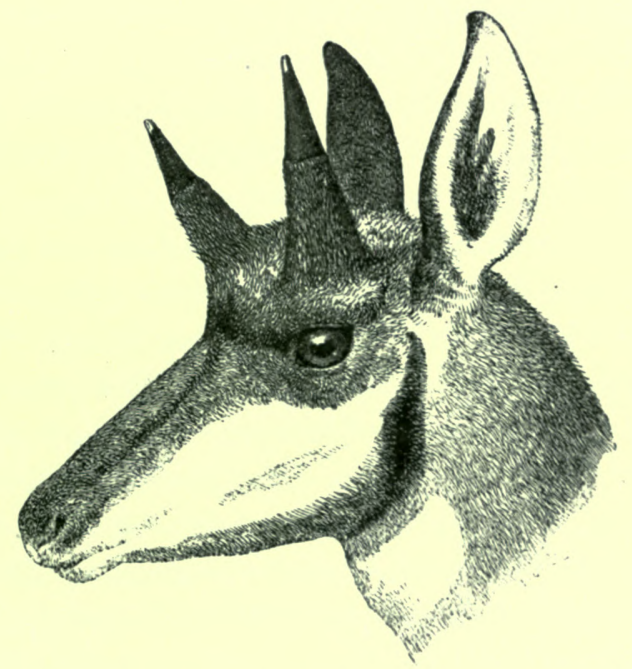

Head of Prongbuck immediately after sheding the Old Horns.

it is perfectly manifest that, as the new horn was extended in length above the core, it must have carried with it the old horn, which it detached from the core, and tearing out the hairs, the roots of which were in the skin, and many of which extended into or through the old horn. Until these were mostly torn asunder, or were withdrawn from the canals by which they had penetrated the shell, they served to prevent it from being easily lost; but finally, when these were all, or nearly all severed, it fell off as a favourable position occurred, or some slight violence assisted the removal.

If any further evidence were wanting, it may be found in the remarks of the late $\mathrm{Mr}$. W. A. Forbes, prosector to the Zoological 
Society, on a young pronghorn in the gardens, purchased Dec. 4, I 879, that cast its horns on Oct. I 8, I 880. The horns were shed in the night, but no trace of them could be found. Mr. Forbes suggested they had been carried off by a rat or a visitor, but it is probable that the Antilocapra may, like the Cervidx, eat the shed horns. Mr. Forbes's remarks were illustrated by a drawing, by Mr. Smit, of the head of the animal immediately after the old horn had been shed-this is reproduced-and also of the young horn after four weeks' growth. The same animal shed its horns during the following year, one on Nov. I5, the other on Nov. 24, thus furnishing additional proof, if any were required, that the shedding of the horns of the prongbuck is an annual process.

When discussing the process of shedding, with Western hunters, amongst whom many, if not the majority, refuse to believe in the regular occurrence of it or deny it altogether, one generally is told that were it really the case, that all adult antelopes annually shed their horns, the latter would be found lying about. This, it is true, one very rarely does, and, taken in conjunction with the disappearance of the sheaths in the Zoological Gardens in the night $o$ I 8 th October, 1880 , it would point to the explanation suggested by Mr. Tegetmeier, i.e., that they are eaten by them. In any case, further light upon this point would be most acceptable.

In I 894, while studying some MSS. in the private family library of the Emperor at Vienna, I came across a curious bit of evidence which would show that the fact of the antelope shedding its horns was known already in the sixteenth century. In a beautifully illustrated large folio MS. prepared for the Emperor Rudolph II., by Tycho Brahé, the great astronomer, I found among the numerous skilfully executed tinted drawings relating to curious animals inhabiting distant lands, a, perfectly correctly drawn horn sheath of the American prong-buck. Its perfect fidelity to nature, and the fact that no other animal bears horns of anything like the same shape, dispels all doubt as to the identity of the original, though, curiously enough, there is some evidence to show that it was believed to be the horn 
of a unicorn! Among some autograph letters from this monarch I found one where the following passage occurs. The letter is dated Prague, 23rd May, I598, and is addressed to the head of the great Fugger family, who were then the Rothschilds of European finance. In it the Emperor acknowledges the receipt of Fugger's letter of the 8th May, referring to certain "Ainkhurns" (One Horn or Unicorn) and states that as this horn is not in Frankfurt he will have search made for it elsewhere. I hope, at some future period, to investigate this matter further; the prominence given to this picture leaves no doubt in my mind that the object it represented was considered of exceeding rareness.

Concerning the chase of the antelope little need be added to the voluminous literature that exists.

In the old days, when one struck a country where little hunting had been done, the once much-talked-of "flagging" of antelopes gave fair sport. By displaying on the top of any rising ground a red handkerchief tied to a stick, so that it should flutter in the breeze, it was easy to decoy a band, particularly during the rutting time, up to short rifle range, for the antelope in its primitive condition exhibits extraordinary curiosity. The shooting itself on such occasions was, of course, a very tame proceeding, but the animals' amusing tactics were interesting to watch. Now approaching at a trot the fluttering rag that had aroused their insatiable curiosity, then circling to one side, or turning back altogether, but looking over their shoulders, till they stopped and again faced the flag, angry stamping of the fore feet betokening their impatience; then, resuming their progress towards the flag at a mincing gait, they would finally, if the wind did not betray the hidden watcher, come up quite close.

On plains that are dead level antelope shooting was often quite difficult work, for even the best Sharp rifle won't shoot into the next county, and judging distances was not easy, and any slight mistake had more serious consequences than would now-adays follow the same error in the case of a $\cdot 256$ Mannlicher, which, of course, is an ideal weapon for this sport. 
Much has been written about the fleetness of the antelope, no animal, not even the fleetest greyhound, being able, so it is said, to overtake it. That this is not always true I can state with some positiveness, for I know that occasionally one strikes bands of antelope that can be overtaken on a moderately fast horse. I have done so on several occasions, killing one or two out of the band with my six-shooter. Another circumstance for which it is difficult to offer a reasonable explanation is the obstinacy they evince in continuing their course in a straight line, irrespective of the obvious danger into which it takes them. Many a time, when riding in a file over the steppes of Wyoming or Montana, a string of antelope would be seen in the distance making at right angles for the buffalo trail along which we were riding. If we kept on at an even pace the herd would do the same, sometimes crossing the trail less than $100 y d s$. in front or at the rear of our small column. In one instance, I distinctly remember, a four-horse waggon followed our party at an interval of not more than I 5 oyds. or, at the most, 2ooyds. A band of antelope, numbering between twenty and thirty head, actually crossed the trail in this gap without evincing much fear, and as if nothing could turn them from the line they had once decided upon.

Another curious trait about the antelope is their faculty to shed tears when in pain or in a state of great alarm. Though I have never seen tears actually streaming from their eyes, I have noticed unmistakable tears in their large beautiful eyes when wounded. Caton recites a very curious instance in his own experience which is well worth quoting. This is what he says:

Our antelope has the faculty of weeping when in affliction. I first observed this in a specimen which had been taken wild when adult, and still retained all its natural fear of man. I had placed him in a close cage in the evening, intending to familiarise him with my presence, and divest him of his fears when he saw me, by convincing him I would not hurt him. When I approached him the next morning he seemed struck with terror, and made frantic efforts to break out, which he soon found was impossible. His great black eyes glistened in affright. I spoke 
softly and kindly, while he stood trembling, as I introduced my hand and placed it on his shoulder. Despair now seemed to possess him, and he dropped on to his knees, bowed his head to the ground, and burst into a copious flood of tears, which coursed down his cheeks and wet the floor. My sensibilities were touched; my sympathies were awakened, and I liberated him from his cage as quickly as I could tear the slats from one of the sides. Whether he appreciated this or not I cannot say, but his great fear seemed to leave him as soon as he was liberated; he ran but a little way, and not at full speed, when he stopped and began to pick the grass. 


\section{CHAPTER VII.}

\section{THE BEAR AND THE BISON.}

EvERY sportsman who has been to America is asked whether there are one, or two, or three species of black bear; whether the cinnamon is identical with the brown bear, and what difference there is between the true grizzly and the silvertip; whether the former is really confined to California; what the Roachback bear is; to what family the bald-faced bear belongs; and, of course, what the weight was of the biggest bear he killed. Now, to speak authoritatively upon the subject of bears one should be very thoroughly acquainted with the various localities in which members of that family are to be found. This means, practically, that one knows the whole of the continent. One should have roamed from the Gulf of California to Slave Lake and Hudson Bay, from Cape Prince of Wales, America's jumping-off place towards Asia, down along the continental backbone to the Sierras of the south, across the Staked Plains to the scorched mesas of Mexico, and then up through the arid regions of Southern California. Upon such a wide field of observation, I will at once admit, I cannot draw, nor was my bag of some sixteen or seventeen bear in all the years I was in America one to be in the least proud of. Friends who made bear the special object of their trips to the West, accomplished very different results, one man killing, in a less number of years, more than half a hundred in excess of my small bag.

Bear stories, as a rule, make me feel tired, for not only do they remind me of the bad luck I had in getting myself in the way of 
Bruin, but also because there is extremely little to be learnt from occasional encounters. About no sport is there such an element of luck; and I am sure I am not the only man who has wandered about wild regions for months at a time without setting eyes on the shuffling form of even as much as a black bear. Nor am I alone, I fancy, in experiencing such instances of bad luck as happen to the most persevering. Bear straying right into camp and being slain by the cook lying lazily in his tent, while the rifle that should have done the deed is being carried from dawn to dusk all over the mountains by a weary hunter, are not the least annoying instances which have personally happened to me.

Before leaving the subject of bear varieties I should like to say that the division made by Mr. Theodore Roosevelt in his capital "The Wilderness Hunter" struck me as an eminently sensible one. $\mathrm{He}$ divides the bear of North America, leaving the Arctic bear out of the question, into two classes - the tree climbers, who have short claws and a soft fur, and the long-clawed non-climbers with coarse fur, the chief mark of distinction being the claws, and the claws alone. It is one which settles all question as to identity, even if one has no more than the track on soft ground to go by. That the extremes in the short-clawed kind are as wide apart, specially regarding weight, as those in the long-clawed kind is perfectly true, but the same is, I believe, the case in any other sub-division of Bruin's race by the various distinguishing marks which are the stock in trade of the majority of bear hunters.

There is no doubt that the extreme north-west corner of British Columbia and, even more so, Alaska, are the best ground for bear, and the stories told by creditable sportsmen of the size of the various sorts to be found in the latter region are enough to send a young blood in hot haste to these northern hunting grounds where, if he is as energetic and as thirsty for the blood of Bruin as the mosquitoes are for his, he is bound to succeed beyond the dreams of Nimrod. To read Mr. H. W. Seton-Karr's account of the brown bear which a camp follower of his brought to book, and 
the skin of which measured 65 square feet, being at the narrowest point $6 \mathrm{ft}$., and in length $9 \mathrm{ft}$., makes one's mouth water.

Of a yet larger Nevada grizzly skin Sheard, the Tacoma taxidermist, sends me an interesting photograph.. This skin, he says, measures I Ift. 4in. in length and soft. in width. These dimensions are almost a match for the famous San Francisco show grizzly, who is said to have weighed 1800 lb. An essential point, which the bear hunter should never forget, is the fact that to. be successful, local knowledge concerning the feeding places of Bruin is absolutely necessary. During the warmer season of the year Bruin is constantly on the move, following up the various growths of wild fruit and berries of which he is so fond. "Hunt the berries and you will find the bear," is a saying of the Northern Coast Indians, and from what I have seen, this holds good also for the interior.

Bear often behave in the most unexpected manner. One of the first silvertips that I killed-it was, I must at once confess, a partnership-bear-fell victim to suicidal recklessness of this kind. It was in the Big Windriver Valley, and I was camped at "Neversweat," as Bonanza Clark, a great old hunter, had called his log shanty on account of its elevation. He was then the only white man who had settled in the valley, the nearest habitation, Fort Washakee, being ninety miles off. He knew the mountains round his home most thoroughly. I had been complaining to him about my bad luck with bear, and he had proposed to accompany me on a week's trip to a certain square-topped mountain where he said "bear was as thick as foolhens." We were to start the following morning, and dąw saw us getting ready.

Bonanza Clark's little shanty-the photograph of it was taken for me some years later by Mr. E. N. Buxton, who enjoyed some good sport in that vicinity-stood with its back close to the bank of the river, where it was possible to ford it. In front of the shanty there was a large bit of open, fairly level ground, covered with sage brush two feet or so in height. We were having our breakfast, and as 
the cabin had no window, its interior was rather dark. For this reason I was sitting on the door sill, from which I could overlook the open stretch. I was just finishing a frying pan full of trout, prior to saddling old Benjamin, who was picketed in front of the cabin, when I happened to glance at the further end of the level ground.

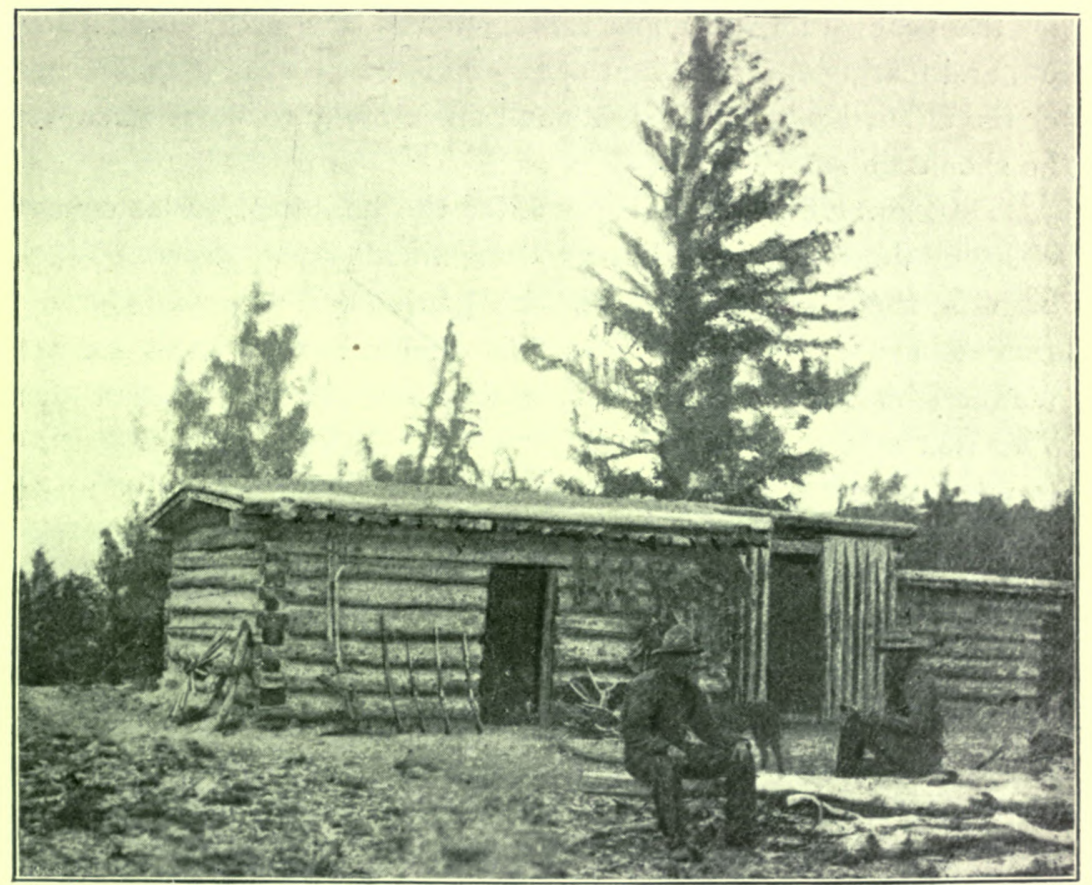

"Never Sweat," Bonanza:Clark's Cabin in the Big Windriver Mountains, Wyoming.

(Photographed by E. N. Buxton, Esq.)

There, indistinctly visible in the early morning light, I saw something black come "loping" towards the cabin. "Is that an Indian on horseback, or one of your cayuses?" I asked Clark, who was busy behind me. Stepping up to the door and reaching down his glass, a brief glance sufficed to convince Clark that it was a big grizzly. 
"'Tis, I guess, that tarnation skunk who got away with the blacktail I hung up behind the corral last week. He is making for the ford, but he ain't going to get there," he replied, not half as excited as I was by the sight of the 'bar coming straight for the log cabin. "Sit quiet, and let him come close," he said, as he handed me my rifle from the peg where it was hanging, and taking down his own. By this time Bruin was about three hundred or four hundred yards off, and fearing that he might at any moment swerve off to one side or the other, I put up my sights and made ready to shoot whenever he should do so.

This, however, did not happen, for the bear kept on his course, charging down upon the hut as determined as you please. When he was about eighty yards off, he paused for a second, for old Benjamin was careering round his stake in the most excited manner, his keen old eye having detected Mr. Bruin from afar. This was a favourable moment, I thought, to shoot, quite forgetting to put down my sights, which, at the first alarm, I had put up to 400 yards. Of course, I overshot the bear by feet, a slight rise behind the animal showing the impact of the bullet. Clark, who had killed more grizzlies than there were weeks in the year, burst out laughing. The cartridge in the left barrel went nearer the mark, but though it rolled over Bruin by grazing the backbone, it by no means stopped him, for he was on his legs, and, wonderful to relate, still making straight for the cabin, as if those two 500 bore shots were so many puffs of air. Before I had time to find and insert two cartridges, the bear was not thirty yards off, and at that moment the old man's rifle, a short, old-fashioned carbine, shooting a sixteen to the pound pointed bullet, had its say, and the "tarnation skunk" rolled over, this time to rise no more. That I felt thoroughly ashamed of my execrable shooting I need hardly say, and though I think Bruin would have succumbed finally to the wound inflicted by my second shot, I well deserved the old man's sarcastic advice, that in the case of grizzlies closer shooting was in order, if I did not want to get chawed up. The bear's conduct was really less inexplicable than it looked, for he was making straight 
for the ford behind the cabin, where the carcase of a deer killed the previous day was probably the goal for which he was making. I have never had another chance to shoot grizzlies from the door of a cabin, though Clark said he had done so on several occasions before. This I quite believe, for in spring, to judge by signs, bear were plentiful about that little $\log$ hut, separated as it was by ninety miles of wilderness from the nearest human habitation.

The bagging of another large partnership grizzly was also fraught with an amusing incident. My trapper companions were in the habit of erecting gun traps for bear. These contrivances consisted of an old double-barrelled gun with barrels cut down to half their length, and loaded with two spherical bullets. The trap consisted in a sort of passage six feet or so in length, constructed of logs piled upon each other, at the end of which the bait, consisting of a quarter of deer, was displayed in such a manner that the bear when making a grab at the meat would pull off the two barrels and receive the full charge in his breast or throat. On the day in question I thought I would accompany Port on his round of beaver and bear trap inspection. When we reached the first bear trap we saw from quite a distance off that it had been sprung, for the snow was stained with bucketsful of blood, and it was surprising that the animal was not lying there dead. But gone the bear was, and we at once followed the gory trail at a gallop. The trap, we knew, had been sprung the evening before, and as no animal could survive such a wound very long, we expected, of course, to come upon our dead prize any moment. On the other side of the valley the ground rose quite steeply, and the slope was covered with the - scrub cedar so often found close to the timber-line. To our surprise the trail led up this slope. In following it, it was all our horses could do to scramble up, and we had our hands full steering clear of the low-growing branches, which obliged us to lean forward as far as we could. I was leading; suddenly Boreas seemed to crouch down under me in abject terror, and, looking up, I saw a very live and very large looking grizzly standing in a raised position not I $2 \mathrm{ft}$. from the horse's head, pawing the air with one foreleg 
while the other was hanging down helplessly, evidently shattered by the trap-gun. How an animal with this wound could have got so far uphill was decidedly a puzzle which, at the time, however, we did not try to solve. For our escape from being dashed to pieces against the low-hanging branches of the scrub cedar, as the horses, terrified out of their senses by the close proximity of the bear, dashed down the slope, was almost as miraculous as the bear's performance. Behind us came Bruin, though it was probably more in consequence of his wound, which had stiffened all his muscles during the interval, that he preferred a downhill course, for I think he was too sick to show fight. How we got to the bottom I don't know, but as soon as we did, and could pull up the horses, we got off to settle our foe. The bear was not hunting trappers that day, for as soon as he reached level ground he took the opposite direction, and it was all we could do to follow him, shooting as we ran, which is not farourable to good practice. When we came to skin him, after a stern chase of over a mile, we found over a dozen holes in him, and how many we drilled into space in the bear's vicinity history does not relate. Considering that one of the trapgun balls had shattered the bear's fore shoulder, and the other barrel had sent two balls through the upper part of his chest, the immense vitality of a grizzly was well illustrated by this episode.

I have already hinted that I have no exciting bear adventures to relate, though oddly enough, in illustration of oft-told experiences, I was never nearer coming to an undesirable end by 'bar, than when I was furthest away from them. I had sent home my selfcured skins in two or three big bundles. Getting home before they did, I was keenly anxious about the condition of the pelt after its long journey. On receiving the notice that the bales had arrived at the nearest railway station, I myself drove at once to fetch them. The smell of 'bar, as this incident proved, terrifies horses who have never seen, and much less scented, a live one; for the two old stagers, quiet as lambs under ordinary circumstances, took fright at the scent, and made matchwood of the rehicle and a much bruised individual of the writer. 
As my quaint old trapper friend, "Bonanza Clark," has figured in these pages as a slayer of 'bar, the reader may like to obtain a closer view of this hardy "old timer," by perusing the following sample of his epistolary powers. He will also see from it that in places big game was still plentiful, for it was written not so many years ago. The passages I give are copied verbatim.

MY VERY DEER FRIENI), your letter of July 24 surprised me very much for I had come to the conclusion that you had forgoten me and this part of the country. I was ever so glad to hear from you and had I hav known your address I should hav joged your memary long ere this. Well by the way Mr. Grohmen there is no one living whom I would bee more pleased to see here than your humble self. Elk is quite plentiful here yet But the bear and mountin sheap is geting quite scearse. By the way there is quite a number of moos near here but they are the Devils to hunt there are some very large bulls north and south from my place come to see me and we will go for them read headed. I think there is more moose here now than there was when you were and I have killed (?) bulls since you were here. 'The country you speake of between - Peak and - peak is or has never been hunted and in fact is full of game, every Faul a few tender feet occasionally come up from L., but they generly are afraid of geting lost and never stay but a few days. If it is possible for you to come doo so and we will hav a good oald Bear Hunt. 2 nice Bear passed my Place, or rather the mining cabin Early this spring and went in the direction of Fish Lake one was a very large grisley. Hoping to hear from you more often I remain as of Oald a true and trusty liriend, yours very truly.

Oh, By the Heavens, I come very near forgeting to 'Thank you For those two Books you sent me for the same l am ever so much obliged; they were very Interesting, esspecialy Maister Oldenbuck and the German Dusterswivel. The About [Abbot] was also Interesting, perticularly' "that portion refering to Mary Stuart Qeueen of Scotland. I could but wish I had been Born a woman and as prety as she was, though Beauty has ruined many and Sent millions to an untimley grave. In her case it brought grief and sorrow. Allow me to inquire If you hav a Dusterswivel in your Book and to remark if 'There is any Oldentree It must be me. At least $I$ am over anxious to see it and will peruse it with much interest. I hav the nicest curosity that I hav ever come acrost in those mountains or any where else it is the skin of a Lynxs fore Paws. I intend sending them to $\mathrm{my}$ Girl, but will keep them for you 
to see until you erive. Come if you possibly can no one in this world would be glader to see than Mr. Grohmen. I jist came ny gettin chawd up by a big sun of a B--- of a She Grezzlie whos cubb I had roped, hit was a close call and no mistake.

In conclusion, I would like to point out that when speaking of grizzlies, I use that term in the usual Western sense. The true Californian grizzly I never killed, and I believe the only place where it can be shot to-day is Alaska.

\section{THE BISON.}

So much has been written about this animal, and so familiar is everyone with the picturesquely ungainly appearance of this extinct beast-extinct so far as the sportsman is concerned, that it is quite

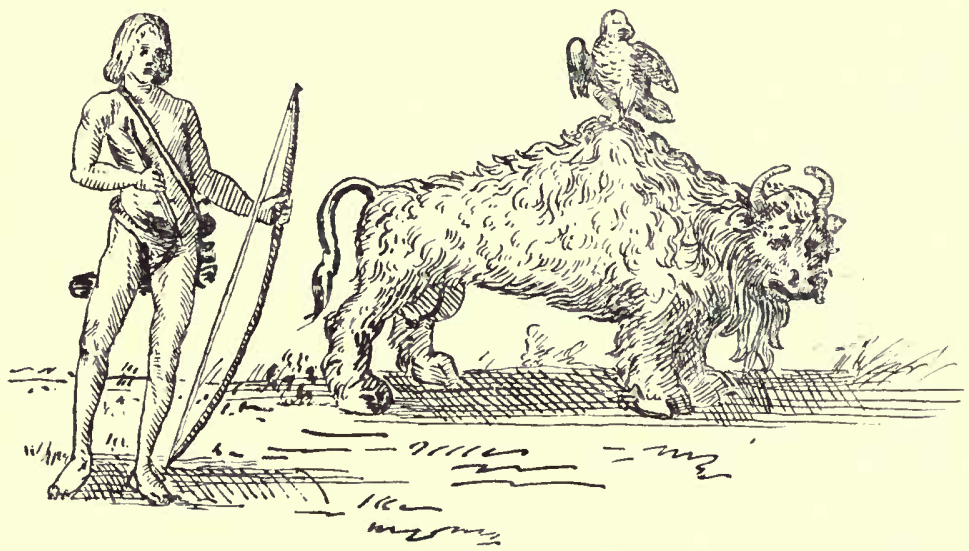

One of the Oldest Pictures of the American Bison.

(From Hispaniae Novae, I595.)

unnecessary to add more than a few personal notes. Though I was still fortunate enough to see them by thousands, the enormous herds of hundreds of thousands that existed half a dozen years before my first visit to America had already been decimated and broken up. 
The chase of the bison, I must confess, when once the novelty had worn off, had but little attraction for me. When old De Bry, 300 years ago, adorned the early American explorers' books with his quaint portraits of the Vacca indica, as he called his grotesque dachshund-like bison with elephantine legs and with an eagle perched on its hump, it was considered a semi-domestic species of cattle.* This impression it also left upon my mind, and I did not add half a dozen victims to the appalling slaughter committed all over the West. Of this wholesale destruction many a man spoke with proud satisfaction, though not all the stories of wholesale slaughter are as well authenticated as Buffalo Bill's notorious bag of 5000 in less than eighteen months when he hunted for the Kansas Pacific Railway Construction Company.

There were, however, degrees in the wantonness of slaughter. It has always seemed to me that the worst of all were the tourists and pistol-flourishing cowboys, who emptied their Winchesters or Colts at a retreating herd "for the fun of the thing," without even taking the trouble to go a step out of their way to put wounded beasts out of their misery.

What vast quantities still existed a quarter of a century ago hardly needs telling. Colonel Henry Inman, late Assistant Quartermaster of the U.S. Army, tells us in his interesting "The Old Santa Fé Trail," that in Kansas alone, between I868-i88 I, 2,500, ooodol. were paid out for buffalo bones gathered on the plains and used by the carbon companies. The price paid averaged 8dol. per ton of bones, so that according to his calculation the above sum represented the skeletons of over $3 \mathrm{I}, 000,000$ buffalo. -As Colonel Inman is particular in stating that he carefully gathered his figures from the railway companies who transported the bones,

* In a work published ${ }_{16} 1_{3} 3$ it is stated that the adventurers in Virginia discovered a "slow kind of cattell as bigge as kine with goode meate." In the "New English Canaan," I637, are described "greate heards of well growne coues " that live about Lake Champlain. Cortez is supposed to have been the first European who saw a bison (in $152 \mathrm{I}$ ), when he was shown a specimen in a kind of menagerie in Mexico. Coronado, twenty years later, was the first to see the vast herds. 
and from the works who paid out the money, reliance can, I think, be placed in his statistics.

On the Canadian plains leading up to the eastern foothills of the Rockies this industry was also followed for the first few years after the completion of the C.P.R., but the crop was not a perennial one, and the farmers' off-day work collecting buffalo bones had soon cleared from the plains the last vestige of the untold millions of bison that had inhabited them.

Of the three great herds, or rather assimilations of herds, known as the Southern, the Middle, and the Northern, the second one was practically wiped out of existence by 1875 . Hides, when baled and delivered at the railway, were worth $\$ 2 \frac{1}{2}$ (IOs.) for bull, and $\$ I \frac{1}{2}$ (6s.) for cow hides. Bull hides were all hides that weighed over $32 \mathrm{lb}$., everything below that were termed cows.

The buffalo hunter's outfit consisted of one killer, three dressers, three teamsters for the three four-horse waggons, one cook, and one roustabout, who had to attend to the grinding of the skinning knives. The chief killing time extended from October to January. In May, June, July, and August the ravages of the "hide-bug" were dreaded. The shooting required first-class marksmanship, for one bad shot under or over the beasts would spoil a "stand." A good man would, under favourable circumstances, get in as many as 250 shots at one "stand." The secret of success being to hit the animals so that they did not instantly drop and thus frighten the rest. What was desired was that the animal should circle about and slowly sink down as if in the act of lying down. The shooting was done at what was then considered long ranges, 2ooyds. to 3ooyds., the outside stragglers being picked off first. The rifle most generally used for this purpose was the Sharp, weighing I 4 lb. to $16 \mathrm{lb}$., shooting a patched ball, and "rest-sticks," to rest the rifle on, were almost invariably used. So long as the wind was favourable and the bullets did not spatter up earth or go whistling over their heads, a herd would stand a lot of shooting from the invisible marksman lying behind a sage bush. A good shot would use an average of two cartridges to the skin, 


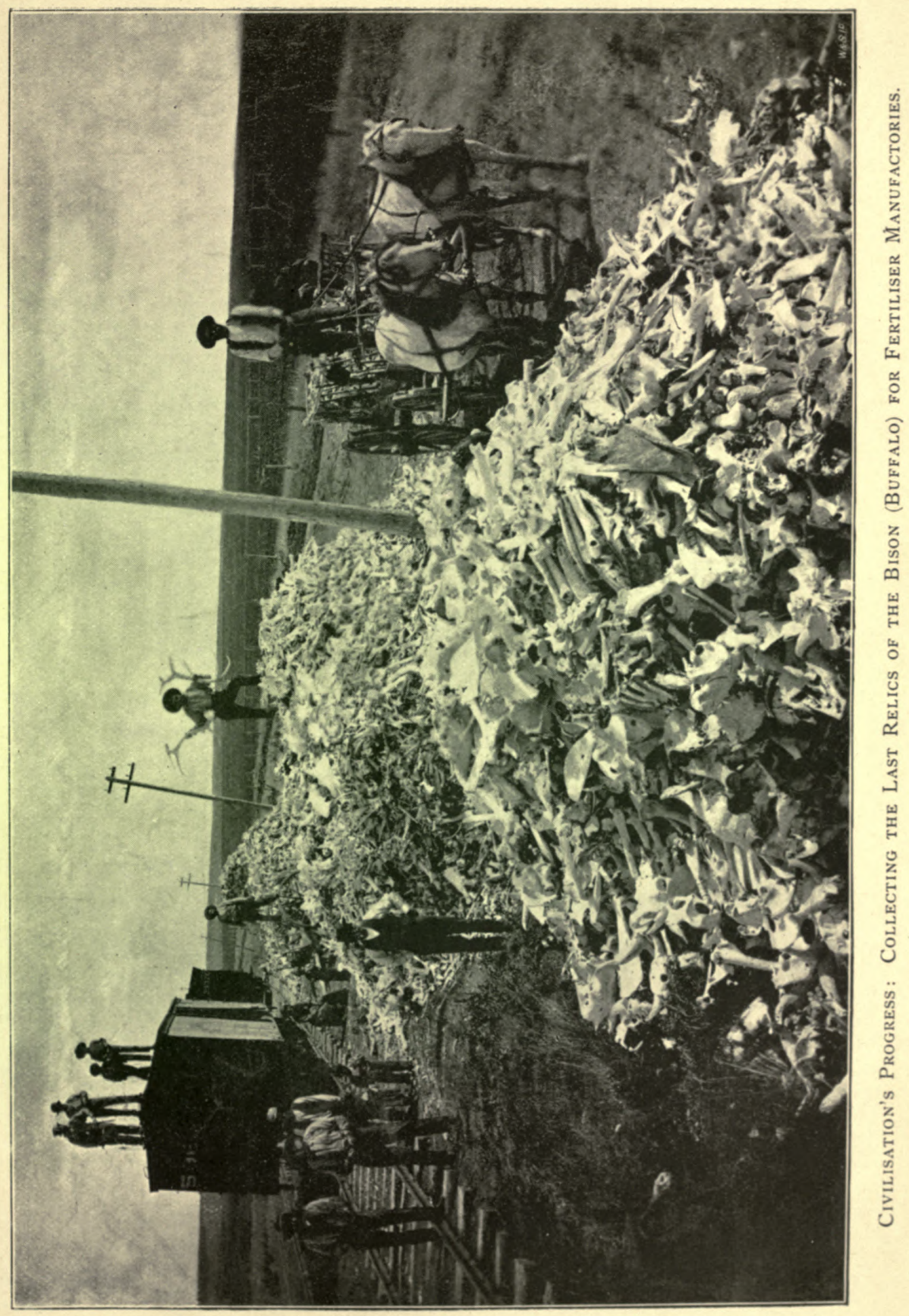



and from 500 to 800 skins would be secured per month by one killer.

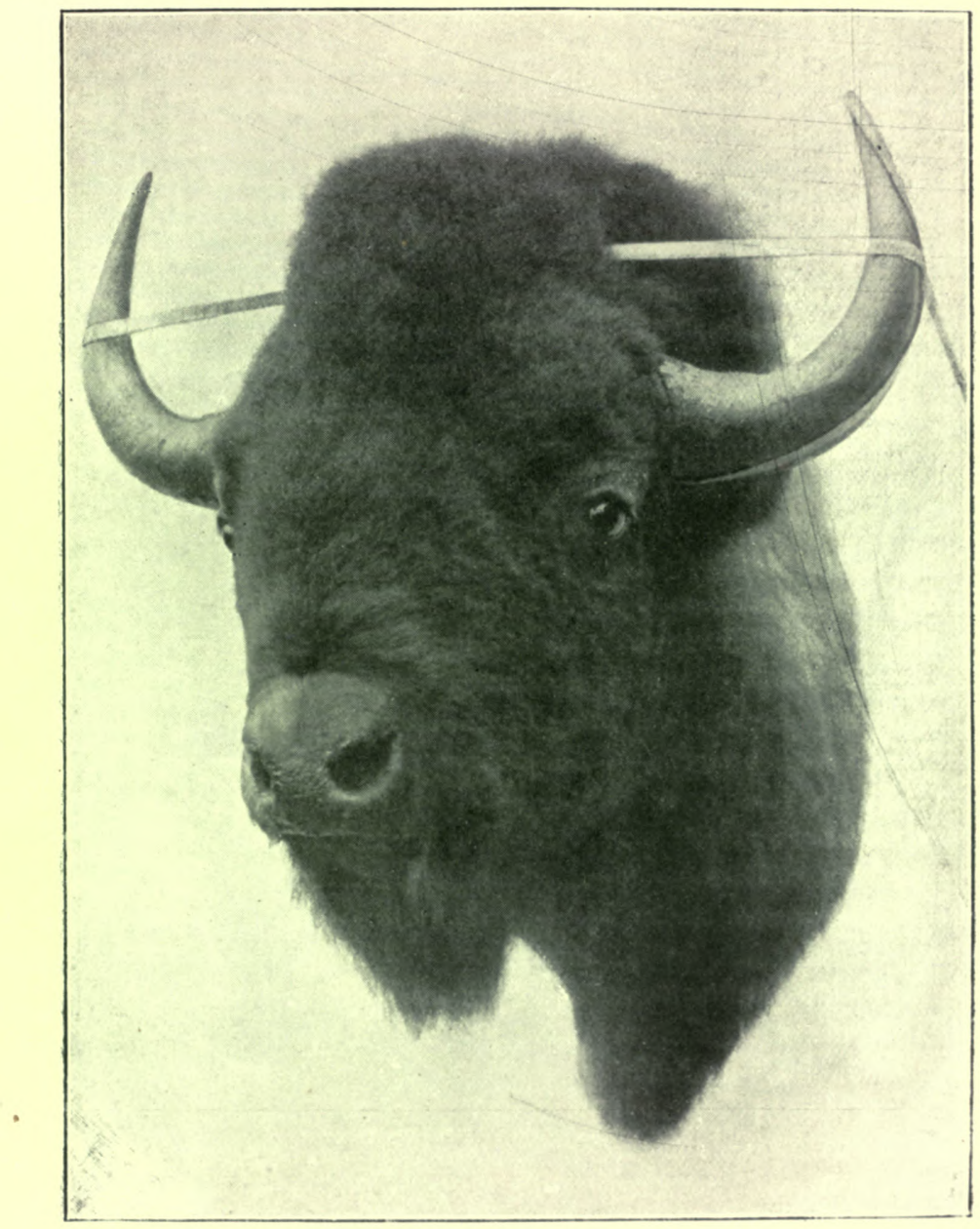

Bison Head claimed to be the Largest on Record.

(Owned by W. F. Sheard, of Tacoma.)

There are several small herds of domesticated bison in various parts of the West. To Jones's herd in Garden City, Neb. (five 
miles from Omaha), I have already referred, and the National Park herd is one of the sights of that interesting region. Another small

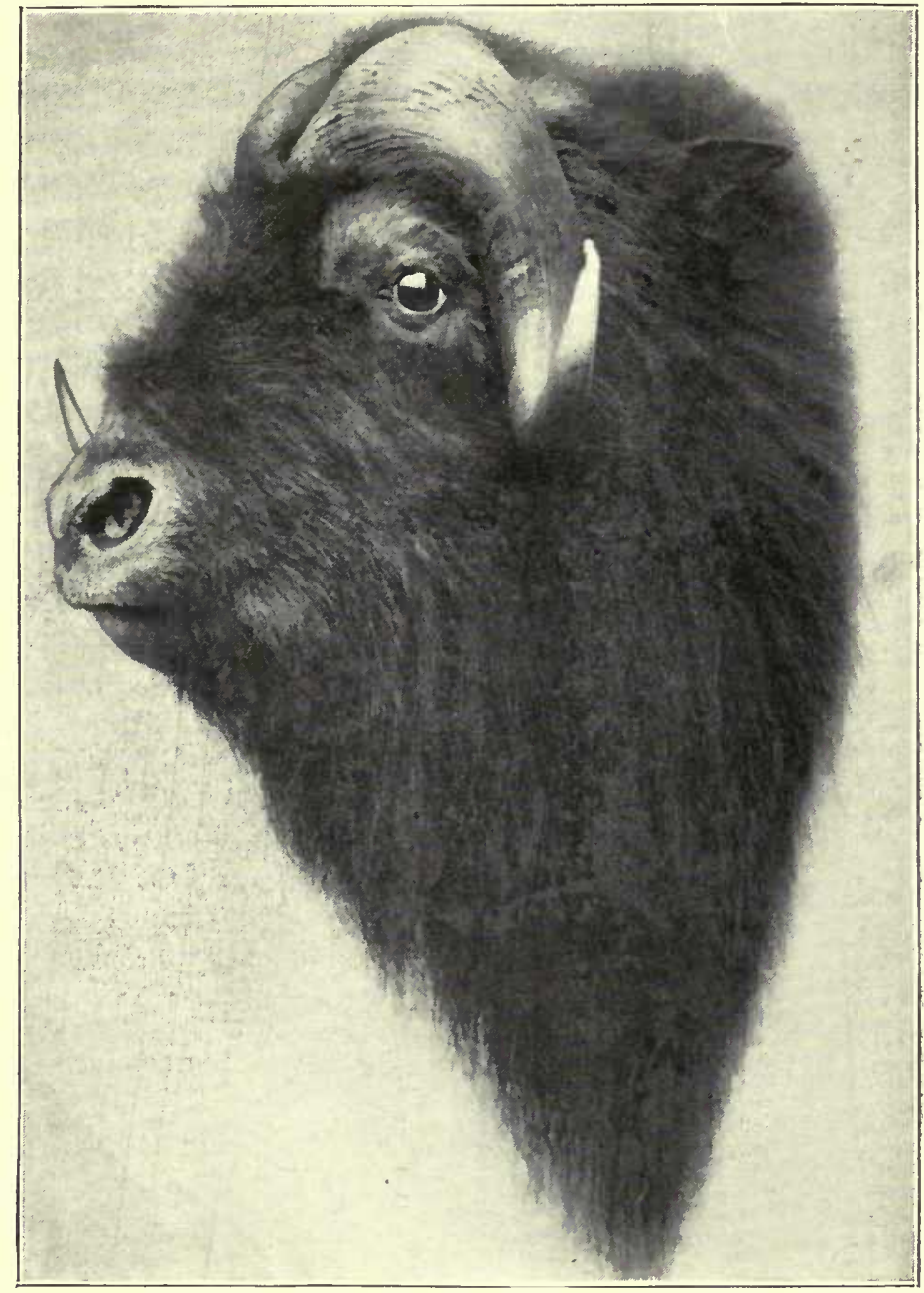

Bull Musk Ox Head belonging to W. F. Sheard, Tacoma.

herd I saw in the Flathead country, where an intelligent Indian started it in the beginning of the eighties. It was transferred later 
on to an island in Flathead Lake, where they did well, but I do not know whether it is still there. The herd once kept by Mr. Bedson, the Warden of the Manitoba Penitentiary, near Winnipeg, was sold a number of years ago. The small bunches of bison that are reported to exist to-day on the Peace River in the N.W.T., northwest of Edmonton, are, it is said by those who should know, not the true bison of the Plains, but the smaller, darker, and finer fleeced wood bison. A skin I once saw at Calgary, reported to have come from that region, was certainly much darker and finer haired than any Plains bison hide I ever saw. In the Appendix (Note 2), I have added a description of Jones's "Buffalo Ranch," published some years ago in the Tribune. I understand that Mr. Jones has since sold his herd to two half-breed Flathead Indians living on the Flathead reservation in Montana, named Charles Allard and Michel Pablo. A Mr. Goodnight, in Texas, has another small herd of forty head; and on the Sioux reservation in South Dakota there is another small band of twenty-five head. In a few private preserves, such as the Corbin preserve in New Hampshire, and the Whitney preserve in Massachusetts, there are also small bunches. According to accounts just received, the National Park (Yellowstone) herd of bison consists now of some fifty animals only, daring poachers raiding the herd every winter.

The Sheard collection appears also to include a remarkable bison head, of which the owner sent me the fine photograph here reproduced on a reduced scale. He gives these measurements: 36 in. spread, $2 \mathrm{I} \frac{1}{2} \mathrm{in}$. length of horn, and $\mathrm{I} 5 \mathrm{in}$. circumference. 


\title{
CHAPTER VIII.
}

THE FUR-BEARING ANIMALS OF THE PACIFIC SLOPE.

\author{
The Fur Seal.
}

THE million and a half sterling paid for Alaska in 1867 secured to the United States the last remaining retreat of the pelt-bearing ferce nature on the globe. To pay for a territory nine times the size of England and Wales what we would expend upon two firstclass ironclads was not a bad bargain. A fraction less than a penny per acre permits a good many of them to consist of barren rocks or uninhabitable swamps, without making it a losing transaction. And when we hear that on two of its tiny little islands, sixty square miles in extent-the famous Pribylofs-Nature has created and is maintaining a unique mine of untold wealth, that has already more than repaid the Government dollar for dollar the millions paid to Russia, the true character of astute Brother Jonathan's last "Conquest by the Almighty Dollar" begins to dawn upon one. If we add the further trifling detail that on another tiny isle there is a gold mine that has already produced more gold than the whole country cost, our admiration for America's commercial wisdom is only increased. We begin to realise, too, the true meaning of Charles Sumner's words when advocating before Congress the acquisition of the Russian possessions in America: "By this purchase," he is reported to have said, "we dismiss one more monarch from this Continent."

So much has been written about the seal that my attempt to add to a large literature another general, though brief, summary will probably be considered an unnecessary infliction, but these pages 
would hardly be complete without some reference to a denizen of the Pacific Slope as interesting as it is important.

Curiously enough the international difficulties recently set at rest by a peaceably assembled company of diplomatists and scientific men in a Paris salon, were not the first that had been caused by the pelt hunting industry on that far-off north-west coast of America.

Sixty odd years ago hot rivalry between the two great fur monopolies of North America, one operating in Russian the other in British territory, led to a dangerous crisis. As the Dryad, a Hudson's Bay Company's ship bent on fur trading, was entering the mouth of the Stikeen river, of which only the lower part was in Russian, the upper part, on the contrary, in British territory, the Tsar's ships opened fire on her. Fortunately bloodshed was averted on that occasion, as it was in the recent difficulty, when U.S. revenue cutters seized Canadian vessels bent upon the chase of the fur seal. Friendly relations were finally restored by much the same means as those lately employed.

A preliminary glance at the origin and growth of the pelt hunting industry in Alaska will be the best possible introduction to the subject of these pages.

From the very first pelt hunting methods in the Russian possessions were quite different from those employed in the country immediately to the south of it, over which the Canadian fur companies held sway. The methods were as much at variance as were the sober and disciplined "Voyageurs" unlike the drunken, semi-civilised "Promishleniki," or Cossack fur hunters; as different as were the respective routes by which these trappers and traders reached their hunting grounds in the unexplored north-westerly corner of the continent. The one travelling from the Atlantic westwards, followed the setting sun, carrying on his barter for furs through the Canadian wilds in an orderly and systematic manner, entirely in the interest of his masters, the company, and treating the aborigines with just but kindly firmness. The Russian, on the other hand, lured from his old trapping grounds round the 
Black Sea, advanced eastwards, following the ever-retreating sable. Crossing the Volga, he climbed the Ural, traversed the vast table lands of Central Asia and the steppes of Siberia, and finally set sail in crazy craft from the desolate shores of Kamchatka. Braving the ice-floes and storms of the Behring Sea, he at last reached the Alaskan Archipelago and the American mainland. Banded in rowdy undisciplined crews, he acknowledged no superior authority, and exploited the docile Aleuts and mainland Indians with truly shocking rapacity and cruelty.

The extension of Peter the Great's rule over Siberia in the first quarter of the eighteenth century had first disclosed to Europe the presence of hitherto unknown fur-bearing animals on the shores of Behring Sea. Wonderful tales of the enormous prices Chinese mandarins were willing to pay for the pelt of the sea otter had filled the mind of Russia's enterprising Tsar with the desire to extend exploration and land-capturing beyond the semiarctic sea of Okhotsk, on the shores of which the timber Ostrog or fortress of the same name had been constructed by his orders. Vitus Behring, a Dane in Russian service, was destined to be Peter the Great's Columbus, for to him did the Tsar entrust the command of the expedition in quest of furs and the mysterious land opposite to Kamchatka. The Tsar himself, on his deathbed, drew up Behring's instructions, and it is safe to say that no exploration of subsequent days had about it so much of romantic as well as tragic adventure. Starting from St. Petersburg in February, I 725, just three days before death claimed Russia's Imperial ship carpenter, it took Behring and his caravan, comprising a vast number of carts and sumpter animals, by which were conveyed the iron and fittings, as well as provisions required for the construction of the two vessels in which they were to brave the unknown seas, more than two years to cross the Continent of Asia. It took the same space of time to hew the timber, build and equip the ships, every nail, every rope, every tool having to be transported 5000 miles across inhospitable wilds! Behring's warrants for provisions required for the expedition, and which, according to Bancroft, are still to be 
seen in the Imperial archives at St. Petersburg, display an amusing disparity between two important articles, for of flour and shipbiscuits there were requisitioned only five and a half tons, of brandy I 003 " buckets."

The first start Behring made occurred in July, I 727 , the object of this N.E. cruise being to explore the coast of Kamchatka, and to ascertain whether Asia and America were really separated by a navigable channel. It took Behring three years-and what years of suffering-to solve the mystery, for it was not until I 730 that he returned, some of his men in canoes, some overland. But he had attained his object, and the Behring Straits immortalise his name.

The second expedition, which was destined to "discover" America, started in I 740 from Okhotsk in two vessels-the St. Peter, commanded by Behring himself; the St. Paul, by Chirikoff or Tchirikow.

They set sail from Okhotsk in September, I 740, but the voyage began as it finally ended, with shipwreck on Siberia's barren coast. Patching up the injuries sustained in the first stranding, they again set sail the following spring, and in July the mutinous, scurvystricken crew of the St. Peter at last sighted, when still far out at sea, the great iceclad dome of North America's highest elevationMount St. Elias. Riding, as it seemed to them, far up in the heavens-for the coastline was enveloped in a dense bank of fogone can imagine with what awe men reared on the steppes of Siberia must have regarded this peak, rising to an elevation of over i 8,oooft. over their dwarf heads.* Behring's vessel never 'reached the home port, and neither did its commander; for Behring and thirty of his crew succumbed to scurvy on the barren island, on which a great gale cast the ship. It was named after the explorer, whose bones found an unknown resting-place under

* Chirikoff, as a matter of detail, actually sighted the coast some hours earlier (on July 15), for the two vessels had separated in a gale and were destined never to meet again. 
one of its sand dunes. The survivors, after subsisting during the six winter months on the putrid carcases of two whales, finally managed to reach Okhotsk in an open boat constructed out of some of the planks of the St. Peter.

The second vessel was more fortunate, and the furs brought home by her, and which were sent by a special caravan to the Tsarina Catherine, proclaimed far and wide the rare beauties of the Alaska peltries. From that time on numerous private furcollecting expeditions set sail from Kamchatka; but, unlike the first, which was entirely a Government undertaking, with the Imperial Treasury at its back, their equipments were of the most wretched kind. In barge-like boats made of hewn boards, fastened together with raw hide thongs, caulked with moss, the sails made of reindeer hides, and straps of elk skin used in lieu of ropes, these bold freebooters set out from Kamchatka for the land of furs. What wonder that many failed to return from across a sea which, when not enveloped in mist, was swept by terrific gales. Those that did reach the home port safely brought back enormous quantities of the richest furs, over which the nobles of Russia and the Mongolian mandarins went wild. Those were the days of prizes when, as happened to one trader, 200 sea otter skins, worch then between $£ 2000$ and $£ 3000$, were obtained in exchange for an iron chisel, the like of which the unsophisticated natives had never seen, or when the innocent Aleut was willing to barter his long cloak, made of the same precious pelt, worth many hundreds of pounds, for a woollen shirt. Some of the hauls made by the Russians in the virgin Behring Sea hunting grounds, and of which record has come down to us, are worth mentioning. Thus one Bassof garnered on his first trip I 600 sea otter as well as 2000 blue fox pelts, netting him, when he landed at Kamchatka, the then enormous sum of over $£ 20$,ooo sterling, their value in St. Petersburg, it must be remembered, being quite four times as great. Another-the noted "foxhunter" 'Tolstykh-as the result of three trips to the Aleutian Islands, returned with I0, 168 sea otter, 2572 blue fox, and 840 seal skins, their value at the present prices exceeding half a million 
sterling. As the hunters extended their discoveries in the Alaskan Archipelago new kinds of furs were found to be peculiar to certain islands. Thus, besides the blue fox, there were discovered the black, the silver, and the white or ice foxes. The first-named put for a short time even the sea otter in the shade; the discoverers ( 1762 ), by a judicious present of a bale of this exquisite fur to the splendour-loving Catherine of Russia, not only caused this speciality to become the rage of the hour among the higliest of the land, but reaped for them gold medals and other honours from the grateful Empress.

At that time fur sealskins were worth only from 5 to 7 roubles $(\grave{a} 3 s .6 d$.$) , while sea otter skins fetched in the chief fur market of$ those days, namely, in China, from $£ 15$ to $£ 22$ sterling each. The channels of the fur trade during the eighteenth century were singularly round about. All Alaskan as well as all Kamchatka peltry was sent overland to Kiakhta, an important trading place just south of Lake Baikal on the Mongolian frontier. There the furs were bartered at top prices for tea and silk, but chiefly the former, which was sent to St. Petersburg by caravan, a name by which, as everybody knows, the best tea in Russia is still designated. The profits on a single chest, when it finally reached the capital, were from $£ 40$ to $£ 60$ sterling. It must be remembered, however, in view of these gigantic gains, that it always took six, and often eight, years from the day the sea otter was caught or traded from the natives in the Aleutian Archipelago until the tea caravan passed the gates of the capital. Till Capt. Cook's famous second and third expeditions, American fur traders appeared to be unaware of the possibility of reaching the Chinese ports by sea, for as late as 1775 the Hudson's Bay Company shipped some of their beaver skins, obtained on the slopes of the Rocky Mountains, to the number of 46,450 , viâ London, St. Petersburg, and Siberia, to the Mongolian and Chinese markets.

As was to be expected, the enormous profits made by the fur hunters in those early days attracted general attention in Russia, and towards the end of last century various companies came to be 
formed, having for their object the establishment of trading posts in Alaska. The history of the great fur hunting-corporations of the Rocky Mountains, who for years waged bitter war with each other, repeated itself also in these northern latitudes, till, finally, in the last year of the century, a grand amalgamation of the Russian companies was effected. By imperial ukase the Tsar Paul confirmed the consolidation and gave the "Russian-American Company" full and exclusive privileges for twenty years over all Russian discoveries in North America, and took the company under his protection. It is characteristic of Russian ways to find, as Bancroft mentions, that throughout the company's first charter these discoveries are spoken of as being situated in the northeasterly instead of in the north-westerly part of America. The boundary to the south was the $55^{\text {th }}$ degree N. lat. The company was of high standing, many of the great nobles and two princes of the Imperial House were members of it, while the local administrator, who was called governor, was practically the supreme ruler of the country. The operations of the company were very successful, and at the expiration of the term a renewal for a second, and subsequently for a third term of twenty years each, was obtained. The profits and the number and kind of peltry are particularised as follows :-

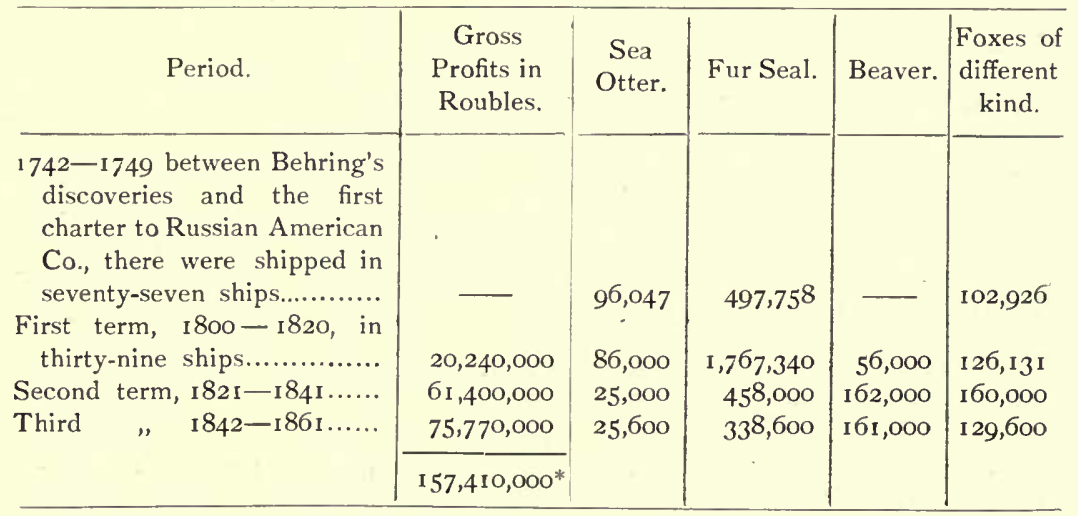

* Or about $£ 27,500,000$ sterling. 
The list here given represents only pelts sent by the company to Asia, and does not include the very large number obtained by poaching vessels of all nationalities who frequented the Behring Sea, nor the pelts used by the company's officials to barter for food supplies to relieve the distress of their hunters and servants, who, at their isolated posts on the storm-beaten Aleutian Islands, were often placed in the direst straits by the non-arrival of their year's supplies from Russia. The directors in their palace at St. Petersburg usually showed, as there is ample evidence to prove, far greater solicitude respecting the precious sea otter than concerning their very much forgotten employés. That large quantities of peltry were used for this barter is shown from one transaction of Baronoff, the most noted of the governors, who traded 20,00o fur sealskins at the Sandwich Islands for an old trading vessel worth, we may be sure, not a tenth of that number.

Two events to which brief reference must be made occurred when the company's charter was renewed for the second and third terms. With one the history of the 'early times in Oregon makes us acquainted. When the first renewal was granted, in 1821 , the Tsar's protectorate was suddenly extended to the southward for 4 degrees-i.e., to the 5 Ist $\mathrm{N}$. lat., or, in other words, to the northernmost extremity of Vancouver Island, and all foreign vessels were prohibited not only from landing on the mainland coast and islands, but also from approaching them within less than 100 Italian miles. In view of the somewhat comprehensive claim which the United States lately raised, as Russia's successor, to the whole of the North American portion of Behring Sea, it is noteworthy that it was the Government of that country who first remonstrated with the Russian Government against any such extension of its maritime and territorial rights. The dispute was finally settled, as one knows, by the Anglo-Russian and Russo-American treaties of 1824 and 1825 , in which the Tsar surrendered his maritime claim, and the $54 \cdot 40^{\circ} \mathrm{N}$. lat. as southern boundary was agreed upon.

When the third extension was granted the following occurred: A new industry, that of whale fishing, had, it seems, been started in 
Behring Sea, but it was chiefly in the hands of foreigners, and Ethoen, the then Governor, intending to secure for his ships also the monopoly in this business, addressed earnest representations to the Russian Government, requesting that armed cruisers might be sent out for the preservation of Behring Sea as a mare clausum. This demand, notwithstanding the prodigious influence exercised by the company at St. Petersburg, the Minister of Foreign Affairs refused to comply with, on the grounds that it would be necessary first to abrogate the treaty stipulation in force between Russia, America, and England, which gave American citizens and British subjects the right of free navigation, fishery, and trading in Alaskan waters. At the expiration of the third term Californiam capitalists came forward, and offered the Russian Government a million sterling for a twenty years' lease of Alaska, and, as this was far more than what the Government had hitherto received for the franchise, the proposition was on the eve of being accepted when Seward, Secretary of State, suddenly stepped in and made his now famous offer on behalf of the United States. The final bid was made on March 23, 1867, through the Russian Minister at Washington by cable, and already, on the 3 oth of the same month, at four o'clock in the morning, was the treaty signed. Its ratification by Congress was obtained only after a hard fight.

For the first two years after the purchase no serious attempt was made by the U.S. Government to protect the seal rookeries; and in consequence great slaughter occurred. More than a quarter of a million skins are said to have been taken there in 1868 , so that when, after two years' lobbying at Washington, the subsequently so-much-talked-of lease for a term of twenty years of the Prybiloff Rookeries was granted to the Alaska Commercial Company of San Francisco, it was the highest time stringent protective measures were instituted. The main conditions of the lease were briefly these: The take of pelts annually to be strictly limited to roo,ooo skins of male seals, to be obtained under Government surveillance. of the U.S., revenue cutters, to assist the company in preventing poachıng. The rent was $£ \mathrm{I}$, ,ooo per annum, and for every skin a 
tax of half a guinea (2.62 $\frac{1}{2} \mathrm{dols}$.) was collectable, while the company undertook to provide the natives on the islands with all the necessaries of life, schools, \&c. After 189o, when this lease expired, the annual take was reduced to 7500 skins, in accordance with the conditions of the modus vivendi, the U.S. Government claiming that, in consequence of pelagic or open sea sealing, chiefly pursued by the "Canadian poachers," the herd on the Prybiloff Islands had been greatly reduced.

On the Prybiloff group are, as has already been mentioned, the only breeding grounds of the fur seal in North American waters. The only others known to man worthy of any note in the northern hemisphere are those on three small islands on the coast of Asiai.e., the Commander or Komandorski group, consisting of Behring and Copper Islands, and in the Okhotsk Sea, Robben Island. The distance between the Prybiloff and the Commander Rookeries is about 750 miles, and between these two groups runs the line dividing the Asiatic from the American Behring Sea according to the Treaty of March 30, I867. Whether American born seals frequent these rookeries on the Asiatic coast, and vice versâ, is a disputed point, both sides producing evidence in support of their theories, the conflicting nature of which illustrates the difficulties that beset the paths of the arbitrators.

Having said so much regarding the history of our subject, one is tempted to take a closer look at the Prybiloffs during the breeding season, when the beaches on these islands present scenes described by those who have visited what is probably not only the most isolated spot on the globe, but also one of the most unique sights in the animal kingdom.

Of the two islands St. Paul and St. George, with a superficial area of thirty-three and twenty-seven square miles respectively, the former is by far the most important, for of its forty-two miles of coast line, sixteen and a half miles are seal beaches, the other island having only two and a quarter miles of its coast line used as breeding ground. This "hauling-up ground," as it is technically known, consists of shelving shore covered with large boulders, 
smooth sandy beaches being avoided except by the young seals as play ground. Here, during the breeding time, which lasts from May to September, several million fur seals are found congregated in densely packed, ceaselessly moving masses.

The first to arrive at the rookeries are the bulls, or full grown males over five years of age, for, unlike the females or cows, who begin to propagate when they are two years old, the males, until the sixth year, are not allowed by their elders to start harems of their own. The bulls begin to arrive in May, and from the moment they haul up the fierce battles for which they are famous commence. The object for which they strive is to secure front positions, as near as possible to the water's edge, where, as the cows gradually commence to land, which they do a fortnight or three weeks later, the bulls who have secured "front stalls" can pounce upon and secure for themselves the greatest number of wives, the weaker bulls being driven further and further back as stronger rivals renew hostilities, till the shelving beach is occupied by tier upon tier of fighting males to a depth back from the water of i 5 oft. The old warriors, who have been able to make good their claim to the front row by dint of a fortnight's almost incessant fighting, present often shocking sights, their blubber-coated bodies being gashed and torn, and their bleeding heads minus an eye. They grow to a formidable size, the grotesquely overweighted upper part of the body being a mass of blubber, upon which, during the long fast and constant drain upon their virile forces, they subsist by absorption, for, from the moment they land in May to the end of the rutting season about the first week of August, they never leave their posts night or day, thus entirely abstaining from food and water for a period of eleven or twelve weeks. Their weight, when they first land in the full prime of strength as well as beauty of fur, often exceeds 55 olb., and even 6oolb., the average being about 4oolb. Very different looking objects are they when, worn to shadows, their fur and long over hair on the point of being shed, they drag themselves back to the element which remains their home for the next eight months, and where their voracious appetite and a plenteous supply of fish 


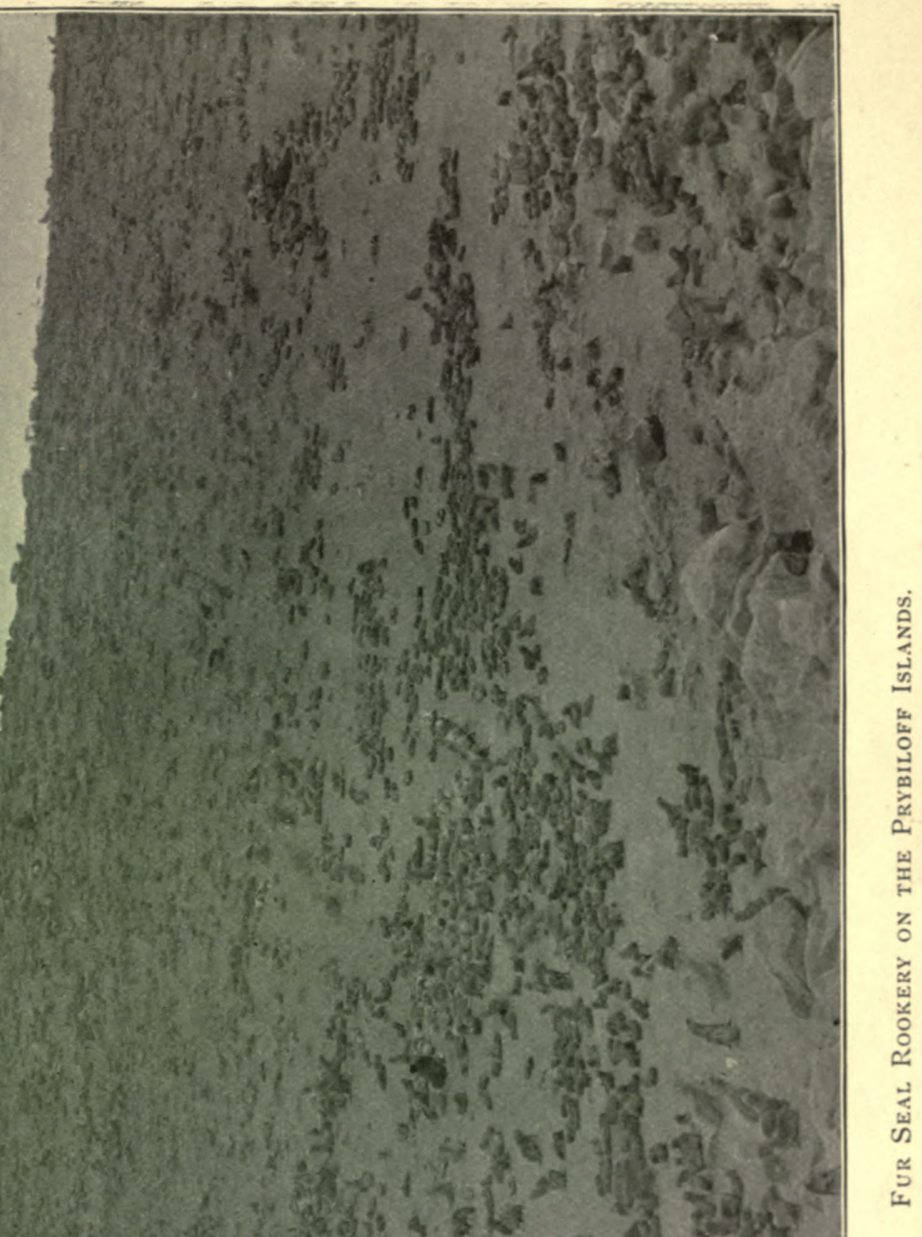



soon enables them to recuperate. The cows are only about a fifth or a sixth of the size of the old bulls, weighing about 8 olb. or 9olb., their timid disposition contrasting as markedly with the aggressive temperament of their lords as does their weight. The female, the instant she drags herself on shore, is seized and appropriated by the nearest bull, and if she is one of the first arrivals, a battle royal between her captor and the next neighbour will at once ensue to decide the mastership over her body, a struggle in which her skin is sadly gashed by the jealous warriors, as they seize her with their powerful canine teeth and tug her to and fro, her body being often suspended in the air. This rough handling is all the more unnatural, as the unfortunate cow is at that moment on the eve of becoming a mother, the young being born on land almost immediately after she drags herself on shore, the period of gestation being practically a full twelve months, less a few days.

The victorious old polygamists, heroes of countless fights, who have managed to secure positions in the front row, surround themselves with wives galore, often as many as forty, instances of eighty being not unknown, while their less fortunate fellows in the rear ranks have to manage matrimony with six or seven better halves only. Considering that this taking unto themselves wives means also the immediate starting of a nursery of other folks' offspring, it does not surprise one to hear that the stepfather entirely ignores the young pups, who, by taking up valuable space, for every inch of which he had to fight so hard, only incommode his ponderous majesty. Hundreds of pups are, it is said, annually crushed to death in this way by the bulls. On the breeding ground, which is exclusively occupied by the full grown males and females and the pups of the season, the ground is covered by a more or less uniformly distributed dense mass of seals. Quite apart from the breeding ground, but near it, is a general hauling-up ground, frequented by the young males, or bachelors as they are called, and one year old cows. These cover the ground in a much less even manner, and are given to roaming, but woe to the young buck who dares to stray in the wrong direction towards the married quarter, or as much 
as sniff across the broad pathway which separates the two spaces, and by which the young generation passes to and from the sea.

The Prybiloff Islands were discovered much subsequent to all the other Alaskan islands, for in spite of most assiduous search by the fur hunters, who knew perfectly. well that breeding grounds existed somewhere in that ocean, their efforts in this direction had failed until the year I 786 , when a trader, after whom they are called, more or less accidentally stumbled upon these fog-hidden specks in the broad Behring Sea. When he left them a few weeks later, he had $3 \mathrm{I}$, roo sealskins in the holds and on the decks of his

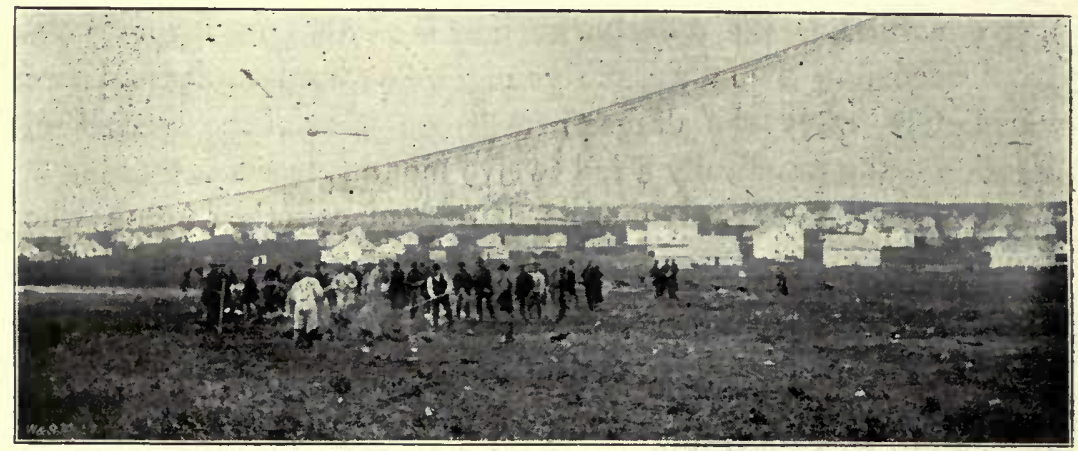

The Native Village on St. Paul (Prybiloff Islands), with a Seal Drive in the Foreground.

two vessels. The islands were found quite uninhabited, but, in order to assist the fur hunters, a colony of Aleuts was imported and the present population, some $35^{\circ}$ souls, consists of the third and fourth generation of the first immigrants. Their lot is a remarkably comfortable one, for the company, besides providing them with the necessaries of life, have to pay them a royalty of 40 cents a skin, which is divided among them in certain proportion, and in their eyes represents wealth. No other natives are permitted on the islands, the killing and skinning of the seals being exclusively their prerogative. The former is done in a methodical manner, entirely free from wanton cruelty, and is accomplished by surrounding 
outlying bands of a hundred or so on the outskirts of the bachelor ground in the early morning, when the dense mist of that moist region hides the men's approach. With as little noise as possible the band is driven off in the direction of the slaughtering ground, which is from half a mile to two miles away. All but the males fit to kill are allowed to drop out in the course of the drive. The fur seal's progress on land is, with the exception of the startwhen in his fright he launches himself forward in a series of bounds

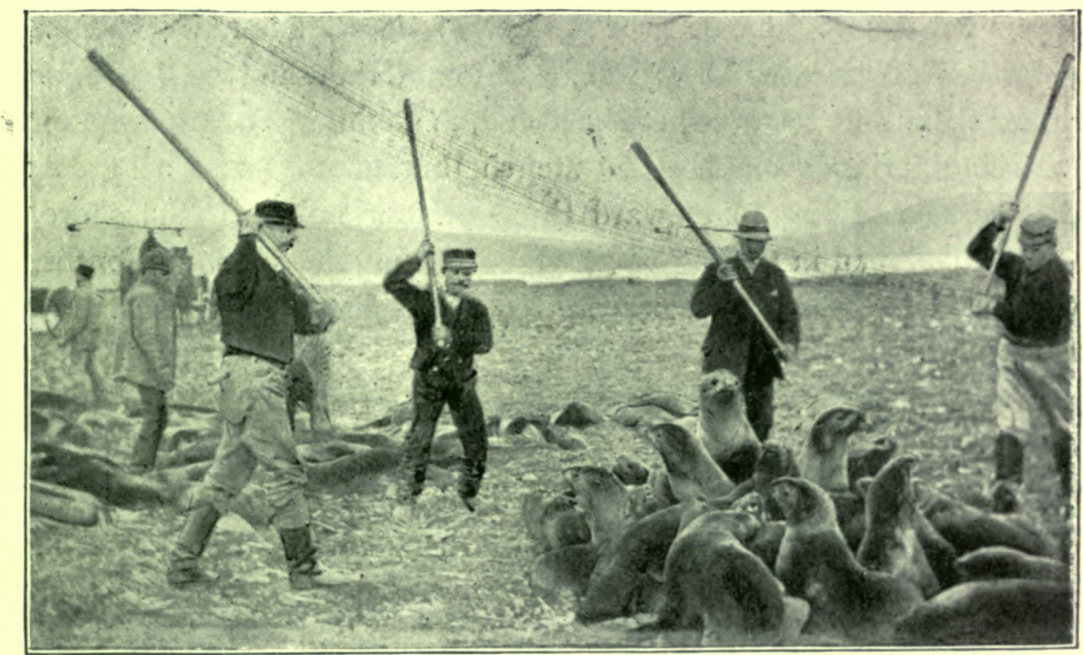

Killing Fur Seal on the Prybiloff Islands.

-an excessively slow one. As overheating of the blood spoils the 'pelt, the seals are allowed to drag themselves along at a very slow pace, averaging less than half a mile per hour, the rattling of castanet-like bones by the natives being sufficient to make them resume their march towards the slaughtering place after the frequent halts in which they are allowed to indulge. During these rests, these curious animals will squat down and fan themselves with their glove-shaped hind flippers, while their heaving flanks indicate what exertion the drive imposes upon their unwieldy 
bodies. Four Aleuts will in this manner drive many hundred seals, and they do also the killing, which is done by a blow on the head with a heavy club. For the skinning a far larger force is required, for the pelt, to ensure its prime condition, must be removed as soon as possible after death. A good skinner takes one and a half to four minutes per carcase, which is a truly remarkable feat. The natives dwell in little villages as far as possible removed from the rookeries, but, in view of the confined area of the islands, the distance intervening between the residences of man and these marvellous accumulations of animals in a perfectly wild state is nowhere very great. The carcases of the slain hundred thousand seals are, or rather were, left to rot where they fell, the skinning being done on the slaughtering ground. The stench thus created was so great, that vessels sailing to leeward three or four miles off the shore, when enveloped in the fog so prevalent during the summer months, were said to shape their course by this somewhat novel "dead reckoning."

In 1889 the first American lease of the Prybiloffs expired, and a fresh lease for a similar term of twenty years was entered into by the United States with the North American Commercial Company, the terms of which were far more advantageous to the Government than those of the last one, for, while the rent was raised from

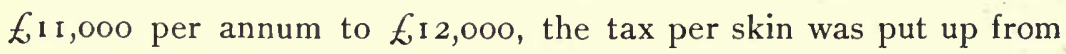
г $0 s .6 d$. to $£ 22 s$. $6 d$. (I $0.62 \frac{1}{2}$ dols.), and the number of skins was reduced, at any rate for the first year, from 100,000 to 60,000. As a natural consequence of this greatly increased surcharge on the Prybiloff skins the profits of the pelagic sealers were correspondingly enhanced, profits which were yet further augmented by the modus vivendi of $189 \mathrm{I}$ and $\mathrm{r} 892$, in accordance with which the annual take of skins on the Prybiloffs was reduced to 7500 .

To revert for a moment to the pelt itself. It is, of course, in its natural state far less attractive looking than when in its final stage. The fine fur is concealed completely by a coat of coarse over hair of dull grey brown colour, and the skin undergoes some nine or ten different processes before it reaches a marketable dressed stage. 
Almost the entire catch from the Prybiloff Rookeries goes to England for dressing, the Government of the United States reaping a further profit by collecting a high duty on the dressed skins re-entering the States, more than half of the whole catch returning, it is said, to that country. What a profitable investment the purchase of Alaska has proved to be for the United States is shown by the fact that in the twenty-one years (1870-90) the rent and taxes of the Prybiloffs amounted to £I,250,000, and the duties on returning dressed skins, amounting to over one million sterling, brought the total up to $£ 2,250,000$. Verily a famous purchase!

The fur and the hair seal are often mistaken for each other by persons unaware of the slight generic resemblance between the two, and the valuelessness of the latter's skin as a pelt. It arises probably from the fact that while the eastern ports of Canada annually send large fleets of "sealers" to catch hair seal in the Atlantic for the sake of their oil, the western ports of the same country, i.e., British Columbian ports (chiefly Victoria), fit out sealers who hunt the fur seal in the North Pacific by means of the open sea or pelagic fishing.

While this is not the place for an academic discussion of the much vexed question whether pelagic sealing is really so enormously wasteful of seal life as the Americans declare it is, the following brief, description of the industry may be of service to those who did not closely follow the evidence adduced by the Paris tribunal. To understand what is meant by pelagic fishing it must be remembered that after the conclusion of the breeding season the seal return once more to their true element, and, passing through 'the gaps between the Aleutian Archipelago, follow up, it is believed, in the warmer waters of the North Pacific, the vast shoals of their food fishes (the oolakan or candle fish and the herring) which do not frequent the Behring Sea. The area they frequent during the seven or eight months of their marine existence is an immense one, hardly less than ten million square miles, and, as they never land, and are at this time of the year shy and wary, the chase is by no means a sure one. Pelagic fishing is chiefly pursued in the spring, 
when the seals are travelling northwards back towards their rookeries, and the nearer the vessels engaged in it get to the Aleutian Chain, which forms the southern boundary of the Behring Sea, the latter being now closed to them during certain months of the year, the better is the chance of securing pelts. They are obtained by shooting or spearing the seals, mostly when they lie asleep on the water. The former method is the one chosen by the white hunters, the other by the Indians, of whom all of the sealing vessels carry a complement. Both methods make it impossible, except in the case of the undesirable large bulls, to distinguish the sex of the sleeping victim, so that many females and cows in pup are killed or wounded. Moreover, and particularly in the case of the shot seal, a certain number escape, to die of their wounds later on, the percentage of these cases being a point concerning which testimony varies to a surprising degree. That pelagic sealing. causes a more or less considerable waste of seal life only unreasonable partisanship can deny, and, comparing either of these methods with the businesslike and painless manner of killing on the rookeries, where only animals of suitable age and sex are taken, no possible doubt can remain in one's mind which method is the least wasteful.

Pelagic sealing in its modern sense, in distinction to the "coastwise" sealing by Indians, is a thing of very recent origin as an occupation of whites, who until about thirty years ago never troubled themselves about an industry concerning which nobody on the coast knew anything, for trade with the Aleutian Islands was, until I 867 , entirely in the hands of Russian traders hailing from Russian ports on the coast of Asia. The first vessel, it is said, that engaged in open sea sealing was a small twenty or thirty ton schooner, the Kate, of Victoria, whose captain, "Dutch Harry," left that port in I 866 on a sealing and trading venture to Behring Sea. Whether he ever entered that ocean is not known, nor what results were attained, for both captain and crew are either dead or have disappeared. At any rate they were not of a kind to tempt others or cause a boom, and the old routine of the Hudson Bay Company, of buying sealskins from the coast Indians, who did 
the killing in canoes, going but a short distance from the shore, was continued. Three men engaged in this trade, James Warren, Hugh Mackay, and W. Spring, perceiving that far larger profits might be gained by engaging in the business on a larger scale, in schooners that could steam out farther to sea and were able to reach the narrow passages between the Aleutian Islands, through which it was known that the seals passed in great numbers. They purchased suitable vessels and went into the business systematically. In the year 1879 they had four vessels engaged in the business, the catches averaging from 1500 to 2000 skins per vessel in the season, and, although the London sales, that govern to this day the prices on the coast, even in the most remote Indian settlement, had then not yet experienced the important rise which presently came, the profits were large enough to attract other British Columbians. In 1883 there were nine Canadian vessels, and on one of these I made a short trip up the west coast of Vancouver Island to see how sealing was conducted. Victoria has always been the headquarters of the business. In I 886 quite a number of vessels were added, and the American naval circles in the Puget Sound cities (U.S.) began also to fit out a number of sealers. In that year, too, the first seizure by the U.S. cutters were made, three Canadian and one American "poacher" being taken; in 1887 six Canadian and ten American sealers; and in I 889, which was the last year seizures were made, four Canadian and two American vessels were seized. When America's rather far-fetched claim to the ownership of the Behring Sea and to a portion of the North Pacific was disposed of by the Paris arbitrators, public attention at once fastened upon the hotly discussed but little understood pelagic sealing. All reasonable and uninterested persons from both sides versed in the details of the business at once recognised that it was a question which should be decided solely on the ground and upon the facts of natural history. That Canadian rights to pursue a marine industry to which they had every right, and in which much capital was sunk, had to be respected, went without saying. 
To the writer, who has no interest of any sort or kind connected with sealing, but who saw a good deal of what was going on on the Pacific coast, the conflicting character of the evidence collected together by the commissioners deputed to examine into all the facts of pelagic sealing, was simply incredible. Never was black painted a more virgin white, never did white assume such dark hues.

There is one very regretable feature about the British side of the question, which is that it is antagonistic to all the humane considerations connected with seal life. Pelagic sealing* is a cruei and most wasteful method of obtaining peltry which can be secured by "land killing" at the rookeries without inflicting suffering and without any appreciable waste. Those who dispute this do so either from ignorance of the true facts or from interested motives. This being the writer's firm conviction, he is unable to agree with the reported dictum of Sir George Baden-Powell and others, who, it is said, consider that "pelagic sealing is the most humane and least wasteful method of killing seal."

If the hunters are unskilled-and many of the new hands shipped every season must necessarily at first prove inexperienced and bungling shots-the waste and suffering inflicted is appalling. Take such instances as the following, contained in Par. 614 of the I 892 Blue-book (Report of the Behring Sea Commission). In the log-book of the Angel Dolly, when seized, was found the following entry: "Issued to-day to my boats 300 rounds of ammunition; all expended, and got one sealskin." This, of course, is an extreme case of bad marksmanship; but that the percentage of wounded animals escaping capture is far greater than many of the sealers pretencled is a fact too obvious to anybody conversant with the use

* The latest returns of the catches made in the past season (1897) by pelagic sealers demonstrates the result of indiscriminate killing. The total catch in the North Pacific in 1897 was only 38,700 , against 73,000 in 1896 . Of these 30,800 skins were taken by British (or Canadian) vessels, 4 Ioo by American, and 3800 by Japanese. The catch in the U.S. portion of the Behring Sea was 16,650 , against 29,700 in 1896 , and of these 15,000 skins were taken by British craft. 
of firearms and the peculiarities of seal shooting to require further proof.

The hunters, who leave the vessel in small boats, each being manned by two or more rowers and one "killer," are, even in the smoothest sea, awkward craft for close shooting; for, unlike the Indians, who in their canoes manage to creep up to the sleeping seal to within a few yards and then discharge their barbed spear, from which no escape is possible when once " in," the white hunters do most of their shooting at double or treble the distance. The seal, if not hit in the head or neck, is not killed outright, but dives and gets away, body wounds inflicted by the buckshot, of course, ending often, after much suffering, in slow death.

Most of the seals obtained in spring by pelagic sealing are females heavy with young, while those caught after the breeding season is over, or while it is still going on, are also with young; and as many of the seals shot in July and August are females who have temporarily left their rookeries in search of food, the death of a suckling female at that season means practically the death of three seals, i.e., the mother, the unborn young, and the pup, which, as ample evidence has shown, dies of starvation at the rookery if left to itself before it is three months old.

One plea advanced by those blindly favouring the British case, which otherwise is such a pre-eminently sound and just one, is particularly unfortunate. When condemning the land killing as conducted on the rookeries in the manner already described as "rank butchery," as a "revolting destruction of animal life," "as cruel as it is unsportsmanlike," "slaughter of animals without giving them a chance for their lives," \&c., one can only shake one's head in indignation at such unreasonable special pleading. Even some of those voicing their authoritative opinions in the British Blue Book pander, one regrets to see, to this inhuman pleading. Par. 6ro says: "The accusation of butchery laid against those who take the seals on shore cannot be brought against this pelagic method of killing the seal, which is really hunting (save the mark !) as distinguished from slaughter, and in which the animal has what 
may be described as a fair sporting chance for its life." Was ever more mischievous nonsense written? Does it not stand to reason that the method which eliminates all chances of-(I) a lingering death from wounds, (2) that spares all females, (3) that prevents all avoidable waste of life, (4) that kills in a merciful way only those animals that are best suited for the uses to which their pelt is put

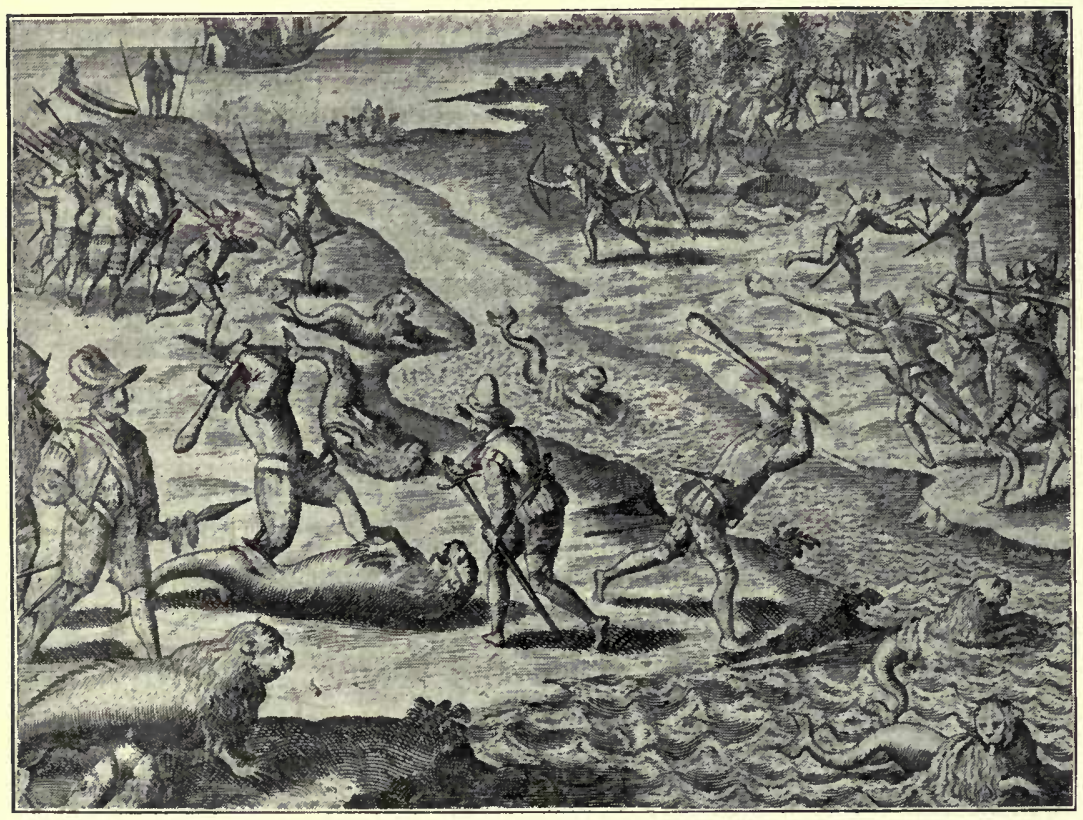

How Seals were Killed in the Sixteenth Century.

(From De Bry's Narrative of the English navigator Cavendish's Expedition, 1586.)

and that can best be spared in the economy of seal life, is a better and more humane method than one which fails to regard any one of these important considerations? One might just as well argue that, instead of putting our cattle to a speedy and painless death, we should turn them loose in a deep lake and shoot them or wound them from unsteady boats, letting those that are not killed instantly 
die a lingering death and sink out of sight. There is no more reason for depriving a steer of a "fair sporting chance for its life" than a bachelor seal when its skin is at its best.

If Victoria newspapers write such rubbish as: "The method of land killing on the rookeries is cruel and unsportsmanlike. The animals have no chance for their lives, but are slaughtered like sheep in the shambles," one can, by stretching leniency to near breaking point, make excuses, for they are writing for a circle of readers pecuniarily interested in the continuation of pelagic sealing. But to find that persons outside that circle, and occupying positions of responsibility at home, can advocate such inhumane proceedings, passes one's understanding. To bring into such a discussion any question of "sport" is, indeed, adding injury to insult, and can certainly not tend to uphold Britain's reputation for fair play. The preservation of the fur seal is, it is almost needless to observe, more feasible than that of any other wild animal. So long as the proper restrictions respecting number, sex, and age of the animals annually killed are rigorously enforced by a strong hand, Nature has provided in a truly marvellous manner for the perpetuation of this interesting and valuable pinniped. It is to be sincerely hoped that a saving hand will stay the hammer of the London and Leipzig auctioneer from tolling the fur seal's death knell.

With a birth rate of about 143,000 , as estimated by the most recent and entirely trustworthy examination by Professors D'Arcy Thompson, for the British, and Starr Jordan, for the United States Government, it is surely possible to insure the perpetuation of the race; while $£$ roo,ooo would, it is said, amply indemnify the Canadians for completely ceasing pelagic sealing.

\section{The Sea OtTer.}

This sketch of the North Pacific peltry would be incomplete without a few words regarding the animal that provides, of all furs known to the fancier, the most valuable, i.e., the sea otter. If the fur seal is often mistaken for the hair seal, something similar 
occurs in the case of the enhydra, for those who have never seen the sea otter usually take it for granted that he is a close kinsman of the land otter. The two are, however, very dissimilar animals, the sea otter having a body more like the beaver. It is an intensely vicious looking animal, its small, snaky eyes gleaming with a wild and cruel expression. It lives a solitary marine life, is never seen in numbers, rarely even with a mate, and is excessively shy and wary. It rarely lands for any length of time, except to bring forth its young, and, indeed, Indians maintain that it does not even then do so, but that it gives birth on floating beds of seaweed and kelp. Very few white men ever see it alive, for its chase is almost exclusively in the hands of the hardy and wonderfully persevering Aleuts, to whom a single prime pelt means a twelvemonth of plenty. Clad in their waterproof garments, made out of the intestines of the sea lion, of whose hide the "bidarka," in which frail craft they go to sea, is also constructed, and armed with the best rifles money can purchase, for everything depends on clean shooting, they pursue their vigilant game on the rugged reefs girding the North Pacific. Occasionally stray sea otters are heard of much further south, on the coast of Washington, Oregon, and California. The wariness and cunning of this animal, always of the highest order, have, of course, not been decreased by the relentless persistency with which its pursuers have followed it for the last century and a half, and it is only wonderful that an animal whose pelt realises for the lucky captor as much as $£ 5^{\circ}$ should not have long ago shared the fate of other animals upon whom fashion had pronounced the death sentence. In the beginning of this century we hear still of single cargoes of I5,000 sea otter skins being sent from Alaska. In I 89I, according to trade journals, only 2395 pelts reached the London and Leipzig markets, which practically means the entire catch of the world, and they averaged over $£ 57$ each. In I 898 only 955 skins reached the market, the best skin fetching $£ 255$. Nothing can be done to save the sea otter from extermination. In a decade or two it will have shared the fate of the huge rhytina or 
sea cow, once at home in the same ocean, an animal that was destroyed in the sea in the same ruthless manner that the bison of America was exterminated on the plains. It was a fate which we

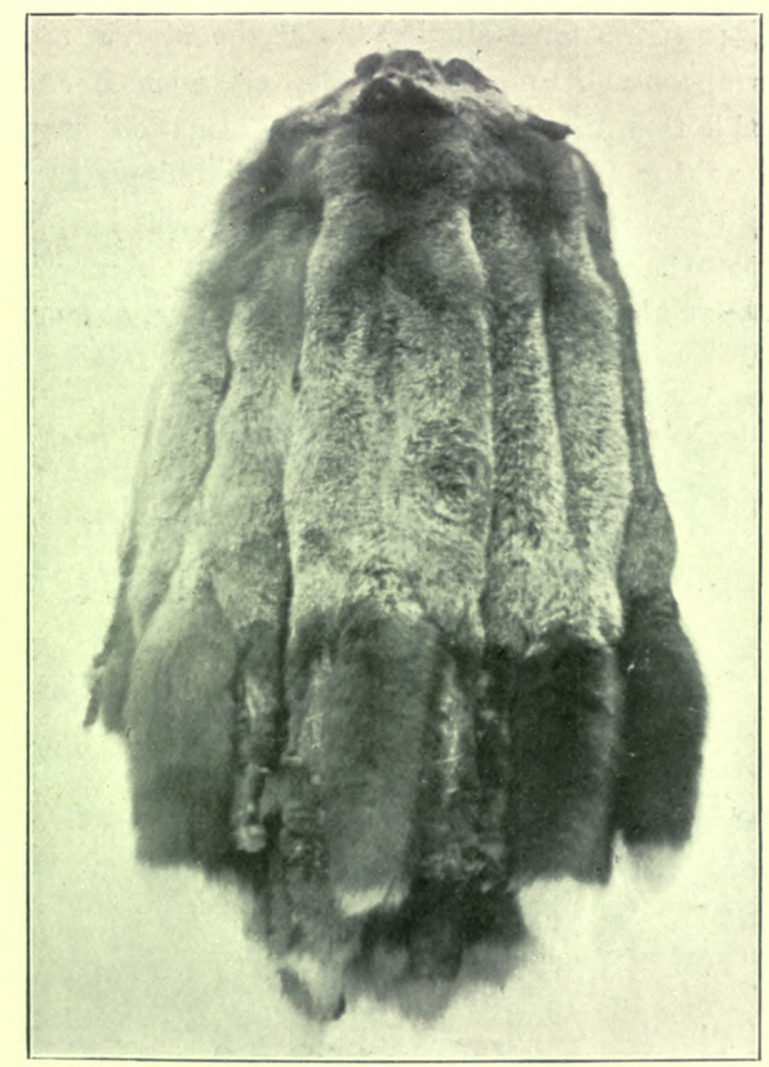

Thirty Silver Fox Skins, belonging to W. F. Sheard, TACOMA, WaSh.

(One Silver Fox Skin was sold in London, March, 1899, for $£ 340$.)

know overtook the millions of fur seal that once bred on ownerless islands in the South Pacific, where nothing stayed the hand of the slaughterer. 
Of the numerous other fur-bearing animals on the Pacific Slope I do not propose to speak, for I know too little about them. The rare and exquisite pelt of the silver fox is probably, next to the sea otter, the most expensive fur. Indeed, to judge by the record price of $£ 340$ given for a single skin at the March, I899, sales of Messrs. Lampson and Co., London, first-class specimens are even more valuable than those of the sea otter. In 1898 , i 245 silver fox skins were sold in London, the best skin fetching $£ \mathrm{I} 55$. For the picture of thirty prime silver fox skins which I append I am indebted to Mr. Sheard, of Tacoma (Wash.). According to late prices the bunch here depicted is worth, probably, at least $£ 2000$. 


\section{CHAPTER IX.}

\section{THE SALMON OF THE PACIFIC SLOPE.}

IN a region where settlers feed their cows with canoe loads of salmon, and where pigs and bear grow fat and sleek on the same diet, it is but natural that there is much that is new to be learnt by the traveller interested in ichthyology. The following stray notes upon the salmonoids found in the rivers, lakes, and along the coast of Western North America are the result of such unscientific observations as any "globe trotter" has the opportunity of making.

If, as some authorities claim, there are five, six, or seven different kinds of salmon in the waters of the Pacific Slope, there are at least seven times seven different classifications and names for them, for there exists an extraordinary confusion and divergence of opinion among persons claiming to be authorities upon this question. We have, first, the practical abhorers of all theories, i.e., the fishermen who catch the various species of salmon; then there is the cannery man, who exploits by legal and illegal means this vast source of wealth; then there is the local "scientist," who, if he is not as well up in ichthyology as he should be, has made a study of it "since he first came to the Slope"; then we have the American boná fide scientific man, hailing from the Smithsonian or kindred institute; and lastly, but not least, we have the political fish authority, whose appointment to the post of Fishery Inspector, or Fishery Commissioner, be it by the Dominion or the United States authorities, is not the result of his possessing any special 
qualifications for the duties imposed by his office. He gets the post because he is a "deserving" Conservative or Liberal, a "good" Democrat or a "worthy" Republican.

There are, if we give it a thought, surely few provisions of Nature more mysteriously wonderful than the circumstances surrounding the salmon run. Common to Europe, Asia, and North America, wherever the widely spread salmon famiiy exists, the North-West Coast of America is decidedly the region where it can be studied to best advantage, where the wonderful phenomena springing from an animal's instinct impress themselves most on our mind.

Let us follow for a moment the fortunes of a lordly tyhee or king salmon, denizen of the Pacific, a realm as vast in area as it is profound in depth. Hundreds, perhaps thousands, of miles out at sea, he has roamed in his home element during the four years that have elapsed since the little orange-coloured egg, one of the 3000 or 4000 carefully deposited by his parent in the sand of some nameless stream heading in the heart of the Rocky Mountains, gave him to the world. Now the all important moment of his life is approaching, the instinct of his race is full upon him, and with millions and tens of millions of his kindred he is making for the great mountain range that rises abruptly from the black depths of the ocean's bottom. Possibly, nay probably, he is the only surviving offspring from a batch of carefully deposited ova to which he owed his existence, for from the very first moment the enemies of his race have been numerous and proportioned in size to his own growth at the various stages of his existence.

Whether his instinct is so perfect a guide as to lead him unerringly to the scene of his own birth is a question that has puzzled many, but which remains unsolved. What evidence has been collected by means of marked fish from hatcheries would, it is said, almost prove that such is the case, while the fact that the several larger rivers are frequented by fish distinguished by some peculiar quality or other, certainly goes a long way towards demonstrating the probability of such being the case. 
On, towards those uprising cliffs, clothed with algous forests, does the racial instinct drive our sleek four-year-old. The closer he approaches these submarine foothills of a vast continent the greater becomes the number of his fellows, all heading in the same direction. Three spots, many hundreds of miles apart, appear to be favourite rendezvous; the most southerly of these being the great shoals near the mouth of the Columbia; the next, in a northerly direction, the storm-beaten Straits of Fuca, by which access is gained to the great inland ocean of Puget Sound, into which numerous streams empty themselves; and lastly, the region north of the 300 mile long Vancouver Island, to the extreme northern limit of salmon life, which is the Yukon.

Of the three great rivers of the north-west-the Columbia, the Fraser, and the Yukon-that are ascended by salmon to their furthermost head waters, each has a distinctive peculiarity. In the Yukon, that being the longest of the three, the length of the inland journey is the greatest, namely, more than 2000 miles; in the Fraser, salmon cannot travel more than some $75^{\circ}$ miles or so, but in none other is the force of the current so great for such long stretches; while in the Columbia, in a journey of about I 300 miles the salmon climb a sheer altitude of 2900 or 3000 feet.

Curious as is this diversity, a yet greater difference exists in the temperature of the streams frequented by the Pacific Coast salmon. Almost the same difference that exists between a tropical and an arctic climate marks, say the Sacramento or San Joaquin rivers, where the water is said to reach a temperature during the salmon run of $80^{\circ}$ Fahr., and, on the other hand, the glacial water of most of the Alaska streams. The water in some of these streams was some hours before solid ice, for it is a well-known fact that the salmon's spawning beds are often in close vicinity to the glaciers from beneath which issues the trickling brook which finally becomes the nursery of our fish.

Let us follow our quinnat as he crosses those deadly shoals at the mouth of the Columbia, here some seven miles wide, upon 
which, from the very earliest times unto this day, a number of human lives are yearly sacrificed, for they are the most treacherously shifting banks known to the navigator in any part of the world. A little further up the river, where the channel gets narrower, begin the various deadly snares that waylay our friend. Two thousand seine nets, from I 500 to 1800 feet in length, spread their deadly snare without "let up" from the first day of the run to the last.* They bar, or to speak more correctly, they barredfor since the Columbia catch has fallen off to the extent of fifty per cent. a decrease in the number of nets has occurred-the salmon's progress most effectually. Further up the river those of the fortunate few who escaped the meshes had to run the gauntlet of traps and salmon wheels, $\uparrow$ mechanical contrivances by which thousands of these noble fish were caught or scooped up and delivered over to the choppers and knives of the pig-tailed employees standing alongside of the wooden troughs into which the wheel threw the fish. So quick is the manipulation that the lordly quinnat, weighing in the Columbia from 15 to $7 \mathrm{olb}$., is decapitated, "tailed," gutted, and cut up and placed in the vats from which the pieces find their way into the tins, all within less than five minutes from the time that the fish was stemming the current of the majestic Columbia. The heads and tails were flung

* There is a law which prohibits Sunday fishing in order to allow a day of grace, but it is for various reasons practically inoperative.

+ This was a huge erection, like a broad mill wheel, but furnished with wire buckets instead of paddles. The current set it in motion, and the buckets, rotating round the axle, scooped up the fish and deposited them in a trough, which brought the fish in a never ceasing stream, under the knives of Chinamen employees. These deadly contrivances, which during the run worked day and night, Sunday and week-days, and were the cheapest of all the means employed to catch salmon, were subsequently suppressed by the Federal Government to protect the fisheries. It was not accomplished, however, without bloodshed and the loss of lives, for your genuine frontiersman, selfish and improvident as he generally is, believes in grasping with both fists the easiest harvest provided by an over-bountiful Providence, and is hostile, on principle, to all interference by a paternal Government-however much it may be one of his own choice-that curtails in any way the profits of his wasteful ways. 


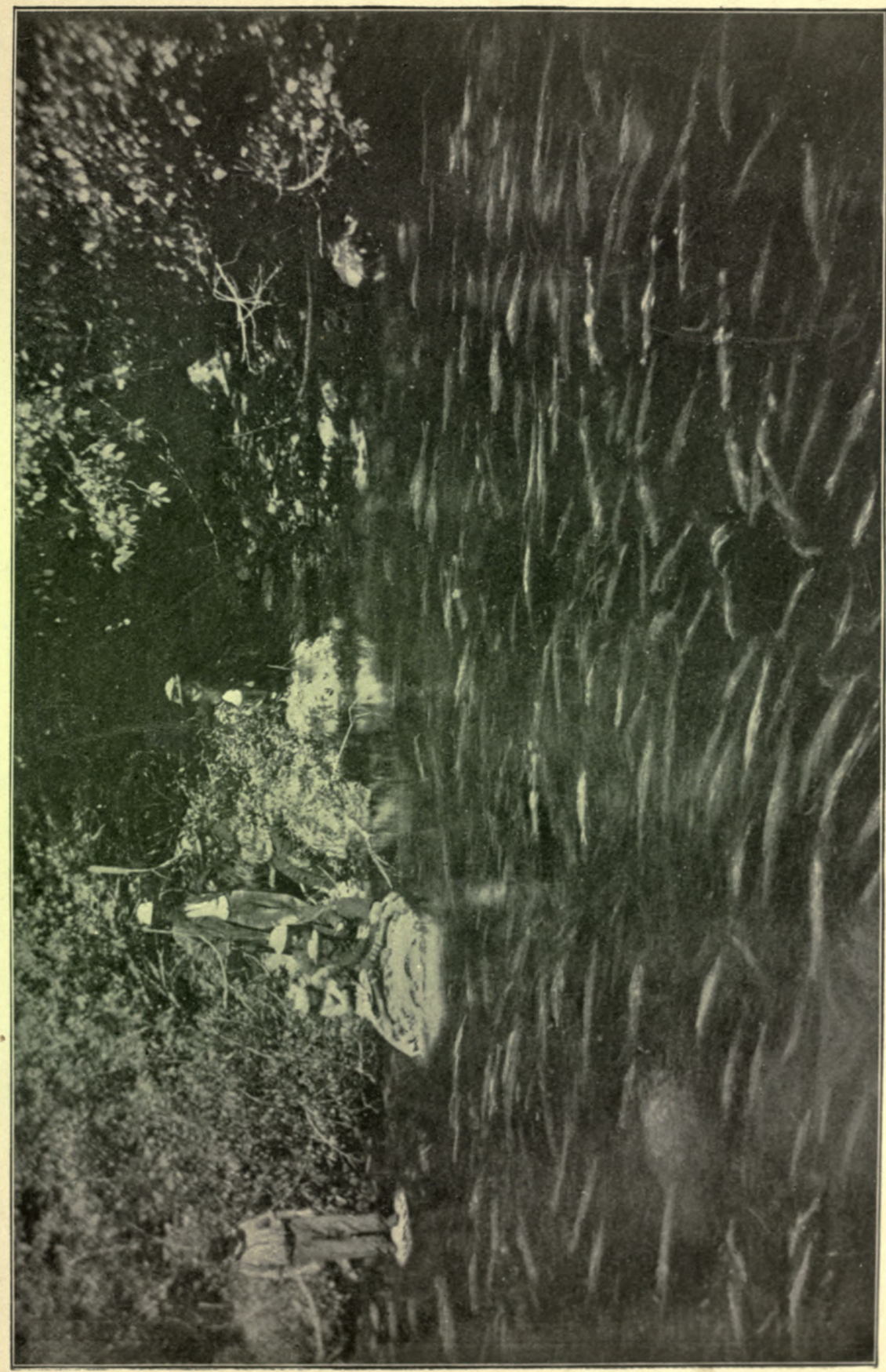

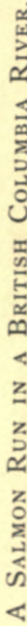



back into the river,* warnings that were, alas, left unregarded by the hosts below. Yet further up the river the naked son of the soil, with his unerring salmon spear, waylays those that have escaped the seine, trap, and wheel. In past years, before the introduction of the nets at the mouth of the river, the Indians were in the habit of rigging up primitive but quite ingenious traps at the highest falls that exist on the Columbia, i.e., the Kettle Falls, which are about 675 miles from the ocean. These falls consist of a series of cascades, the highest of which varies between $\mathrm{I} 2 \mathrm{ft}$. and 2 oft. of sheer fall, according to the stage of the water, and we have here what is generally acknowledged to be the highest fall up which salmon are known to leap. In the old days, when Dr. Lord, the well-known naturalist, who accompanied the Boundary Commission, which carried the International boundary line just forty years ago through an entirely wild and uncivilised country, visited the spot, one could see hundreds of the larger salmon in the air at the same moment, leaping or attempting to leap the falls, for few fish succeeded at the first attempt in stemming the impetuous flood that swept the fish back into the deep pool at the foot of the falls. The Indians used to drag great trees down to the water at the brink of the falls, and place them in such a manner that a portion of the trunk protruded over the falls, and here, within a few inches of the water, they would hang frail-looking basket work scoops, that would catch all but the strongest fishes as the force of the water whirled them back.

I would like at this point to revert to the question, how high can salmon leap. The Kettle Falls have always been considered among the highest in the world ascended by these fish; indeed, if one visits them at a low stage of the water it seems impossible that any fish could leap those perpendicular walls, quite 3 oft. in sheer altitude. That a 4 olb. Columbia salmon who, in the course of his long journey of upwards of 650 miles from the Pacific

* Of late years most of the offal of canning establishments is used as manure or treated for the oil which this waste matter contains. Where settlers are near pigs are fattened on it. 
against some of the most terrific mill sluice currents to be found in any river, should have lost a great deal of its encumbering fat, and found itself in the pink of condition, makes it credible that a clean leap of from $15 \mathrm{ft}$. to $16 \mathrm{ft}$. was not beyond the scope of possibility. Recent investigation, with the faithful assistance of the camera, made by Dr. Robert T. Morris, of 49, West Thirty-

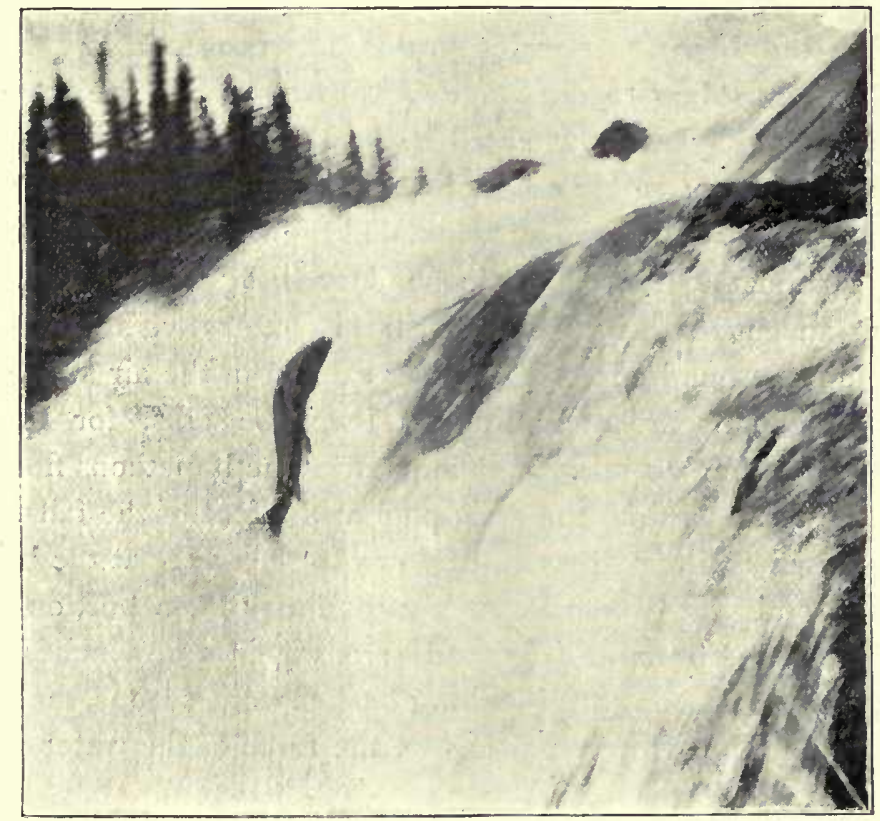

Salmon leaping an i8ft. high Fall on White Bear River, LABRADOR.

(Photographèd by Dr, R. T. Morris, of Nerw York.)

ninth Street, New York, on Labrador and Newfoundland rivers, give countenance to the latter feat; indeed, as this gentleman, who has been good enough to send me a large series of his highly interesting negatives for reproduction in these pages, mentions that he accurately measured a clean leap of $\mathrm{r} 8 \mathrm{ft}$. The first illustration 
is an accurate reproduction of an instantaneous photograph of this record leap at one of the falls of the White Bear river in Labrador, as photographed by him in the month of August, I897. The other illustration shows the almost horizontal "sailing home" pose, illustrating the wonderful elasticity and muscular force possessed by the salmon at that season of the year.

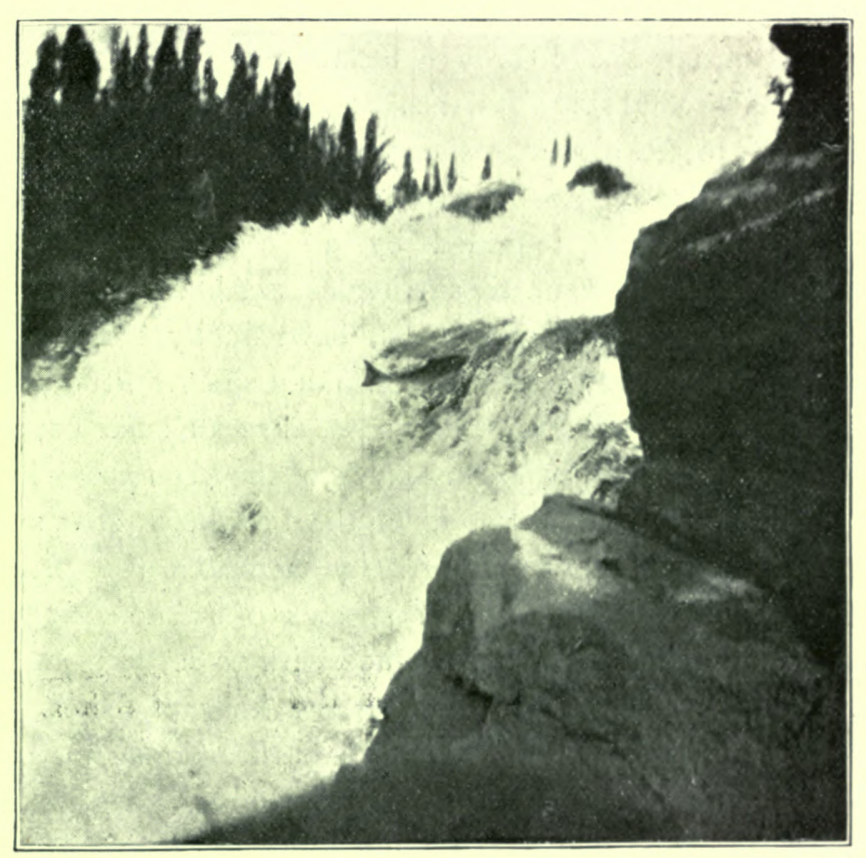

Salmon "SAIling home" in Leaping an i8ft. high Fall on White Bear River, LABrador.

(Photographed by Dr. R. T. Morris, of New York.)

Once over the Kettle Falls, no traps or wiles obstructed their path, though the natural difficulties for the remaining six hundred miles are all the greater. Past the now abandoned, but once important, old Hudson Bay Company's post, Fort Sheppard, over innumerable rapids, through the Arrowlakes, as lake-like 
expansions of the great river are called, under the two just erected Canadian Pacific railway bridges that span the turbulent, but wonderfully picturesque Upper Columbia, at the west and at the east crossing (the river making a great bend 200 miles long in the interval), past flourishing little mining towns, here stemming a current no craft of man's design can ever venture to face, there rushing through whirlpools that knock into splinters the great monumental trunks of giant white pines, or breasting the stream as it rushes at lightning speed through formidable cañons where a vast river seems as if set up sideways, the surface of the water being convex and some $4 \mathrm{ft}$. to $5 \mathrm{ft}$. higher in the centre than where it touches the smooth walls of the imprisoning rocks. Past all these dangers and perils rush the salmon, impelled by an all-powerful instinct to ascend the swirling stream till further ascent becomes impossible, and the cradle of the great river has been finally reached after a perilous I 300 miles long journey, in which a sheer altitude of about 3oooft. has been attained. Few spots are of such captivating and ichthyological interest as the source of the Columbia; for here, in the shallow and limpid waters of the new-born stream is, or rather was, offered a rare opportunity to watch the process of spawning peculiar to the several species of salmon, and also a wonderful abundance of material wherewith to settle some of the most vexed points in the history of the king of fishes. Forty years ago the number of fish who reached these beds was so great that the receding waters (the freshets from melting snows cause a considerable rise) would leave millions of dead salmon strewn along the banks, emitting a stench that could be smelt miles off, and which never failed 10 attract great numbers of bears. To count fifty of these animals within an hour's paddle was, in those days, so the Indians say, an ordinary event, a circumstance that appears to be confirmed by the fact that the nearest Hudson Bay Post that drew its supplies of this pelt exclusively from this region ordinarily baled from 800 to 1000 bear skins every year, and this at a time when these Indians had but few firearms, and necessarily made walking pincushions of 
Master Bruin with their arrows before he succumbed. The salmon, by the time they reached this remote spot, after their long journey, occupying the strongest fish, according to the Indian version, from three to five weeks, were wretched looking objects. Battered, weak, covered with sore places, gaunt, minus an eye, or a portion of the upper or lower jaw, they presented spectre-like wrecks of the sleek, lissom, strong salmon as he entered the great river bent upon that wonderful journey. According to the Indians, and I have elicited the opinion of a good many during my long stay in this locality, none returned to the ocean after spawning, death being the invariable end; there is, however, on this point a great divergence of opinion among piscatorial authorities.

Of the five, six, or seven different species of salmon in the waters of the Pacific Slope,* the chinook, quinnat, tyhee, or king salmon, by which various names this fish is known on the Slope, is the most beautiful and interesting species. It also bears, so far as outward appearance goes, to an unprofessional eye the greatest resemblance to the British salmon. The recently inaugurated industry of importing this fish in a fresh but frozen condition from British Columbia to the London market, and which I believe is a business that has a large and profitable future before it, naturally invests the quinnat with features of particular interest. For this reason I am tempted to transcribe some remarks published in the Field by the well-known English ichthyologist, Dr. Albert Günther, concerning the Columbian salmon, as he calls the quinnat.

?.

* (I) Quinnat, or Oncorhynchus quinnat or O. tschazutsoka, according to Ashdown Green; (2) the sockeye or blue back salmon (O. nerka), though some consider them different fish; $(3)$ the cohoe $(O$. kisutch $) ;(4)$ the dry salmon (O. keta); (5) the humpback salmon (O. gorbusca); (6) the cut-throat, really a trout $(S$. mykiss $)$; and $(7)$ the steelhead, which also is a trout, but generally spoken of as a salmon $(S$. gairdneri $)$. Writers that should be consulted by those desirous of amplifying their knowledge are: Professors Jordan and Gilbert, Livingston Stone, J. K. Lord, Seth Green, Ashdown Green, Dr. Suckley, and the various official publications of Washington and Ottawa. 
Referring to the first large consignment of Fraser river salmon that reached the London market, Dr. Günther says :

These fish were packed in cases, each holding about a dozen, separately wrapped in paper, frozen hard as stone, but beautifully preserved and looking as fresh as if they had been caught an hour ago. Their size and weight varied (judging by the eye, from $8 \mathrm{lb}$. to I $8 \mathrm{lb}$.), but otherwise they were singularly alike; not showing any of those variations of form and colour which so often puzzle those who critically examine a lot of British sea trout, or even salmon. However, among about twenty specimens inspected, I found one which differed from the other fish, and which, on closer examination, proved to be a different fish altogether, viz., a so-called "steelhead," a kind of sea trout very much akin to the British species.

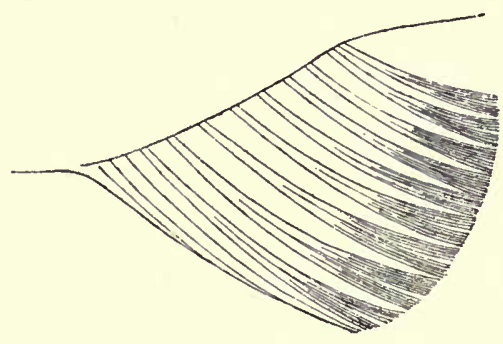

Anal Fin of the European Salmon (Salmo).

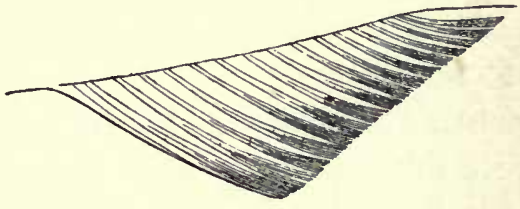

Anal Fin of Quinnat (Oncorhynchus).

A question having arisen whether these fishes were salmon or trout, in the sense and with the limits in which and with which these terms are applied to salmonoids of British waters, the answer is that they are neither. No one would call a charr or a trout a salmon. They all belong to the family of salmonoids or Salmonida; but this family comprises several distinct divisions (or genera), and the fishes in question belong to one of them, that is very different from any salmonoid which we have in European waters, or, indeed, in any river flowing into the North Atlantic.

They are so easily recognised that no one could be at fault who has to determine their origin, The anal fin (that is, the fin behind the vent) tells the whole story. In the salmon and trout (genus Salmo) this fin is short, composed of only nine or ten long rays, whilst in the fish from the Fraser river it is supported by sixteen rays, and is therefore much longer. (See illustrations above.) 
Ichthyologists have placed the salmonoids with the long anal fin in a division, which they have called Oncorhynchus, and of which some five or six species are now more or less perfectly known. All of them come from waters that flow into the North Pacific Ocean, whilst they are entirely absent from Atlantic waters.

To prevent any misunderstanding I must mention that, on the other hand, there are, beside these Oncorhynchi, on the Pacific coast of North America, plenty of real trout and sea trout with short anal fin, very similar to ours. Only our real salmon is absent. It occurs in many of the Atlantic rivers of Canada ; and therefore the term "Canadian salmon" is an obvious misnomer, if applied (as has been (lone) to the fish from British Columbia.

The fish sent from the Fraser river belong to a species which takes its highest place among the Oncorhynchi. In European and part of the American literature it is known as the quinnat (Oncorhynchus quinnat); in the trade as Californian or Columbian salmon; on the Columbia river as chinnock**; $^{*}$ in other parts as saw-kwey, or suck-eye; in Alaska as the king salmon (if, indeed, the Alaskan fish is the same species). But these vernacular names are, as is always the case, frequently applied to different species, according to locality ; and it is certain that in many of the factories several species are used for canning.

Among the salmonoids of the Pacific with which we are acquainted at present, the quinnat carries easily off the palm with regard to size, abundance, flavour of flesh, and economic importance generally. It abounds all along the Pacific coast and in the Pacific rivers, from the Sacramento river in the south to Alaska in the north, and is stated to be equally abundant in the rivers of Kamtschatka. When in full condition, on its arrival at the mouths of the rivers, it is adorned in its brightest silvery coat with steel-blue back, and not very numerous small black starlike spots above the lateral line. It has not the same graceful lines of the build of the body of the salmon, its head being thicker, the eye conspicuously smaller, the back broader, and the tail shorter; but it exceeds the salmon in size, on the Columbia river specimens being on record of above $80 \mathrm{lb}$. in weight, and others of $6 \mathrm{olb}$. not being scarce. Farther northwarls, in Alaska, Dr. Bean has met with indiviluals of $100 \mathrm{lb}$. and more. Sixteen pounds are stated to be the average size of the fish caught for the canneries on the Sacramento, and $20 \mathrm{lb}$. on the Columbia rivers.

* Dr. Gïnther spells this word chinnock, but this is probably a misprint. So far as I know the word is invariably spelt with two "o's." 
When the fish arrive in the lower reaches of the rivers their flesh is of an intensely deep red salmon-colour, and as regards flavour not inferior to that of our best salmon; and it seems that the excellency of its flavour deteriorates in a much less degree by freezing or other methods of preservation. From my own limited experience I should pronounce it to be firmer, less oily, and more easily digested. After the fish have been some time in fresh water the flesh pales, and becomes unfit for canning purposes, and towards the end of their fresh water career their flesh has become white and flabby.

As in all migratory salmonoids, locality much affects the season of the wanderings of the quinnat, and modifies its habits; it is also probable that in the accounts of some of the older naturalists the observations on the quinnat refer to more than one species; at any rate, we meet with some contradictory statements which otherwise cannot be accounted for. But the following facts seem to refer truly to the quinnat of the Californian and British Columbian waters.

Early in spring, by the end of March, when icy cold freshets come lown the rivers in consequence of the melting of the snow and ice of the mountains, the quinnat assembles in its hosts near the mouths of the rivers; at this time of the year it refuses to enter rivers which are not fed by snow-water torrents. As long as the fish are under the influence of sea water they continue to feed well, freely taking any natural or artificial bait. Gradually they work up higher, entering pure fresh water after a week or fortnight. From this time they cease to feed; in fact, every other instinct seems to be suppressed but the one which impels them to push up stream to their spawning grounds near the sources of the rivers, often many hundreds of miles distant, and reached only after several months of incessant travel. During this journey the quinnat has never been known to take or attempt to take any nourishment. The rich store of nutritious substance which it has accumulated in its tissues during the time of plenty among the crustaceans, worms and fish of the ocean, is now gradually used up to supply the muscular energy for its long journey, and to bring the generative products to maturity.

The run of the quinnat lasts throughout the summer, apparently in diminishing numbers. But a new though-smaller contingent arrives in the autumn for those rivers which are not fed by snow water coming from the mountains of the interior, and which then have their water raised by autumnal rains. The years vary locally with regard to the abundance of quinnat. A writer in "The British Columbia Annual" for I 894 informs us that a regular cycle of four years obtains in the Fraser river; after a year 
characterised by an extraordinarily heavy run, the year following is fairly good, the third year is bad, and the next very bad. This does not hold good for the neighbouring rivers, some of which have never failed.

In favourable years the number of schools of ascending fish, and the mass of individuals composing them, baffle calculation; eye witnesses say that, when the schools arrive at the narrower or shallower parts of the rivers. the fish actually push each other out of the water; or that a stone thrown into the midst of a school could not sink to the bottom without touching several fish. In such localities the native population reaps a rich, and to them a most important, harvest, as these roughly cured fish are their only means of subsistence during the winter, when other sources of food have failed or are exhausted.

The spawning time varies within the same river system from July to December. The earliest arrivals in the river are said to ascend to the greatest distance from the sea. After the deposition of the spawn is finished, the quinnats are completely exhausted. Total abstention from food for several months, combined with the exertions of the journey and the spawning operation, besides wounds and bruises received by contact with rocks during the passage of rapids, have reduced the fish to a condition from which they are unable to recover. Their body is lank and emaciated, their skin mottled with red patches and covered with a thick slime, under which fester sores with fungoid growths. Even the instinct of returning to the sea is lost; some of the fish linger for some weeks near the spawning beds, soon to join the majority which helplessly float down the river. All are said to perish long before reaching the sea, and this is certainly the fact as regards those which are beyond 150 or 200 miles from the coast. However, some must succeed in regaining salt water, as it is highly improbable that fish of 2 olb., 3olb., or 5olb. do not spawn oftener than once in their lifetime. Probably the majority of the fish of the autumn run, and such as have spawned in the lower tributaries, within a moderate distance from the sea, are the fortunate survivors.

The early life of the quinnat does not differ from that of the salmon in any essential point. But when the young fish has once succeeded in reaching the sea, and commenced to feed on the marine creatures with which those waters teem, its growth must be more rapid than that of the young salmon. I infer this from the comparatively soft character of the bones of the adult fish, which can easily be cut through with the knife; a character much more conspicuous in quickly than in slowly growing salmonoids. In the stomach of quinnats caught at sea animals have 
sometimes been found which are known to live in deep water;* and from this the conclusion has been drawn that the quinnat during his sojourn in the sea frequents such depths as would be inaccessible to seals and porpoises, which are its principal enemies.

Factories in which the fish are cured for export, called "canneries," have been established for years on all the principal rivers of the Pacific coast, and "canned salmon" is an article of trade carried all over the world. This industry far exceeds now in importance all the other fishing interests of the coast taken together. It began with small means on the Sacramento river in 1863 , extended to the Columbia river in 1870 , and to the Fraser in 1876 , On the latter river seventeen extensive factories were at work in 1890 , all crowded together within twenty-five miles of the tidal and estuary portion of the river. They employ 350 boats, each using a drift-net I 50 fathoms long, to catch the fish on their entrance into the river. One would suppose that not many quinnats can escape through such a web of nets. Indeed, in the course of one day, in the very good season of 1890 , some 150,000 fish (O. quinnat and O. nerka) were delivered at the canneries, and converted into "canned salmon" within twenty-four hours. The statistics of the canneries of the Columbia river furnish still more startling evidence as to the abundance of the quinnat and the extent of this industry. In the six years preceding 1884 nearly $200,000,000 \mathrm{lb}$. were canned on this river alone. Taking the average weight of the quinnat of this river at $20 \mathrm{lb}$., we find that in each of these six years $1,660,000$ have been taken; a number much below the truth, as no allowance is made for the weight of the offal, and the fish consumed fresh or captured by the native population in the upper parts of the rivers are not included in it.

It is not surprising that the annual destruction of such a vast number of fish before the spawning season should have raised doubts as regards the continuance of this prosperous state of things in the minds of those most interested in this industry. But whilst some perceived a distinct diminution in the number of fish captured, others deny it, basing their view on the experience of the annual variations in the abundance of fish. Years of great scarcity, indeed, seem to have been very few, local, and accounted for by the state of the water in a particular river. However, to prevent a possible exhaustion of this mine of wealth, regulations have been put in force in the United States as well as in the British territories. In addition,

* In the Appendix I have printed what are probably the oldest notes made by a scientific observer on Pacific coast salmon-i.e., the late Mr. A. C. Anderson, one of the earliest pioneers of scientific attainments on the Northwest coast. 
hatcheries have been erected, but these, I am afraid, would have to be on a gigantic scale to have any conspicuously beneficial effect. On the Fraser river a weekly close time, besides other regulations, has been provided for the protection of the fish, and I trust that the Canadian Government will see fit to adopt Mr. Wilmot's wise recommendation of an annual close time if they should not have done so already.

So far Dr. Günther, and if I venture to disagree on the following points with him they are details which came under my personal notice while living in British Columbia.

Dr. Günther says : "When the fish (quinnat) arrive in the lower reaches of the rivers their flesh is of an intensely deep red salmoncolour. . . After the fish have been some time in fresh water the flesh pales, and becomes unfit for canning purposes." If one who has only such practical knowledge as was derived in the course of fifteen years' travels on the Pacific Slope, in the course of which, I may add, I have at times subsisted for months on end almost exclusively on the finny subject of this correspondence, may venture to differ from such an accepted authority, I would say, firstly, that there is a white and a red-fleshed quinnat; secondly, that it is only owing to a stupid prejudice entertained by European consumers, who will persist in demanding red-fleshed fish, that the white-fleshed fish is considered "unfit for canning purposes." The white-fleshed fresh run quinnat is quite as good as the red one; in fact, the opinion that it has a more delicately flavoured flesh is shared by many connoisseurs on the coast. An enormous amount of waste is the consequence of this ignorant prejudice, for all "white" fish are thrown away, and the sooner the European consumer takes these remarks to heart the longer a business will last, the life of which, in spite of regulations and hatcheries, is not likely to be a long one.

Probably Dr. Günther will be better satisfied of the correctness of my statement if I quote the result of two scientific examinations which were made on this head by well-qualified persons.

Some years ago, Mr. T. Mowat, Inspector of Fisheries for British Columbia, sent one white and one red-fleshed quinnat to Prof. 
Baird, of the Smithsonian Institution at Washington. In an accompanying letter Mr. Mowat explained that the two fish were fair samples of the September run, and in their external appearance were in every respect the same as the quinnat that run in June and July. "I found," he continues, "in making an examination that some of the run is pure white, some very pale pink bordering on white, some a little darker pink, and others a full colour, as per sample sent. I also find some of them white on the outside near the skin for about an inch in depth, then they gradually turn a pale pink, deepening in colour as the bone is reached. There are a few fish of this description found in the June and July run, but the majority of the quinnat salmon running now (September) are white or pale pink. In concluding his letter, Mr. Mowat states his belief, from careful examination, that the white and red fish are one and same species (O. chowicka). Mr. K. Ito, Fish Commissioner of Japan, also agreed with this, having made an examination when visiting the Pacific coast. He considered that they were a different species of white salmon from those found on the Asiatic coast. When Mr. Mowat's letter and the two salmon reached Washington, the Smithsonian Institution and the American people had just sustained an irreparable loss by the sudden death of Prof. Baird. In consequence, the newly-appointed United States Fish Commissioner, Prof. G. Brown Goode, replied to the above letter. He pronounced the white and the red salmon to belong to the same species.

The canning industry on the Columbia river is rather older than Dr. Günther supposes when he gives the year 1870 as the one that witnessed its commencement. It began on that most important and earliest known of the Pacific coast rivers in the year I866, and, as a glance at the rapid growth of the industry, at the corresponding increase in the cost of the fish, and fall in the price received for the canned salmon, shows the extraordinary rapidity with which a new industry is developed by the cute Westernerand is, consequently, overdone $-I$ append a table covering twenty-five years, and giving ( $\mathrm{I}$ ) the number of cases packed (each 
case containing forty-eight Ilb. tins), (2) the number of boats engaged in the business, (3) the cost of each fish, which are bought irrespective of weight by the owner of the establishment, and (4) the market price per case.

\begin{tabular}{|c|c|c|c|c|}
\hline Year. & $\begin{array}{l}\text { No. of cases } \\
\text { packed. }\end{array}$ & No. of boats. & $\begin{array}{l}\text { Cost of each } \\
\text { fish. }\end{array}$ & $\begin{array}{l}\text { Price obtained per } \\
\text { case of } 48 \mathrm{lb} \text {. }\end{array}$ \\
\hline $\begin{array}{l}1866 \\
1867 \\
1868 \\
1869 \\
1870 \\
1871 \\
1872 \\
1873 \\
1874 \\
1875 \\
1876 \\
1677 \\
1878 \\
1879 \\
1880 \\
1881 \\
1882 \\
1883 \\
1884 \\
1885 \\
1886 \\
1887 \\
1888 \\
1889 \\
1890\end{array}$ & $\begin{array}{r}4000 \\
18,000 \\
28,000 \\
100,000 \\
150,000 \\
200,000 \\
250,000 \\
250,000 \\
350,000 \\
375,000 \\
450,000 \\
400,000 \\
400,000 \\
480,000 \\
530,000 \\
550,000 \\
550,000 \\
629,000 \\
600,000 \\
550,000 \\
448,000 \\
356,000 \\
366,000 \\
318,000 \\
436,000\end{array}$ & $\begin{array}{r}2 \\
15 \\
25 \\
35 \\
50 \\
75 \\
100 \\
125 \\
250 \\
300 \\
400 \\
450 \\
550 \\
750 \\
900 \\
1200 \\
1500 \\
1700 \\
1800 \\
1800 \\
1900 \\
1900 \\
1900 \\
2000 \\
2000\end{array}$ & 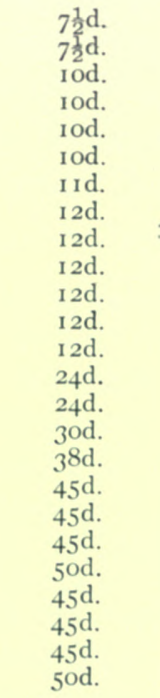 & $\begin{array}{l}64 s . \\
52 s . \\
48 s . \\
40 s . \\
36 s . \\
38 s . \\
32 s . \\
28 s . \\
26 s . \\
22 \frac{1}{2} s . \\
18 s . \\
21 s . \\
20 s . \\
20 s . \\
20 s . \\
20 s . \\
20 s . \\
20 s . \\
20 s . \\
20 s . \\
20 s . \\
22 s . \\
24 s . \\
22 s . \\
20 s .\end{array}$ \\
\hline
\end{tabular}

I have taken the cent as one halfpenny, and the figures are collected from official sources.

To arrive at the truth concerning the many points connected with the salmon canning industry, concerning which "authorities" differ, is by no means as easy as would appear to the stranger, who is unaware to what great extent large pecuniary interest gives colour to the views one hears. As an instance of this may be cited the divergence of opinions concerning the "valuable report of $\mathrm{Mr}$. S. Wilmot," as Dr. Günther epitomises an official blue book report upon the Salmon Fisheries of British Columbia.* This report by

* S. Wilmot. Special Report on the Salmon Fishery and Fishery Regulations of the Fraser River, B.C. Ottawa, 1891. 
Mr. Wilmot created, at the time, a great stir in British Columbia, for it was said by those engaged in the business of canning that Mr. Wilmot's qualifications to write such a report were of a meagre kind. The following passage from the official annual report of the British Columbian Board of Trade for I890-I throws so much light upon the alleged nature of this report that it is worth quoting. After tracing the falling off in the prices which the salmon cannery owners were receiving for their canned salmon, owing to the competition by Alaskan canners, who are "not hampered with stringent and undesirable regulations in the pursuit of the industry as are the British Columbian canners," the Board of Trade report proceeds thus:

In the last report of the Board of Trade it was pointed out that strong efforts had been made to induce the Minister of Marine and Fisheries. Department at Ottawa to visit the province with a view of a thorough inquiry into the general working of the salmon industry and the regulations in force, which have caused so much friction between the canners, fishermen, and the department. The Minister, while favourable to the suggestion, did not find it convenient to carry it out, but instructed Mr. Wilmot, who is connected with the Fisheries Department, to visit the province, and give his views upon the question. These latter were obtained during a visit of two days on the Fraser river, and were duly communicated to the Minister in a report since published (the one referred to), and which, owing to the few hours in which the observations were made, was consequently full of inaccuracies, exaggerations, and statements of a generally misleading character throughout, and was therefore of little practical value. The indulgence in gratuitous and insulting reference to our cannery proprietors is a marked and regrettable feature of Mr. Wilmot's. report.

The following winter, which I happened to pass in Victoria, a new Fishery Commission was sitting in Victoria, again under the chairmanship of Mr. Wilmot, sent by the Dominion Government to collect on the spot evidence bearing upon the framing of suitable regulations to protect the rivers from over-fishing and from other abuses. More contradictory evidence than was elicited by this commission it would be difficult to invent. While one 
witness, owner or manager of a salmon cannery, and evidently not over favourably inclined towards the proposed Government interference, would solemnly testify that he had never seen dead salmon floating on his river, and that, to the best of his belief, the greater part of the salmon that ascended the rivers during the run returned to the sea, another witness would testify that he had seen rivers for miles covered with dead salmon, and that he believed not one fish in a hundred ever got back to the Pacific!

I remember once taking a globe-trotting friend, who had been only a few days on the Pacific coast, to one of these sittings. He knew nothing whatever about the subject, and had never heard the old yarns of pigs in Oregon and California being fattened on salmon and peaches, of the up-country farmers who annually manured their fields with these fish, or of inland settlers who, it was said, used to be able to walk across streams on the backs of salmon. Hearsay evidence was also allowed by the Fish Commissioners, and some strange stories were related, but nothing was more startling than the conflicting "personal knowledge" of witnesses. As we entered the hall where the commission was sitting, the owner of a salmon cannery happened to be under examination, and by his evidence was trying to oppose a prohibition the Government was endeavouring to enforce, preventing cannerymen from casting the offal of their establishments consisting of hundreds of tons of fish entrails, and other equally offensive refuse, back into the stream, which had been the general practice throughout the coast country. He declared that he had never heard of those people who lived further down the stream being injuriously affected by it. "He had lived at the cannery half the time, and his tea, coffee, and other food were prepared with water out of the river." "Hogs," he went on to say, "are also very fond of salmon, some people cooking the salmon before giving them to the hogs." At this point the chairman of the commission, Mr. Wilmot, interrupted the witness by stating that " he had seen a herd of cows eat a canoe-load of salmon in a day; 
the salmon weighing from $35 \mathrm{lb}$. to $4 \mathrm{olb}$. each, and they were caught by himself."*

Of the vastness of the supply of salmon that swarmed up every stream, along the littoral of the north-west of America as late as fifteen years ago, it is difficult to give an adequate idea. Though I have never performed the feat of walking across a stream on the backs of fish, which many an old-timer will swear he has done, I have certainly seen the fish so numerous near their spawning ground that nowhere could you have thrown a stone into the water without hitting a salmon. I remember well how surprised I was with what I saw when I first reached the Pacific coast waters. I was travelling in a canoe along the coast of Puget Sound, and had stopped at a little settlement at the mouth of a stream to buy a box of matches, which happened to be the last one the storekeeper had on hand. It cost a "bit," equal to $6 d$., which was then the smallest coin in currency on the Pacific Slope. When I made some joking remark about the profitableness of selling matches at $6 d$. a box, the man replied, that, as he usually sold three boxes for a quarter (Is.), he would give me a trifle to level up the bargain. Going to a huge fish-drying rack adjoining the store, he came back and presented me with a freshly-caught $25 \mathrm{lb}$. tyhee salmon (or quinnat), as beautiful a fish as you could wish to see anywhere. This gift he valued at less than a halfpenny box of matches. Those days have long passed away, for trans-continental railways connecting the North-west with the Eastern States, a greatly increased population, and lastly, but not least, the scores upon scores of salmon canneries along the coast, waylaying the salmon at the mouth of every larger stream, has not only created markets which formerly did not exist but has caused a great diminution in the supply, particularly in the rivers on the American side of the line.

There are one or two points in Dr. Günther's account to which I would like to refer.

* I quote literally from the report of the proceedings in the Victorian Times of the following day. 
Another detail that must not be overlooked is that Washington and Oregon have different and far less strict fishery laws than those in force in British Columbia. Looking at the issues involved by this difference from the two standpoints, i.e., of an American and of a Canadian business man, the following are the conclusions at which each will probably arrive.

In Washington, the waters of which state are not separated from those of British Columbia by a more tangible division than a line drawn on the maps, the passage of the anti-fishtrap law was recently made the subject of hot political strife, the pecuniary interests involved being very considerable, and of widespread influence. Fishtraps, be they salmon wheels, traps, or other mechanical contrivances to catch the ascending salmon without allowing any to escape to propagate their species, reflect, of course, most injuriously upon the whole business. Nobody, and the shrewd American least of all, can entertain any doubt about that, but so reckless of the future are your true "builders of the great Western Empire," as they love to call themselves, that no consideration whatever is given to the future outlook. Let every salmon perish, let the species become extinct, provided the next few years' harvest fill their tin cans and their capacious pockets. But the shrewd manipulators of salmon traps in American waters had enemies in their own camp, for the seine men, as the fishermen using the far more legitimate nets are called, seeing what a speedy end to the whole industry traps were bound to bring about, rebelled, and brought all their influence to bear in fostering popular demonstrations in favour of anti-trap laws. In this, those of the British Columbian cannery-men, who had no interest in American water, helped as much as they could, for, of course, traps were almost as fatal to them as they were to American cannery-men. Curiously enough, not all, however, of the British Columbian representatives of the canning industry joined in this wholesome crusade, at least if one can believe accounts published in the Seattle and Tacoma newspapers. There existed among the British Columbians interested in the business a considerable number 
who had invested their dollars, to the extent of many hundred thousands, in canneries and in traps on the American side of the line, where a far more unrestricted exploitation of fish-wealth was possible. From this it can be seen what multifarious interests are at stake, and how careful one has to be in the examination of evidence bearing upon all questions when important interests are at stake.*

Every few years the run of salmon is so great and so concentrated as to cause a glut in the market and at the canneries. Thus the year 1897 was such a great season, and some perfectly authentic instances of enormous catches by the most primitive means were recorded. In the open Puget Sound waters immense shoals of salmon approach the passages between the numerous islands, and here the Indians make big hauls. Provided with a large wide-meshed net they go out in their large war canoes, and placing the net blanket-like upon the water sink it in that position, a big canoe being anchored at each corner, where the net is held by a strong rope. By keeping a sharp look-out, and the use of a white cord running at an angle up from the depth attained by the net, the catchers perceive when a shoal is passing over the net. Then as quickly as possible the net is drawn up at the four corners, the fish accumulating in the sag of the net. Last year, according to the Victorian Times, six big war canoes fishing in this manner caught 10,000 salmon in a little over three hours off the coast of Vancouver Island (Beecher's Bay). Four thousand were taken to Victoria, the rest were smoked by the Indians for their own use. As there are no canneries in the neighbourhood of Beecher's Bay or Victoria, the fish had to be disposed of among the inhabitants, who thus obtained three or

* The British Columbia pack during the last three years, concerning which statistical details have just reached me, was as follows: In I $897,1,105,477$ cases; in $1898,496,529$; and in $1899,679,600$ cases. In 1897 the Fraser river pack was 860,459 cases; Skeena river, 65,905; Rivers Inlet, 40,207; Naas river, 20,847; Lowe Inlet, 10,666; Namu Harbour, 4357 ; Alert Bay, 8602 ; West Coast, V.I., 4434. Each case contains forty-eight Ilb. tins of salmon. 
four big salmon for a quarter (shilling), for the market was, of course, overstocked.

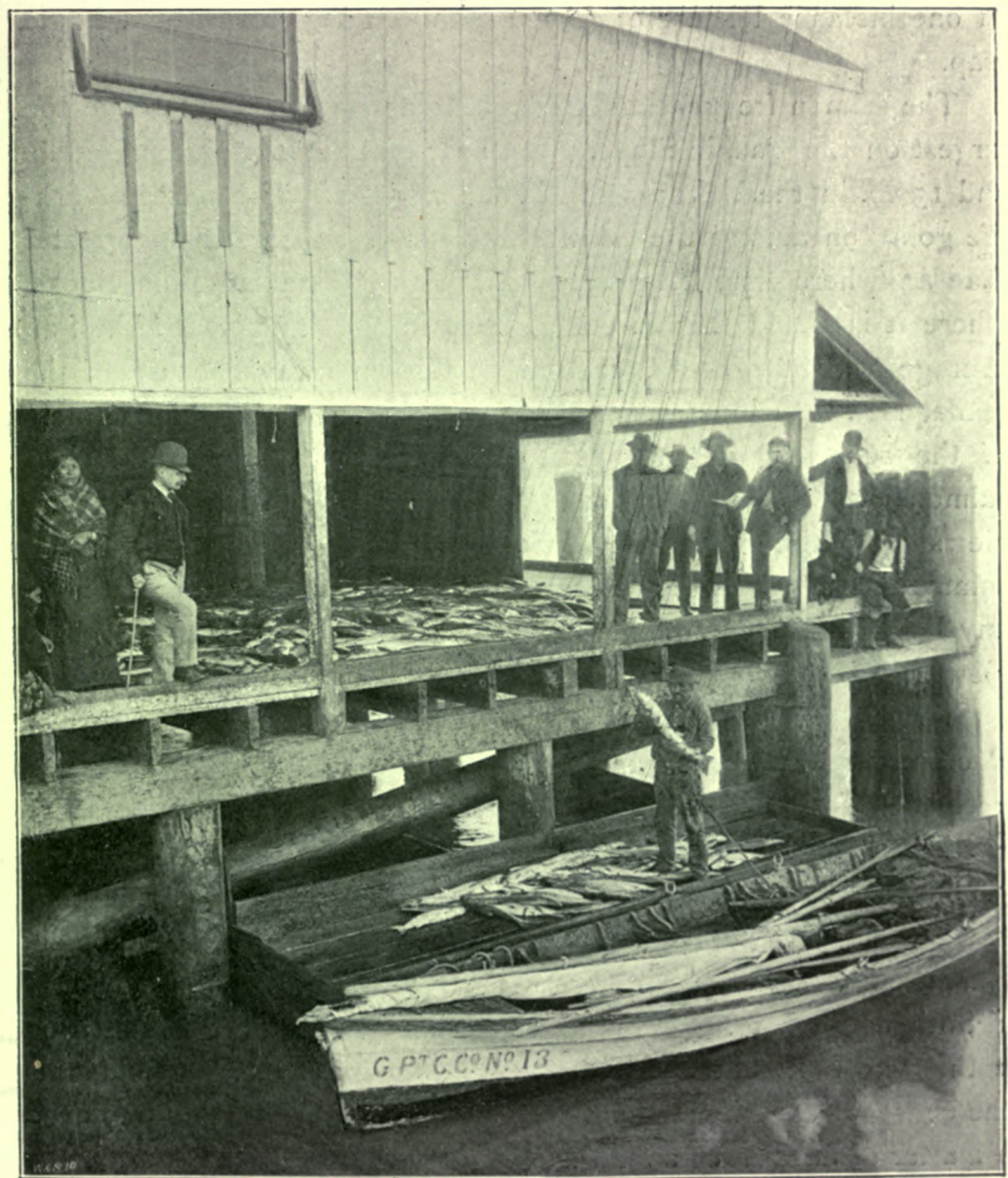

Fraser River Fishermen landing a Forenoon's Catch of Salmon.

In that part of Puget Sound which is in American territory salmon traps were still at work last year. Ranchers and farmers living near the banks of any of the scores of streams emptying 
into Puget Sound are in the habit of running these traps in conjunction with the nearest cannery. The latter furnish the traps, and send small steamers or scows to collect the catch. In one instance I heard of 40,000 salmon being caught by a single trap.

The salmon frequenting Alaskan streams are reputed to be the largest on the Pacific Slope. We hear of salmon weighing I 3 olb. and ${ }_{5}$ olb. in the Yukon and Kadiak regions. The waste of fishlife going on among the Alaskan canneries appears to be greater than anywhere else, if we can believe the Canadian Blue Books, where it is stated that at one cannery in one day 20,000 fish of an average weight of $\mathrm{I}$ olb. each were thrown away because of the inadequate appurtenances of the establishment and the suddenness of the run. The same Blue Book refers to the land-locked salmon of British Columbian lakes, but though I hold strong views upon the matter, the scientific evidence which has been summed up against the presence of true land-locked salmon in any British Columbian lake makes me afraid of giving an outsider's views.

To the native population dwelling on the upper reaches of Pacific Slope streams, and who, from time immemorial, relied exclusively upon the salmon run for their winter provender, more exclusively even than did the Indians of the Plains upon the "buffalo," the immense diminution in the number of salmon that reach the upper waters has been a most serious matter-it spells starvation. For, unlike his brother east of the Rockies, who could kill other big game when the bison became scarce, there was little or nothing to fall back upon in the interior of British Columbia, and the chase of occasional deer or bear in the dense forests was ever a matter of dangerous uncertainty.

It was said that every tie of the Panama railway cost a human life. It would be an exaggeration to say that every cwt. of salmon which is dipped out of the muddy water at the Columbia or Fraser estuaries condemns one native to starvation; but it comes unpleasantly near the truth if we remember that, by depriving him 
in a wholesale manner of the only food with which nature in many of the interior gameless regions has provided him, starvation could be avoided only by becoming homeless wanderers. And this is what has happened to thousands during the past quarter of a century. Only those who have been among them can realise the inexpressible misery of the lot which our boasted civilisation has thrust upon beings who, a lifetime ago, were " monarchs of all they surveyed."

Considering that some perfectly incorrect information concerning salmon fly-fishing has been disseminated by the English press, it is as well to repeat what really everyone at all interested in the matter does know, i.e., that the salmon of the Pacific coast does not take the fly.*

Quite good sport with the spoon can be enjoyed near Victoria, and round the coast of Vancouver Island, when the various species of salmon come in from the open Pacific and the run commences. It is nothing unusual to catch half a dozen big salmon in a short afternoon, and if you are in a canoe you will get all the fun you want before you have these big 'uns lying dead in the bottom of your canoe.

I cannot refrain from concluding this chapter with an account of a very curious fish said to belong to the salmonoids, and which is believed to exist in some of the mountain lakes of Oregon, at least it does so in the imagination of journalists, who have given much space to accounts of it. The following appeared in the San Francisco Examiner:

A wonderful fish is becoming numerous in Goose Lake. It is called by some the "greenback" fish, for it is certainly an inflationist. It has the power to fill itself with air until it becomes very much like a round ball. Of evenings about sundown they may be seen playing on the surface of the water. They will swell up by taking in the air, and the wind will blow them over the lake. They reflect all the colours of the rainbow, and when

* The "steel-head," which, as already said, is really a trout, will not infrequently rise to the fly in fresh water. 
sporting over the lake are a grand sight. A hunter several weeks ago saw a crane swallow one of these fish when in its normal condition, but before the crane had got more than fifty feet up above the lake the fish had taken in enough air to explode the crane, which, at the sound of a report like that of a gun, flew all to atoms, and the fish came lightly down on the water, no worse off for the short ride in the air. The fish is a great curiosity, never having been found, I believe, in other waters.

The last statement is true. 


\section{CHAPTER X.}

PIONEERING IN KOOTENAY.

\section{How Kootenay Emerged from its Wild State.}

UNDENIABLY true as is the trite saying that a country in a state of perfect wildness lacks human interest, it is equally certain that the first stage on the road to settlement, accentuated by that dishevelled go-as-you-please look which is inseparable from it, arouses regrets at the disappearance of the primeval in inanimate as well as animate Nature. A few roving prospectors, birds of flight, tarrying no longer than their scanty "grub outfit" permits, and flitting to more settled regions when the first autumn snowstorms threaten to cut them off entirely; the first log cabin wherein a white man has passed in dreary solitude the long winter; more prospectors, more log cabins, followed some months later by an organised miners' camp, with a white woman or two to grace it-that is the story of the first opening up of a "new country" in the Western sense. Having had a small personal share in precisely this evolution in the case of a district which now ranks among the most important in the whole of Western Canada, from that early stage when there was not a single white settler in it, I propose to give a prosy account of my experiences. It may perhaps have some interest for those who know only by hearsay what pioneering means, and who live their lives with a policeman trying their front door every night, and a post-office round the corner. As it is, moreover, the fashion to show no shame when betraying ignorance concerning geography, and to say: "Wasn't taught at school where your 'Far West' commences or where it leaves off," a few geographical details may make it unnecessary to resort to the usual "sufficient for the day is the West thereof" kind of excuse. 
Youthful enthusiasm and a thorough belief in the future of the beautiful Kootenay country I had accidentally stumbled upon caused me to shoulder tasks as novel as they were trying. As the scene of my pioneering has now become an important mining region, where many millions of English and American capital have been invested, it may be as well for me to state, before entering upon my task of devoting a chapter or two to its as yet unwritten history, that I no longer have any pecuniary interests in the district.

The present division of Kootenay District into West, East, and North Kootenay came into force only recently, many years after my first introduction to this land of silver mines and lovely Alpine scenery. The latter event occurred in $\mathrm{I} 882$, when I made a hunting expedition to the northern part of Idaho, which was then about the most remote territory of the United States outside of Alaska. The southern part of the Kootenay country lies in Idaho, and here comes in a necessary explanation concerning the spelling of that name, for it is safe to say that it holds the record for variety. In the first Blue Book dealing with Kootenay (Palliser's), we find it spelt Coutanie, Kootanie, Kootonay, Kootenai, and Kootenay. Other writers have varied it into Kutunas, Kootanas, Kutnehas, Kutonas, Coutanies, Cotonoi, Kitunahas, Kootenuha. The derivation is probably to be traced to the word "co," water, and "tinnéh," people. To-day the Surveyor-General of the Dominion Government spells it Kootenay in his official documents, while the chief of the Dominion Geological Survey rigorously abides by Kootanie. The British Columbia Government, on the other hand, invariably uses Kootenay, while the United States Government, in its official maps of that part of the district which lies south of the $49^{\circ}$ in their own territory (Montana and Idaho), sticks to Kootenai. As the Governments of British Columbia and of the United States are those most immediately interested, I shall follow the example of the inhabitants of the district and use Kootenay for the British Columbia portion, and Kootenai for the United States part.

That part of Kootenay now known as West Kootenay was in 
I 882 a perfectly uninhabited wilderness, not a single settler, not a single house marred the solitude of this vast tract, quite twice the size of Wales. Its mountains were untrodden, and, excepting caribou and mountain goat trails, without a path of any kind. Only one of its broad rivers and lovely lakes was occasionally scored by the quaintly modelled pine bark canoes of the Flatbows, craft unlike any other in the whole world.* The Indians were a smiling, primitive lot, a breechcloth their only garment, a tent-like teepee made of reeds their only dwelling. Towards the north-east and west the district was completely shut off from the rest of the province by impassable mountains, for the old Dewdney trail that once passed through West Kootenay had long become completely blocked by timber and slides, and not a human being had been over it for more than ten years. The three trans-continental railways that now tap Kootenay were as yet things of the future, and it took weeks of horseback and canoe travel to reach Kootenay Lake. The only point from which it could be approached was from the south viâ Sinyaquateen, near the present Sandpoint, the nearest larger settlement being Walla Walla, more than 400 miles off.

Up to 1883 no quartz mines of any sort had ever been found in either of the Kootenays, for the good reason that no prospecting had ever been done there for quartz.

In East Kootenay, a country into which Wales could be fitted one and a half times, matters then stood a little differently. It had had a short-lived mining boom, but had long subsided into its primeval state, the eleven grizzly old timers who made up the white population accentuating, if anything, the remoteness of Kootenay from civilisation. How the one subject of their thoughts, the "boom," had come about can be told very briefly. Indians had discovered in 1862 rich alluvial diggings in a little gulch penetrating into the western face of the Rockies, here rising from the valley

* The Indians inhabiting the Lower Kootenay Valley (or West Kootenay) were often called Flatbows in the earlier histories of the North-west. It was a literal translation of the name given to them by the French voyageurs in the Fur Companies' days. 
like a giant wall 8 oooft. high. A couple of wandering trappers heard of it, and through them the news spread, and eventually populated this remote creek, which at first was known as Studhorse and then as Wildhorse Creek, with the usual seething mass of excited miners. From the nearest settlement, the already mentioned Walla Walla, 500 miles of impenetrable forests separated them. All necessaries of life kept at famine prices, flour selling at from $4 s$. to ros. the pound, and even the simplest mining tools being practically unobtainable during the first season. Only very rich claims could under such circumstances pay, wages being, of course, extraordinarily high15 dol. a day for the ordinary miner. For a season or two hundreds of miners sunk shafts, built flumes to carry water, and blasted into the banks and bed of the creek, only a minority, however, making sufficiently rich strikes to pay them. Then other distant camps to the north and to the south (Big Bend and Helena) came to the fore, fascinating tales of their superior richness causing the ever restless miners to stampede thither with the same speed that had marked their advent. Not long afterwards Wildhorse was a deserted camp, untidy heaps of tailings, scores of tunnels and laboriously constructed water ditches, and hundreds of prospect holes sunk at likely looking spots on the banks of the creek, with some scores of deserted log shacks telling the pathetic tale of a forsaken mining camp.

What the "old camp," as in later years it was familiarly called, must have been like in its heyday in the early sixties, no one who has knocked about Western placer mines need be told. For one season it had been a very live camp, for it was remoter from civilisation than any other in North America, and the pistol flourishing cut-throats of Californianand Montana mining camps flocked hither in full expectation that here at least they would be safe from unpleasant interviews with that terror to their class, Judge Begbie, to whom more than to any other man is due the province's fair reputation. Among the lawless parasites that infest every camp, British Columbia was anything but popular. In 
Wildhorse these gentry expected to have a "high old time," for the nearest jail, police officer, or magistrate was more than a month's journey off, and the outlawed gamblers, murderers, and out-of-a-job desperadoes flocked to Kootenay in numbers that boded ill for the camp. But they had counted without Judge O'Reilly, who, accompanied by a single constable, hurried up from the coast to Wildhorse as fast as horses and canoes would take him, reaching the remote gulch with the first rush of the dangerous element. Assembling as many of the miners as chose to attend in front of the single-roomed log cabin which he had turned into a temporary courthouse, while a larger one was being built as fast as liberally expended gold would fell and square logs, Judge O'Reilly made a famous speech which is still remembered throughout the mining camps on the Slope. Standing near the pole from which floated the Union Jack as the only symbol of authority to be seen, he said: "Boys, I am here to keep order and to administer the law. Those who don't want law and order can 'git,' but those who stay with the camp, remember on what side of the line the camp is; for, boys, if there is shooting in Kootenay there will be hanging in Kootenay." *

There was but one murder in old Wildhorse, that of Jack Lawson, the constable. An old grave at the trail side, near Bonner's Ferry, which I have passed scores of times, and near which, oddly enough, a similar end as Lawson's nearly overtook me, marks the spot where, after a three weeks' hunt, justice, in the shape of rifles in the hands of deputy sheriffs, ended the career of the defiant murderer.

- The Wildhorse boom was, as I have said, but a short-lived one, and in 1882 , when I struck the country, the latter had long reverted to conditions almost as primeval as before the rush. Only eleven white settlers lived in the vast East Kootenay

* Two old miners, Clark and Doyle, who were present on the occasion, gave me this version of Judge O'Reilly's speech. It varies but triflingly from Bancroft's version. When I asked Mr. O'Reilly for the real version, he told me he had long forgotten the exact words he had used. 
District. Most of them were living round the old camp, where some scores of Chinamen, who had wandered into Kootenay after the exodus of the white miners, were now digging-over the old ground, and washing the old tailings for a second and third time, with the tireless diligence of their race.

This community of eleven white men was a somewhat unique little settlement, and a more isolated one it would be difficult to imagine. As a relic of the days when the population of this infinitely remote gulch in the heart of the Rocky Mountains had been counted by hundreds, the camp still held its old franchise of returning two members to the provincial House of Parliament, which in 1882 consisted of twenty-four or twenty-five members. So evenly matched had been the "ins" and the "outs" in provincial politics that neither party had dared to disfranchise Wildhorse. The place also boasted of a gold commissioner, who acted as his own constable, returning officer, and registrar, a postmaster, who made up and received four mails in the year, and who was one of the two storekeepers in Kootenay, and a Roman Catholic missionary, who was at the head of the primitive little Indian school and mission that had been started many years before by the famous Father De Smet. The two white women in the camp had come in during the boom fifteen or twenty years before, and had never been out of the camp since then, and as they were the wives of the two rival storekeepers they had not even the chance of enjoying each other's company. If I add that seven of these eleven old timers were Irishmen, to which nationality also the two women belonged, it will be acknowledged that there was present the element for a good deal of political fun. To the two legislators. their parliamentary duties were better than a gold mine, for their travelling allowance of Io cents a mile of the very roundabout route to Victoria amounted to more than did the sessional allowance of $£ 80$, which was attached to the office of M.P.P. (Member of the Provincial Parliament). It was none too much, for a journey to the capital was in those days a formidable undertaking, that occupied several weeks, and which meant a 
horseback ride of some five hundred miles over the worst trails imaginable, through Idaho and Washington, until the Oregon Short line to Portland, in Oregon, was reached, where a coast steamer could be taken to Victoria. By no other means could the coast country of B.C. be reached at that time from Kootenay. During the winter months Wildhorse was entirely shut off from the world. In consequence of this the two M.P.P. had to start for Victoria in the autumn so as to reach Victoria when the House opened in January.

The election which preceded my visit led to a remarkable imbroglio which made it an historical one. Ten of the eleven voters, so the story goes, had split into two equal parties, while the eleventh, upon whom rested the fate of the election, was kept for a week before the important day in such an incapable condition by both parties that the returning officer refused to accept a vote given by such a "corpse." As the law required that the senior member should be elected by a majority, and there was no majority, there could necessarily be no senior, and hence also no junior member!

Bad as this was, worse was to follow, for presently an express rider brought the paralysing news that the election of the whole country depended upon the Kootenay members, the two parties being very evenly matched. Another election became necessary. The result was a matter of indifference to the population of Wildhorse in comparison to one entirely unforeseen upshot. This was nothing less than an appalling whiskey famine, which lasted more than six months. To this day the survivors will tell you with deep pathos how, for one whole winter, the camp had to "go dry."

But now let me get back to the tale I have got to tell about the Kootenay Lake country or West Kootenay. In the spring of I 882 three roving prospectors had betaken themselves in a boat they had knocked together out of whipsawed boards from Dick Fry's ranch at Bonner's Ferry, in Idaho (then the only white man's habitation in the Kootenai Valley), down the Kootenai and Kootenay River to Kootenay Lake, where they proposed to 
put in the summer prospecting. While slowly making their way along the east shore of the lake the attention of the leader of the little party, one R. E. Sprowle, an experienced miner, was attracted to a large iron stain on the face of a cliff rising out of the water. It formed the southern declivity of a rocky nose sticking out into the lake.

This rock rises to about 150 feet over the water, and is about three-quarters of a mile long, the shore of the lake falling off into profound depth. Kootenay Lake is one of the deepest on the continent, and its shores shelve away so suddenly, that in many places a 1000 foot line does not touch bottom close to the shore. Iron stains of this sort in a limestone formation are a promising indication, and it was decided to prospect the stain. They made camp in a little cove in the centre of this promontory, a spot which subsequently became the scene of the tragedy I am about to relate. A closer examination of the spot* showed that the rusty looking rock was the "capping" of an extraordinarily wide ledge or vein of argentiferous galena or silverbearing lead. Further prospecting along the ledge showed that the vein matter cropped up in parallel streaks almost twenty feet wide along the whole length of the promontory, disclosing a magnitude of deposit which, if it was a continuous one and not merely a "blow-out," was almost unique in the history of mining. As the men had no appliances for assaying the ore, for their object in coming to Kootenay Lake was to prospect for placer (alluvial)

* To be quite correct, I must mention that Sprowle's discovery was really a re-discovery, for I subsequently found, while making some researches, that this very same big iron stain on the cliff, which was visible for some distance off, had attracted the attention of the famous naturalist David Douglas (after whom the chief tree of British Columbia has been named). Douglas, who was the first white man unconnected with the Hudson's Bay or North-West Fur Company that travelled in British Columbia for scientific purposes, went through the Kootenay country in I 825 , and had sent a specimen or two of the glittering ore home with his report. In $183 \mathrm{I}$ these or other samples were assayed and their low grade established, for though running as much as 70 and 80 per cent. in lead, the ore of this famous ledge contains but Io to 5 ounces of silver to the ton. The claim had never been worked till Sprowle re-discovered it. 
gold deposits, they were unable to decide there and then the all important question how high in silver these solid masses of glittering ore would run. They thought themselves all ten-fold millionaires, and really, to the eye of an ordinary prospector, not without good reason. At that period the mining laws of British Columbia were framed exclusively for the placer mining industry which had hitherto been the only one in which men had engaged. It was only in $1882-3$ that the first quartz mining regulation in British Columbia were passed by the local legislature, but owing to a legal flaw the Dominion Government had disallowed them. Consequently, when the litigation concerning this ledge arose, the old placer laws were the only ones in force. According to them the discoverer of a claim had to register his discovery forthwith at the nearest gold commissioner's office, and could not absent himself from his claim at any period during the open season for more than seventy-two hours at a time. To reach the nearest gold commissioner's office, which was the one in Wildhorse, meant a journey (there and back) of 480 miles by canoe and trail!* Counting twenty-five miles as a fair day's journey, the trip, without counting any of the many probable delays arising from storms on the lake, blocked trails, straying of horses, \&c., \&c., would occupy twenty-two days, and yet the law required that to keep intact the title to a discovery the unfortunate discoverer could not absent himself for more than seventy-two hours at a time! $\dagger$

Such was the position of these pioneers, and, as the sequel showed, the first quartz mining litigation in the province, which arose in consequence of the discovery of the big ledge, turned to a great extent upon this very regulation.

* On the map the distance is very much shorter, but an immense detour through Northern Idaho had to be made to strike the only trail that led to Wildhorse.

+ To the local historian the document I have copied in Note V. of the Appendix will be of interest. It is the first of its kind ever drawn up there, and as every white man in the district excepting three (Hammil, "Sailor Jack," and "Cut-mouth Smith ") signed it, one sees that twelve men resided in West Kootenay in October, 1883 . To-day there are more than twice as many thousand! 
To make a long story short, Sprowle and his companions were not the only party of prospectors on the look-out for mines on Kootenay Lake in I882. A rich capitalist from San Frisco, Captain Ainsworth, the founder of the Oregon Navigation Co., had sent a trustworthy prospector named Thomas Hammil to Kootenay Lake. Hammil's outfit was better prepared than Sprowle's to take speedy advantage of any discovery the party might make. He had a number of men with him, and as Ainsworth was at that time proposing to undertake a large railway scheme in the Kootenay country, Hammil, who was a pleasant mannered young Cornishman, had the command of all the money he required. Hammil and his party struck the Big Ledge very soon after Sprowle reached it, and, as the trial proved, both parties were guilty of some sharp work in the way of staking out claims on the ledge. Hammil had somehow managed to induce the Wildhorse Gold Commissioner to visit Kootenay Lake with him-it was the official's first visit-and he thus secured priority on the register. This alone did not make good Hammil's title, priority in the posting of the notices on the ground itself being the important act. As a result of all this Sprowle saw himself face to face with a legal fight, in which he feared that he, as a poor man, was bound to be the loser in the end. As a wise man, Sprowle recognised the importance of interesting others in his cause, and through an acquaintance he heard of a United States Government official in Helena, to whom he offered a substantial interest in the claims provided he helped him to fight the battle against the Ainsworth party. This was in the winter of 1882 , and hearing from the Helena man the particulars, I accepted his proposal to join the enterprise if on a personal inspection of the claims I found the details to be correct.

One reason that tempted me to go in for this adventure was the fact that I had commenced negotiations with the Government of British Columbia with the object of obtaining a concession for an extensive tract of land lying between the boundary line and Kootenay Lake. This land, some 48 , ooo acres in extent, 
consisted of level alluvial bottoms lying on both sides of the river. Of their high value as agricultural land there could be no doubt, provided the overflow (lasting about six or eight weeks), to which they were subject every summer when the river rose in consequence of melting snow in the main Rockies, could be stopped. Ainsworth's agents had also recognised the value of this tract, which practically embraced every acre of good agricultural land in the whole of the vast district. When the British Columbia Legislature assembled in Victoria for the session of $1882-3$, a private Bill, granting the Ainsworth party not only these lands, but also others amounting to about 750,000 acres, had, when I appeared on the scene, already been read in the House, and would certainly have passed, for the Ainsworths had many friends in the province who desired to see American capital enter this hitherto entirely unexploited country. The principal reason why the Ainsworth party failed to get their concession in the form they wanted was that at this juncture my offer, which was backed by influential letters, came before the provincial Government of British Columbia. The Ainsworths wanted a free grant of these $75^{0,000}$ acres, which practically took in the whole country round Kootenay lake, which has since turned out an immensely rich silver bearing district, in return for building a short narrow gauge railway twenty odd miles in length to connect Kootenay lake with the Columbia river, along the outlet of the lake where that waterway is unnavigable. My offer, on the other hand, was to reclain the 48 ,00o acres that were subject to overflow, and pay one dollar an acre for it within ro years.

It is easy to be wise after the event, but there is no doubt that it would have been far wiser for both of us to have bought outright the land we wanted, which we could then have done at the rate of one dollar an acre, instead of bothering about concessions, which, as my subsequent experience showed, are always dangerously subject to the unexpected. In 1882 British Columbia was still so little known, and land there of so little value, that one could buy every acre of the unoccupied Crown land, which practically meant 
nineteen-twentieths of the entire province, for four shillings an acre! Men like Vanderbilt and Astor certainly missed a rare chance to make themselves, at the cost of a few of their millions, masters of a realm where the cost of government and the maintenance of law and order would have been defrayed by others.

My offer having been accepted by the Government, the years 1883 and 1884 would have been busy ones for me, even without any mining interests to look after. When in the early part of 1883 I inspected the "Big Ledge," of which perhaps I had in future better speak as the "Blue Bell," which was the name which the principal claim received, for the "Blue Bell murder" made' it a notorious spot, I was as much taken with its appearance as were the others. Everywhere one put pick into the ${ }_{1} 5 \mathrm{ft}$. or 2 oft. wide vein, solid chunks of galena could be prised off the mother lode. Of bright, silverlike surface where it had been separated, heavy as were it solid lead, which it almost was, one's imagination, of course, invested this likely-looking ore with a Comstock-like contents of the more precious metal, and one remembered the old yarns about Indians shooting their game and their enemies with bullets of almost pure silver. Silver, it must not be forgotten, had in 1882-3 not experienced the great depreciation which has since overtaken it, and was worth almost double what it is to-day. The assays, too, for some mysterious reason, ran to higher figures than was warranted, probably in consequence of my having unwittingly picked specially rich pieces. Quarrels out West come rather more quickly to a head than they would in a civilised community, and the two camps on the Blue Bell Claim, within rifle shot of each other, soon had about them somewhat warlike features. Winchesters and six-shooters were a good deal in evidence, and had the incident occurred on American territory some "gun play," it is safe to say, would have speedily occurred.

The remoteness of the spot from Victoria caused the preliminaries of the pending lawsuit concerning the title to the mines to consume the best part of the summer. This in spite of my personal efforts in Victoria, whither I had hastened after my 
inspection of those delusive masses of glittering ore. There being no officer of the law or Gold Commissioner nearer than Wildhorse (240 miles away), the Government asked me to become a Justice of the Peace for the Kootenay District, and as such-the first one who ever acted in what is now West Kootenay-I returned to the lake. I was accompanied by two commissioners appointed by the Government to look into the details of my reclamation scheme, and to report upon the country generally, and some months later the newly-appointed Gold Commissioner, who was to try the suits, also arrived. Our opponents had secured the best mining lawyer in British Columbia, and as I deemed it wise to take a similar precaution, I had engaged the only other available Victoria lawyer. The latter (a subsequent Premier and then Chief Justice of British Columbia), was at the last moment unable to come, and, as a postponement of the cases for that reason was impossible, I had to undertake the defence myself. Not having had the slightest training in law, and being, until I read up the statutes sent me from Victoria, totally ignorant of the provincial mining laws, it looked indeed a hopeless case. The three men who were now my partners, for I had stipulated that I was to become a part owner in the mines if I won the suits, were keen-uncomfortably keen I might almost call it - to win their cases, coute que coute. I soon recognised that however good our case was from the standpoint of prior discovery, there were about it several weak points, as the natural consequence of the remoteness of the spot. The total absence of the means provided by law to register one's title, take out mining licences, and obtain official "leave of absence" from a claim, without thereby imperilling one's title to it, had been most unfortunate for us. The issue would depend, I was convinced, to a great extent, upon the view which the Gold Commissioner would take. If commonsense justice ruled his decision we were all right ; if, on the contrary, he were to insist upon a strict interpretation of the various legal requirements, our case was a bad one.

Judge Kelly, a genial old timer, whose silvery locks and quaint Irish humour soon gained him the respect of all concerned, 
arrived in due time. It was a somewhat memorable scene. The canoe bringing him had jeen sigited from the enemy's camp, for the little cove in which it lay faced the south. Forgetting for the moment all the dire threats exchanged by the two camps, Winchesters and six-shooters were laid aside, and the inmates of both camps streamed down to the shore to receive the representative of the law. We were a motley little crowd, six or seven on our side, for some necessary witnesses had arrived, and twice that number in Hammil's party. The two camps had each built themselves a $\log$ cabin or two, which, by the way, were the first houses in West Kootenay, there being no others within roo miles. Hence it became unavoidable that Judge Kelly should take up his quarters in one or the other of the rival camps. "Now, boys," he addressed the crowd, "I think it will be fair to both camps if I grub in the one and sleep in the other, so just let me know who has got the better grub outfit," a little joke which was greeted with merriment. A hasty exchange of information concerning our respective culinary possessions between Hammil and myself, left no doubt that the enemy's yrub box was far better stocked than ours. Molasses, onions, and canned stuff, of which we had none, decided the question in which camp the judge would take his meals. Every morning and evening he was escorted to and fro from one camp to the other by one or more of his late hosts, the distance being a few hundred yards.

The largest of the three shanties in the two camps was selected as the court-house, where the trial took place. Every soul except the judge was, of course, deeply concerned in the issue of the litigation; millions, we all thought, were at stake, and feelings therefore ran very high, for Sprowle's intense animosity had communicated itself to his witnesses as well as partners. That in such a rough crowd, composed to a great extent of men who had passed their lives in American mining camps, where men very frequently take justice into their own hands, a trial lasting for some weeks was not marred by a single affray was, under the 
circumstances, very creditable to the man who had to decide the issue. The Court opened on Aug. 3I, and the first thing Judge Kelly insisted on was that all revolvers were to be deposited in a box at his side so long as the Court sat, a precaution which, alas, succeeded only for the time being to save the life of one of the two persons most concerned. The litigation had resolved itself into four distinct cases, for each of the two parties had taken up the same four claims on the big ledge.* As several important witnesses were absent, two or three short adjournments became necessary, $\dagger$ and it was only on Oct. I6, I $88_{3}$, that Judge Kelly gave his last judgment. All four were decided in our favour! Judge Kelly was an old miner himself, and knew little of law; hence he took the view which from the first I had recognised as the saving of our case, namely the commonsense interpretation of the actions of men who, from causes beyond their control, found it impossible to comply with the strict letter of the mining regulations.

The six weeks which the trials lasted were to me anxious times, for our adversary's lawyer was a very capable man, and as, moreover, he was the only person present who knew anything of legal procedure, it was easy for him to declare evidence to be inadmissible, and score numerous other points. To his credit I will say that the Supreme Court, when subsequently deciding the appeals of these cases, supported, in several instances, his contention on this head, though, poor fellow, it came too late for him to hear, for he succumbed to an illness brought on by the exposure and privations he underwent on his journey to Kootenay.

- Our "court" must have presented an amusing spectacle to a stranger fresh from formal European law courts. Here we were,

* The discoverer of a new mining camp has the right to take up, besides the one claim to which every miner is entitled, a second location known as the discovery claim.

+ The nearest post office was then at Sandpoint, more than 150 miles off. The Indians, of whom there were always a number about our camp (they took side with one or the other of the two parties), acted as our messengers, and some wonderfully fast trips were made by these then still thoroughly unspoilt and reliable Flatbows. 
the first white men in the country, fighting and squabbling over a heap of glittering stone which had been there since the world was created, and of which the surrounding mountains contained a limitless supply! And not only palavering and chattering and hissing at each other like angry geese, but a few months later some of us were shooting each other down in cold blood! What were, one might well ask, the thoughts of our quaint audience, silent natives, who, all but naked, squatted on the floor of the court-house, smoking countless cigarettes made of brown paper, and listening with incomparable patience to the proceedings, of which, of course, they did not understand a single word?

The losing side determined to appeal against the decisions to the Supreme Court of British Columbia, sitting in Victoria. Important business, in connection with my land concessions, which called me to England, made it impossible for me to give my personal attention to this part of the fight. Before leaving Victoria for England I intrusted the defence to the same competent lawyer whose services I desired to secure for the first trials in the lower court. In a series of interviews, I put him in possession of all the facts in connection with the involved appeals, and paid him his roo guinea fee.* Unfortunately, a more important case before the Supreme Court of Canada, sitting in Ottawa, on the other side of the broad North American continent, in which he was playing an important rôle, obliged him at the last moment to remain in Ottawa, at the very time our appeals came on in Victoria. Another counsel, who naturally knew but little of our cases, took his place. The appeals heard by the late Chief Justice Begbie, than whom no more respected judge has graced the bench in any part of the Empire, and one whom in later years I was privileged to count among my warm personal friends, decided three of the four cases against us, upholding only one of Gold Commissioner Kelly's decisions. It was a terribly unexpected blow which affected one man most

* In Canada a client deals direct with counsel, the intervention of a solicitor being unnecessary. 
disastrously, more particularly so in consequence of the unfortunate but not uncommon sequel of costly litigation. As the winning side got the costs of three of the suits, and Sprowle could not settle the large amount which now was claimed by the Ainsworths, an attachment to cover their costs was issued against his remaining interest, and the latter was sold by the sheriff. This unfortunate ending unhinged Sprowle's over-excited mind altogether, and he now also turned against me, blaming me for the loss of the appeals, which he said was caused by the lawyer's absence, but with which I had, of course, nothing whatever to do, being away in England at the time. Hammil's and my life, he openly threatened, should pay for the loss of his mine. That he meant what he said few doubted who knew Sprowle, and who now witnessed his intensely vindictive anger. Of these threats I heard as soon as I returned to Kootenay in the spring of I884, and for all that season I did not for a moment feel safe from Sprowle's gun.

What made it infinitely worse was the fact that my land interests in Kootenay, which had assumed larger shape than I had originally intended, as such matters often will, obliged me during I 884 to be frequently for days at a time in Sandpoint, the nearest rail and post station, which then afforded the only approach to Kootenay. In this wretched hole, one of the "tough" towns in the tough territory of Idaho, where shooting scrapes and "hanging bees" were common events, Sprowle had many friends, for he had lived there a winter or two. Though neither a gambler or a drinker, merits which had prejudiced me at first strongly in his favour, Sprowle's venomous talk soon surrounded me with enemies, and it was not long before I was told by one of the few respectable citizens of the place, that the town was freely betting on the shortness of my shrift. My turn did presently come, and the man with whom a few months before I had lived in closest community, at whose side I had slept for weeks, sharing even blankets, during many weary I50-mile rows to the mines, and whose indomitable courage and perseverance in his law fight I could even now not abstain from admiring, would have shot me 
down like a dog. I was riding at a trot towards Sandpoint, along the narrow trail at a point where it twisted through a particularly dense bit of forest, when suddenly I saw Sprowle, half concealed behind a big pine, with a rifle to his shoulder, taking deliberate aim at me. The tree was fortunately not more than $3 \mathrm{ft}$. or so from the trail, and my horse, suddenly perceiving the figure, shied violently, providentially, the very same instant that Sprowle pulled the trigger. He missed me clean, and the next second the terrified animal was tearing along the crooked trail, taking me out of Sprowle's sight before he had time to pump a second cartridge into his rifle. The shot was fired at such close quarters that my right hand, which, I suppose, I must have thrown up instinctively, bore powder marks. It was a close shave, and the speed at which I sent good old "Boston" over the intervening twenty miles to Sandpoint was, perhaps, not the kindest reward for the service the old horse had just rendered me in saving my life by that lucky shy.

The absence of any police or Justice of the Peace at Sandpoint, where the only representative of the latter class-a notorious gambler-had lately "run agin a gun and passed in his chips suddenlike," made it impossible for me to take any steps to have Sprowle arrested, and I knew only too well, that it was useless, in the presence of a number of toughs who were practically running che "town," to appeal to the few decent citizens in the place.

The nearest "town" where I could swear out a warrant was Rathdrum, a settlement some forty miles to the west. The only Westbound train of the, day had gone hours before I reached Sandpoint, and, as I was expecting a friend from England, Messiter by name, next morning, I decided to stay the night in Sandpoint. Sprowle I did not set, but I heard that he had arrived shortly after my reaching Sandpoint, his horse dropping down dead as he rode into the single street consisting of two rows of shanties that faced the railway track. My lighter weight and better horse had probably saved me a second time, for had he overtaken me in the 
solitude of the forest, Sprowle's aim would probably not have failed him a second time. But another crisis was approarhing. Sprowle had for some time past worked up the feelings of the Sandpointers against me by telling everybody that I refused to pay him his wages for his last summer's work. It was a clever trick, for, of course, I owed him not a cent. By my undertaking to find the money for the defence of his suits I should, if I had won them, have become entitled to a share in the mines, the risk of losing the lawsuits being my business. Sprowle's charge at once enlisted the fullest sympathy of all the gamblers and bad characters of the place. To play the fool with a "bloated capitalist," and that one a Britisher, was a chance too good to let pass.

There were only three men in Sandpoint I could trust. One was Weeks, the postmaster, who had charge of the ready money I needed, and who was the owner of the only store, on the counter of which I was in the habit of sleeping when in Sandpoint, for the only "hotel" had been burnt down some weeks before; then an English civil engineer in my employ, who had just returned from the Kootenay country, where he had looked into my scheme; and lastly F_- a young Englishman who had strayed West after a two years' "undoing" in Manitoba what English parents and Marlborough had drilled into him. Fortunately, one British quality it had not undone, and during the somewhat anxious hours of that night he stood by me with rare pluck. The first inkling of what was brewing was Weeks's suggestion that as he had heard there might be some trouble he would prefer my seeking other quarters for the night. His whole capital was in the store, and in the back room slept his wife and child, so his request was but a prudent precaution, and, as he pressed upon me two new 45 Colts out of his stock, and offered me an empty shack, standing a little distance off as quarters, I knew he was doing the best he could for me. The engineer, also a married man, insisted, as his errand was completed, and the coming storm was none of his funeral, on taking the afternoon Eastbound train, strongly urging me to leave the place at once with him. In his palace sleeping car he no doubt passed a 
pleasanter night than I did, discretion being no disturber of slumbers.

The next thing that happened was a call from three half-tipsy gamblers, the "committee of the town" as the spokesman announced himself. I was sitting in my shack reading my accumulated correspondence, seated on an old packing case, before me a larger one which I had pressed into service as a table, the bundle of $\mathrm{F}$ __ 's bedding and my own thrown into one corner of the "room" with our saddles, completing the furniture. The upshot of the interview was the peremptory order that I should leave town by the Eastbound night freight, which passed through the place about midnight, or take the consequences. My curt reply that I proposed to take the latter "straight," made even more unpalatable by F__'s loud chuckle at my indulgence in the idiom that was best suited to my audience, was answered by some allusion that I wouldn't be laughing twelve hours hence. As daylight waned F-, who went to get some canned stuff at Weeks's, reported that two men, friends of Sprowle, with rifles, were posted as sentries in front and behind the cabin. "Look's like business, eh," said F_-, "but they don't amount to much, for they've got a full bottle each." The correctness of this opinion speedily was seen, for the rear sentinel presently joined the one in front, leaving me every opportunity, had I wished to take advantage of it, to get away into the woods which began immediately behind the shack.

Towards evening one unpleasant fact came to my knowledge, which, had I known it earlier, would, I think, have caused me to follow my engineer's advice. It was that the monthly pay-car had passed through Sandpoint that afternoon, and hence all the male population in the place with the exception of Weeks were "filling up" as fast as the six whiskey dens in the place could bring about that happy end. Added to the local population came sundry trackmen and section hands, for the nearest settlement towards the west was Rathdrum, forty miles off, and to the east Clark's Fork, some twenty odd miles away, not a single human dwelling being found 
nearer than those two points, save the shelters occupied by the railway hands. After a month's solitude in the dense forest, or in the yet more dismal lake-side swamps in this part of northern Idaho, the average human nature to be found out West will invariably "blow in" the hard-won dollars as speedily as poisonous whiskey will do it. Hence it was quite an understood thing that pay-day was followed by a night or two of the rowdiest debauch. I had been a witness at different times of dozens of such pay-day pandemoniums in railway camps, and I knew Sandpoint-known also as Hangtown-could hold its own for depravity. But a few months before, during construction days, a pay-day "bust" had ended in two men being lynched who, it was afterwards found had nothing whatever to do with the crime of which they had been accused, i.e., sand-bagging a contractor's paymaster. The only excuse, that the whole camp was "hanging drunk on $\mathrm{X}$ - 's poison," did not mend matters so far as the two victims were concerned, and, of course, no steps whatever were taken to punish the drunken crowd.

In other places, to break the thread of my story for a minute, I knew to what lengths a crowd of Western labouring men, tuned up to deeds of violence by bad whiskey, would go. Thus on one occasion during the miners' strike in Butte City a few months previously, three thousand of them went out on the question of a proposed reduction of the daily wage from 4 dols. to 3 dols. 5 o cents. A friend of mine, Frank Medhurst, was manager of a well-known mine in that town owned by Parisian capitalists. These 3000 drunken fellows late one night came crowding round the hoisting shed to compel him by threats of instant death to have the miners who were still at work in the 7 ooft. and 8 ooft. levels to stop work. The rowdies struck the wrong man, however, and Medhurst, with two friends and some loyal employees, stood off the 3000 men at the point of their rifles. Had all the managers shown the same bold front as did this Englishman the bloody riots that made those Butte strikes so notorious would have had another ending. These strikers, mad with whiskey, would have sentenced 
their fellow miners to the same cruel end which they had threatened to the manager, for they deliberately set to work to ring the men at work into the hoisting cage with the intention of throwing a stick of dynamite with a lighted fuse down the shaft, which would, of course, send them all to a shocking death. Regrettable as it is, there is no doubt that the Western labouring man-not the prospector, for him I have found, with but few exceptions, to be a manly and courageous fellow - when his passions are inflamed by the terrible stuff on which he loves to intoxicate himself, and, when under the spell of the glib tongues of inciting agitators, will commit crimes of the foulest kind.

With such surroundings I knew I had to reckon on the occasion in question. Sprowle was just the man to inflame the score or so of drunken railway hands to participate in mob law, and it was merely a question whether the odds of two sober men against two dozen drunken men, led by a sober but half crazy desperado, was not too heavy a one.

My refusal to leave the town seemed to surprise Sprowle's party, and it upset their plans, which, as I subsequently heard, was to get me away from Sandpoint, stop the train in the woods, and, after a rope's end inquiry, let Sprowle wreak his revenge. Their next move was to intimidate young $\mathrm{F}_{-}$- , who, however, remained perfectly uninfluenced by their threats, and told them to go to the warm place that figures so largely in Western conversational efforts. But for his popularity in the place, the proposed "rush" would, I firmly believe, have occurred, and blood would have been spilt. One fellow, a bridge night-watchman, on whose vigilance depended the lives of all the railway passengers passing at night time over those many miles of long wooden trestle bridges near Sandpoint, which were constantly catching fire-made bolder than the rest by the "tangle-foot" he had imbibed, volunteered to take me single-handed, and he really did burst in the flimsy door of our shack. Young $\mathrm{F}$ — , disdaining to use firearms, made a sorry looking individual of this bold "bad man," and put him "to sleep" with his fists very effectually. In the struggle in the dark, the 
fellow's six-shooter went off, and but for F___'s speedy assurance that he was unhurt, the aggressor would not have had the chance of getting off with a sound pummelling.

It subsequently came out that this man's very foolish attempt was the consequence of the belief that as I was known never to carry a six-shooter-in Western eyes a bit of unprecedented follyI would, under no circumstances, use a firearm in self-defence.*

Next morning a thoroughly paralysed town met the gaze of the one or two passengers who arrived by the train at Sandpoint. Among these was Messiter, who had heard from some trainhands of the proposed little "fun" that was to have taken place during the preceding night, and who now, relieved to find me safe and sound, very good naturedly offered to stand by me in any further trouble that might arise. I had, however, decided on my course, which was to go on to Rathdrum for the purpose of swearing out a warrant, and get Sprowle arrested. Bi.ding good-bye to Messiter I stepped on board the Westbound train, and took my seat in one of the smoking cars. It was a "light" train, and there were only five or six men of the ordinary nondescript Western type distributed in various parts of the car. The train, after its short halt at Sandpoint, was already moving fairly fast towards the long trestle bridge which spans an arm of Pen d'Oreille Lake near Sandpoint, when, from the window out of which I was looking, I saw Sprowle make a jump for the footboard, and get on the rear part of the car I was in. This was an unexpected move on Sprowle's part, and I began to wish I had not refused the proffered six-shooter. I had but a brief moment to consider what had best

- Out West I always went unarmed, except perhaps in countries where the Indians could not be trusted. As a means of protection against white men the pistol is ordinarily worse than useless, for the class of man who would use the six-shooter against one is far too quick in the handling of the same to give onc the ghost of a chance. If you are shot, the fact that you have no gun on your person makes matters decidedly more awkward for the murderer than if a pistol is found even in the depth of your pocket, for in the latter case the usual plea of self-defencc is easily set up, and a sympathising jury, if indeed it comes to a jury at all, is easily prevailed upon to return a verdict of justifiable homicide. 
be done, for the next second Sprowle stood before my seat. None of the passengers were seated near me, and Sprowle's burly frame screened the movement of his hands from them. His eyes, no longer those of a sane being, were filled with such intense malevolence as haunts me to this day.

My tongue almost clove to the roof of my mouth when replying a husky "Yes" to his peremptory query "You're going to Rathdrum to swear out a warrant against me?" Trying to be as calm as I could, I did not even rise from my seat, though keeping my eyes steadily fixed upon his. The next thing I knew was that the muzzle of Sprowle's cocked 45 Colt, a big frontier six-shooter with which I had shot many a foolhen (timber grouse) and duck for the pot during the preceding summer, was within 4in. of my forehead. "Yol: wont do it, for that'll stop you right here if you don't step off the train with me at Algoma," the next stopping place, some few miles ahead. "Some few miles ahead," how easily one writes those words, but what an eternity they seemed to me while the train was bumping and swaying on the execrably laid road-bed, so that Sprowle had to steady himself with his left hand to keep his legs. Every moment might be my last one, for the deadly muzzle continued to be held between my eyes. The nervous twitching of the fingers near the trigger betrayed, it seemed to me, the tiger in that man's heart; they were but the premonitory flickers of the animal's tail before he makes his leap.

Long, desperately long miles they seemed. On the train rushed, jerking and jolting all the more in consequence of its accelerated speed. To get off at Algoma, a wretched siding, where the station shed was the only building, and the two railway officials the only inhabitants, would be madness, for it would have enabled Sprowle to do away with me on the quiet, the presence of witnesses being, I knew full well, the only thing that deterred him from doing so there and then. To say I would not get off the train might precipitate the action of those twitching fingers at the trigger, and to argue with him was, I felt, as useless as it would have been dangerous to call for help. Silence was therefore my 
best policy, and silent I kept, though I suppose my eyes may have conveyed to him some inkling of my determination to refuse his demand. Hours instead of seconds seemed to go by; at last I felt the train slackening up. "You won't leave the train?" he hissed as we drew up to let a freight train pass. "Then, by God, you're a goner." That moment the conductor's heavy foot kicked the swinging door of our end of the carriage open, and with lightning rapidity the cursed six-shooter disappeared under Sprowle's coat, and the two men, who knew each other, entered into conversation, leaving me time to collect my senses. There was, however, no need for me to take any immediate steps, for when the train went on, it did so without Sprowle, and indeed it was the last time I set eyes on him. His next act of violence terminated his career on the gallows in Victoria jail. This was the event to which I have already alluded, namely, the assassination of young Hammil while at work on the Blue Bell. Firing at him from ambush, Sprowle's bullet broke the poor young fellow's back, condemning him to terrible suffering that ended in death a few hours later. So cleverly had Sprowle planned the whole affair that he got a six hours' start before the constable who, after Judge Kelly's departure from the lake, represented law and order in the lake district, could get together a party of Indians with whom to pursue the fugitive. It was by the merest chance that he was captured. Constable Anderson judged very correctly in supposing that Sprowle would make for Idaho, where he could not be followed by British officials, and where he could not be taken at all until long-winded formalities had been gone through. Anderson therefore made as good time as he could with his two canoes to the lower end of the - lake, and up the winding Kootenay river, violent storms delaying progress very materially. Dividing his force in two parties, each took up a post close to the international boundary line on either side of the river. The boundary consists in this densely wooded country of a line Iooft. in width cut through the forest by the Boundary Commission some quarter of a century before Sprowle's crime. Dense underbrush had since overgrown the cleared 
space, and, as the base line of the Kootenay District triangle, where it rests on United States territory, is some I 40 miles long, and the country of the most rugged character, the chance of selecting the spot where Sprowle would cross was one in a million.

But Providence evidently considered that Sprowle's dossier was about full, for he literally walked up to the muzzle of the constable's Winchester. It appears that the only precaution Sprowle had failed to take was to provide himself with sufficient food in his flight. After abandoning his canoe and taking to the woods, he hid on the British side for four days. Want of grub compelled him, however, to proceed Idaho-wards, for he was afraid of using his rifle to kill game. Anderson and his Indians had practically given up all hope of capturing Sprowle, and were also beginning to suffer from the lack of provisions. A black bear being seen close to camp, one of the Sywashes, more hungry than the rest, without asking Anderson's permission, which would, of course, have been refused, fired at the walking fleshpot. The shot was heard by the now half-starved Sprowle, who, thinking that it was fired by an Indian or by a prospector out hunting, made straight for the spot from whence the sound came in the hope of obtaining food, for, as he quite reasonably argued, no party of watchers would have betrayed their whereabouts by shooting. Anderson, in the meanwhile, after soundly scolding the Indian who had killed the bear, was lying under some bushes waiting for a bit of bear's meat, when he suddenly heard something make its way through the thick brush at his side. Taking up his rifle, but never dreaming it could be Sprowle, he kept on the alert. To his intense surprise Sprowle, ragged and with drawn face, stepped out into the little clearing, and, seeing only the Indians at their fire, was in the act of stepping up to them when Anderson's order to throw down the Winchester he held in his hand struck his ear. For the first moment he seemed to collapse, but, recovering himself with amazing rapidity, he appeared for an instant to hesitate whether to obey the order or fight for his life, but the levelled rifle and Anderson's stern command to instantly do his bidding or be shot 
down, had the desired result, and the next moment his hands were bound behind his back.

Sprowle's crime and capture made a great stir all over the Slope, for he was an American, and, as his brother was a wealthy man, a prolonged legal fight ensued, which did not even end when the Victoria jury found him guilty and the judge passed sentence of death. Three times these efforts to get him retried or delivered to the U.S. authorities, secured him respites, and I believe even the President of the U.S. made efforts in the same direction. They were in vain, however, and Sprowle paid the penalty he so richly deserved.*

During and after his trial sundry facts about his earlier career came to be known, which threw light upon this man's desperate character. Even American papers acknowledged that he had killed at least one man in California, and was wanted in Tacoma (Washington Territory) for arson and manslaughter.

One of the most curious points in the man's character was his undeniable skill as a pioneer, and his intuitive prevision concerning the spots where settlements would spring up. He not only discovered the exceedingly valuable coal beds near Tacoma, but part of that now very populous city and port on Puget Sound is located on land which he pre-empted in what was then a perfectly wild spot, some fifteen years before he turned up in Kootenay. In the latter country he discovered not only the Blue Bell, which has turned out to be one of the biggest bodies of low grade argentiferous lead on the continent, but he also took up on the same lake 160 acres of land where the town of Ainsworth stands. His ungovernable hatred of opposition, and the length to which he carried his vindictiveness, were his ruin. But for them he assuredly would have died a millionaire.

* The fourth victim of the "Blue Bell" murder was the aged mother of young Hammill. She fell dead (so the papers reported) when she heard of her son's pitiful end. 


\section{CHAPTER XI.}

\section{PIONEERING IN KOOTENAY.}

\section{EARLy DAYS IN KoOTENAY.}

ONE of the conditions of my land concession from the British Columbia Government was that I should forthwith place a steamer on the navigable portions of the Lower Kootenay river and lake. This was a far more formidable job than I had anticipated, for, as I have said, the country was then a perfectly wild region, Dick Fry with his squaw and half dozen half-breed children at their "ranch," where now stands the thriving town of Bonner's Ferry, being the only resident white man in the whole of the Lower Kootenay country. After obtaining prices from Oregon boatbuilders at Portland, I came to the conclusion that the speediest and probably cheapest way of fulfilling my engagements was to bring a steam launch owned by an English friend, who, with a few others, had joined me in carrying through the land enterprise, over from the old world, and take her by rail as far as Sandpoint, and from thence transport her overland to Dick Fry's ranch, which was the nearest point on the Kootenay river. She had last navigated the waters of Norwegian fiords, so, though small in size, her teak hull made her a staunch little craft. I brought her across the ocean on deck of the Polynesian, landing her at Montreal, from whence, by taking advantage of the artificial and natural waterways that penetrate into the heart of the continent, she was finally put on two Northern Pacific cars at Duluth, almost half-way across the continent of North America.

Canada we know protects her home industries by a very high Customs tariff, and among the few articles that can be taken in free 
of duty are "settlers' goods," including agricultural machinery that had been previously used. On landing at Montreal the Customs officials demanded several hundred dollars duty on the old steam launch. To this I objected, and as I had letters from a member of the Cabinet at home to Sir John Macdonald and others in high official positions, I thought I would test their efficacy at Ottawa. The amount and rigidness of the red tape that manacles the official

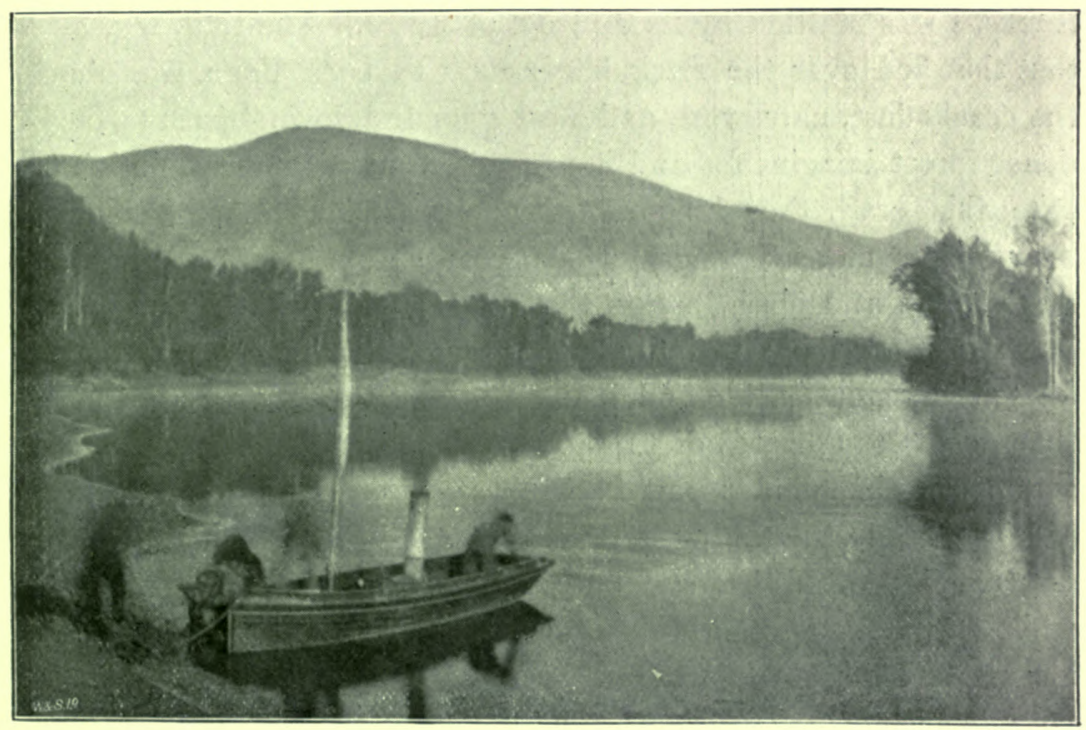

The “Midge," the first Steamcraft on the Kootenay Waters.

Transported by the author, on men's shoulders, over a pass in the Selkirks.

world of Canada is something incredible, and while I soon saw that the head of the department was anxious to meet my views, he could, of course, only do so by abiding by the regulations. The point I tried to make was that if settlers could bring in a steam plough free of duty, I should be enabled to do the same with the steam launch, for, as I laughingly argued, in the present overflowed condition of the tracts of land I was acquiring in Lower Kootenay, 
it would certainly require a steam launch to draw the plough. The Minister smiled benignly at my feeble joke, and, to the utter consternation of the Montreal Customs authorities, I returned from Ottawa with a permit in my pocket authorising me to clear in the launch free of duty, as a settler's agricultural implement. I was told subsequently that this was quite an unique instance, and deserved being put in "a glass case."

When the steam launch arrived at Sandpoint on its two long trucks, I was startled by its size out of water. The trail, which at that time led over the Pack River Pass to Dick Fry's, was about. the crookedest, narrowest, and most " up and down " path through dense forest imaginable, and it seemed an utterly impossible job to take this craft, though lightened of its somewhat old-fashioned heavy boiler and machinery, which we took out before loading her on the cars at Duluth, across this pass in the Selkirk range. A large force of Kootenay Indians and some ten or twelve white men, assisted by stout tackle and pulleys, at last managed the business, though it took upwards of three weeks and cost an unconscionable sum. For the greater part of the forty miles-the present good waggon road, by taking a straight course, has cut down the distance by two-fifths-the hull was carried bodily by the men; while on the steep hills, where she could not be carried, we pulled her up or let her down on rollers with pulleys fastened to trees. On one such occasion, when we were letting her down a very steep hill, one of the ropes broke just as I was lying on my stomach underneath the bow of the hull, fixing the rollers. Fortunately for me, these rollers, which consisted of barked logs cut from a tree, were more than a foot in diameter, and the squeeze I got as the liull skidded over me was not very serious, but it was a decidedly unpleasant sensation. The hull was brought up at the foot of the hill by a bank of clay soil, into which she buried her bow, "hurting the bank more severely than she did herself or the boss," as the men observed, after they had helped me to my legs and seen that I had escaped from what at the moment they imagined meant instant death. 
The Midge was the first steamer to navigate any part of the Kootenay river or lake, and can therefore claim to be a historical craft. Amongst the Flatbows she created the most profound surprise, the whole tribe dashing down to the river bank when they heard her infantile puffs. The biggest thing about the Midge was her whistle, and to get permission to pull the string and send forth a shrill blast was the most prized privilege I could bestow on any buck I desired to distinguish. This I turned to practical use, for as dry wood was unobtainable for fuel, driftwood on the river banks had to be used. So long as I provided a "buck-saw," the like of which instrument these primitive Indians had never seen, they were quite ready to cut up big stacks at different points of the river in return for a few minutes at the whistle, or, what was equally prized, getting their canoes towed. This was. an economical way of solving a difficulty which besets most pioneer steamers navigating the waters of uninhabited countries, and generally causes either much delay in having the crew land and cut the necessary supply, or considerable expense by having to establish wood camps along the route.

The experience of that summer, I884, in spite of the hard work and the sinister events to which I have already referred, were of the pleasantest kind, for there is something strangely attractive about the exploration of virgin wilderness amid such superb scenery as met the eye at every point along the winding Lower Kootenay river and the seventy miles long lake. Camping now on smooth sandy beaches of the lake, or, when overtaken by the violent gales that occasionally sweep its length with a force to which in later years much larger steamers have succumbed, running for some rock-encircled cove where our little craft could be snugly anchored; or, at other times, trying to force a passage up the swift Lardo, one of the principal feeders of the lake, which led into unknown regions beyond, every day brought new experiences and fresh scenery.

I have mentioned that Dick Fry was the only white resident in all that vast country, the American portion of the Lower 
Kootenay country being then as uninhabited as was the British portion. But I must not forget to mention a very interesting old character who lived Indian fashion in a miserable hovel close to where the 49th Par. (there forming the boundary line) crosses the Lower Kootenay river at right angles. This was old Dave MacLoughlin, only surviving son of the famous Dr. MacLoughlin, once absolute monarch of a realm much larger than Germany or France, extending from California up to Alaska, and comprising part of both. This remarkable man was, in days anterior to the treaty of Washington, the supreme ruler of the Hudson's Bay Company's territory on the Pacific Slope. Old Dr. MacLoughlin, like all of the Company's officers who took unto themselves wives, had, in the early days of his career, married a native woman, by whom he had two sons and a daughter. The eldest son, who was addicted to drink, was killed in a drunken brawl while in command of Fort Stikeen in 1842 . The second, David, a boy of a more genial and adaptable character, was sent in the thirties to Europe to be educated, and even when I knew him as a very old man who had long relapsed into the dirt and savagery of Indian life, one soon discovered that he had received the education of a gentleman, was versed in three or four languages, and had seen the world. An old cone-shaped hat, adorned with a few glass beads, and as dilapidated and dirty as any the naked Indians wore, covered his long matted hair, and it was this hat which gave him his name, by which he was known among all the Indians in the country, i.e., Kiskayooka, or "very old hat."

When I first saw him I had no idea who he really was, and was also unaware that he disliked being spoken of by his nickname. My reception, therefore, when I landed near his hovel, and asked whether he was "Kiskayooka," was not as cordial as it would have been had I been aware of this singular old man's history. At the same time, there was so much of the inbred gentleman about him, that his invitation to enter the miserable hut, which was bare of all furniture except one old stool, and which even had no glass in the one window-oiled paper taking its place-was tendered with the 
grandeza of the old school. Old Dave, I soon discovered, was a most interesting relic of the early pioneers of the Slope, and it was indeed singular to meet this son of a remote past in these late tımes, when literally millions inhabit the country over which this man's father had ruled in days when, outside the Fur Company's employees, there were not a score of white men in the whole vast territory. Close to the hovel in which he and his large Indian family dwelt in all the unspeakable squalor and filth of savage life, there stood a big $\log$ structure, which had once been the Hudson's Bay Company's trading post, known as Fort Flatbow. It was entirely empty, and as the ill-fitting logs of which it was built were shaped with the axe, the storms and sunshine of half a century had not improved their weather resisting qualities. Hence the chinks and crannies were numerous and big enough to dispense with the windows, over the sashless emptiness of which rough boards had been nailed. This building and the miserable pigsty inhabited by MacLoughlin were the only roofed habitations in the Kootenai Valley, when once Fry's ranch, at the extreme south end of the valley, was left. The former stood but a stone's throw from the boundary; in fact, the stone pyramid which the Boundary Commissioners caused to be built at this point a quarter of a century before, to mark the place where the line crossed the river, stood in Old Dave's potato patch at the back of his liut. Erected by the Hudson's Bay Company, the post had reverted to the United States, when, after the Washington treaty, the Company abandoned its possessions south of the 49th Par. Old Dave, born and reared in a similar, though much larger, fort, i.e., -Fort George on the Columbia, had in him all the instincts of the old days, and had settled on the spot on which I found him more than a third of a century before. He pre-empted 320 acres of the land round it, and on a quarter of an acre of it he grew his only crop of potatoes. The old barn-like main building was far too roomy for his wants in summer and too cold in winter, so he forsook it, and took up his abode in the pigsty close by:

A hasty examination of the walls of the former convinced me 
that with a little patching up and filling in of the chinks the building could be made fairly weathertight for a year or two longer. And, as I was badly in want of some such place where I could store things, and which I could use as headquarters while in that part of the country, I determined to make Old Dave an offer for it. No great run had apparently affected the price of "old forts." Moreover, Dave's potatoes, upon which he and his family subsisted, had not done very well that year, and whiskey galore could be had at the other end of a seventy mile ride-at Sandpoint. Dave's squaw and entirely naked children looked so miserable and half starved that I framed my offer with an eye to their condition, and the roo dollars I gave for the "Fort" was made up of a 5 olb. sack of flour, which then was worth rodols., and godols. in cash. It was jumped at with alacrity. Five minutes later I had Dave's neat signature to the short conveyance I scribbled on the only paper available, a leaf out of my note-book. It is not the least interesting memento I still possess of my fortbuying days.

Poor, good natured Old Dave would not have occupied the sorry position I found him in had not whiskey ruined his life; it had been his deadliest foe. He was, moreover, as is generally the case with a squaw-man's establishment, constantly preyed upon by his squaw's numerous relations, who sponged on him with the callous persistence of their race.

Within ten minutes after I had passed over the greenbacks to Dave, who at once hid them away in the cone of his hat, his tattered shirt and trousers being, apparently, unprovided with pockets, his scantily costumed "tillicums" came rushing in from their camp close by, laughing and chattering at the good news of the untold wealth of "chikamen."

How to get quickly to Sandpoint seemed to be the most exciting question. The Flatbows on the British side possessed no horses whatever, but their kinsmen in the Kootenai Valley possessed just then a few, for they had been having for once good luck in their gambling with the wily Kalispels, the worst of the Cœur d'Alene 
tribe, who periodically visited the Flatbows, on gambling bent.* As a rule, the far more simple minded Kootenais fell easy victims of their rascally opponents' numerous ruses.

The nearest Kootenai camp was many miles off, but by some mysterious means the news of Kiskayooka's fortune spread so quickly that in two hours three unspeakably sorry looking steeds were standing outside old Dave's shack. Only one had a saddle on, while the other two were disfigured by great running sores on their backs and cruelly scored flanks, which made them pitiable looking objects. Upon these three depressing specimens of man's best friend Dave and four of his tillicums proceeded to ride off. Dave had the horse with the saddle, while on the other two wincing beasts blankets were strapped, two bucks, absolutely naked but for their breechclouts, bestriding each of the undersized, wretchedly thin steeds. Entirely disregarding their horses' condition, the party proposed to ride through to Sandpoint, for the Indian is quite void of all mercy in regard to animals, and when he wants to get to any place he rides his poor brute until it drops. Business took me away for three or four days, and when I returned Old Dave was just coming back in a canoe minus the ninety dollars and the three horses, but plus a formidable Katzenjammer. The horses and the dollars had been gambled away or expended upon a grand debauch in Sandpoint, where, though it was a criminal offence to supply Indians with whiskey, drunken natives could be seen staggering through the streets almost any day. Occasionally a white man's life paid the penalty, for whiskey makes the Indian a dangerous customer, but the profits of the business were then, and are still, too great not to attract the scum of the whites. In a lawless country as Idaho then was, the trade was carried on with impunity and quite openly.

* This vice is deeply ingrained in all the Indians of this region, the favourite game of chance being a sort of tippets, which they play for days and nights at a stretch, the nature of the stakes being as heterogeneous as the game itself is simple. A " cleaned out" Indian, who has gambled away everything he possessed, including the gaudy shirt on his back or his single blanket, was one of the commonest sights. 
To understand the scheme I was desirous of carrying through by means of my concessions it is necessary to cast a glance at the map. It will elucidate the somewhat remarkable orographical features which came into play. The Kootenay river heading in the heart of the Rocky Mountains, in a region where not half a dozen white men had then been, and which is not more than a score of miles south of the Kicking Horse Pass, over which the Canadian Pacific Railway now crosses this formidable chain. After winding for some eighty miles through dark cañons, the river finally debouches in a westerly direction from its mountain home at a spot called Canal Flat.* Turning sharply southwards it keeps, for upwards of 120 miles, along the western base of the main Rocky Mountains, and forms the Upper Kootenay valley, now generally called East Kootenay valley. This southward course leads it across the international boundary line into Montana, where it again, turning to the west, strikes into a mountain chain known as the Purcell range, which is nothing but a southern extension of the Selkirk Mountains. After forcing a passage through these uninhabited regions by a series of cañons, the river, apparently disgusted with the inhospitable fastnesses through which it has delved its way, enters. Idaho, gradually turning northwards. This it does near Fry's. ranch, where once more it exchanges the gloomy solitudes of cañons. for a smiling valley, viz., the Lower Kootenai valley. Reminded of its unpatriotic desertion of its native soil, the now 8ooft. broad and 3 oft. deep river re-enters British territory at a point already described, i.e., the pyramid in Dave MacLoughlin's potato patch. Another twenty-five miles of great loops through the three mileswide valley, which consists here of the broad stretches of rich alluvial bottom land which had taken my fancy, and the Kootenay river empties itself into the Kootenay lake. This large sheet of water has only one outlet, an unnavigable gorge with numerous falls and rapids, some twenty miles in length, by which the water

* On some of the official maps this place is called Grohman, the Dominion Government naming after me the post-office it established at this point during: the cluration of the canal works. 
flows into the Columbia river at a point (Robson) more than 400 miles from its source, and about 5ooft. lower in altitude than the Kootenay lake, and I $200 f t$. lower than Canal Flat.

Curiously enough, the source of the Columbia river is less than a mile from the Kootenay river at the already mentioned Canal Flat. This latter is a level sandy flat a mile or so wide, which separates the stream from the Columbia lake, which is the source of the Columbia river. In other words, the erratic courses of the two rivers form a great " $\mathrm{O}$," some 800 miles in length, round the Selkirk Mountains. It is certainly an unique instance of two rivers, at one point less than a mile apart, taking opposite courses, then turning back and meeting, each river having performed a journey of some 400 miles through some of the most formidable mountain systems on the broad continent of North America.

My land concession in the Lower Kootenay valley comprised every inch of valley land between the boundary and the lake. In autumn and spring no finer stretches of rich alluvial grass land could be discovered in any part of America, but in summer the enormous freshets, which caused the river to rise from ioft. to $2 \mathrm{oft}$., turned these flats into swamps and lakes, the duration of the overflow depending on the amount of snow in the high mountains and the rapidity with which it melted. The American and English engineers who examined into the feasibility of preventing this overflow pronounced the idea I had formed a practical one. It was to turn the Kootenay river at Canal Flat into the Columbia lake. The piece of land lying between the two waters was a level stretch of gravel shelving from the river to the lake, the latter being about - I Ift. lower than the Kootenay. With such a fall in less than a mile it practically needed very little work, for, once a big ditch was cut, the rushing Kootenay, at that point a rapid stream some $300 \mathrm{ft}$. wide, would soon do the rest. By turning off such a large quantity of water it was expected that the overflow of the bottom land 300 miles further down would be prevented. It was really restoring things to their original condition, for there is no doubt that a comparatively short time back the Kootenay river forked at 
the Canal Flat, the northern branch flowing over the flat where I proposed to make the canal, while the southern occupied its present bed.

My concession contained, of course, a clause giving me permission to carry out this turning of the Kootenay river, for this was the vital point upon which the whole undertaking was based. For two reasons this sanction should never have been given by the Government. In the first place it had not the right to grant it, for by the Act of Confederation, which regulates the relations between the Provincial and the Federal Government, the latter had reserved to itself, amongst other powers, that of dealing with all future canal works in the province. As mine were the first ever undertaken in British Columbia, the legal advisers of the Crown, as well as my own lawyers, overlooked this important fact. Consequently the signature of the Chief Commissioner of Lands and Works was as valueless as was the formal Order in Council which approved of the concession. The second reason was that had the other interests that came into play been examined into by the Government ere sanctioning the turning of a big river from one valley into another, leaving its old course dry, and at least trebling the quantity of water in the other, the dangers of such a proceeding would have become apparent. In I 882, when this scheme first came up, there was not a habitation or a single white resident in the Columbia valley between the mother lakes, or source, and the American boundary line, more than four hundred miles away following the course of the river. Had the scheme been carried out in that or in the following year no existing interests would have been endangered, for none existed then.

But important interests soon arose, for in 1883 the Yellowhead and other northern routes by which the Canadian Pacific Railway Company proposed to get across the Rockies were abandoned, and the Kicking Horse Pass definitely selected. This forced the railway to cross the Columbia valley and the Columbia river about a hundred miles from its source.

Large forces of railway engineers had been surveying the passes 
over the Rockies and the Selkirk Mountains, and, though the Provincial Government was ignorant of the fact when, in $188_{3}$, they granted my concession, at that very moment the railway company was already building into the Columbia valley in accordance with surveys, which, of course, did not consider the possibility of a vast volume of water being added to that of the Columbia. In the narrow gorges through which that river flows the railway was intended to run just above high water mark as it then existed. The proposed turning would, of course, have necessitated changes as great as they would have been costly.

The railway company, when they learnt of the proposed turning of the Kootenay river, at once took steps to stop the work, and as the fate of the then Federal Government was bound up hand and foot with the success of the railway to an extent only those in the swim can realise, their request was fulfilled with a promptness very unusual in the unravelling of departmental red tape. To me the upshot of these remonstrances, addressed by the Dominion tc the British Columbia Government, were disastrous. The latter, recognising the great mistake they had made in granting my concession without first consulting the Federal authorities at Ottawa, declared that the concessions would have to be annulled if I did not agree to the insertion of a clause obliging me to obtain the consent of the Dominion Government to my canal works. It would have been far better had I abandoned the whole scheme at this stage, but as I had already expended some thousands of pounds, and others were also pecuniarily interested in carrying out the works, I was loth to make this sacrifice.

In the end I foolishly allowed myself to be persuaded to accept the quid pro quo offered by the Provincial Government for my consenting to the insertion of the above clause. This bait consisted in the gift of 30,000 acres of picked land in the Upper Kootenay valley. This land I was to have the right to select, free of cost, as soon as we had completed the canal works on the lines satisfactory to the Dominion Government. To cut short a long story of lobbying at Ottawa, which disclosed some peculiar 
features of the inner life in official circles, I succeeded in getting the new scheme passed by the Dominion Minister at Ottawa.* Its chief feature was that the turning of the upper Kootenay river at Canal Flat was done away with altogether, and instead of it there should be constructed a small navigable canal, provided with a lock to overcome the difference in the two water-levels. The dimensions of this canal were laid down by the Government, and the work was to be carried out under the superintendence of a Government engineer at our cost, and the works had to be completed within two years after the plans and specifications had received the approval of the Provincial Chief Commissioner of Lands and Works.

It had taken me the best part of four years to fight matters out in Victoria and Ottawa, for it was not until late in the summer of 1887 that the canal plans, officially approved by the two governments, were handed to me. By dint of hard work I completed the canal within the prescribed time limit; it was a job I can honestly recommend to those desirous of committing suicide in a decent, gentlemanly manner. As a test of temper and of perseverance against the forces of nature, the malignity of man, and the cussedness of fate, there is, I can assure the reader, nothing like building in a wild uninhabited country, far removed from civilised means of transportation, a canal according to plans imposed upon you by people who have never been to the spot, and who have no conception of what is really required.

There were three bad features about this, the first canal of British Columbia: the first was that it cost about twenty times as much as would the infinitely more useful turning of the Kootenay river; secondly, it did not help the reclamation of the land on the Lower Kootenay, for the lock gates could not be left open during high water; and, thirdly, the Government insisted upon details in the construction which, taken together, made the future use of the canal as a navigable connection between the Columbia and the

* My dealings were largely with Sir Hector Langevin, Minister of Public Works, whose political career came to a sudden termination not long afterwards, in consequence of disclosures which did not surprise me. 
Kootenay river, if not exactly impossible, at any rate very problematic. To expend ten thousands of pounds upon a work which one feared could never fulfil either of the principal objects for which it had been intended, was in itself an unsatisfactory lookout, though its ulterior inutility did not affect us, for the 30,000 acres in the Upper Kootenay valley and the rights to the overflowed land were secured by the completion according to the plans settled by the Government, and the canal became public property.

The construction of the canal itself was the easiest work, for no rock or other obstruction was encountered, and as it was only $45 \mathrm{ft}$. in width and $670 \mathrm{ft}$. in length it was really not much more than a big ditch. Very different, however, was the construction of the lock and flood-gates imposed upon me by the Dominion Government, for as soon as the excavation got below the level of the Kootenay river an immense body of sepage water was struck. As the foundations of the rooft. long lock had to be sunk to a great depth, several large steam-pumps had to be brought from the coast and rigged up to allow excavation and the laying of the ground sills. This, of course, cost thousands of pounds. My appeals to the Government to sanction certain very obvious alterations in the construction of the lock were futile; one of those unpleasantly sudden changes in the ministry having placed a new Chief Commissioner of Lands and Works in power. This official turned a deaf ear to all reason, and as the resident Government engineer was no sufferer by the prolongation of the works, for his monthly salary was paid by us, it was useless to expect any help from that quarter. This gentleman was by profession and by previous training merely a land surveyor, but he was the brother of the Deputy Chief Commissioner of Lands and Works-one of the permanent officials of the administration.

Thus it came to pass that, in defiance of reason and common sense, the works had to be completed at the cost of sums which might as well have been thrown into the sea. But the punishment 
followed rather more swiftly than was expected, and, short-lived as was the reign of this particular head of public works in British Columbia, it was yet long enough to witness his discomfiture. Within twelve months of the issue of the Crown grants for the twenty-nine estates, in which form I had picked our 30,000 acre grant, this minister of the Crown had to insert in the estimates presented to Parliament a sum of 25 oodols., wherewith to close up the canal, which had cost the country 30,000 acres of the best land in the district! For it was feared that during an exceptionally high water the Kootenay river might get the better of the gates and lock, and take it into its head to carry out my original scheme, and flow into the Columbia.

I am rather impressed by the necessity of explaining the râison d'étre and history of this useless canal, for I feel no desire to have this work, as carried out, go down to posterity as either proposed or desired by me. The last writer on matters British Columbian, Miss MacNab, makes the following remarks about it: "A more useful work could hardly be imagined: but the way it was carried out rendered it speedily abortive. On my return journey I went to see the ruins of this miserable little canal. The only result of the canal at the present time is to render the navigation of the Columbia river more difficult than before by turning the water into the Kootenay."

If critics, so blind to primary facts as is this good lady, are to sit in judgment on one's deeds, another attraction will be added to suicide by canal building. Whatever natural wonders Miss MacNab discovered in her hasty skim through the province, the feat of the waters of the Columbia being turned by the canal into the Kootenay is by far the most remarkable; for, as the Kootenay is at least I Ift. higher than the Columbia, Miss MacNab wants her readers to believe that water in British Columbia is able to climb upstairs!

Those two years of canal building brought with them quite a little crop of "experiences" ; let me relate a few for the benefit of those attacked by that insidious malady, the pioneering fever. One 
of the first things for me to do after the Government had settled the canal plans was to erect a steam sawmill at Canal Flat, wherewith to cut the half million or so feet of timbers and lumber (boards) for the lock and the buildings required for the works, for of course there was not a habitation larger than a Io by 12 log shanty within a radius of a hundred miles.

Nothing is easier than to buy a sawmill such as I wanted. You get prices from the various leading manufacturers, you consult a reliable expert in sawmills, who will give you his opinion concerning style, make, and size of mill you require. You follow his advice or you don't, you wire to the people who are to have your custom, and as the last act in the drama you draw your cheque, for as you are not known in the world of sawmill-men, the terms are strictly cash, though you do manage to get off a good discount by paying "spot cash." There you are, happy owner of the latest style of steam sawmill, guaranteed to accomplish a wonderful variety of jobs, known by as many technical names that convey no meaning to an outsider's mind. But there is an "if " in the case; that nice mill machinery is 2000 miles away-at Toronto, or Brantford, or Chicago-and not on Canal Flat, for your blandishments to induce the manufacturer to quote you a price for the mill put up ready for work have entirely failed. "Never sold a mill yet on those terms to British Columbia, don't know enough about the country to risk that," says the shrewd business man, and the older you get the shrewder that man will grow in your estimation. Vainly you urge upon him that Canal Flat is but a trifle over ıoo miles from the nearest Canadian Pacific Railroad station, and that the great Columbia, "one of America's longest rivers," affords a connecting link all the way up from the last railway station. A glance at a map betrays the fact that these hundred miles are unfortunately not at the business end, but at the nursery end of the Columbia, so you fail to convince that man. The next person you try to wheedle is the mighty arbitrator of man's fortune out West, i.e., the head of the freight department of the Canadian Pacific Railroad, upon whose word hang, in your case, 
hundreds of pounds. This dignitary's time is worth more than that of the Premier, Finance Minister, and President of the Privy Council of British Columbia put together, and the personal interview you have at last obtained with him in his luxurious office in distant Montreal, is necessarily of the briefest. For though he receives you in his shirt sleeves, lounging back in his swing armchair with a cigar in his mouth and his hat on his head, the fact that half a dozen shorthand clerks and typewriters, seated at the back of the gigantic writing desk, are awaiting their chief's dictation, indicates what a busy man you have before you.

All freight handled by railways in America is classified in ten or twelve classes, light and bulky articles paying ten times as much as castings or other heavy things. You state your case as briefly as you can; you want a certain number of cars from Brantford, in Ontario, to Golden, on the Columbia, a matter of fifteen hundred miles or so. The principal articles you want to send are the aforesaid sawmill machinery, the goods for the store, and some heavy draught-horses trained to haul logs. The point you desire to have conceded is to get machinery rate for the whole lot; but a brief glance at the list of goods you hand to the railway magnate settles the matter; you have to pay " 2 . Class mixed car-load rates," i.e., pay for the machinery the high rate, or ship one whole car-load of each article, which in this case would have meant a dozen trains. The plausible arguments you have prepared for the occasion to convince the official that, as the sawmill and the store are pioneers of their kind in the vast Kootenay country, and hence should receive encouragement from the railway company, are, somehow, left unsaid, for you instinctively feel that the magnate's reply will be a cynical inquiry whether you think that the Canadian Pacific Railway is being run for the health of British Columbia pioneers! It needed not to remember the old, and I believe quite true, story told of the Canadian Pacific Railway autocrat's facetiousness to convince one that the "Damn the public and God bless the Canadian Pacific Railway" principle of doing business was not one from 
which to expect favours.* So you betake yourself off to more genial regions with the knowledge that you have to pay some $f, 150$ freight for each car-load, and your heart is filled with gratitude that the great line, built with the people's money, deigns to handle your poor little freight at all.

By the time those capacious freight cars reached their destination at the primitive little "siding" at Golden, the completion of the Canadian Pacific Railway, a year or two

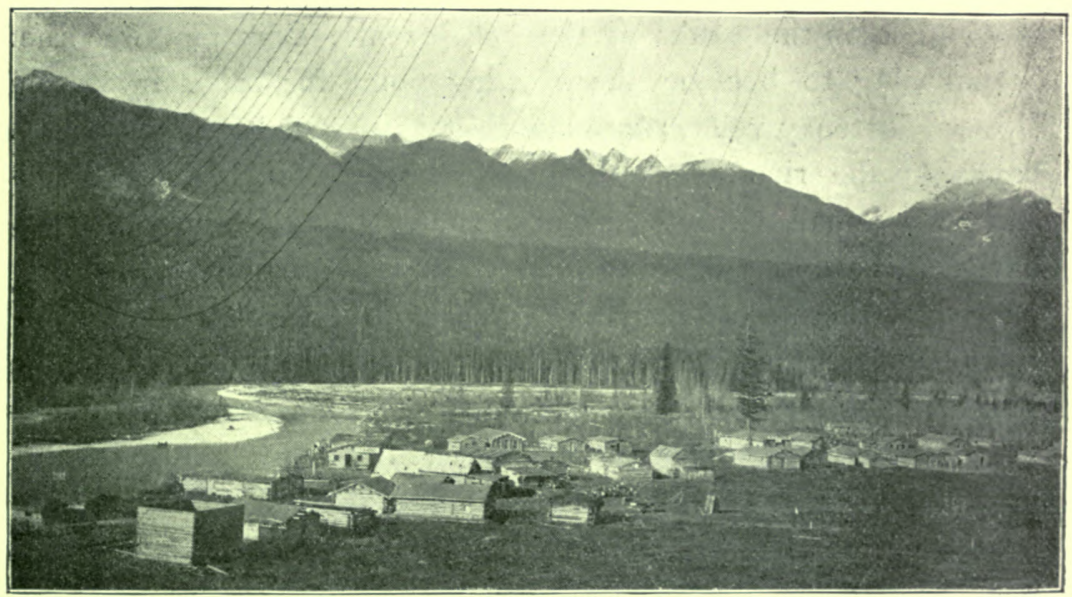

Golden City, B.C., in I886.

previously, had peopled the Columbia valley with some scores of whites, all more or less connected with or dependent upon the railway which had so boldly pushed its iron way into absolutely uninhabited and heretofore entirely unexplored regions. They

* As this story may not be known to all, it is worth repeating. In the town of Portage la Prairie there lived a lawyer of a rather nervous and exacting temperament. He had ordered some articles shipped to him by freight. There was some delay in their arrival, and he went a number of times to the station, with growing impatience, to inquire why they did not come. One day the station agent was busy and worried with more important matters. Two trains were coming in, and there were a lot of things to be attended to ; so when the 
formed little communities at Golden and at Donald, where whiskey saloons and gamblers "rounded up" most effectually the dollars paid out by the railway company to its employees. The first named of these little shanty settlements, now the flourishing little "city" of Golden, was then a somewhat "tough camp," consisting of a dozen or so of $\log$ cabins, and resembling in other respects that idyllic Northern Pacific station Sandpoint, though, I must say, that murders were not quite so frequent, for it actually possessed a constable, with a beat the size of Wales with Cornwall thrown in.

Golden, on the banks of the yet juvenile Columbia, was then commencing to become the starting point for travellers to the Upper Kootenay valley; a make-shift trail had been cut on the banks of the river, and an enterprising Canadian had actually started a small flat-bottomed steamer, wherewith he hoped to navigate the upper waters of the rivers as far as the mother lake, on the furthermost banks of which lay Canal Flat. When my freight at last arrived, the cars were uncoupled from the train, and I received notice that I must empty them within twenty-four hours. Pleasant outlook! The station consisted of a single little building in which the agent slept and lived, and as there were no buildings near in which the closely packed goods could be stored, the packing-cases and machinery, the casks and kegs and bales had to be unloaded and stacked alongside of the track in the open. A spell of "wet weather," to use a mild term for a week of rain by the bucket, the absence of all means to shelter the things from the wet, and the presence of sundry suspicious characters about

importunate attorney began to scold about that freight, he lost his temper, and said, "You go to hell." The indignant lawyer, a pious man by the way, wrote a complaining letter to President Van Horne about the delayed freight, and ended it thus: "And this is not all. When'I again brought the matter to the attention of your agent at this place he treated me with rudeness, and told me to go to hell." By return mail a reply came from Montreal, which read as follows: "Dear Sir,-I am in receipt of your letter of the I6th inst., in which you inform me that our agent at Portage told you to go to hell. In reply I have to say that you need not go to hell.-Yours truly, W. C. VAN Horne, President." 
"town," from whose depredations it was necessary to guard the goods day and night, made things the reverse of pleasant. How high-handed are the proceedings of railway companies in a new country, where the absence of all competition makes them lords supreme, can be seen from the fact that although I had insured the rapid transit of the goods by paying a higher rate of freight, a delay of weeks on the journey, which caused me very serious loss, was laughed out of court by the company. I was, moreover, obliged to sign for the goods before I was allowed to take them over, thus preventing me from making any claims for things stolen during transit. One of the valuable horses I had on one of the cars was so injured by an accident to the train that it died, but never a penny was to be obtained from the company.*

But let us hie back to the sweet solitude of the Columbia. The most unpleasant result of the railway's tardy delivery of my machinery was that the water in the Columbia, at all times precariously low for steamer navigation, had by the end of August sunk to such a low level that the one existing steamer could not reach points higher than half-way up the river. Indeed, her last trip had ended disastrously, and she was now lying in the deepest hole she could find in the river, with a huge snag through her bottom, and all but her smoke-stack under water. Matters looked serious, for it meant a delay of quite eight months in getting the sawmill to the spot, which would have been fatal to my enterprise for the completion of which the Government had fixed two years.

Help, however, came from an unexpected quarter. To realise - the primitive means of travel in those days, it must be remembered that there was no road up the Columbia from Golden to Canal Flat, and the few existing row-boats were far too small to take the big

* In another case a big box full of new clothes, sent to me from England to Victoria, via the C.P.R., arrived broken open and a lot of things abstracted, and though I drew the attention of the officials to the condition in which I received the box when I signed for it, I never received any compensation. Numerous other instances of such thefts could be cited. See Appendix, Note VI. 
sawmill boiler, which alone weighed over 5ooolb. A short time before an Indian rising had occurred in the Upper Kootenay valley, caused by natives having murdered two prospectors near Canal Flat. When the Upper Kootenay settlers arrested the culprits, the latter's kinsmen, with cocked Winchesters released them by force. This had caused the Government to send a small detachment of some fifty or sixty mounted police into Kootenay. Instead of sending them over the Crow's Nest Pass, where a trail had been cut, they were sent in via Golden, and this unprecedented influx of travel had, of course, caused a boom in all means of transportation from Golden up the river.

A scatterbrained young Canadian had been bitten with the idea of starting a rival steamer, and he invested a few hundred dollars in buying up a square-ended barge that had been used in the railway construction to drive piles. She was made of four-inch planks, and was of the unwieldiest shape, i.e., about as broad as she was long. Somewhere else he had picked up cheap an old upright boiler that had once formed part of a Manitoba steam plough, and in another place he had obtained at "old iron" prices the discarded machinery of a small river tug. These three component parts of a steamer were awaiting the advent of a deus ex machina, who could put them together, and make a steamer of them. This the skilled mechanic I had, fortunately, brought out from Ontario to superintend the erection of the sawmill proved to be, and by using a few parts of my sawmill machinery, a unique "steamship" was patched together.

Nothing quite so odd as this pile-driver steam plough-sawmill combination steamer has, I am very sure, ever navigated water, and as we took twenty-thrée days to cover the hundred miles, our rate of progression can be easily calculated, every minute of daylight being, of course, made use of. Her little boiler, that had once careered about Manitoba wheatfields, had a fire-box constructed to take coal, but as this article was unobtainable, we had to cut up sticks of wood to about the size of grown-up toothpicks and soak them in coal oil or the fire simply refused to generate steam. The 
boiler, in the absence of a suction pipe, was kept filled with a hand bucket. As the banks of the Columbia are mostly dense swamps, out of which the mountains forming the valley rise precipitously on both sides, and the rains had drenched all the dead wood we could find, the fuel question was a momentous one, and firewood collecting expeditions into the swamps every few hours were the result. The huge planks out of which the Cline was constructed made her "sit kinder heavy in the water," as the owner expressed himself, and as there was no room on board the Cline, her chief load, the sawmill boiler, was placed on a sort of raft and towed. The much rivetted interior of this boiler was about the only dry place during most of those twenty-three nights, and I bagged it for my sleeping quarters the very first day, a sensible dog, who made the ninth of the Cline's crew, and whom I found curled up in the fire-box the first afternoon we were out, giving me a lead in this bright idea.

The funniest thing about the Cline was her steering. So uncompromisingly square was her trough-like hull, that but for the little stern wheel at one end, it would have been hard to tell which of her four sides was supposed to act as bow. Her persistent desire was to go up the Columbia broadside on, hence this did not matter so much. So ludicrous was this at first, until the novelty was worn off, that we passengers, seated on cogwheels or kegs filled with nails, whose business ends wore out the seats of our breeches, made the silent scrub-clothed banks of the Columbia ring with our laughter. If the craft was a singular looking one, the river we were on was but a counterpart to it. Such a variety of sand and mud banks, such an array of snags, consisting of wholly or partially submerged tree trunks, lying with the stream, and hence forming dangerous projections for crafts to impale themselves on when going up stream, had never been seen. At numerous points the river, winding through the swamps, splits into a multitude of channels, their deceptive appearance luring one into cul-de-sacs miles in length, out of which one had to retrace one's course when at last the true character of the blind 
waterway dawned on one. In other places again, as if nature had not done the best she could to puzzle the navigator and try the length and strength of his temper, the animal kingdom had come to her assistance. In the days preceding the inauguration of the salmon canning industry at the mouth of the great river, where now some 2000 great seine nets bar ingress, untold quantities of the royal fish ascended the I 200 or I 300 miles to its very source, i.e., the lake which we were striving to reach, and which lies about 3000 feet over the Pacific Ocean. There all the conditions of water, gravel, and slow current favoured the process of spawning. The countless ridges in the gravel bottom of the young Columbia where it emerges from the mother lake,* cast up during untold ages by the tails of the parent fish, gave in 1887 still silent evidence of the vast quantity of fish whose instinct had driven them to perform what is undoubtedly one of the most remarkable journeys percormed by any denizen of the ocean. These salmon beds extended for three or four miles, ridge following riage, the depth of water on the top of each crest, at the time, hardly exceeding a foot.

Not far from these salmon beds, by which name the locality is still known, a side stream puts in from the neighbouring Selkirks. These mountains, though not more than ten miles or so in an air-line from the parallel ridge of the Rockies, have much more rain than the latter. In consequence of this, the tributaries from the Selkirks often come down in full flood, with the result that the current of the Columbia above the junction suddenly changes into the opposite direction, flowing up to instead of down from the source. Almost incredible as this sounds, I have seen it do so on several occasions, the effect of this extraordinary state of things being that the water in the Columbia below this tributary would suddenly fall, leaving one stranded until the flood had ceased. $\dagger$ We came in for two of

* There are really two lakes connected by a short "gut."

+ In recent years considerable sums have been spent by the Government in dredging the salmon beds, thereby increasing the current, so that this turning of the current no longer occurs. 
these riverine coups de théattre, for, of course, it was on the upper part of the Columbia just below, and just above where the sportive Toby Creek set all natural laws at defiance, that most of our twenty-three days were spent.*

There, too, we did the most execution among the sandbanks and snags, and I am sure those coming after us found many a well-known old mudbar shoved out of position, many a veteran snag twisted from his well-known post of vantage; at least if the

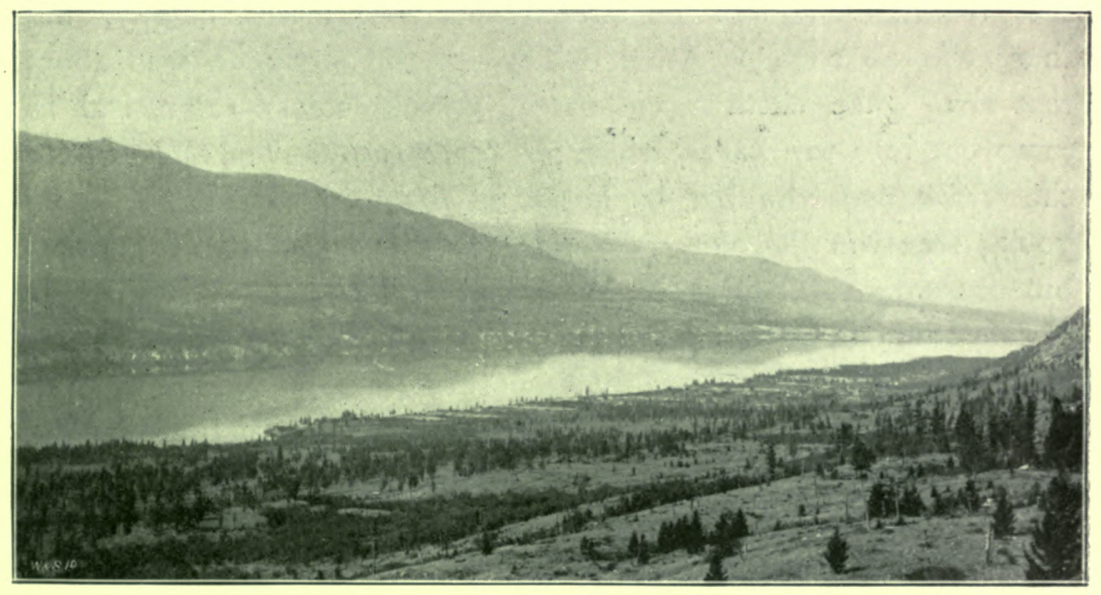

The Upper Columbia lake, the source of the Columbia River, looking towards the Foothills of the Selkirk Chain.

The photograph was taken from the Foothills of the Rockies rising steeply.

-vigour and frequency with which the broad-breasted Cline rammed them, counted for anything. There was no fooling about it: with a full head of steam we went at them, and the safety valvebut there, I won't say what we did do with that self-same safety

* There is one other river where this most singular phenomenon can be observed, i.e., the Sumas river, which flows out of Sumas lake into the Fraser river. When the latter rises very suddenly the current in the Sumas river is reversed. 
valve, assisted by a good coal oil fire, for I believe there are such beings as steamboat inspectors. But presently even a $200 \mathrm{lb}$. pressure of steam and a ton pressure of western eloquence failed to secure a sufficiently broad high-road through an obstinate old mudbar which stoutly refused to be shoved on one side, and disputed with more might than right the freedom of the highway. The Cline, and not the bar, was shoved aside by the current, and we got stuck hard and fast in the clammy embrace of good stickfast Columbia mud. The water looked, and felt, cold; snow was low down on the mountain side, and the air was, to say the least, "chippy," but there was no choice. All of us, except the engineer, who about that time gave extra attention to the old safety valve, had to jump out into the water, which reached to our waists, and to prise the Cline over the bar by means of long crowbars made from young trees on the bank. This we had to repeat more than once, but presently this no longer sufficed, and we had to make portages of her load, or, in other words, take out half of her load of bulky machinery, \&c., dump it on the bank, make a bold dash at the bar and shove the lightened steam-trough over the obstructing bank by the sheer lifting power of eight men, then unload what remained of the cargo above the bar and go back for the first half, and repeat this steamer shoving ad infinitum. That the novelty of this sport began presently to pall, need not be said, and by the time we did get to our goal, I was quite of the same opinion one of my fellow sufferers had expressed respecting the desirableness of forthwith ordering a glass case wherein to preserve for all time the Cline, lock, stock, and barrel.

A description of the difficulties obstructing access in those days would not be complete were the "rustlers" to be omitted.

What is rustling? Rustling! Well, rustling is a pleasant way they had on the romantic Columbia in those early days of raising a winter's supply of grub, liquor, stoves, coal oil, clothing, canned fruits, and all the etceteras a man wants to carry him over the winter in a pleasant manner. People living in other countries might have transgressed the ethics of the Columbia by giving it 
some such hard name as Grand Larceny or Wholesale Stealing, but then it would not have been safe for such high-toned morals to be bandied about within earshot of your genuine knight of the river. The way it was done is simple in the extreme. Wherever the steamer, row-boat, or pack-train dumped its load on the lonely banks of the idyllic Columbia to await further transportation, which might occur after a couple of days, or only after a fortnight, during which the bags of sugar or flour, sacks of bacon or ham, boxes of dried fruit or tobacco, remained exposed to rain and hail, the ravages of wolves, skunks, and rats, and, worst of all, to human animals of prey. There the rustler rustled in the darkness of the night, in the silvery romantic light of the moon, or, if pressed for time, even in broad daylight, for your true rustler knew no fear in a country where officers of the law were exceedingly far between. Some of these pleasant gentry were modest, and contented themselves with a half, nay, actually even with a third of the contents of the tobacco caddy, coal-oil case, tea chest or coffee bag, and I have actually received, among the thousands of pounds of provisions needed for my different camps, tobacco caddies where only a fourth of the contents had been rustled, tea chests reduced by only a third, but then I was told I was in luck, in big luck, and I think I was, if I compare with it some other people's experiences, whose kegs, boxes, cases, and bales reached them only on paper, i.e., on the bills of lading.

Some of the rustlers went in for the ornamental as well as the useful, and filched sets of tableware, fancy dress goods; and one, evidently a stranger, even fitted himself out with some wash-boards, but no doubt he soon found that one could get along in Kootenay without "cottage pianos." Those who were getting machinery of any kind into the valley were even worse off, for the loss of any one part, impossible to replace at any price, caused, of course, the whole to be useless, and great pecuniary losses were thus inflicted upon people getting in agricultural and mining machinery. The western man, they say, has always his wits about him, carries them ready in his waistcoat pocket if he has 
one, but the man from the Columbia had them safely stowed away in his neighbour's pocket. If one or more pack-horses broke down, and a sack or two of oats were badly wanted to put a spark of life into shadowy, anatomical specimens of the genus horse, you heard such reassuring words as, "Here, Jack, run down and 'rustle' a bag or two of them oats from soand-so's outfit, and mind you don't pick the smallest." The horses are fed, and away, well pleased with himself, went the amateur rustler, for amateur and nothing better was he who did no more than such slight pilfering, and did not "stay with the pile to the end of all things." Of course, now and again excuses for a little amateur rustling were to be made in a country where there were no ranches or other human habitations, and an instance in which I figured as such an amateur carries its own point. Some of my mill machinery had, notwithstanding my best personal efforts, got astray between Golden and Canal Flat, and while looking for it along the banks of the Columbia, I found myself one afternoon alone at one of these dumping places where lay, entirely unguarded, huge piles of many thousand dollars' worth of freight, left there a day or two before by the steamer, which could not get farther up the river on account of the rapidly falling water. I was wet and hungry, for I had been for hours up to my waist in the Columbia, and I had had nothing to eat since 6 a.m. The first thing my eyes lit upon was a roolb. bag of beans, and, not having any grub of my own with me, I "stayed," in local parlance, with a potful of them as only a very hungry man can. My meal finished, and in decidedly better humour with myself than when I commenced, I prepared to proceed on my journey, but before doing so I thought I would examine the bag to see to whom I was really indebted for my free feast, when lo! on turning over the sack I found my own name in big letters on the back of it! 


\section{CHAPTER XII.}

\section{RUNNING A SAWMILL AND A STORE UP COUNTRY.}

My millwright, though one of the most objectionable Canadian bounders I have ever had anything to do with, was a splendid worker, and ten days after we had unloaded the boiler and machinery at the Flat our small force of eight men had completed the foundations of the mill out of hand-squared logs, and the first shrill blast of the mill whistle sounded the death knell for many of the giant yellow pines $(P$. ponderosa) growing in stately groves within handy distance from the mill.

From that day boards-lumber they are called in Americaflowed freely from that gleaming blade revolving at lightning speed through ponderous logs $3 \mathrm{ft}$. or $4 \mathrm{ft}$. through. Soon we had the mill housed, and had put up some shelter shanties, for winter came early that year, and our flimsy tents were in the habit of collapsing in the most uncomfortable manner under the pressure of the sleet and snow-laden gales by which winter heralds itself in that region.

Man is born and man dies, and these two principal incidents of our existence the new sawmill accentuated rather oddly. The "first slab* which that circle of bright steel sliced from a bulky log I happened to present to an Indian squaw standing by, in mute amazement watching the invisible power first drag the great tree, nearly twenty feet long, up to the saw, which then bit its way through it as were it so much cheese. She evidently prized the relic, for next day she showed me part of it turned into

* The technical term for the first and last longitudinal piece cut from the log. 
a cradle, or, rather, into a papoose-board, on which babies are strapped for transportation when the mother makes horseback journeys.

Death, as we shall see, did not lag far behind the primitive cradle. The police force, who had previously garrisoned a post in the swamps of the North-West Territory, where mountain fever, which is nothing but a form of typhoid, was a frequent visitor, had brought with them the germs, and soon an epidemic of it was raging in the otherwise extremely healthy Upper Kootenay country. Two of their men, returning from a long ride to Golden, were suddenly taken ill while resting themselves near our mill. Within a couple of hours they were so bad that I sent one of my men to the headquarters of the force about fifty miles off, where they were erecting a regular post, the present Fort Steele, for the Indian troubles did not promise to be over just yet. The man rode the night through, and next evening one of the police freight waggons drawn by four steaming horses was back, though not with the doctor, whose assistance was so urgently needed. The sergeant in charge of the conveyance had orders to bring the men to the fort, for the doctor had his hands full there, and could not possibly leave, and civilian doctor there was none nearer than Donald, four days' journey off. I felt very loth to let the sick men leave, for they seemed as bad as they could be. But the sergeant would hear of no delay, so, after giving them strong doses of anodyne, the poor fellows were lifted into the waggon-bed, a layer of fir branches, which I placed underneath them, softening a little the terrible jolting in a springless waggon driven at a trot through the woods over stumps, and roots, and through waterholes.

It was raining heavily at the time, and as the driver had forgotten to bring the canvas waggon cover, the doctor's instructions to the sergeant to bring with him as much inch lumber as he could find room for were acted upon, by lashing a sort of roof over the waggon-bed in which the sick men lay. Death is habitually taken in a lighter vein by western men than it is among more civilised surroundings, where accidents are rare, but 
nevertheless the sergeant's reply, when I asked him for what purpose those inch boards were required at the fort, must have seemed of grim significance to the invalids lying there in plain hearing. "Oh," said the sergeant, "the doc. told me that if the men were looking bad, I should bring enough lumber along to bury them with, for they have more dead men than lumber at the fort, and whipsawing ain't healthy this weather."

The sergeant wasn't out very far, one of the men, we heard, was dead when the post was reached, and the other one "used up the balance of the lumber" a day or two later, as the driver laconically wrote to one of my men.

The fever epidemic came nigh making also me a customer for my lumber. It attacked me quite suddenly, while on a long ride, and, being unprovided with blankets, I was laid low in the only human habitation in that part of the Columbia lake country. This was a little whiskey den just then frequented by drunken freighters, gamblers, and "toughs." It consisted of a log shanty, i.e., one room, the floor of which was unboarded and reeking with tobacco juice, and other even worse filth. There was no bed or table or chair in the place, everybody "going to.bed" on the floor. The bar consisted of boards laid across supports, and the seats were empty casks. There, in a corner of this den, which was in full possession of drunken men, I lay for days, huddled in a blanket or two which the owner had lent me. Those who. have read the first book ever written on Kootenay, by the witty authors of "Two in Norway," * may remember the description the authors give of how they found me lying on the floor in that miserable den. I would not mention this highly uninteresting circumstance, but for an amusing error into which these writers fell. The only adornment on the walls of the room was a horse's jawbone, nailed to one of the logs over the bar. On pieces of paper nailed up to the left of it was the word "No," and on the other side of it the word "Here," the whole reading, of course,

* "British Columbia in 1887 ; or, a Ramble in British Columbia." By Lee and Clutterbuck. Longmans, 1888 . 
"No jawbone here," which translated means, "No tick." Ready money or gold dust, which latter, until the advent of the police, was the usual currency, had to be in sight ere "poison" could be tasted. The authors of "British Columbia in 1887 " noticed this adornment also, but they misunderstood its meaning, for they say of it: "A quaint conceit, which, in the interest of truth, might

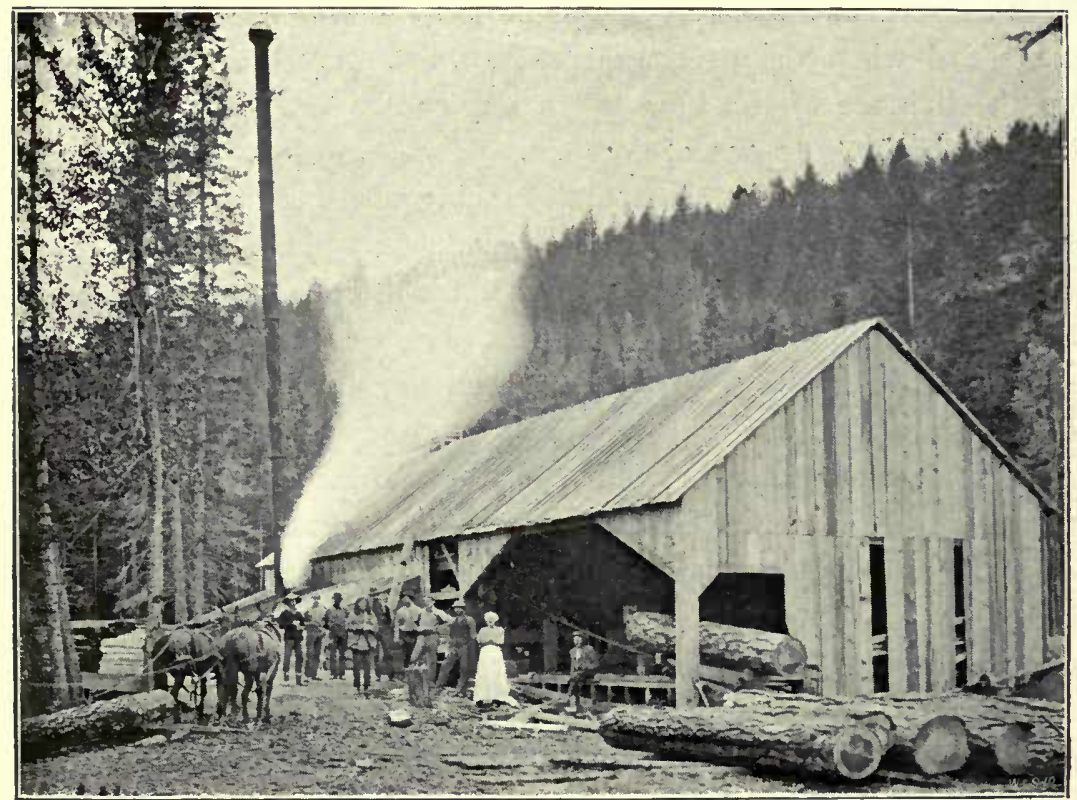

WEEK-DAY WORK,

The Sawmill at Grohman, B.C. (the first Steam Mill in the Kootenay Valleys).

be adopted in most of our .English gun-rooms and smoking-rooms." I much fear that truth is an article considered much too priceless out yonder to deserve such marked attention.

I had a busy time of it that autumn, for as soon as I could sit a horse again, I had to start out to organise and superintend two outfits of surveyors, and to select in a valley 90 miles long the 30,000 acres comprised by the concessions. This was not 
easy work, for the future value of the various twenty-nine estates would, I knew, largely depend upon a judicious selection.

When winter obliged us to shut down work in the mill we had already cut a considerable quantity of the lumber required for the lock, which was commenced at the first possible opportunity in the following spring.

The season of 1888 brought also lots of work for me, for the

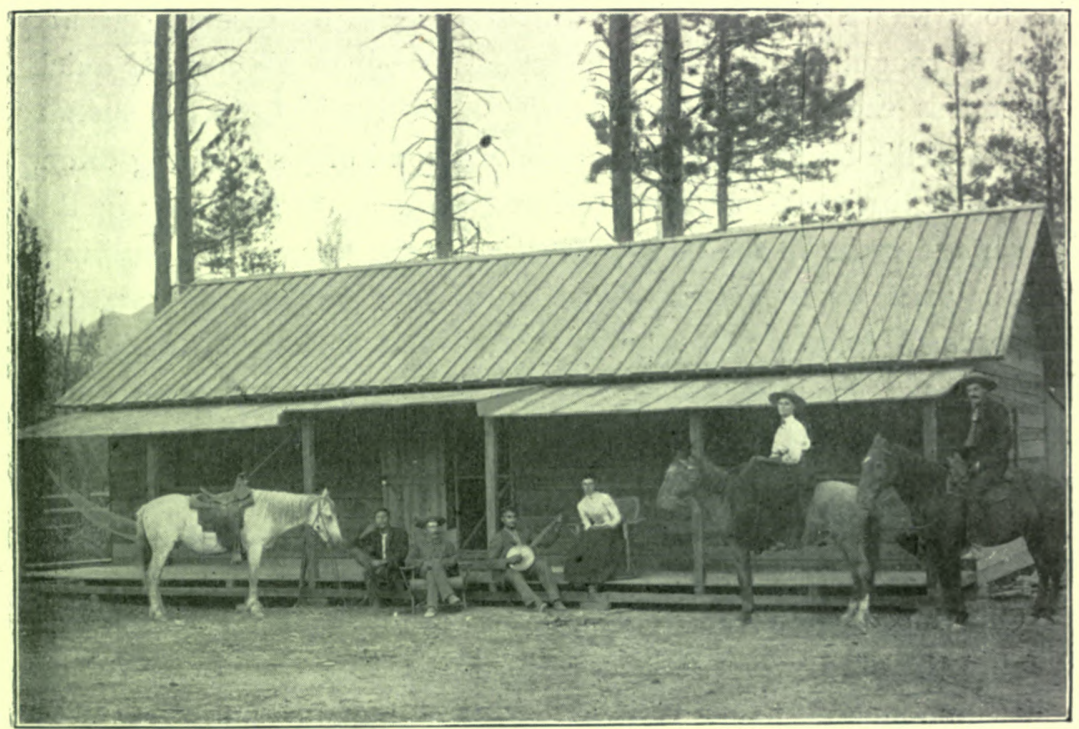

Sunday Rest.

The Managing Director's "Palace" at Grohman, B.C.

contractor had put a couple of hundred men to work on the excavation of the canal, and Grohman, now boasting a post-office, was a lively little place.

The post-office was in the store I had started. The latter, as well as the hotel which I built close to it, and which was licensed to sell whiskey, did a roaring business, and as the nearest general shop was at Golden, roo miles off, we had not only the custom 
of all the men in the Company's employment, but also that of all the Indians.

Our force was a decidedly heterogeneous lot, white men from all parts of the civilised world, not forgetting Africa's contribution in the shape of a funny old Boer, Van Moerkerke by name, Chinamen, French half-breeds, Italians, Swedes, Indians, and even a nigger.

The foreman of the timber men employed in the construction of the lock was a Liverpool-born Britisher, Bale by name. Twenty years of roughing it in Western camps had given his natural quick wittedness that smack of Western humour which forms such a feature of life on the frontier. Bale was fond of his morning dram, and when the autumn frosts rendered work up to the waist in the icy sepage water in the lock-excavation, more than ever uninviting, Bale's visits to the store, where a private bottle was kept for purposes of Western hospitality, threatened to become a regular institution. As I generally was to be found in the little office attached to the store, and it was worth while keeping burly Bale in good humour, he usually found me responsive to his gentle hint that the morning was particularly frosty, and that the ice that had formed on the water in the lock overnight was inches thick.

One morning, upset by something or other, I was seated as usual in the office when Bale came in just before the seven o'clock bell summoned all hands to work. Out of humour, and cross with everything visible or invisible in the raw dawn of a frosty November morning, Bale's usual hint found for once an unexpectedly curt reception.

"Look here, Bale, over yonder is the hotel where you can get as much whisky as you like for 25 cents a drink; you get 5 dols. a day wages, and I don't see why you should want a free drink every morning when none of the other men get it."

Bale's good humour did not leave him for a second, and he cheerily replied :

"All right, boss, no harm done, for you can dock me all the free drinks I have had." 
Bale, however, did not forget my churlish reprimand quite so readily, and paid me back a day or two later in the following amusing manner.

It was Sunday morning, when the men lay off until noon. I was attending to postal matters-for the Government had heaped insult upon injury by making me Postmaster at Grohman at the regal salary of 4 dols. a month-and the store was full of men. Awaiting his opportunity, Bale presently approached me, and in his good-natured way commenced conversation respecting the topic that of course lay nearest my heart, i.e., the lock construction. Breaking off, presently, he said:

"Say, Boss, I had a mighty funny dream last night, all about the canal and you and miracles!"

"Well, Bale, let's have your dream; if it was about the canal and miracles it's sure to be interesting."

"Well, Boss, I dreamt that I was dead, and that I was being interviewed by old Nick himself. 'Bale,' says he, 'you are a damned good chap; I have heard of you before up at Grohman, and I want you to see what kind of a show I run down here, so you can just ask me to do the most difficult thing you can think of, and it will be done before you have time to wink those goggle eyes of yours.' Well, I kinder thought for a minute or two, and then said: 'Say, old gent, take up yonder Rocky Mountains and dump them where those Selkirks are, and put the Selkirks where the old Baldies were.' And before I had finished, the job was done, and no mistake about it."

"'You have got to try something harder to stump this child,' . said old Nick; so I axed him to make the water out of the Columbia lake climb up the canal into the Kootenay, and hardly were the words out of my mouth when a big wave came a-busting up the canal, climbing over the lock works, and rolling on as gay as you please till she fetched up in the old Kootenay."

"' 'That's nothing,' says the old gentleman, good-humoured like, 'can't you think of something harder than making water climb upstairs?' Well, I sets to and turns it over in my mind, and says 
to old Fetch-me-down: 'Just you dry up the Columbia lake, and make a big city, with saloons and hurdy-gurdies and variety shows, and a theatre or two, and streets, where the lake is deepest.' 'Well, Bale, you are an old duffer,' says the old man; 'can't you think of something that's not quite so easy as that-something that'll make me think twice before I can do it!' And really, there, deep down in the hole where the lake had been, stood a mighty purty city, full of people and streets and gay places, and I could hear the steam whistles all a-tootling in fine shape. What to wish next I no more knew than that son of a gun of a Chinaman yonder ; but sudden like I did remember what I thought would rattle the old cove, so I up and says to him, 'Well, make Grohman stand a free drink.' And, by Jove, that did the trick, for old Nick turned palelike, and, after some humming and hawing and scratching of his tassel ears, he says, says he: 'By golly, if you haven't gone and done it this time, old chap! Make Grohman stand a drink! Why, that's the one thing even old Nick can't do,' and he shook his horns to let you see he meant it!"

Needless to say the drinks I had to stand all round to the crowd of laughing men was not the last I heard of old Bale's dream. Months afterwards, while travelling across the Continent, an objectionable Chicago drummer was good enough to read out to me from a New York newspaper an embellished version of what he called one of the best Western stories he had heard for a long time. He little thought that its victim was sitting opposite to him in the Pullman.

The Boer Van Moerkerke, better known by his nickname: the Major, was great on trades, i.e., swapping. One day he came to me, requesting me in his quaint Dutch-English to draw up a bill of sale-J.P.'s are supposed to be able to do and to know everything in connection with the law-by which he conveyed a mining claim he had recently discovered to a French half-breed in consideration of the following articles: a pair of gum-boots, a Colt frontier pistol, the third of an alluvial gold claim, a shotgun, and a saddle. To the latter there seemed to hang a tale, for the vendor in a 
separate clause agreed that if the saddle should be claimed, or, in other words, if the real owner should turn up, the one-third interest in the mine should be increased to one-half. As several saddles of my own had lately gone astray, I expressed a desire to see the article reputed to be worth one-sixth of a gold mine. The Major promptly produced it, and the J.P. as promptly claimed it ; it was an old saddle, to say the best I could for it, for I had given only 5 dols. for it, being minus the "horn," and was so badly constructed that it could safely be warranted to give a sore back in the first hour. That was probably the reason why I recovered it so easily.

Another nationality was even more largely represented, namely. the B.B.'s-Busted Britishers, as the Canadians are wont to call that unfortunately largely represented immigrant type. Some of them had reached the "public nuisance" stage, and were "handed their passports" after a day's trial, others were merely financial wrecks, and among these there were several of gentle birth and public school education, who were willing and able to earn their "two-and-a-half" just as honestly as any Italian barrowman or Cannuck axeman. Our carpenter foreman was a London University M.D., who years before had migrated to Manitoba and "had gone broke holding down a quarter of a section," i.e.. trying to farm 160 acres. I was very glad to have him, for sawmills and larger timber works are usually fruitful causes of accidents, so he made some extra dollars binding up wounds and prescribing pills, which, of course, had to be bought at our store. There was a certain absence of professional etiquette about the whole proceeding that was amusing. The doctor was exceedingly deaf, so deaf that when the twelve o'clock whistle sounded for dinner he frequently failed to hear it, and would go on quite calmly shingling a roof or joisting a shanty. Patients of the non-urgent class would grenerally choose the dinner hour to interview the B.B. M.D. If the latter happened to be seated on the top of a roof diligently wielding his hammer some tall shouting had to be done to make him hear the patient's symptoms, and of course everybody round that particular spot heard them too. I have rarely heard a man laugh more heartily 
than did old Sir Mathew Begbie, who, on one of his circuits through Kootenay, stayed with us on the way. He and I were sitting on the verandah of my shanty, a hundred yards or so from where a new cabin was being shingled by the doctor. Twelve o'clock whistle had just sounded, and, as usual, he had not heard it. Calmly he continued his hammering. Presently a loud shout was heard, "Doc, I say, Doc, those pills you gave me yesterday weren't worth a damn; you have got to-," further details were suppressed, for the doctor had by this time turned round and noticed his patient. He came tripping down the ladder at a great rate. Arrived at the bottom he lugged his patient off into the brush, for that was the only private place for further consultation. Whenever any indistinct shouting was heard on the Flat one knew the doctor was being consulted, a particular thick patch of willows being soon known as Harley Street.

The Canadians did not get on well with the "Upper Crusts" or B.B.'s, of whom they were jealous, for I had the B.B.'s, often over at my house for meals and an evening pipe. Much of this ill-feeling was really caused by the evil-tongued millwright, and one day it came to a head. H—, one of the B.B.'s, was a very powerful young chap, whose work in the mill was about the hardest going. He was a slab carrier, i.e., he had to remove the slabs, or first and last outside boards, as they fell from the log that was being cut up. Not only is this stiff work, but it is dangerous too, for any mistake or inattention is likely to cause severe injury or worse, to himself or the other men about the place. Now, slabs can be cut large or small according to the discretion of the millwright who guides the saw. The larger the slab the heavier, of course, it is, and the more difficult to remove quickly. Of this fact the millwright took advantage to bother the B.B., till finally the slabs became so big that the B.B., herculean as he was, found he was unable to tackle them, and the millwright came to me to complain of him, demanding that I should discharge him. Knowing how matters stood, I was waiting for some such chance, for a more doggedly willing hand than was $\mathrm{H}$ - - that Canadian bounder never had in a mill. It was in this 
instance easy enough to turn the tables on him, for of course such unnecessarily large slabs meant a waste of wood. The reprimand I was able to give the fellow was followed by a very deserved bodily chastisement by hands that had long been itching for the chance. Going with the millwright to the mill, I demonstrated to him the injustice of his complaint by ordering him to lift the last slab cut. $\mathrm{He}$ was unable to do this, and, nettled by the unexpected turn things were taking, he was foolish enough to give the B.B. the lie direct concerning some statement of fact the latter made. Two black eyes and a flattened out nose to keep them company taught the Canadian a lesson which made him civil in future.

The store, which was doing a rushing business with the employees and with the Indians, was also the source of some funny little experiences. I had put it under the charge of another B.B., who declared himself specially fit for that duty, for he proudly informed me that he had been a clerk in a Lombard Street bank. His book-keeping was faultless, also his adaptability to the exigencies of running a brisk trade in an up-country general store where the "general" covered every conceivable article from hand-me-down boots and ready-made clothes to saddles and ammunition, from flour and bacon to syrup, from rope to nails and axes, from felt hats to drugs, patent medicines, and stationery. The only detail of the business he objected to was the Indian trade, for their practice of pricing every article in the store, tantalizingly slow ways, and ignorance of money values-by the end of the summer they knew more about it -raised his ire. I had ordered from a Montreal wholesale house some gaudily coloured "flannelette" shirts, specially recommended for the Indian trade. I did not know what flanrelette was, and I don't know now, but they were remarkably cheap. They were also beautiful to look at as they came out of the packing cases, for the reds and blues and greens stood up and shrieked at you, and made your eyes bulge and parched your mouth. Nothing like them had ever been seen in the Kootenay country, and I thought they would sell well towards winter, when nice warm colours would be acceptable. The summer toilette of the Kootenays, as already mentioned, 
consisted of a scanty breech-cloth, and, if money was flush, of a pair of leggings, to which in winter a blanket was added. To my astonishment - it was then June - the Indians took to those shirts right off. Laid down at Grohman, the B.B. storekeeper calculated they stood in some cents under half a dollar (two shillings), and as they were all sold within a fortnight at 2 dols. 50 cents, those potent reds, blues, and greens seemed to be altogether irresistible. The Kootenays are a fine stalwart race of men, and to see a six-footer stalk into the store and proceed to climb into one of these 2 dols. 50 cents articles was a sight worth more than the shirt cost. For a fortnight we had bucks careering about the Flat on their ponies, showing off those shirts fluttering from their Centaur figures. At night you would see them stand round their camp fires still engaged in blissful admiration. Then something unexpected happened. That June fortnight had been a very dry one, not a drop of rain fell. Then we had a day when it arrived by the bucketful. It was a deluge which precipitated matters, for the very next day came flocking in from all sides Indians covered no longer by shirts, but by waistcoasts of gauze-like fabric to which dimensions and substance these flannelette articles had shrunk.

Not all, it is true, had fared thus, for some of the Indians had enough sense to go in when it rained. But this was only putting off the evil day for the storekeeping B.B., who, of course, would have to face the music at some future occasion. Loudly protesting that the Indians would kill him, he would rush over to my office. "Here is another of those shirt chaps, snapping his Winchester at me, and flourishing his scalping knife; his darned shirt don't cover his ribs any longer, and he swears it got wet only once." "Give him a packet of our 'best' cigarettes, and tell him those shirts are fine-weather shirts, the same the white tyhees (chiefs) wear going to church," came back my reply. But events march fast out West, as a horse thief is reported to have exclaimed when he was caught, tried, sentenced, and was about to be strung up, all within six hours after he had levanted with the prospector's horses. By July those shirts were tight fits for 
the six and seven year-olds in the Indian camps, and by August they were worn as comforters-and it wasn't a particularly wet summer either!

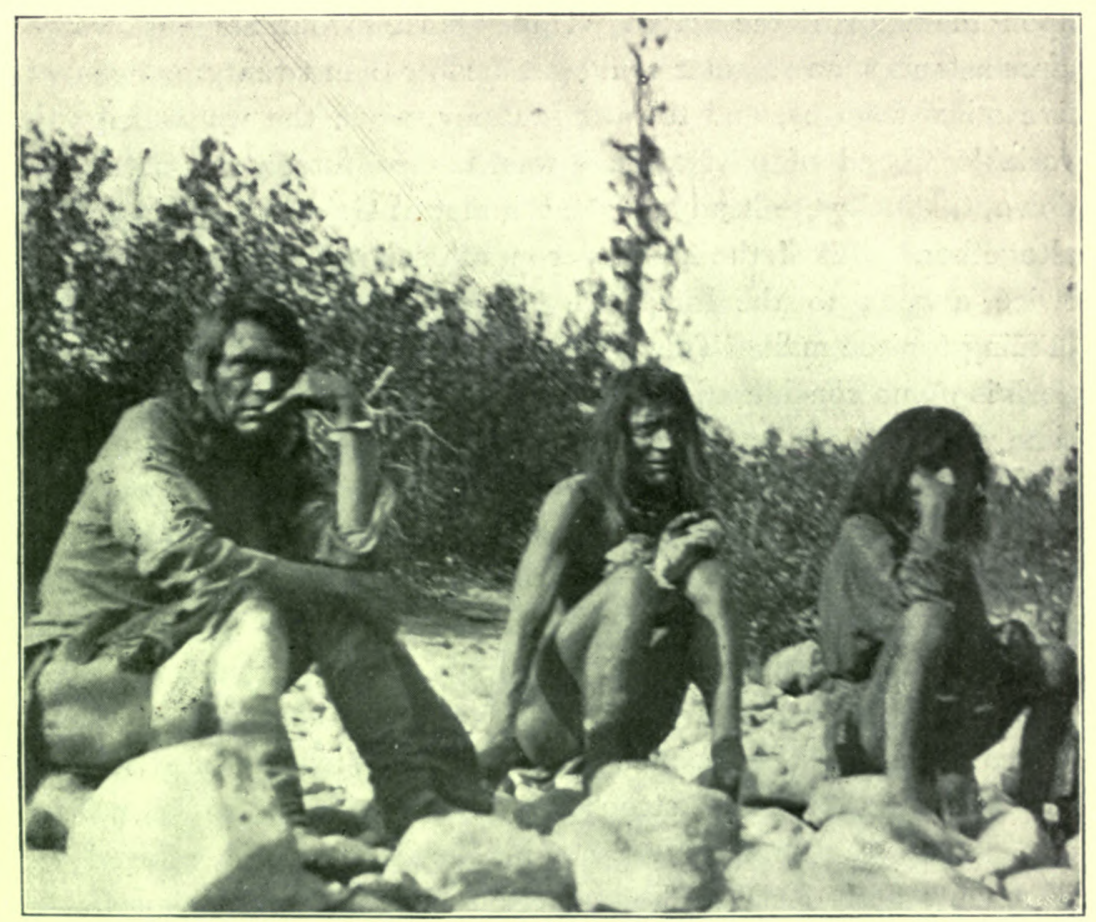

Kootenay Indians pondering over their Short Shirts.

But that was not quite the last I saw of these desirable , garments. In October circumstances arose which compelled me to buy one of them myself for 2 dols. 50 cents hard cash. It came about this way. As the munificent salary of 4 dols. a month, which the Government paid to the postmaster of Grohman, held out insufficient inducements to the several B.B.'s to whom I generously offered the deputy post-mastership, nothing was left but to be my own postmaster.

The distributing office was at Golden, and the Grohman mails $\mathrm{U} 2$ 
would be sent up by the bi-weekly steamers in old gunny bags, invalided flour sacks, ruins of biscuit boxes, or any other handy receptacle. Navigation on the upper reaches of the Columbia, as already described, was somewhat uncertain, entirely dependent upon the state of the water. Under most favourable high-water circumstances no steamer could get nearer than twenty or twentyfive miles from us, and towards autumn, when the water fell, the variable "head of navigation" was ten or fifteen miles further down, till finally the head and the tail met at Golden, i.e., it stopped altogether. Out of the 4 dols. per month salary I had to pay 2 dols. twice a week to the Indians I employed to ride down to the landing for the mail. They were quite trustworthy, and as horseflesh is of no consideration to them, they made the trip in half the time which a more costly white messenger would have taken.

Well, one October afternoon I sent Kootenay Pete on this errand. The outgoing mail was small, tied up in a little bundle, it no more than filled his hat-one of our "best" 8 dols. "cowboys" (cost laid down, 95 cents). It was the only pocket which that stalwart native had about his nut-brown person. Pete was back from the lower landing, thirty miles off, the next day at noon. When he arrived I happened to be away, but instead of giving up the mail bag to the B.B. storekeeper and getting his 2dols., which, as a rule, was promptly spent in the store, Pete refused to dismount, and declared he wanted to see the boss himself. I was fetched, and Pete handed me a hastily scribbled note from the captain of the steamer informing me that an accident had happened to the Grohman mail bag in consequence of lying too close to the boiler, but the contents had been saved. Not having any spare box or sack, he had handed the letters and papers loose to the Indian with instructions to tie them up as best he could. In a postscript, he added that as the Indian wanted his money he had paid him his usual 2dols. As soon as I had read the note I held out my hand for the bag which the Indian had tied to the off side of his saddle, where I could not see it. Instead of handing it to me, he said: "Hello 2dols. 5o cents, 
hello ticktocalilka," which translated amounts to "No 2dols. 50 cents, no mail bag," or, in other words, he refused to hand out the bag if he didn't get first 2dols. 5o cents down. To make me better understand the position of matters, wily old Pete held out the mail bag. Then I tumbled to it. It was one of those flannelette shirts roughly stitched together in the shape of a bag wherein reposed H.M. mail! A great shout went up from the group of inconsiderate bystanders, and a smile childlike and bland passed over the classic features of stern Pete as I handed him the dollars!

Some other funny stories were accredited to the Grohman store. They weren't necessarily all true, but they were amusing. One was, that having sold to some Chinamen some waste unplaned boards at the price of choice mahogany, that B.B. storekeeper made an extra charge for the knot holes in the boards on hearing that the lumber was required for a coffin for a Chinaman who had died in camp. "You'll be better able to identify the corpse later on when shipping-time comes round, if the coffin has air holes," said he, alluding, of course, to the fact that all Chinamen send their dead back to China, hence are particular as to the identity of their corpses.

Another unkind tale was about a certain apparently quite unsaleable stock of brass-headed nails. All comes to those that wait. The mountain fever did not draw the line at white men, but occasionally picked up stray Indians. Presently a young buck passed in his chips not far from the Flat, and his people came to me for boards for his last teepee. I told the carpenter to doctor-no, the doctor to carpenter-a coffin, and to use those brass-headed nails for the job. Instant success, and from that day on brass-headed nails became the height of fashion for the last ceremony for which nails are required.

Those who have read the present Duchess of Somerset's pleasantly written "Wanderings of a Tenderfoot," in which she describes her adventures in Kootenay, will, perhaps, remember her mentioning the fact that her husband bought a pair of moccasins at the Grohman store, "of which he is very proud." 
I don't quite know why he should have been proud of that fact, out, at any rate, there it is in black and white, and as I found but that that B.B. storekeeper charged the Duke his favourite 2dols. 5o cents for something that hadn't cost-well, I won't divulge what the cost price of those moccasins was-but it wasn't 2dols. 5o cents-this feeling of pride must have been caused, so I have heard it said, by the fact of his succeeding in getting out of the store with some money left in his purse.

The St. Maurs-the name by which the Duke and Duchess are still pleasantly remembered in Kootenay-were that summer our nearest neighbours. Joined by Lady Adele Cochrane and Lord Norbury, they were, camping out about ten miles from us, high up on Finlay Creek, where the last named in partnership with Mr. T. Cochrane owned a gold mine, on which a small force of men were at work. It was a very lonely spot in the middle of a forest wilderness where the party was camped, for the mine was some distance up the creek, and when the two men were away on their frequent hunting expeditions in quest of mountain goat, the two ladies were left alone with no male but a Chinese cook near the spot. As they were to be there some time, a small shack had been erected. The lumber used for it was quite unseasoned, and the most amusing consequences resulted from it. Under the hot Kootenay summer sun the boards shrunk to an extent one could hardly believe. When it rained one had to go to bed with an open umbrella, and so large were the spaces between the roughly nailed together boards forming the outside walls, that windows were superfluous. It was a house made of cracks with occasional boards to mark where each commenced and ended.

One could not help admiring the courage of the two ladies who, attending themselves to their horses, rode about in the wilderness as if they were at home in quiet English country lanes!

Let me conclude these jottings with a snapshot view (the first one ever taken) of a somewhat unique natural curiosity. It is a natural hot bath just as nature formed it, and is situated on the slopes of the Rocky Mountains about 4ooft. over the source of the 
Columbia (part of the lake being visible in the picture), while the mountains in the background are the foothills of the Selkirks. The water wells up at blood heat, clear as crystal. The view which you enjoy while indulging in a dip in this curious tub is magnificent, for the photograph fails to take in the great snow-capped peaks of the Selkirks that tower up behind the foothills.

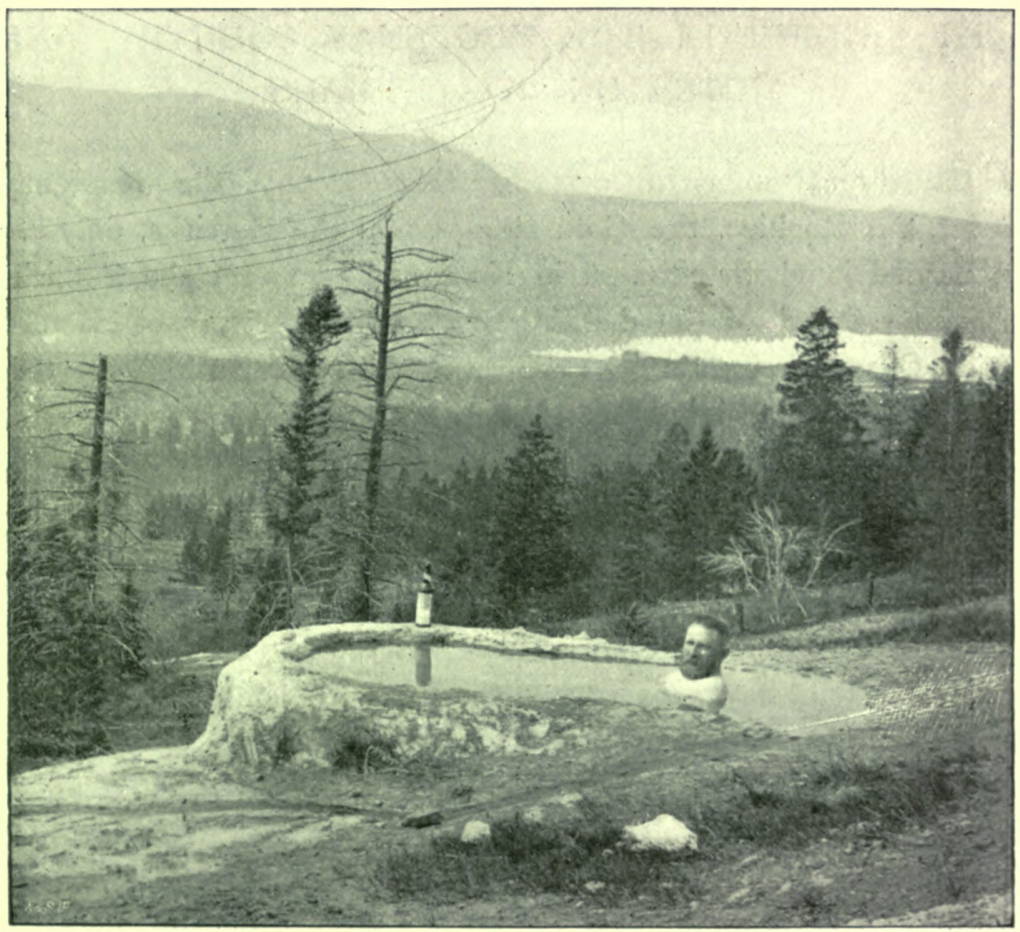

Natural Hot Springs near the Source of the Columbia River.

(Photographed just as Nature made them.)

There is a sad interest attached to this photograph, for it was the last picture taken of a well-known early pioneer of the Pacific coast, viz., Dr. Miner, of Seattle, who, with some venturesorne companions, made a canoe trip through the Kootenay country and was drowned a short time afterwards. 


\section{CHAPTER XIII.}

\section{PATH FINDING IN THE KOOTENAY COUNTRY, AND NOTES ON THE INDIANS.}

OF the three mountain systems that occupy the Kootenay district, the Rockies, the Gold Range, and the Selkirks, only the last named is wholly situated in Kootenay. In fact, the Selkirks occupy the heart of the district, the two great rivers of Eastern British Columbia forming, as we have already described, a great "O" round these mountains, the little one-mile long canal of blessed memory thus making an island of the Selkirks.

They are interesting mountains; " a region of rushing streams, towering forests, rugged peaks, and fine glaciers," as the first properly fitted out mountain explorer of the Selkirks has tersely and correctly described them. This was the Rev. W. Spotswood Green, the well-known explorer of the High Alps of New Zealand.* For, though my explorations in this range commenced five or six years earlier than did his, I can lay no claim to have done genuine mountain exploration on scientific principles. In my case the attractions of the rifle were more powerful than those of the sextant and plane-table, and though I always promised myself a good long summer's holiday of mountain climbing, the unexpected exigencies connected with my pioneer enterprise in Kootenay never permitted the execution of this design.

To-day one can no longer speak of path-finding in Kootenay. Half a dozen live towns, with a population in some cases of seven thousand, half a hundred mining camps, five

* See his "Among the Selkirk Glaciers." Macmillan. I89o. 
railways, with two or three more coming in, a score of river and lake steamers, telephone and telegraph lines that connect the remotest camps, electric lighting and magnificent electric power plants that rank among the largest on the continent, roads and trails up every creek almost, while ladies eareer through the country on book writing bent, these are the truly wonderful result

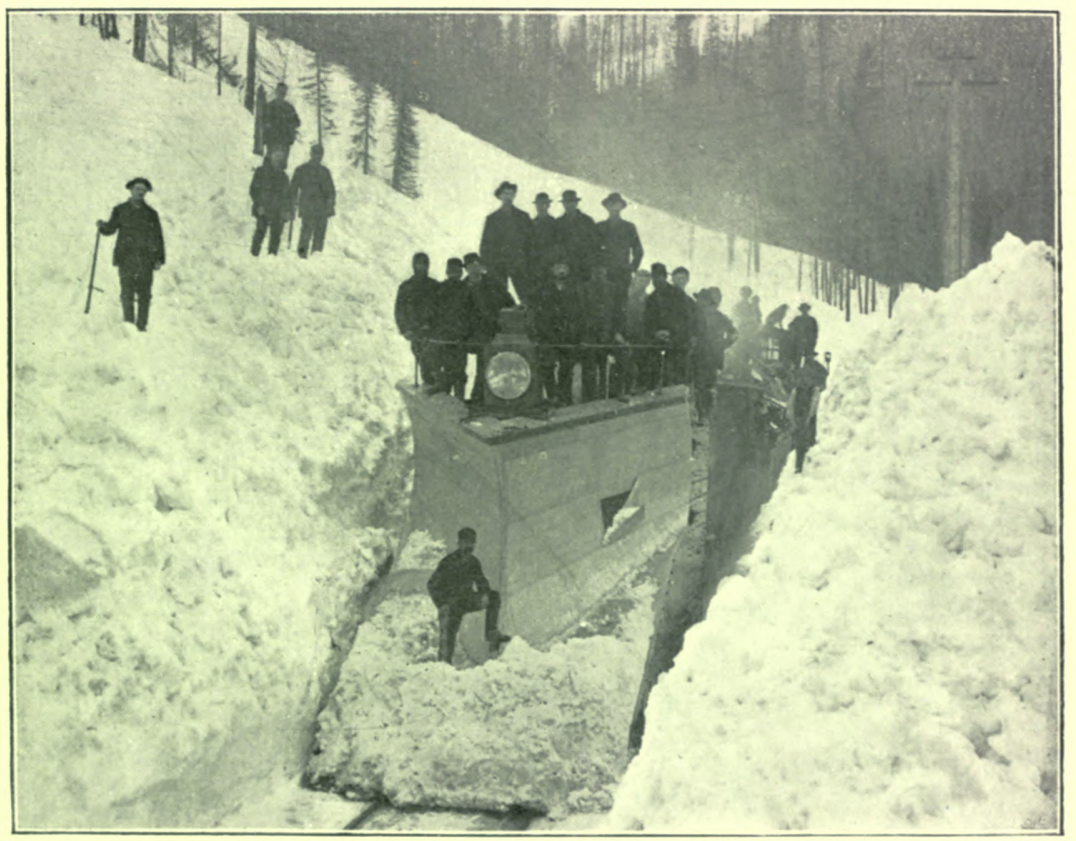

A Snow Plough at Work on the C. P. Railway in the Kootenay Country.

of ten years of Western activity, in which the Yankee has again given us a lead. Without it Kootenay would probably still be the wilderness in which I found it in $1882-3$. True, nature has suffered to a corresponding degree. Vast areas of fine forests have been burnt with the ruthlessly wasteful haste of the pioneer prospector, to whom nothing is sacred. Rivers and creeks no longer flow clear 
and sparkling. The drains of mining camps and sluicing operations on their banks have long turned them into muddy, beautiless waterways, not infrequently reeking with the poisonous stench of putrid animal matter, while huge smelting-work chimneys belch forth noxious fumes. Game and fish, if they have not entirely disappeared, have suffered sore decimation, the one in consequence of the good prices obtainable in the camps, the other by fair and foul persecution, in which the deadly dynamite wreaks wholesale destruction in the deep pools once famous for trout of a size hard to be equalled anywhere else in the world.

All this, not to forget the books the aforesaid ladies have written, has, it is to be feared, removed for good and all the charm of wildness from a lovely country. There are, however, extensive areas in the Selkirks from which one unsuccessful prospector after another has returned ragged and gaunt after his summer's work high up on the mountain, on the fringe of glaciers. There Nature is to-day much as she was at any time, for the exploration of these incredibly rugged mountains is no child's play. It takes men of great tenacity and great bodily vigour to prospect the Selkirks. In the several weeks of the hardest Alpine work Mr. Green had ever undergone, he was unable to reach a point further than seven miles from his starting point (in a straight line), and to cover a mile and a half through the dense underbrush and over fallen trunks of gigantic size, took his party no less than seven hours.

The difficulties that obstruct exploration arise from a twofold cause, the creative and the destroying agencies of nature. The forest vegetation is very luxurious; the trees are large, some gigantic, and they grow very close together, only too generally with thick underbrush surrounding their base. In the underbrush the treacherous "devil's club" - a rankly-growing weed, pleasing to the eye, with its bright green wide-spreading leaves and clusters of red berries, but whose thorns, often very difficult to avoid, create most annoying sores-is only too often to be found. The dense foliage overhead makes the ground retain much moisture. 


\section{Path Finding in the Kootenay Country, Ec.}

Avalanches are very frequent in spring, and even in early summer; in fact, I know no mountain system where the eye meets on every side with more numerous evidence of these phenomena; and there is decidedly no mining ccuntry in the world where so many human lives have been lost by avalanches.

The path of the snow slide that swept the forest from the face

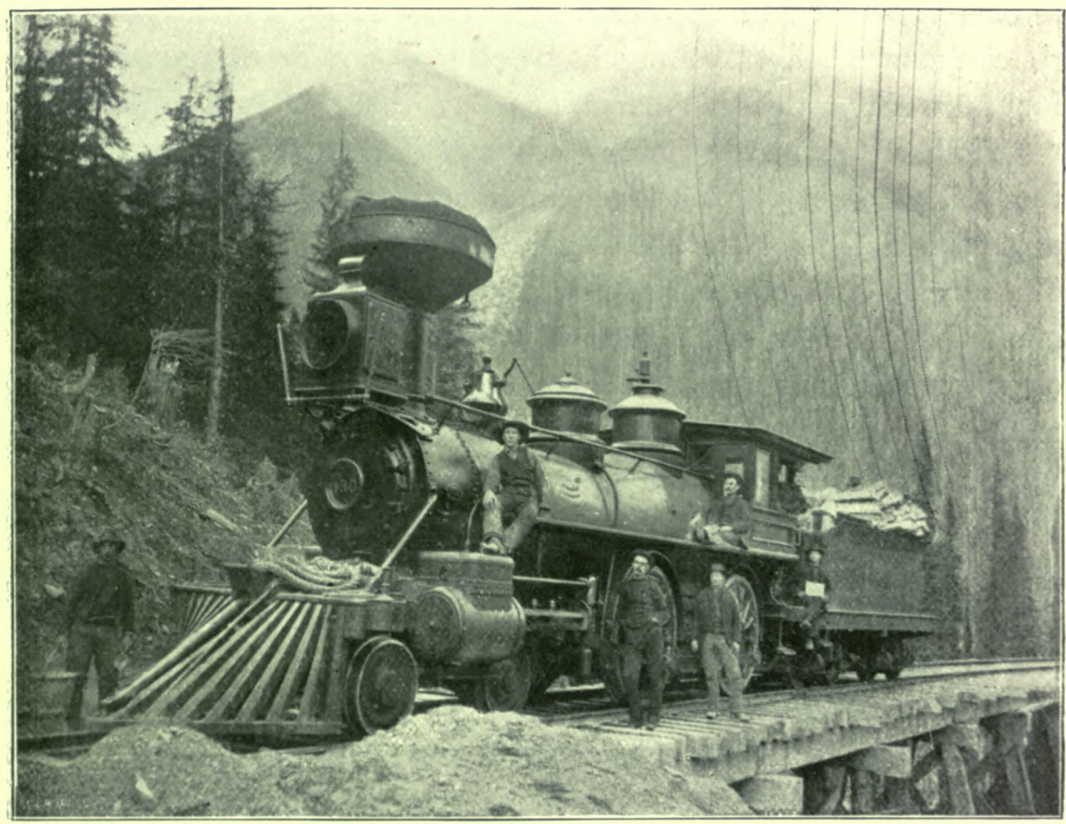

A "Mogul" Locomotive, used by the C. P. Railway to cross the Selkirk Mountains, Kootenay, B.C.

of the mountain to pile it up in vast masses of débris beyond the foot of the slide, becomes a year later the scene of a new and rank vegetation, and the third or fourth year already these brushy areas, covering hundreds and thousands of acres, become so dense that progress through them is almost hopeless. More erratic and more widespread is the course of the forest fires. These fires, 
of vast extent, burn in some exceptionally dry years literally from spring to autumn. Thus, in 1883 , the fires north of Kootenay Lake were burning for more than four months to my certain knowledge. The bare and blackened trunks of the trees, the sap of life burnt out of them, frequently remain standing for months, until an unusually severe gale lays them low by the hundred at a time. If the traveller happens to be caught in one of these burnt forests by a gale or thunderstorm, some lively, and at the same time circumspect, travelling had better occur, or there will be a funeral without a coffin, hearse, or parson.

Timber line in the Selkirks ranges occurs about 6oooft., and the valleys from which the mountains rise and by which one has approached their base, are usually only from $1800 \mathrm{ft}$. to $2500 \mathrm{ft}$. in altitude, so that one has almost invariably about 3 oooft. of very steep and densely wooded slopes to overcome ere one reaches the clear rocks above; and one can speak of luck if, in ascending a slope, one does not strike either the bed of an old avalanche perfectly impassable, owing to the denseness of the young vegetation on it, or has to climb for half a day over, under, along, and across prostrate trunks of huge trees piled up in the most puzzling manner, obliging one often to walk along a slippery trunk I $2 \mathrm{ft}$. or $\mathrm{I} 4 \mathrm{ft}$. above the ground, or crawl for many yards under a network of fallen monarchs, pushing one's sleeping bag, rifle, and grub sack in front of one, as there is no space to do otherwise. Once the rocks are reached the conditions become more favourable, in fact, one is in the hunting country as soon as one is out of timber line; and the nearest ridge, often only 5 ooft. higher, and easily attainable by a steep rock climb, will almost certainly reveal the presence of "goat." "Goat" have a predilection for promenading along impossible looking knife-back ridges, from whence both slopes can be seen. They are anything but shy animals, their innate sense of curiosity being remarkably great. They are easier prey to kill than the bighorn, when once the sportsman has managed to reach their home. Bighorn, as already stated, do not inhabit the Selkirks, but only the Rockies 
of Kootenay. The Indians do often great execution among "goat" at the licks, and I know an old Kootenay hunter who killed eleven without taking his Winchester repeater from his shoulder; while others in my day still used the old Hudson Bay Company musket, or "firesquirt"- - a very antiquated percussion smoothbore, with which they, nevertheless, managed to do some very creditable shooting at close quarters, and often succeed in bringing down two or three before they get out of range. It is surprising to see how close these stealthy moccasin-shod, almost naked stalkers, will manage to get to their quarry, the dusky hue of their skin assisting them in this. This I had once occasion to find out in a rather startling manner, when, after a painful half an hour's wriggle, ventre à terre, up a jaggy slope, I suddenly found myself looking into the glittering eyes of a Kootenay, literally not more than i $2 \mathrm{in}$. from mine. He was lying on a slab of rock, his body being invisible to me from below. When I did see the latter, flesh and stone were almost undistinguishable from each other.

Mr. Green's explorations covered but a small area, for he tackled his mountains from the wrong (northern) side, starting from the Canadian Pacific Railway station (Glacier) at the base of Mount Sir Donald. Had I met Mr. Green before instead of after his trip, I think I might' have saved him a considerable amount of hard work, and assisted him in the defining of the more prominent, though nameless, landmarks he saw from the elevated points he reached. One great advantage he would have gained had he directed his attack from the southward, would have been the presence of the Lower Kootenay Indians living near the Kootenay Lake. Picked men from this tribe could have been used with much advantage as porters.

These Indians do all their hunting on foot, using the larger streams (such as the Lardo) as far as they can take their canoes. In most cases the squaw, who, as is so common among the American aborigines, is used more as a pack animal than as a human being, and even the half-grown children "pack" up the mountains till a suitable camping place near timber line is found. 
There they will remain for weeks, the noble lord of creation hunting the goat, which more often than not he does by lying in wait for them at the licks, which are much frequented by these animals in spring and early summer.

Whites are perfectly useless as porters in exploring or hunting

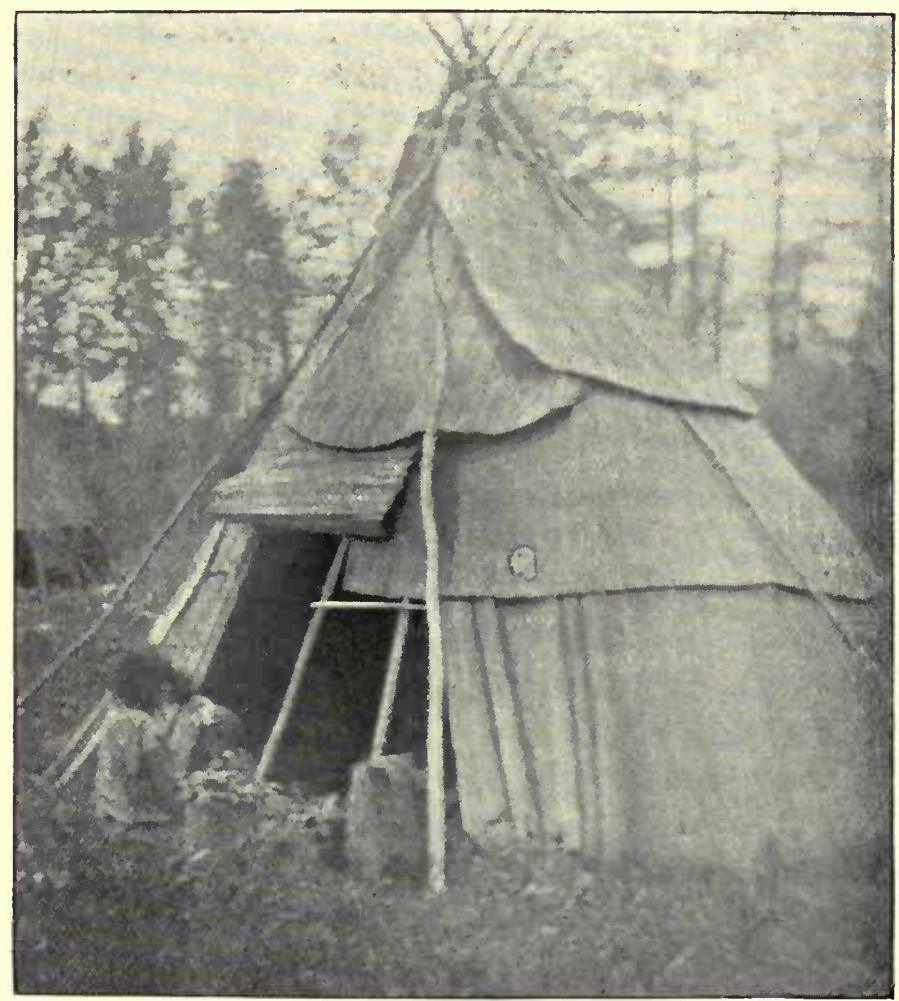

Flatbow Teepee of Reed Mats.

Flatbow mother "on the hunt" on her papoose's head.

in the Selkirks, for, as Mr. Green found out to his own cost, white porters require so much for their own comfort in the shape of blankets and food, and are generally so unused to it, that they can "pack" but little besides their own outfit; while one of these extraordinarıly hardy and frugal Kootenays, with nothing but a 
breech clout and an old goatskin of his own to carry, will, with a 6olb. pack on his back, walk and climb away from an average mountaineer; while, unburdened with ought but his own outfit of ounce weight and his rifle, I will back a Kootenay to beat by miles in a long day's climb the best white mountaineer that Switzerland or Tyrol ever turned out. The services of the Lower Kootenays were even then not always easy to be obtained; but direct application to their chief (St. Pierre), with a little present of tobacco to that personage, worked generally very well, though I remember one or two expeditions had to be given up by me at the last moment owing to the sudden refusal of my native companions to start. A dollar a day (4s.) and food satisfied them; but if game is the sole object, I would advise a stipulated price per head killed by the sportsman, and no day wage. The Kootenays, like all Indians, are great gamblers, but as they invariably try conclusions with the wily Kalispels and Spokanes, hailing from more civilisation-haunted localities, who visit them bent on regular gambling raids, they are generally fleeced. Many a time have I seen the results of a winter's trapping or a summer's hunting gambled away in one night. They are fast losing their artless simplicity; indeed, as I cannot speak by personal experience of the last few years, they may now, for all I know, be altogether useless for hard exploration work. In my time I invariably found them faithful, honest, and (for Indians) unusually clean, the way that my camp soap used to vanish being quite unique in my Western experience, though I must in explanation mention that it was perhaps more in consequence of the novelty of that article than for any other reason.

If the ascent of the higher peaks in the Selkirks be the object of the traveller, difficulties of a different and more riskful sort will have to be combatted. None, or, at least, very few of the higher mountains can be ascended without traversing snowfields or glaciers, where great caution will become necessary, for, what with Bergschrunds, overhanging ice and snow cornices-those perhaps most dangerous pitfalls of all-the traveller should have mature 
Alpine experience for such work, and be well supplied with all the essentials, such as suitable rope, ice axes, and the most compact camp equipage. The Indians are no good on the ice, and won't go on to it, and I have only once been able to induce one of them to cross a narrow icefall. The moraines, existing in the Selkirks in great number, are often distinguished by the great size of the blocks of rock. They occur frequently in such quantities that progress over such a moraine is desperate, if not impossible, work. The noinenclature of the Selkirk peaks has so far, with the exception of those overlooking the C.P.R. track at Roger Pass, been attended to by Tom, Dick, and Harry among the prospectors who first clambered up their sides, or picked specimens on their slopes. Rarely were the higher snow-covered eminences scaled, for, of course, mines cannot be discovered under eternal snow or ice. When, after one or two season's unsuccessful search, the first prospector strayed to other regions, the next man to explore the mountain, and who had perhaps never heard of his predecessor's existence, will give another name to the peak. So that until good maps of the Selkirks come into existence, one and the same hoary giant will remain known by a variety of names.

Of the higher peaks immediately adjacent to the C.P.R. that have been christened in proper form-Mr. Green named quite a number-the Matterhorn-like Mount Sir Donald is the highest. It is rather a pity, from a national standpoint, that the several attempts to conquer this formidable peak made by English climbers should have failed, and that it was left to two enterprising young Swiss climbers, Messrs. Sulzer and Emil Huber, to achieve the feat of first scaling the top.* Similar regret fills the English climber's heart at the fact that Mount St. Elias (18,092ft.), the highest mountain in North America, $\dagger$ was conquered not by the British

* They wrote an interesting account of their ascent.

+ This statement needs qualification, for Mount Orijaba, in Mexico, has now been determined to be $\mathrm{I} 8,3 \mathrm{I} 4 \mathrm{ft}$., and there are pcssibly higher mountains behind Mount St. Elias, the unexplored Mount Logan being thought by some to overtop the former. 


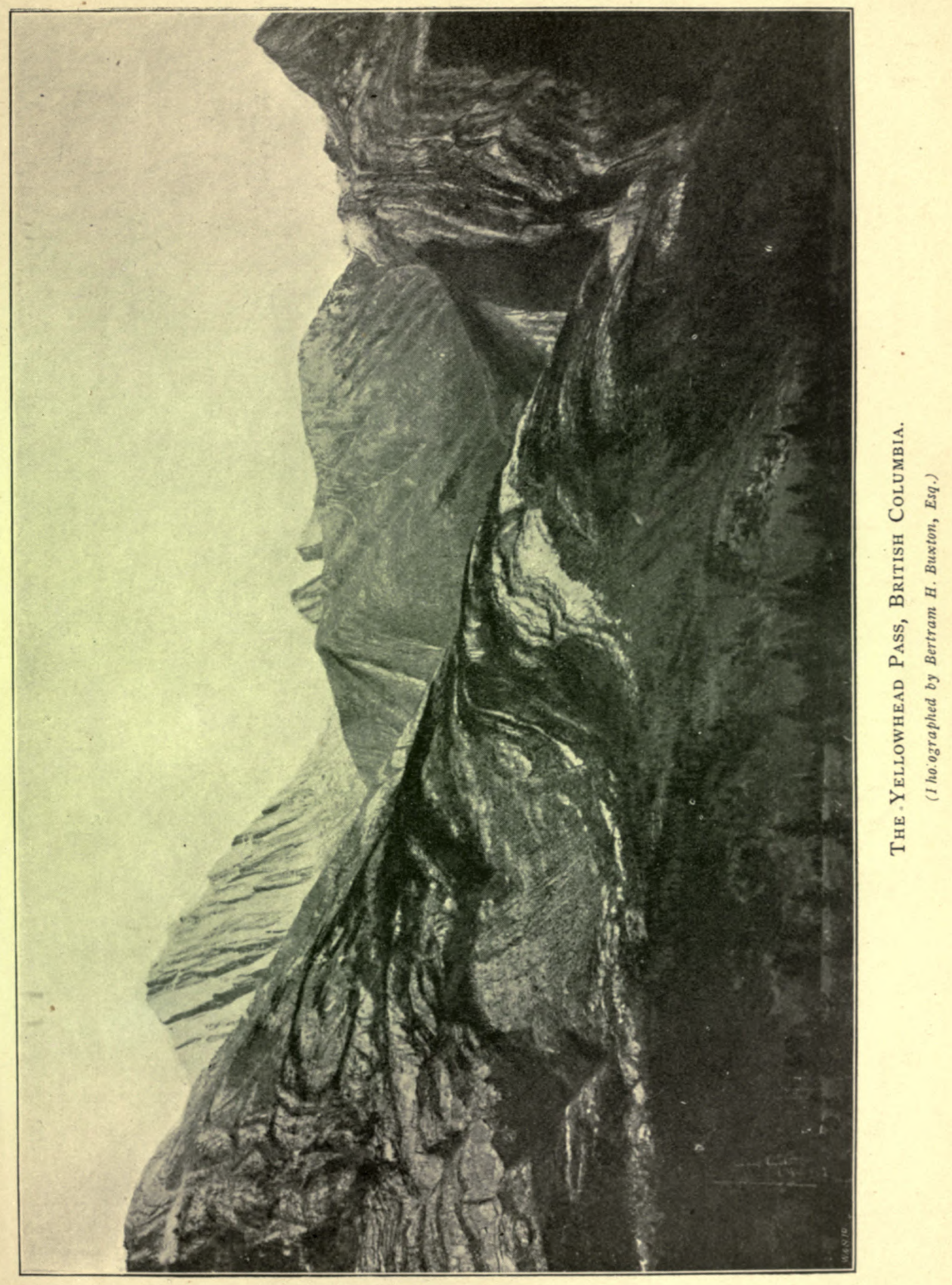



experts who had repeatedly attempted the feat, but (1897) by an Italian expedition led personally by H.R.H. the Duke of the Abruzzi (Prince Louis of Savoy) who thus earned the hearty congratulations of all mountaineers.*

Four previous attempts had been made to reach the top of St. Elias, the difficulties being not so much those of climbing, but rather of approach and of transportation. Mount St. Elias is a superb peak rising in one grand sweep from the Pacific Ocean, and those who have seen from the ocean what is the greatest vertical sweep of snow and ice yet discovered in the world-Malaspina glacier alone is said to cover $\mathrm{I} 500$ square miles-will ever remember that most impressive sight.

Let me say a few words about the Indians of the North-West. The native tribes inhabiting the country between the Rocky Mountains and Manitoba have, as every traveller knows, long passed from their primitive condition to one more akin to civilised existence, i.e., poverty and debauched depravity. Very different from these aboriginal inhabitants of the Great North-West were, at the date of my Western rambles, the tribe immediately to the west of the indicated locality, i.e., in the Kootenay country between the crest of the main chain of the Rocky Mountains and the Gold Range that runs parallel to the former, and cuts off this most easterly strip of British Columbia from the rest of the province.

The Kootenay Indians were, in the days I refer to, with the exception, perhaps, of some of the interior tribes of Alaska, at once the least known, and, from an ethnographical point of view, one of the most interesting families of the North American aboriginal population. I had been hunting among United States Indians, and also knew something of the tribes in Canada east of the Rockies, and they had all impressed me as debased remnants of once powerful and warlike clans, who, even as late as 1878 and

* The Alpine Fournal, of May, $\mathrm{r} 898$, contains an account of this expedition and the Duke, I was told, is writing a more voluminous account of it. 
I 879, spread dismay and death among some of the white settlers invading their hunting grounds. I was agreeably surprised, therefore, to find that the Kootenays were a tribe practically untouched by the baneful influences of the aggressive civilisation of the West. They had no reservation; they had no agents over them; they received no assistance from the Government; no official census had ever been taken of them; they lived entirely upon the products of their rivers, lakes, and forests ; they spoke a tongue unknown to their next neighbours; they kept strictly to themselves, and, with the exception of their annual buffalo hunt, they never left their own beautiful mountain-girt home. They were peaceful, and they had been won over to the Roman Catholic religion by missionaries, who have dwelt in their midst since the year $1842 . *$ A more unsophisticated and at once attractive race than the Kootenays it would have been difficult to find.

The two sub-divisions of the tribe (the Upper and the Lower Kootenays), in consequence of natural features, differed considerably. The home of the former is the country round the Upper Kootenay river, from its source in the very heart of the Rocky Mountains, to where it enters U.S. territory. Here, under the shadow of the towering main chain, this singularly isolated tribe of Indians have lived and thrived. They were Horse Indians, in distinction to the Canoe Indians, to which the Lower Kootenays or Flatbows belong. And a wonderful playground to run their hardy beasts their mountain-girt home afforded them. Undulating hill-land, with occasional "bunch grass" prairies, fringed by fine forests, make it the very ideal of an Indian country, such as we read of, but, alas! very rarely indeed discover. The Kootenays were a fine, manly-looking race. In one of the most interesting reports of the English International Boundary Commissioners, Captain (now Sir Charles) Wilson, when speaking of these

* The Kootenays' independence ended soon after my first visit, when an agent was appointed, and "reserves" given to them. According to the first official census, which was taken a year or two later, the whole tribe numbered about 600 souls. 


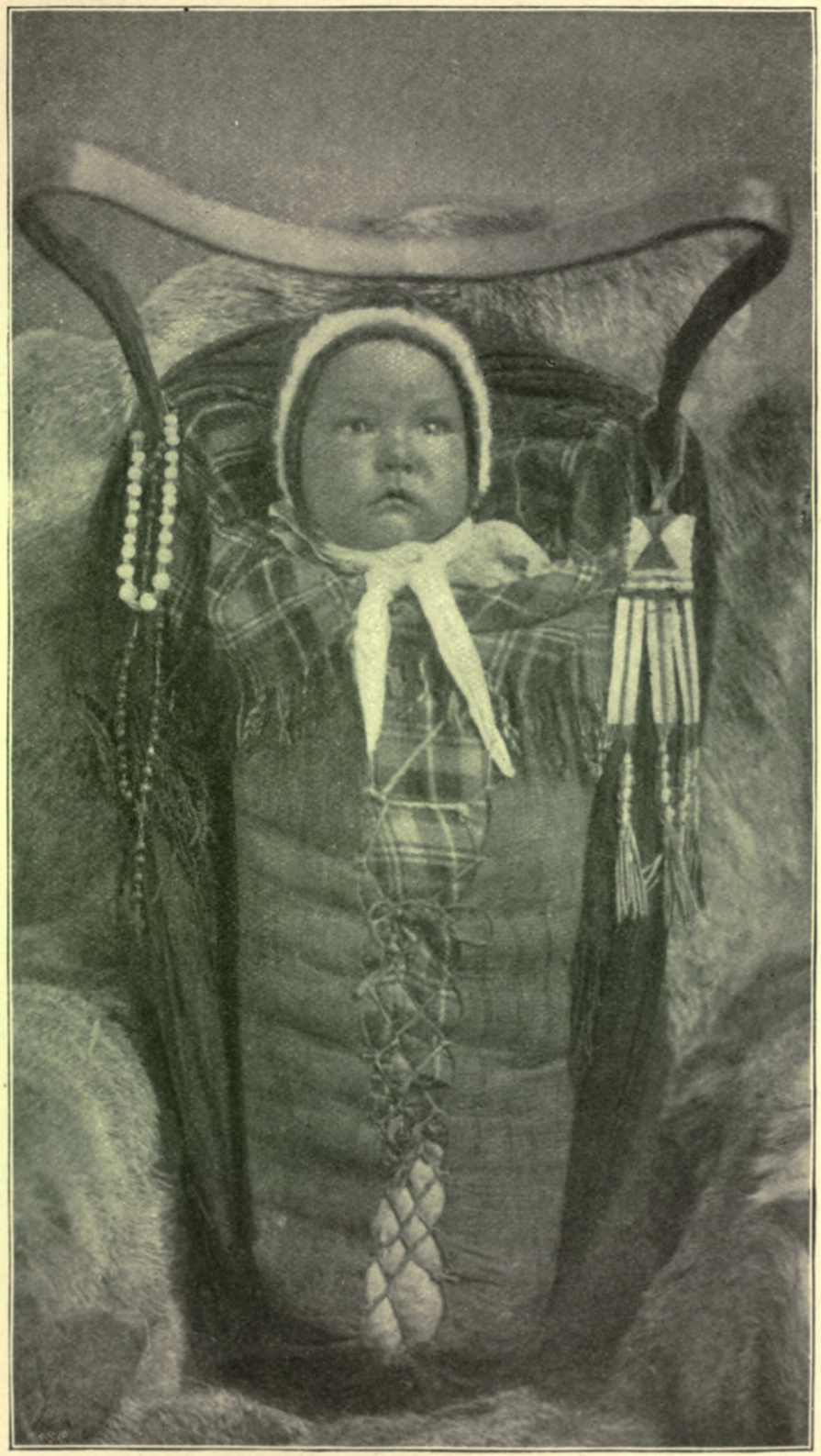

Indian Papoose on Cradle Board, in which manner Babies are carried on Horseback. 

Indians, through whose territory the international boundary line was run, says that " the Kootenays were decidedly the finest race of Indians met with during the progress of the Commission, though but few particulars could be learnt about this very interesting tribe, which, speaking a widely different language and walled in by high ranges of mountains, is entirely isolated." "The Kootenays bear the reputation of being brave, honest, and truthful, and prided themselves on the fact that no white man has ever been killed by them."

They had one noticeable peculiarity, especially the Lower Kootenays, which I have never remarked in any other North American Indians-it was their merry and laughter-loving disposition, affording a striking contrast to the sullen moroseness usual among most other Indians, especially those in U.S. territories. Each of the two sub-divisions had two chiefs, one elected by themselves, the other chosen by the missionary, to whose teaching they lent an appreciative ear. The Lower Kootenays or Flatbows, to give them their old name, live, as we have already heard, on the Lower Kootenay river, and those of my readers who happen to be acquainted with the quaint drawings of Indian life by De Bry, who illustrated the early travels in Florida and Virginia in the sixteenth century, would, were they to have seen this Lower Kootenay country when I first saw it, no doubt have been as much struck as I was with the similarity in the customs and occupation of the natives of these two widely separated districts of North America.

As the mountains round Kootenay Lake rise very precipitously from the water's edge, there is on the banks hardly a square rood of ground available for Indian settlements, hence their villages, consisting of teepees, covered with mats made of reeds, called kloosquees, are all confined to the grass-covered flats in the valley between the lake and the boundary. The lake and the mountains were only visited for hunting and fishing. If for the former, they betook themselves in their light pine bark canoes to the upper end of the lake, and, landing at one of the 
many sandy beaches hemmed in on all sides by red cedars and pines of great growth, câched their canoes, and proceeded to climb the mountains on foot. Often away for a month at a time, they scrambled about the singularly rugged cliffs and peaks that rise from the lake (which is only $175^{\circ}$ feet over the Pacific) to a height of goooft. Their large game consisted of the woodland caribou, deer, bear, and the Rocky Mountain "goat" (Haplocerus montanus), the two former keeping on lower levels, while the latter are only found above the timber. The chase was of an arduous nature, but those of the tribe who devoted themstlves more exclusively to goathunting were all uncommonly good mountaineers, and carried their 6olb. or 7 olb. loads all day with surprising ease. Their hardiness was simply surprising, and when starting on their winter hunt, with which they generally combined some trapping of the more valuable fur animals, they only took one blankrs with them, their sole garment being made of dressed buckskins.

The Lower Kootenays fish as much as they hunt, and I was surprised what big hauls they managed to make with their very rude contrivances; for only a few of the bucks possessed a spoon troll, which, next to a Winchester repeater, represented the Flatbow's earthly ambition.

Kootenay lake was then full of the finest fish, five different species of the trout family inhabiting it. It was a common feat to catch $30 \mathrm{lb}$. or 4 olb. of the so-called land-locked salmon in an hour with one spoon troll out; at least, we often exceeded that bag as we rowed from point to point, bent more on business than pleasure, and doing our fishing merely for the pot. They run up to about $25 \mathrm{lb}$., though Indians say that there are very much larger ones in the lake; but even a zolb. fish will drag a Kootenay brave, seated in his frail bark canoe, after him for long distances-a fate which even befel one of our party, an experienced salmon fisher, who was dragged for more than half an hour, the boat he was in being quite a massive craft of inch planks nailed together, and hence not very easy to move. 
A singular feature about the tribal relationship of the Flatbows was the fact that the hunting grounds in the mountains round Kootenay lake was laid out in sections, each brave and his family having a huge slice of this American Switzerland, which was called after him; so that, when inquiring for the name of any prominent peak, you were told the name of the buck in whose preserve it happened to be located. Thus, we would find that a district the size of the Engadine, and in many ways not unlike it, would be known as Kankusco's hunting ground, and nobody else but old Kankusco, or his sons and their females, would invade this vast preserve.

It is a widespread belief that all the British Columbia Indians are rapidly decreasing in number. This is only the case among those coast tribes where disease has been rife. In the interior no great decimation by smallpox, diphtheria, and tuberculosis is to be noted, and, indeed, in some few cases tribes are to-day more numerous than they were a generation ago. These are unique instances in North America, north of Mexico.

In this connection I am tempted to give a brief summary of my old friends the Flatbows, as it will throw light upon this question. The first quite unofficial count ever taken of this tribe was obtained in December, $\mathrm{I} 848$, by Edouard Berland, $\mathrm{Mr}$. Anderson's interpreter. The latter's MS. notes on the subject were given to me by Dr. Tolmie. In this census the old division of Indian tribes is still observed, for we find the tribe sub-divided into warriors, lads bearing arms, and lastly women and children. This census shows in a striking manner the preponderance of the two latter when compared with other less warlike tribes. The Kootenay tribe were a gallant lot, and from time immemorial they had fought against heavy odds when they crossed the Rocky Mountains and descended in their annual hunts upon the plains in quest of the prized buffalo, which did not exist in their own home. Their mortal foes were the bloodthirsty Blackfeet, whose country extended up to the foothills of the Rockies. Retribution was, of course, wreaked by the Blackfeet, who came down 
upon the Kootenays in much the same stealthy manner in which the former surprised the prized bison herds in the enemy's country.

The second count of the Flatbows was taken by me in 1883 , old Dave MacLoughlin assisting me in the task. In those days they had long been under the influence of the French missionary, established in his remote little mission in Upper Kootenay, so that the majority of the males were known by names given to them by the latter. These, pronounced invariably in the French manner. such as Cyprian, Donnace, Vital, Basil, St. Pierre, Placide, Augustin, Alexandre, Celice, sounded quite as strange in the mouth of natives as did their aboriginal names. Amongst these figured, phonetically reproduced, Sokanepacker, Kalsaytavon, Anatavon, Skincoots, Tameeya, Lapoony, Neguala, \&c. The third count and first official census was taken quite recently by officials of the Indian Bureau. Summarising the three counts, we find that in 1848 the Flatbows consisted of 397 souls, of which seventyeight were adult males. In 1883 their number had decreased to 157 souls (of which thirty-five were heads of families), while in 1896 they had increased to 162 souls.

In the northern interior parts of British Columbia the Indian population has undergone, of course, on account of the unexplored and unsettled state of the country, very much less change than on the coast, where constant contact with white men and the ruder forms of civilisation has changed the bearing and the appearance of the natives, though never to the same wholly demoralised extent observable in those parts of the Canadian North-west and Manitoba touched by the railways, or in most parts of the United States. The only exception being, perhaps, the large Indian reserves, such as the Crow, Soshoné, Flathead, and other strictly defined and as strictly watched reserves in United States territory.

To return to the Indians of the northern interior of British Columbia, they still live in much the same way they did when stray white men were first seen by them two or three generations 


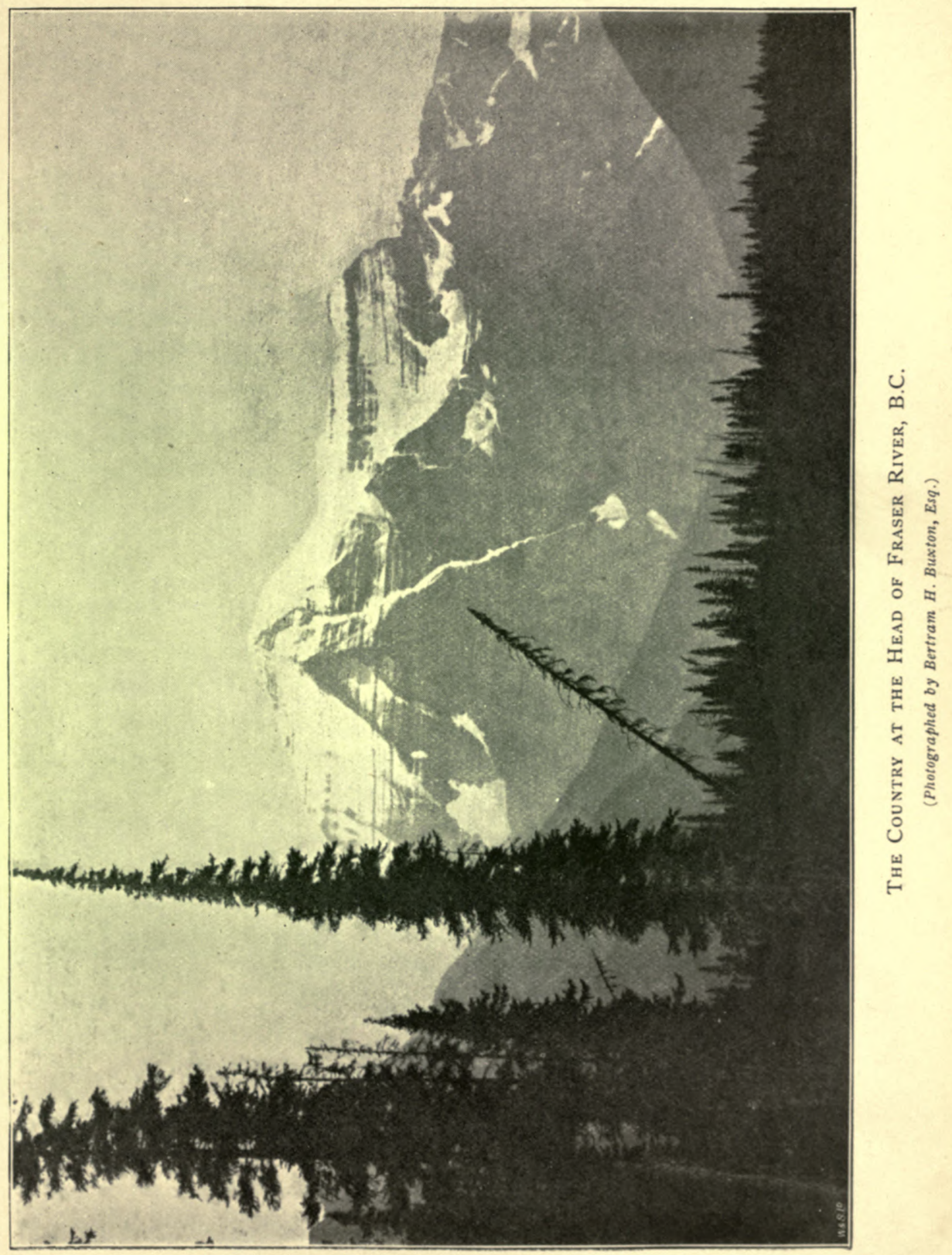



ago, i.e., in families scattered over the whole country. Twice a year these nomadic groups, of which the tribes are composed, assemble at a well-known tribal rendezvous. From two to four weeks of social intercourse and feasting mark these periodical meetings. Affairs affecting the whole tribe are discussed and smoked over, marriages are contracted, and the necessary arrangements for the forthcoming fur hunting campaign are entered upon. Then they disperse, each family in its own direction, not to meet again until the next assembly at the common rendezvous, unless by special appointment between individual families, at some known trysting spot deep in the dark and moisture-laden fastnesses of the forested mountains, where, far away from human associations, in the midst of vast and dense woods, these nomads of the forest will hive a life very little superior in its accessories to that of their prey, the industrious beaver or the restless and wily caribou. Untiring application to the chase, an intimate knowledge of every possible resource afforded by the country, and an unwavering self-reliance go hand in hand to enable these nomads to sustain life in these very inhospitable wilds. The many devices they adopt to economise their trifling little stores of essentials, and the habits of providence which the nature of the life they lead necessitates, have in them something pathetic, and none more so than the custom of caiching (hiding) articles specially needed against times of dire want. I am not referring here to the large caches of peltry or dried meat or fish-carefully done up in pine bark-which are made to save transportation when moving camp from a place which on their return journey they must pass, but rather to the small wayside ciches of trifles. To make these cáches, a dead, but still standing, tree is selected, if possible in a spot which has already been burnt over by forest fires. With his axe the Indian takes out one big chip, which is carefully preserved. He then hollows out a more or less spacious cupboard-like receptacle, wherein he deposits his valuables. perhaps a few charges of powder and ball, a bit of tobacco, a spare flint, a piece or two of old wire, a few fish-hooks, or some other 
trifle of value. Then the squaw steps up and puts in possibly an awl, a few needles and thread, and the like, and even the children may have a few beads or some trifling brass ornament wherewith to bedeck themselves when they return to the rendezvous. The chip is then replaced, the edges plastered with resin, and then duly besmeared with charcoal so as to conceal all trace of the little store. From time to time, as the family proceed on their rambles

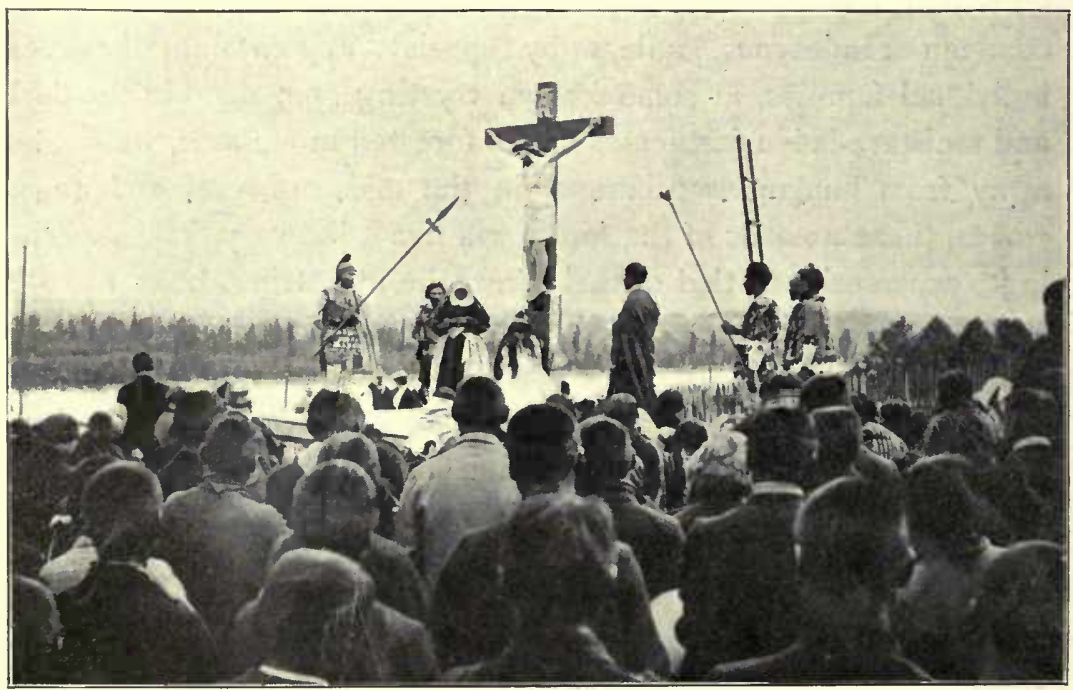

Passion Play performed by Roman Catholic Indians on the Fraser River, B.C.

through the vast, silent, and trackless forests, other similar deposits are made, so that on their return several months hence a welcome source of supply is constantly in advance. Besides which, there is always something pleasant in this finding or lifting of câches, a feeling which even the white man experiences, and the raison d'être of which, I suppose, one has to ascribe to the fact that to make a successful câche, particularly of large and bulky articles, is by no means an easy task, for the Wolverine is a 
wonderfully accomplished câche lifter, whose sharp scent and great climbing powers, formidable strength, and general "cussedness" few methods of either burying the valuables underground, secreting under piles of heavy logs, or suspending from high trees can withstand.

Some of the northern coast tribes were, until comparatively

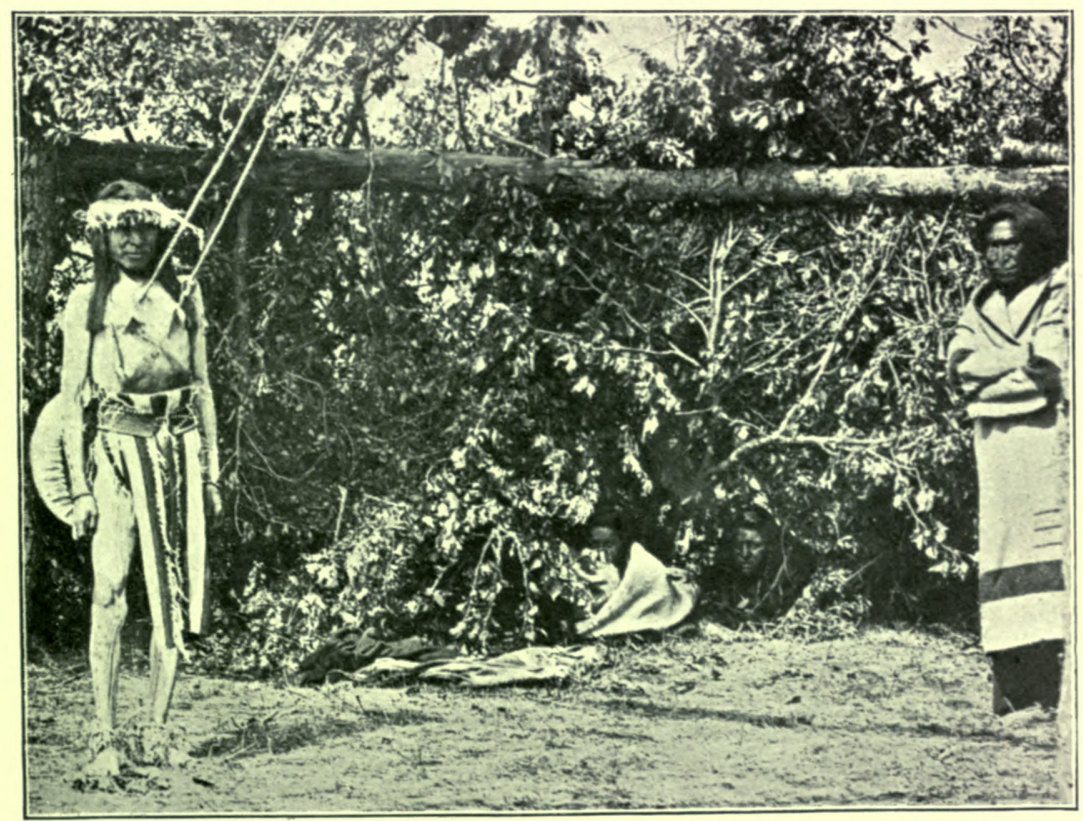

Self-inflicted Torture at an Indian Sun Dance.

"Making a Brave" by forcing wooden skewers through the muscles of the chest and then suspending the man by them.

recent times, cannibals, and I am told that one peculiar custom has not died out to this day amongst the Milbank tribe. It is that at a certain feast held in the autumn each sub-chief bites a mouthful of flesh from the arm of those of his adult male followers who have not yet been so distinguished. The flesh is chewed and swallowed. 
Speaking of such voluntarily endured tortures, suggests a brief reference to another species of self-inflicted martyrdom in use among the Kootenay's old foes, the Blackfeet Indians on the eastern foothills of the Rockies. "Making a brave" at the annual sun dance is a sight that I believe can be watched at the present day. 


\section{CHAPTER XIV.}

\section{SOME PERSONAL RECOLLECTIONS OF VICTORIA.}

IT is not much more than a generation ago that the Colonial Secretary of the day, when replying to one of the first questions ever put in the Commons concerning the newly-hatched colonial bantling British Columbia, remarked that its population consisted of a "motley inundation of immigrant diggers." It was language that befitted the mouthpiece of a policy that was fast estranging the Mother Country from her much disparaged colonial offsprings. Happily, we have changed all this, and not a day too soon, for if ever there was a colony that by the force majeure of its geographical position, was being driven into the arms of Britain's formidable rival on the North American Continent, it was the then infinitely remote and isolated British Columbia.

Wedged in between Alaska to the north, and Washington, Idaho, and Montana to the south, peopled to a considerable extent by go-ahead sons of the "greatest country in the world," neglected by the Mother Country, slighted by the Naval and Colonial Office authorities, totally ignored by British capital and by globe-trotters, the nimble Yankee dollar-than which there is no more insidiously active coin - was quietly working its sweetly innocent little victory. How near it came to add one more bloodless conquest of territories to the long list which have made the United States what they are, only those on the spot at the time could realise. 
The history of British Columbia is brief. Gold made it, and gold unmade it. Its start was precisely the same as California's, and the Klondyke boom, which is to-day luring thousands to untold hardships, is, with certain differences caused by the latter's extreme climatic conditions, but a repetition of what occurred in California in 1848 -9, and in British Columbia ten years later. Unlike California, the climate, natural resources, and topography of British Columbia are such as failed to hold out inducements to settlers so long as the "attic of North America," as it was called, retained the isolated position which it only lost by the completion of the Canadian Pacific Railway fourteen years ago. British Columbia's early boom was a short-lived one, for in a country so extremely inaccessible as was the interior, mining claims had to be extraordinarily rich to pay for working.* With wages for the ordinary miner at $60 s$. per day, and the simplest tools and hardware, such as nails and axes, costing $2 \frac{1}{2}$ dols. (IOS.) the pound, all but the cream of the thousands of claims staked out in the wilderness of Cariboo, or Wildhorse, or Cassiar, were quickly abandoned by the disappointed owners. Other gold discoveries in Montana, Idaho, Nevada, which latter, though its later career was that of a typical silver camp, had been started in consequence of auriferous riches, soon lured the " disgruntled diggers" back to regions south of the 49th Par., and British Columbia, after two or three years of feverish life, began rapidly to lapse to the condition of a "peter'd out" mining community. Something that was worth doing the boom had, however, achieved, for not all of the 20,000 miners who had flocked to the northern Eldorado turned their backs in disgust upon this beautiful mountain country. The first arrivals had found, where now stands the city of Victoria, a cluster of log cabins and a storehouse, surrounded by a business-like stockade, the usual make-up of a Hudson's Bay Company fort. Victoria, after the retreat of the great fur-trading company from United States

* Between May I and June 15, I 858, there sailed from San Francisco for Victoria and the Fraser 10,573 persons. 
territory in consequence of the Washington Treaty (1846), was selected by the Company as their future headquarters on the Pacific Coast. It was nothing more than a remote little trading post, where life passed in monotonous regularity, and newspapers a year old brought the latest news. To the utter surprise, and at first disgust, of the staid old factor and officers, who were the sole white inhabitants, came the first rush of the Californian miners. Many a time have I listened to the story of this unwelcome invasion from the mouth of the two men, Roderick Finlayson and Dr. Tolmie, who as chief factor and doctor of the Hudson's Bay establishment, had been two of the principal actors in those scenes. Prior to the rush of the fifties, gold dust or nuggets were as unknown as was any coin or banknote, for the Indian trade was, of course, the only trade, and was carried on in kind. As there was nothing to buy in the country, and nobody to sell goods to except natives, the salaries of the clerks and factor accumulated in the coffers of the company's head office in distant London town or in the Montreal office.

The following incident, told me by Finlayson, the founder of Victoria, for it was he who ordered the first $\log$ to be "squared" that went into the walls of Fort Camosun, on June I, I 843 , will show how entirely unknown gold then was among the fur traders. When Finlayson, about six years after founding the post, was about to marry, the visit of a priest to the settlement was to be taken advantage of to bind the sacred knot with a daughter of the soil. For this purpose a wedding ring was needed. "It was a case of steal, borrow, or buy a ring," as the venerable old gentleman with a kindly smile on his face expressed himself. "But that was easier said than done, for in those days that conventional symbol was, in our part of the world, an unobtainable attribute of civilisation, and to wait for eighteen months or two years till the annual ship could take home the order and bring out the precious article was not to be thought of. Money there was none in the place, for the Indian trade was exclusively carried on in 
goods, and our salaries were paid in drafts on Montreal, or credited to us in the London books. About that time the Company's local steamer, the old Beaver, paid us a visit, and from her captain I traded a sovereign. This relic of far-off home I took to the blacksmith of the fort, who finally succeeded in hammering it out into a passable imitation of a hoop, and with that ring I was married."

But now comes the strange part of the story. While the fort blacksmith was occupied on this unusual job, a few Indians, as is to this day the wont of the more unsophisticated natives, stood about the door of the smithy silently watching the doings of the hammer-wielding blacksmith. They saw what great store was set upon that round disc of yellow metal, and how carefully it was handled by horny hands. "Not long afterwards," Finlayson informed me, "one of these Indians brought me, wrapped in the toe of an old moccasin, a big thimbleful of coarse 'dust,' which he said he had obtained from Indians on the opposite mainland, who had got it on the banks of the great river." This happened, if I remember the date correctly, in the year I850, and that thimbleful of "dust" was, I believe, the first sample of the precious metal touched by the hand of white men north of California. Its discovery was bruited about, and led to more intelligent prospecting on the Fraser, the results of which brought about the big rush of I 858 and 1859 .

But let me resume the thread of history. The men who did not return to California's sun-baked valleys, or who refused to be lured to any of the new discoveries, but who decided to "stay with" the new born colony at whose cradle they had all stood, were happily of the warp and woof best fitted for the hardy pioneer colonist, such as have made the Greater Britain of to day. The old flag in their eyes covered a multitude of sins, the salubrious, comparatively mild Devonshire-like climate of the coast districts, or the keen bracing air of the breezy interior, with its cold winters and hot summers, the wild and beautiful scenery, the facilities presented in 
almost every corner of the colony for the enjoyment of the best of fishing in the world and fair sport for the gun, presented attractions which many of those who had seen other parts of the world knew how to value. It is true that some of those who made British Columbia their home had not the wherewithal to leave for pastures new-a standing joke in the Cahlfornian press-the mining ventures having "cleaned them out to bedrock." On the other hand, men who could have got away would not. "B.C. is good enough for me, though it is B.C.," was a play of words one often heard even in later years. Thus it happened that the older type of Victoria homes one saw peeping out of groves of trees, were unpretentious cottages, covered with honeysuckles and clematis, while rambling outhouses added at odd times in humble imitation of England's old manor houses, only heightened the likeness to farmhouses at home. They made upon one a pleasing impression, which was not decreased by the gardens, where flourished in great, though perhaps untrimmed, profusion the old-fashioned flowers so dear to those who have turned their backs on their native land. The men one met in the streets of Victoria were of the English country-town type - sturdy, well-nurtured, florid complexioned men - beings that took life easily, that ate their dinners of wholesome roast beef in a tranquil frame of mind, and that drank their Scotch or Irish whiskey to "keep out the damp," as they said in the humid coast districts, while in the rainless up-country regions it was imbibed to "irrigate the interior of a Christian."

No greater contrast can be imagined than the conditions of life in British Columbia produced by these features, and, on the other hand, the everlasting hurry and feverish high pressure existence in the larger towns of Washington or Oregon, immediately to the south of British Columbia. True, dollars accumulated very slowly in sleepy Victoria, where the shops and offices opened and closed at hours that made the visitor hailing from Yankeeland rub his eyes with surprise. Millionaires were conspicuous by their total absence, and the wealthy men, who could be counted on the fingers of one hand, 
were richer in land, cattle, or timber, for all of which there was then but little demand, than in cash balances at their bank. Mails viô the Isthmus every three weeks or so, and a peaceful absence of telegraphs added to the country's somnolence. Gradually, with the completion of the various transcontinental railways, communication with the old and new world became more rapid; but it was not till the completion of the Canadian Pacific Railway, fourteen years ago, that British Columbia, which in the meanwhile ( $187 \mathrm{I}$ ) had joined the eastern provinces of Canada in the general scheme of confederation, of which the Dominion of Canada was the outcome, really awoke and began to realise what vast resources Nature had bestowed upon her. To prove her treasures to the outside world has been an uphill game, and one fraught with some bitter experiences, for the baby "boomlet" that swept over the country soon after the opening of the railway which she had so dearly bought, brought ruin to many.

British capitalists who entered the lists during the first awakening of British Columbia, had, as a rule, good reason to deplore their haste, for, with only very few exceptions, not a single enterprise started or sustained by British capital in the earlier days ended otherwise than disastrously. It was this which gave British Columbia the name of being the land of unfulfilled promises. Smelters erected by English Trust Companies in impossible places before a ton of ore had been found in the neighbourhood; steamer lines that ran nowhere, and started from nowhere; mines which only a balloon or a mountain goat could reach; quartz claims that consisted of fine quartz, but narry an ounce of the precious metal; alluvial gold mines, where the quicksilver employed in the clean-up came out of the riffles as bright and silvery as it went in; land companies that owned more acres than shillings, and who, having started with insufficient capital, were done to death by the exorbitant wild-land tax and the absence of purchasers; paper pulp-mills, land reclamation schemes, and timber businesses that either lacked proper local management, 
or uninterested technical advice, were some of the many undertakings in which British capital has paid a high price for experience, and the non-success of which has given the country a black eye.*

Nor can the conduct of those entrusted with the government of the country awaken other than regretful feelings. Enough has been said lately by the financial press of London and other centres in condemnation of certain misguided ministers of the Crown who, in their official position, joined boards of highly speculative townsite and mining enterprises for the purpose of thereby attracting the $£ s . d$. of foolish investors at home.

At the date of my first visit to Victoria, it was still the Sleepy Hollow of America, for only one transcontinental line (Union Pacific) was in operation in North America, and mails reached the province every ten days, via 'Frisco. Nevertheless, it struck me as one of the pleasantest towns I had ever been in, and it certainly was the most convivial one. Its once famous hotel, the old Driard, was still managed by the best French chef it has been my luck to run across in any part of the world (he died soon afterwards), and coming from the wilds of the upper country, or from the inferior food of Oregon hotels and steamers, the cuisine of mine host added another charm to life in old Victoria. Old Victoria! Changed in many vital respects it is to-day. The advent of the "stranger" from Canada was not an unmixed blessing, nor has the completion of the C.P.R., with its selfish policy of pushing its own terminal town (Vancouver), benefited the old capital of the country.

Invidious task it would be to search for the causes. The absence of all push, which made life pass so pleasantly in the old town, was, no doubt, one of them. For certainly in no other city of its size was existence taken so easily as there. Time was reckoned by the ten days spell between each incoming mail.

* In one year during the boom 336 mining companies, with a capital of $£ 70,000,000$, were formed in British Columbia. I doubt if a score have paid dividends. 
About tradesmen, merchants, and officials there was a sublimely deliberate slowness, as amusing to the idle man as it was tantalizing to the busy one. The number of holidays was as phenomenal as the shortness of office hours. I had come expressly from England to interview the Attorney-General and

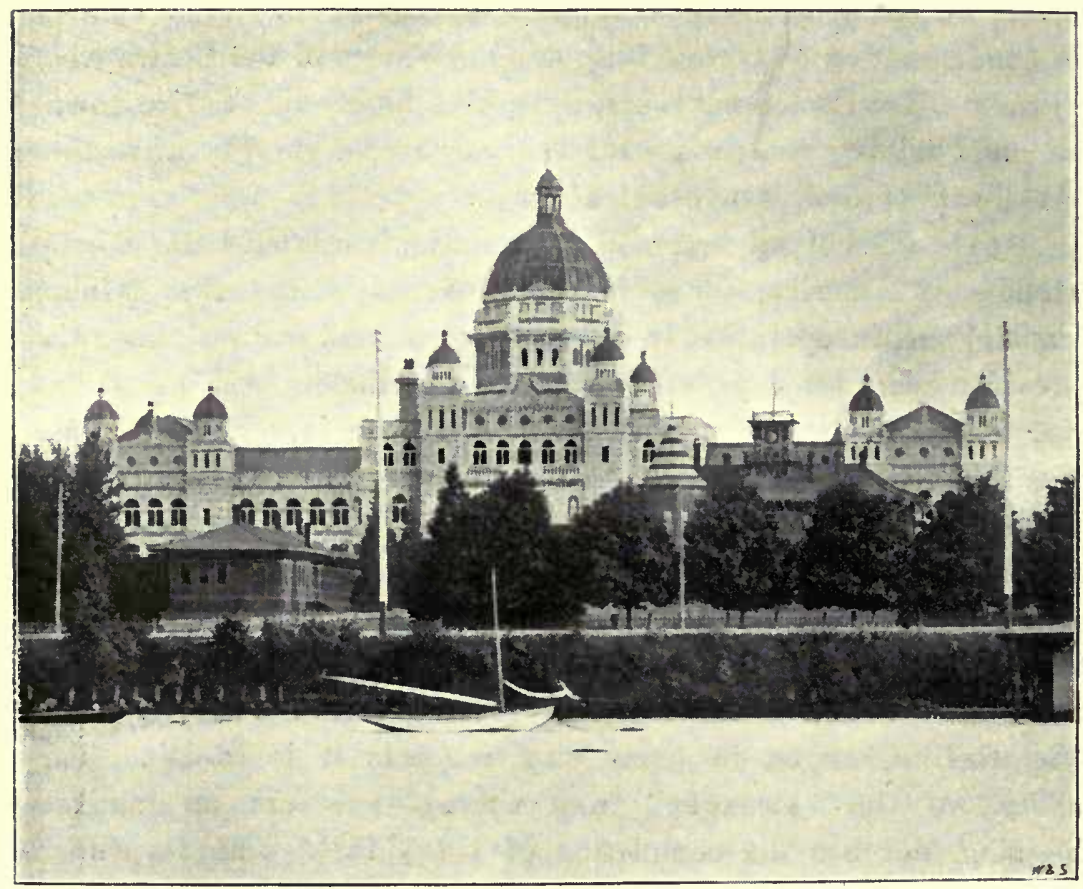

New Government Buildings in Victoria.

Small house in foreground is the old office of the Chief Commissioner of Lands and Works.

the Chief Commissioner of Lands and Works anent my concessions. Well do I remember my experiences. My first visit to the Honourable Mr. X-, one of these officials, occurred on the 29th June. As the office hours were from ten to four, I thought eleven o'clock would be a suitable hour. On reaching the funny old Government Buildings, Japanese cottage-like erections of very 
miniature proportions, ${ }^{*} \mathrm{I}$ was told that $\mathrm{Mr}$. X- never arrived before II.3O. I called again at I2.40, just in time to miss him"he had just gone to the club for lunch." The club was then over the principal butcher's shop in Government Street, and as I was lunching there myself I had every opportunity to satisfy myself of the truth. After its conclusion I had the opportunity to watch a few games of billiards, which occupied Mr. X-until half-past three o'clock. Following Mr. X- - five or ten minutes after his departure, I was again doomed to disappointment. "He just looked in, and then left for the day; he has probably gone to Sir Matthew's tennis party," was the office boy's report. Next day was Saturday; the cricket match of the season, Victoria versus the Fleet, was on, and Mr. X- though not a player, was giving the assembly the benefit of his presence. Monday, July 2, was, of course, a public holiday, for Dominion Day (July I) had to be duly celebrated. Tuesday at last dawned, and, somewhat impatient with the delay that had already occurred, I was at the office soon after Io a.m. My friend the office boy had got there apparently a few minutes earlier, and was passing his time with some desultory dusting, relieved by cracking nuts under the office copying press. Otherwise he was a model office boy, for he professed to know nothing except that, if I waited long enough, Mr. X-'s clerk and deputy would by-and-bye turn up "for sure." This happened about eleven o'clock. Tying his pony to the ring in the wooden planks of the footway, to show that his presence was only a passing incident in the day's work, Mr. Z - sauntered in, and after a casual " Good morning," seated himself, his hat on his head and his pipe in his mouth, in his chief's chair, and took up the morning paper, without vouchsafing a look at the stranger. I was amused. Placing my hat on my head, and lighting a cigar, I turned round my chair, and, leaning over the back, awaited further developments. This was evidently the kind of free and easy

\footnotetext{
* Really magnificent buildings have now been built, the old ones being left standing.
} 
manners Mr. Z_ was accustomed to, for presently he looked up, and, swinging his right leg over the arm of his roomy chair condescended to ask the stranger whether he could do anything for him. "Won't you finish your paper first, there is no hurry ; I have been trying to see Mr. X- for the last four days to deliver to him an unimportant letter or two about some unimportant business." "Well, I guess you'll have to wait another four days before you'll be able to do that," said Mr. Z— with innate dignity. "Mr. $\mathrm{X}$ - has gone fishing to Cowichan, and won't be back before Saturday, or possibly Monday, which is mail day." "Gone fishing to Cowichan!" I exclaimed; but no, there was no use getting angry, so with the deputy's gracious permission I entered into further explanations, and some more revelations were sprung upon me. I was told that, as the "Fourth" was also a public holiday (indeed, in those years one saw quite as many Yankee flags flying on Uncle Sam's national day as Union Jacks on the Canadian one), people considered the intervening days a sort of thrown-in holidays, no busy mail day interfering with that comfortable little arrangement. Presently the deputy closed the interview by informing me that if my business was very urgent I could take that afternoon's steamer to Cowichan. "You'll find Mr. S- (the other Minister) there, too ; they are staying with the latter's brother; he is the blacksmith in Cowichan."

I had read that some of the old kings and grand dukes in Germany were such keen sportsmen that they made their ministers, and even foreign ambassadors, seek them in their sylvan retreats in the dense forest, so I could not help drawing the moral that hunting and fishing were now, as ever, the most important part of a ruler's vocation, for it kept the anointed ones, as well as the brothers of village blacksmiths, at least out of mischief.

There were some other funny things to be observed in Victoria, the post-office being not the least remarkable. "Ways that are dark and tricks that are vain" is a mild description. There was then, and I believe there is still, only one post-office in the town, which now boasts of some 25,000 inhabitants. "Take that and 
be grateful," the Dominion authorities said, and Victoria took it, but whether she was grateful I have my doubts, for, mind you, there were no postmen, not a single one, and one had to go to the one office to get one's letters. So long as there was only one mail in every ten days this was no hardship, but Victoria continued postmanless for eight or ten years after a daily mail had been established, first via the Northern then by the C.P.R. Another and perhaps even more singular fact about that post-office was that it was the last place to go to if you wanted postage stamps. On inquiry you were informed that the Dominion postal regulations prohibited the sale of stamps by the post-office officials! "Go to the barber opposite, or to So-and-so's whiskey saloon, or to Mr. Hibben's book-store 'cross the street, you can get them there," was the invariable reply one received, and go across one had if one wanted to save one's friend the treble fine on an unprepaid letter. But no, there I am wrong; if the letter was destined for the United States, and it was insufficiently stamped, the Government was good enough to save your friend that fine by simply burning the letter. Incredible as it sounds, this is an absolute fact, which to discover cost me dearly.

The Government having broken faith with me in relation to my concessions, I had commenced a Petition of Right against the Crown. There was only one really "live" lawyer then practising in Victoria, and him I had retained by a 5oodols. fee. Other business of importance obliged me about that time to run over to London, making a stay of some days in New York. While there my lawyer forwarded to me certain documents on which my cases largely rested. His clerk stupidly put a one cent stamp too little upon the letter and also omitted to register it. The letter never reached me, and on making further inquiries by cable, I received a notice that such a letter was held by the Dead Letter Department in Ottawa,* and that it would be forwarded on

* There was then only one Dead Letter Office in the whole of Canada, viz., at Ottawa. 
receipt of one cent (halfpenny). I had in the meanwhile gone to London, and immediately sent the cent stamp in a registered letter to Ottawa. The following is the verbatim copy of the official letter I received in reply :

Dead Letter Office, Ottawa.

Mr. W. A. Baillie Grohman, \&c., England.

The letter to the address of

Mr. Baillie Grohman, \&c.,

New York,

Which was held at the Dead Letter Office for deficient postage, was kept for one month, and not having been claimed was disposed of in the usual manner. This letter not having been registered, no record of its disposal has been kept. The one cent postage remitted is therefore returned herewith.

J. Walsh, Superintendent.

My letter with its contents had been destroyed "in the usual manner!" This is the most charitable conclusion one could put on this singular proceeding. There were some other important documents connected with my case, and these, oddly enough, disappeared too, when some months subsequent to my having won the first step in the Supreme Court, my lawyer thought proper to abscond from Victoria and British Columbia, to the ruin of more than one of his clients and to the upsetting of my chances to succeed in the courts. Stock Exchange men will tell you that the great secret of not going to the wall is to know when to "cut one's losses." I thought that moment had arrived for me, and so I "closed the account," and soon afterwards bade good-bye to the picturesque land of unfulfilled promises.

A word must still be said about the fate of that large block of splendid agricultural land in Lower Kootenay covered by my concession. These 48,000 acres I had proposed, as the reader will remember, to reclaim from the annual summer overflow by turning the Kootenay river. When that intention had to be abandoned, an equally effectual cure presented itself. It was to widen and deepen the only outlet of Kootenay lake. By so doing an increased outflow 
was made possible, and, in consequence, the dangerous rise of the Kootenay river, where it flows in great serpentines through the vast stretches of meadowland I proposed to reclaim, would have been prevented. Upon the feasibility of this project English and American engineers had expressed favourable opinions, and I had already spent several thousand pounds in beginning this extensive though perfectly easy work, when I finally decided that to continue my single-handed legal fights with the Government of the province and with the London company who were bent upon ousting me from the control, was beyond my power. Hard as it was to retire from an enterprise which I had created and to which I had sacrificed some years of hard work, I cut myself loose from the undertaking. The company who stepped into my shoes were, however, not predestined to succeed. Influenced by technical advice suggested by the Government of the province, they abandoned my project and decided to reclaim the overflowed land by dyking it, an engineering feat upon which they worked some five years and spent about a quarter of a million of dollars. It has proved entirely abortive, for the overflow has continued in spite of the high dykes many miles in length. To-day the company is in liquidation, and sums which, I am convinced, would have completed the radical remedy I had commenced, have been utterly wasted. The application I recently received from the liquidator of this ill-advised company, to assist him in saving as much as possible from the wreck, needs no further comment on my part, more particularly so as the man who brought about this unfortunate ending is no longer alive.

There was one other little experience I was to undergo before I could cut myself loose from my enterprise. It occurred on my last journey from England to Victoria, some months after the Ottawa Dead Letter Office and my absconding lawyer had done their worst.

In all my journeys in various parts of the world I had never been in a wreck or in a serious train accident, and I was beginning to think that averages were not made for me, for according to statistics I should have been drowned or smashed up long ago. 
Sailing on the 23 rd November, 1892 , from Southampton for New York on the fast liner Spree, just about daybreak on the fourth day out, when we were about a thousand miles from land, the neck of the propeller suddenly snapped clean off and the great flanges dropped to the bottom of the sea. Before doing so, however, that vile old screw did not hesitate to give the old ship a parting kick by knocking a huge hole in the stern, I $2 \mathrm{ft}$. below the waterline, where, of course, it was quite out of reach. In five minutes the whole aft compartment, comprising the second class saloon and cabins, was full of water-3oft. of it-causing the stern to be flush with the sea, and the bows of the ship to be cocked high up in the air. The hole was much too large for the pumps to make the slightest impression, but fortunately it was fairly smooth at the time, and the plates forming the compartment withstood the vast pressure. There was no disguising the fact, however, that the first rough sea would at once send a thousand souls after that vile old propeller. The huge steamer was totally helpless, and rolled heavily in the swell, our only hope being the speedy appearance of a rescuing vessel. After a few hours of semi-panic, with fainting women, \&c., on deck and in the saloons, people began to settle down, and the lifebelts with which they had adorned their persons when the lifeboats were got out, were taken off and sat on. The worst about our position was that every hour the Gulf stream was taking us further north out of the usual route across the Atlantic. This, and prayer meetings under the active leadership of Mr. Moody, who was on board, continued for three days. Long days they seemed, which some of us tried to while away by whist, and others by poker in the smoking room. On the fourth mornıng, just at dawn, we were picked up by the little Lake Huron, our Captain having informed some of us the evening before, that if we were not sighted during the night our last chance to be seen by vessels was pretty well gone. Our happy rescue was brought about by the fact that we burned barrels of pitch all night, the reflection of which prompted the captain of the Lake Huron to leave his course believing that it was a ship on fire. 
It is curious how true that old saying about misfortune never coming singly often is, even down to the merest trifles. As a rule I am a very lucky card player, but during the first day after the mishap-I had been seasick until then-I lost over a hundred and twenty points at whist, and the next day fared not much better. The day we were rescued luck turned, and by the time we were landed at Queenstown, on December 3 rd, I was nearly two hundred points to the good.

The Spree, during those three days, when every moment might be our last, was a sort of accentuated "West ;" you saw people as they really were-morally naked. There were a good many North Germans on board, who were decidedly the most lugubrious, and, it seemed to me, also the most irritable. The first evening after the accident I sat at dinner next to a North German merchant. To change conversation at last into other channels, I asked him what a certain dish before us was like. He answered rather impatiently, angry, I suppose, to be interrupted in his interminable tale of woe concerning his wife and sundry children, who now would soon be a "viddow and urphans." Soon afterwards another dish, the nature of which I did not know, came round, and again I asked my neighbour what it was made of. "My Gott, do you think I'm your tam taster; eat, and find out for yourself," he ejaculated, and forthwith jumped up, and left the table in high dudgeon.

That morning, in the first moment of panic, when the lifebelts were being served out, 1 had noticed this very man angrily grab two of the latter, and put them on, though others had not even one. Another man, quite a young fellow, who, it appeared after"wards, had run away from home after a quarrel with his lady love, was fairly calm during all the anxious time; but, oddly enough, lost his reason after our rescue, and committed suicide by deliberately jumping overboard. Others again would sit for hours below on the lowest deck, and anxiously watch the thin iron partition between the flooded aft compartment and the centre one, upon which our safety depended. So great was 
the pressure of that solid 3oft. of water behind those bulging $\frac{1}{2}$ in. plates, that had they not at once been shored up with stout beams, disaster would have speedily followed, and even then the water kept spurting through the smallest crannies it could find. The swish of the water, together with the resounding blows of the floating furniture, piano, \&c., striking the iron sides, as the ship lurched from side to side, heard down there in the semi-darkness, were among the spookiest sounds imaginable, the anxious suspense of the whole situation making it, of course, all the worse.

One funny little incident connected with this mid-ocean adventure may be added to this, I fear, tedious chapter. At the time the shipwreck occurred my wife was in Victoria, happily unconscious of my plight. As it happened, the first garbled and much exaggerated Press cables published in the local paper also escaped her notice. Others, however, read it, and soon it became known in Victoria that I was one of the passengers on the liner. A dear old lady, rather hard of hearing and an old resident of Victoria, who in her earlier life had been much troubled by a husband and by a son addicted to what out West is known as going on the spree, grasped the details of the rumour concerning poor "Mrs. Grohman's husband" in a mistaken sense. She rushed off to my wife to offer her deep sympathy: "Such a dreadful thing, you know, to have a telegraph from the other end of the world that one's husband is on the spree!"

To speak in guide-book fashion of the various resources of British Columbia would be an unnecessary infliction. Some remarks about the mines I have confined to a few pages in the Appendix (Note IV.). Of the wonderful timber along the coast. everyone has heard, so I will not add to that literature. Of British Columbia farming I would prefer to let others who know more about it have their say. Hitherto it has not been the general success it should be, considering the splendid markets which the mining camps furnish. It is generally said that the outrageous freight charges of the C.P.R. in the interior of the 
province $^{*}$ is the chief cankerworm. A look at the imports and exports shows that the old saying that British Columbia does not raise even the chicken feed she needs is not so grossly exaggerated. Thus, in the year I89I, five years after the completion of the C.P.R., the province imported and exported :

\begin{tabular}{|c|c|c|c|}
\hline & Imported. & & Exported. \\
\hline & 39,788 head & … & 2 head \\
\hline & 809,7 & ...... & none \\
\hline barrels) $\ldots . .$. & $3^{1,692}$ & ...... & 5 \\
\hline & $306,297 \mathrm{lb}$. & ...... & $3743 \mathrm{lb}$ \\
\hline & I 97,254 dozen & & I5 dozen \\
\hline
\end{tabular}

A duality of Government is hardly an unmixed blessing for a country three thousand miles from the central seat. All matters connected with the post, customs, marine, justice, and Indian affairs are exclusively Dominion matters, and are therefore managed from the other side of the continent. The public accounts show that British Columbia is subjected to a great drain. Its population was, in $189 \mathrm{I}$, less than 100,000 , including nearly 30,000 Indians and Chinese. The average rate of taxation in the whole Dominion from the two great sources of revenue, customs and excise, is $\$ 5.92$ per capita, yet the public accounts show us that British Columbia contributes $\$ 16.97$ per head of its population, or, if one excludes the Indians, over $2 \mathrm{I}$ dollars per capita. This shows that British Columbia pays i I dollars a head more than the average share. What does this Province get from the Dominion Government for this million and odd dollars a year more than the average share of taxation? Not its proportionate share of appropriations certainly.

* The following may serve as an instance of C.P.R. charges which a Victoria merchant had to pay. The goods were destined for Ashcroft, an up-country settlement about 200 miles from the coast. They had been imported from Glasgow by sea to New York, and from thence via one of the American lines across the continent to B.C. The freight charges from Glasgow to B.C., more than 6000 miles, came to 24dols. per ton, while from the coast point to Ashcroft (204 miles) they amounted to 2 Idols. per ton. 
The following tabulated statement is based upon the public accounts for 1892 , and the census of $189 \mathrm{I}:-$ $\begin{array}{ccc}\text { Pevenue : Customs } & \text { Per Capt. } \\ \text { and Excise. } & \text { Population. } & \text { Pevince. }\end{array}$

Ontario.

$$
\text { 2. I I 4,32 I }
$$

Quebec I, 488,535

Nova Scotia

450,396

New Brunswick

321,263

Manitoba

I 52,506

British Columbia......

P. E. Island ...

97,6 I 3

I09,078

N. W. Territories _.. $\quad 98,967$

Dominion of Canada
$4,832,679$
\$ I $2,054,4$ I I

$$
10,509,632
$$

$1,689,242$

I, 336,745

I , I 45, I 89

I, 656 , I 56

2 I 2 . I 35

$\begin{array}{lr}\ldots \ldots \ldots \ldots & \quad \mathrm{6} 6,649\end{array}$

....... \$5.70

…... 7.06

........ 3.75

4.16

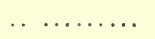

$\ldots \ldots \ldots$

28,63 I , I 66

5.92

That the revenue of a country should, if needful, be raised by a stiff tariff is quite reasonable, but the authorities should not evince the excessively petty spirit of exaction of which all settlers in the interior of the country so loudly complain. A sixpenny book, a shilling doll, a Christmas plum-pudding, nay, even a single pair of gloves sent by post in a letter, are stopped at the frontier and a notice sent to the addressee, and till the money is received the articles and letter, if there be one, are retained. In a country where the more isolated settlers receive perhaps only one mail in a month such delay is exceedingly irritating, particularly as the regulations require that the money must be sent, not in stamps, but by postal order or cash, which latter again means registering the letter and obliging the settler to ride, drive, or walk to the nearest post-office, perhaps forty or tifty miles or more from his cabin. I have heard from English and American settlers in British Columbia more angry comment anent this pettifogging meanness of the "smallest government God ever allowed to exist," than about anything else. Most men would prefer to pay one dollar in direct taxes than have ro cents exacted by such irritating proceedings. 


\section{CHAPTER XV.}

\section{THE YELLOW AND WHITE AGONY.}

(A Chapter on Western Servants, by Mrs. Baillie-Grohman.)

When I first went out to British Columbia with my husband, although, of course, the early pioneer days were a thing of the past, I do not think that there were more than three families in Victoria, the capital, employing white servants. These could not be obtained in the country, but had to be imported at their employers' expense from the old country. The white girls thus brought over seldom stayed in their places long, as they quickly married, or left to obtain higher wages.

It is difficult to give an entirely satisfactory answer to the question so often asked: "What kind of servants do Chinamen make?" It must always depend on the individual man; as an average they are good, comparing more than favourably with the ordinary Western help, which is generally an untrained white girl who has to be taught all her work, and who expects to be treated as an equal. It is scarcely fair to compare poor John with the trim English maid in her cap and apron, who has been well trained in modern civilities as well as her duties, nor can his culinary productions compare with those of a finished European cook; but with the average plain cook and the inefficient housemaid the contrast would be all in his favour. He does twice the work, he is far more cleanly in his manner of doing it, he is always sober, and fairly honest. It is marvellous how he adapts himself so well to the many strange duties required of him. It is less difficult 
to initiate him in the ways of an English household than any average Continental domestic, and I have had a fair experience of the training of Bohemian, North and South German, Tyrolese, as well as English and American servants. But perhaps a few incidents of personal experience will be more interesting than generalities, and I will give a few from my period of housekeeping in British Columbia.

On arriving in Victoria we were undecided whether we would winter there or not, so we took some furnished rooms in a cottage belonging to a widow and her daughter, with whom I lived and boarded during some months while my husband was up in the Kootenay country. The widow did the cooking, but a small Chinese boy of about fourteen years old was trained by her to wash dishes, scrub floors, and do all the little menial "chores." The first day of my arrival, just before luncheon was to be announced, I became aware of a scuffle going on outside the door, and remonstrances being exchanged between the widow and the boy. "Me no likey, me no likey," he exclaimed, as the door opened suddenly and Sing was shoved into the room, the widow prompting him from behind. He spread out his hands, made an awkward bow, saying, "Dinner he ready," and then, ducking his head, turned tail and escaped out of the room from the widow's clutches. "I am trying to teach him manners, but he has no savey," explained the widow. This was my first introduction to the Chinese domestic.

After a few weeks the widow fell ill, with bronchitis if I remember rightly. On the second day I was coming out of her room, when I met Sing rushing up from the kitchen stairs. "Come quick, she got debil," he cried. On going into the kitchen, I found the daughter in a fainting fit on the floor; she came to in a few minutes, and I helped her to her room. A few minutes later, in came Sing, with a bundle done up in a red handkerchief.

"Good-bye, Mrs. Gloman, I go now."

"When will you be back?"

" No more. Debil in this house, I no stay." 
No persuasion, not even of extra dollars, would alter his decision, and for some days no Chinaman nor any cther help could be procured. It was impossible to leave the mother and daughter alone, as the latter, I discovered, was subject to hysterical or epileptic fits, so I had no alternative but to initiate myself into the mysteries of cooking, making poultices, and brewing beef-tea, in fact, the duties of a general servant, plus those of a nurse. It was really a most exciting time, the anxiety with which one watched the boiling and the baking, the triumph one felt when any dish was absolutely cooked and served up, looking at all like the work of a professional cook; the delight when the fire did burn without any trouble, and the pride when the beef tea was pronounced "the very thing" by the invalid, are all beyond description. I felt almost disappointed of my mission in life when a white woman help was found at last, and when after a short time the widow got well and began to reign again.

We then took a furnished house, and the Chinaman who had been a couple of years with the owner of it offered to stay on with me. A great relief, as I felt he would know all about the house work and cooking. So he did, but he was much put out if I deviated a hair's breadth from that which had been. customary with his former mistress. He was clean, and good looking for a Chinaman, and said he was eighteen. He could cook fairly well, he could roast and boil, and make clear soup, good pastry, and mayonnaise sauce ; everything devoid, however, of pepper and salt, as he carefully explained to me, "That no matter, I put him on the table." (Him meaning pepper and salt.)

One day I found a broom and a dust-pan left in the drawingroom. On telling him to remove it, he said: " $O$, I tink you sweep out dlawing-loom to-day, velly good." I retorted that I thought it would be better if he swept it out. "No, no, I no do that loom ; missus she do him evely week; I no time." He really seemed to be doing the work of three English servants, as he was laundress, as well as cook and housemaid; so I resolved to follow in his former mistress's footsteps. I had vivid recollections of the 
housemaid's "doing" rooms at home, and of seeing all the furniture turned topsy-turvy into the passage, and tea-leaves being sprinkled over everything, and I was soon at work in a businesslike fashion, with my dress pinned up and my apron on, when up came Gee with a clean duster. "Velly good, you tie him over your head, missus did." Accepting the suggestion, I then began to move the furniture, and sweep. Presently the door opened a little, Gee's head was inserted in the crack, and he watched me in silence as I continued to raise as much dust as possible, and pretended not to notice him. Then, after a few seconds, he exclaimed: "Missis Gloman, you go out walk, I tink."

"No time, Gee; what do you want?"

"I sweep this loom, you no can do him; my missus, she velly strong, she savey." Then with scorn he added: "You no know how, you give me bloom, you go lunch with Missus Dlake." Then following his head into the room, he seized the broom, tied on the apron, and put the duster, which I had just relinquished, on to his head, and, thankful for the release, I acted on the suggestion, and went out to lunch with my friends.

For more than two months I was alone with Gee in the house, my husband still being detained up country. Gee had asked me when he first entered our service who was boss, master or missus, whereupon I promptly replied that I bossed the Chinaman and the master bossed me. Readily accepting this state of affairs, he had never been disobedient, and always tried his best to please, but much resented any order being given to him direct by my husband when the latter returned. Gee did not sleep in the Chinese quarter, as most of the servants do, but preferred occupying a tiny room off the kitchen. This he kept scrupulously clean, all his boots and shoes, five or six pairs in all, were arranged in a methodical row under his deal table, and his clothes were done up in kerchief bundles, and placed side by side on the table. As soon as he had finished his work, about eight o'clock in the evening, he would go off to the Chinese quarter, and return about twelve or one o'clock at night. As he neither gambled nor smoked opium he probably 
spent his time gossiping with his friends. As the days drew in, I disliked being alone in the house during the long November evenings. Although I had many kind friends who took pity on my loneliness, very often I felt it would be more canny if Gee could be induced to stay in the house till nine or ten o'clock. He did not seem to like the idea at all when I suggested it, and nothing more was said about it for a few days. Then he came with a proposal: "Missus Gloman, I velly solly you all alone evening. I stay till half-past nine or ten, but I like you teach me lead and write English ; I get book. After work I come in? You tink so?"

This was a quid pro quo with a vengeance; but we soon settled down to the evening lessons, and in six weeks' time, when my husband came down for the winter, and the lessons had to be given up, Gee could already write and read fairly well. Gee was the only Chinaman I have ever seen on a horse, and when he went out on the old white pony that his former master had left in our stable, it was truly a sight to behold. The first time I saw him he was carrying a huge bundle in one hand, the reins and his hat in the other, his pigtail floating in the wind as the old pony ambled into town. The evening afterwards when he came to have his lesson he knelt down to the table to write.

"Take a chair, Gee, you can't write like that."

"O, yes! I wlite like' that to-day, I no can sit; I lide too far yesterday."

My son was born during the winter, and Gee's delight knew no bounds. hope."

"A boy all light, girls no good; one day he be judge, I

The one damper on this event for him, was the arrival of the English nurse. He almost always turned his back when she spoke to him, and was as disagreeable in every way as he could be to her. Probably he considered she had an evil eye, for later on I had a small boy in my employ who invariably turned his back on me in the same manner, and when I asked him the reason he told me I had "heap bad eye." One day Gee's complaints 
burst forth. Nurse was a bad woman, soon she would kill the child, she was tying it too tight round the waist; white clothes were not good for babies, they should have nice wadding and red flannel; they should not be washed so often. He knew a Chinese woman who brings up babies very well, would I let her come?

"No? Too bad. If you get another man to do washing and cook, I look after baby, you tell me; Chinese woman tell me, I soon can do it all light."

Gee's ancestors were his religion, as they seem to be of all his race; at least, that part of religion that consists of worship and veneration. All the rest was fear-fear of an unknown evil, fear of invisible demons. Not always invisible either, for, as he said, "Some man can see debils, some man no can see them; he there all the time, air he full of them." Probably the Chinaman who sees devils sees them through the medium of opium, for they must often get to the state the hard drinker was in, who, when a mouse ran across the floor of the saloon at the bar of which he was standing with some friends, exclaimed, "I say, you fellows, you may think I saw a mouse run across the floor, but I didn't."

"If you believe in a joss," I said to Gee one day, "why don't you go to the joss-house more often?"

"It cost me two bits" (about one shilling).

"Why do you have to pay to go to the joss-house?"

"All the same you pay in church, to keep the debil away."

* $*$ * $*$ * * *

"Why do you take chickens and wine and cakes to the graves of your uncles, and then bring them back to Chinatown and eat them yourself? You must know, as you eat them yourself, the things can be of no good to your dead relations."

"You see," replied he quickly, taking up a cup, and holding it in front of a lamp so that a sharp shadow was thrown on to the white tablecloth. "You see that," pointing to the shadow, "dead men all the same that, he eat all the same that (shadow) of food 
and wine, I this," flicking the cup with his finger; "if I no get all the same this, food and wine, me pretty soon die quick."

* * * * * * *

"Pull down the other blind, the sun is coming in."

"This morning I pull down one blind, sun look in that window, now he look in this window, by and bye he look in another window, and then white man say sun he no walkee, he walkee all the time ; white man heap liar."

* $*$ * * * * *

There were two great events in Gee's life that winter. $\mathrm{He}$ became the owner of a silver watch and chain, and he had his photograph taken. The watch and chain were laid on the table for my inspection, and I was anxiously watched while I handled them. Then I suggested that he should have a washleather pocket for it. The next day a large piece of washleather was handed over to me, with a "Please, you sew me one watch-pocket?" and his delight knew no bounds when he received it, with his name stitched in silks in English on one side, and in Chinese hieroglyphics on the other. I little knew what this would lead to. "Oh, much too good evely day; please make me just common one, I keep him for best days." Then a week later he came with another petition: "I got one friend, he got good missess, but he see my watch-pocket; he say, 'Your missess all the same one mother to you, you ask her to be all the same one mother to one more poor Chinaman, and make him bag for his watch, too.'" This was, of course, irresistible, and a third one had to be manufactured.

"My mother pretty old now, Missus Gloman, she fifty, I think soon she die; I likee vely much send her my picture, you tink man hurt me vely much, he make my picture."

"No, Gee, he won't hurt at all." This was received with incredulous looks by Gee.

"I see your father and mother's picture, very old man and woman, are they dead now ?" 
"No, they are alive and very well."

"He no die, I tink go tly to; I heap scared."

A day or two after a savoury odour attracted me to the kitchen, where I found Gee cooking bear's paws, bacon, and a lot of herbs.

"I take this as medicine," he said. "I feel velly sick since two days ago, when my photograph taken."

He survived it, however, and the photo quite came up to all his expectations, and the watch and the chain, and his English reading book were all displayed therein, to the greatest advantage.

One night I was awakened by a tremendous crash, quickly followed by another. Lighting a candle and going to my bedroom door, I saw the glimmer of a light shining from underneath the closed kitchen door, at the end of the passage. It was past two in the morning. Could it be a burglar? I called out to know if it was Gee, whereupon the light was quickly extinguished. Feeling far too nervous to explore farther, I locked myself in my room, and, having listened in vain for an hour or two for any further sounds, went to sleep. Gee called me as usual next morning, but after his knock, instead of departing without waiting for any answer, as was his custom, he called out, "You all light?" and, receiving a reply in the affirmative, went away chuckling audibly.

"Why did you ask me if I was all right this morning ?"

"Oh, last night I hear heap noise, I get light, then I hear you call Gee, I tink for sure white man get in and kill you; I heap solly."

"But why did you not come and see, instead of putting out your light?"

"Oh, I no good; he can kill big English woman, he velly easy kill poor little Chinaman, too; so I put out light and locked door. Oh, I laugh, I so glad to hear you no killed this morning."

The crash had been really occasioned by the cat in the china cupboard. On unlocking it we found her imprisoned there, among the shattered remains of two large glass dishes. It was not comforting to know that one's only protector in the house would 
quietly retire to sleep, although convinced that one was being murdered.

* $* * * * *$

"How much boss he give your father for you?"

"In England fathers don't get paid for their daughters; boss gave him no money."

"Oh, too bad, I tink your father heap foolish. He ask lot of money for you, I tink boss would give it; too much pity your father get nothing. Girls cost heap money, and no can do business for father when they grow up; oh, too much pity your father get nothing."

He told me that for 250 dollars or 300 dollars he could get a wife, and when he had saved that he should go to Hong Kong, and his mother, or another old woman who was used to the business, would speak to the parents who had a suitable marriageable daughter, and they would come to terms with them for him. Then he would marry, and, like the rest of his compatriots, wait to welcome the much longed-for son, or wring his hands over the unwelcome and despised daughter. Then probably he would return to work on the Pacific coast for ten or fifteen years before returning home again to his family.

"Too bad for poor Ah Wan," said Gee, one day; " his wife she kill herself; he save up money and mally her last year, now she kill herself, he wasted all his money."

"Why did the poor woman kill herself ?"

"She live with Ah Wan's mother, his mother velly cross 'woman, she velly unhappy; oh, I velly sorry; he never get money now for another wife, he no can save up before he die, he velly old man now."

The regret was so ludicrously simple; it was merely for the loss of his friend's money, not for the sad tragedy enacted by that neglected little Chinese girl in far away Hong Kong. Ah Wan, I may say, was our "vegetable man," who brought us fresh lettuces, asparagus, and peas, and all the season's delicacies in his quaint 
wicker baskets, cleverly balanced on the end of a curved stick carried in the familiar way over the shoulder.

One day Gee rushed in in great excitement. Ah Lam Sam, a friend of his, the head of his company (they all belonged to

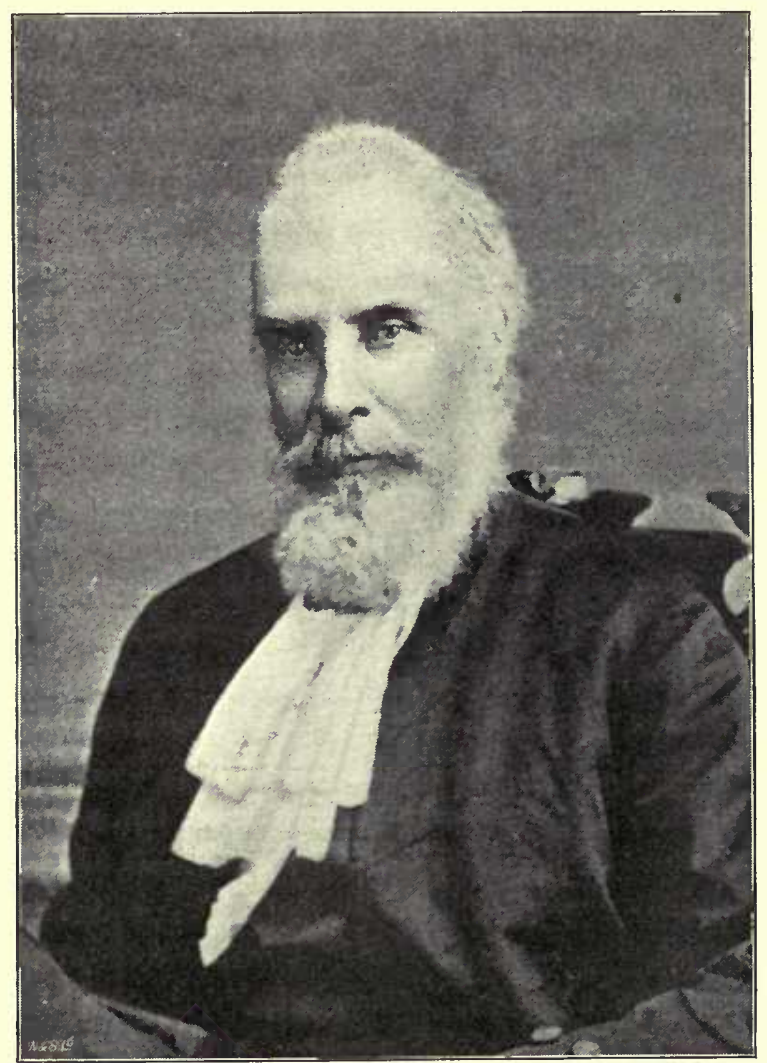

Sir Matthew Baillie Begbie, Chief Justice of British Columbia.

societies of some sort), had been put in prison on what he said was a false charge of writing a threatening letter to the English Government interpreter.

"Too bad, too bad," moaned Gee. He really seemed in great 
distress. Ah Lam Sam was what they call a boss Chinaman; he owned a shop in China town, and was a contractor for Chinese labour. While he was in gaol, his wife and little girl used to drive by our house once a week on their way to visit him, but he remained there some months, and, as he was not allowed out on bail, his business languished, and ready money became short. Soon his wife and child, instead of driving, hobbled painfully on their little feet along the two miles or so of wooden sidewalk that led from their house to the City gaol. As my house was little more than half-way between the two, Gee asked me if the woman and child might rest in my kitchen, so for the time that Ah Sam was in prison they had tea once a week there. During that autumn and winter the late Sir Matthew Begbie, the Chief Justice of British Columbia, came to lunch with us every Sunday. As soon as his duties in the choir of St. John's Church were over, he would stroll on to our cottage, which was near by, would knock the ashes of his pipe out on the doorstep, would put this dear friend of his, from whom he was never separated, into his waistcoat pocket, so that the bowl stuck out as a reminder to all that it must be filled again at the very earliest opportunity. After a few Sundays his appearance would be preceded by a Chinaman or two, who would go round and gain entry by the kitchen door; these were not Chinamen of the ordinary domestic class, but such whose rank entitled them to wear a black silk cap, with a black or coral topknot to it, instead of the ordinary soft felt wide-awake adopted by those of meaner degree. More Chinamen would hang by twos and threes outside the gate. Just before lunch was ready, Gee would come and call - me out of the room, and beg me to come into the kitchen. I soon found that I was expected to interview these Chinamen, who had come on behalf of Lam Sam. The Chief Justice lunched at our house. I was a good friend of his, I could talk to him, and tell him how wrong it was to keep Lam Sam in prison; they wanted me to introduce them to "Judge Begbie," and say they were honest men; they would takee their affidavits that the incriminating letter was not in Lam Sam's handwriting, they would prove this to me, 
then I could take my affidavit. It was hard to convince them that I could see no difference in Chinese hieroglyphics. I was to take my affidavit that Lam Sam was a very good man, and "Judge Begbie" would believe me if he would not believe a Chinaman, and, beyond everything, I was to get plenty of presents if I could induce "Judge Begbie" to let him out on bail. It was no use explaining that I would not be bribed, that I could not possibly mention the subject to "Judge Begbie." I only made my escape on one Sunday to receive the same application the next Sunday. Gee would, or could, not keep them out of the kitchen, and there they would sit for hours till I went in and peremptorily dismissed them, when they would seize the opportunity and eagerly offer me papers and proofs and affidavits. Having at their request told them which lawyer to go to for their defence, they acted upon my advice. At last Lam Sam was brought up for trial, and his case dismissed at once, as nothing could be proved against him. But Sam and his friends persisted in being grateful to me, and did not seem to believe that it was the absolute lack of proof of any kind against Lam Sam that let him off so easily, but that it was because the lawyers and judges were "velly good friends of yours, Missus Gloman." The very day Sam was released, Gee, who had arranged a cold lunch for me and put it on the table as soon as the breakfast was cleared, so as to hurry off to the court where Sam's case was coming on, soon came back in a frantic state of glee. "Lam Sam all light, he heap pleased; he thank you and judge and lawyer velly much, he come see you light away; he go off now, put on good clothes, he come up see you. You let him come in drawingroom, he boss, he not all the same one poor cook."

"Well, Gee, you had his wife and child in the kitchen."

"Woman, he no count, he no matter; Lam Sam he big boss."

The hired hack and pair of horses soon drove up, Lam Sam, his wife, and little girl, whose name, by the way, was Fung, and who was about twelve years old, and one of the friends who had besieged me on Sam's behalf on many Sundays, were ushered into 
the drawing-room. Lam Sam preceded them all, and with beaming smiles came forward to shake hands, and then made way for his wife and child, who were laden with pots of ginger, cumquets, packets of special tea, huge paper parcels of lychee nuts, and a pair of Chinese shoes, a little red flannel wadded waistcoat. a green silk overcoat, and a curious little Chinese head-dress. All these garments, excepting the shoes, having been made by Mrs. Lam Sam for my baby. "We thank you velly much, you velly good friend, we have brought you little presents, if you like any more will you say so?" Gee then handed round sherry and cake, and suggested that I should bring in the baby. The visitors all stood solemnly round gazing at it, then Lam Sam, raising his glass, said, "Good luck to the son, I hope one day he will be big man, and take on father's business. I hope one day he will be a big judge." The sequence was not clear, but the judgeship was evidently considered the result of success to which any profession might lead.

When the Chinese new year came round, and Gee, like every other Chinese servant in the town, departed to the Chinese quarter to enjoy a few days' holiday, he deserted us for a whole week, returning to us only once during that time, to enquire after the baby, and hold up his hands in holy horror at the mess and muddle the charwoman was creating in his realm. Then came invitations from Lam Sam and his wife. Would we go to the theatre with them; my husband was to be given a good supper and champagne and good cigars if he would honour Lam Sam by going to his house. I was invited to go to Mrs. Lam Sam and have wine and cakes, and then we were all to go to the theatre, where he had taken a box for us. This invitation was delivered to us through the telephone by Gee, from Lam's store, and I do not know anything funnier than pigeon English coming through the telephone. As I knew the Chinese theatres to be frightfully dull and lengthy performances, and I was only just recovering from an attack of bronchitis, I had to refuse this alluring programme. Then through the telephone came exclamations of disappointment, and a great chattering in Chinese. Then Gee called out: "You wrap up, 
Lam Sam send his wife, come and fetch you in a hack, no catchee more cold ; tell boss champagene heap good."

After an interval of a year's absence in England, I met Lam Sam in Victoria again. He rushed up, greeting me effusively, and asked me to come and see his wife on the following Sunday. It was rather a shock, however, to my friend who went with me, as well as to myself, to find on entering the woman's room two wives, one of whom was much older than the one whom I had seen before.

"This my oldest, first wife," explained Sam, "this wife you know, she young." They both rose and shook hands, the younger woman having to climb over the piles of blue cotton Chinese blouses by which she was surrounded, and the buttonholes of which she seemed to be manufacturing. Fung had grown into a lanky damsel, and had her face already much rouged and powdered. There were two smaller children in the room, who, in their fits of shyness alternately took refuge first with one woman and then with the other, so that we never knew which was the mother, and felt a certain delicacy about asking. Neither of the wives spoke English, but smiled and nodded at us continually, while the younger one shuffled in and out of the room, bringing us sweetmeats, wine, and cake, and what we did not eat they insisted on doing up in two bundles, wrapping each in a red handkerchief, and presenting one to my friend and one to me. With these we had to leave the house, and run the gauntlet of all the town. We should dearly have loved to leave them behind or drop them, but were afraid of mortally offending our hostesses.

When my husband advertised for Chinese labour for some work up in Kootenay, there was great rivalry between the would-be suppliers of this labour. The Chinese contractors all called on him, and tried to find out the terms offered by their rivals, and if possible to underbid them. One Chinaman came upon me unawares in the garden one day, after he had left the house, where he had been confabulating with my husband. Looking round cautiously to see if anyone was within hearing, he came up and 
asked me if I was "missus"; he told me he wanted to take Chinamen to Kootenay for Mr. Gloman, and if I would make my husband employ him, and let him provide rice (he pronounced it lice), he would give me five per cent. cash on every Chinaman, and on all the rice he sold. "No? Six? No? Oh yes; I no tell boss, he can't know ; you buy plenty things with money."

The whole experience was so novel that I laughed aloud. "Oh yes, I see, you takee." And a very much disconcerted Chinaman left the place when he found that I " no would takee."

The way some of the white "Hoodlums" of the town behaved to the Chinamen was disgraceful. They frightened my man so much, that, for some time he scarcely liked to go outside the gate to pass a large vacant place close to us which the boys of the town had made a playground of. One day they knocked him off the sidewalk, and at the same time cut his head so badly with a stone that he rushed home to me, and I had to plaster and bandage his head and eye. I telephoned at once to the police station. The conversation I had was somewhat characteristic of the happy-golucky colonial way of doing things.

"The boys on the green opposite my house attacked my Chinaman, who was going into town; they have knocked him about very badly. As they are still playing on the green the man is afraid to go out. Send a policeman up."

"Well, take the names of the boys and send them to us."

"I can't go out and catch them, that is your business."

"See if there ain't a policeman on Douglas-street, and put him on to them."

- "I can't see one my end of Douglas-street; what is the man to do?"

"Well, I guess, if he is scared he best stop at home; or you could walk down the street with him a bit, they won't go for him if you are there; we are too busy to look after every Chinaman that has a stone thrown at him."

Cool, but as there seemed that no more help was forthcoming, I did accompany Gee past the dangerous playground. 
"I got something for boys now, when he come and throw stone at me," chuckled Gee, a day or two after this, and with this he produced from his wide sleeve a large iron crowbar. "I tuck him up my sleeve," he said; "boy come, I just knock him hard on head."

"Give it to me, Gee; where did you get it?"

"I go hardware (ironmonger) store; man there he know me, he ask me what the matter with my head, I tell him all about boy, then he give me bar, he tell me that settle boy pletty soon."

"Yes, Gee, and that will settle you, too; for if it killed the boy you would be hanged."

I kept that bar, and returned it to the man at the hardware stores, whose only excuse for having supplied him gratis with such a murderous weapon, was-well, they all carry them.

Gee was certainly a most satisfactory Chinaman, as he not only could work and did work, but he was so communicative, and amused me so much, that I am afraid I spoilt him rather, for he was getting somewhat cheeky before he left, and on several occasions I had to give him one or two severe reprimands on this head. As I was dining with some friends one day, I told him to come and fetch me at a certain hour. Long before that time had arrived one of the daughters of the house told me I was wanted at the telephone (nearly every house in Victoria possessed one of these useful instruments).

"Who is there?"

"Hullo, Missus Gloman; please you tell me name of all men who dine at Mrs. D— to-night."

"What do you mean, Gee?"

"Oh, please, I tink some man dine there, my friend he say he tink not, I bet one dollar ; please you so good to tell me."

$$
\text { * } * \text { * } * \text { * * }
$$

People have said that they are safe servants as they never repeat conversations, and don't gossip as do white servants. My experience is quite different, and no greater gossips exist than 
these silent, solemn-looking celestials; and I am sure that everybody's business and family affairs are well discussed and exaggerated at all the various Chinese stores where the domestics congregate of an evening. The qualities of every mistress are well known, and some in consequence find it difficult to induce any Chinaman to enter their service. Certainly everyone's income is speculated upon, and if one lives in a house which fetches a certain rent, one will only be able to procure a Chinaman at corresponding wages. A man who had been with me, receiving I 8 dols. a month, and whom I had sent away, was offered 2odols. by another lady, yet he begged to come back to me. Not wanting him, I told him to take the other place: "Too little money," he said. "But it is more than I gave you." "No matter," he said; "that house twenty-five dollar Chinaman, I no go there, she no give me twenty-five; you eighteen dollar house, I likee stay with you." Later on, when we took a house where the former owners had always paid 3odols. a month for their cook, I could not get a man to come for a cent less.

One winter when I was in Victoria there was an unusual scarcity of Chinese servants, and I tried in vain to procure a suitable white girl. I at last engaged a small six-dollar boy. $\mathrm{He}$ could say "Yes," and "Boot," and "Knife." He knew absolutely nothing. When one has to train a boy like this, one recognises what it is not to have an European groundwork to begin on. The most elementary things must be taught from the beginning. $\mathrm{He}$ could not light a fire, he had never used a scrubbing brush, and he had not yet realised that empty saucepans left on a red-hot stove will burn, and that tin ones invariably melt. But once shown how to do anything, the boy, whom we called Charlie, not having been able to understand his real name, never forgot how to do it.

It was only when a circumstance arose for which he had not received instructions that he would act on his own initiative in the most unexpected manner. For instance, he showed a poor woman who used to come round hawking fruit... and vegetables into 
the drawing-room. I told him next time she came, he was to take her round the back way, and I would interview her in the kitchen. A few days later I overheard him telling a lady, who had come to call, that she was to go round to the back door, that I always saw women in the kitchen. My appearance on the scene put a stop to this ungracious reception, and when I asked him afterwards if he could not see the difference between the two women, he replied, "that he thought 'vegetable lady' and other woman all same; all go round to back door," and that only men were to be admitted by the front door. He became a fairly reliable plain cook and a good housemaid in a few months, but he always remained too shy to become a satisfactory parlourmaid. At first he would deposit all the dishes that he brought from the kitchen on the hall table, announce their being there by a loud knock on the dining-room door, and before one could open it he had taken refuge in the kitchen. It was some time before he would remove the plates and wait at table, and if one had a guest of whom he felt in awe, he would return to his original methods, or, at best, put the whole trayful of things on the sideboard, and make his exit rapidly, not heeding any remonstrances from me or the boss. One of his performances almost rivalled that of the hero of a now classical story. The mistress of this Chinaman is said to have shown her man how to make a cake; taking six eggs for this, she broke them one by one, in the orthodox manner, into a cup, and then pouring each into a basin. The third she came to was bad, so she threw it away, the like fate befell number four, and two more were taken to replace them. Next time the Chinaman was told to make a cake, he also took six eggs, the third and the fourth he threw away, although they were perfectly fresh, and he replaced them, as the mistress had done, from the egg basket from the store-room. Charlie's act was similar. One day I undertook to show him how to bake, and I had got as far as ten minutes' kneading of the dough out of the thirty required, when I suddenly remembered that my last bread had not been successful, because the oven had not heated properly. As this was probably owing 
to the stove pipe being full of soot, I determined to have it remedied at once, and, covering up the dough, I made the boy take down the stove pipe, clear out all the soot, and clean up the stove again, before proceeding with the bread making. When his turn came to make the bread, I went into the kitchen to watch him and see that all went well; everything was imitated exactly, when he suddenly stopped kneading, and said: "Ten minutes now," and, covering up the dough, disappeared to fetch bucket and broom for the cleaning of the stove pipe, which, of course, did not want doing again.

One gets accustomed to the funny way in which they invariably open a house door, only by an inch or two, when one calls, and stick out their heads and ask who you want and who you are. If they are uncertain as to whether their mistress is at home or not, they as often as not shut the door in one's face, leaving one on the doorstep while they go and inquire. I tried to correct this in Gee, but the result was not much better, he would throw the door wide open, and stand in the hall and shout for me to know if I were at home, and if I would see Mrs. So-and-so. Sometimes when their mistresses are out they don't think it worth while to answer the door at all, in which case one shoves one's cards under the crack of the door, lodges them on the handle, or puts them under the doormat. On Sunday afternoon every household is emptied of its Chinamen, for they all expect half a day off, and, leaving as soon as the mid-day meal is cleared away, often refuse to come back and get the supper, and do not appear again until Monday morning. Visitors on a Sunday afternoon expect the ladies of the house to prepare the afternoon tea and supper, and to answer the door. As long as everyone understands this arrangement it is all right, but when strangers from the East or the Old Country arrive, such ways of roughing it in an otherwise civilised town, is apt to astonish them.

On one occasion, having let nurse have a holiday as well as the Chinaman, I was expecting a friend who had promised to come over and help me with the baby. There was a peal of the door- 
bell ; I thoughtlessly went out with my apron on. On the doorstep was the Flag Lieutenant, and in the carriage at the door was the newly arrived Admiral and his Post-Captain, in all the grandeur of uniform and white kids, come to return my husband's call.

"Is Mrs. Grohman at home?"

"No, she has just gone out; she will be very sorry to have missed you."

I received the cards, and felt that under the circumstances my presence of mind had saved both the visitors and myself a bad quarter of an hour. How could one entertain formal visitors when one would be expecting to hear a howl every minute from the neglected son and heir in the next room.

Some tales can be told about the disadvantages, or rather dangers, in having Chinese domestics, which, if ihey were the rule, and not rare exceptions, would certainly soon prevent any of their race being employed in any household. One of these incidents happened during the time I was out west. A lady had a few friends to lunch. Her Chinaman was a trusted servant, who had been in her employ two years as cook and parlourmaid. Between the serving of two of the courses there was a long pause. The bell was rung, but still John did not appear; at last, wondering and impatient, the hostess went to the top of the kitchen stairs, and called to know why he did not come. He looked out of the kitchen, and asked her to wait a minute. He seemed to be cleaning up something. She told him not to do that now, but to bring the luncheon quickly; a few minutes more delay and he appeared with the rest of the meal, when everything went on all right. A few days later a policeman came to search the premises for a Chinaman, whose friends said, when he was last seen in China town he had announced his intention of calling on this lady's cook to collect a debt that he owed him, and he had never been seen since. The premises were searched, and to the mistress's horror the missing Chinaman was found, with his throat cut, crammed into an old tub or dust-box in a small outhouse close to the kitchen. It had appeared that the man had called repeatedly 
to collect this debt, and the last time, just as lunch was going on, John said he had no money, and the man threatened him, whereupon John took up the kitchen knife and murdered him, hid him away, and cleaned up the "mess" actually between the courses. As the man had until then borne an excellent character, and this was put in for his defence, he got off on the charge of manslaughter.

Some friends of mine had a man who got sullen and refused to go into town on any account on the plea that he was frightened that someone would attack him. One day he ran in to the family, and announced that the house was on fire. The kitchen really had been set on fire, and he, being arrested, confessed to doing it, and said that he had been threatened by his society or other Chinamen that if he did not obey them and set fire to the house that he would be killed. For some time he had not done so, but fear at last had overcome his fidelity to his employers. Probably some of these men hoped to profit by petty theft during the fire. These solitary instances cannot condemn the whole class of Chinaman any more than the fact of criminals being found occasionally in the ranks of British domestics would justify one in pronouncing them all a set of burglars and thieves, and as a class dangerous to the community. Besides being servants, they also act as "sewing women." If one requires a lot of shirts or any kind of undergarments made, one has to cut out an exact pattern, and have one pattern garment ready-made. Then one can engage the Chinaman, who brings his own sewing machine, and will cut out and make the garments precisely like the pattern, and all the seams, tucks, and gussets will be most neatly done; or if one wants a habit or man's suit made, one has only to send the stuff and pattern, habit or suit, to a Chinese tailor, and he will turn out one exactly like it in every respect. If there happen to be patches in the old garment sent, these patches will be carefully imitated in the new garment, unless one has been thoughtful enough to warn th tailor against it.

A friend of ours engaged a new Chinaman, who declared he A A 
knew how to saddle and harness horses. The first morning after his arrival his master went out to the stable, saddled his own horse, and went for a ride. Later on the Chinaman was told to bring round the pony chaise to the door. When he did so, it was discovered that he had saddled the pony and shoved the shafts through the stirrups, tying them in with pieces of cord.

If you want your lawn mown or your garden planted, John Chinaman is quite in his element. Once I was rash enough to turn off my Chinese gardener and give the work to a white working man, who came round with a pitiful story of having been out of a job for weeks. I said I could only give him a dollar a day, which was what the Chinaman had been earning, but that I would give him his breakfast, dinner, and tea. It was a bad exchange for me, he was three substantial meals to the good a day, and he took three days to do badly what John would have done well. in one, and at the end of the third day he came to me, and, in an insolent manner, said if I was only going to pay him Chinaman's wages he wasn't going to stay. So he went. Not that I would infer the Chinese gardener is always better than a white gardener, but that it is much easier and cheaper to get a good Chinese labourer than any other, and too many vagabond white loafers have been "dumped" on the Pacific coast.

I said good-bye to Gee when I went to spend a summer with my husband in the wilds of Kootenay, as Gee refused to go so far from his beloved Chinese quarter. When we got there I engaged a Chinaman, who had been used to up-country ranches, at 4odols. a month. He was to cook for my husband, a friend, Miss D- and myself, and three young.Englishmen who were also up at Grohman in my husband's employment. Everything went on swimmingly for the first fortnight, but one evening after supper he called me into the kitchen, and there displayed his apron, his knife, his shoes, and various odd garments. "You see, these all mine, I no take anything of yours." "Yes," said I, "but where are you taking them to?" "Oh, I go away now." The supper table was not 
cleared, nor anything washed up. "Are you going to clear up to-morrow morning?" said I. But I found he intended to go for good, and although I told him he would not get his 2odols. wages for the fortnight he had been with us, he said, "No matter, I got plenty money, I make him cards last night; never work any more now." The next morning, as my friend and I were engaged upon our new household duties, we saw our Chinaman with a basket slung over his shoulder and a fishing rod in his hands, walking towards the river behind the house. He was looking for grasshoppers. "Good morning, you all light?" he asked. Having informed him that we were all right, he told us he thought we should be able to cook and wash up without him. At this moment "boss" appeared on the scene, and used such emphatic language towards the bland Sing that he went speedily to hunt for grasshoppers on more distant banks of the river. It was some satisfaction a month later to see him wheeling a barrow and employed in the hard work of excavating, where he got much less pay and less food than he would have done as our cook.

Given good health and spirits, with a little patience, and a general resolution to take things as they come and not worry about trifles, housekeeping with Chinese servants is rather entertaining than otherwise for a short time. I have no doubt after some years the novelty would wear off, and when John disappears without warning, as he often will, and the intervals between Chinamen become too long and too frequent, the situation is apt to pall, especially when the dinner has to be cooked and the thermometer registers ninety in the shade. This is what it registered when our man left us in Kootenay to enjoy himself fishing. A good fortnight had to elapse before we could possibly get another man from Victoria, so I established myself as cook, and my friend, Miss D-, kindly came to the rescue by turning housemaid for the occasion. At first our new duties were the subject of much fun and laughter, but when there is no water laid on, and all has to be fetched from the river, and when there was no. firewood cut, things did not go so smoothly. With forest A A 2 
all around us, it was difficult to get satisfactory wood to burn in our stoves, and, although a large monarch of the forest was hauled to our back door, it was some time before the huge trunk was sawn in pieces and chopped up for cordwood.

The unpleasantest part, perhaps, was the daily duty of providing a joint of meat. The nearest butcher's shop was four days' journey off. To provide meat for the camp some bullocks were driven into the corral once a week, and one or two shot. These were cut into four quarters, and hung in a small ice-house my husband had had built and stocked with ice during the winter. Having only studied the superficial anatomy of the human frame at a School of Art, I was truly puzzled in the study presented to me by a quarter of beef. I had not the slightest idea where to cut the joint from, so I decided beef steak would be the easiest, and, as there is nothing like courage on such occasions, I sliced away till I had got several pieces that, at any rate, looked like steaks. They were so successful when cooked that I went on steadily slicing away at the quarter of beef for several days, always avoiding any bone. Then the storm burst. The cook at the working men's camp, who had about ninety men to cook for, and had also to take his beef from the quarters in the ice-house, complained to my husband that I had hacked one bullock all to pieces and had not left him a decent joint. So we struck a bargain that in future we would visit the ice-house together, and he would joint the beef for me. Another difficulty was the bread. At this period of my housekeeping bread making was an unknown art to me, but luckily one of the young Irishmen who was having his meals with us kindly volunteered to show me how to make bakingpowder bread, at which he was an adept. As the oven was small, bread had to be baked twice a day, so with this and the meals we were kept pretty busy, and I was really thankful when the same young Irishman and his brother kindly offered to wash up the dishes after supper, as well as cut firewood for us. It was more than kind of them, as they had the ordinary labourer's day's work, beginning at 7 a.m. and ending at 6 p.m., and only knocking 
off an hour for dinner. It was very amusing, however, how much more saving they would be with plates, \&c., at meals, when they knew they would have to wash up. "No gravy, thank you-oh! thank you, this plate will do quite well for pudding," and so on.

One thing puzzled us-how to get the kitchen floor scrubbed. It was daily getting blacker, and although the men declared that a clean floor up country was an unnecessary luxury, and not at all in place in a kitchen, I felt it was a blot on my household arrangements. So I resolved to enlist the services of an old Indian woman. She and her blind husband, both riding on the same horse, came over from their Indian camp every morning, and, tethering their cayuse to a tree, the blind man and his clootchman would sit on our verandah for a couple of hours. He would murmur "muck a muck" (food), and then "mamook wash," mamook meaning to make or to do. So one morning I accosted him with: "How much clootchman mamook wash?" He understood quickly, and, after speaking in his native tongue to his wife, he said : "Two dollars fifty, muck a muck (here two fingers were held up), smoke." 2dols. 50 cents a day, two meals and tobacco, was a high price for a scrub, but after a little bargaining we settled it for 2 dols., and the clootchman was taken into the kitchen and provided with hot water, scrubbing brush, and soap. She seated herself on the floor, and proceeded in a diffident manner to scrub a square foot or so in front of her. Then she rested, took out a clay pipe, and murmured: "Smoke, smoke." So that she might be assured of our goodwill I produced tobacco, whereupon she shuffled out to her brave, filled his pipe, and then returned to squat near the spot she fondly believed she had cleaned, and smoked placidly. It was hours before that little tiny bit of a kitchen was scrubbed, and although perhaps the floor was a little cleaner, it was so filled with the odour of smoke and Indian that the last state of the room was worse than the first. I was glad to turn her out with her money and her food, and a very emphatic "hyack klatawa," which was the nearest I could get in Chinook to get out quick. I refused the services of "mamook wash," as we nicknamed 
her, when she offered them a few days later to wash clothes. She stood watching me with longing eyes, and I had to give her a smoke to get rid of her. I felt that even the men's way of washing their flannels would be more successful than any the old " clootchman" would be likely to adopt. Theirs was a simple method. 'They would put their flannel shirts into the river, weight them with a stone, and after they had had a day's soaking they were hung up to dry.

When I went back to Victoria the second time, Gee had long gone back to Hong Kong. He had written to me twice from there; once to tell me that he was married, and that he had a son, and the second time in answer to my inquiry as to whether he would come back to my service. To this he answered that he was going to stay and help his father in his store in Hong Kong, so I thought that I would try a white servant. I advertised for a " general," but got no reply, then I advertised for a "help." The next day a nice-looking girl, becomingly but quietly dressed, applied for the place. She told me that she had seen my advertisement for a general servant, but she was not going to answer that kind of advertisement, but when she saw my last she thought that she would come round and have a look. I explained that she would have all the cooking and housework to do, excepting the nurseries, and a good deal of ironing. Did she think she could do it? She was so pretty and languid and lady-like, that I felt I could never ask her to scrub a floor and clean up. "Yes," she would do everything, or rather she could do everything, but whether she did do it would depend entirely on what I did myself. "What part of the work do you do?" she asked. Although somewhat taken aback, I answered as deliberately and quietly as I could that I had a great amount of needlework and letter writing, and many social duties, and a great deal of necessary reading to get through. In fact, if she only left off being busy when I did, she would have a hard time. I fully expected to see her depart at once, but, to my surprise, she rose from her chair with dignity, and said, "Wal, I reckon we'll suit each other, shall I come right in to-night?" 
She came "right in," and she stayed on for ten months, when she went the way of all fair maids out West, and married. She cooked capitally, and did all the rough work without a murmur, and was never idle, but she was certainly unconventional. She insisted on "waiting table" at breakfast in a wrapper and curl papers. When I gently broke it to her that my husband objected to this, she remarked that she considered he should know "most enough of womenfolk by this time to guess that they couldn't have a smart curled bang at one o'clock if the hair was not in paper all morning," but she supposed he, like all men, would want his own way, and she didn't mind giving in to his fads. So the curl papers disappeared, but the dressing-gown was never discarded until twelve o'clock.

Then she went out at odd times, whenever she considered that there should be an interval at her work. She said she had never been accustomed to ask for permission to go out, and she never meant to. Then I argued that even my husband did not go out of the house without informing me of his intention, and if one is to manage a house, one must know the movements of the inmates; that even were my sister staying with me, she would consider it rude not to tell me when she intended being away, or to go without asking if it were convenient. "Is that so? Well, I see the reason of that, and on that kind of footing I don't mind telling you beforehand." So I had no more difficulty on that score.

One day, being laid up with bad neuralgia and headache, some callers came, and my husband told the girl to say I was not at home. After they had gone she discovered me on the drawingroom sofa, and immediately rushed into my husband's study with a, "My, what a corker you made me tell; your wife was all the time in the parlour."

Her "best man" used to fetch her with a buggy and pair of horses for a drive on Sundays and holidays. When she was married the same one called, and, not finding her in the kitchen, came to ask me where she was. "I thought you had married her," was my answer. "She left here to be married some days ago, and 
my nurse went to the wedding." "Married!" exclaimed he with astonishment; "well, that is a rum go; no, ma'am, she did not marry me." Asking me for her address, which I luckily couldn't give him, he left looking much grieved and upset. Soon after another man came with the same inquiry, who used very strong language on receiving the surprising news, and said that he had been engaged to her for some time. He was very mad about it, and left swearing bloodthirsty revenge on the faithless one and her husband.

The day she left me she appeared in a pearl-grey cashmere dress of the latest fashion, with a picturesque grey straw hat trimmed with white, and grey ostrich feathers to match. This was her wedding gown. "Well, good-bye, Mrs. Grohman; I should be real sorry to go if it was not to be married; you've suited me better than anyone I've come across yet, and I guess I was as well fixed up here as ever I was in my life." This was not a bad character to get from one's servant!

Sometimes one had to call in the help of the occasional "char." She was very occasional, and could only be induced to come as a great favour, and in a great emergency, and then she would appear in a flowered cretonne gown, and a hat much trimmed with white and blue ostrich feathers. This hat was a fixture on her head; it was never moved whatever work she was doing. It was funny to see her blacking grates and scrubbing floors with this headgear. She informed nurse that print dresses such as nurse wore were not considered of any account in British Columbia, and that if she wished to be visited by real nice people she must give up those large aprons of hers.

Nurse herself was a typical old English servant, with a good hospital training added to her other virtues. Nothing daunted nurse, she was ready for any emergency; and whether one were camping out in tents, as we did for three months one summer, or whether we were in Victoria, or travelling on the cars or on shipboard, she took everything quietly, and the children were looked after as thoroughly as if they were in their English 
nurseries. On the cars she made friends with the coloured porters, who would appear with cans of hot water just before the children's bed time, and nurse, tying her apron round her, would in some way manage to give the children their evening baths quite comfortably in those small inadequate lavatories reserved for women on the transcontinental sleepers. The children's hot milk and beef tea and other food was always ready for them at the right time; she had a thousand little ways of keeping them clean, well fed, and amused during long and trying journeys. At one time, having left the two children with their grandparents, intending to join them in the autumn, we found we should have to stay the winter in Victoria. We wrote to nurse to bring the children, aged four and three, out to us, and at the end of the twenty-one days' journey she handed us the babies safe and sound, with the complacent "Here we are, ma'am," as if she had merely just stepped across the street with them instead of having brought them a journey of some 7000 miles. 



\section{APPENDIX.}

\section{NOTE I.}

To the naturalist the following more scientifically arranged synonymy of the Haplocerus will afford information concerning the early literature of this interesting animal. My early labours in this direction were subsequently considerably augmented by the pen of the well-known American naturalistsportsman, Mr. Geo. Bird Grinnell, editor of Forest and Stream. Not only has he written more about it than any man I know of, but he is ever ready to place his knowledge at the disposal of fellow sportsmen. The following synonymy was published by Mr. Grinnell in Forest and Stream of Dec. 5, I 889 :-

\section{Names of the White Goat.}

A glance at the list of names which have been applied by systematists to the white goat-antelope, as given below, will serve to show the uncertainty which existed in the minds of the earlier writers as to the systematic place which this animal should occupy. The reason for this ignorance is not far to seek when we consider the very slight material which was at their disposal.

Lewis and Clark, who brought home from their expedition a hunter's skin, speak of the animal as a sheep. Ord, who described it from this same meagre material, followed them, and placed it in the genus Ovis, perhaps for no better reason than that the pelage of his specimen was in part woolly.

M. de Blainville, however, who saw the complete specimen in the museum of the Linnean Society, recognised its true affinities, and in his description assigned it to the genus Antilope, and to the sub-genus Rupicapra, thus placing it near the chamois. A year or two later Rafinesque characterised very imperfectly the genus Mazama, in which he seems to have intended to group this antelope, the pronghorn, and one or two species of deer which can probably never be identified. He stated that the white antelope and another species in this genus would probably 
be found to represent a new group, which he called Oreamnos,* and announced that this group would be fully described in a forthcoming work, which, however, was never given to the world.

A little later, in 1822 , came Hamilton Smith's excellent description in the Linnean 'Transactions, accompanied by a figure which, so far as I know, is to-day much the most life-like and the best that has been published. Smith had before him a complete specimen of Mazama montana, and thus avoided some of the mistakes committed by American writers. $\mathrm{He}$ regarded the animal as an antelope.

Nisled by the fact that the white antelope lives among the rocks and has a tuft of hair on its chin, Harlan and Godman called it a goat (Capra), as did also Richardson in 1829 , Baird in 1852 , Audubon and Bachman in 1853 , and the Prince of Wied in 1862 , while Fischer, who in 1829 quoted from Desmoulins (Dictionnaire Classique d'Histoire Naturelle), throws doubt upon this generic reference by writing Capra $(P)$ columbiana.

It is not strange that Lüben should have remarked in his Säugethiere that it is difficult from the descriptions to know whether this is an antelope or a goat.

In 1827 Hamilton Smith formed the sub-genus Aplocerus, which was adopted by Turner in 1850 , by Richardson in 1852 , and in this country by Baird in 1857 , by Coues and Yarrow in their excellent Report of the Zoology of the Surveys West of the rooth Meridian, and generally in the Government reports. Rafinesque's name Mazama was revived in 1850 by J. E. Gray in the Knowsley Menagerie, in his paper in the Proceedings of the Zoological Society, and in his various catalogues down to 1873 , and was then laid aside until brought up by Dr. Gill in his catalogue of the "Collection to Illustrate the Animal Resources of the United States," which is a "List of the Principal Useful or Injurious Mammals," a paper published in connection with the Centennial Exhibition in 1876 .

The generic name Oplacerus, proposed by Haldeman in 1842 (Proc. Phil. Acad. Sci., pp. 187-188), to take the place of Mazama, only needs to be alluded to, to say that it evidently has no connection with the species under consideration. To,what use of the term Mazama he referred seems uncertain, but that it was not to the white antelope is made evident by the reason advanced for the adoption of the name Oplacerus instead of Mazama, "this [latter] name having been preapplied to Ovis or Capra montana, Ord, by Rafinesque."

Almost as many specific as generic names have been given to this animal. Ord, translating the English name given it by the explorers who

* Am. Month. Mag., Vol. II., I817, p. 44. 
reported it to him, called it monlana, and this name, having priority, must stand.

There seems to be no doubt that Rafinesque's genus Mazama should be adopted for this animal. It is true that no less an authority than the late lamented Baird expressed in most unmistakable terms the opinion that this name "is utterly inadmissible as a genus of mammals," but this was written more than thirty years ago, and we may doubt if he would look at the matter in the same way if he were alive to-day. In his article (Pacific R. R. Reports, 1857 , p. 665 ) on the genus Antilocapra he writes as follows: "The generic name of Mazama, as established by Rafinesque, II., 1817, 44, has been quoted by some authors for the American antelope, as well as for the mountain goat and the smaller deer. An examination of his diagnosis will show very satisfactorily that the name cannot be used at all, on account of its embracing too many incongruous elements, as follows :

MAZAMA.- - Wight front teeth on the lower jaw, none in the upper, no canine teeth, grinders truncated; head with solid, simple, straight round and permanent horns, uncovered by a skin; neck and legs not very long, cloven hoof. Tail short. Obs. 'This genus differs from Cervus by having simple permanent horns, from the genus Giraffa by not having a skin over the horns, nor a long neck, and from the genus Gazella by its horns not being hollow. It belongs to the family Ruminalia, sub-family Stereoceria, next to the genus Giraffa. It appears to be peculiar to America, and contains many species which had been taken for deer, sheep, antelopes, $k \mathrm{c}$.

Mazama tema, Raf.-Yellow-brown above, white beneath. Horns cylindrical, straight and smooth. 'This is the Temamazame of Mexico.

Mazama dorsata, Raf.-Entirely white and woolly, a mane along the neck and back; horns conical, subulate, acute, slightly curved backward, base rough. Obs. This animal has been called Ovis montana by Ord, but the genus Ovis, or rather Aries, has hollow and flat horns, $8 \mathrm{ic}$.

Mazama sericea, Raf.-White with long silky hair, no mane, \&c. 'This is the Rupicapra americana of Blainville, but he has not ascertained the horns to be hollow.

"Were the genus Mazama less decided in its expressions, it might be taken for either the antelope or mountain goat (better the latter), but when we are positively assured that it differs from the antelope in having solid horns, and from the deer merely in the horns being simple and permanent, instead of branched and deciduous, there is no alternative but to expunge the name from the systems until we find an aninal with horns like the giraffe, only much longer, and not covered by a skin."

Except in respect to its so-called solid horns, Ratinesque's diagnosis of the genus Mazama agrees sufficiently well with the characters of the white antelope to be applied to it, and the whole question as to whether 
this generic name should or should not be employed seems to turn on what that author intended to imply by the use of the term solid horns.

It has been suggested to me in conversation by that eminent naturalist Dr. Theo. Gill, that Rafinesque's idea of what constitutes solid horns was not what we understand by the same term to-day, and that the agreement of the other characters given with those of the white antelope and the doubt as to the sense in which Rafinesque used the term solid justify us in employing this generic name.

It is perfectly clear that Rafinesque intended his description of Mazama dorsata and sericea to apply to the white antelope and to no other animal. Of this there is no shadow of doubt. The animal is identified beyond a peradventure. This being the case, and Mazama being the earliest generic name applied to it, it should be retained, and the white antelope becomes Mazama montana (Ord), Gill.

The local names in use for this species and those applied to it by various authors are numerous. The older writers called it mountain sheep, Rocky Mountain goat, and white goat, and these names still obtain in various localities where it is found. On the eastern flanks of the Rocky Mountains and generally in the United States it is commonly called "goat" or "white goat"; but among the Canadian Indians, who speak a little English, it is more often spoken of as "sheep," and this term is universal among the Indians, and nearly so among the white population, of the north-west coast through Washington and British Columbia to Alaska. In south-western Montana, in parts of Idaho, in eastern California, and perhaps in other places, it is sometimes known as "ibex," a name which is also often applied to the two or three-year-old male of the mountain sheep (Ovis canadensis). Lewis and Clark state that the Indians spoke of the white antelope as "white buffalo." Mackenzie, according to Richardson, says that his Indians designated Ovis canadensis by the same name, but it seems likely that the reference may have really been to Mazama, to which such a name would be especially applicable, as will be recognised by any one who has had ample opportunity of observing these high-shouldered rock climbers.

Most of the Indian names for Mazama montana, so far as I have been able to gather them and to learn their significance, have reference to its colour; thus the Blackfoot name Apoh'-mah-kee-kinna appears to mean "white head," the Cree name is Wa-pa-tik, which signifies "white deer." The Indians of British Columbia, as stated, call it "sheep," and where the bighorn (Ovis canadensis) also occurs, the former is known as Taculp sheep (white sheep), and the latter as Klale sheep (black or dark sheep). Both these adjectives are from the Chinook jargon. The Squawmisht 
Indians of Washington and British Columbia call the white antelope Hohhsolken, The meaning of this name is unknown to me. The name Krohait-lii, given this species by the Comox Indians of Vancouver Island, signifies "very white," while Mullukhtlaw, as it is called by those of Seymour Narrows, means "white beast."

As the local names are all misleading, for the reason that the animal is neither a sheep nor a goat, nor an ibex, it is a pity that some one of those employed in the books could not come into general use, for two or three of them are very striking and characteristic. Schreber's name, "wool antelope," is one of these, so is "white antelope," "mountain antelope," and others. Brehm calls it "snow goat," "white goat," and "mountain goat."

In the synonomy set down below I cannot hope to have given all the references to this remarkable animal. My opportunities for consulting any satisfactory zoological library have been very limited, confined in fact to a very few hours spent in Washington libraries during two brief visits within the last year, and while I have turned over many books in my efforts to get all the references possible, yet I have been wholly unable to go into the bibliography of this species with that thoroughness which the subject deserves. I am especially conscious that I have failed to record any considerable part of the references to this antelope which are scattered through the fugitive literature of sport. If those who see this paper and who notice these omissions will kindly call my attention to them, I shall be greatly indebted, and such references will be supplied if this and the succeeding papers on this subject should appear worthy later to be published in more permanent form.

I wish here to express my indebtedness to Dr. C. Hart Merriam, the accomplished chief of the Bureau of Economic Ornithology of the Department of Agriculture, who has kindly looked over my synonymy, and has verified a number of references which I have been unable to see myself.

\section{Synonymy of Mazama Montana.}

Ovis montana, Ord, Guthrie's Geography (2d Am. ed.) II., I8I5, pp. 292 and 309.-Journ. Acad. Nat. Sci., Phil., I., i, I817, pp. 8-12.-Journ. de Phys., lxxxv., I817, p. 333.-Tilloch's Phil. Mag., lii, 1818, pp. 8-1 I, fig. of horn.

Antilope (Rupicapra) americana, Blainville, Nouv. Bull. Soc. Philom., I816, pp. 73 and 80.

Mazama sericea and dorsata, Raf. Am. Monthly Mag., II., 1817, p. 44.

Rupicapra americana, Ord, Journ. de Phys., lxxxvii., pp. I46-155, Paris, I8I8.

Antilope americana, Desmarest Mamm., II., I822, p. 478. 
Antilope lanigera, C. Ham. Smith, Linn. 'Trans., XIII., I822, p. 38, pl. IV.Boston Journal Philos. and Arts. Vol. I., I824, pp. 338-40 (Reprint from Linn. Trans.).-Isis von Oken, I826, col. 96-7.-Griff. Cuv. IV., 1827, pp. 286-9 (plate).-Lïben, Naturgeschichte der Säugethiere, I 848, p. 799.-Giebel, Säugethiere, I 855, p. 303.-Wagner in Schreb. Säugethiere, I., I 855,460 .

Capra montana, Harlan Faun. Am., I825, p. 253, fig. of horn.-Godman Am.

Nat. Hist., Vol. II., p. 325 (plate).-Harlan Med. and Phys.

Researches, Phil. I 835, pp. 63-67 (figure).-Sundevall Kong. Svensk.

Vetens Handl. for I844.-Archiv Skand. Beit. II., I 85o, p. 279.

Antilope (Aplocems) lanigera, C. Ham. Smith, Griff. Cuv., V., I 827, p. 354.

Antilope (Aplocerus) mazama, C. Ham. Smith, Griff., Cuv., V., I827, p. 354.

Antilope lanata, C. Ham. Smith, Feruss. Bull. Sci. Nat., Paris, I824, p. 375

(from Linn. Trans.).-Lesson. Man. de Mammalogie, Paris, 1827, p.

388.-Bennett, Cat. Mam. Zool. Soc. I828, I4 fig., and I829, I 8 fig.

Capra columbiana, Desmoulins Dict. Classique d'Histoire Naturelle, III.,

pp. $580-1$.

Capra (?) columbiana, Fischer, Synopsis Mamm., I829, p. 487.

Aplocerus, Swains. Nat. Hist. and Classif. Quad., London, 1835, 380.-Brehm,

Thierleben, Säugethiere, III., p. 335 .

Mazama, D'Orbigny, Dict. Univ. D'Hist. Nat., Paris, I 846, 40.

Antilope (Haplocerus) lanigera, Wagner, Suppl. Schreb. Säugethiere, I843, p. 462.

Aplocerus lanigera, J. Wilson, Encyc. Brit., VIII. ed. XIV., 2 I I, I 857.

Capra americana, Rich. F. Bor. Am., I., I829, p. 268, plate XXII.-Ogilby

Proc. Zool. Soc., IV., I836, p. I37.--Richardson, J. Report on N. A.

Zool., Report of Sixth Meeting Brit. Assoc. Adv. Sci. for 1836, Vol. V., I837, p. I6I.-Baird, Rep. U.S. Pat. Off. Agricultural for I85 I (1852), pp. I 20-I2I, (plate from Rich.).--Aud. and Bach., Viv. Quad. N. Am.; Vol. III., I853, p. I28, pl. cxxviii.-Maximilian zu Wied, Reise in

Nord Amerika Säugethiere, Berlin, I862, p. 23 I.

Capra lanigera, Schinz, Säugethiere, I845, II., pp. 468-9.

Mazama americana, Gray, Knowsley Menagerie, I850, p. I9.-Proc. Zool. Soc., Lond., XVIII., I850, p. I36.-Ibid. Cat. Bones of Mam., Brit. Mus., 24, Iondon, I862.-Ibid. Cat. Kum. Mam., 4I, London, I872.-Ibid. Hand list Edent., Thick-skinned and Rum. Mam., Brit. Mus., i I I, London, 1873 .

Aplocerus americanus, Turner, Proc. Zool. Soc., Lond., XVIII., I850, p. I74. (Meeting misdated July 9, I851, instead of $185^{\circ}$.)

Aplocerus montanus, Rich. Zool. of Herald; Fossil Mammals, II., 1852, pp. viii. + I3I-8, plates XVI.-XIX. (Osteological).-Baird, Cat. N. A. Mam., chiefly in Smiths. Inst., Wash., I 857 , p. I9 $[=$ p. xlvi., Vol. VIII. Pac. R.R. Repts.] -Ibid. Pac. R.R. Rep., Vol. VIII., pp. 67 I 672, Wash. I857.-Suckley, U.S. P. R.R. Exp. and Surv. 47th Par., Vol. XII., Part II., No. 2, Chap. II., p. I06, Washington, I860.Gibbs and Suckley, U.S. P. R.R. Exp. and Surv., 47th Par., Vol. XII., Part II., No. 2, Chap. III., pp. I36-I37, Washington, 
I860.-Ross, Can. Nat. and Geol., VI., I861, pp. 40-441.-Forbes,

Prize Essay, Vancouver Island, Resources and Capabilities, \&c.

[Victoria], 1862, App., p. 11.-Agric. Rep., Wash., 1868, p. 218 (plate).-Macoun, Rep. of Sel. Com. of Sen. on Great Mackenzie Basin, Ottawa, 1888, p. 263.-Shields, Cruisings in the Cascades, Chicago, I889, p. 236.

Haplocerus montanus, Baird, A. J. Sci. XXVI., 1858, p. 145.-Flower and Garson, Cat. Oste. Vert. An. Mus. R. C. Surg., II., p. 257, London, I884.-Bell, Proc. Zool. Soc., p. 579, 1887.-Loder, Proc. Zool. Soc., p. $5^{8}, 1889$.

Aploceras montanus, Cooper, Am. Nat. II., pp. 537-8, I869 (1868-9).

Aplocerus columbianus, Coues and Yarrow Rep. Exp. and Surv. West of Iooth Meridian, Vol. V., \%ool. Chap. II., p. 68, Wash., 1875.Hallock's Sportsman's Gazette, p. to, New York, 1877.- "Mowitch" (pseudonym, J. C. Hughes), Forest and Stream, XIII., 926, I879.

Haplocerus laniger, A. W._—, Encyc. Brit., IX. ed., Vol. II., I878, p. I02.Standard Nat. Hist., Boston, I 884 , Vol. V., p. $3 \neq 3$.

Mazama montana, Gill, Internat. Exhib., l.ist of Useful or Injurious Mammals, p. 5, Wash. 1876.-Goode, Bull. U.S. Nat. Mus., 14, Wash., 1879, p. 7.-True, Proc. Nat. Mus. I.ist of Mammals, \&c., Washington, 1884 , p. 8. - Allen, Rep. Exp. to Copper Tanana and Koyukuk Rivers, Wash., 1887, p. 150.-Grinnell, Forest and Stream, XXX., 328.Shufeldt, Ibid. XXX., 472.

Rocky Mountain Sheep, Jameson, Trans. Wern. Soc. of Edin., Vol. III., p. 306. Mountain Sheep, Lewis and Clark, Exped. to Rocky Mountains and Pacific Coast, Vol. II., pp. 149 and 169 , Phil. and N. Y. Isit.

Rocky Mountain Goat, Lord, Student and Intellect. Vol. I., I868, pp. 14-21, (coloured plate).-Baird, Agricultural Report, Wash., 1868, pp. 218 219.-Merrill, Proc. U.S. Nat. Mus., Wash., 1879, II., pp. 283-4.Bendire, Forest and Stream, XXIV., 84.-Baillie-Grohman, Century Mag., I884, XXIX., I93.

Mountain Goat, Wood, in Wayne's Four Years in Brit. Col. and Vancouver Isl., London, 1862, p. +17.-Batty, Forest and Stream, X., +21.Fannin, Ibid. XVI., 64-5.-Ibid. XVII., 45.-U.S.A. (pseudonym), Ibid: XVIII., I87.- "Stalker" (pseudonym, (?) W. A. BaillieGrohman); Field (London), I.X., fo8.-Fannin, Forest and Stream, XX., 202-3.-Ibid, XXIV., 62.-Garman, Ibid. XXIV., I 25 (erroneous).-W. N. B. [yers], Ibid. XXIV., 125.-Reed, Ibid. XXV., 4.-W. B. A., Ibid. XXVIII., 153.- "Nica" (pseudonym, W. E. Carlin), Ibid. XXX., 430 .

White Goat, Geo. H. Wyman, Forest and Stream, XII., 307.-Bendire, Ibid. XIII., 525 [volume wrongly paged].- "Ten-Bore" (pseudonym), Ibid. XVIII., I 45.- "Mesatchie" (pseudonym) Ibid. XXIll., 45.Hughes, Ibid. XXIV., 26.-Baillie-Grohman, Ibid. XXIV., 468.Griffin, Ibid. XXV., 82.-Fannin, Ibid. XXV., I 44.-Hughes, Ibid. XXV., 325.-Griffin, Ibid. XXV., 325.-Schultz, Ibid. XXVII., 43, 462.-Fannin, Ibid. XXVIII., 66. 
Antelope Goat, Baillie-Grohman, Forest and Stream, XXV., 225.

"Sheep" of the Pacific Coast Indians, and generally of the white population of western British Columbia and northern Washington; also, to a less. extent, of Indians and whites of the northern Rocky Mountains.

"Ibex" of the whites in certain parts of Montana, Idaho, and California.

Apoh'-mah-kee-kinna of the Blackfoot Indians.

Wa-pa-tik of the Cree Indians.

Kzohait-lii of the Partlage, or Comox, Indians of Vancouver Island, British Columbia.

Mullukhtlaw of the Yokwiltulth or Seymour Narrows (B. C.) Indians.

Hohh-solken of the Squawmisht Indians of south-western British Columbia.

Shogkhli't of the Similkameen Indians.

P'ka'lakal of the Ft. Hope, B. C. (Fraser River) Indians.

Matte of the Tsimpsheans (Fort Simpson, B. C.) Indians.

Mut of the Skidigate Indians of the north-west coast.

Taculp Sheep of the Indians of the interior of British Columbia.

Illustrátion: Partington's Brit. Cyclopædia Nat. Hist., Vol. II., I836, fig. facing p. 614. [This figure (slightly modified from Landseer's in Richardson's Fauna Boreali-Americana) is one of several on the same page, illustrating the article "Goat." But there is no reference to the Rocky Mountain Goat in the text.]

NOTE II.

'The Jones' Butfalo Ranch.

The following description of the Fones' buffalo "ranch" was written and published in an Anverican journal before the establishment was disposed of. As the precise locality has not much to do with the experiment, I have thought it better to leave the description as it stood.

Five miles west from the city of Omaha, Neb., grazing over a magnificent rolling prairie, may be seen these days a herd of strange looking animals. A barbed wire fence limits their wanderings, and a group of whooping cowboys, mounted on branded ponies, rounds them up morning and night into a corral, where the curious are permitted to view them at 25 cents a peep. 
They are American bison, curiosities even in this Western city and on these hills, which, only a few years ago, shook with the tread of the mighty armies of their ancestors. What magnificent monsters they are, and how grandly they loom up over their puny kindred on the neighbouring hills, the domestic cattle!

There are sixty in the herd, and Jumbo is the monarch. Plainsmen who have slaughtered his kinsmen by the hundred say they never saw a finer animal. He weighs $3000 \mathrm{lb}$; his brown beard nearly sweeps the ground; his strong black horns are almost lost in a magnificent crest of silky brown hair, and his shoulders are level with the head of a tall man. "Devilish Dick," as he is called, is almost as fine a specimen, but there is a vicious gleam in his eye which prevents a very close inspection of his points. Four years ago one of the cowboys came a little too near this tremendous brute, and one sudden toss of the massive head sent the cowboy to the country where there are not supposed to be buffaloes.

This is the C. J. Jones herd of buffaloes, one of the few melancholy remnants of the millions that once swarmed over the plains, and almost the only hope of the perpetuation of the species.

The disgraceful story of the extermination of the American bison has no parallel in the history of game slaughter.

Forty years ago it would have been as easy to number the leaves of the forest as to calculate the strength of the vast hosts which swarmed over all the Western plains and hills, from the Mississippi to the Pacific, and from Canada to the Gulf. Of all the quadrupeds which ever inhabited the earth, naturalists tell us, no one species ever marshalled such innumerable armies as did the American bison. As late as $187 \mathrm{I}$ it is estimated that there were in the great southern herd, which covered the country south of the line of the Union Pacific Railway, between 3,000,000 and 4,000,000 head. In that year the railroads penetrated the country and the systematic slaughter began.

The report of the Smithsonian Institution gives these figures for the "hunting" for the three following years:

- In I 872 white hunters killed $I_{1,491,489}$ buffaloes and utilised the hides of 497,163 , in 1873 the number slaughtered was $1,508,658$ and the number used was 754,329 . In 1874 only 158,583 were killed and 126,867 were used. Of the gigantic army of $3,158,730$ butchered by white men during these three years, over half were left lying untouched where they fell.

To-day even the bones which whitened the plains for miles have disappeared, and there is not known to survive a single specimen in a wild state.

In 1887 there was a herd of 200 under Government protection in the B B 2 
Yellowstone Park. There may be a few there now, but none have been seen for a year or more, and they are supposed to have been killed off.

Besides the Omaha herd there are a few others in captivity, some kept for breeding purposes and others for exhibition. Mr. Charles Allard, in the Flathead Indian reservation, Montana, has thirty-seven head. Buffalo Bill's Wild West show numbers among its attractions a herd of thirteen buffaloes, subject to so many dangers from disease and accident that very little can be hoped from it in the way of perpetuating the species. Mr. Charles Goodnight, of Clarendon, Tex., had nine head. In the Philadelphia Zoological Gardens there are eight. In Lincoln Park, Chicago, there are six head, and in half a dozen other places there are held groups of two and three and several single animals.

With the Jones herd an earnest and intelligent effort is being made to save the species from utter extinction, and the fact that the animals may be domesticated and made a source of profit has also been demonstrated.

Mr. Jones is perfectly well qualified for this task. He was in the centre of distribution of the great southern herd from 1866 until their final disappearance, and was by profession a buffalo hunter. When the great slaughter began in 1871 he was employed by his neighbours to shoot buffalo at 50 cents a head, and they would follow him and secure the hides. His method was what is known as "still-hunting," and he has averaged from thirty to forty head a day. On one occasion he shot seventy-two head without shifting his ground. He acknowledges that he was frequently ashamed of his work, but with the whole country out hunting he did not feel like missing his share. In 1873 he began to realise that the wholesale slaughter was beginning to make inroads upon what then appeared an inexhaustible supply of game, and made his first efforts to preserve the species. On the Solomon river in Western Kansas he captured seven calves, which he subsequently sold. He went on expeditions to the fast receding haunts of the animals each year afterwards until I 888, and the herd now at Omaha is a testimonial to his courage, skill, and pluck in the chase. Every one of the adult animals was run down, lassoed, and tied with his own hands.

His last and greatest feat was in May, $\mathbf{1} 888$. There was known to be at that time a small herd in the uninhabited "panhandle" of Texas which could not long escape the rifle. With an elaborate "outfit" of men, horses, and camp equipage, Mr. Jones started from Garden City, Kas., to capture it. For forty-two days and nights the party followed the animals across the staked plains until they had finally lassoed or rounded up the entire herd. Only buffalo hunters can realise what such an achievement means. 
From this herd "Buffalo Jones" now secures three or four full-blooded buffalo calves each year, and a number of half-breeds- " catalo" he calls them. The hybrid product of the buffalo and Galloway cattle is a magnificent animal. Its robe is nearly black, fine and silky in texture, and with a brilliant lustre characteristic of the Galloway cattle. For enough of one of these robes to make a coat Lady Foster, wife of Treasurer Foster, of Canada, once offered Mr. Jones zoodols., saying she preferred it to seal.

In half breeds the domestic animal seems to predominate, and the casual observer might not notice the long hair, the small hump at the shoulders, and the slight shagginess about the head. These catalo have been bred back until they were only one-sixteenth domestic, when even his trained eye could see no difference from the full-blooded buffalo.

The profits of buffalo raising are considerable. The animal feeds cheaply, and looks after himself in all sorts of weather. His robe alone is worth the price of two good bullocks. In domestication his meat is equal to any range beef. One good animal will yield each year fur sufficient to make a blanket. A taxidermist will give from Ioodols. to 5oodols. for his head, and if Mr. Jones's big bull, Jumbo, were put on the market he would bring rooodols.

What the possibilities of domestication may be are yet to be determined. The two big bulls of the Omaha herd are driven to a cart by the owner, and when it is considered that their agility is remarkable for the size of the animals, that their strength is tremendous, and that they have the speed of the average horse, this means something. This novel chariot team, with perhaps the whole herd, will form one of the attractions at the World's Fair.

Mr. Jones is more than an adventurer or a speculator. He has become an enthusiast on the subject of buffaloes, and no man ever rode hobby more honestly or earnestly. When he began capturing these animals he knew no more of their peculiarities than other plainsmen, but his association with them has filled him with a love for the great shaggy brutes and a zeal for their salvation that is quite sublime in its way.

In beginning the work of subjugation pitchforks were used by men when going about among the animals, but the buffaloes were intelligent enough to comprehend the nature of the sharp tines, and when the pitchforks were not to be seen they reasserted their majesty. Mr. Jones hit upon the device of having short pieces of gaspipe plugged at either end with wood, and these plugs filled with sharp brads. These weapons were 
carried concealed, and when the animals became demonstrative they were jabbed into the tough hides or hurled at the big humps with all the force possible. At first the burly fellows received these attacks with a pained surprise, but in time they apparently concluded that these mysterious prods were a part of man and they had better not provoke attack. At any rate, they have become quite docile under that treatment. Men go among them freely, separating them or driving them about as readily as though they were so many cows.

In connection with his work of domestication Mr. Jones has experimented with the buffalo's fur, and has succeeded in making a cloth as fine as lamb's wool. Under the long coarse hair of the animal is a soft fur of the softness of swansdown. When the hair is shed in the summer the under fur either falls off or is plucked by hand. In the latter case the animals are tied, and the more unruly are thrown to the ground and their legs fastened by ropes to posts fore and aft. There are ten to twelve pounds of fur on an animal-enough to make a big brown blanket as warm as an old-time buffalo robe and as light as a bedspread. This cloth sells as high as zodols. a yard. Mr. Jones wears in winter an overcoat made of it and trimmed with the glossy fur of the catalo, and underclothing, stockings, and other garmerts have been woven of the same material. He presented one of the blankets to the Prince of Wales for use as a lap robe, and received a grateful acknowledgment of the unique gift.

In his several expeditions Mr. Jones captured 130 buffaloes, eighty-two of which survived. Full-grown animals taken wild invariably died in captivity. He had no success saving any over six months old. Many animals, even among the younger ones, died apparently in fits of anger. When they found themselves prisoners they went into a fearful rage, stiffened their limbs as though in cramps, lay down, and died. Others broke their necks in trying to escape.

On his first expedition Mr. Jones captured eleven buffaloes, but saved only four. He was 200 miles from a ranch having a cow, and he had to feed the little fellows on condensed milk, which did not agree with them. On his third trip he took cows with him to the staked plains of Texas, and out of thirty-seven buffaloes saved thirtyatwo.

Most of the animals that survived were from three weeks to four months old. The buffalo calf is of a tawny colour, resembling the hues of the sand and the grass and the shrubbery of the great plains. For the first three weeks of its life it is hidden by its mother, and its colour blends so closely with its surroundings that wolves and other enemies may pass within a rod of it without discovering its presence. 
In addition to his own captures Mr. Jones bought forty-two buffaloes in Manitoba, fourteen of which succumbed on the journey south. $\mathrm{He}$ raised seventeen buffalo calves in captivity, six of them dropped this year, and has every prospect of continued success in that direction. He has ten of these catalo. The buffalo and the catalo, by the way, run together, and the domestic cow suckles a full-blooded bison as calmly as though an infant of its own species.

Mr. Jones has furnished buffaloes from his herd to parks all the way from the Golden Gate on the Pacific to Austin Corbin's rock-ribbed estate in Vermont. Others have gone to stir the curious interest of gazing holiday crowds in Europe. Wild West shows and rich individuals with private zoos to stock have also drawn on this herd for their supplies.

The oldest buffalo living is supposed to be one in a Paris zoological garden, which is known to be twenty-nine years old. Jumbo, nine years of age, is the patriarch of the. Nebraska herd.

Some time ago Mr. Jones made a generous proposition to the Government looking to the regeneration of the race. He offered, if the Government would provide the land and pay the bare expenses, to take his herd to Texas, watch them carefully, and let them breed for twenty years without taking any of them away. A Congressional committee made a report favouring the setting aside of the land, but omitted the necessary appropriation on the plea that all of Uncle Sam's spare cash was needed for dredging unknown creeks and filling fathomless wallows. Unfortunately Mr. Jones is a poor man. Austin Corbin and certain Englishmen are scheming for possession of the herd, and there is danger that this, the buffalo's last hope of salvation, may be ruined.

NOTE III.

For these interesting notes by the late Mr. A. C. Anderson, of British Columbia, I am indebted to the late Dr. Tolmie, who informed me that Anderson wrote them in the fifties:-

"Reasoning from analogy a doubt might possibly arise that conclusions may have been too hastily arrived at, when it is asserted that the salmon 
ascending Fraser River do not return to the sea.* I can see no room for such possible doubt. The experience of the natives (who, by the way, are keen observers of natural events) is supported by the concurrent observation of the European residents. No solitary specimen has ever been discovered endeavouring to descend; and there are certain positions where it would be impossible for the fish to pass downward unobserved or undetected.

"For instance, at the discharge of Fraser's Laket the narrow outlet is constantly occupied with nets, set both by the natives and the whites, for the capture of trout and other fish. These nets, completely investing the shallow passage, are set throughout the year, save only during the ascent of the shoals of innumerable salmon ( $T a \dot{a} l o$ ), when it would be impossible to keep them down. These shoals, after passing through the lake, die in myriads amid the shallows of its feeding tributary, where they spawn. The same condition of circumstances exists at the outlet of Stuart's Lake, and: elsewhere.

"The process by which the continuation of the species is carried on seems to be as follows:-In the month of April the fry are hatched, and descend in the course of the summer to the ocean, meeting the grown up shoals then ascending. Remaining in the sea until they reach maturity, the recent fry in turn ascend; and thus, from year to year, the periodical supply is maintained.

"It is impossible, however, to conjecture what length of time elapses between the hatching of the spawn and the period of maturity. Making every allowance for the rapidity of growth for which the genus is remarkable, we can scarcely conceive the variety in question to attain to their full size within a year; we must therefore assume that the young fish, after reaching the ocean, remain there for several years, until at length, in perfect maturity, they are impelled irresistibly by their instincts to ascend the rivers, there to accomplish the last important function of their existence. $\neq$

* "Upon Fraser's River the utmost limit to which the salmon attains is Tête Jaune's Cache, distant 725 miles from the sea. Upon the Columbia they reach, by the McGillivray Fork, to its very source, a small lake in the spur of the Rocky Mountains, heading in with the Kootanais River. This lake, before the winter sets in, is filled with dead and dying salmon. The distance from the sea is about I 300 miles."

† "Here, as at the discharge of all the lakes, there is a considerable space of open water throughout the winter. These mares, as they are technically called by the French-Canadians, are but slightly affected by the severest cold."

‡ "In support of this position, I may mention that in the Gulf of Georgia, and throughout the Straits of Fuca and its neighbouring waters, the several varieties of salmon are caught, in sound condition, throughout the year." 
"If there be one circumstance more than another that might seem to militate against the facts I have related, it is the waste of life which is implied, so different from the economy which Nature generally adopts, in regard to animals occupying this scale in the wonderful order of creation. Breeding but once in the course of their lives, the supply is constantly in the process of renewal, and consequently more subject to occasional derangement from accidental causes than it otherwise would be.

"Upon this principle, indeed, the partial failure of the supply which occasionally occurs in Fraser River might satisfactorily be accounted for. It has been asserted that this partial failure recurs at certain regular intervais; by some limited to cycles of four years, by others to a longer period. The very fact of this diversity of opinion shakes confidence in the conclusions of either party ; and for my own part I must confess that I am sceptical as to both. My own observation, supported by a careful collation of all the old official journals dating from the first settlement to which I have had access at the different posts of the interior, leads me to the conclusion that the failures alluded to are too irregular to be referred to any fixed principle. I conceive them to be owing to latent and accidental causes which it were vain to seek to penetrate; and I infer that some fortuitous coincidence must have been too hastily adopted as a general rule.

"The general habits of the Pacific salmon differ in no obvious respect from those of the Atlantic varieties; their food, too, I conceive to be the same. It is by no means easy, however, to decide this latter point, Digestion with the salmon is so rapid, that upon examining the intestines a mucous substance alone is found, showing no recognisable trace of its original composition. Flies and certain aquatic insects doubtless afford them sustenance; but the fact of there being no solid remains apparent in the intestines of the fish has given rise to a notion among the natives that they exist without palpable food of any kind." *

"Subsequently to the period when the above notes were written, I have had the opportunity of examining the fish as caught in the sea. In some I have found prawns, in others herrings; and in one instance recently I counted twenty.four smelts, when the process of digestion had scarcely commenced."

* "On asking the natives of the interior to account for the reason of the salmon jumping, obviously after flies, they have an answer to solve the difficulty which is rather ludicrous. They are fully persuaded that they do so in order to ascertain what progress they have made ; and, in short, to take a sly observation so as to find their way. " 


\section{'The Saluon Canning Industry.}

The following notes contain a brief summary of the history of salmon "packing" or canning:

The packing of salmon in tin cans was an established industry on the North-East Atlantic coast twenty-three years prior to the inauguration of the industry by William Hume, in $\mathrm{i} 864$, on the Sacramento River. In 1866 there was one cannery on the Columbia River which turned out 4000 cases. In 1883 the pack consisted of 629,000 cases. In I84 I Mr. Chas. Mitchell, of Aberdeen, Scotland, who had learned his trade of Jno. Moir and Sons, of Aberdeen, Scotland, and had been in their employ for some years, came to Halifax, N.S., at the request of Alex. Davidson, to there establish the packing of salmon. The business at that time was almost in its infancy. 'The bulk of the salmon packed by Mitchell at Halifax was shipped to England. Mr. Wm. Underwood had been at that time importing English or Scotch-packed salmon in 2 lb., 3 lb., and 4 lb. tins, which cost him in Liverpool about $9 \frac{1}{2} \mathrm{~d}$. sterling per pound. The $3 \mathrm{lb}$. and $4 \mathrm{lb}$. tins were taper cans, oval in shape. Davidson did not make a financial success of the business and abandoned it. Chas. Mitchell, however, in January, I 843 , went to Eastport, Me., and eventually formed a partnership with IV. S. Treat and a man named Noble. This firm was first Treat, Noble, and Co., and afterwards Noble and Mitchell. 'They conducted a general canning business, packing lobsters, partridges, meats of various kinds, corn, peas, \&c.; they also packed salmon at St. John, N.B. William Underwood was one of their principal customers, and in 1845 bought out the Eastport establishment, taking Mr. Mitchell into his employ and giving him charge of the canning business.

In a short time the establishment at Eastport was abandoned, and the "plant" removed to Boston, Mr. Mitchell still being in charge. From that time on the salmon sold by Underwood was packed in Boston, he receiving the fish in ice by steamer from St. John, N.B. The business increasing and the supply of fish being precarious, a salmon canning establishment yas started at Bathurst, N.B., in $\mathrm{I} 854$, which continued to be operated till 1865 , at which time freezing establishments were put up near the fisheries, and, which could afford to pay higher prices than could the canners, who abandoned the business there, and did not start in a new venture in that direction. At that time W. J. Fraser, of Miramichi, N.B., was heavily engaged in the salmon packing business, and there were also factories on the Restigouche River and at New Bandon, N.B., also at other points. All these continued to operate until the low price of Pacific coast canned salmon and the facilities 
of getting New Brunswick fish to market in ice, increased their value in New Brunswick, rendering packing in that province unprofitable. In a letter-book of $\mathrm{r} 844$, belonging to Mr. Underwood, is a letter addressed to the Eastport firm of Treat, Noble and Co., finding some fault with their prices and asking their figures for salmon, and saying that some parties who were packing in Newfoundland were offering it at less price than the Eastport people had been giving. So there must have been salmon packing going on in Newfoundland in 1844 , but the names of the parties is not accessible. The process employed was the "water bath," heated by fires. The cans were bathed about two hours, then opened for the escape of steam, closed again and again bathed about the same length of time-this for Ilb. cans. The larger cans were given a longer time in processing.

In the Province of British Columbia the first canning of salmon was attempted in $\mathbf{r} 86 \mathrm{I}$ by Capt. Stamp at Alberni. It was on a small and very primitive scale. In I 870 , Messrs. J. S. Deas and Co., under the agency of Messrs. Findlay, Durham and Brodie started to pack on the Fraser. This firm was followed shortly thereafter by Messrs. Alex. Ewen and Co., and others.

NOTE IV.

\section{Some Notes on the Mines of British Columbia.}

THE following brief summary of the mineral resources of Britain's Pacific province may, perhaps, have interest for some.

There are three mining regions which by name are now familiar to everybody; they are the Klondike, the Caribou, and the Kootenay camps. To take them in the above sequence, it must be at once said that the Klondike River itself is not in British Columbia, but in that vast western extension of the North-west Territory of Canada, a realm so huge that its eastern boundaries march with those of Manitoba almost in the centre of the broad continent of North America, while on the other side the Pacific bounds it. So suddenly has this remote tributary of the Yukon burst upon the world, that the Canadian Government has not had time to sub-divide, 
as it should, the North-west Territory, letting the Rocky Mountains. form the separating line of two new Territories, as they do further south. Up to 1897 this western trans-montane portion of the North-west Territory was a country that possessed neither settlements, resident population, law officers, postal facilities, or roads of any sort whatever. The spot where to-day stands that collection of some hundreds of $\log$ shanties known as Dawson City, was, until the famous Canadian surveyor Ogilvie's determination of the I 4 Ist meridian, actually claimed by the United States authorities as part of Alaska.

Of the Caribou mines it is necessary to give some account in consequence of the renewed activity evinced by European and American capital in the exploitation of its once famous auriferous treasures.

We have already heard that from 1858 to 1863 British Columbia was. the centre of the world's attention as a gold field. In the first-named year the Fraser River excitement broke out, and the restless adventurers that had drifted to the Pacific States and territories rushed recklessly to the new El Dorado, which had then been developed on the bars and benches of the lower Fraser, between Forts Hope and Yale. Pushing their way up the narrow defile known as Big Canyon, by which means the great river gains a passage through the lofty Cascade Mountains to the sea, the more venturous of this army of gold seekers entered the interior of the province in open defiance of the opposition of the native tribes which flocked to the river to challenge their right to pass. Boston bar, Lytton, Lillooet, the lower Thompson River, Big Creek, Soda Creek, and the mouth of the Quesnelle were in turn reached and explored. At this mouth of the Quesnelle the golden trail, which had been followed up the valley of the Fraser, left the main stream, and the greater part of the vanguard of gold hunters turned their faces towards the mountains, which the increasing coarseness of the gold found indicated to the quick-witted miners as the source of the supply of the precious metal of which they were in search. The main body of the pioneer gold seekers of the district that subsequently became famous under the name of Caribou thus left the main valley of the Fraser at Quesnelle mouth and entered the spur of the Rockies known as the Blue Mountains by way of the Quesnelle river. Another lot of prospectors who had pushed higher up the Fraser valley, finding the river bars getting poorer in gold, left it at the mouth of the Cottonwood and entered the Blue range through the tributaries of that stream-Willow Creek and Lightning Creek.

As all roads lead to Rome, so the various valleys which the pioneers of Caribou adopted to enter the Blue Mountains all led to one common point, or rather peak - a cone-like, bald-topped mountain situated in the 
very heart of the range, and rising between $6000 \mathrm{ft}$. and $7000 \mathrm{ft}$. above the sea level. From this mountain, known as Old Baldy, almost every goldbearing stream in the Caribou district takes its rise, and a dozen or more of them whose names have been familiarly associated with the province for thirty-five years radiate from the hub of a wheel.

The rich discoveries of gold made in 1861 and 1862 in Antler, Keithley, William, and Lightning Creeks electrified the world, and the great rush in 1862 and 1863 followed, in which tens of thousands-how many nobody knows - of adventurous spirits participated. The gold found was coarse, and in William Creek and some of the tributaries it was easy of access, and was deposited in enormous quantities. The source of the yellow stream of the precious metal which extended nearly 500 miles to the lower reaches of the Fraser River had thus been found, and great fortunes were made in the brief period of a few weeks by some of the more fortunate claim holders.

But the golden days of Caribou were short-lived. With the exception of a few shallow places on some of the streams named, it became apparent very soon to every miner that the bulk of the precious metal contained in the placer deposits radiating from Bald Mountain would have to be won by hard labour, at considerable expense, and be attended with general risk. Deep gravel mining there was accompanied with many drawbacks that deep gravel mining in California had not experienced. The summers in Caribou are short. They begin toward the latter end of May; they close at the beginning of October. The rest of the year the snow flies and the ice king reigns. When the "Chinook" wind comes up the valleys from the south in the latter part of April, it sweeps over a blanket of snow from $8 \mathrm{ft}$. to I $2 \mathrm{ft}$. thick lying over the face of the country, and which the dense forest timber shields everywhere up to the limit of timber growth on the flanks of the higher peaks in the range. 'The melting of such a mass of snow naturally lasts several weeks and saturates the ground with water, and with this the deep-gravel miner of Caribou in the sixties found it impossible to cope. In the early sixties it cost a dollar a pound for transpiortation of miners' supplies, provisions, and machinery from the seaboard to the mining camps easiest of access. Capital was scarce, and the natural resources of the country were inadequate.

As a gold mining country for the poor man Caribou, therefore, soon began to decline. In 1863-while William Creek was still in its prime as a gold producer-the exodus began. Tens of thousands of disappointed and "disgruntled" miners left it. By the close of the "sixties the entire mining population of Caribou had fallen off to about 2500 , and the annual yield was only a tithe of what it had been in previous years. 
Since then the district has had a fitful experience. For a time there was a spurt in quartz, but it developed as a stock-jobbing affair, and went through the usual experience of such movements. For thirty odd years Caribou has consequently been regarded as a "petered-out" mining camp. The old-timers have been digging away in the old claims from which immense volumes of "dust" were taken in early days, uncovering now and again a spot of rich ground that had escaped notice before, and prospecitng for lost leads on the various creeks heading from "Old"Baldy" or Mount Agnes.

During the past three or four years, however-that is since the new developments made in Kootenay district-Caribou has shared, in common with California, the attention of capitalists, and money for mining development in and around "Old Baldy," the scene of the gold supply of the Fraser valley, has been gradually flowing in.

At present it is being diverted to the development of the deep placers in the district and the washing out of the gold which has been released in times past from its native matrix in the rocks and is lodged in the beds of the living and dead rivers. Perhaps some day capital will branch out and attempt one of the most gigantic engineering feats of the ages-the piercing of "Old Baldy"-in search of the veins of the precious metal now concealed from the miners" gaze by the forest growth and the dense lining of moss underlying it and covering the entire face of the country, excepting in such places as the miner has removed the placer deposits in his search for the gold. Such veins are supposed to be ribboning the famous peak and to have yielded, through the elemental erosion of agés, the metal which enriched the gravel deposits.

The later development made in Caribou indicates strongly the presence there of the same kind of auriferous dead rivers as mark the flanks of the Sierra in California and extend into Southern Oregon, and to which have been applied the name of the Blue lead.

The "giant" has been introduced into these latter-day hydraulic operations in the Caribou district, and volumes of water quite as large as any used in California in the best days of hydraulic mining there, are being handled during the "open season." There is no obnoxious anti-débris law to interfere with mining operations, nor are there any farming lands in danger of being flooded by the overflow of the rivers as was the case in California. The Fraser and all its tributaries flow in deep beds between high banks or benches, or in narrow robky gorges where the mountain ranges are pierced. The navigable waters of the Fraser are too remote from the scene of mining operations to be affected by them, and the fierce, floods of spring and summer scour the river channels and keep them at 
their normal depth. Hydraulic mining of the highest and most perfect development is therefore possible in the Caribou district, with nothing to hinder or to interrupt it except the long and severe winters, during which the snowfail is measured by feet and the thermometer drops often below the freezing point of mercury, and at times touches a record quite as low as any Arctic explorer has experiencel in the far north.

Almost all of the pay dirt in the placer deposits of Caribou resembles the material contained in the Blue leads of California.* It is a sticky, compact conglomeration of highly washed gravel, sand, and clay, with which every placer miner is familiar, and from which, when found, he always hopes to reap that rich reward for which he is in search. In the Horse Fly hydraulic mine the dirt hitherto worked has been a free washing gravel, but two seasohs ago it changed to a hard, compacted, cemented gravel, that must be crushed before washing to win from it all the gold it contains. Since this change presented itself in the face of the pit only a small portion of the gold contained in the gravel piped off has been recovered, chunks of the cemented gravel being found at the foot of the sluices. A ten-stamp mill with a capacity to crush from 100 to I 20 tons per twenty-four hours, is, I believe, about to be erected there. It is estimated it will cost from Idol. 50 cents to Idol. 75 cents per ton to mine and mill the cement, which working tests show contains from 4 dols. 82 cents to 5 dols. 56 cents per cubic yard of gold. The mill will be operated during summer with water power, and during winter with steam, as drifting can be carried on winter and summer alike.

The vastness of the deep gravel deposits of the Caribou district is shown in the pit of the Caribou hydraulic mine. 'The company controls about three miles of the ancient river channel, which is roooft. wide between the rims, and the bank of auriferous gravel rises from $350 \mathrm{ft}$. to $400 \mathrm{ft}$. above the head of the sluices, while it is estimated that from $80 \mathrm{ft}$. to rooft. more pay dirt lies between the present workings and the bedrock. The latter cannot be touched until the upper stratum is worked off. This is the mine that yielded two seasons ago 128,000 dols. worth of gold at a total cost of 85,000 dols. An early setting in of winter is said to have deprived them of the means of taking out from 50,000dols. to $70,000 d o l s$. additional. There were four giants in operation last summer. 'Two more giants were to have been put into operation last season.

How puny the efforts of the hydraulic miners of Caribou of the sixties were, when they worked with canvas hose and rin. nozzle pipes, compared with the operations now going on in the district, is shown by the fact

* I copy this statement from an able account in the San Francisco Chronicle. 
that the canal and reservoir capacity of this mining company amounts to I0,000 miners' inches of water delivered from the big nozzles of the largest giants manufactured, and the company claims that there is nothing superior to its system of pipes, canals, and reservoirs on the coast.

Everything has drifted into big companies in the way of mining in that district now. The Miocene Gravel Mining Company possess claims that cover four miles of the Horse Fly to the mouth of Beaver Lake Creek.

The Harper claim on the same creek is owned by a San Francisco syndicate, and is to be worked by a hydraulic elevator.

Seven miles south-east of the town of Quesnelle Forks is carried on one of the most gigantic placer mining operations ever attempted on the coast. It is at a point where the great Quesnelle Lake empties its overflow waters into the south fork of the Quesnelle. There the Golden River Quesnelle Company, of London, is employing now about 400 white men and 100 Chinese in excavating for an immense waste weir that is intended to divert the waters from their natural outlet. When this waste weir and the necessary gates are completed, the construction of the dam to hold back the waters of the great Quesnelle Lake, which is 100 miles long and from one to five miles wide, will be commenced. The overflow waters which it is intended to divert cover a space $300 \mathrm{ft}$. wide and are now at the lowest stage of the river-flowing, it is said, $8 \mathrm{ft}$. to 1 oft. deep. As the lake rises $6 \mathrm{ft}$. or $8 \mathrm{ft}$., I believe, each season, one can realise what a gigantic piece of work the company has undertaken.

It is estimated that the dam will cost $228,000 d o l s$., and other work will probably bring the expenditures up to a larger sum before the company completes the work and gets ready to clean up the gold from the bottom of the South Fork River, eight miles of which it controls. It is expected that all of this will be worked out before the lake overflows the dam erected to hold it back.

But the attack on the auriferous deposits of Horse Fly and Quesnelle Forks represents only one side of the base of "Old Baldy," the supposed source of Caribou's golden wealth. On all the creeks taking their rise in it-Keithley, Snowshoe, Cunningham, Harvey, Willow, William, Grouse, Antler, Goose, Lightning, and other water courses equally familiar to old-timers-new efforts on a correspondingly large scale to those named are being instituted. The Caribou Goldfields and Exploration Company, organised in London, with a capital of $£_{1}, 000,000$, have purchased many of the old claims on the famous William Creek at Barkerville, in the Caribou district, and have expended several hundred thousand dollars in bringing up a bedrock drain tunnel to relieve the deep gravel claims of the water that caused the former owners to give up their enterprises. The old 
channel of Antler Creek, for which unremitting search has been made for over thirty-five years, is claimed to have been discovered at a remote point from the present stream, and extensive operations for working the dead river channel are being made. A Canadian company with a capital of $2,000,000$ dols., has taken up twenty miles or more of Lightning Creek from its junction with Cottonwood, with the intention to hydraulic it.

A Seattle and New York company has been organised, with a capital of 5,000,00odols., to work twenty miles of the bed of the Quesnelle River. A French syndicate and a Montreal syndicate, the latter with a capital of $2,500,000$ dols., 500,000dols. of which is to go at once into reservoir and ditch construction, are also operating at Quesnelle River. These are only a few of the big companies with large capital that have recently entered this old-time and supposed "petered-out" mining district. Even the beds of the Fraser and the Quesnelle, which cannot be reached by pick, shovel, or hydraulic monitor, are being attacked by dredgers in hopes of winning the golden contents of their sands. The Caribou miner of thirty years ago looks on, scratches his head, and marvels.

Of the West and East Kootenay mines much might be written, particularly of the former, for they are in a far more advanced state of development than the latter, good water and rail communication having for almost ten years assisted the exploitation of the West Kootenay camps. But, as I am neither an engineer nor a mining expert, and as such reliable technical reports as Dr. Dawson's, Mr. McConnell's, and Mr. Carlyle's are within reach of the reader, I will refrain from taking up space by repetitions. For silver and lead, and, to a lesser degree. copper ores, West Kootenay is to-day the most promising region in North America, though it is a regrettable fact that nearly all of the good mines, with a few recent exceptions, are or were in the hands of American capitalists who turned their attention and their dollars Kootenay-wards several years before the fame of the district reached the financial men of Britain or Eastern Canada.

In gold-bearing ores West Kootenay is not as rich as its well-wishers might desire; but there are very hopeful indications, and the experience of several magnificent mines of the Rossland district, in which the grold values of the ore improved as greater depths were reached, augurs well for other mines. Such changes are, we know, by no means infrequent. Nevada began as a gold mining country; it ended as one of the richest silver camps known. And the reverse is, I am told by good authorities, just as likely to occur.

Of the British Columbian mining laws no very satisfactory account can be given, not so much in consequence of any radical defects, but principally" on account of the constant tinkering in which the Government and the legislature indulges. Since 1882 , when the first quartz mining regulations 
were passed, I do not think that a single year has gone by without some change or other being made. Now of a radical nature, reversing the whole principle of taking up claims, then of a more unimportant kind, this uncertainty has worked havoc in quite a number of instances, and has done much to disgust capital, for nothing is more fatal to the fortunes of a mining district than liability to litigation. This the ever-changing regulations encourage, for it is easy to get up adverse claims on the strength of old laws, under which perhaps the mine was started, or under partnership laws that have long been cancelled. I am told that there is not a single lawyer in the whole of British Columbia who can tell a client off-hand what merits a case may possess. Considering the stability and effectiveness of the American mining statutes, it is very singular that those of British Columbia cannot be framed on the same lines and adhered to with the same immutability which experience has shown to be one of their chief merits. Nuch the same complaints the miners of Klondike will have to make, for, short as is the existence of this camp, the laws have already been changed three times by the Federal authorities at Ottawa, under whose jurisdiction the North-west territory stands. This is such a fatal policy for all but the lawyers, that stern protest should be raised by those in a position to do so.

For the convenience of those wishing to learn the rough outline of British Columbian mining laws, I have appended a digest of the laws in force at the moment of writing. By the time these lines will be read others will probably have been substituted.

The Gold Commissioners administering the laws in the districts into which the country is divided are, as a rule, appointed for political reasons, and rarely possess training or technical knowledge.* They are, however, generally honest men, who do the best they can, which is to let the Superior Courts do the work of finding out the rights and wrongs of disputes.

\section{Digest of the Mining Laws of British Columbia.}

\section{Interpretation of Terms.}

The following is the interpretation of terms used in the construction of the Mineral Act:

"Mine " shall mean any land in which any vein or lode, or rock in place, shall be mined for gold or other minerals, precious or base, except coal.

* Not a bad story is told of a Canadian mining official who, when he entered upon his duties, was not even conversant with the commonest mining terms. The wag of the camp one day came before him, demanding that a warrant to arrest a certain person "for stealing the hanging wall" in complainant's mine be issued. It is said that the warrant was issued. 
"Mineral" shall mean all valuable deposits of gold, silver, platinum, iridium, or any of the platinum group of metals, mercury, lead, copper, iron, tin, zinc, nickel, aluminium, antimony, arsenic, barium, bismuth, boron, bromine, cadmium, chromium, cobalt, iodine, magnesium, manganese, molybdenum, phosphorus, plumbago, potassium, sodium, strontium, sulphur, or any other combination of the aforementioned elements with themselves or with any other elements, asbestos, emery, mica, and mineral pigments.

"Limestone, marble, clay, or any other building stone, when mined for building purposes," shall not be considered as mineral within the meaning of the Act.

"Vein," or "Lode."-Whenever either of these terms is used in the Act, "rock in place" shall be deemed to be included.

"Mineral claim " shall mean the personal right of property or interest in any mine.

"Mining property" shall include every mineral claim, ditch, mill site, or water right used for mining purposes, and all other things belonging to a mine or used in the working thereof.

"Legal post" shall mean a stake standing not less than $4 \mathrm{ft}$. above the ground, and square or faced on four sides for at least $\mathrm{rft}$. from the top, and each side so squared or faced shall measure at least 4 in. on its face so far as squared or faced, and any stump or tree cut off and squared or faced to the above height and size.

"Mill site" shall mean a plot of ground located as defined by the Act for the purpose of erecting thereon any machinery or other works for transporting, crushing, reducing, or sampling ores, or for the transmission of power for working mines.

"Streams" shall include all natural watercourses, whether usually containing water or not, and all rivers, creeks, and gulches.

"Ditch" shall include a fume, pipe, or race, or other artificial means for conducting water by its own weight, to be used for mining purposes.

"Ditch-head" shall mean the point in a natural watercourse, or lake or other source, where water is first taken into a ditch.

"Free miner" shall mean a person, or joint stock company, or foreign company named in, and lawfully possessed of, a valid existing free miner's certificate and no other.

"Record," "register," and "registration" shall have the same meaning, and shall mean an entry in some official book kept for that purpose.

"Full interest" shall mean any mineral claim of the full size, or one of several shares into which a mineral claim shall be equally divided.

"Cause" shall include any suit or action.

$$
\text { C C } 2
$$


"Judgment" shall include " order" or " degree."

"Real estate" shall mean any mineral land in fee simple under any Act relating to gold mines, or to minerals other than coal.

"Joint stock company" shall mean any company duly incorporated for mining purposes under the "Companies Act, 1890," and any company duly incorporated in British Columbia for mining purposes under the "Companies Act, I862" (Imperial), and shall include all "Companies Act, I $894 . "$ c. 32, s. 2.

\section{Free Miners and their Privileges.}

Every person over eighteen years of age and every joint stock company may become a free miner by taking out a miner's certificate, the cost of which is 5 dols. per annum.

Miners who take the benefit of this Act are regarded as of full age in all mining transactions.

Miner's certificate to a joint stock company must be issued in its corporate name. Such a certificate may be issued for one or more years, and cannot be transferred.

A fine of 25 dols. is provided as a penalty for such as work at mining without first obtaining the necessary certificate.

Every owner of a mine or contractor for the performance of work upon a mine must take out a license certificate for each and every employee, or, upon conviction, pay a penalty of Ioodols. in addition to the unpaid license fees.

A free miner may kill game for his own use.

A free miner may obtain a new certificate for one lost on paying Idol.

Should co-owner fail to pay for his free miner's certificate his interest goes to his co-owners pro rata according to their former interests.

A shareholder for a joint stock company need not be a free holder.

A free miner may claim I500ft. by I50oft. But all angles must be right angles, and all measurements must be horizontally.

A free miner may cut timber on Crown lands.

A free miner may obtain a five-acre mill site upon Crown lands in the form of a square.

A claim may be held from year to year by work being done to the value of Ioodols.

Two claims in each mining division, not on the same vein or lode, may be held, and more than one on the same vein, if held by a purchaser.

A claim must be marked by two legal posts, each 4 in. square, and not less than $4 \mathrm{ft}$. above the ground. They must be numbered $\mathrm{I}$ and 2 . 
A legal post marked "Discovery post" must also be placed on the lode where it was discovered.

On No. I post must be written: (I.) Initial post. (2.) The name of the claim. (3.) The name of the locator. (4.) The date of location. (5.) Approximate bearing of No. 2 post. (6.) Length and breadth of the claim. (7.) The number of feet to the left of the location line.

On No. 2 post must be written: (I.) The name of the claim. (2.) The name of the locator. (3.) The date of location.

The line from No. I to No. 2 must be distinctly marked by blazing trees or planting posts.

Locations made on Sunday or public holidays are not for that reason invalid.

Lodes discovered in tunnel may be held if recorded in fifteen days.

A free miner may, on the payment of 500 dols. in lieu of expenditure on claim, obtain a Crown grant.

Any miner may, at the discretion of the Gold Commissioner, obtain a water right for a term of twenty years.

No transfer of any mineral claim or interest shall be enforceable unless in writing, signed, and recorded.

No miner shall suffer from any act of omission or commission, or delays on the part of the Government officials.

No claim shall be open to location during the last illness of the holder, nor within twelve months after his death, unless by permission of the Gold Commissioner.

A mineral claim must be recorded within fifteen days after location, if within ten miles of office of the Mining Recorder. One additional day is allowed for every additional ten miles or fraction thereof.

Partnerships, unless otherwise specified, will be deemed to be annual. The business shall pertain to mining, and to mining only. Partnerships can locate and record one claim for each partner.

\section{Law concerning Placer Mines.}

Placer claims shall be divided into creek diggings, bar diggings, dry diggings, bench diggings, and hill diggings.

Every free miner shall be entitled to locate and record a placer claim on each separate creek, ravine or hill, but not more than two claims in the same locality, only one of which shall be a creek claim. $\mathrm{He}$ shall be allowed to hold any number of placer claims by purchase.

A "creek claim" shall be rooft. long, measuring the direction of the 
general course of the stream, and shall extend in width from base to base of the hill or bench on each side, but when the hills or benches are less than rooft. apart, the claim shall be rooft. square.

In "bar diggings" a claim shall be a strip of land rooft. long at highwater mark, and in width extending from high-water mark in the river to its lowest water level. Dry diggings, 1ooft. square.

In "bench diggings" a claim shall be rooft. square, provided that the Gold Commissioner has authority, where a bench is narrow, to extend the limits of the claim beyond the limits of the bench, but not to exceed rooft. square.

In "hill diggings" a claim shall have a base line or frontage of $100 \mathrm{ft}$., drawn parallel to the main direction of the stream or ravine on which it fronts.

Parallel lines drawn from each end to the line at right angles thereto, and running to the summit of the hill, shall constitute the side lines thereof. Legal posts shall be placed rooft. apart on both the base line and the side lines, and no claim shall extend beyond the posts so placed.

If any free miner, or party of free miners, discover a new mine, placer claims of the following sizes, in dry, bar, bench, creek or hill diggings, shall be allowed, viz.: To one discoverer, one claim 3 ooft. in length; to a party of two discoverers, two claims amounting together to $600 \mathrm{ft}$. in length; to a party of three discoverers, three claims, amounting to $800 \mathrm{ft}$. in length; to a party of four discoverers, four claims, amounting to roooft. in length; and to each member of a party beyond four in number, a claim of the ordinary size only. A creek discovery claim shall extend on each side of the centre of the creek as far as the summit of the hill, but not exceeding roooft.

A new stratum of auriferous earth, gravel, or cement, situated in a locality where all placer claims are abandoned, shall be deemed a new mine.

In defining the size of placer claims, they shall be measured horizontally, irrespective of inequalities on the surface of the ground.

Any location made on Sunday or any public holiday shall not for that reason be invalid, any law or statute to the contrary notwithstanding.

\section{What must be Recorded.}

Placer claims must be recorded within three days after location, if within ten miles of the Mining. Recorder's office, and one additional day is allowed for each additional ten miles or fraction thereof. 
Placer claims may be recorded for one or more years on payment of fees-2dols. 50 cents for each year.

Transfers must be in writing signed by the transferer and recorded in the Mining Recorder's office, and within the time required for recording placer claims.

The holder of a placer claim has no right to any vein or lode within its limits, except by location and record under the Mining Act.

\section{Legal Forms.}

Under the law of British Columbia the Government has prescribed certain forms, and these must be followed absolutely: Such as Location Notice, Record of Mineral Claim, Record of Partnership Mineral Claim, Application for Certificate of Work, Certificate of Work, Certificate of Improvements, Application for Certificate of Improvements, Mining Recorder's Certificate, Mill Site (notice), Mill Site (affidavit of applicant prior to lease), Lease of Mill Site, Mill Site (affidavit of applicant prior to Crown grant), Mill Site (certificate of improvements), Tunnel or Drain License, Mill Site (application for Crown grant), Water Notice, Water (grant of water right), For a Full Claim, For a Fractional Claim. These may be found in the Act relating to gold and other minerals, excepting gold. Passed April i 7 th, I 896 .

\section{Scale of Fees to be Charged.}

For every free miner's certificate (for each year) $\ldots \ldots \ldots \ldots \ldots \ldots \ldots . . \ldots 5 . \ldots 0$

Every substituted certificate ..................................... I.00

Recording any claim............................................. 2.50

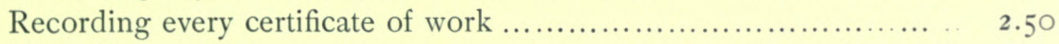

Recording any "lay over" or every other record required to be made in the "Record Book" "................................... 2.50

Recording every abandonment, including the memorandum to be

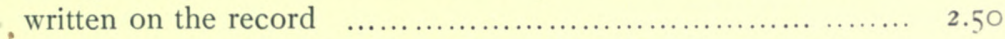

For any other record made in the "Record of Abandonments "..... 2.50

For recording every affidavit, where the same does not exceed three

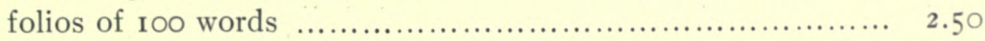

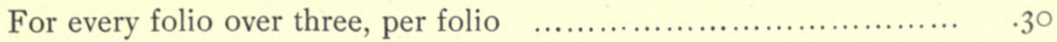

The above rate shall be charged for all records made in the "Record of Affidavits."

For all records made in the "Record of Conveyances," where the same do not exceed three folios ................................ For every folio over three a further charge of 30 cents per folio. 
For all copies or extracts from any record in any of the above-named books, where such a copy or extract shall not exceed three

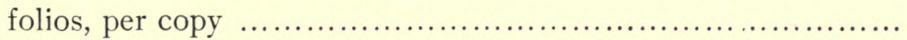

Where such copies or extracts exceed three folios, 30 cents per 2.50 folio for every folio over three.

For filing every document...................................... $\quad .25$

For a Crown grant............................................... 5.00

NOTE V.

THE following is the first document of any sort or kind drawn up in what is now the rich West Kootenay District. As such it has historical interest.

\section{Kootenay Lake Mines,}

British Columbia,

October 12 th, 1883 .

\section{Petition to the Chief Gold Commissioner of the Province of British Columbia.}

We, the undersigned, humbly petition for the granting of the following concessions, alike important to us and to the proper development of the mineral resources of the Kootenay Lake district:

Firstly.-That the statutes incorporated in the Mineral Act of $\mathrm{I} 882$ and the Mineral Amendment Act of $\mathrm{I} 883$ be brought into force in this district in time for the opening of the season of $\mathbf{1} 884$. There are no placer mines in this district, at least, none have as yet been discovered; the mineral resources, which are of a most promising character, consisting chiefly of silver and lead ores that cannot be worked by poor men, and hence do not return any immediate profits to the prospectors who find them. The discoverers have to hold their claims till they can find a purchaser, which is impossible at short notice considering the extreme remoteness of this district. It is therefore very hard upon prospectors that the above-mentioned two Acts were disallowed, much more so than were this a placer mining district. 
Secondly.-That a Recorder, or Deputy Gold Commissioner, with powers to issue mining certificates and records of mining claims, be appointed for the season $\mathrm{I} 884$, or that powers be granted to the district Justice of the Peace to appoint one of our number elected by ourselves as temporary Recorder of the Kootenay Lake district. The great distance to the Assistant Gold Commissioner's office at Wildhorse Creek, Upper Kootenay, a journey there and back of 480 or 500 miles by boat and bad trail, making it impossible for us to comply with the requirements of the law respecting miners' certificates and records, while at the same time the law requires that work be done on a claim every seventy-two hours.

W. A. Baillie-Grohman, J.P., free miner.

MARTIN M. FRY, free miner.

ROBERT GORSuch, free miner.

Jesse Hunly, free miner.

Јасов A. Meyers, free miner.

R. E. Sprowle, free miner.

G. E. Harman.

A. O. FRY.

Gay ReEDer.

\section{NOTE VI.}

As a warning to travellers, I may narrate the following little experience in connection with trans-continental railways in America. When I was leaving Victoria for good, the Victoria agent of the Northern Pacific Railway made me more advantageous terms for the transportation of my party and luggage to New York than I could obtain from the agent of the C.P.R., viz., the former agreed to charge me the same rate for the tickets that the C.P.R. asked, and made no charge for my luggage, which latter 
the C.P.R. people would not transport free of cost. As I subsequently learnt, this concession was contrary to the regulations of the Inter-state railway combination, and C.P.R. "spotters" somehow discovered the reason why I had given the N.P.R. the preference. All went well until we reached New York on the evening preceding the day when the steamer upon which I had engaged, weeks before, several staterooms was to sail. When I claimed my luggage I found that I could obtain possession of it only by paying for the excess beyond what was allowed free upon each of my tickets. The rate was at that time 10 cents $(5 d$.) a pound, and as I had some sixteen or seventeen heavy trunks this amounted to about $£ 20$. The N.P.R. company refused to recognise the agreement which I had made with their Victoria agent, for they feared that they would thereby be mulcted of a heavy fine, and as there was no time to appeal to the law, I was forced to pay this iniquitous charge or lose my steamer transportation, for the rush of travel at that season-it was during the World's Fair at Chicago-was so great that the steamer people were unable to transfer my party to a later boat. 


\section{IN DEX.}

Abdy, Captain, 57.

Abruzzi, Duke of, 304.

Adventure in Sandpoint, 244.

Agassiz, Prof., 86.

Ah Wan, 34I.

Ainsworth, Captain, 234-244.

Alaska, moose in, I22, I 24. caribou in, I30.

bighorn in, $\mathrm{I} 5 \mathrm{I}$.

bear in, $\mathrm{I} 6 \mathrm{I}$.

salmon in, 20I, 222.

purchase of, I 74, I82, I 89 .

Commercial Co., I 82 .

Aleuts, I 86.

“Among Selkirk Glaciers," 296.

Alleghany Mountains, 72 .

American millionaires, 43.

Trophy Show (I887), 44-59,

I 43 .

exhibitions, 83 .

elch or moose, izo.

Anderson, Constable, 249.

Anderson, Mr., 309, "Appendix,"

Note III.

Anglo-Russian treaty, $\mathrm{I} 8 \mathrm{I}$.

"Annals of Shooting," 82.

Antelope (prongbuck), I5I-I59.

shedding horns, 152 .
Antelope - goat (Haplocerus montanus), 85-I 2 I, and "Appendix," Note I.

Antler lore, 48.

Aparejo, 20.

Arcles, 93.

Arco, Count, 74.

Arms of British Columbia, I 49.

Arrapahoes, I 7 .

Assassination of Hammil, 249. attempt at, 242 .

Audubon, 152.

Ava, Lord, 57.

Baden-Powell, Sir G., I 92.

Bad lands, 59, I 40.

Badminton Library, 48 , I 7 .

Baillie-Grohman, W. A., 45, 47, 49, $52,57,62,63$, I I 2, I 35, I 43 , 225-332.

Baillie-Grohman, Mrs., 333-36r.

Baird, Prof. Spencer, 6I, 86, I37, I $52,214$.

Baker, Sir Samuel, 57.

Bale, 284 .

Bancroft, 176 .

Bartlett, 152.

Bassof, 178 . 
Bate, T., 45, 56, 87, I 24.

Bath tub, story of, 4 . natural, 295.

Bear of America, I6o-1 68.

Beard of the Alps, 96 .

Beaver skins, I 80 .

Beaver steamship, 3 I 9 .

Bedson's bison, 173 .

Begbie, Sir Matthew Baillie, 33, 38, 228, 288, 342 .

Behring Sea, I76, I8 I-I 98 . commission, 192 .

Behring, Vitus, 176 .

Bentley, W. R., I 13 .

Berchtesgaden, 74 .

Berland, Ed., 309.

Bierstadt, I 22.

Bighorn, the, 4I, 83, I39-I 5 I.

Bighole river, 90.

Biological Society, 7I, I5O.

Bison, the , 7, 83, I68-1 73, "Appendix," Note II.

Bitter-root Mountains, 88, 90, 94, 97.

Black Coal, Chief, 17.

Blackfeet Indians, 3 I 4 .

Black-tailed deer, 38, г 33-г 37 . bear, $4 \mathrm{r}$.

Blainville, de, 86.

Blue Bell mine, 232.

Bonanza Clark, I62, I67.

Bonner's Ferry, I05, 252.

Border-Roughian war, I 4.

Boreas, 22, I30, I 65.

Brahé, Tycho, 156 .

Bridger, I I.

British capitalists, 320 .

British Columbia, arms of, I 49 .

Board of Trade, 2 I 6.

companies in, $320.32 \mathrm{I}$.

game in, 34, 35, 37, 39-42, 54, 88 , 9 I, I05, I 45-8, I6 I.
British Columbia, game laws of, 33-42.

imports and exports, $33 \mathrm{I}$.

legislators, 34, 235 .

mines in, 32I, Note IV., "Appendix."

mining laws of, 232, Note IV. and V., "Appendix."

settlers in early days, 315-323. Indians of, IO5-II3, 301-314.

Government of, 226, 234-237, 252, 262-266, 271, 32 I-322, 325-327.

British Museum, 87 .

Brooke, Sir Douglas, 5 I.

Buckland, Frank, 64 .

Buffalo, see Bison.

Buffalo Bill, 169.

Busted Britishers, 287.

Butte City, 92, 245.

Buxton, E. N., 45, 51, 57, 69, I62.

Gerald, 45, I 43 .

Caches, I Iо, 3 I 1 .

Cameron, Allan Gordon, 75 .

"Camps in the Rockies," I 51 .

Camp leaving, $x$.

Camp outfit, 5 .

Canada, Custom-house, 253, $33 \mathrm{I}$.

Dominion of, 320 .

duality of government, 330 .

imports and exports, $33 \mathrm{I}$.

Canadian-Pacific Railway, 37, 4I, I 70, 262, 267, 271, 30I, 316, 320 , "Appendix," Note VI.

"Canadian Poachers," I 83.

Canal, the, 260, 265.

Cannibals, 3r 3 .

Capture of Sprowle, 249.

Caribou, 83 , I3 I-133.

Catalogue of the American Trophy

Show, 45,57 . 
Caton, Dean, 59, 61, 67, 69, 72, I33, I35, I37, I54, I 58 .

Catherine, Empress, I 79.

Cattle ranching, 6, 29.

Census of Flatbows, 309.

Chamois, extinction of, 139 .

Chinamen as servants, 330-356.

Chinese New Year, 345.

wives, 346 .

contractor, 346 .

Chinook, ro6.

Chinook salmon, 207.

Chirikoff, 177 .

Cimarron, 143.

Cirneo, Pietro, I 49.

Clark, Bonanza, I 62, I 67.

Clark, Joe, I I.

Cline, steamer, 272.

Clootchman, I07, 357 .

Cobbold, T. D., 57.

Coburg, Duke of, 49.

Cochrane, Lady A., 294 ,

Mr. T., 294.

Cœur D'Alene, 94.

Collecting bison bones, I 70 .

Colonial Secretary, 3 I 5 .

Colorado, 33,64 , I 6 , I 34 , I 36 , I 43 , I 5 I.

Columbia River, salmon in the, I 99-224.

source of the, $105,26 \mathrm{I}, 27 \mathrm{I}$ 276.

Commander Islands, I 83 .

"Committee of the Town," 244.

"Conquest of the almighty dollar," I 74 .

Cook, Captain, I79.

Cooper, Frank, 46, 48, 57.

Cope, Prof., I 52.

Copper Island, 183 .

Copper river, 124.

Corbin's game preserve, I73.
Cortez, r69.

Coronado, I 69.

Cost of outfit, Io.

Cows eating salmon, 2 I 7.

Crooke's deer, I34.

Crossman, General Sir W., 65.

Crow Indians, 17.

Crows Nest Pass, $4 \mathrm{I}$.

Daily News of Victoria, 40.

Dall, Prof., I 5 I.

Darby and Joan, I08-I I 4.

Dashwood, General, 125.

Dead letter office, 325 .

Deadman's Flat, 92.

Deer, see Wapiti, Moose, and Small Deer.

Deer antlers, 80.

Deerlodge, i 14.

Demidoff, Prince, 70 .

Desmarest, 86.

Dewdney trail, 227.

De Smet, Father, 230.

Diamond hitch, I, 2 I.

Doctor at Grohman, 287 .

Donald, 280 .

Douglas, David, 232.

Dream, Bale's, 284 .

Dunmore, Lord, 57.

Dunraven, Lord, 7.

East Kootenay, see Kootenay.

Edd, I 4.

Election in East Kootenay, 230.

Elk-horn pyramid, 72.

Elk river, I30-I.

Ellis, Hon. Ch., 57.

Major C. C., 57 .

Emperor of Germany, 64 .

Encyclopædia Britannica, 85 .

of Sport, 70.

English nurse, $36 \mathrm{I}$ 
Fannin, J., I 8 .

Farquhar, Ernest, 55, 57.

Field, the, 48, 64, 67, 8o, 85, I 25 . I $30,1_{2}, 148,{ }_{52}$.

Finlayson, Roderick, 317.

First Pacific water, 3 .

Fischer, 86.

Fishing with "bugs," I 9.

Flannelette shirts, 289 .

Flatbows, see Kootenay Indians.

Flathead Indians, I04, 173. country, 69 .

Forbes, W. A., 155.

Forest fires, 30 .

Fortnightly Review, 149.

Fort, buying a, 257 .

Fort Steele, I 45, 280.

Foxes, Silver, 180 .

Fraser river salmon, 208.222.

Freight rates on American lines, 268, 330.

Fremantle, Hon. T. F., I03.

Fremont, 149.

Frewen, Moreton, 45, I35, I36.

Fry's ranch, 105.

Fugger family, 157.

Funny stories, 289, 29 I, 293, 330.

Fur-hunting corporations, I74-I 98. Fur seal, see Seal.

Fur trade, I 74-198.

Gambling Indians, 259.

Game in British Columbia, 34, 36$42,54,88,9 \mathrm{I}, 105,145-148$, I6 1 .

Game laws in America, 27, 33, 42.

British Columbia, 34, 35, 37, 39.

Game preserves, 28, 173.

Gee, 334-350.

Geikie, Prof. Sir A., I 40.

Goat, see Antelope-goat.
Golden City, 260.

Gold, first in British Columbia, 318.

Goose Lake fish, 223.

Grant, E., 57.

Gray, 86.

Great Divide, 7.

Great Northern Railway, 105.

Greenriver City, I I:

Grizzly, see Bear. of San Francisco, I62.

Grinnell, Geo. Bird, II6, I I g, "Appendix," Note I.

Grohman, see Baillie-Grohman.

Grohman, post-office at, 260, 291.

Grosse-Corne, 143.

Gros Ventre Creek, 49.

Günther, Dr., 208.

Hammil, 233, 249.

Hanbury, J. M., 45.

Hangtown, 245.

Hankey, General, 63.

Haplocerus, see Antelope-goat.

Harlan, 86.

Hauling-up ground, 183 .

Harting, J. E., 45.

Haynes, F. J., 73 .

Henry, the Kid, 3, I 4.

interview with the cattle boss, I 6 .

Hide hunters, 3 I.

Hohenlohe, Prince, 49.

Hoyos, Count Ernst, 53, 57.

Huber, Emil, 304.

Hudson's Bay Company, 175, I79, 206, 256, 3 I 6 .

Hunter, Joseph, 35 .

Hunting grounds, extent of, 5 .

Idaho, 8, 37, 57, 88, I 29, I34, I37, I 40 .

"Immigrant diggers," 315. 
Indian Passion Play, 3 I 2.

Inman, Colonel Henry, I69.

Ito, Fishery Inspector, 214.

Jackson, Sheldon, I 32 .

Jones, C. J., 30, I7 I, "Appendix," Note II.

Jordan, Starr, 195.

Judge Neversweat, 93.

Kalispels, 258.

Kamchatka, I76, I77, I78.

Kansas, I3, I69.

Kelly, Judge, 237 seq.

Kenai mountains, I5I.

Kettle Falls, 203 .

Kicking Horse Pass, 262.

Kirwan, Major Maitland, 57.

Kiskayooka, 256.

Kit Carson, I I.

Kootenay, concession, 235, 241, 252-4, 26I-266, 282, 322, 325-327.

division of, 226-229.

game in, 4I, 54, 88, 9I, 105 , I 45 -I 48 .

lake and river, I05-II3, 307-9. manner of spelling, 226 .

reclamation scheme, 235, 24I, 252-4, 261-266, 282, 322, 325-327.

steamer, first, 253-255.

Kootenay Indians buy shirts, $28 \mathrm{~g}$.

$\because$ canoe, Io6.

census, 309 .

customs, IO5-II3, 30I-3 IO.

messengers, 239, 292.

names, 3 Io.

rising of, 272.

Pete, 292.

shooting with, I05-II 3 .

teepees, 106, 302.
Labrador salmon, 204.

Lake Champlain, I69.

Lake Huron, the, 328.

Lam Sam, 343-346.

Land concessions, 235, 24I, 252-4, 26 I-6, 282, 322, 325-7.

Land and Water, 148 .

Langenburg, 49 .

Langevin, Sir Hector, 264.

Laudonniere, 68.

Lawson, Jack, 229.

Lawsuits, 236-24I.

Leases of the Seal Islands, see Seal.

Lee and Clutterbuck, $28 \mathrm{I}$.

Le Moyne, 68.

Leonardslee, 58 .

Lewis and Clarke, 86.

Literature on Western Sport, 7.

Littledale, St. George, 57, I 43, 144.

Loder, Sir Edmund, 58, 69, 87, 89, IO3, I I 5, I I 9 .

Lodge, G. E., 47.

Lydekker, I34.

MacDougall, Scotty, 147.

Nackay, John W., 28.

MacLoughlin, David, I०8, 256, 310.

MacNab, Miss, 266.

Malaspina Glacier, 305.

Mammoth hot springs, 73 .

"Mamook wash," 357.

Mannlicher rifle, 102, I39, I57.

Mare clausum, $\mathbf{1} 82$.

Matzen, Schloss, 62 .

Mauser rifle, IO2, I 39 .

Mauvaises terres, 2, I 40.

Mayne, Lieutenant, 39 .

Measurements, see under Wapiti, Bighorn, \&c.

how to take them, 45 .

Medhurst, Frank, 120, 245. 
Merriam, G. Hart, 7 I .

Messiter, 242, 247.

Meux, Sir H. B., 57.

Midge, the, 252, 255.

Miner, Dr., 295.

Mining in British Columbia, "Appendix," Note IV. and $\mathrm{V}$.

Mining laws in the United States, 386.

British Columbia, 233, 239, "Appendix," Note IV. and $\mathrm{V}$.

Mintz, Dr., I33.

Modus vivendi, 183 .

Mogul locomotive, 299 .

Moncreiffe, W., 57 .

Montana, 8, 29, 37, 42, 43, 57, 59, 69, 72, 9I, 92, I05, I I3, I 29, I34, I36, I 40, I5 I, I 58 , I 73 .

Mountain Fever, 280.

Mount Elias, I77, 304.

Shasta, I 15.

Sir Donald, 301, 304.

Whitney, Ir 7 .

Moose, the, 84, I 22 -I 3 I.

Morris, Dr. R. T., 204.

Mowat, Inspector, 2 I 3

Mule-deer, 84, I 33-5.

Murray, Lord James, $8 \mathbf{2}$.

Musk ox, 84, i6o.

National Park, see Yellowstone Park.

Natural History Museum in Washington, 6I, 7 I, 84, 88, I33.

Nelson, F. W., I 50.

Nevada, I62.

Neversweat, 162 .

"New English Canaan," I69.

$\mathrm{Nez}$ Percé's war, 90.

"No jawbone here," $28 \mathrm{r}$.
Norbury, Lord, 294.

North American Commercial Co., I 88 .

Northern Pacific Railway, "Appendix," Note VI.

Ogilby, 86 .

Ogilvie, Canadian surveyor, 380 .

Okhotsk, I77.

Olympic Mountains, 70.

Oncorhynchus, 209.

Ord, 86.

Oregon, 70, I8I.

Oregon salmon, see Columbia River.

O'Reilly, Judge, 229.

Overflowed land, 326 , see Kootenay Concession.

Ovis montana, see Bighorn.

Ovis dalli, $15 \mathrm{I}$.

nelsoni, 150.

nivicola, $\mathrm{I} 5 \mathrm{I}$.

Packing horses, 2 I.

Pack River Pass, 254.

Pack saddles, 2 I.

Parker Brothers, 59.

Passion play of Indians, $3 \mathbf{I} \mathbf{2}$.

Paul, Tsar, I80.

Peace River, 7, I73.

Pelagic seal fishery, 189.

Pen d'Oreille Lake, 247.

Pete, Indian, 292.

Petition of Right, 325.

Phillipps-Wolley, 48, I 17.

" Piccadilly deer," I34.

Piccolo, Father, 85.

Pike, Warburton, 38, II6, I3I, I36.

Pless, Prince, 74.

Poland, 30.

Port, 9, I3, I65.

Portland (Oregon), 65. 
Post office at Grohman, 292. Victoria, 324.

Powerscourt, Lord, 58, 64 .

Prairie à la corne de Cerf, 72 .

Pribyloff Islands, I74, I83-I 95.

Promisńleniki, 175.

Prongbuck, I5I-I 59 .

Puget Sound, $22 \mathrm{I}$.

Purcell Mountains, I46.

Quinnat salmon, 199-224.

Raffinesque, 86.

Rathdrum, 242.

Rawlins, 4, II.

"Records of Big Game," see Ward. Red Deer of Europe, 67, 68, 80.

Reinhardsbrunn, 49.

Richardson's Fauna Bor. Amer. 86. Robben Island, I 83.

Rocky Mountains, I, 2, 4, 5, 24, 28, 4 I, 71, 86, 88, 93, гі 6, І 24 , I3O, I34, I40, I43, I46, I50. Roosevelt, 28, 57, 70, I35, I6I.

Root, 83 .

Rudolph II., Emperor, I 56.

Russian trappers, I75-I8I.

Russian American Company, I 80.

Russian trade, I74-I 90.

Rustling, 276.

Salmon on the Pacific Coast, I 99224.

leaps, 204 .

nets, 202 .

quantities of, 218 .

wheels, 202 .

not taking the fly, 223 .

land-locked, 308 .

spawning beds, 274 .

Sandpoint, 227, 242, 258.

Saussure, de, I 49 .
Sawmill at Grohman, 267, 279.

Scientific American, 73.

Seal, the, r 74-r 95.

birth rate of, 195 .

islands, I 74-I 87 .

Sea otter, I 80, I95-1 97.

Selkirks, the, 37, 94, I45-148, 297306.

Seton-Karr, H., M.P., 45, 54, 57, I 43 .

Seton-Karr, H. W., I6 I .

Setting back, 75 .

Seymour, Sir Michael Culme, 4I.

Shaw, Otho, 57, 122.

Sheard, W. F., 66, 67, 70, 1 22, 144I 48, I62, I7 I, I 72-I73, I 97.

Shirt story, the, 289 .

Schoverling and Daly, 63 .

Silver Fox, I 96-8.

Sinyaquateen, 227 .

Sioux Indians, 72 .

sing, 334 .

skin hunters, 31 .

Slaughter of game in America, 27$42,139$.

of bison, r69-1 73, "Appendix,"

Note II.

of seal, 180, 192.

Slave Lake, I3 1 .

"Slope, the," 4.

Smith, Hamilton, 86.

Smithsonian Institute, see Natural History Museum.

"Smoothbore," 8 o.

Snake River, 53.

Somerset, Duchess of, 293.

Soshoné Indians, I, I 6. mountains, 26,28 .

Sporting literature, 7, 149.

Spree, the, 327.

Sprowle, R. E., 232-251.

Steamboat springs, 33 . 
Steelhead trout, 223.

Stikeen river. I 75 .

St. Maurs, 294.

Stony Indians, I I 7.

Store at Grohman, 279-289.

Sumas lake and river, 275.

Sulzer, 304,

Sumner, Charles, 174.

Sun Dance, 3 I 3.

Teepee of Flatbows, 302,307 .

Tegetmeier, 152 .

Teton Basin, I 29.

Thomas, Oldfield, 45 .

Thompson, Prof. D Arcy, I 95.

Thomson river, swimming, 13 .

Tolmie, Dr., 317.

"Topshelfer, the," 9.

Torture at Sun Dances, 3 I 3 .

'Trapper, the, I 2.

Trafford, Sir H. de, 57 .

'Trauttmannsdorff, Count, 53, 57 .

Tulloch, IV. A., 59.

Turner-'Turner. I 36 .

Two in Norway, 28 I.

Tyhee salmon, 207.

Unicorn, I 57.

Upper Columbia lake, 26I, 27I276.

" Upper Crust," 288.

Upper Kootenay, see Kootenay.

Ute Indians, I0, I 6, I 7, 25.

Vancouver, 85 .

Vancouver Island, 38, 40, 7 I, I 50, I $8 \mathrm{I}, 223$.

Vancouver City, $32 \mathrm{I}$.

Van Horne, Sir W. C., 270.

Van Moerkerke, $284,286$.

Victoria, impressions of, 315-324. foundation of, 3 I 6 .
Victoria, early days in, 317 .

fishing near, 223.

easy going, $32 \mathrm{I}$.

museum, i 8 .

new government buildings, I 59, 322.

post office in, 324 .

white servants in, 333, 359363.

Vienna, Imperal library in, i 56 .

Vivian, Pendarvis A., 45, 57.

Voyageurs. I 2, I7 5 .

Walker, Sir Peter, 83, I 24.

Walla Walla, 105, 106, 227.

"Wanderings of a Tenderfoot," 293.

Wapiti, the, $25,27-42,43-84$.

antlers, pyramid, $7 \mathbf{2}$. size of, $43-84$.

distribution of, 72 .

fighting, 76

measurements, $43-84$.

Rooserelt, 7 I.

skins, 30.

slaughter of, 30-42.

weight of, 69,70 .

Ward, Brothers, of Rochester, U.S.A., I 33 .

Ward, Rowland, 44, 58, 64, 65, 67, 72. 82, I I 7, I 23, I 24, I 33 , $145,1+7$.

Washakie Chief, I 6 .

Weeks, postmaster, 243 .

Weese, Dall le, I5I.

Westminster, Duke of, I 23.

White, G. D., 57.

White-tailed deer, 23, 83, 133-5.

White servants in Victoria, 333, 358$36 \mathrm{I}$

Whitney's game preserve, I 73. 
Wied, Prince of, 6, 72 .

Wildhorse Creek, 228, 233.

Wiles and traps, II.

Wilmot, Inspector, 2 I 5 .

Wilson, Sir Charles, 306.

Windriver valley, Big, 162 . mountains, I, 53, 64, 69.

Winter cold in Wyoming, 26.

World's Fair, 83 .

Wreck of the Spree, 328 .
Wyoming, I, 8, I0, 37, 43, 46, 49, $5 \mathrm{I}, 56,57,69,76,83$, 105, II6, I34, I36, I40, I5I, I58.

Yellow Head Pass, 262.

Yellowstone Park, 30, 32, 42, 73, I 72-3.

Yellow and white agony, 333 .

Yukon, moose on the, 124. river and salmon, $20 \mathrm{I}$. 



\title{
OPINIONS OF THE ENGLISH AND AMERICAN PRESS
}

\author{
ox
}

\section{MR. W. A. BAILLIE-GROHMAN'S WORKS:}

\author{
"Tyrol and the Tyrolese," "Gaddings with a Primitive People," \\ "Camps in the Rockies," "Sport in the Alps."
}

"We have read nothing of the kind that has struck us so much as this book of Mr. Grohman's. We can recommend the book as singularly readable from the first chapter to the last."-The Saturday Review.

"Mr. G. is so familiar with his subject, and he ivrites so well that it would be almost impossible for him to be anything but interesting." - The British Quarterly Review.

"The book is eminently readable."-Westminster Revien".

" His natural history notes seem to us admirable. The book deserves little but praise." -The Academy'.

"A delightful book. Very few sportsmen, we fear, can write so delightfully as he can, for he is not only a sportsman with a considerable literary gift, but he has a keen sense of humour and a very happy way of expressing and communicating that sense on paper."-The St. Fames's Gazette.

"A prize! A most fascinating book, which I could not lay down at meal tumes or at bedtime until 1 had unfortunately finished it. Full of most vivid pictures and grood amusing and characteristic stories." -Truth.

"A book of rare interest and charm ... such as the public seldom has the opportunity of reading, and indeed as a necessarily rare combination of circumstances can alone produce. A book of quite unusual charm."-The Spectator.

"The pictures could hardly be better chosen or better drawn. A pleasanter or more entertaining book we have not seen for a long time. The book is thoroughly fresh an I interesting. "-The Examiner.

"This is a work of which it is hardly possible to speak in too flattering terms." - Land and Water.

"A most delightful volume."-Graphic.
"A most interesting volume. Everything is vivid and forcible and fresh "- The Field.

"A perfect book of its kind. The charm is irresistilule. A very bright, agreeable, and interesting volume." -lllustrated I.ondon Nea's.

"It is seldom that we have read a better book. . . A more real and better book we have not met with for some time." - The Literary World.

"It is not often that a book has equal claims to the attention of the scientist and gencral reader." Scotsman.

"Amung the legions of books on the Far West we have found none so fresh, so full of the truth of its $\mathrm{Al}$ pine woods and peaks, and giving withal so fair and representative a view of frontier life, as Baillie-Grohman's 'Camps in the Rockies.' "-The Nation (New York).

" There has been no more entertaining and honest book written on the liar West than this of Mr. BaillieGrohman's." - Literary World.

"An exceedingly bright book, as good reading as anything we have seen on our frontier life."-Boston Advertiser.

" It is, without any qualifying adjective, the best book of the kind we have ever seen."-Eoston Times.

"One of the most delightful as well as truthful descriptions of Western out-door life that we have ever read." -Inter-Ocean.

" His narrative is an admirable book-full of delightful descriptions and accurate information." Philadelphia Press.

"It is an honest book, $t(x)$; a record of interesting adventures, robust and full of grood humour and good stories." - New bork World.

"There is a freshness and a charm about his narration of scenes and circumstances that is very 


\section{Press Opinions-(continued).}

delightful. It is a very entertaining book, and on the whole very true to nature."-Forest and Stream (New York).

"It rarely happens that any work of this kind is at once so plain, honest, and truthful as this." -The Post (Boston).

"The book is one of the best that has appeared on such subjects." - The Spirit of the Times (New York).

"It is seldom one meets with a volume more replete with entertainment and information "Herald.

"The best book of frontier life and sport."Philadelphia Bulletin.

"One of the best books on Western travel and adventure that have yet appeared."-Providence Fournal.

"One of the most delightful books conceivable." - C. Ch. Standard.

"Some of the stories are better than anything in Bret Harte's pages." -Intelligencer.

"The most noteworthy book of its kind." Chicago Advance.

" "Sport in the Alps" is altogether one of the most complete existing accounts of a fascinating subject . . excellent dissertations on the history of sport."-Times.

"A really good book."-Field.

"A book where all is interesting" -Spectator.

"Is to an unique degree redolent of the atmosphere of the chase."-The Speaker.

"From the sportsman's point of view an ideal production. . . . An extremely interesting and valuable account."-St. Fames's Budget.

"Certainly one of the best books on sport which has appeared for some time. . . . Most pleasantly and ably written."-World

" A delightful book."-Truth.

"Is a work which should have an honoured place in every sportsman's and naturalist's library." Sporting Life.

"A magnificently produced volume. . . one which anybody might justifiably be proud to possess."-Sportsman.

"The book is one that will be appreciated by everyone who can recognise good sport and literature combined." $-S t$. Fames's Gazette.

"The critical and historical portions of his book being exceptionally well done.... About this distinctly successful work there is a thoroughness that we can only expect from one who is master of his subject."-Literary World.
"Full of interest and of curious information ... is, in short, a book to be very heartily recommended both to sportsmen and to the general reader." National Observer.

"A very complete and admirable vade mecum. ...Thorough and most interesting manner in which the author has carried through his extended task." -Daily Telegraph.

"Is one that we may cordially recommend to the perusal of our readers. His descriptions are excellent, and the historical information extremely interesting." - The Zoologist.

"This is a work which can be very cordially recommended."-Baily's Magazine.

"From beginning to end the volume is packed with interesting and, in many cases, instructive information, yet there is not a dull page to be found."-Sketch.

"We heartily recommend Mr. Grohman's important work to the attention of all lovers of natural history and sport."-Pall Mall Gazette.

"Is so thoroughly practical as well as entertaining, that it will possess substantial value as an authority on the subject with which its author is so familiar. The Queen has accepted a copy of the volume, and has been, it is stated, much interested."-Court Fournal.

"An admirable volume .. . full of interest. . . Both author and publisher may be congratulated on having produced the sporting book of the year."-Country Sport.

"A very interesting book." - Westminster Budget.

"An excellent sportsman, who writes well of that which he knows well."-Vanity Fair.

"Sportsmen will delight in this well-written volume, which is an encyclopædia of hunter's lore.'-Daily News.

"Superbly illustrated with drawings and photographs, which add to the interest and the value of a noteworthy contribution to the literature of sport."-Referee.

"A well-written and extremely interesting book. ... Will be seen in every country house during the shooting season."-Illustrated London News.

"As a contribution to the natural history of the Alps, no less than to their attractiveness as a hunting field, it is of the greatest interest and value."-Daily Graphıc.

"Admirable use has the author made of his opportunities."-Land and Water.

"The work of a sportsman and a mountaineer of the first order."-Daily Graphic. 



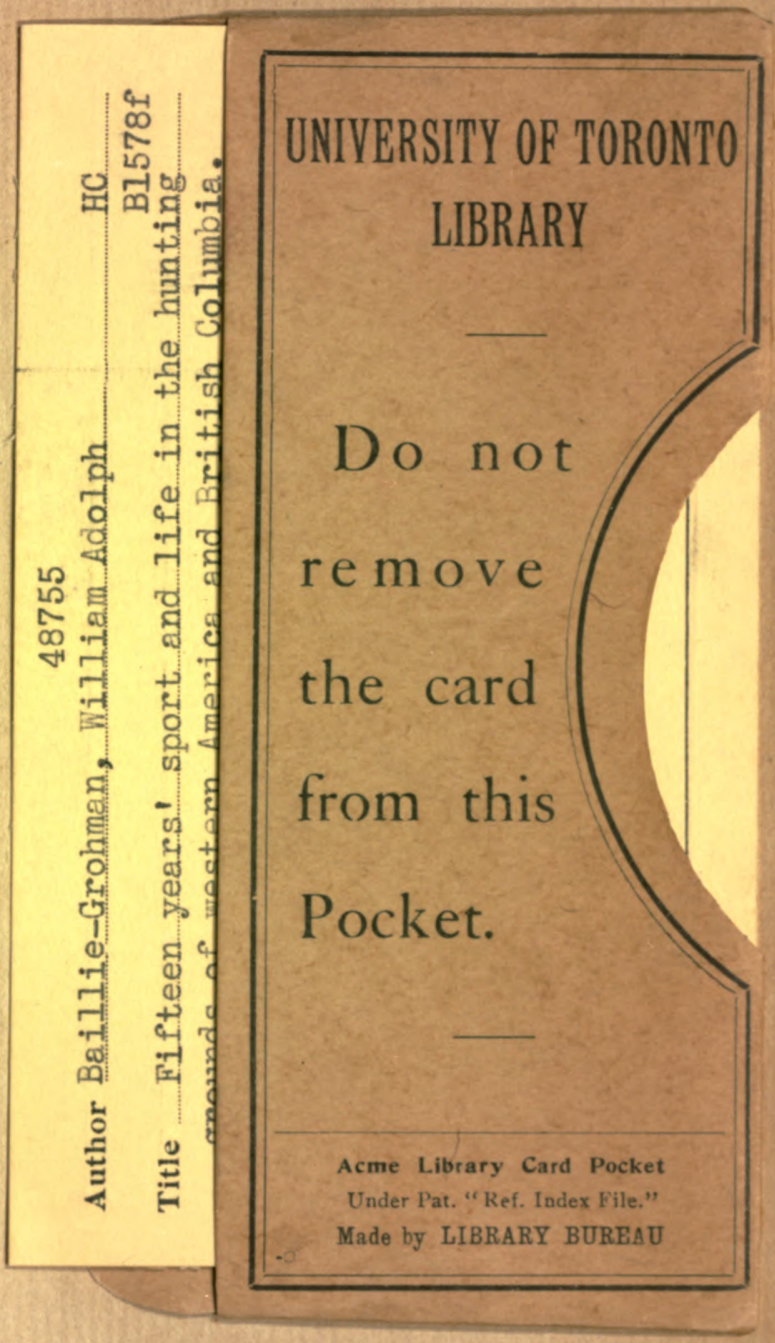


